\title{
AS TRANSFORMAÇÕES ARQUITETÔNICAS E URBANAS NOS SÉCULOS XVIII E XIX NA CIDADE DE PARANAGUÁ, PARANÁ
}

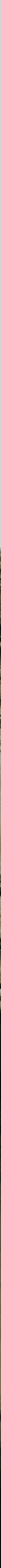





\title{
AS TRANSFORAÇÕES ARQUITETÔNICAS E URBANAS NOS SÉCULOS XVIII E XIX NA CIDADE DE PARANAGUÁ, PARANÁ.
}

\author{
Dissertação apresentada ao Departamento de \\ Arquitetura e Urbanismo da Escola de Engenharia \\ de São Carlos da Universidade de São Paulo, para a \\ obtenção do título de mestre em Arquitetura e \\ Urbanismo. \\ Área de Concentração: Teoria e História da \\ Arquitetura e do Urbanismo \\ (Versão Corrigida)
}

Orientador: Prof. Dr. Luiz Antonio Recamán Barros

São Carlos

2010

Apoio: CNPq (Conselho Nacional de Desenvolvimento Científico e Tecnológico) 
AUTORIZO A REPRODUÇÃO E DIVULGAÇÃO TOTAL OU PARCIAL DESTE TRABALHO, POR QUALQUER MEIO CONVENCIONAL OU ELETRÔNICO, PARA FINS DE ESTUDO E PESQUISA, DESDE QUE CITADA A FONTE.

email: rodrigosjab@yahoo.com.br

Ficha catalográfica preparada pela Seção de Tratamento da Informação do Serviço de Biblioteca - EESC/USP

Jabur, Rodrigo Sartori
As transformaços arquitetônicas e urbanas nos séculos
XVII e XIX na cidade de Paranaguá, Paraná / Rodrigo
Sartori Jabur i orientador Luiz Antonio Recamán Barros. -
- São Carlos, 2010.
Dissertação (Mestrado - Programa de Pós-Graduação em
Arquitetura e Urbanismo e Área de Concentração em Teoria
e História da Arquitetura e do Urbanismo) -- Escola de
Engenharia de São Carlos da Universidade de São Paulo,
2010.
1. Paranaguá. 2. Transformações urbanas e
arquitetônicas. 3. Erva-mate. 4. Porto. 5. Ferrovia.
6. Vila e cidade. 7. Centro histórico. 8. Preservação.
I. Título.




\section{FOLHA DE JULGAMENTO}

Candidato (a): Arquiteto e Urbanista RODRIGO SARTORI JABUR.

Dissertação defendida e julgada em 17/12/2010 perante a Comissão Julgadora:

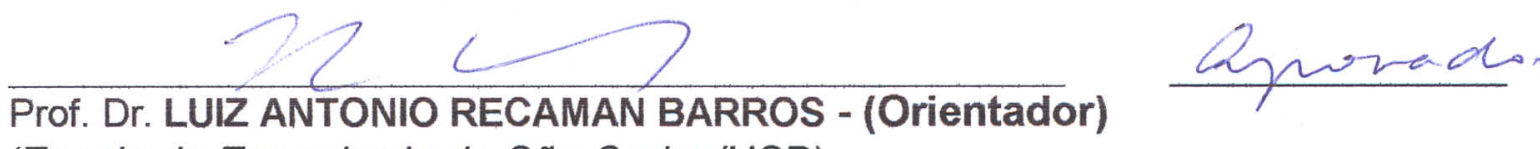
(Escola de Engenharia de São Carlos/USP)

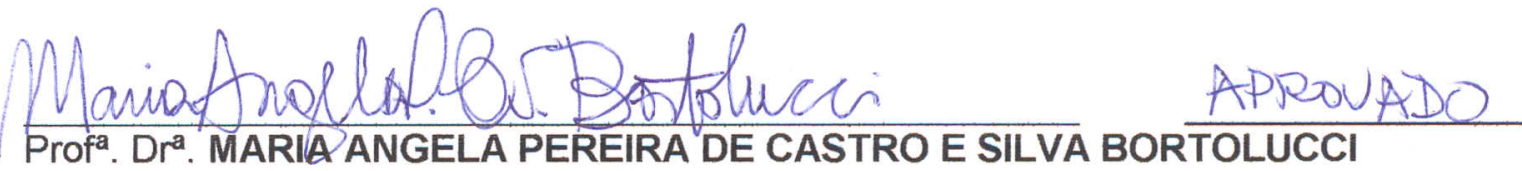
(Escola de Engenharia de São Carlos/USP)

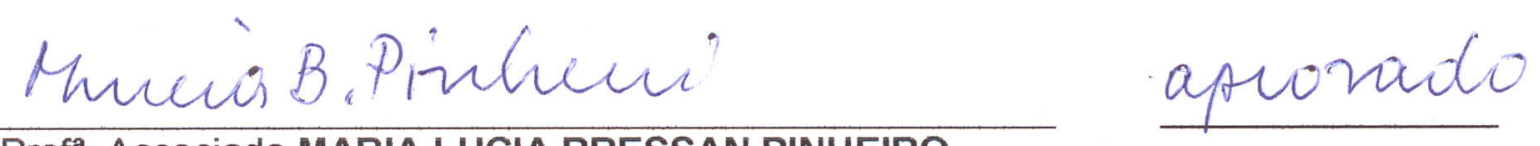

Profa. Associada MARIA LUCIA BRESSAN PINHEIRO

(Faculdade de Arquitetura e Urbanismo/FAU)
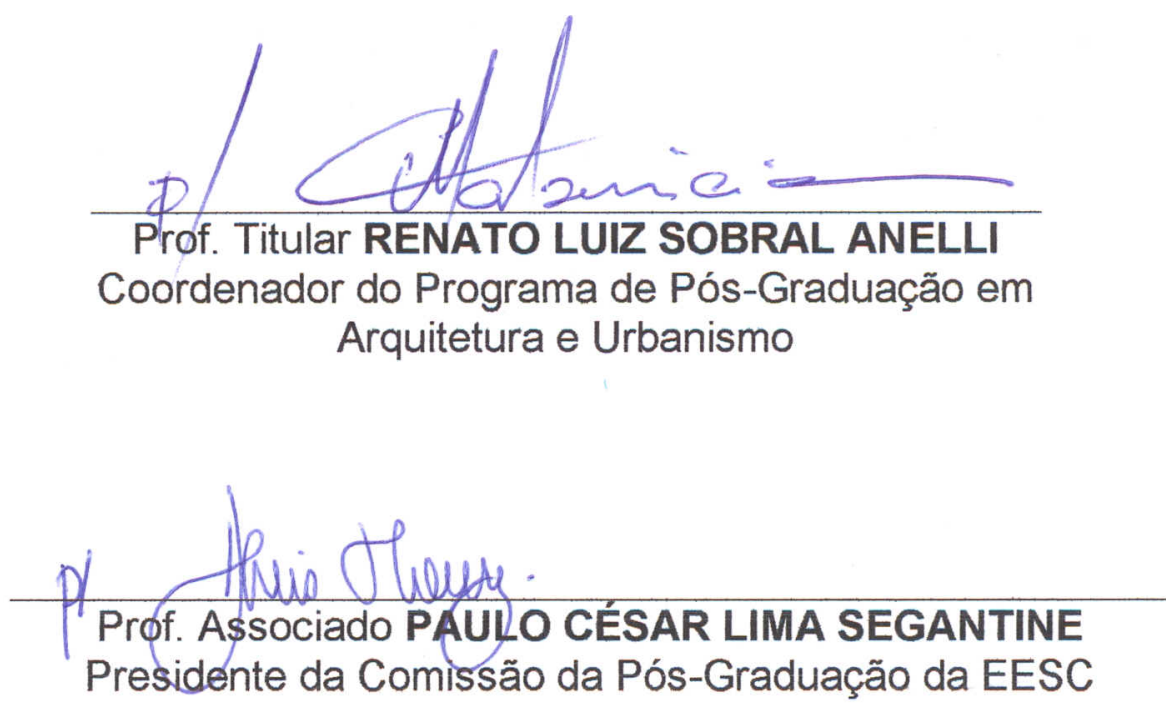

Prof. Thutar Denis Vinicius Coury Supderte do Presidente da CPG-EESC-USP 



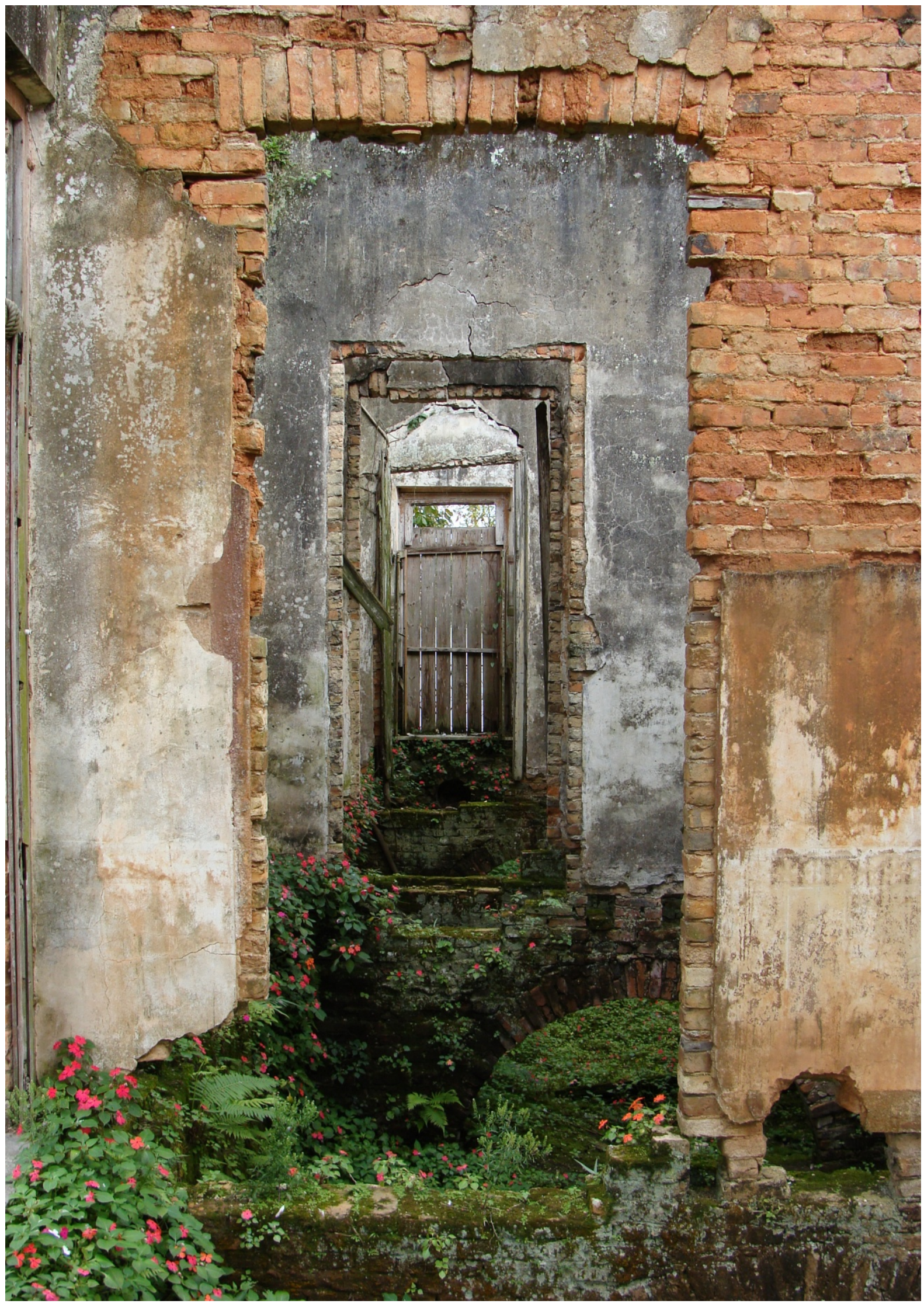



Espero aqui apresentar minha gratidão a todos aqueles que de alguma forma colaboraram para que esta pesquisa se tornasse realidade, pois suas colaborações foram importantes nesse caminho percorrido e que se encerra nesse momento. Primeiramente, agradeço ao Prof. Dr. Luiz Antônio Recamán Barros pela orientação e análise desta pesquisa, desde seu início e por ter apoiado esta proposta desde a seleção para o programa de pós-graduação, em 2008. Também quero agradecer ao importante apoio dado pelo Conselho Nacional de Desenvolvimento Científico e Tecnológico (CNPq), que possibilitou minha dedicação exclusiva à pesquisa e permitiu realizar viagens, levantamentos nas instituições e aquisição de bibliografia e outros materiais para o desenvolvimento desta dissertação.

Quanto às instituições pesquisadas, gostaria de agradecer algumas das quais tive boas experiências e que marcaram esta trajetória. Primeiramente agradeço ao Instituto Histórico e Geográfico de Paranaguá, por possibilitar a pesquisa em todo o seu acervo, que contribuiu profundamente no embasamento da dissertação. Agradeço ao seu presidente o Sr. Alceu Maron, e a seus membros que muito me auxiliaram com as conversas no meio da tarde e a troca de informações e bibliografias, enquanto eram feitas as investigações. Portanto, agradeço imensamente o Sr. José Maria Faria de Freitas e o Sr. Luiz Siqueira, que mantêm acesa a memória da cidade de Paranaguá, principalmente de seu folclore e de sua população e ao Sr. Ennio Luz, pela companhia nos levantamentos; também quero agradecer à funcionária do IHGP, a amiga Zélia, sempre presente nas pesquisas 
nessa instituição e nas conversas divertidíssimas que tivemos durante as semanas de pesquisa e também ao Wilson que nos acompanhava nessas conversas.

Agradeço à Prefeitura Municipal de Paranaguá, em nome do arquiteto Luis Marcelo Bertoli de Mattos, responsável da Divisão do Patrimônio Histórico de Paranaguá, pelo auxílio bibliográfico e por sanar as dúvidas em relação ao Centro Histórico da cidade, também quero agradecer a amiga e arquiteta Geisa Maria, por me auxiliar nas pesquisas documentais dentro da prefeitura e também a funcionária Maribel Morena, pelo auxílio na busca de projetos e mapas nos arquivos municipais. Agradeço a Associação dos Portos de Paranaguá e Antonina (APPA) e a seu fotógrafo Rodrigo Leal, por disponibilizar imagens do Porto de Paranaguá.

Nas pesquisas em Curitiba, gostaria de agradecer ao Círculo de Estudos Bandeirantes e sua bibliotecária Lúcia, por permitirem a pesquisa e auxiliar nos levantamentos realizados naquela instituição, também agradeço ao Instituto Histórico Geográfico e Etnográfico Paranaense, e sua bibliotecária Lívia, pela ajuda nos levantamentos e informações sobre este acervo. Por fim, quero agradecer ao Museu Paranaense, em nome de seu Diretor Euclides Marchi por permitir a pesquisa no acervo fotográfico desta instituição e também pela fantástica ajuda e acompanhamento de Vera Coelho e Lourdes Maingue na biblioteca do museu, Marcia Medeiros, Denise Haas e Sílvia Marchiorato, pelo auxílio nos levantamentos do acervo fotográfico e aos outros funcionários que me receberam tão bem e de forma tão carinhosa que não mais esquecerei.

Em São Carlos, quero agradecer a muitas pessoas das quais convivi e que ajudaram no andamento da pesquisa, primeiramente aos funcionários do Programa de Pós-Graduação, principalmente ao Marcelinho, Geraldo e Kaio, por sempre 
serem solícitos ao sanar as diversas dúvidas, auxiliando de prontidão. Também quero agradecer ao Paulo, Oswaldo, Evandro e Zanardi, pelos auxílios nas temáticas da informática.

Às professoras Dra . Cristina Meneghello e Dra . Maria Ângela Pereira de Castro e Silva Bortolucci, pelo apoio e pelas importantes contribuições dadas no exame de qualificação e a professora Dra. Maria Lucia Bressan Pinheiro por sua importante contribuição no exame de defesa, que ampliaram os horizontes desta pesquisa. A professora $\mathrm{Dr}^{\mathrm{a}}$. Telma de Barros, pela ajuda nas bibliografias no decorrer de sua disciplina e a professora Dra. Anja Pratschke, pela oportunidade de participar do Pinhal Digital e ampliar o conhecimento das possibilidades de organização das informações sobre o patrimônio cultural.

Quero também deixar minha gratidão aos amigos que me acompanharam nesta jornada em São Carlos e foram importantíssimos nesta primeira experiência longe de casa. Primeiramente as irmãs Marieli Lukiantchuki e Juliana Lukiantchuki, que desde a minha primeira ida à São Carlos, estavam sempre prontas a me ajudar, tanto nas horas boas como nas horas ruins, estas palavras não expressam toda a minha gratidão por elas, que me acompanharam nessa trajetória e foram minha família em São Carlos, possibilitando um ótimo período na cidade.

Também quero agradecer aos amigos que fiz durante o mestrado e que também foram marcantes em minha estada, pessoas que também acompanharam todo o processo e sempre incentivaram o trabalho, quero aqui agradecer a fantástica Ana Barbosa, pela ajuda nas bibliografias e por transmitir suas experiências em relação à preservação do patrimônio, a Lorenza Pavesi, amiga de todas as horas, pelo abstract, sempre me ajudando e incentivando, tenho eterna gratidão; à Carolina 
Fróes, que também agradeço pela ajuda durante a estada em São Carlos, sempre me motivando e auxiliando com sua experiência de mestrado e aos amigos que me acompanharam nos estudos na sala da pós: Thais, Josi, Christiane, Vanessa e Rérisson.

Quero agradecer a professora e amiga Aline Montagna, que me ajudou nas bibliografias e que desde a graduação, orientando-me no Trabalho Final, me incentivou a continuar a investigação sobre Paranaguá e foi importante no desenvolvimento do primeiro projeto para o mestrado. À grande amiga Ariadne Batinga por sempre me apoiar e pelas diversas caronas à rodoviária de Maringá. A amiga Profa. Odete Starke Moro pela minuciosa revisão final dos textos dessa dissertação.

Por fim minha família, da qual foi responsável em parte por esta trajetória e que sempre foram meus incentivadores, quero primeiramente agradecer aos meus pais Issa e Elair que são minhas fontes de inspiração, os maiores exemplos que tenho e por isso meu eterno amor e gratidão. Às minhas irmãs: Simone, que me acompanhou nas pesquisas em Paranaguá e foi importante na fase dos levantamentos, Danielle, que me ajudou na revisão dos textos, e Andrea, pela ajuda nas bibliografias, todas de alguma forma participaram desta pesquisa. 


\section{Buscando o Sentido}

O Sentido, acho, é a entidade mais misteriosa do universo.

Relação, não coisa, entre a consciência, a vivência e as coisas e os eventos.

O sentido dos gestos. O sentido dos produtos. O sentido do ato de existir.

Me recuso a viver num mundo sem sentido.

Estes anseios/ensaios são incursões conceptuais em busca do sentido.

Por isso é próprio da natureza do sentido: ele não existe nas coisas, tem que ser buscado, numa busca que é sua própria fundação.

Só buscar o sentido faz, realmente, sentido.

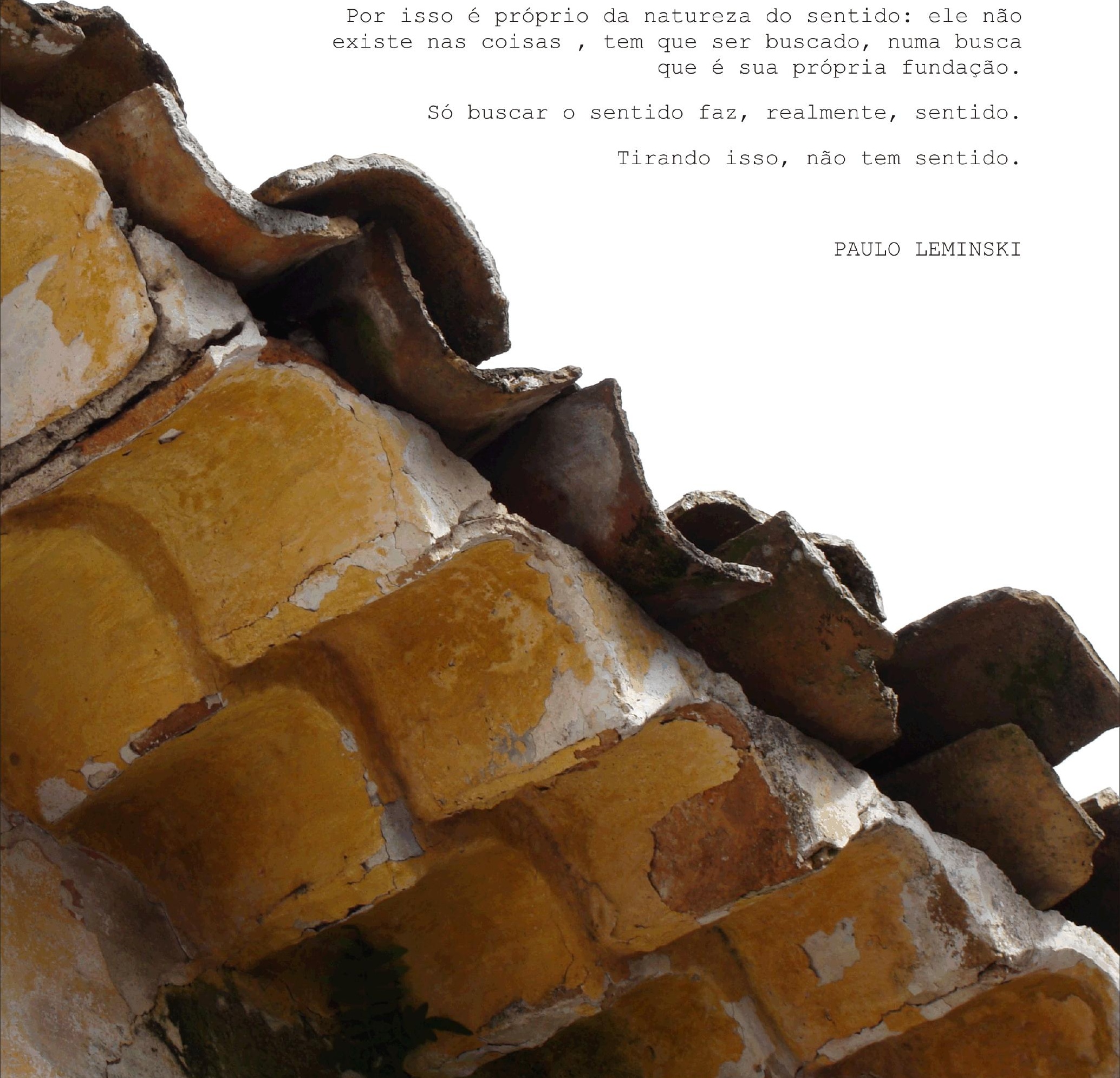



JABUR, Rodrigo S. (2010). As Transformações Arquitetônicas e Urbanas nos Séculos XVIII e XIX na Cidade de Paranaguá, Paraná. Dissertação (Mestrado) Escola de Engenharia de São Carlos, Universidade de São Paulo, São Carlos, 2010.

\section{RESUMO}

Estuda as transformações urbanas e arquitetônicas na cidade de Paranaguá, no litoral do Paraná, durante os séculos XVIII e XIX, analisando desde a ocupação do continente, ainda no século XVII, passando pelas provisões do Ouvidor Rafael Pires Pardinho nos anos de 1720, continuando com o desenvolvimento de seu porto, o impacto da economia da erva-mate, as mudanças nas edificações e em seus métodos construtivos, assim como nos Códigos de Posturas, na chegada da ferrovia, nas preocupações de higiene e salubridade e por fim na mudança do porto para a baía de Paranaguá. A partir da consulta a documentos primários como jornais, leis provinciais, relatórios, manuscritos, relatos de viajantes, fotografias, mapas e aquarelas, compreende como se deu o desenvolvimento da vila e depois cidade de Paranaguá. Também analisa as características de seu Centro Histórico e as leis vigentes neste local atualmente, finalizando com a proposta de um roteiro de visitas para a cidade.

Palavras-chave: Paranaguá, Transformações urbanas e arquitetônicas, Erva-mate, Porto, Ferrovia, Vila e cidade, Centro Histórico, Preservação. 

JABUR, Rodrigo S. (2010). Architectural and Urban Transformations during the 18th and 19th centuries in the city of Paranaguá, State of Paraná. M.sc. Dissertation - Escola de Engenharia de São Carlos, Universidade de São Paulo, São Carlos, 2010.

\section{ABSTRACT}

This dissertation studies the urban and architectural transformations occurred in the city of Paranaguá, located on the coast of the Paraná State, during the 18th and 19th centuries. It analyses the occupation of the continent, starting from the $17^{\text {th }}$ century, going through Ouvidor Rafael Pires Pardinho's provisions during the decade of 1720 e continuing with the development of its harbour, the impact of the erva-mate's economy, the changes in the buildings and in the methods of construction, as well as in the Codes of Practice, the advent of the railway, the preoccupations with hygiene and salubriousness and finally the harbour's move to the Bay of Paranaguá. These analyses are based mainly on primary documents such as newspapers, provincial laws, reports, manuscripts, travellers' accounts, photographs, maps and watercolours, understand how the development of the town and later of the city of Paranaguá occurred and subsequently, to analyse the characteristics of its historical centre and the laws that are still into effect today, offering new proposals and suggesting a visitors' route.

Keywords: Paranaguá, urban and architectural transformations, Erva-mate, harbour, railway, village and city, historical centre, preservation. 



\section{ÍNDICE DE FIGURAS}

Figura 1. Esta imagem possibilita visualizar a cidade de Paranaguá, a ilha da Cotinga, ilha do Mel e parte da entrada da Baía de Paranaguá.............................42

Figura 2. Parte da ilha da Cotinga, observada da rua General Carneiro...................42

Figura 3. Mapa da baía de Paranaguá de 1653................................................43

Figura 4. A rua Vieira dos Santos, antiga rua do Fogo, indicada em amarelo no mapa.

Figura 5. A Fonte de Beber Água e sua localização, indicada com o ponto, nas proximidades da igreja de São Benedito.

Figura 6. Aspecto da rua João Régis, antiga rua da Matriz, destaque em amarelo no mapa.

Figura 7. Rua Pecego Junior, antiga rua do Meio ou da Baixa, destaque em amarelo no mapa. 60

Figura 8. O projeto da Casa de Câmara e Cadeia, entregue por Pardinho em 1720.

Figura 9. A Igreja do Bom Jesus no início do século XX.

Figura 10. O Colégio dos Jesuítas e detalhes de sua construção, na parte superior direita o cachorro em cantaria e na parte inferior uma das aberturas do edifício.....73

Figura 11. O pátio interno do Colégio e suas arcadas.

Figura 12. A igreja dos Jesuítas retratada por John Codman na metade do século XIX e publicado no livro "Ten Months in Brazil". 76

Figura 13. Vista do Colégio e das ruínas da igreja no final do século XIX..............76

Figura 14. Uma das paredes internas do Colégio, no detalhe as conchas misturadas a argamassa de argila.

Figura 15. O recuo das paredes pode ser observado na fachada do Colégio, ao lado direito uma das bases da estrutura que se inclina, para estabilizá-la. .78

Figura 16. As estruturas internas do Colégio, pela janela percebe-se a grande espessura de suas paredes

Figura 17. A estrutura inacabada das obras dos Jesuítas. ................................. 79

Figura 18. Frontispício da igreja da Ordem Terceira. .........................................84

Figura 19. Na esquerda a igreja da Ordem e na direita a igreja de São Benedito. ...84

Figura 20. Detalhe do frontão sinuoso e do óculo central. .................................85

Figura 21. Brasão dos franciscanos, localizada ao centro das duas janelas frontais.

Figura 22. Interior da igreja da Ordem Terceira, o arco em cantaria marca a metade do edifício.

Figura 23. A torre sineira da igreja da Ordem, na imagem superior direita a data de sua edificação.

Figura 24. A igreja de São Benedito e alguns de seus detalhes. ...........................90

Figura 25. Fundos da igreja de São Benedito. .....................................................90

Figura 26. Matriz de Paranaguá. ................................................................ 92

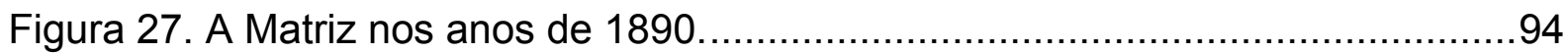


Figura 28. A casa de pau-a-pique em 1966, vista da rua Vieira dos Santos. 96

Figura 29. Último remanescente de construção em pau-a-pique, localizado na rua Vieira dos Santos, nota-se as vergas em madeira e o detalhe da beira seveira. .... 96 Figura 30. Lacunas existentes na casa localizada na rua Vieira dos Santos, em detalhe a amarração das taquaras com cipó................................................ 97

Figura 31. Detalhe da amarração das taquaras e da massa de argila. .................... 97 Figura 32. Quadro de janela em pedra situado no claustro do Colégio, observa-se abaixo do peitoril a laje de pedra, também denominada janela com avental......... 100 Figura 33. Sobrado situado na rua Pecego Junior, detalhe de sua janela em cantaria, semelhante à encontrada no Colégio dos Jesuítas. 101

Figura 34. Detalhe do cunhal em cantaria e do revestimento em argila e cal, encontrado no sobrado da rua Pecego Junior.

Figura 35. Casas situadas no largo da Matriz.

Figura 36. Detalhe das portas pertencentes ao sobrado do largo da Matriz, ao lado direito a estrutura de cantaria e ao lado esquerdo a estrutura provavelmente de tijolos.

Figura 37. Ruína na rua Vieira dos Santos, onde foi encontrado o tijolo de tonalidade amarela nos quadros dos vãos da estrutura. 105

Figura 38. Detalhe de uma das portas do Colégio dos Jesuítas, percebe-se a rusticidade no entalhe da cantaria, ao lado um das janelas deste edifício com a verga desalinhada.

Figura 39. Casa na rua Marechal Deodoro, onde é possível perceber os tijolos assentados nas estruturas dos vãos.

Figura 40. Ruína na rua Faria Sobrinho,no detalhe a utilização da técnica de tijolos nas estruturas de portas e janelas.

Figura 41. Outro exemplo da aplicação dos tijolos nas estruturas dos vãos, agora na rua Pecego Junior. 108

Figura 42. Ruínas da igreja de São Francisco em Curitiba e detalhe das arcadas em tijolo maciço. 108

Figura 43. Fotografia do começo do século XX, na rua Faria Sobrinho, em que se observa o sobrado com sacada de madeira.

Figura 44. Casas na rua Marechal Alberto de Abreu, com suas portas e janelas em canga. 110

Figura 45. Rua XV de Novembro em 1900, área em que predominaram sobrados e

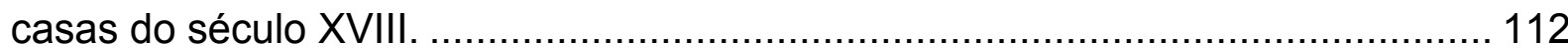
Figura 46. A Casa de Câmara e Cadeia de Paranaguá, em fins do século XIX .... 112 Figura 47. Rua Conselheiro Sinimbú, antiga rua da Fonte, começo do século XX, observa-se os sobrados localizados no lado direito e no lado esquerdo, ao fundo.113 Figura 48. Rua Conselheiro Sinimbú, vista a partir do largo da Matriz em 1922. ... 113 Figura 49. Mapa de Paranaguá em 1815. ......................................................... 119 Figura 50. Mapa de Paranaguá de 1895.................................................. 120 Figura 51. Aquarela de autoria desconhecida que representa Paranaguá em 1874. 
Figura 52. Duas fotografias panorâmicas de Paranaguá, a primeira de aproximadamente 1880 e a segunda de 1900.

Figura 53. A visão da igreja do Bom Jesus a partir da rua Direita, em 1920, a rua converge a perspectiva para este templo.

Figura 54.Uma procissão passa pela rua Direita em 1927, ao fundo o campanário da igreja Matriz.

Figura 55. Dois aspectos da rua Senhora do Terço, a da esquerda do começo do século XX e a seguinte da década de 60 do mesmo século.

Figura 56. A rua da Boa Vista, antiga Visconde de Nácar, por onde passava uma procissão em 1897.

Figura 57. Principais eixos de formação da vila de Paranaguá em 1815..............135

Figura 58. Principais eixos de formação da cidade de Paranaguá em 1895..........136 Figura 59. Salão Nobre da Prefeitura Municipal de Paranaguá, começo do século XX

Figura 60. Os primeiros presidentes brasileiros sob o olhar da imagem de D. Pedro II.

Figura 61. A Praça do Mercado em fins do século XIX

Figura 62. A lateral da Praça do Mercado e ao fundo, do lado esquerdo, pode ser observada parte do telhado da antiga Casa de Câmara e Cadeia de Paranaguá, começo do século $X X$.

Figura 63. Em meio aos populares, observa-se do lado direito da fotografia, de fins do século XIX, o mercado com suas janelas em arco e no lado esquerdo está o chalé de pescados em pleno funcionamento.

Figura 64. Defronte ao chalet dos pescados, o rio Itiberê, onde estão atracados os barcos dos pescadores que já entregaram a coleta do dia, fins do século XIX. ....159 Figura 65. A residência descrita por Vieira dos Santos, final do século XIX.

Figura 66. Nesta aquarela de William Michaud, de 1890, percebe-se a lateral desta residência com sua porta principal em arco pleno.

Figura 67. O Palacete Visconde de Nácar, no quadro superior direito a data colocada em sua platibanda, no quadro inferior o jardim lateral.....................................180

Figura 68. Fachada do Palacete Nácar e seu acesso principal............................180

Figura 69. Detalhes das aberturas do edifício...............................................181

Figura 70. O Palacete Nácar no começo do século $X X$, e no início do XXI. ...........181

Figura 71. O grande jardim lateral do palacete Nácar......................................183

Figura 72. Os bancos do jardim embrechados com conchas, que formam o nome do prorietário.

Figura 73. Anúncios encontrados no jornal Commercio do Paraná da década de 1860.

Figura 74. A residência Veiga em fins do século XIX ou início do XX, nota-se a simetria do edifício através dos dois grandes portões em suas laterais.

Figura 75. A residência da família Veiga em seu estado atual, com a eliminação dos portões laterais. 
Figura 77. Perfil de Alfredo Andersen, provavelmente década de 1920.

Figura 78. Um dos frisos decorativos localizados na sala de jantar, de autoria de

Alfredo Andersen.

Figura 79. Fundos da residência Veiga e detalhe de uma das arcadas de sua

Figura 80. As arcadas em tijolos maciços e as fundações externas em pedra da residência Veiga.

Figura 81. As paredes em tijolo maciço e o detalhe do reboco muito espesso da residência Veiga.

Figura 82. A residência do Coronel João Guilherme Guimarães, início do século XX.

Figura 83. A residência João Guilherme Guimarães em 2009.

Figura 84. A casa azulejada situada na rua XV de Novembro.

Figura 85. O Chalet azulejado na rua XV de Novembro.

Figura 86. A rua XV de Novembro em 1897, no lado direito ao fundo está o chalet azulejado.

Figura 87. A rua Direita em fins do século XIX, observa-se a disputa entre os beirais coloniais e as platibandas ecléticas.

Figura 88. A residência Elfrida Lobo. 200

Figura 89. Acesso para o jardim lateral e alguns detalhes da residência Elfrida Lobo.

Figura 90. Detalhes da casa Elfrida Lobo.

Figura 91. Interior da casa Elfrida Lobo e o acesso ao jardim.............................. 201

Figura 92. Aspecto do jardim lateral da residência Elfrida Lobo........................... 202

Figura 93. $O$ anexo da casa Elfrida Lobo e o detalhe dos pisos hidráulicos........... 202 Figura 94. O casarão em fins do século XIX e o aspecto atual do Palacete Mathias

Bohn. 204

Figura 95. Detalhes do Palacete Bohn. 204

Figura 96. O acesso lateral do Palacete Bohn e seus detalhes, como o rosto feminino, acima das portas superiores e o friso com meandros, abaixo das sacadas de púlpito. 205

Figura 97. Mais alguns detalhes do Palacete Mathias Bohn, em destaque a figura de Netuno, no canto superior a figura feminina, representando uma das estações do ano, no canto inferior direito as iniciais do proprietário. 205

Figura 98. Interior do Palacete Mathias Bohn em 1962. 206

Figura 99. Exemplo de adaptação de construção do período Colonial, na rua Mal.

Deodoro. 206

Figura 100. Atividade portuária no rio Itiberê, em fins do século XIX. 209 Figura 101. Região do porto no Itiberê, ao fim da rua da Cadeia e da Ordem, fins do século XIX. 209

Figura 102. A estação do Porto D. Pedro em 1880. 217 Figura 103. Telha Francesa encontrada nas ruínas da estação do Porto D. Pedro II. 
Figura 104. Localização da estação de Paranaguá em 1910.

Figura 105. A estação ferroviária da cidade e o depósito de mercadorias, nos fins do século XIX

Figura 106. Postal colorido da estação de Paranaguá, em 1903.

Figura 107. A estação em 1884, fotografada por Marc Ferrez e ao lado o pequeno edifício em demolição para dar lugar ao depósito de mercadorias.

Figura 108. Estação da cidade de Paranaguá no início do século XX, com o depósito de mercadorias já construído.

Figura 109. A estação de Paranaguá no início do século $X X$.

Figura 110. Grande movimentação de pessoas na chegada do trem à estação de Paranaguá, início do século XX.

Figura 111. Ponte metálica entre as cidades de Morretes e Antonina, fins do século XIX.

Figura 112. Estruturas metálicas provenientes da Bélgica, como a ponte São João, fins do século XIX.

Figura 113. Anúncio bilingue encontrado no jornal Dezenove de Dezembro de 1882.

Figura 114. As estações ferroviárias da cidade de Paranaguá.

Figura 115. Defronte às construções que margeiam o Itiberê, este navio está atracado para desembarcar um carregamento de sal, começo do século XX .......234 Figura 116. Este pequeno trem ligava a Alfândega do Itiberê ao porto D. Pedro II, início do século XX.

Figura 117. Bonde de tração animal, passando pela igreja da Ordem, fins do século XIX.

Figura 118. Bonde provavelmente nas margens do Itiberê, início do século XX ....235

Figura 119. Mapa do Setor Histórico de Paranaguá.

Figura 120. Construções na lateral da igreja de São Benedito, em que se permite a demolição.

Figura 121. Casa térrea situada na esquina da rua Sinimbú com Antonio Bittencourt, em que se permite a demolição.

Figura 122. Pequena casa localizada na rua Conselheiro Sinimbú.

Figura 123. Conjunto de construções localizadas na rua Conselheiro Sinimbú......251

Figura 124. Conjunto de sobrados baixos na rua Sinimbú.

Figura 125. Cachorros em pedra do sobrado localizado na rua Sinimbú...............252

Figura 126. Construções encontradas na rua do Fogo, atual Vieira dos Santos. ...254

Figura 127. Ruínas encontradas na rua Vieira dos Santos.

Figura 128. A última casa de pau-a-pique de Paranaguá, vista da rua Cel. Antonio

Bitencourt

Figura 129. A casa de pau-a-pique, vista da rua Vieira dos Santos.

Figura 130. Largo da Matriz, do lado direito a casa de Brasílio Itiberê e a rua da Matriz, do lado esquerdo o sobrado e a rua Senhora do Terço.

Figura 131. Perspectiva da rua João Régis, antiga rua da Matriz.

Figura 132. Perspectiva da rua Professor Cleto, antiga rua Senhora do Terço. 
Figura 133. Antigo sobrado de esquina existente entre as ruas Faria Sobrinho e Professor Cleto.

Figura 134. Detalhe da beira-seveira, reconstituída no sobrado da rua Professor

Cleto. 260

Figura 135. Interior do sobrado localizado na rua Professor Cleto........................ 260

Figura 136. Rua Princesa Isabel, em branco ao lado direito o antigo estaleiro. ..... 261 Figura 137. O estaleiro da rua Princesa Isabel e suas janelas e portas com umbrais e vergas de tijolos maciços. 261

Figura 138. Sobrado localizado na rua da Praia, restando apenas sua fachada.... 263 Figura 139. Ruínas de dois sobrados, localizados na rua da Praia, esquina com a

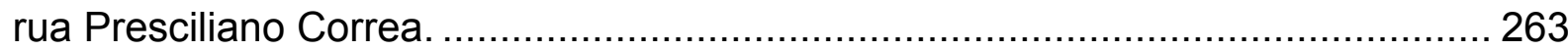

Figura 140. Grua existente no final da rua da Praia. ....................................... 265 Figura 141. Em primeiro plano uma âncora com placa comemorativa de aniversário da cidade e ao fundo a antiga grua. .............................................................. 265 Figura 142. Os cinco principais eixos de formação da cidade de Paranaguá......... 266 Figura 143. Casa Dacheux, localizada no largo da Matriz, em processo de restauração pelo IPHAN. 271

Figura 144. Ao lado esquerdo, os fundos da casa Dacheux, com a nova parede refeita no restauro realizado pelo IPHAN.

Figura 145. Aspecto da casa Dacheux, vista da rua João Régis, antiga da Matriz, após a nova pintura.

Figura 146. Ruínas encontradas na rua da Praia, as duas casas da esquina sofrem o risco de desmoronamento.

Figura 147. O grande vazio existente onde um dia esteve situada a casa de Câmara e Cadeia de Paranaguá.

Figura 148. Neste local esteve construída a casa de Câmara e Cadeia de Paranaguá, demolida no começo do século XX.

Figura 149. Visão da antiga rua Direita e logo à frente o vazio produzido pela demolição da igreja do Bom Jesus.

Figura 150. No espaço deste posto de gasolina esteve construída a igreja do Bom Jesus. 275

Figura 151. Mapa do roteiro de visitas ao Centro Histórico de Paranaguá. 285 Figura 152. Ladeira que liga a fonte d'Água aos fundos da igreja de São Benedito.

Figura 153. Fundos da igreja de São Benedito

Figura 154. Início da rua Marechal Dedodoro, antiga rua Direita. 287

Figura 155. Rua Prisciliano Correa, antiga travessa da Ordem. 290

Figura 156. Esta construção contemporânea é o acesso principal ao Museu de Arqueologia e Entografia de Paranaguá, situado na rua XV de Novembro. 293 Figura 157. Local onde estava situada a igreja dos Jesuítas, ao fundo observa-se o arco cruzeiro. 293

Figura 158. A Praça do Mercado, reformada no primeiro decênio do século XX, localizada na rua da Praia. 
Figura 159. O rio Itiberê e parte do casario existente na rua da Praia. 295

Figura 160. A estação de Paranaguá, construída nos anos 20 do século $X X$ 298

Figura 161. A Antiga estação de Paranaguá, que tornou-se depósito da nova estação e foi recuperada recentemente, servindo de posto de informações turísticas.

Figura 162. Os fundos da igreja Matriz.

299

Figura 163. Rua Professor Cleto, ao lado da Matriz, ao fundo, as casas existentes no largo da Matriz 299

Figura 164. Evolução urbana de Paranaguá entre os séculos XVII e XIX. 306

Figura 165. Evolução urbana de Paranaguá entre os séculos XVII e XIX, versão ampliada. 307

Figura 166. O porto do Itiberê possuía relações permeáveis com a cidade. 312 Figura 167. O Porto da baía de Paranaguá, separado da cidade por grades e muros.

\section{ÍNDICE DE TABELAS}

Tabela 1. População de Paranaguá no século XIX, baseando-se em dados coletados em diversas publicações. 138

Tabela 2. Principais receitas do município de Paranaguá, para o ano de $1902 \ldots . . .166$ 



\section{SUMÁRIO}

INTRODUÇÃO

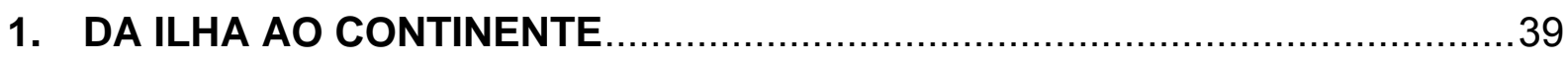

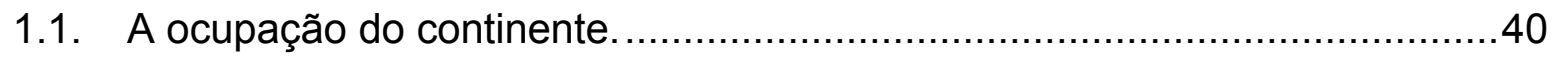

1.2. O doutor ouvidor Rafael Pires Pardinho .................................................52

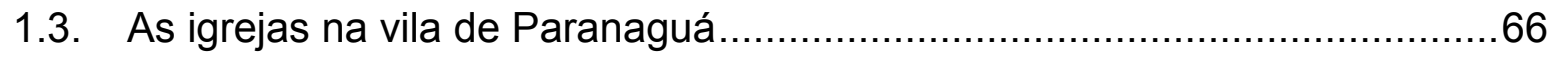

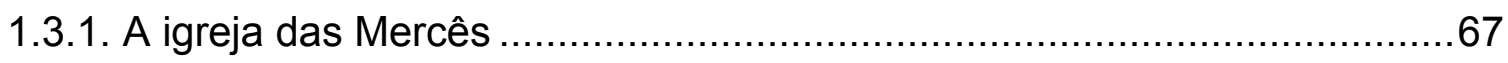

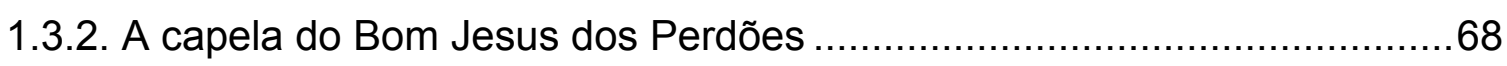

1.3.3. O colégio dos Jesuítas.................................................................... 70

1.3.4. A igreja da Ordem Terceira de São Francisco das Chagas......................80

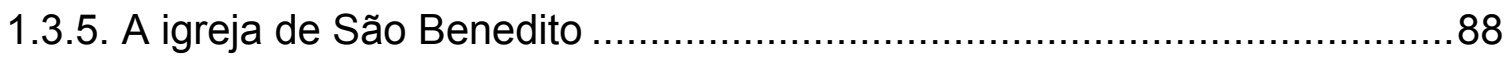

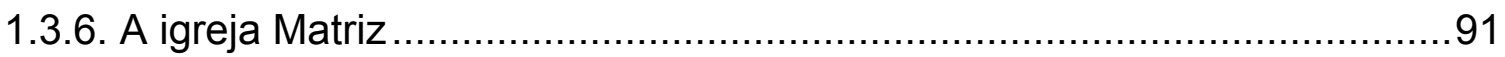

1.4. Construções civis na vila de Paranaguá ………......................................95

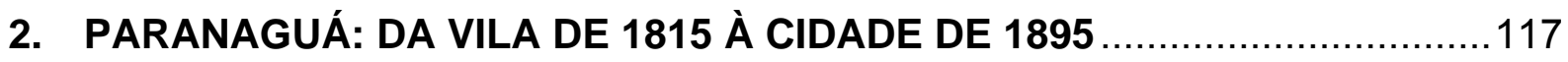

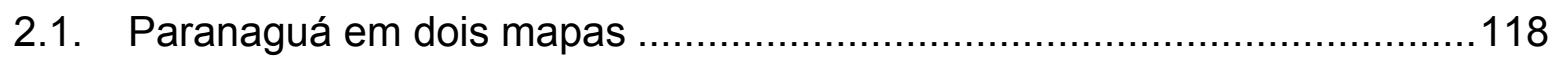

2.2. Cemitério, mercado, posturas: as preocupações sanitárias na cidade de

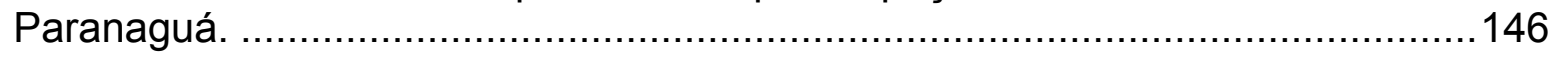

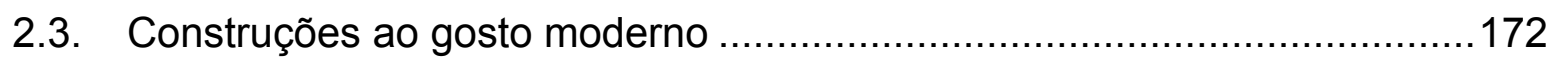

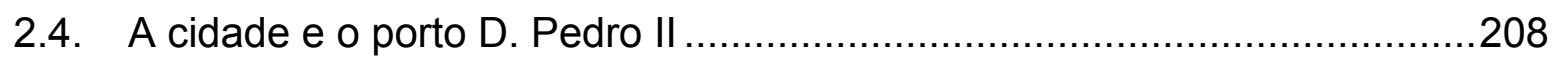

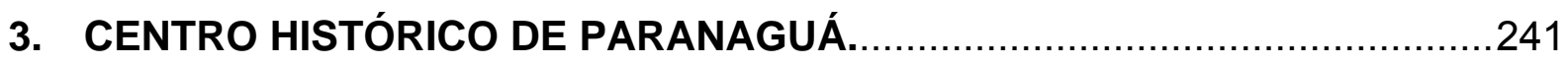

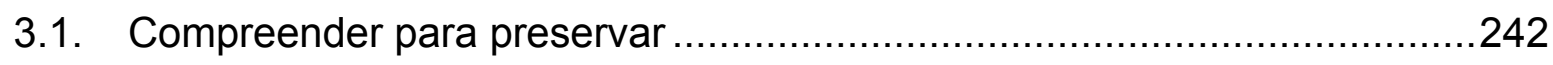

3.2. Conhecendo Paranaguá através de um roteiro de visita..........................282

PARANAGUÁ DE VILA A CIDADE, DO ITIBERÊ A BAÍA, DE PARDINHO A FERROVIA.

REFERÊNCIAS 




\section{INTRODUÇÃO}

Localizada no litoral do Estado do Paraná, Paranaguá é hoje, cidade que possui em sua estrutura urbana uma economia ainda predominantemente portuária. Não é possível imaginar Paranaguá sem citar seu porto, ele a "acompanha" desde a fundação da vila, na metade do século XVII. A vila e depois cidade localiza-se em uma área rodeada por rios e pequenas ilhas que criam uma espécie de barreira para aqueles que adentram a baía pelo mar. Segundo o geólogo Reinhard Maack:

O Conjunto de montanhas e planícies circunda a ampla e serena superfície aquática, refletindo o azul-cobalto de um céu claro ou sobre a qual cintilam os reflexos deslumbrantes da luz solar, reflexos esses que tal prata fundida penetram por entre as escuras sombras das nuvens. Esta é a baía de Paranaguá, na qual o mar avança nos vales, ricamente ramificados, de uma região montanhosa submergida. A silhueta plana, azul-acinzentada, de uma ilha, da ilha do Mel, divide a entrada da baía em dois braços. Para além, no longínquo horizonte, uma linha revela onde o oceano Atlântico curva-se obedecendo à rígida lei matemática. (MAACK, 1963, p.8-9).

Paranaguá possui sua economia voltada ao comércio de exportação e importação, resultante do desenvolvimento de seu porto marítimo. É considerado o principal terminal exportador de soja da América Latina e o segundo maior porto do Brasil em movimentação de cargas $^{1}$. A cidade conta com uma população de aproximadamente 140 mil habitantes, segundo dados estipulados pelo Instituto Brasileiro de Geografia e Estatística (IBGE), para o ano de 2009.

Resquícios da antiga vila ainda são encontrados no Centro Histórico de Paranaguá, importante conjunto urbano em que predominam construções dos séculos XVIII e XIX. Neste contexto, parte da história da formação da vila e depois cidade pode ser analisada a partir desse conjunto. A iniciativa de pesquisarmos a

\footnotetext{
${ }^{1}$ Folha do Litoral. Porto D. Pedro II completa 74 anos. Folha do Litoral, 17 mar. 2009, p. 16.
} 
cidade de Paranaguá, surgiu a partir do Trabalho Final de Graduação em Arquitetura e Urbanismo no ano de 2006, em que propusemos um projeto de restauro de uma antiga residência na cidade, para o funcionamento de um laboratório de análises clínicas. Durante o processo de pesquisa, percebemos a escassez de estudos arquitetônicos e urbanos sobre Paranaguá, já que, não encontramos dados que abrangessem a cidade desde sua formação e o processo de ocupação territorial. Grande parte das pesquisas encontradas naquele período, com a temática sobre a cidade, foi produzida por memorialistas, que de alguma forma contribuíram para o resgate de sua história. Infelizmente os textos realizados por estes são em sua maioria autobiográficos, surgindo dúvidas sobre a veracidade de certas informações. Deste modo, nos primeiros contatos realizados na cidade, ainda na graduação, foi realizado o levantamento no acervo do Instituto Histórico e Geográfico de Paranaguá, constatando-se o extenso número de documentos primários relacionados à cidade, e que possibilitaria desenvolver um estudo mais aprofundado sobre essa temática.

Portanto, a partir deste momento, discutimos a necessidade de alguma forma contribuir para essa cidade, partindo desse material encontrado no IHGP e também de outras instituições, para fornecer novos dados que contribuíssem para a historiografia de forma a auxiliar os pesquisadores da área e também àqueles que trabalham pela preservação de Paranaguá.

Sendo assim, quando lançamos a proposta da referida pesquisa ao Programa de Pós-Graduação em Arquitetura e Urbanismo da Escola de Engenharia de São Carlos, tínhamos como objetivo central contribuir para o entendimento de Paranaguá, investigando suas transformações urbanas e arquitetônicas durante os 
séculos XVIII e XIX. Após a aprovação do projeto, foram iniciados os levantamentos em diversas instituições e acervos que trouxeram à tona uma diversidade de materiais, dentre os quais Relatórios Provinciais, Códigos de Posturas, jornais, revistas, manuscritos, atas, além de mapas, fotografias, aquarelas, descrições de viajantes e a bibliografia em geral, que estruturaram as análises propostas e resultaram nesta dissertação. Dos principais acervos pesquisados podemos citar:

\section{Instituto Histórico e Geográfico de Paranaguá (IHGP) (Paranaguá): O} Instituto Histórico e Geográfico de Paranaguá foi um dos mais importantes acervos consultados para a pesquisa. O Instituto é constituído de uma biblioteca e um pequeno museu, que contam com material relacionado à cidade de Paranaguá. Obtivemos total liberdade para consultar esse acervo, a dificuldade encontrada foi na busca ao material bibliográfico, que não estava organizado e nem catalogado em qualquer tipo de arquivo, seja físico ou digital, o que acarretou em um levantamento minucioso em todas as obras da biblioteca, despendendo-se três semanas para tal demanda.

Dentre os documentos encontrados na biblioteca estão: os Relatórios dos Presidentes da Província do Paraná, desde 1853 até o início do século XX. Esses documentos relatam, sobre diversos aspectos, as tarefas executadas no Governo Provincial: obras, policiamento, saúde, Código de Posturas, situação das igrejas Matrizes, a construção da ferrovia ligando Paranaguá à Curitiba, a estrada da Graciosa e etc. Também foram encontrados Almanaques do Paraná, de fins do século XIX, relatando diversos aspectos sobre a cidade de Paranaguá, Códigos de Posturas do Município do final do século XIX, leis da Câmara de Paranaguá do mesmo século, Relatórios sobre a construção da ferrovia, Relatórios sobre o Porto 
de Paranaguá e Boletins, publicados no século $X X$, que possuem estudos sobre a história dessa cidade.

Dois importantes jornais da Província do Paraná, o "Dezenove de Dezembro", editado em Curitiba e o "Commércio do Paraná", editado em Paranaguá, foram fontes importantes sobre a situação da cidade na metade do século XIX. Além dos arquivos impressos, foram encontrados manuscritos nunca publicados, um exemplo são os fatos mais relevantes ocorridos na Câmara de Paranaguá, desde 1853 até 1903, documento que preservou parte da história da cidade.

Quanto à documentação relacionada ao século XVIII sobre Paranaguá, temos a falta deste material nos acervos, quase tudo se perdeu. Sabemos de sua existência através de alguns autores que comentaram sobre documentos desse período. Um dos mais relevantes é a publicação de Moyses Marcondes, da década de 20 do século XX, sobre as Provisões do Ouvidor Rafael Pires Pardinho para Paranaguá (1721), contendo importantes informações sobre a vila no século XVIII.

Outros importantes documentos, encontrados na biblioteca do IHGP, são as primeiras revistas publicadas em Paranaguá, no início do século $X X$, contendo fotografias e artigos sobre a cidade, dentre as principais estão: "O Itiberê" e a "Marinha”. Em relação ao acervo fotográfico, foi possível consultar uma parte dessa documentação e datar algumas das antigas imagens da cidade. Foi disponibilizado por um dos associados do IHGP, o Sr. José Maria Faria de Freitas o álbum digitalizado de um antigo prefeito da cidade, José Lobo, contendo diversas fotografias de Paranaguá desde o final do século XIX até o início do século $X X$, com anotações de seu antigo proprietário, este associado também disponibilizou em arquivo digital os dois volumes dos manuscritos de Vieira dos Santos, de 1850, que relatam em detalhes a situação de Paranaguá naquele período. 
Prefeitura Municipal de Paranaguá. (Paranaguá): Na Prefeitura de Paranaguá, estivemos na busca de mapas da cidade e antigos projetos arquitetônicos que contribuíssem ao período de estudo. Fomos encaminhados para o setor de arquivos de projetos, neste local encontramos dois mapas de Paranaguá, um de 1910, com um aspecto geral da cidade e do porto D. Pedro II e outro de 1915, apenas com o traçado da cidade e a indicação das vias. Quanto aos projetos arquitetônicos do arquivo, sua catalogação foi realizada através do nome do proprietário, não existindo referencial por datas, o que dificultou a procura, pois além da falta de informações sobre a época dos projetos, relevante nas primeiras buscas, a consulta só era autorizada aos funcionários da Prefeitura. Por isso, solicitamos a liberação para a consulta e depois de alguns dias, foi possível a nossa liberação para consultas diretas e, assim, encontramos alguns projetos de 1911 até os anos de 1930, como reformas de fachadas em casas do período Colonial.

Nenhum projeto do século XIX foi localizado. De acordo com a funcionária do arquivo, ocorreu um incêndio, em data desconhecida, que destruiu parte do acervo de projetos, provável explicação para tal fato.

Administração dos Portos de Paranaguá e Antonina (APPA). (Paranaguá): A referida sede possui antigas fotografias do Porto de Paranaguá, desde o final do século XIX até a década de 70 do século $X X$, que já estão digitalizadas e nos foram fornecidas pelo fotógrafo Rodrigo Leal, desta Instituição. As imagens ilustram alguns fatos importantes da história do porto e de sua configuração no início do século XX.

Instituto Histórico Geográfico e Etnográfico Paranaense. (IHGEP) (Curitiba): O Instituto Histórico Geográfico e Etnográfico do Paraná localiza-se no centro da cidade de Curitiba e seu acervo é referente à história do Paraná. No Instituto, parte da documentação está catalogada e existe uma bibliotecária responsável neste 
setor. O acervo catalogado faz parte da biblioteca do Professor Júlio Estrella Moreira, pesquisador da história do Paraná, que doou seus livros a esta Instituição. Infelizmente ainda existe uma parte significativa do acervo do IHGEP não catalogada, o que impediu o levantamento, pois haveria a necessidade de uma autorização para esta consulta e, devido ao pouco tempo, não foi realizada.

Na consulta ao IHGEP, encontramos alguns boletins publicados pela instituição, com artigos que continham assuntos relacionados ao tema dessa pesquisa: Almanaques, Relatórios da Câmara Municipal de Paranaguá do começo do século $\mathrm{XX}$, artigos de alguns dos membros deste Instituto e o Álbum da Estrada de Ferro do Paraná, provavelmente do final do século XIX. Nesse Instituto, também, encontramos edições do início do século XX das revistas "O Itiberê" e "Mez", editadas na cidade, e o segundo volume do livro de Demétrio Acácio Fernandes da Cruz, relatando sobre Paranaguá da década de 1860.

Coordenadoria do Patrimônio Cultural do Estado do Paraná. (CPC) (Curitiba): Pertencente à Secretaria Estadual da Cultura, essa Coordenadoria é responsável pelo tombamento e catalogação das construções históricas do Estado do Paraná. Seu acervo possui diversos levantamentos e processos, realizados pela Coordenadoria, dentre os quais em Paranaguá.

Nesse acervo, foram coletadas imagens de trabalhos dos anos 60 do século $\mathrm{XX}$, que identificam diversas construções da cidade, dentre as quais algumas já não existentes nos dias atuais. O acervo também possui alguns levantamentos do Centro Histórico de Paranaguá e propostas de intervenção em alguns edifícios. A consulta foi relevante para buscar informações de estudos sobre a cidade de Paranaguá e de antigos registros de seu Centro Histórico. 
Museu Paranaense. (Curitiba): O Museu Paranaense possui uma biblioteca e um acervo de fotografias. A biblioteca está organizada e catalogada, com funcionários para o atendimento aos pesquisadores; nesta instituição encontramos referências sobre Paranaguá, principalmente em relatórios provinciais e revistas do começo do século XX. No acervo fotográfico, também catalogado, encontramos imagens da cidade do final do século XIX, cartões postais de Paranaguá do começo do século XX e fotografias panorâmicas da cidade, contribuindo para o entendimento da evolução urbana de Paranaguá.

Instituto de Estudos Brasileiros (IEB). (São Paulo): Localizado na Cidade Universitária, em São Paulo, o IEB possui importante acervo sobre a história do Brasil. Sendo assim, foi possível coletar algumas bibliografias importantes, como o livro "Apontamentos Históricos Topográficos e Descritivos da Cidade de Paranaguá”, publicado em 1863, que traz uma interessante análise sobre a cidade naquele período. Nessa mesma biblioteca, encontramos a publicação "Au Brésil de Rio de Janeiro à Paranaguá", de 1898, escrito por Émile de Saint-Denis, viajante estrangeiro que descreveu suas impressões sobre a cidade e sua população. Também foram encontradas publicações do começo do século $X X$, que divulgavam - Paraná para fora do Brasil, como por exemplo, o "Le Paraná pour l'Etrager" editado em 1907.

Bibliotecas da Universidade de São Paulo: No levantamento em bibliotecas da USP, foi possível encontrar publicações de viajantes do século XIX, que relatam sobre a cidade de Paranaguá, dentre as quais a biblioteca da Faculdade de Filosofia, Letras e Ciencias Humanas, da Faculdade de Educação, do Instituto de Química de São Carlos e da Escola de Engenharia de São Carlos. Estas publicações são importantes, pois trouxeram informações sobre as dinâmicas da 
sociedade e a situação da cidade naquela época. Também encontramos publicações de autores que trabalham a arquitetura e o urbanismo dos séculos XVIII e XIX no Brasil, que auxiliaram na análise dos edifícios e no estudo do desenvolvimento urbano de Paranaguá. Além do levantamento bibliográfico e documental nas instituições, que acabamos de tratar, realizamos no final do ano de 2009, um levantamento fotográfico do Centro Histórico de Paranaguá, resultando em mais de 2.000 imagens, como parte documental dos períodos de estudo e também entender as mudanças pelas quais a cidade passou durante os séculos, principalmente daqueles que estão inseridos nesta pesquisa.

Portanto neste conjunto de informações coletadas nestas instituições, foi possível reconstruir o processo de transformações da pequena vila de Paranaguá, implantada na metade do século XVII, até seu desenvolvimento no século XIX, com a chegada da ferrovia e da consolidação de seu porto, através da exportação da erva-mate. A análise desse material permitiu compreender como se deram esses processos de transformação urbana e arquitetônica de Paranaguá, entre os séculos XVIII e XIX e assim contribuir para o entendimento da dinâmica dessa cidade e da preservação de seu Centro Histórico.

Para isso, esta pesquisa foi subdividida em três capítulos. No primeiro capítulo, focamos a transferência do povoado, antes instalado na ilha da Cotinga, para a região continental e assim procuramos compreender como se deu essa ocupação inicial nas margens do rio Itiberê. A partir disso, analisamos um dos fatos mais importantes ocorridos na Paranaguá setecentista, a chegada do Ouvidor Pardinho e suas determinações que influenciaram no desenvolvimento urbano da vila. Neste contexto, analisamos especialmente as igrejas que fizeram parte desta 
estrutura urbana, edificadas durante o século XVIII, e que se mantiveram no século posterior.

No segundo capítulo, dedicamos à Paranaguá do século XIX, primeiramente analisando dois mapas, um do começo daquele século e outro do final. Nessa análise cartográfica buscamos compreender como ocorreu o desenvolvimento da cidade nesse período. Baseando-nos na discussão resultante da análise dos mapas, complementamos com as transformações na arquitetura, envolvendo as preocupações sanitárias, a chegada da ferrovia e a exportação da erva-mate. O século XIX foi o período de intensas transformações na arquitetura, nos sistemas construtivos e no modo de viver da sociedade. O terceiro capítulo é uma análise do Centro Histórico de Paranaguá, baseando-se na lei municipal que vigora atualmente, inserida no Zoneamento de uso e ocupação do solo, estabelecido em 1998, para propor a possibilidade de revisão desta norma. Neste capítulo, também sugerimos um roteiro de visita, com o intuito de servir como contribuição para uma percepção mais completa da cidade, uma proposta a ser utilizada pela população parnanguara por seus turistas, interessados em sua história.

Deste modo, esperamos ter contribuído para a construção da história urbana de Paranaguá, através da interpretação de documentação, fotografias, mapas, desenhos, que ilustram essas análises. Poderá ser um auxílio para os interessados na história das cidades em geral, na cidade de Paranaguá e aos que lutam por sua preservação e acesso de todos a este patrimônio. Acreditamos que o caso de Paranaguá, pelos registros existentes e pelo seu estado de conservação, poderá ajudar a elucidar as diversas questões que envolvem a modernização das cidades brasileiras durante o século XIX, a atualização estilística, as influências européias do 
Neoclássico e do Ecletismo, a renovação dos projetos e técnicas construtivas e os meios para sua preservação. 


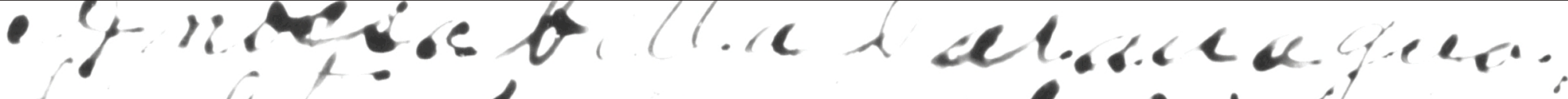

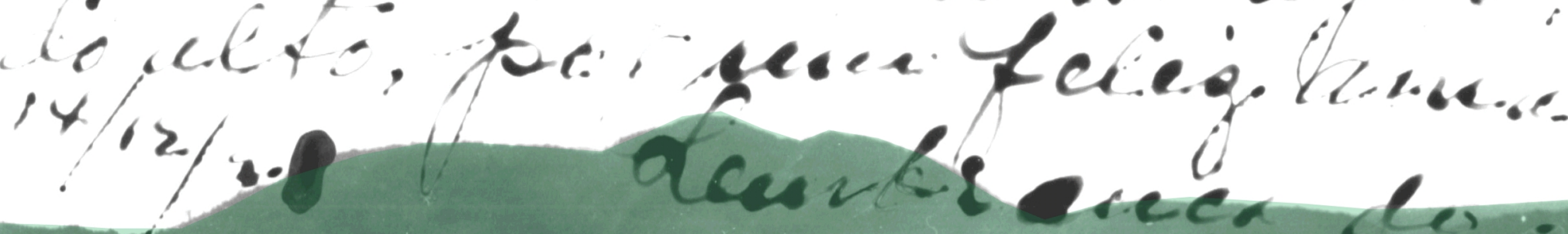

conos

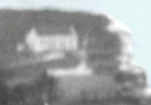

aำ
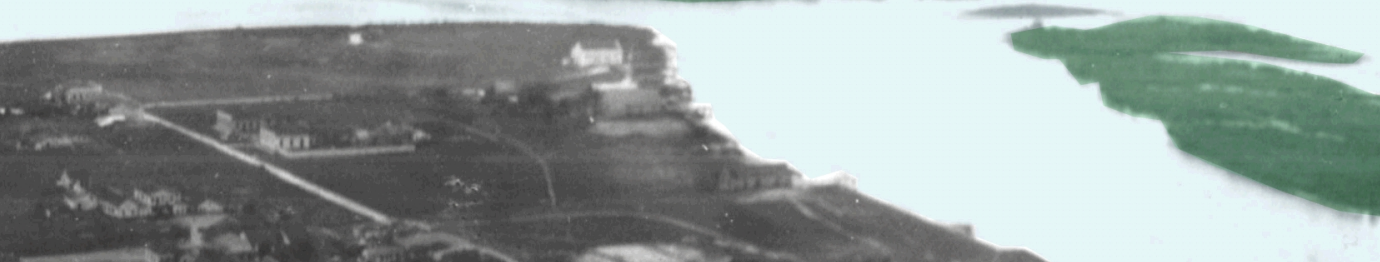

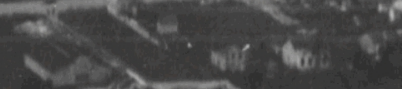

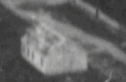

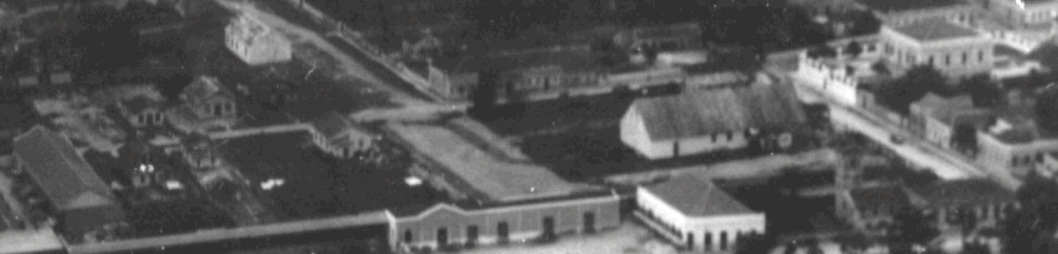

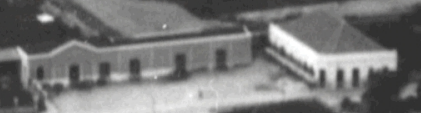
$\sin 2$

1. 19

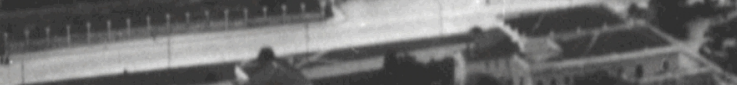

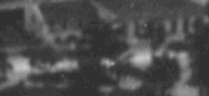

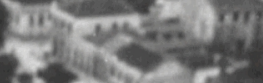

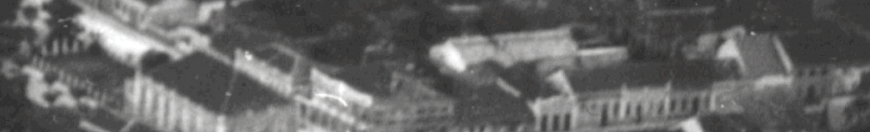

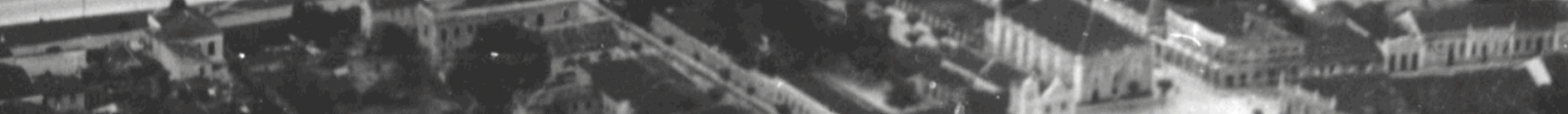
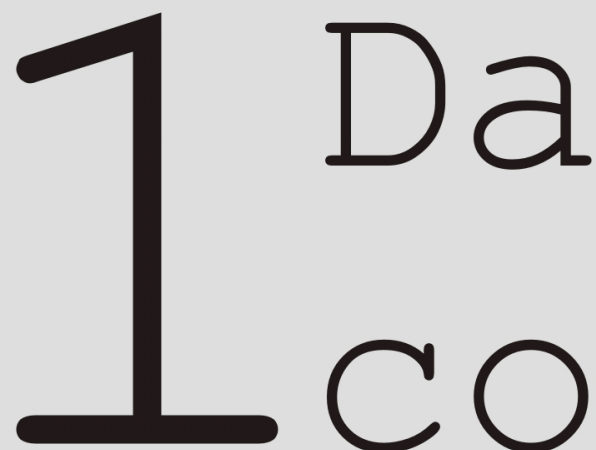

ilha

$\mathrm{a} O$

continente 



\section{DA ILHA AO CONTINENTE}

Muitos livros de atas, correspondência e registros, teriam sido consumidos num incêndio do edifício onde outrora funcionava a Câmara Municipal de Paranaguá. Alguns livros especiais e grande quantidade de velhos documentos teriam sido vendidos ou doados, como papel velho, para uma fábrica de fogos de artifício. (BOUTIN, 1971, p. 375)

Este trecho, retirado de um artigo do historiador Leônidas Boutin, sobre o incêndio, que possivelmente ocorreu entre o final do século XIX e início do século XX, que destruiu parte da documentação pertencente aos arquivos da Câmara Municipal de Paranaguá, ilustra a dificuldade existente, quanto ao levantamento de documentos e textos dos séculos XVII e XVIII, referentes à ocupação desta vila litorânea. Mesmo com a falta destes documentos, algumas referências sobre o século XVII e XVIII são encontradas na obra do cronista Antônio Vieira dos Santos, da metade do século XIX, através de suas transcrições, organizadas pelo autor e preservadas no manuscrito Memória Histórica, Chronológica, Topographica da Cidade de Paranaguá e seu Município.

Outro documento, contemporâneo ao período de estudo, é a provisão que o Ouvidor Geral Rafael Pires Pardinho executou em Paranaguá, nos idos de 1720, publicado por Moyses Marcondes, nos anos 20 do século XX, contendo relatos sobre a configuração da vila naquele período e as primeiras soluções urbanísticas executadas pelo Ouvidor para o seu melhoramento.

Além das duas referências citadas anteriormente, buscamos outras fontes documentais dos séculos $\mathrm{XIX}$ e $\mathrm{XX}$, que complementarão esta fase da pesquisa, para compreender como ocorreu a ocupação inicial de Paranaguá, após sua transferência ao continente e o seu desenvolvimento durante o século XVIII. 


\subsection{A OCUPAÇÃO DO CONTINENTE.}

A partir de expedições realizadas pelos paulistas, através das bandeiras, foi possível o conhecimento de novas áreas ao sul do Brasil, contribuindo para a posterior ocupação dessas regiões. Além do apresamento de índios, os bandeirantes exploravam outras fontes de riqueza, como as minas de ouro existentes na região de Iguape, Cananéia e Paranaguá, as primeiras encontradas na Colônia, animando os moradores das vilas e os governantes da metrópole. (RITTER, 1979)

Esta busca por metais preciosos foi o motivo que atraiu um pequeno grupo de exploradores a se fixar na futura vila de Paranaguá, sendo até nomeado um provedor das minas, para controlar a exploração. Segundo Sérgio Buarque de Holanda (1968, p. 255):

É ali, entre Iguape e Paranaguá, e um pouco nas aluviões auríferas das vizinhanças de São Paulo, principalmente para as bandas de Parnaíba e Voturuna, que se vai desenvolver nessa fase a maior colheita do ouro. Quando, em 1647, se erige o povoado de Paranaguá em vila, com o nome de Nossa Senhora do Rosário, já tinha sido nomeado, no ano antecedente, um provedor para suas minas, na pessoa de Mateus de Leão.

O autor também considera que a exploração das lavras em São Paulo, Parnaíba, Curitiba e Paranaguá, fez parte da "[...] fase preparatória e necessária da verdadeira Idade do Ouro no Brasil." (HOLANDA, 1968, p. 259) Já que, posteriormente, estas minas se escassearam e foram abandonadas após as notícias de descoberta de veios auríferos na região das Minas, no sudeste brasileiro. Neste contexto, a partir do processo que desencadeou a ocupação da baía de Paranaguá, 
passaremos agora a analisar de que forma se deu esta ocupação: da pequena ilha da Cotinga para a vila no continente.

A região continental às margens do rio Itiberê, onde hoje está situada a cidade de Paranaguá (Figura 1), foi definitivamente ocupada após a mudança do povoado que habitava a ilha da Cotinga para este novo território. Esta transferência resultou, em 1648, na elevação do povoado à Vila de Nossa Senhora do Rosário de Paranaguá, com a instalação do Pelourinho.

O território da ocupação inicial de Paranaguá, a ilha da Cotinga, é marcado pela geomorfologia de um morro (Figura 2), de onde é possível a visualização da entrada da baía de Paranaguá, mas também de parte do continente. A escolha deste local para a primeira povoação possibilitou o controle não só da entrada da baía de Paranaguá, mas também de parte do continente, onde os índios Carijós habitavam. Esta implantação, em áreas acidentadas, era muito comum nos primeiros séculos de ocupação portuguesa no litoral brasileiro. Estes pequenos núcleos, assentados sobre os morros e suas vias, não possuíam nenhuma ordenação geométrica e se adaptavam a este relevo. (REIS FILHO, 1968). Seria desta forma a configuração do primeiro povoado na ilha da Cotinga.

Posteriormente, ocorreu a transferência deste pequeno povoado para a região continental, no começo do século XVII, dando início à ocupação efetiva dessa região, no local onde hoje está implantada a cidade de Paranaguá.

A povoação insular e a implantação da vila, no continente, podem ser observados através de um mapa da baía de Paranaguá, de 1653 (Figura 3), pertencente ao Arquivo Histórico Ultramarino. Segundo Reis Filho (2001), este mapa seria o desenho mais antigo de uma povoação de todo o litoral sul do Brasil. 


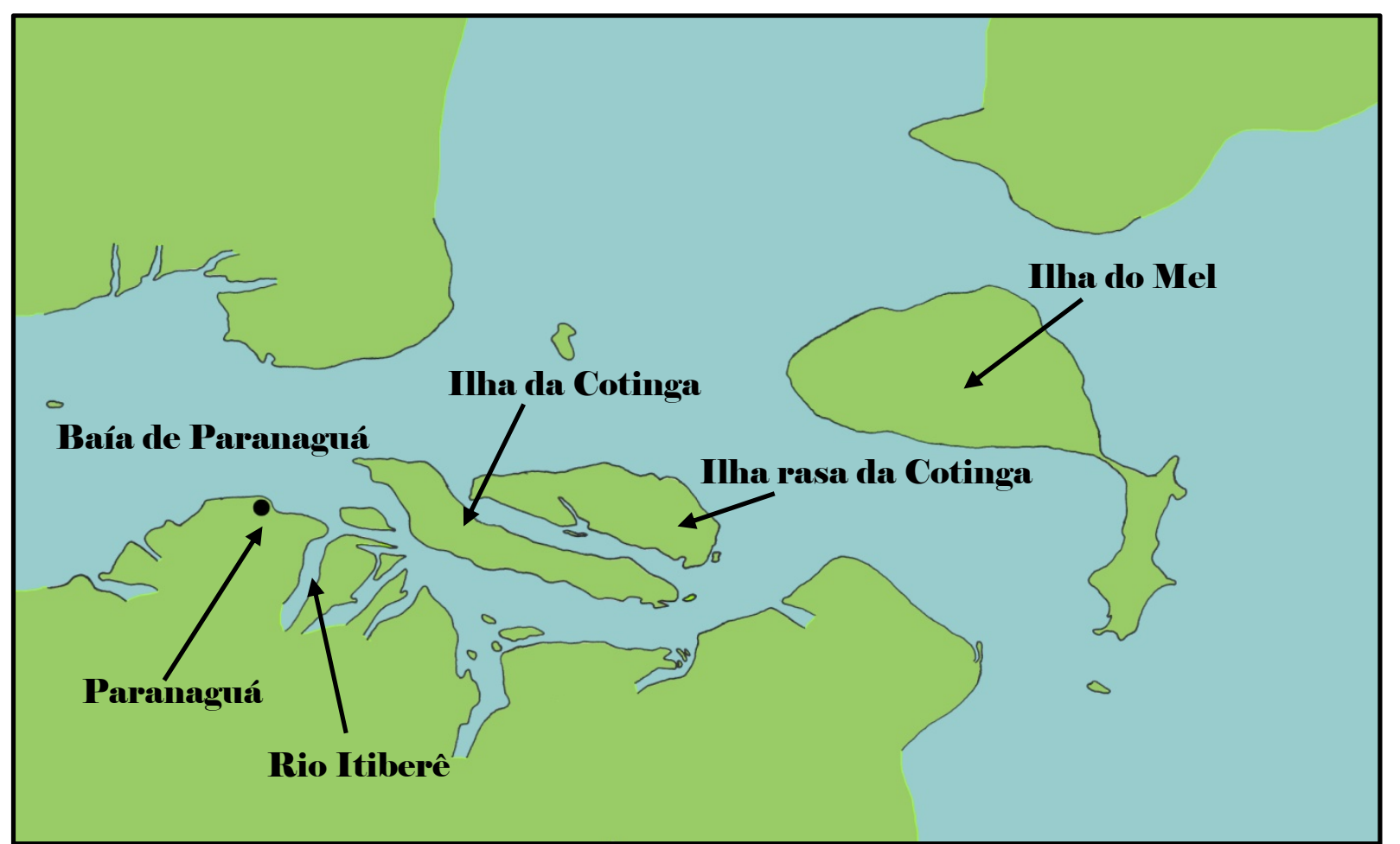

Figura 1. Esta imagem possibilita visualizar a cidade de Paranaguá, a ilha da Cotinga, ilha do Mel e parte da entrada da Baía de Paranaguá.

Fonte: WIGWAM, Sílvio, 1985; Adaptado pelo autor, 2010.

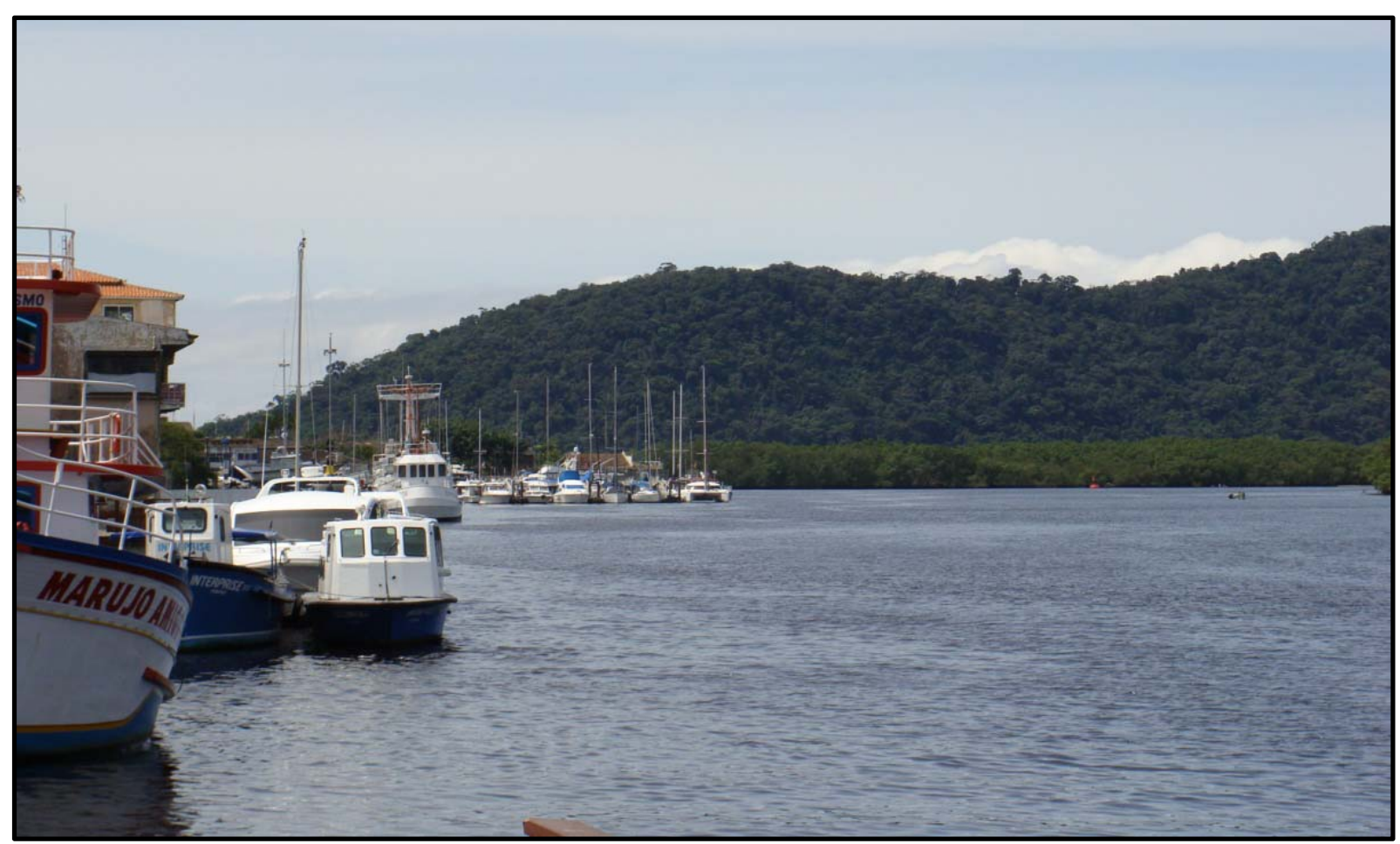

Figura 2. Parte da ilha da Cotinga, observada da rua General Carneiro.

Fonte: Acervo do autor/2009 


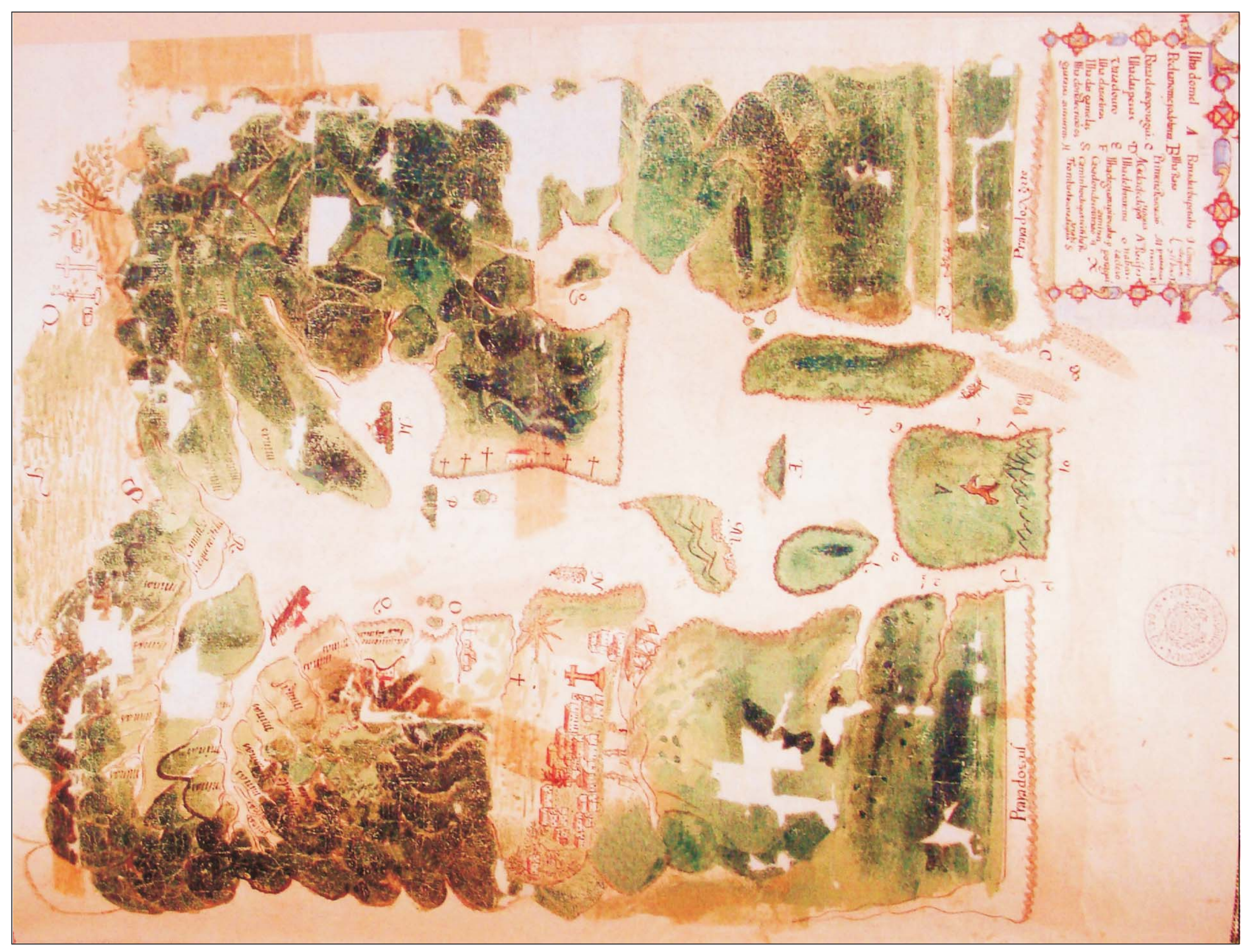

Figura 3. Mapa da baía de Paranaguá de 1653.

Fonte: REIS FILHO, 2001 

O autor indica esse documento como um "desenho de caráter geográfico" (REIS FILHO, 2001, p.381), pois localiza simbolicamente a posição das minas, da vila de Curitiba e do perfil da vila de Paranaguá. Salienta ainda a incerteza quanto à fidelidade desta representação.

O mapa reproduz a baía de Paranaguá, em um desenho sem a precisão cartográfica, mas que possui um grande número de informações sobre esta região na metade do século XVII. Quanto à sua fidelidade, é possível que ele nos traga aspectos sobre a implantação da vila de Paranaguá alguns anos depois da instalação do Pelourinho. Para isso, discutiremos as informações deste mapa, com outras coletadas em bibliografias, confrontando-as e assim traçando o estado inicial desta pequena vila litorânea.

O documento que representa a baía de Paranaguá em 1653, contém, além do desenho, uma legenda com algumas informações. Daquelas que nos interessam diretamente, temos uma pequena ilha, representada com morros e duas construções nas proximidades da vila de Paranaguá, indicada com a letra $\mathrm{M}$ que na legenda significa "Primeira povoação", ou seja, a ilha da Cotinga. A vila de Paranaguá está localizada no mapa, nas proximidades da ilha da Cotinga, representada por um conjunto de construções, onde se destacam o Cruzeiro e o Pelourinho. Estes dois elementos são as primeiras pistas que possibilitam compreender como se deu a ocupação inicial de Paranaguá no continente.

Primeiramente, temos o território onde foi implantada a vila de Paranaguá. A área ocupada se compõe de uma grande planície limitada ao sul pelo rio Itiberê e ao norte e leste pela Baía de Paranaguá. O local foi propício ao desenvolvimento da vila, pois além de possuir terreno quase plano, tem uma importante nascente de água que serviu nos primeiros séculos ao seu abastecimento. 
A escolha desta área não foi ao acaso. A partir do século XVII, no Brasil, existia a tendência das pequenas vilas serem implantadas em regiões mais planas, pois ocorria a diminuição dos riscos de ataques internos, possibilitando um traçado mais regular, tendendo ao xadrez (REIS FILHO, 1968).

Quanto à nascente de água, essa foi denominada "Fonte de beber água", sendo a primeira obra pública dessa vila. São encontradas nos levantamentos da Câmara Municipal, realizados por Vieira dos Santos, descrições sobre reformas e limpezas no ano de 1655 e 1657, ou seja, pouco tempo depois da instalação da vila e contemporânea ao mapa aqui discutido. As primeiras informações decorrentes solicitam, "[...] que se mandasse limpar o caminho da fonte de beber e os demais caminhos das serventias." (VIEIRA DOS SANTOS, 2001, p.39, Vol. I).

Em 1657, a Câmara ordenou a reforma da fonte em que, "[...] o encarregado de o fazer daria os escravos necessários para a condução da pedra, cal e saibro, feita de abóboda com uma janelinha e por ela poder entrar um rapaz para a limpar e com sua bica de pedra [...]" (VIEIRA DOS SANTOS, 2001, p.43, Vol. I).

A partir desse primeiro elemento, a Fonte de beber água, reportamo-nos a outro dado encontrado. Nas proximidades do manancial, localiza-se a primeira rua da vila, aos fundos da igreja Matriz, denominada do Fogo ${ }^{2}$. O próprio nome da rua traz indícios sobre sua antiguidade, que a comprova como núcleo urbano inicial, pois fogo era um termo utilizado no período para casa, portanto, por ser a primeira rua, era a rua das casas, ou fogos. Segundo Vieira dos Santos esta rua:

Foi a primeira, a mais antiga que se fez e a mais freqüentada do comércio; estava cheia de edifícios mas pelo seu crescimento de outras novas ruas que depois se foram fazendo, ficou aquela em abandono, por mais decrépita, seu primeiro esplendor se eclipsou, seus edifícios se desmoronaram, e outros demolidos; ao presente tem medíocres casas [...]" (VIEIRA DOS SANTOS, 2001, p. 19, Vol. II)

\footnotetext{
${ }^{2}$ Hoje denominada rua Antônio Vieira dos Santos.
} 
Deste modo, a partir da região da rua do Fogo (Figura 4) será possível entender como se desenvolveu a vila, durante a metade do século XVII. Provavelmente, existiam dois pontos que atraíram a concentração urbana na pequena vila, o primeiro seria a Fonte de beber água (Figura 5), local de onde era retirada a água para o abastecimento das casas e por isso sua proximidade com a primeira rua de Paranaguá, a rua do Fogo. O outro ponto de atração era a Igreja de Nossa Senhora do Rosário ou Matriz, que no século XVII foi o único monumento religioso na ocupação continental de Paranaguá, centro dos eventos litúrgicos locais. A data de sua construção é desconhecida, mas já nos primeiros anos de fundação da vila são encontradas vereanças nas quais indicavam a necessidade de reparações desde 1661 (VIEIRA DOS SANTOS, 2001, p. 43, v. II).

Observa-se que tanto a Fonte d' água, como a igreja Matriz, passaram por reformas e reparações em anos muito próximos, pouco tempo depois da criação da vila de Paranaguá, em 1648. Indicando a importância destes dois pontos na configuração inicial da vila, citados nas vereanças, através de medidas que buscavam o melhoramento não só destes monumentos, mas em todo conjunto urbano de Paranaguá.

Retornando ao mapa de 1653 , convergindo na representação da vila de Paranaguá, observam-se dois elementos marcantes, já comentados anteriormente: o Cruzeiro e o Pelourinho. O Cruzeiro está localizado defronte à igreja Matriz, representada pelo edifício com a torre sineira. Uma das possibilidades, colocadas por Reis Filho $^{3}$ em sua descrição sobre este documento, é de que este edifício poderia ser a Casa de Câmara ou uma igreja.

\footnotetext{
3 "Destacam-se dois grandes cruzeiros, um edifício com uma sineira, que poderia ser uma igreja ou a câmara da vila e um conjunto de casas, algumas representadas como sobrados, sem que possamos ter certeza sobre a fidelidade dessa representação" (REIS FILHO, 2001, p. 381).
} 

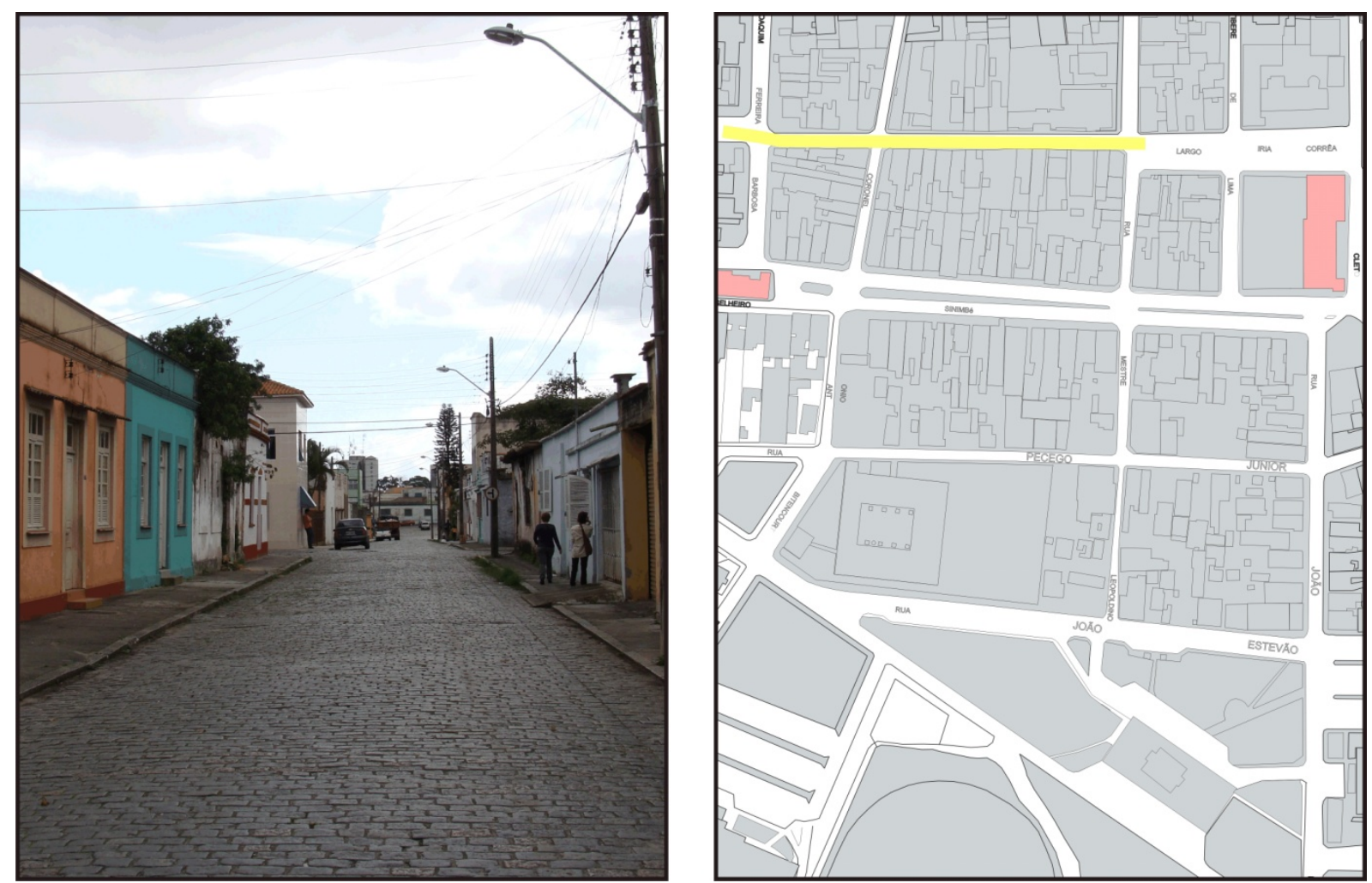

Figura 4. A rua Vieira dos Santos, antiga rua do Fogo, indicada em amarelo no mapa.

Fonte: Acervo do autor, 2009.
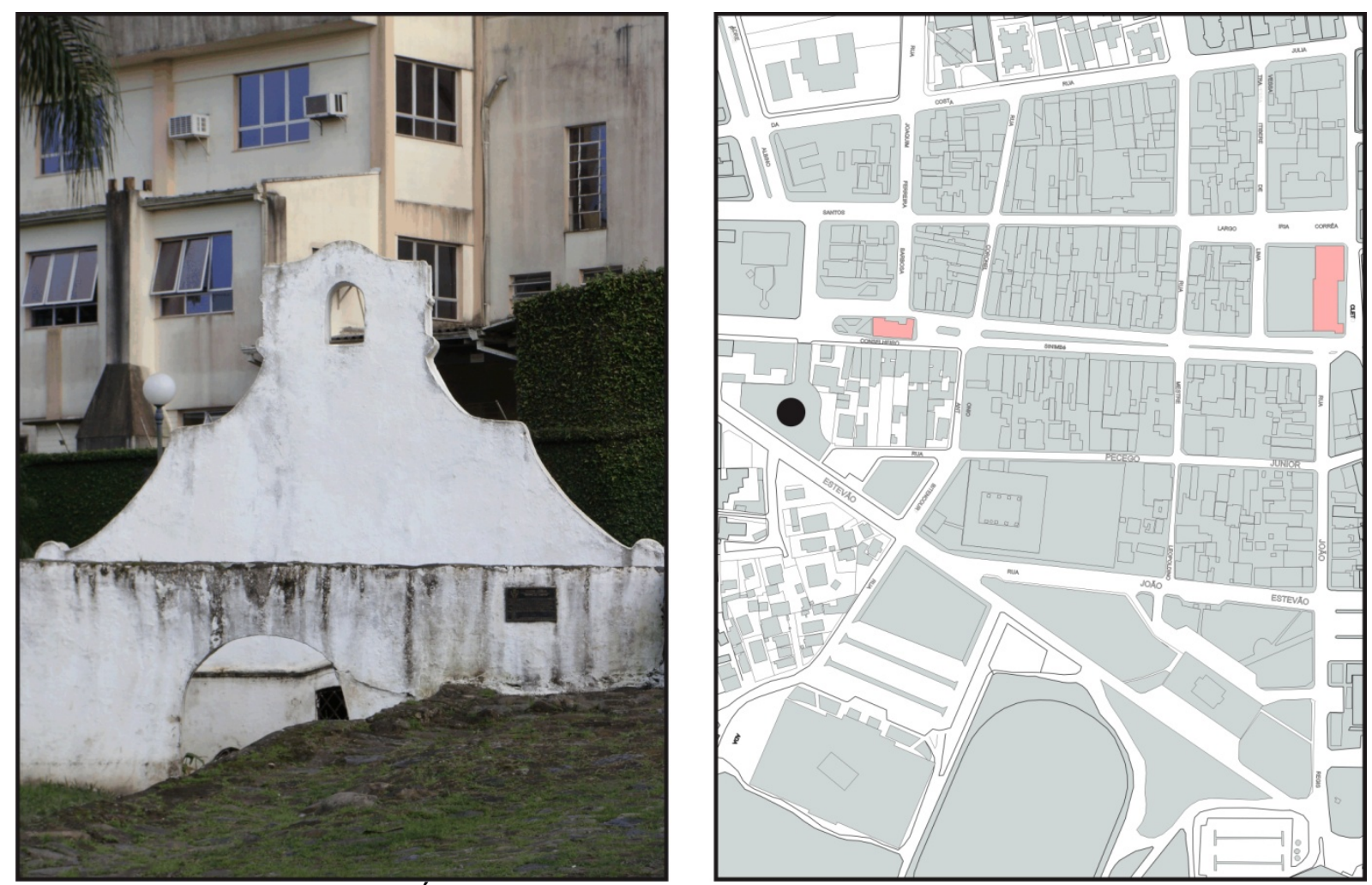

Figura 5. A Fonte de Beber Água e sua localização, indicada com o ponto, nas proximidades da igreja de São Benedito.

Fonte: Acervo do autor, 2009. 
Esta construção não poderia ser a Casa de Câmara, já que só ocorreram solicitações para sua edificação em 1677, mais de vinte anos após a confecção do mapa, ele estaria localizado defronte ao Pelourinho, o que não aconteceu neste caso, já que está em frente ao cruzeiro de pedra.

Já o Pelourinho está situado ao lado esquerdo do Cruzeiro, em uma região mais concentrada de edifícios. Percebemos que os dois elementos implantam-se no mesmo eixo do que seria a rua da Gambôa, ou seja, situados na área entre a Matriz e a Fonte d' água. A fonte não é identificada no mapa, mas estaria à esquerda do Pelourinho na região menos ocupada.

Segundo Romário Martins (1938, s/p), moradores mais antigos da cidade, comentavam que a pedra do Pelourinho foi encontrada, em data desconhecida, na área entre as igrejas de São Benedito e Matriz, no eixo da rua da Gambôa, ou seja, na área em que Paranaguá se desenvolveu inicialmente. Este tipo de comentário, relatado pelos antigos habitantes, mesmo que não possam ser comprovadas, são indícios de que esta área era um ponto importante no início da vila, reconhecido como local da instalação do primeiro Pelourinho.

Quanto ao rio Itiberê, observamos pelo mapa que sua margem não estava ocupada por construções, e que a vila se concentrava na região mais alta do terreno. Já existem, nesse mapa, indícios de um pequeno porto no rio, indicado pela representação de um navio com velas, próximo da igreja Matriz, e uma trilha, representada por linhas pontilhadas, que sai do porto em direção a vila.

Sobre a sede administrativa e de justiça da vila, as primeiras informações encontradas são de que em março de 1677, aos pés do Pelourinho, foi solicitada a construção de uma Casa do Conselho, com previsão de término da obra para outubro, ela seria "[...] de pedra e cal, até ao sobrado e daí para cima de parede 
francesa mui bem rebocada e assobradada com sua porta e alçapão duas janelas no sobrado e uma embaixo na cadeia com seus dois pilares no alpendre e meio sobrado com suas escadas [...]." (VIEIRA DOS SANTOS, 2001, p.53, Vol. I)

Quanto ao aspecto construtivo, uma hipótese que poderemos levantar é de que essa Câmara seria provisória, pois, de acordo com a descrição anterior, a base do edifício foi construída em pedra e a parte do sobrado em parede francesa, termo comum na região litorânea para a vedação de pau a pique utilizada na divisão de áreas internas (CORONA; LEMOS, 1972), mas que neste caso foi aplicada nas paredes externas do edifício, ou seja, uma forma provisória de se estabelecer a sede administrativa e jurídica da vila.

Não existem outras referências sobre a primeira casa do Conselho, apenas constam relatos de que existia uma pequena casa onde ocorriam as reuniões. Mas em eventos maiores, este edifício não era utilizado, já que em 1720 , com a vinda do Ouvidor Rafael Pires Pardinho, para correições em Paranaguá, este fez a leitura de seus provimentos [...] na casa da oficina dos quintos reais por incapacidade das casas da Câmara [...]." (VIEIRA DOS SANTOS, 2001, p.123, Vol. I).

Pelos dados acima relatados, percebemos que a casa do Conselho, especificada em 1677, provavelmente estaria em alguma área próxima ao largo da igreja Matriz. Em muitos casos, isto já era definido durante a fundação da vila, mas em Paranaguá não foram encontrados documentos que especifiquem o local onde se situaria a primeira Câmara. Uma hipótese encontra-se no Pelourinho, já que o edifício da Câmara geralmente era construído defronte a esse marco, e através do mapa comentado anteriormente, a Câmara estaria situada no eixo da igreja Matriz. Poderemos compreender melhor essa situação, através da análise contida nas 
informações colocadas por Paulo Thedin Barreto (1978, p. 137-138), no seguinte trecho:

\begin{abstract}
$\mathrm{Na}$ ereção das vilas, uma das primeiras preocupações era a localização e instalação da Casa de Câmara e Cadeia, do pelourinho e da igreja. Esses três monumentos são as referências de níveis (R.R.N.N) que assinalam os destinos da vila.

[...] Na demarcação do termo da vila, entre outras providências, já ficava reservado e balizado o terreno onde se construiria a Casa de Câmara e Cadeia e, também, o da igreja. Eram ordens de El-Rei que, "em primeiro lugar se (determinasse) área das cazas as que se devem fazer para a Câmara, Cadêa e Caza das audiencias e mais oficina publicas. Os terrenos eram situados na praça, que ficava, também, desde logo alinhada ou cordeada.
\end{abstract}

Ao final do século XVII, temos como marcos importantes da pequena vila, a Fonte, a Igreja Matriz, a pequena Casa do Conselho e o Pelourinho, concentrados na região do eixo da rua da Gambôa, em conjunto com a rua do Fogo, a primeira da cidade. A vila, em sua situação inicial, concentrava-se entre estes elementos, na área mais elevada do terreno, afastada da encosta do rio Itiberê, ainda desocupada. Neste ínterim, temos o porto que inicia seu funcionamento nas margens do rio Itiberê, sendo a porta de entrada para as movimentações de produtos e também aos que chegavam e saíam de Paranaguá.

Uma mudança nesta configuração urbana ocorreu a partir do segundo decênio do século XVIII, quando vai à Paranaguá o Ouvidor Rafael Pires Pardinho, com as Correições que transmitem à vila as medidas que alteram a conformação urbana, estabelecida nos primórdios de sua fundação. 


\subsection{O DOUTOR OUVIDOR RAFAEL PIRES PARDINHO}

A vinda do Ouvidor Rafael Pires Pardinho à Paranaguá, no começo do século XVIII, será marcante para o desenvolvimento urbano desta vila, pois além de determinar mudanças de organização política, define provisões que estabelecem alterações em sua configuração urbana e na demarcação de seu território. Estas prescrições serão determinantes para o direcionamento do crescimento de Paranaguá a partir daquele período e durante todo o século XVIII. Paranaguá, em 1720, era "[...] sendo de todas estas villas a mais povoada, e de maior comércio [...]" e contava com uma população de "[...] 360 cazaes, e mais de 2.000 pessoas de confissão [...]" (PARDINHO, 1721 apud MARCONDES, 1923, p. 22-23).

Uma preocupação, que o Ouvidor descreve em suas correições, é sobre as delimitações territoriais nas quais a vila estava conformada. O problema começa com a doação por Gabriel de Lara, um dos fundadores de Paranaguá, de uma carta de sesmaria à João Veloso, Procurador do Conselho, em 1669, transferindo-Ihe a Ilha da Cotinga e a ilha Rasa da Cotinga. Como estas áreas eram as principais fontes de materiais de construção da vila, como a pedra e a argila, a sua doação, por Lara, as transformou em propriedade particular, impedindo a exploração do território pela população que construía suas casas em Paranaguá. (PARDINHO 1721 apud MARCONDES, 1923).

Em 1675, a Cotinga volta a ser propriedade da Vila de Paranaguá, anulando a antiga carta de sesmaria dada por Gabriel de Lara. Mas em 1677, um novo personagem entra no conflito. Manoel de Lemos Conde, com sua grande influência dentro do governo da vila, pois era Provedor das Minas, apropriou-se da metade da 
ilha da Cotinga e da Ermida de Nossa Senhora das Mercês. Lemos Conde era patrono desta pequena igreja, qual financiou a construção do santuário no topo do morro da Cotinga, em 1677. Contudo, apesar de se tornar proprietário destas áreas, assinalou que autorizaria a população da vila a explorar as rochas e a argila da ilha, para a construção de suas propriedades. (PARDINHO 1721 apud MARCONDES, 1923)

Com o passar dos anos, o que ocorreu foi o contrário, o proprietário Lemos Conde e depois seu filho, Antônio Morato, provavelmente não autorizaram a extração de materiais de construção da ilha da Cotinga, de forma gratuita. O possível interesse por trás destas posses era a possibilidade de lucrar através da venda destes materiais à população parnanguara. Percebemos que o próprio ouvidor Pires Pardinho constatou que a população teve que se adaptar ao problema, como identificado no seguinte trecho:

Proveu, que os Officiaes da Camara sub pena de se lhe dar em culpa trataram logo de toda a Ilha da Cotinga como de propriedade do Conselho, e tam precisa ao augmento desta Villa, que não tem seus moradores outra paragem, donde commodamente possam conduzir cantarias, pedra, area, e barro, para seus edifícios e nem ao prezente, nem pello tempo futuro, em caso algum a deixem senhorear de outras algûas pessoas de qualquer qualidade, ou condissã, que sejam, porque estes moradores nam venhão a comprar os taes materiaes tam necessários a formarem cazas, e edifícios permanentes, que possas deixar a seus filhos, e descendentes; e qualquer morador os poderá hir buscar a dita Ilha da Cotinga, sem ao Conselho pagar couza algũa, para que assim se desterre o fazeremsse cazas de pao a pique, em que os homens nestas Villas quase inultimente gastam o seu trabalho, e tempo. (PARDINHO 1721 apud MARCONDES, 1923, p. 22, grifo nosso)

Vemos, portanto, que entre os anos de 1677, até a volta das propriedades ao Conselho em 1726, a vila de Paranaguá foi, em grande parte, construída em pau-apique como forma de se adaptar aos problemas ocasionados pela Câmara de Paranaguá e as diversas idas e vindas sobre a possessão da ilha da Cotinga. A técnica construtiva provavelmente trazida pelos primeiros exploradores de São 
Vicente e Cananéia, foi a forma na qual os habitantes encontraram para continuar construindo e habitando a vila de Paranaguá. A ação de Pardinho, determinando o cancelamento da doação da Cotinga pela Câmara e permitindo o uso dos materiais ali existentes pela população, foi uma medida da coroa, para incentivar o aumento do número de edificações dentro da vila e também cuidar de sua durabilidade, através da construção de casas em alvenaria de pedra. Eram resoluções também no intuito de incentivar uma ocupação efetiva do local e manter as possibilidades de exploração do ouro, que já se tornava escasso naquele período.

Ainda na direção de ocupação da vila, encontramos outra determinação da Correição de Pardinho, relatando a existência de muitos terrenos vazios dentro de Paranaguá. Neste caso, o Ouvidor decidiu que, "[...] os chaons, que daqui em diante derem na Villa, sempre será com condiçam de que dentro dos primeiros seis mezes edificaram nelles cazas [...]" (PARDINHO, 1721 apud MARCONDES, 1923, p. 73). Essa resolução foi uma forma de evitar o que ocorria frequentemente na vila, resultante das antigas ações da Câmara de Paranaguá na doação de terrenos no início do seu povoamento, criticado por Pardinho no seguinte trecho:

[...] deu o Conselho a muitas pessoas largos chaons, que lhe pediram para nelles fazerem cazas, que nunca nelles fabricarão, antes por esse modo impediam aos mais vesinhos a que as podessem fazer em lugares convenientes, de que resultou estar esta Villa com as ruas por fazer e cheas de chaons devalutos [...](PARDINHO, 1721 apud MARCONDES, 1923, p. 73).

Quanto aos seus limites territoriais, as primeiras demarcações ocorreram em 1654, quando ficou definido que Paranaguá "[...] começava no tabuleiro da ribanceira da Vila, seguindo rio acima até adiante de uma fazenda de João Peneda, uma ponta de terra, donde fizeram a quadra [...]" (VIEIRA DOS SANTOS, 2001, p. 
39). Essa área seria entre o antigo Mercado direcionando-se para detrás da Igreja de São Benedito.

Com a vinda do Ouvidor Pardinho, essas áreas do rocio foram novamente demarcadas, já que existiam os problemas territoriais entre o Conselho e os herdeiros de Lemos Conde. Pardinho proveu que a demarcação fosse novamente colocada na região da ribanceira "[...] correndo pelo rio assima a rumo de Sudueste na forma que elle corre, athé se acabarem de medir as mil e quinhentas brassas de terras [...]" no mesmo termo o Ouvidor decreta que, "[...] a margem deste rio Taguaré se porá hum marco, do qual se hirá buscar o rio Ambuguassu pello rumo de Noroeste, ou quarta de Oeste, e chegar ao rio, em cuja margem se porá outro padram, e entre ambos estes marcos, ou padroens pella terra firme se porám mais dous [...]." (PARDINHO, 1721 apud MARCONDES, 1923, p. 54)

Portanto, as terras que estavam:

[...] dentro dos ditos marcos, e entre o mar do dous rios e Bahia, fica sendo Rossio da Vila, como também o fica sendo a terra, que desta barranseira, corre athé a margem do furado, porque ainda que hoje seja inútil, e sem provimento, pelo tempo adiante o pode ter; e sempre he conveniente aos moradores da Villa para se approveitarem das lenhas; e de tudo devem os Officiaes da Camara tratar como propriedade deste Conselho. (PARDINHO, 1721 apud MARCONDES, 1923, p. 54)

Sendo assim, a área do rocio de Paranaguá teve suas delimitações ampliadas e identificadas pelos principais cursos d'água, ou seja, pelo rio Taguaré (atual Itiberê) e o rio Ambuguassu (atual Emboguaçú), além da baía de Paranaguá. Neste mesmo raciocínio, Pardinho já pensava no crescimento da vila, agrupando novas áreas para esse fim, englobando terrenos próximos ao rio Itiberê, em direção a sua foz.

Segundo Marx (1991), o rocio era uma área de expansão da vila, para a abertura de novas vias e a cessão de terras. Era também destinada para pastagens 
dos animais, a retirada de madeiras e o plantio, "[...] em linhas gerais, constituir uma área para usufruto comum dos moradores e servir às necessidades de expansão da nova vila." (MARX, 1991, p.68). Isso é observado nas colocações do Ouvidor, que ampliou a área do rocio de Paranaguá, com a intenção de possibilitar o seu crescimento e também para que a população a utilizasse na retirada de materiais, como a lenha.

Além destas medidas de delimitação das áreas da vila, as provisões de Pardinho também enfocavam o traçado de Paranaguá e a configuração dos lotes. Uma das principais medidas implantadas pelo Ouvidor foi o controle sobre as construções. Qualquer obra deveria ter primeiramente a licença expedida pela Câmara. Depois de obtida a licença, o Conselho enviaria um arruador para que, "[...] Ihe assine chaons, em que a fassa, continuando as ruas que estam principiadas, e em forma, que vam todas direitas por corda, unindosse humas cazas com outras [...]." (PARDINHO, 1721 apud MARCONDES, 1923, p. 74-75)

Pois segundo o Ouvidor, não deveriam mais:

[...] daqui por diante se fassam cazas separadas, e desviadas para os matos, e sós, como se acham algũas, porque alem de fazerem a Villa, e Povoação disforme, ficão os vezinhos nellas mais expostos a insultos, e desviados dos outros vezinhos para the acudirem em qualquer necessidade, que de dia ou de noite, Ihes sobrevenha, e he melhor, que em pouco terreno esteja a Villa bem unida, do que em largo com tantos despovoados (PARDINHO, 1721 apud MARCONDES, 1923, p. 74-75)

Está, portanto evidente que existia a preocupação com a regularidade do traçado e a ocupação dos lotes, a Correição também determina que a doação de quintais seja de acordo com a dimensão das fachadas e "[...] com tanto fundo como as mais tiverem, e serám obrigados os vezinhos a fazerem nelles seus cercados para ficarem feixados, e livres de desacatos, e offensas de Deos, que resultam dos 
quintaes estarem abertos, e mal tapados [...]."(PARDINHO, 1721 apud MARCONDES, 1923, p. 74-75)

A demarcação dos lotes definiu, através da interferência do governo colonial, a divisão de áreas públicas e privadas. Esta forma de regulamentar a ocupação com leis e decretos foi comum neste período, como comenta Mary del Priore (1997, p.276):

[...] entre os séculos XVII e XVIII a oposição entre o público e privado começava a delinear-se e que a privacidade, na América portuguesa, tinha sua especificidade: se na Europa a mudança deu-se no sentido de apurar, aguçar os projetos individuais contra os do Estado Moderno, aqui, como diz Emanuel Araújo, "a ordem pública portuguesa estruturou-se ao arrepio do povo que a habitava, tudo controlando e tudo provendo por meio de um cipoal de leis" [...].

Segundo Murillo Marx (1991, p.75), nesse período (século XVII e XVIII):

As datas ou dadas de terra eram cessões feitas gratuitamente de parcelas do solo pertencentes à municipalidade. Eram resultado, portanto, do parcelamento do rossio, orientado pela câmara, a partir do pedido de algum pretendente a morador ou de algum vizinho detentor de glebas rurais no termo municipal

Com o intuito de organizar o modo de habitar na vila, são estabelecidas na Correição de Pardinho as seguintes determinações: "[...] obrigaram aos vezinhos que tenham todas as portas das suas cazas fechadas sempre, ou tapadas, e que nam haja na Villa pardieiros nem ranchos abertos, de que se servem muitos dos servissos de Deos: sobre o que farám suas posturas, e acordaons [...]". (PARDINHO, 1721 apud MARCONDES, 1923, p. 74-75)

Portanto, as correições não só têm como proposta a mudança na estrutura urbana da vila, mas também a mudança comportamental dos moradores, disciplinando novos hábitos e costumes, como as obrigações da população e dos governantes da vila de acompanharem em datas específicas, procissões e na doação de dízimo à igreja. Quanto às procissões, foi determinado que: 
[...] todos os moradores do Rossio, e de hũa legoa ao redor da Villa serão obrigados sub pena de hũa pataca para as despezas do Conselho de virem assistir a dita procissão [Corpus Christi], e todos os vezinhos das ruas por onde a procissão passar mandarão carpir e alimpar de mato as suas testadas, e emrramalas com palmas, e ramos e outros ornatos sub pena de duas patacas para o Conselho. (PARDINHO, 1721 apud MARCONDES, 1923, p. 31)

Já no pagamento do dízimo à igreja:

[...] encommenda muito aos Juízes e Officiaes da Camara, e homens bons da governanssa desta Villa como pessoas principaes, frequentem o culto divino, e sejão os primeiros em concorrerem para elle com suas esmollas, para que os mais moradores á sua imitassão o fassão, como athe agora louvavelmente tem observado nesta Matriz: e se possam fazer outras Igrejas e Capellas nos recôncavos destas Bahias, em que se celebrem os officios divinos, e a que possão assistir muitos moradores, que ficam em grande distancia desta Villa, com que se hiram povoando em seu augmento muitas das terras, que ainda estão desertas. (PARDINHO, 1721 apud MARCONDES, 1923, p. 75)

Percebe-se que a população já tinha o costume de pagar o dízimo à Matriz, mas Pardinho queria que isto se refletisse em outros eventos religiosos, como a Procissão de Corpus Christi, possibilitando que com os valores arrecadados, outras igrejas fossem construídas na região e assim atraindo moradores para esses locais. Isso nos mostra o importante papel das igrejas nas povoações, sendo elementos essenciais na concentração das populações e na formação das vilas e povoações no Brasil Colônia.

Esta interferência da Coroa sobre os procedimentos da Igreja Católica, foi feita através do Padroado, que transferiu parte das obrigações eclesiásticas para a Coroa Portuguesa, como a nomeação dos clérigos e a cobrança dos dízimos. A partir da metade do século XVIII, os sacerdotes tornaram-se:

[...] autênticos funcionários da monarquia. Como resultado, constituiu-se uma organização eclesiástica muito dependente das autoridades civis, o que entre outros fatores, explica o peculiar processo de cristianização a que a população foi submetida. (VAINFAS, 2001, p. 466-467) 
Voltando às Correições, Pardinho determina a abertura de novas ruas na vila. O ouvidor mandou que se abrisse uma rua defronte a porta principal da igreja Matriz (Figura 6) "[...] direita ao rio [ltiberê] [...]", com 40 palmos de largura "[...] por ficar assim mais decente, e vista a mesma Igreja [...]" (PARDINHO, 1721 apud MARCONDES, 1923, p. 75). Uma forma de melhorar a perspectiva deste monumento, que era o centro religioso local naquele período.

Outra via citada em sua Correição é a rua da Baixa (Figura 7), que deveria ser ocupada em ambos os lados, com seus quintais fechados. Era necessário o calçamento desta rua, antes das outras "[...] para que as águas, que para ella correm no tempo das chuvas, lhe não leva a terra, e intulhe as cazas, que ficarão no fim." (PARDINHO, 1721 apud MARCONDES, 1923, p. 75). Essa rua é a atual rua Pecego Junior (Figura 7), situada próxima à fonte da Gambôa, que margeava o rio Itiberê, cruzando com a rua da Matriz.

A partir da Correição de Pardinho em 1720, houve o interesse de que a vila se desenvolvesse na margem esquerda do rio Itiberê, ainda desocupada naquele período. $\mathrm{Na}$ área denominada sítio da ribanceira, encosta do rio, determinou-se a construção da nova Casa do Conselho, em que:

[...] se nam daram chaons para cazas a pessoa algũa, pois hade ficar servindo de prassa ao paço do Conselho, que lhe devem pello tempo adiante mandar fazer seu cães e molhe, para melhor desembarcadoiro das fazendas, e hum muro forte na barranceira, para que a rua, e serventia do paço do Conselho fique direita. (PARDINHO, 1721 apud MARCONDES, 1923, p. 76)

Com essas determinações, o pequeno porto foi beneficiado, já que defronte à nova casa do Conselho seria construído um cais para a chegada de navios, ou seja, o porto está assentado próximo a este importante edifício, demonstrando que aquele elemento já era necessário ao desenvolvimento da vila de Paranaguá. 

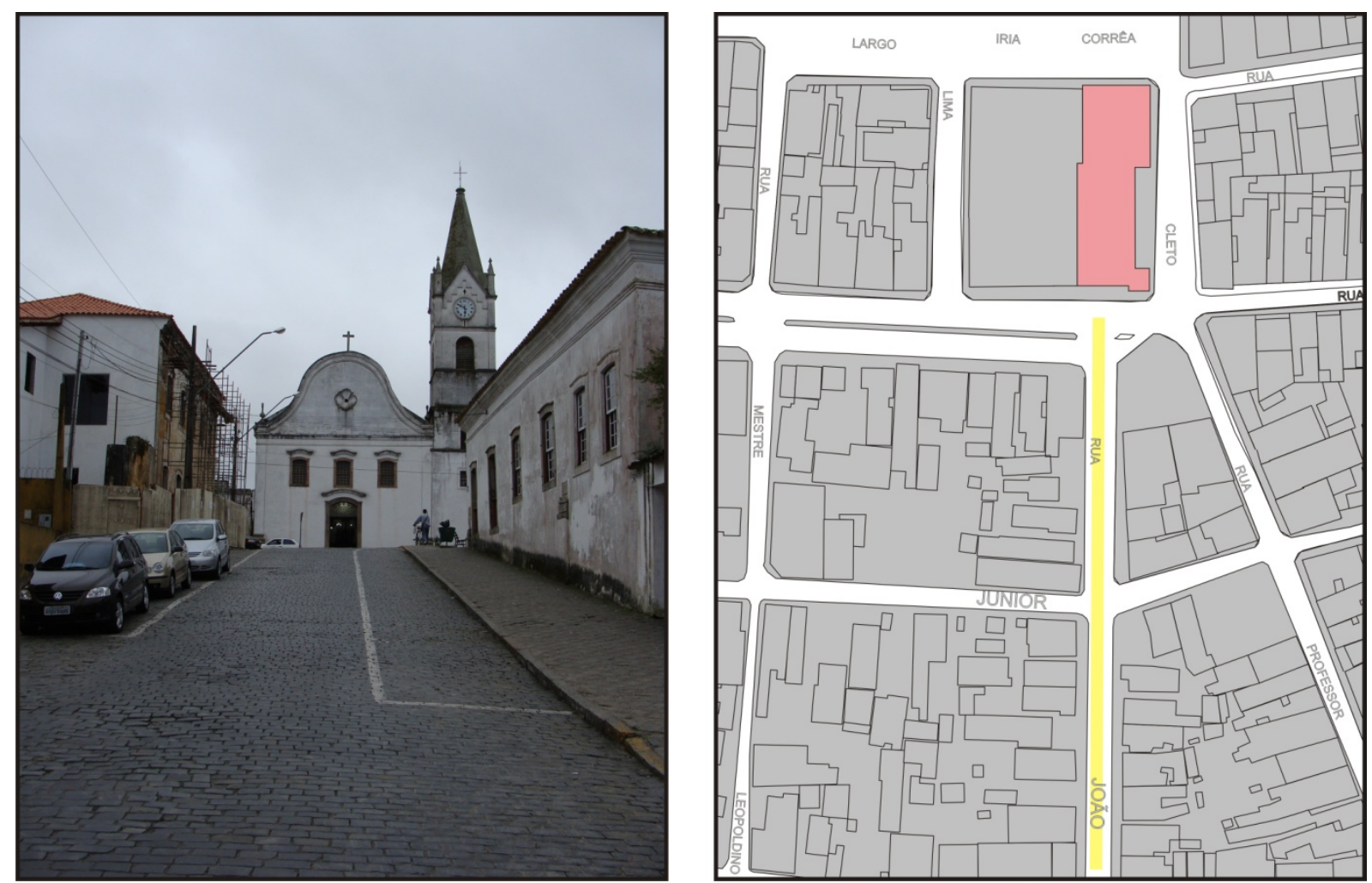

Figura 6. Aspecto da rua João Régis, antiga rua da Matriz, destaque em amarelo no mapa.

Fonte: Acervo do autor, 2009; Prefeitura Municipal de Paranaguá, 2006; Adaptado pelo autor, 2010.
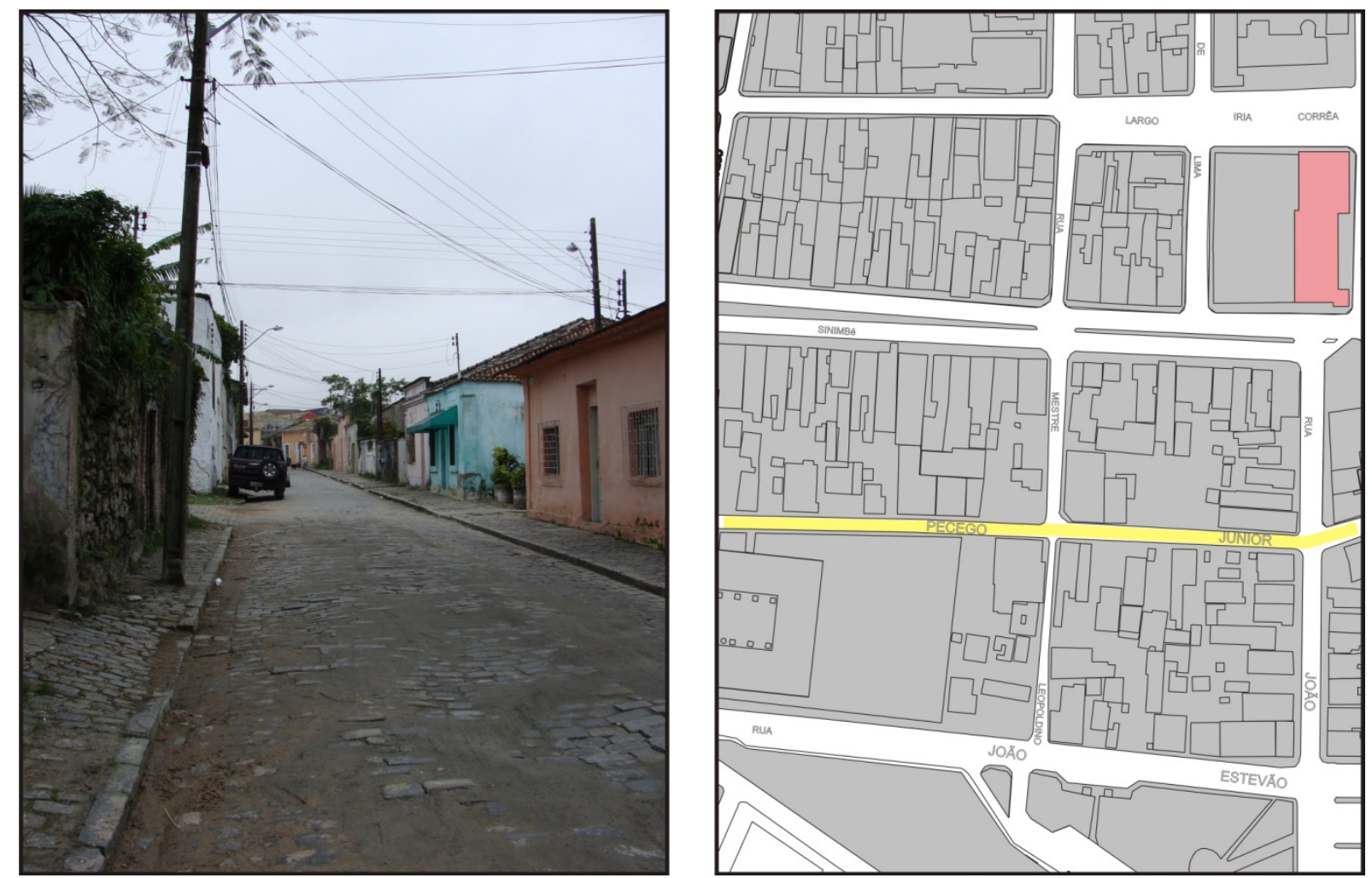

Figura 7. Rua Pecego Junior, antiga rua do Meio ou da Baixa, destaque em amarelo no mapa.

Fonte: Acervo do autor, 2009; Prefeitura Municipal de Paranaguá, 2006; Adaptado pelo autor, 2010. 
Portanto, após as determinações do Ouvidor, constituiu-se no local do sítio da ribanceira uma praça para onde foi transferido o pelourinho. Essa mudança deu nova importância para aquela região, definindo a área de influência da ocupação urbana de Paranaguá com mais um ponto - do largo da Matriz e da fonte d'água, para a região da praça do Pelourinho e da Casa do Conselho.

Neste momento, temos a extensão do poder na vila, de uma área inicial de concentração urbana, localizada no envoltório da igreja Matriz, agora deslocando-se a partir da construção da nova Casa do Conselho, em local ainda desocupado, mas que a partir daquele momento, em conjunto com o porto, seria um foco de atração de moradores e comerciantes para a margem do Itiberê.

Intencionalmente ou não, nesta Correição, notam-se alguns tópicos que de certa forma lesam a Igreja. Primeiramente, temos essa mudança da sede política local, fora do foco de atração da Matriz. Além disso, Pardinho obriga as Confrarias, Irmandades, Clérigos e Sacerdotes a pagar dízimos à vila sobre as produções agrícolas, de animais, pesca e de escravos em suas fazendas, "[...] como todos somos obrigados por preceito divino, e da Santa Madre Igreja, e do mesmo modo os devem pagar quaesquer Religiosos, e ainda Religioens [...]"(PARDINHO, 1721 apud MARCONDES, 1923, p. 33).

O ouvidor também determina que nenhum edifício religioso poderia ser construído na vila sem a licença da Coroa Portuguesa. E também que os terrenos doados a estas instituições, não poderiam ficar por mais de um ano desocupados, caso em que voltariam para a posse do Conselho. Da mesma forma que o Ouvidor implantava medidas impopulares em relação a Igreja, ele também determinava que a população pagasse dízimos aos cultos divinos, para que fossem construídos 
novos templos em toda a região e que a população ajudasse os Jesuítas enquanto não ocorresse a liberação da construção do Colégio.

Através das informações discutidas anteriormente, percebemos que as determinações de Pardinho prejudicavam, mas também beneficiavam as ações da Igreja Católica na vila de Paranaguá. Mas qual seria o motivo de determinações contrárias e favoráveis à essa instituição? No caso da construção da Casa de Câmara e Cadeia, essa determinação seria uma forma de desviar a atração pela qual a Matriz possuía ao seu redor evitando a concentração urbana em um único ponto, para que assim outras áreas como as localizadas nas margens do Itiberê pudessem se desenvolver.

O grande intervalo temporal entre a construção das igrejas do século XVIII, em Paranaguá, poderia ser resultante dessas medidas aplicadas por Pardinho. Depois da edificação da igreja Matriz, ainda no século XVII, ocorreu a construção de outro templo cristão em 1710, a Capela do Bom Jesus. Se descartarmos o Colégio dos Jesuítas, que já possuía intenções de sua construção no começo do século XVIII, as próximas igrejas só foram construídas 70 anos após a do Bom Jesus, já nos fins do século XVIII: a igreja da Ordem Terceira, assim como sua contemporânea, a igreja de São Benedito.

Retornando ao sítio da ribanceira, local da nova Casa do Conselho escolhida por Pardinho em sua Correição, temos neste mesmo documento, um risco da Casa de Câmara e Cadeia de Paranaguá, contendo os desenhos da fachada, e um plano das áreas internas.

O planejamento da obra seria realizado em três etapas, primeiro a construção da parte central do edifício que [...] embayxo sirva de enxovia e, em sima para Sala de audiencias para as Cazas do Conselho [...] (PARDINHO, 1721 apud 
MARCONDES, 1923, p. 72). Depois de concluída esta primeira fase, seria construído o segundo edifício contíguo ao primeiro, localizado na esquina, onde:

[...] á face da rua fiquem duas cadeas, e no vàm de seu fundo se fassam dous segredos, e em sima destes hum corredor em que fiquem três portas para as três cadeas levantadas dez palmos do seu pavimento, e para cada hũa sua vigia com grades de ferro, algum tanto sahidas, para a todo o tempo, e hora se poder ver o que os presos nellas fazem, para o qual corredor ficará hum alssapam na salleta, que se hade fazer no sobrado da caza de sima, com serventia para a salla grande [...] (PARDINHO, 1721 apud MARCONDES, 1923, p. 72)

Concluindo a obra, a terceira parte da casa do Conselho, teria:

[...] em sima servirá para o despacho do Conselho, e embayxo para almazem, ou assogue, para que se extingua a indecência de cazinha, que agora serve de Conselho, e cadea, e possa esta Villa como principal de suas circumvezinhas ter cazas de Conselho, que justamente meressam o nome de protecção real. (PARDINHO, 1721 apud MARCONDES, 1923, p. 72)

Esta construção foi realizada durante o segundo decênio do século XVIII e, em 1726, a obra "[...] tem ido muito devagar, constando-Ihe que o mestre pedreiro tem já muito maior quantia que a que se Ihe deve que, os Oficiais da Câmara o obriguem a que trabalhem continuadamente nela." (PEIXOTO, 1726, apud VIEIRA DOS SANTOS, 2001, p.132).

Através do risco deixado pelo Ouvidor Rafael Pires Pardinho (Figura 8), observa-se que o edifício da Câmara e Cadeia estava, como visto, dividido em três partes construídas em períodos diferentes, definido através da provisão, isto é destacado pelas colunas em pedra nas laterais e no centro do edifício e também pela estrutura do telhado, dividido em três oitões.

Outro elemento de destaque na construção é a escadaria, dividida em duas alas, localizada no ponto central do prédio, dando acesso à Câmara. Sobre o assunto, relata Thedin Barreto (1978, p. 156) que as escadas "[...] incontestavelmente se concentram grandes atenções. Neste ponto diremos apenas 
que as escadas externas caracterizam um grupo de Casas de Câmara, lembrando também sua tradicional expressão: Tribuna."

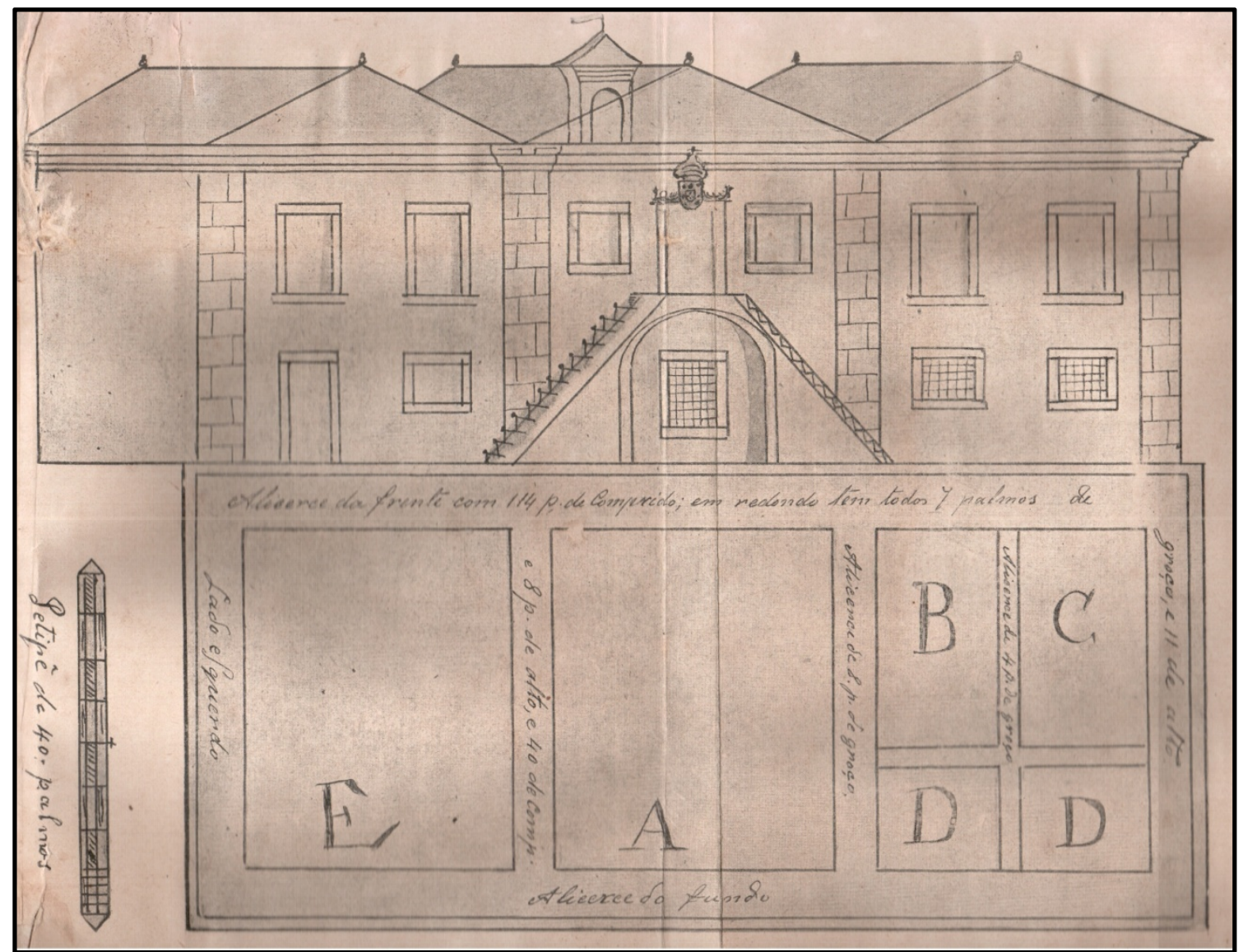

Figura 8. O projeto da Casa de Câmara e Cadeia, entregue por Pardinho em 1720. Fonte: MARCONDES, Moyses, 1923.

As aberturas são todas em verga reta, e as janelas do piso inferior são gradeadas, com exceção da lateral esquerda, pois naquele local seria instalado o açougue. Outro elemento desta obra é uma espécie de camarinha, local onde poderia estar um sino, chamado também de sino do povo, que "[...] comandava e regulava a vida das populações." (BARRETO, 1978, p. 150)

A igreja e o Conselho, a partir das determinações de Pires Pardinho, foram separados. A divisão desses elementos marcantes na vila de Paranaguá foi o marco inicial da ocupação lindeira ao Itiberê, com a construção da nova Casa de Câmara e 
Cadeia, formando a rua da Praia e desenvolvendo, nas margens do Itiberê, o porto de Paranaguá.

Outras providências sobre a ocupação dessa região também foram tomadas pelo Ouvidor, ao proibir o aumento dos quintais das casas que ficavam próximas as margens do Itiberê "[...] pois neste vam, e cham, se poderá pello tempo em diante fazer, e formar hũa rua com a serventia, e vista para o mar, com que ficará a Villa mais vistosa, e bem fortificada, para qualquer ocaziam do inimigo [...]."(PARDINHO, 1721 apud MARCONDES, 1923, p. 76). O mar ao qual Pardinho se refere, seria o rio Itiberê, já que em outro trecho de suas provisões foi encontrado o mesmo termo aplicado na frase "[...] que pellas mais ficou o mesmo mar dos ditos rios [...] (PARDINHO, 1721 apud MARCONDES, 1923, p. 50). As áreas do oceano, na região norte da vila estavam nesta época desocupadas, eram áreas do rocio e por isso não seria este o local citado pelo Ouvidor em sua provisão.

Portanto, a partir de 1720, a vila de Paranaguá segue um novo rumo em seu desenvolvimento, através das normas estabelecidas pelo Ouvidor Pardinho naquele período. Serão estas ordenações que configurarão a vila durante o século XVIII, direcionando o crescimento das construções para as áreas desocupadas daquele território, ou seja, da margem do rio Itiberê em direção à sua foz, e dentro deste direcionamento da vila está o porto, que passa a ter maior visibilidade, já que está localizado nas imediações da Casa de Câmara e Cadeia, onde foi construído um pequeno cais de pedra, inserido dentro do contexto da vila de Paranaguá. 


\subsection{AS IGREJAS NA VILA DE PARANAGUÁ}

O século XVIII, em Paranaguá, assiste a construção de grande parte das igrejas que estão configuradas dentro do espaço urbano desta vila e depois cidade, até o advento do século XX. São elementos que surgiram em sua estrutura urbana em intervalos distantes, delineando o direcionamento de seu crescimento em conjunto com as determinações de Pardinho, colocadas no início dos setecentos.

A igreja, a exemplo do que ocorria no restante do Brasil, possuía papel importante na configuração de Paranaguá naquele período, pois atraía e direcionava o crescimento urbano. Assim como em outras vilas, estes templos são:

Referências consubstanciadas e reiteradas pela evolução da sede municipal. A expansão e o adensamento urbanos se deram em torno desses marcos, ainda que novos elementos de cunho leigo sobrevivessem e constituíssem outros pólos de interesse (MARX, 1991, p. 12-13)

As responsáveis em grande parte foram as Confrarias e as Irmandades, que construíram estas igrejas através das doações feitas pela população e aos que destas organizações participavam, segundo Germain Bazin (s/d, p31-32):

No século XVIII, quando as confrarias começaram a progredir, para elas foi convergindo espontaneamente a maioria das doações. Havia confrarias para todas as classes e condições sociais. As mais aristocráticas foram as Ordens Terceiras, Carmelitas e Franciscanas; estas nos século XVIII, se entregaram a uma rivalidade sem limites, que teve como conseqüência uma verdadeira febre de construção de monumentos. Os negros estavam engajados nas confrarias do Rosário que, em princípio, eram mistas; mas essa promiscuidade acarretou brigas, e os negros, em sua grande maioria, terminaram por formar suas próprias confrarias.

Em Paranaguá, assim como em outras vilas litorâneas, a construção das principais igrejas em grande parte era financiada por essas Congregações e Irmandades, "[...] que também Ihe forneciam projetos, modelos, orientações e até mesmo elementos completos das edificações [...]" (VASCONCELLOS, 1983, p. 45). 


\subsubsection{A Igreja das Mercês}

A igreja das Mercês foi a primeira edificada no século XVIII, aproximadamente em 1704. Para sua construção foram utilizados os materiais resultantes da demolição da antiga igreja, situada na ilha da Cotinga, pertencente a Lemos Conde. A transferência deste templo para a vila de Paranaguá ficou ao encargo de Antônio Morato, que a construiu através da doação de esmolas pela população. (VIEIRA DOS SANTOS, 2001, p.17, v. II)

Mas, de acordo com o Ouvidor Pardinho, em sua Correição, Antônio Morato teria retirado os materiais da antiga igreja localizada na Cotinga, "[...] convertendo indecentemente parte destes materiaes já dedicados ao culto divino em seus próprios, e profanos usos, e fazendo grangearia da sua chamada devaçam." (PARDINHO, 1721 apud MARCONDES, 1923, p. 61). A crítica de Pardinho demonstra que apesar de Morato ser o patrono desta igreja, ela fazia parte de um bem de toda a comunidade e não para o proveito próprio daqueles que colaboraram com sua construção, origem da critica à atuação de Morato neste evento.

A igreja das Mercês foi edificada onde hoje está situada a igreja de São Benedito, na região sudoeste da vila, nas proximidades da Fonte d'água. Essa igreja estava localizada no eixo da igreja Matriz, eixo que percorre a rua da Gambôa. Essa rua possui aspecto peculiar, devido a sua grande largura, fora dos padrões do período colonial e a igreja das Mercês estaria situada em seu centro focal, ao fim dessa via. 


\subsubsection{A Capela do Bom Jesus dos Perdões}

Em 1710, foram solicitadas à Câmara de Paranaguá terras próximas às casas do Alferes João da Veiga da Silveira, para a construção de uma Capela do Bom Jesus dos Perdões, obra iniciada em 1711. De acordo com Vieira dos Santos (2001, p.143, Vol. II), “[...] sua altura é bastantemente baixa com um alpendre e coberto na entrada da porta principal, com botaréus aos lados para segurança das paredes."

A capela (Figura 9), na época de sua construção, situava-se em uma região afastada da concentração urbana. Mantinha-se no eixo da igreja Matriz, no qual os três edifícios religiosos estão alinhados em uma mesma via, começando com a igreja das Mercês na rua da Gambôa, deslocando-se para a igreja Matriz ao centro e finalmente com a capela do Bom Jesus dos Perdões, ao fim da rua Direita.

A rua Direita que se inicia no largo da Matriz, "[...] é bastante larga, mas alguma coisa em linha curva, não correspondendo ao nome de direita [...]"(VIEIRA DOS SANTOS, 2001, p.16, v. II). Esta angulação definiu o ponto focal das duas igrejas que se localizavam no início e no fim desta via. A rua converge, em suas extremidades, para o largo da Matriz e para a capela do Bom Jesus, o que demonstra certa intencionalidade para que esta rua se tornasse curva, com o intuito de criar uma conexão visual entre os dois edifícios. Outro exemplo de solução perspéctica, foi a determinação do Ouvidor Pardinho, em 1720, para a abertura de uma via em frente a porta principal da Matriz, em função de melhorar a sua visual através desta rua. 


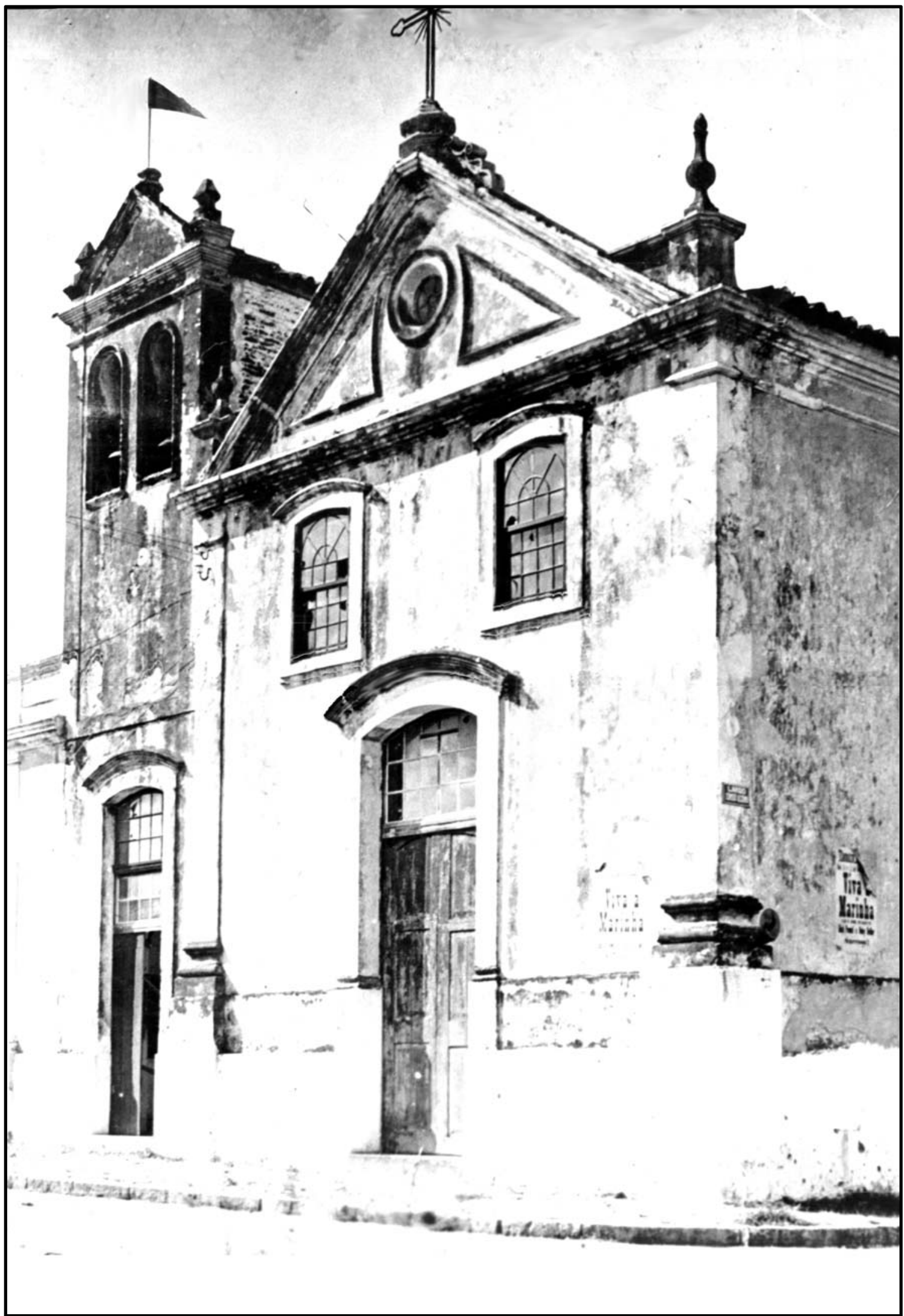

Figura 9. A Igreja do Bom Jesus no início do século XX.

Fonte: Instituto Histórico e Geográfico de Paranaguá. 


\subsubsection{O Colégio dos Jesuítas}

Um importante monumento religioso da Paranaguá do século XVIII foi o Colégio dos Padres Jesuítas. Durante suas obras, ocorreram diversos atrasos por questões burocráticas do governo colonial, sendo finalizado em meados do século XVIII, quando os jesuítas foram expulsos de todas as colônias portuguesas ${ }^{4}$.

A vinda da Ordem dos Jesuítas para a vila de Paranaguá foi solicitada pela Câmara e pela população em 1690, para “[...] darem ensino e educação aos jovens paranaguenses não só da doutrina cristã, mais ainda mesmo de primeiras letras, de latinidade, filosofia e retórica [...]". (VIEIRA DOS SANTOS, 2001, p.201, v. II). A vila os ajudaria com dinheiro, escravos e terras para a construção do colégio.

Os primeiros padres chegaram à vila de Paranaguá em 1699. No ano de 1704 ou 1708, os jesuítas receberam de Antônio Morato a igreja das Mercês e a metade da ilha da Cotinga, além de uma casa nas proximidades da igreja. Quando os jesuítas resolveram iniciar as obras do Colégio, no início do século XVIII, em uma área próxima ao rio Itiberê, no continente, são impedidos por resolução do Ouvidor João Saraiva de Carvalho, alegando que os padres não possuíam a licença do rei de Portugal para construir em Paranaguá. (VIEIRA DOS SANTOS, 2001, p.202)

Com o passar do tempo e sem a liberação pela Coroa da construção do Colégio, o terreno doado pela Câmara no sítio da ribanceira foi, a pedido do Ouvidor Pires Pardinho, desapropriado, alegando-se que a demora na liberação da licença

\footnotetext{
4 "Havia muito que os jesuítas eram acusados de enriquecer à custa dos índios, de privilégios e isenções; na realidade, a organização e a parcimônia explicariam muita prosperidade que causava inveja. [...]"

"Mais de quinhentos religiosos são expulsos do Brasil: do Pará 115, Pernambuco 119, Bahia 133, Espírito Santo 17, Campos 4, Rio 107, Santos 11, São Paulo 23, Paranaguá 5. Grandes fazendas irão arruinar-se. Alguns padres ficam encarcerados em Portugal, outros são remetidos ao Vaticano." (HOLANDA, 1968, p.43).
} 
para os padres prejudicava o crescimento da vila, impedindo seu desenvolvimento para essas áreas. Se posteriormente a licença fosse liberada e o local inicialmente escolhido estivesse ocupado, os Padres poderiam construir na região da Gambôa ou em outro de sua escolha. (PARDINHO, 1721 apud MARCONDES, 1923)

Portanto, a área que pertencia aos jesuítas, no sítio da ribanceira, sofreu o risco de ser desapropriada devido à falta das licenças reais para o início da construção jesuítica. Somente em 1740 foram autorizadas as obras do Colégio, que durariam até 1759, quando então os jesuítas são expulsos das colônias portuguesas, finalizando sua permanência em Paranaguá. (VIEIRA DOS SANTOS, 2001)

O edifício do Colégio (Figura 10) será marcante na paisagem da vila de Paranaguá. Consistindo em uma construção de grandes dimensões, formada pelo edifício do Colégio e pela igreja. Situado às margens do rio Itiberê, o Colégio ocupa a totalidade de seu terreno, configurado como uma quadra, sua fachada possui aberturas de tamanhos variados, além dos cachorros em pedra, entalhados com volutas, que segundo Bazin (s/d, p. 141), são "[...] destinados a apoiar uma tabuinha de madeira ou uma mesinha de pedra (Penedo) sobre a qual os monges, guiados pelo espírito poético de sua Ordem, gostavam de colocar flores". Em seu interior existe um grande pátio, o claustro, comum nessas construções jesuíticas.

De acordo com Lucio Costa (1941, p.23):

O partido arquitetônico tradicionalmente empregado pelas ordens religiosas nos seus mosteiros e conventos, ou seja, o de dispor seus vários corpos da construção em "quadra" como então se dizia, formando-se assim um ou mais pátios, foi mantido também pelos jesuítas.

O autor considera o pátio do Colégio de Paranaguá, "[...] diferente de todos os demais pelo seu aspecto sombrio e pesado de praça-forte [...]" (COSTA, 1941, p.24) 
esse aspecto "sombrio e pesado" se deve às grossas paredes em pedra (Figura 11), de um metro ou mais, que delimitam este espaço e que não foram rebocadas. 0 térreo do claustro é marcado pelas arcadas formadas por grandes blocos de pedra, que permeiam o espaço externo com o corredor interno do edifício.

Três funções principais caracterizavam o Colégio dos Jesuítas: o culto, o trabalho e a residência ou cubículos; que respectivamente significam a igreja, as aulas e oficinas e por fim, a morada, enfermaria, áreas de serviço, horta e pomar. (COSTA, 1941)

A igreja dos Jesuítas de Paranaguá estava anexa ao prédio, com sua porta principal voltada para a rua da Câmara e Cadeia. A igreja foi demolida em 1895, por determinação do prefeito João Guilherme Guimarães, para que no mesmo local fosse construída uma escola. (FERREIRA JUNIOR, 190?).

Quando esteve em Paranaguá no ano de 1855, o americano Daniel Kidder descreve as ruínas desta igreja e o Colégio da seguinte forma:

Em uma destas ruas as ruínas de uma igreja atraíram minha atenção; e informaram-me que era um edifício quase concluído pelos Jesuítas quando foram expulsos. Pode-se raramente viajar centenas de milhas ao longo do litoral do Brasil (que se estende, com suas baías e ilhas, aproximadamente por quatro milhas) sem se encontrar em algum rico vale ou sobre alguma pitoresca eminência, uma imensa igreja, capela ou convento, dessa ordem, cujos membros entraram no Brasil quando sua prosperidade estava no auge e quando sua ambição não fora ainda embaraçada por circunstâncias externas. Surpreendeu-me mais a grandeza excessiva de alguns dos edifícios de conventos do Brasil do que todos os do mesmo gênero que vi na França, Alemanha ou Itália. (KIDDER and FLETCHER, p.16, 1941)

Através de um levantamento gráfico do colégio, realizado por Vieira dos Santos, na metade do século XIX e publicado em sua Memória Histórica, identificase a igreja composta por uma planta retangular, com medidas internas de 8,50 metros de largura por 17,16 metros de comprimento, até o arco do Cruzeiro. 

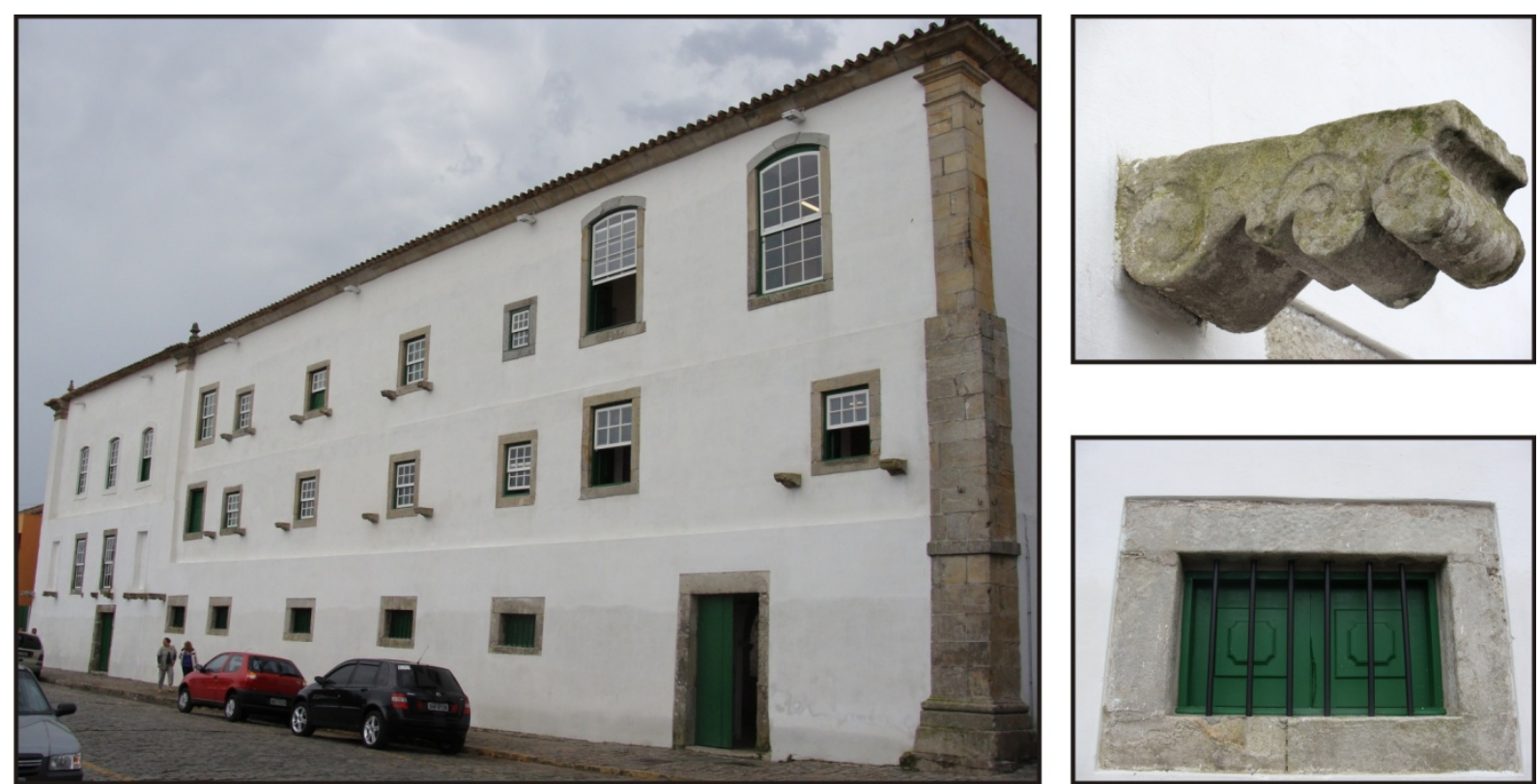

Figura 10. O Colégio dos Jesuítas e detalhes de sua construção, na parte superior direita o cachorro em cantaria e na parte inferior uma das aberturas do edifício.

Fonte: Acervo do autor, 2009.
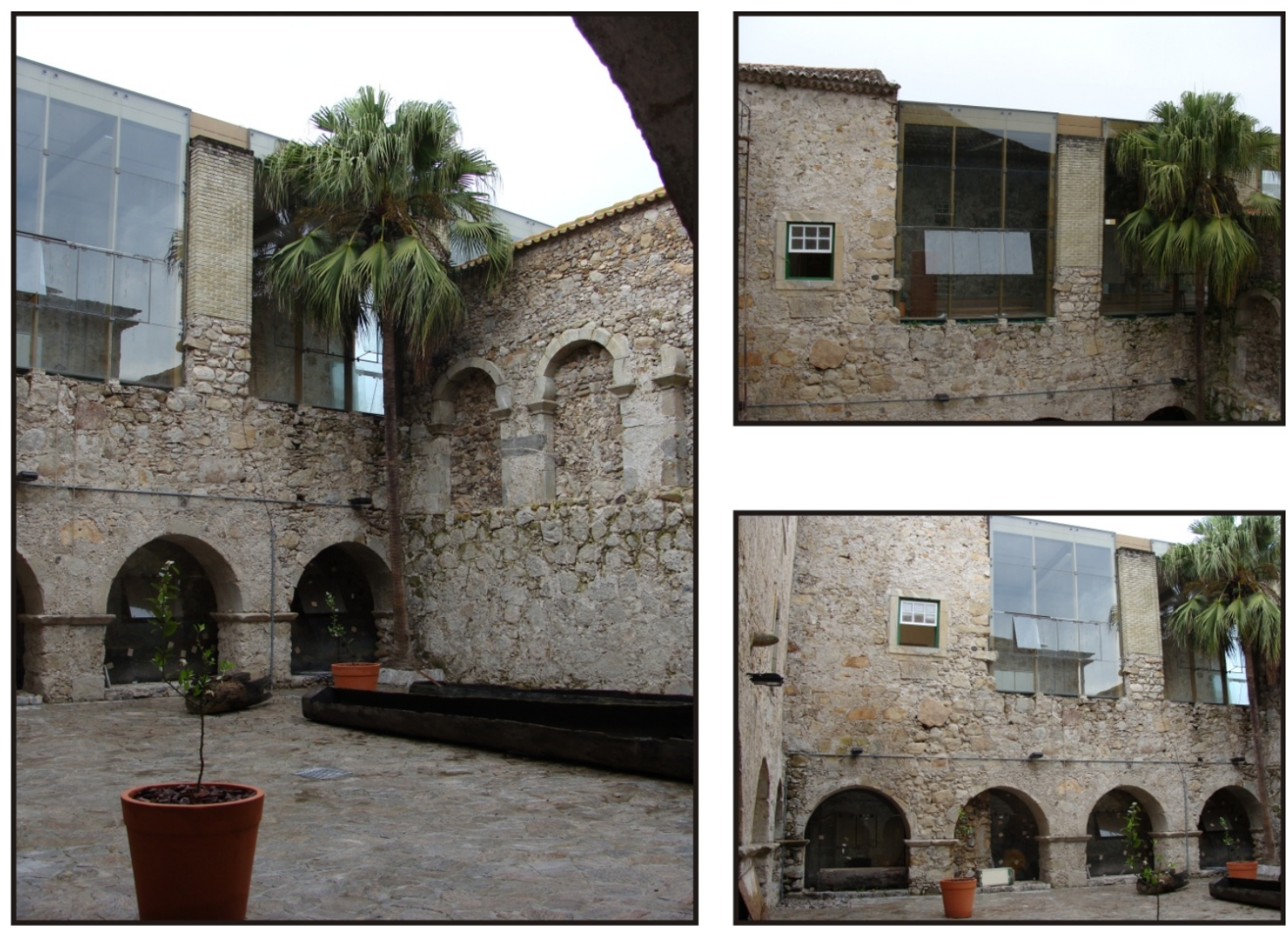

Figura 11. O pátio interno do Colégio e suas arcadas.

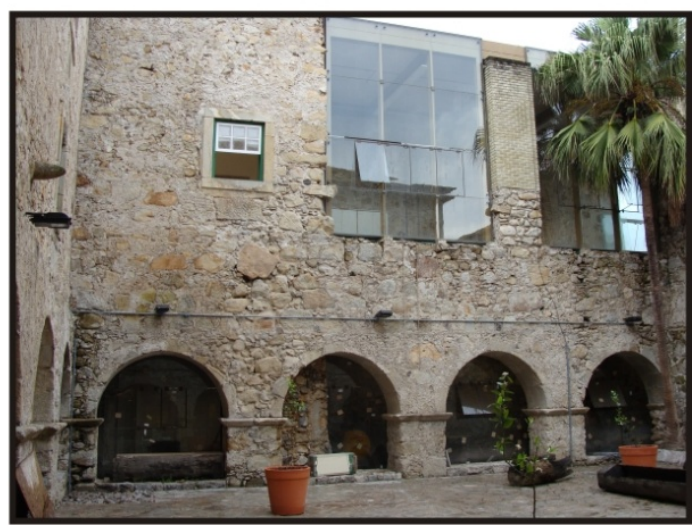

Fonte: Acervo do autor, 2009. 
Contíguo ao corpo do edifício, estava um pequeno corredor que dava acesso à rua da Câmara e Cadeia e também ao centro e ao fundo da igreja, por detrás do altar.

A construção de um corredor lateral nessa igreja possibilitava o acesso ao edifício de forma discreta, não interferindo, por exemplo, nas cerimônias religiosas:

Nascidos de uma necessidade funcional, os corredores laterais são como o renascimento das naves laterais, mas estas foram rejeitadas para fora da igreja. Esses corredores foram criados para estabelecer uma comunicação direta entre a sacristia e os púlpitos, de um lado, e o coro, do outro lado. $O$ projeto de uma nave única trazia, sem dúvida, alguns inconvenientes: não prevendo passagens privativas através da igreja, obrigava os clérigos a circular no meio dos fiéis (BAZIN, s/d, p. 127).

Sobre a fachada desta igreja, Vieira dos Santos (2001, p. 201) comenta:

[...] no frontispício da igreja em frisos, cordões, meias canas, e outros lavores, principalmente no nicho do meio, onde pretendiam colocar $\mathrm{S}$. Inácio de Loiola, o grande patriarca da sua Associação, ao lado da qual estão duas grandes janelas para darem à igreja a competente claridade; seus portais; ombreiras e até mesmo a própria cimalha do remate do edifício é de cantaria.

Em seu interior, a igreja possuía:

"[...] o altar-mor e um colateral. A capela-mor e seu trono feito de entalhadura e molduras ao gosto daquele tempo; neste altar estavam colocadas a imagem de Nossa Senhora das Neves, em seu nicho, e outros laterais o de S. Inácio de Loiola, fundador da Companhia e o de Nossa Senhora do Terço; também tinha as imagens de S. Francisco de Paula, fundador dos Mínimos; e S. Amaro. No altar colateral ao lado do envagelho estava colocada a respeitosa imagem do Senhor Bom Jesus da Cana Verde [...]" (VIEIRA DOS SANTOS, 2001, p.203)

Em sua fachada (Figura 12), a igreja dos jesuítas possuía como características predominantes o frontão triangular, as cimalhas em cantaria e suas duas colunas laterais do mesmo material. Uma porta central era o acesso principal do edifício e na esquina da igreja existia uma pequena porta, que dava acesso ao corredor lateral.

Os elementos utilizados na fachada, principalmente o frontão triangular, são influências clássicas advindas da Contra-Reforma: 
Por enquanto, é suficiente afirmar que os jesuítas trouxeram para o Brasil o tipo de igreja portuguesa da Contra-Reforma, cuja origem será estudada mais tarde: edifício sóbrio, inspirado no de São Roque de Lisboa, sendo que mais simplificado, com um corpo de igreja sem capelas, três nichos com altar, e sem transepto. A fachada com frontão clássico, reproduz o perfil do templo antigo (BAZIN, s/d, p. 68-69).

De uma maneira geral, os edifícios jesuíticos: "São as composições mais renascentistas, mais moderadas, regulares e frias, ainda imbuídas do espírito severo da Contra-Reforma." (COSTA, 1941, p.11). Observamos estas características no Colégio de Paranaguá, um edifício de grandes dimensões, mas que possui características simples, com poucos ornamentos, assim como em sua antiga igreja.

Como não existem referências sobre a torre sineira, elemento não construído, poderia ter sido prevista no canto direito do edifício, finalizando a composição. Assim como em outros edifícios jesuítas na colônia, esta era uma forma comum de distribuição e composição. Segundo Costa (1941, p. 24):

Um dos "quartos" da quadra era sempre ocupado pela igreja, cujo frontispício, mantido no alinhamento do quarto contíguo formava com este, em elevação, um plano só, correspondendo ao Colégio uma linha horizontal continua e ao corpo da igreja um frontão de empena, com a torre servindo de remate à composição. Essa, disposição, clara e coerente, era geralmente adotada quando, de início, não fazia parte do programa a construção de uma segunda torre.

Em uma fotografia do final do século XIX, da rua da Praia (Figura 13), podese notar que essa igreja se destacava em relação ao corpo do Colégio, por sua estrutura e altura, principalmente por se localizar na área mais alta do terreno, no sítio da ribanceira. Seria um elemento marcante no visual da vila quando observada do rio Itiberê. 


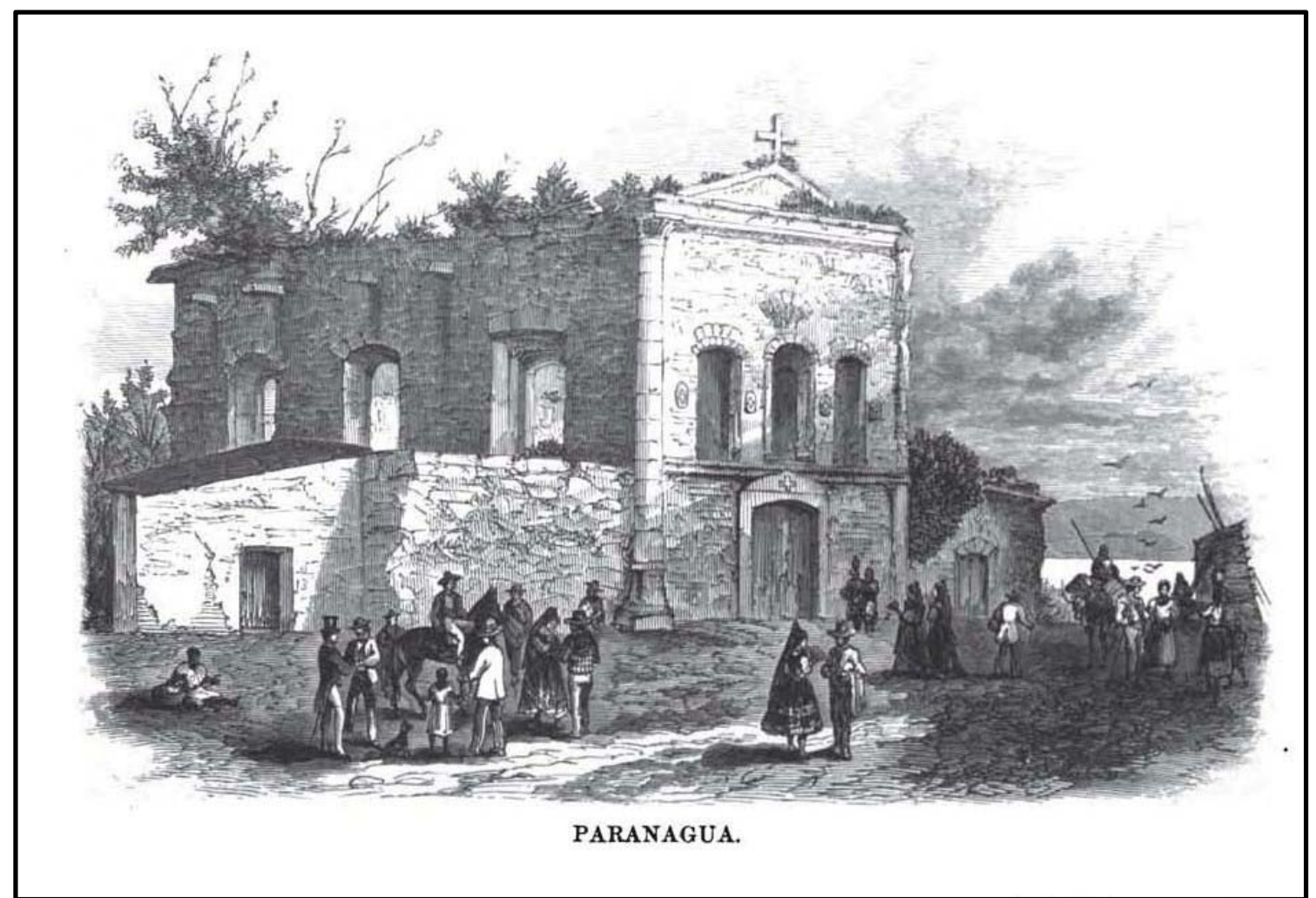

Figura 12. A igreja dos Jesuítas retratada por John Codman na metade do século XIX e publicado no livro "Ten Months in Brazil".

Fonte: CODMAN, 1867.

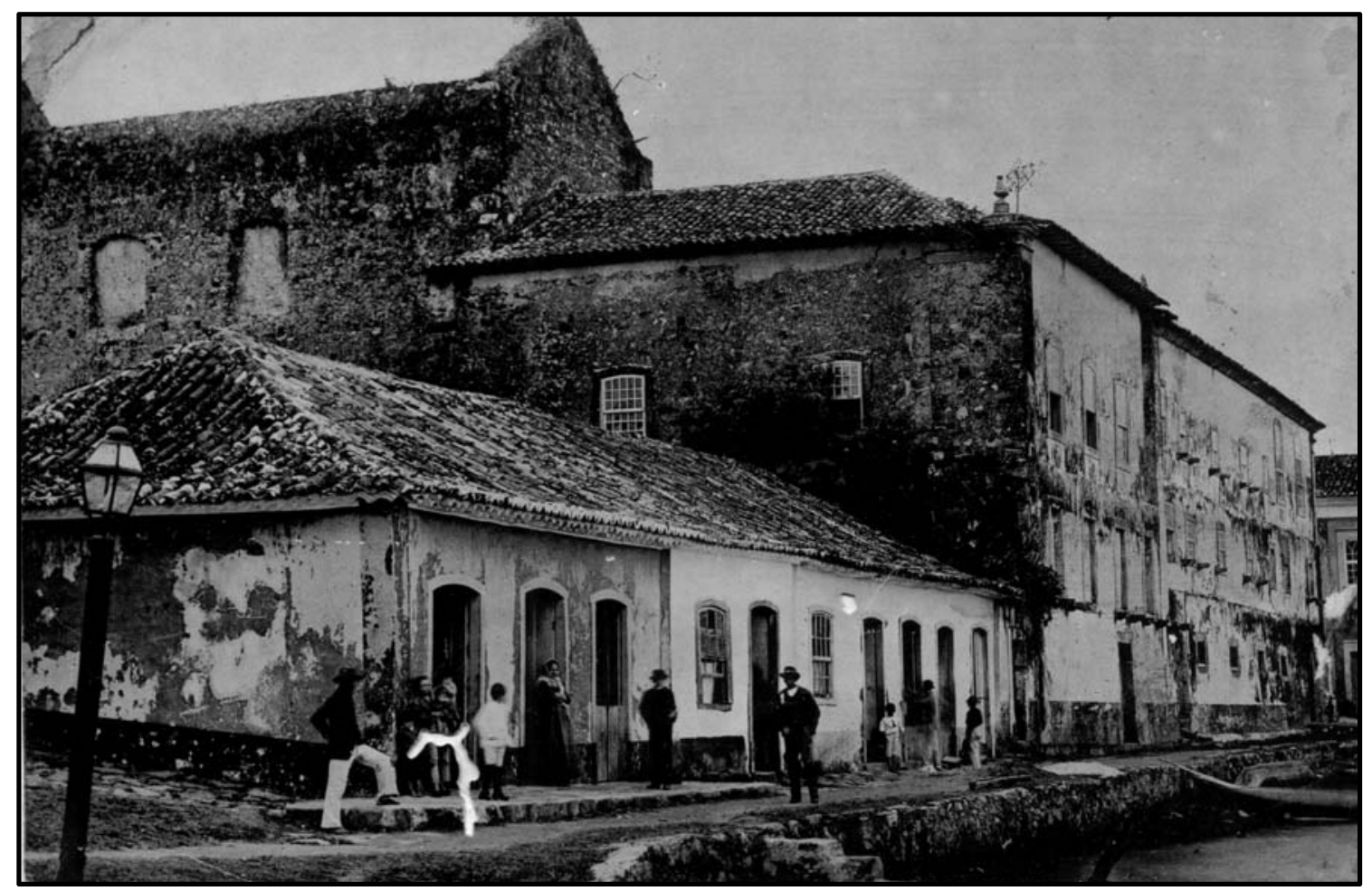

Figura 13. Vista do Colégio e das ruínas da igreja no final do século XIX.

Fonte: Álbum de Juca Lobo. 
O claustro do Colégio e algumas paredes dos ambientes internos, (Figura 14) revelam de que forma eram dispostas as pedras e quais materiais foram utilizados nesta construção. As pedras eram assentadas através da intercalação entre as de maior e menor dimensão (cangicado), unidas por uma massa composta de argila com a cal de sambaqui, resultante do processo de queima e trituração parcial do material.

As paredes da base do edifício são mais grossas, e com o aumento em sua altura, vão diminuindo de espessura. Assim, em sua fachada é possível observar esta característica, pois em cada pavimento acontece um recuo das paredes externas, resultando em três planos horizontais (Figura 15). No interior do Colégio são observados alguns pilares compostos por peças de cantaria de maior dimensão, intercaladas por pedras de menor dimensão (Figura 16), que foram assentadas nos vértices da estrutura, de forma a estabilizar a estrutura e descarregar o peso das grossas paredes.

É possível identificar não só nas estruturas do Colégio e da igreja dos jesuítas, mas em grande parte das construções do centro histórico de Paranaguá este método construtivo, utilizando os materiais locais: cal, pedras e argila. Sendo que a pedra e a argila eram retiradas da ilha da Cotinga e a cal dos sambaquis, encontrados em diversas áreas litorâneas, tornando-se um produto comercial importante na vila de Paranaguá.

Após a saída dos jesuítas, em 1760 o colégio estava da seguinte forma:

Ficou por acabar de se concluir este convento; o lanço do quadro que faceia com o frontispício e rua da Alfândega, em cuja igreja arrematava o mesmo convento; e para a qual concorreram todos os povos de Paranaguá, como lhes haviam prometido, principalmente os homens mais principais e abastados e entre eles se conta por memória o Capitão Manoel Gonçalves Carreira, ter dado para a fatura da mesma obra oito mil cruzados. (VIEIRA DOS SANTOS, 2001, p. 202) 

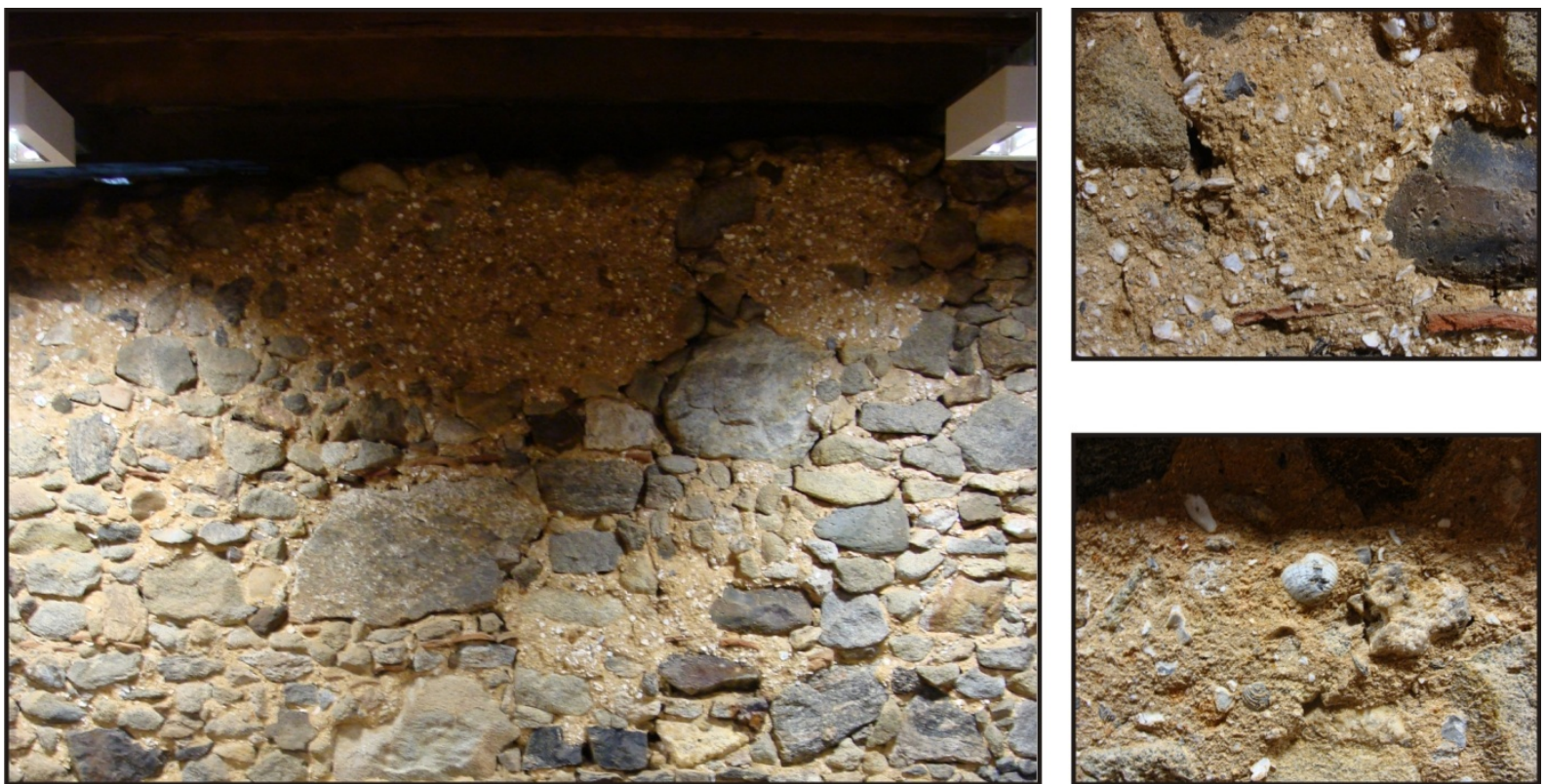

Figura 14. Uma das paredes internas do Colégio, no detalhe as conchas misturadas a argamassa de argila.

Fonte: Acervo do autor, 2009.
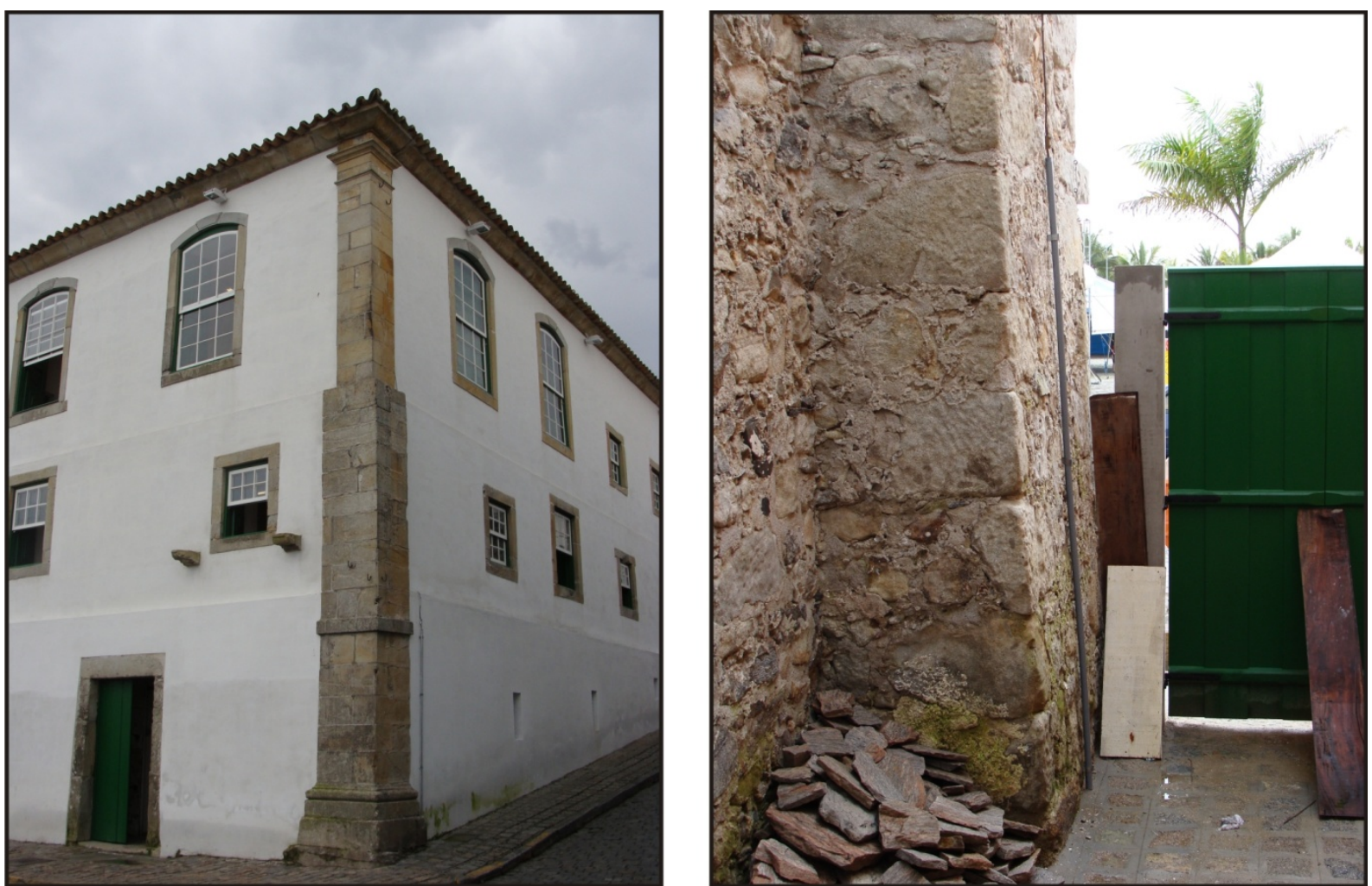

Figura 15. O recuo das paredes pode ser observado na fachada do Colégio, ao lado direito uma das bases da estrutura que se inclina, para estabilizá-la.

Fonte: Acervo do autor, 2009. 

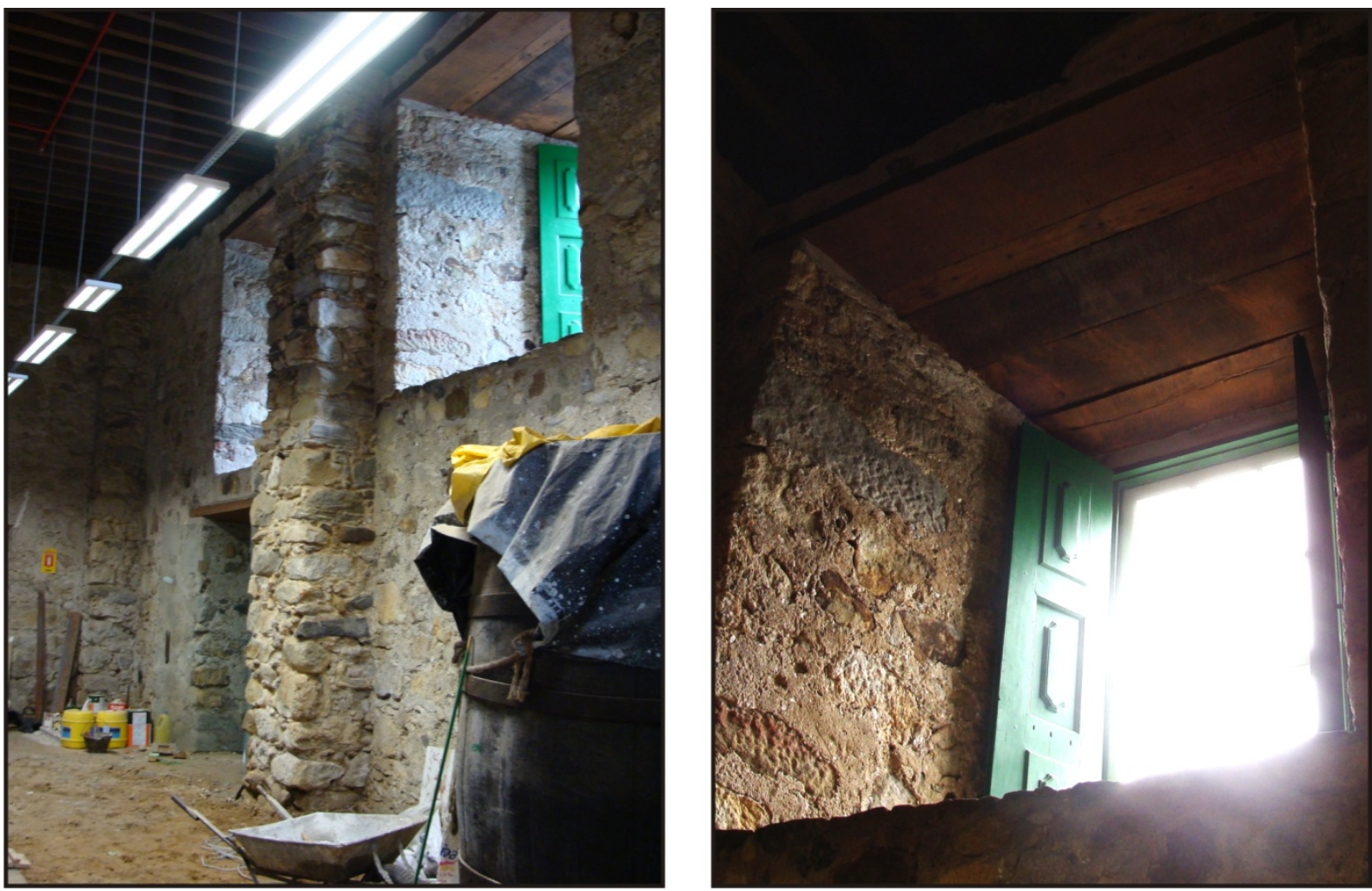

Figura 16. As estruturas internas do Colégio, pela janela percebe-se a grande espessura de suas paredes

Fonte: Acervo do autor, 2009.
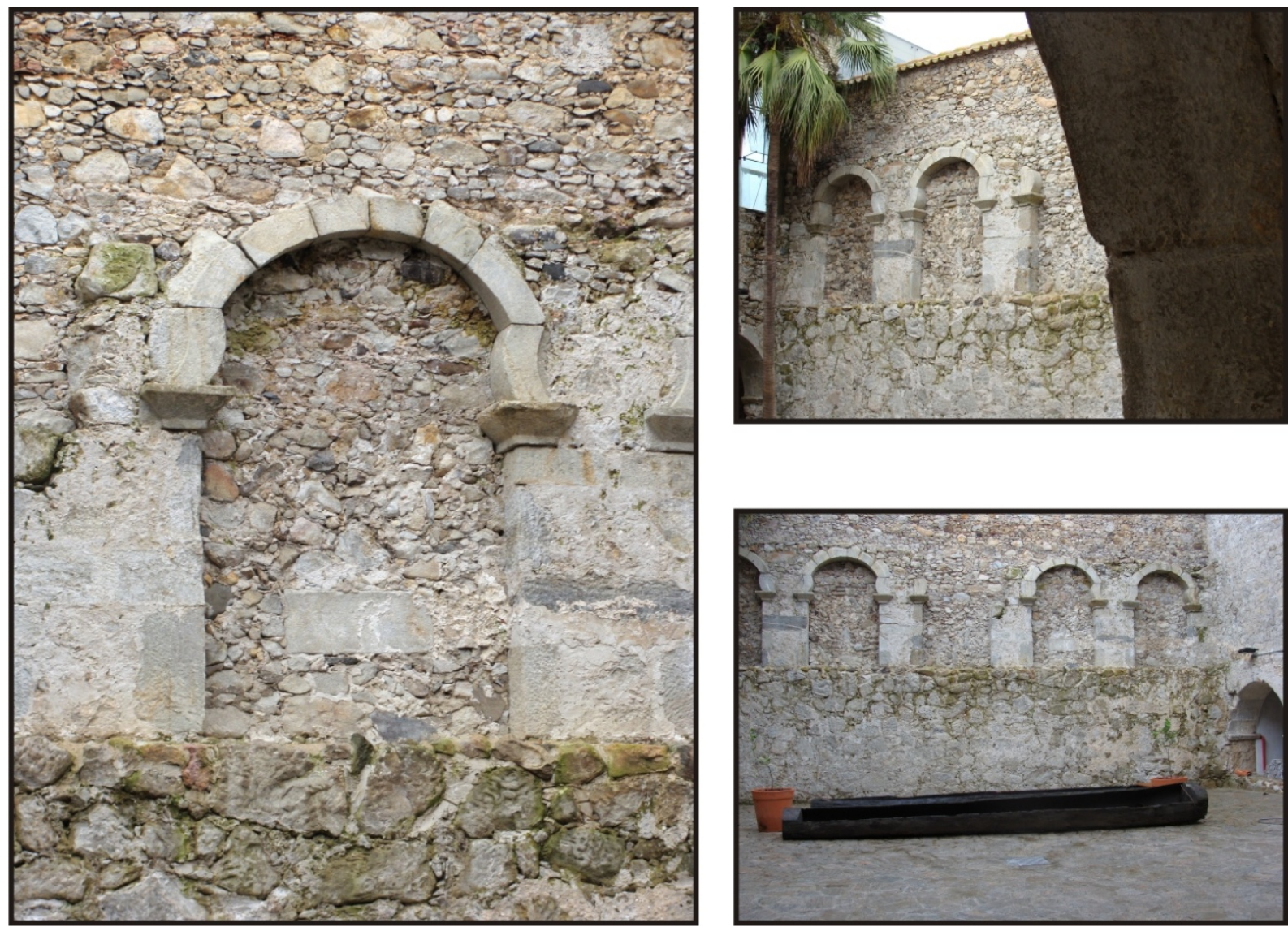

Figura 17. A estrutura inacabada das obras dos Jesuítas.

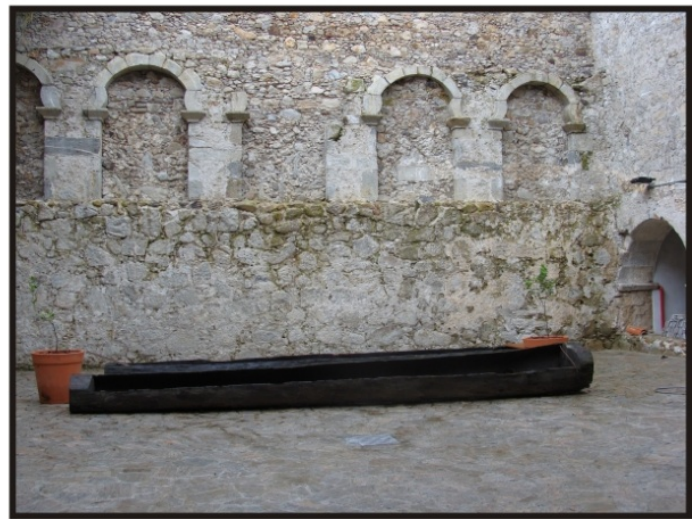

Fonte: Acervo do autor, 2009. 
Esta parte não finalizada seria o fechamento do corpo do Colégio ao redor do pátio; isto é identificado não só na descrição de Vieira dos Santos, mas também no próprio claustro do edifício. Na parede fronteira à rua da Câmara e Cadeia, depois Alfândega e hoje XV de novembro, existem estruturas em arcadas (Figura 17) no nível da rua, identificadas nas visitas ao local, diferentes do desenho das arcadas ao nível do rio Itiberê, portanto as arcadas aqui descritas são as obras inacabadas do Colégio, uma ligação entre a igreja e o edifício. Semelhante ao encontrado em outras estruturas, como o Colégio Jesuíta de São Paulo. A junção do corpo do edifício com a igreja, em um mesmo plano, seria a possível solução aplicada no caso de Paranaguá, mas que não foi executada.

A igreja se manteve em funcionamento até 1790 , quando foi abandonada. A estrutura do telhado entrou em colapso no começo do século XIX, quando as imagens que ali estavam foram retiradas, deixando o edifício em completo abandono. O Colégio permaneceu abandonado até 1832, ano em que se torna sede do aquartelamento da Guarda Nacional e recebe os primeiros consertos de sua estrutura, tempo depois outra parte do edifício tornou-se a sede da Alfândega de Paranaguá. (VIEIRA DOS SANTOS, 2001, Vol. II).

\subsubsection{A igreja da Ordem Terceira de São Francisco das Chagas}

Uma das últimas igrejas edificadas no século XVIII na vila de Paranaguá, foi a igreja da Ordem Terceira de São Francisco das Chagas. Construída entre os anos de 1770 a 1784, em terreno localizado na região noroeste da cidade, próximo ao 
desnível existente nas margens do rio Itiberê, na esquina das ruas XV de Novembro com Presciliano Corrêa.

Esta ordem já atuava na vila de Paranaguá desde o início do século XVIII, mas os relatos sobre a atuação da Congregação nas primeiras décadas, não foram encontradas por Vieira dos Santos. Os documentos citados pelo autor partem de 1746 em diante. (VIEIRA DOS SANTOS, 2001, Vol. II)

Em 1769, foram dadas as primeiras ordens para o início das obras desta igreja, e para isso o irmão Francisco Xavier da Costa foi encarregado de obter toda a pedra necessária para sua construção. O irmão, em 1774 alegou “[...] o excessivo trabalho que havia tido no tiramento e condução da pedra para o crescente que se havia feito na obra da capela-mor e pelo qual se havia também acrescentado o mestre pedreiro maior quantia do ajuste [...]." ( VIEIRA DOS SANTOS, 2001, p. 132133, Vol. II)

As obras continuaram durante o final do século XVIII, em 1790, a Ordem determinou a escolha de um terreno para o adro, defronte a igreja, e outra área para a construção da casa do noviciado, oficinas e claustro. Uma preocupação da Ordem é o afastamento da Igreja das construções vizinhas pois:

[...] que fique a dita capela separada de outra alguma casa a inquietá-la com ruídos e fumaça na ocasião da celebração dos ofícios divinos e ser de grande indecência; e por isso ordenaram ao síndico, o irmão Tomás de Souza e Silva que levantasse o muro da parte direita da capela. (VIEIRA DOS SANTOS, 2001, p. 133)

Em relação à sua localização, a igreja da Ordem estava afastada da área mais concentrada da vila de Paranaguá, ao fim do sítio da ribanceira, assim como também se configurou a igreja do Bom Jesus dos Perdões, mais isolada da vila do que a igreja da Ordem. A igreja de São Francisco está fora do eixo que se formou entre a igreja das Mercês, Matriz e Bom Jesus, a Ordem estava na rua onde se 
localizava a igreja dos Jesuítas e a Casa de Câmara e Cadeia, rua esta que já se desenvolvia em sua direção.

Quanto as suas características, Vieira dos Santos (2001, p.129, Vol. II) considera o frontispício desta igreja "mais chegado ao gosto moderno". Esta referência ao gosto moderno se deve a ela possuir seu frontão marcadamente sinuoso (Figura 18), ascendendo ao topo de onde existia uma cruz, mesmo desenho que será encontrado na igreja de São Benedito.

As igrejas mais antigas possuíam em seus frontispícios um desenho mais retilíneo, utilizando frontões triangulares, de influência clássica como já comentado por Germain Bazin e Lucio Costa, sobre os templos Jesuítas. Neste contexto, temos a do Bom Jesus dos Perdões, a igreja do Colégio e até provavelmente a Matriz em suas características originais, antes das constantes reformas, continha em sua fachada o frontão reto, que de acordo com Lucio Costa (1941, p. 36-41) "[...] é o que melhor caracteriza as igrejas jesuíticas brasileiras, pois que elas não alcançaram o pleno desenvolvimento do barroco em meados na segunda metade do setecentos." Já nas igrejas do final do século XVIII, ocorreu uma mudança em suas características, dando importância ao movimento, aplicando em suas fachadas elementos curvos, e isto foi a inovação da igreja da Ordem Terceira.

A inovação aplicada através dos elementos curvos, pode ser observada pela análise de John Bury (2006, p.177) sobre a igreja do Convento de São Francisco, da cidade de Salvador:

Essas seqüências de volutas representam o ponto de partida do processo barroco de dissolução e quebra das amarras impostas pelos rigorosos padrões da arquitetura do final da Renascença. A partir desse início, à medida que avançava o século, a progressiva emancipação quanto às regras restritivas da composição clássica se evidencia na substituição das formas ortogonais tradicionais pelas novas formas curvas e móveis, e pelos perfis em forma de "S". 
A igreja da Ordem Terceira e a de São Benedito (Figura 19) são resultantes da influência barroca no litoral, mas de forma mais simplificada: seu frontispício é austero sem muitos adornos. No caso da igreja da Ordem existe um maior apuro nos trabalhos de cantaria, nas cimalhas em granito, nas duas janelas com suas pronunciantes vergas em canga de boi, encontradas também na grande porta principal do edifício.

Ao centro do frontão, existem dois elementos de destaque, um é o óculo em forma de flor de quatro pétalas (Figura 20), cujos vértices convergem para o centro desta estrutura em cantaria, que funciona como ventilação da cobertura; outro é um brasão com um símbolo da Ordem Terceira de São Francisco: dois braços que se cruzam encimados pela cruz cristã, em cada braço está amarrado uma espécie de cordão com três nós, o cinto das vestes dos franciscanos (Figura 21).

Os cunhais da igreja da Ordem Terceira são marcados pelo trabalho em cantaria do mesmo material das janelas e cimalhas, de blocos em pedra de grandes dimensões muito bem assentados, que são interrompidos ao final do frontão, arrematados pelos dois pináculos em pedra que realçam a verticalidade e a leveza da fachada.

Em seu interior, a decoração vai de acordo com os recursos de seus construtores, utilizando-se de técnicas mais simples. Segundo Vieira dos Santos (2001, p.129):

Ornam a esta o altar-mor e dois colaterais; no principal está colocada no cimo da tribuna a imagem do Seráfico Padre S. Francisco das Chagas de vulto não pequeno; [...]. No altar colateral ao lado do Evangelho está colocada a imagem de Nossa Senhora da Conceição e o do lado da epístola o da Nossa Senhora da Guia, e nos dois nichos do altar-mor Santa Teresa e Santa Rosa de Viterbo. 


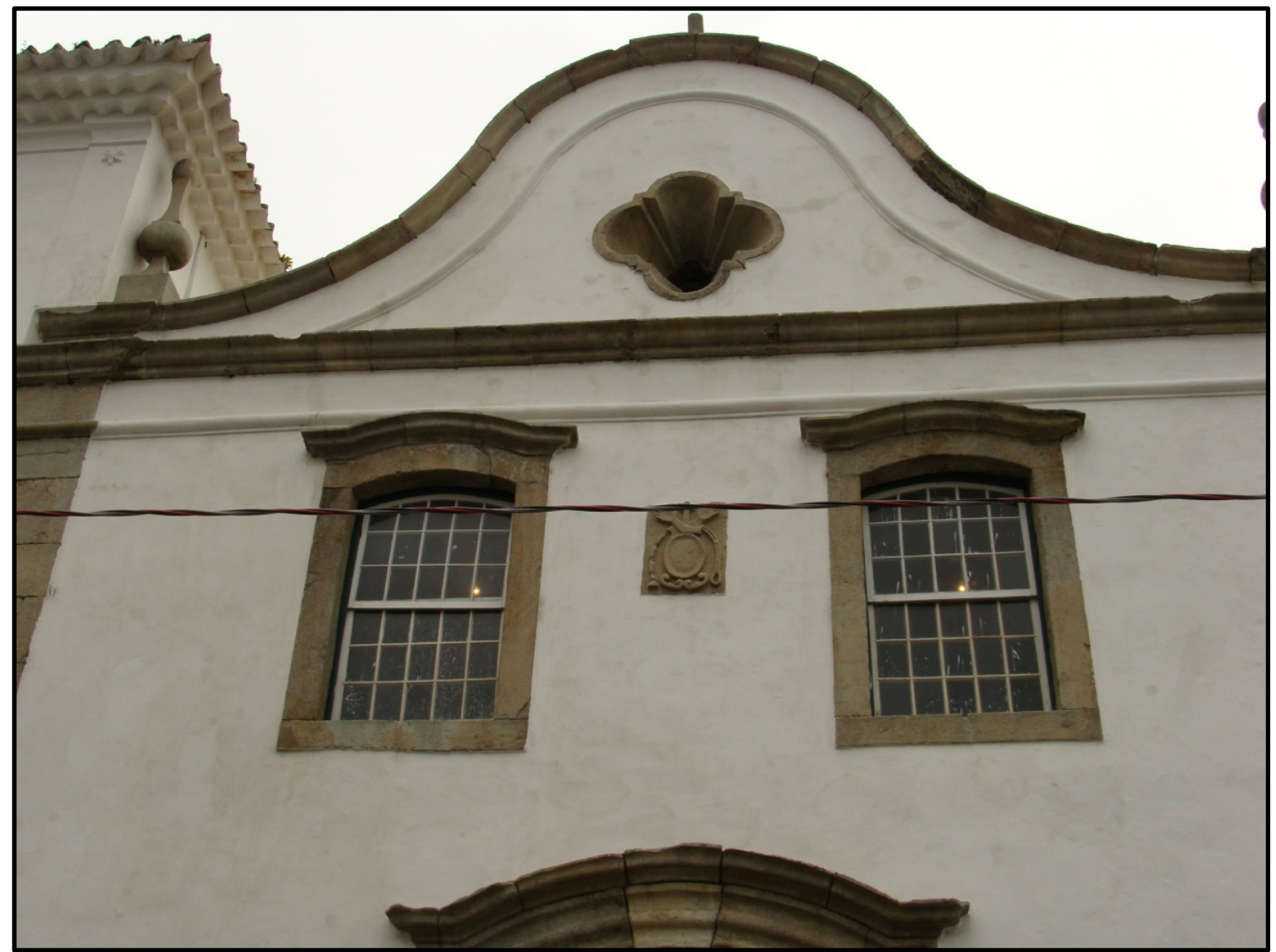

Figura 18. Frontispício da igreja da Ordem Terceira.

Fonte: Acervo do autor, 2009.
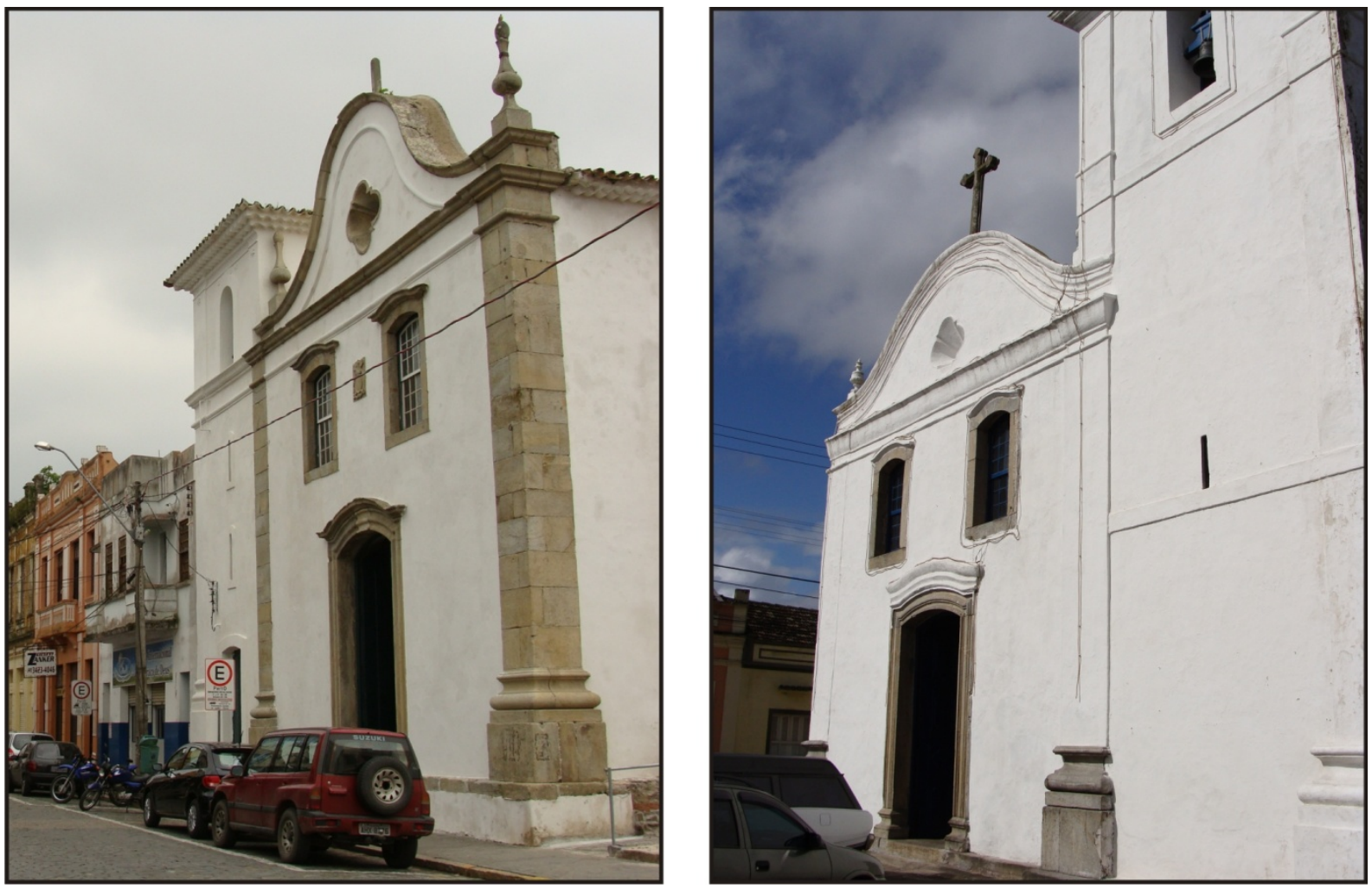

Figura 19. Na esquerda a igreja da Ordem e na direita a igreja de São Benedito.

Fonte: Acervo do autor, 2009. 


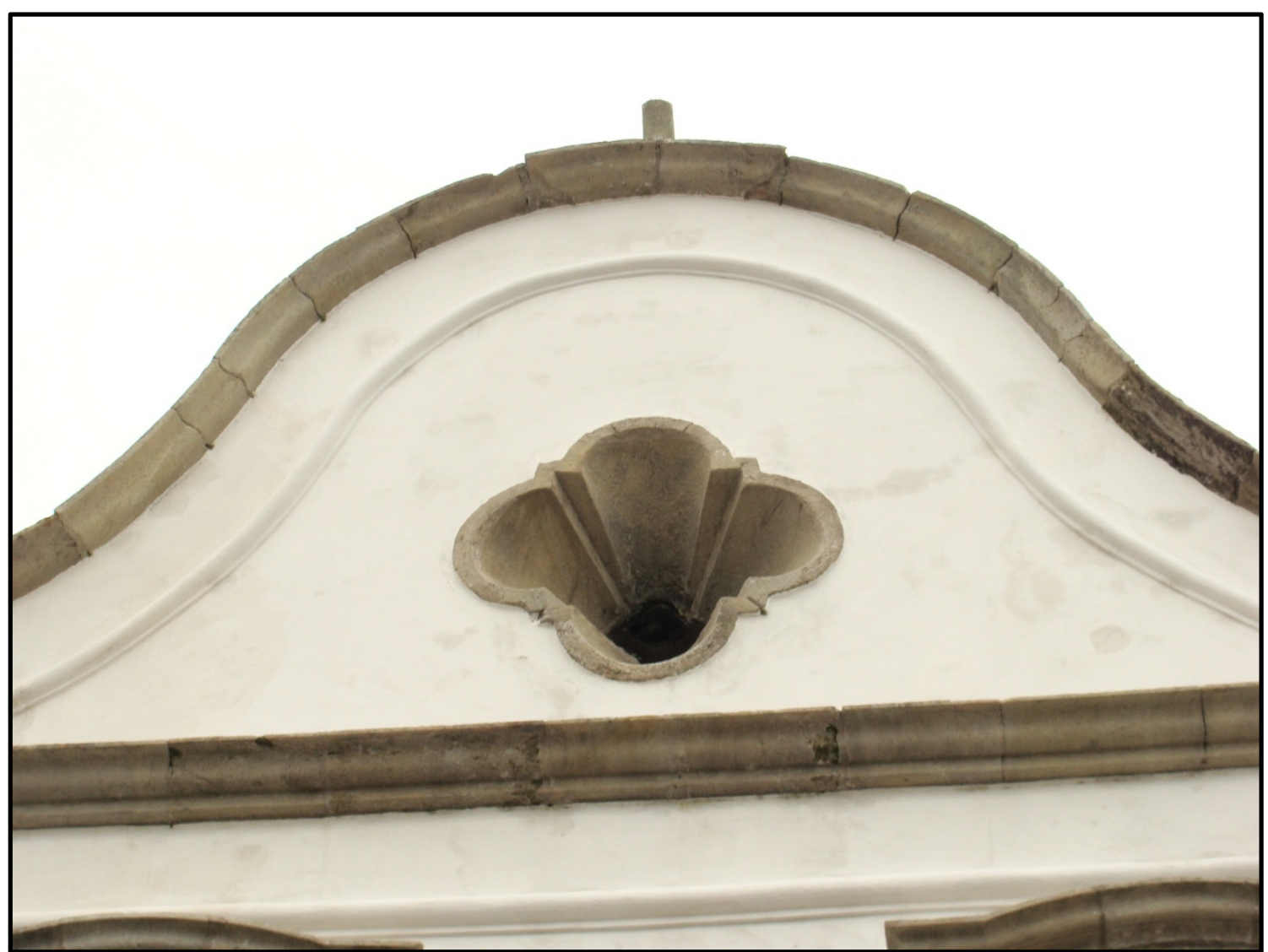

Figura 20. Detalhe do frontão sinuoso e do óculo central.

Fonte: Acervo do autor, 2009.

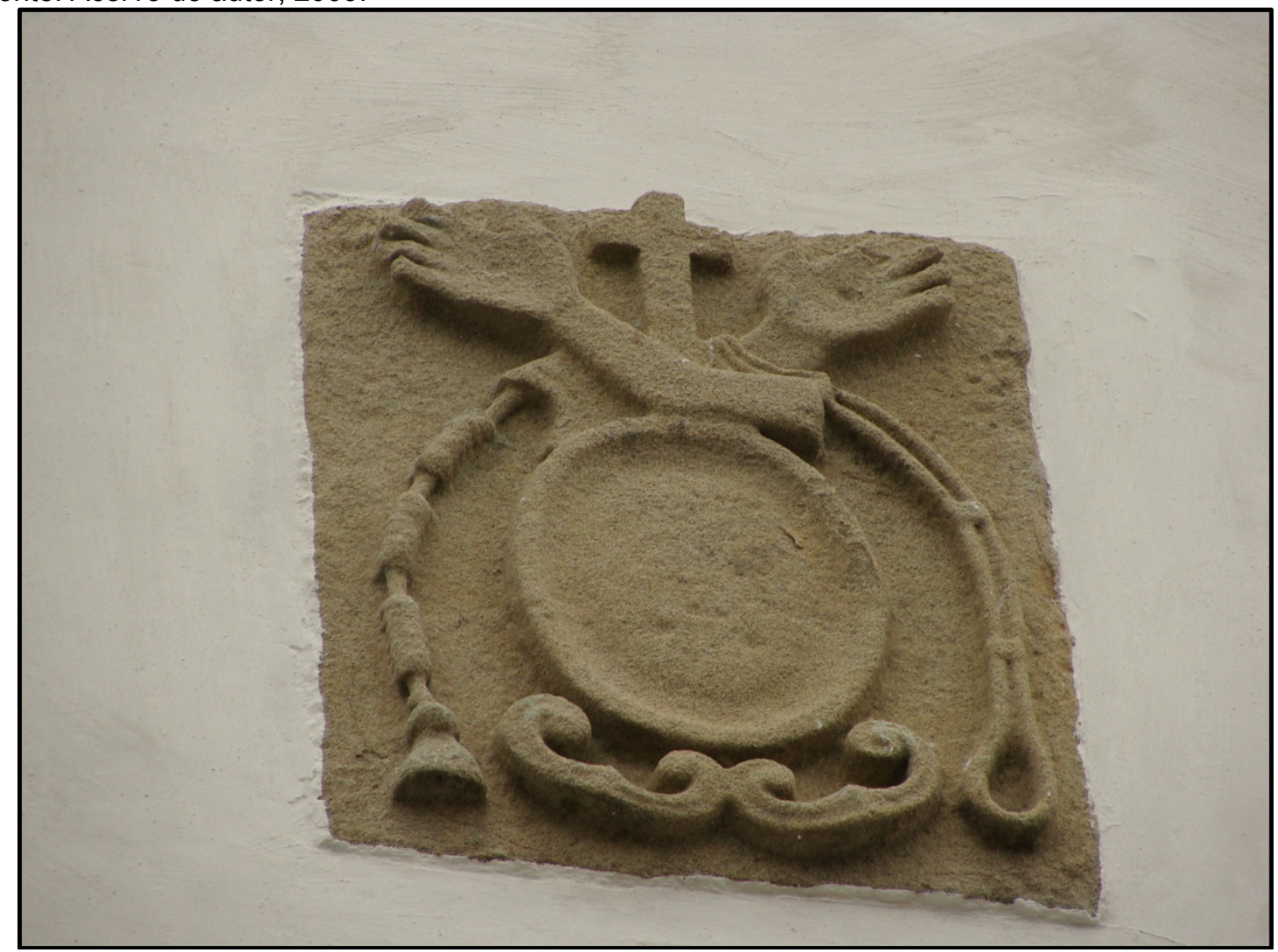

Figura 21. Brasão dos franciscanos, localizada ao centro das duas janelas frontais. Fonte: Acervo do autor, 2009. 
No ano de 1798 foram construídas as quatro tribunas ou púlpitos em madeira, na área da capela-mor, pelo carpinteiro Joaquim Eusébio Gomes. Já no início do século XIX, foram realizadas as pinturas do altar mor e dos altares colaterais. (VIEIRA DOS SANTOS, 2001)

Apesar da simplicidade dessa igreja em Paranaguá, a Ordem Terceira de São Francisco foi, no Brasil, uma congregação de muitas posses, que reunia grandes fortunas nos lugares em que estava presente (BAZIN, s/d). Sendo assim, em Paranaguá, apesar da pouca ostentação desta sede, ela é um referencial estético na vila, pois possui apurado trabalho de cantaria e constitui uma das mais importantes referências barrocas do litoral paranaense.

Já a planta não obteve grandes mudanças em relação as igrejas mais antigas da vila. A igreja dessa Ordem é retangular e dividida quase em sua metade pelo arco em pedra que delimita a nave da capela-mor (Figura 22). Aos fundos encontrase a sacristia, cujo acesso se dá através de corredor lateral com entrada pela capela-mor.

Quanto à torre sineira (Figura 23), esta só foi construída em meados do século XIX, em data aproximada de 1841, como está indicado acima da beiraseveira da torre, que mantém as características do resto do edifício. Sua cobertura, ao contrário das outras igrejas, é em telha portuguesa quase invisível a quem do nível do chão a observa. 


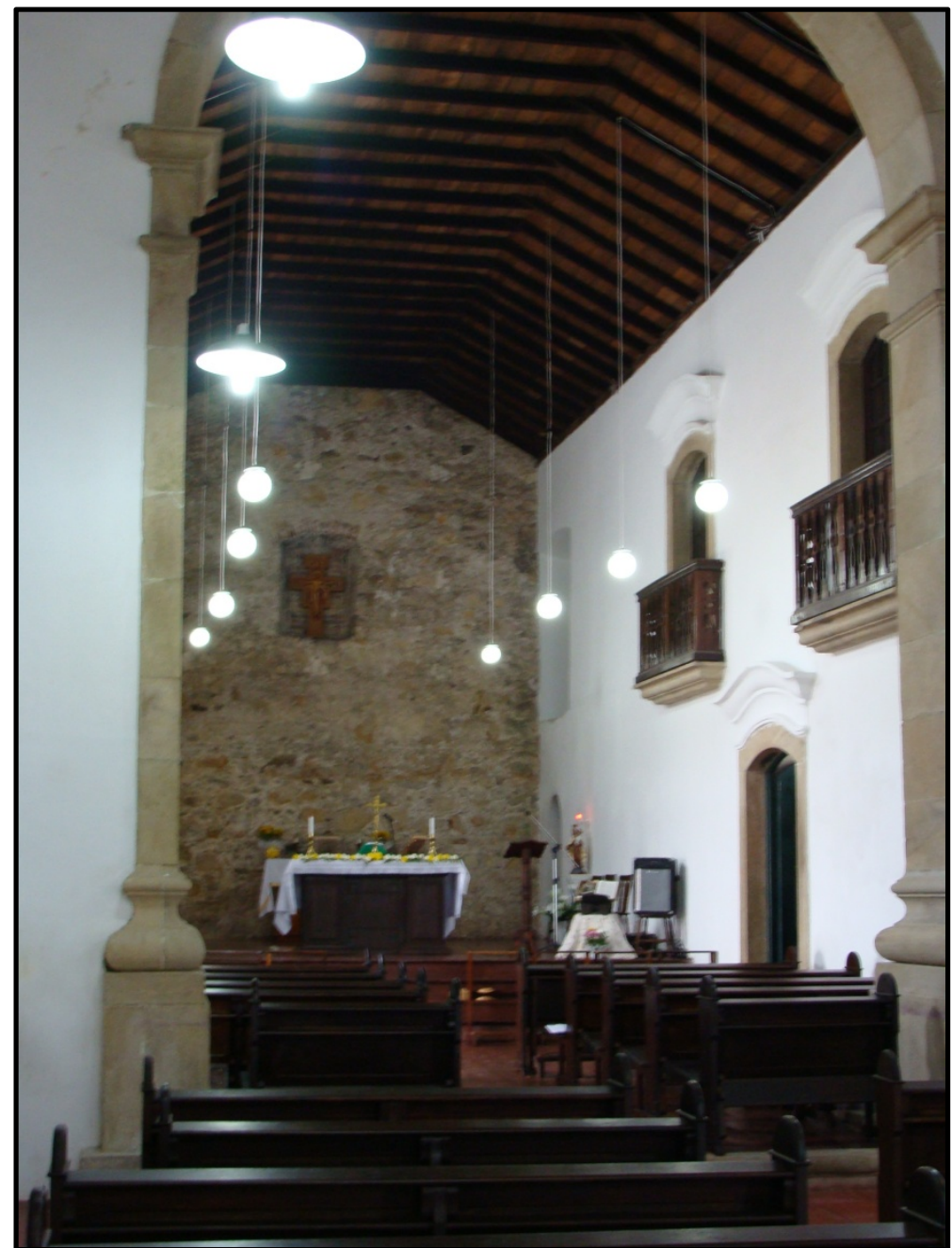

Figura 22. Interior da igreja da Ordem Terceira, o arco em cantaria marca a metade do edifício. Fonte: Acervo do autor, 2009.
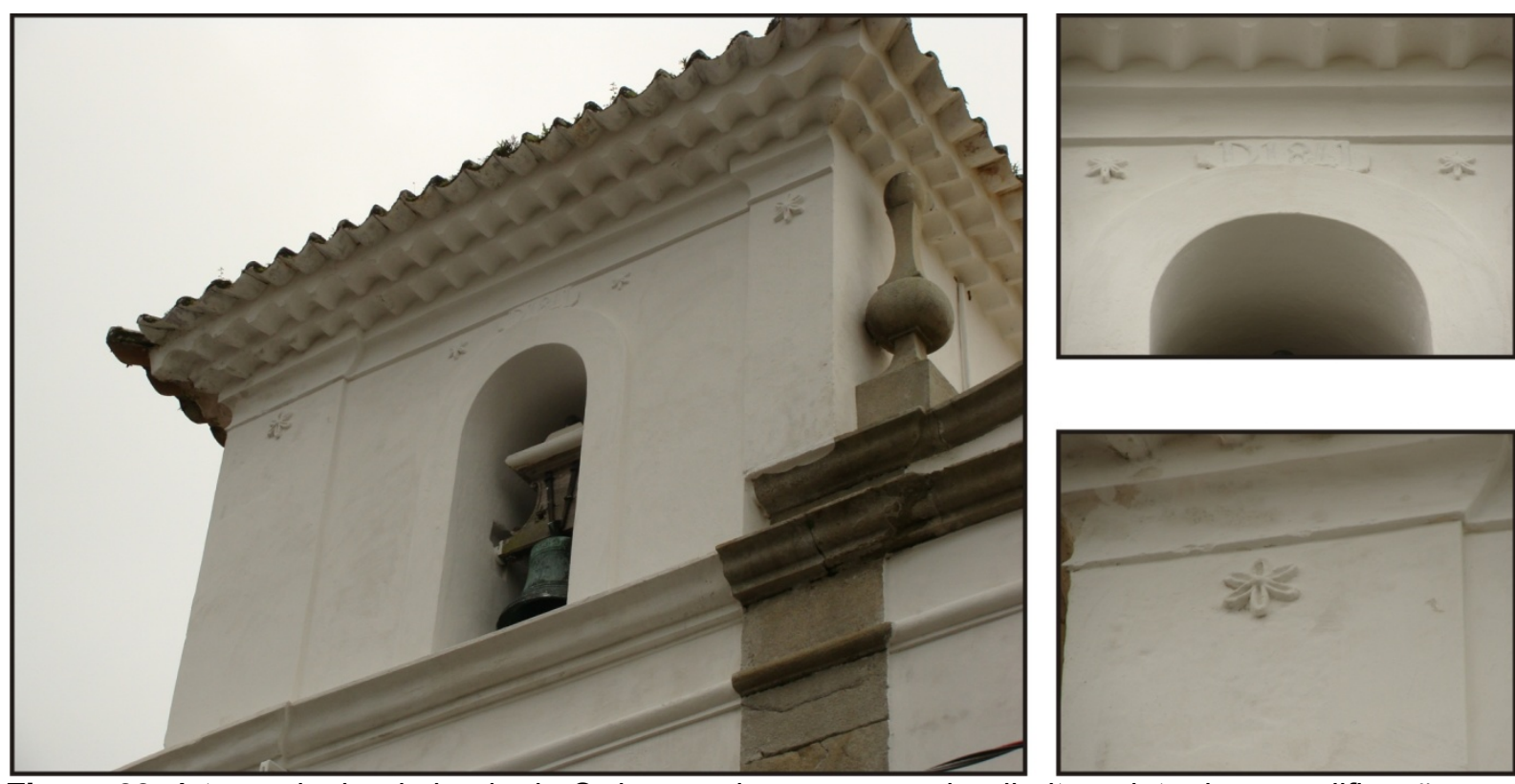

Figura 23. A torre sineira da igreja da Ordem, na imagem superior direita a data de sua edificação. Fonte: Acervo do autor, 2009.

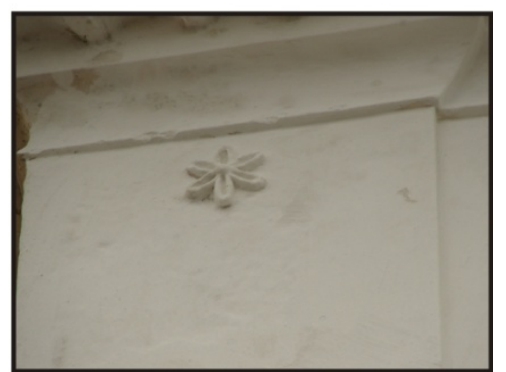




\subsubsection{A igreja de São Benedito}

O último templo, construído no século XVIII, é a igreja de São Benedito, que se situa no local onde antes estava a igreja das Mercês, demolida para a sua construção, no centro focal da rua Conselheiro Sinimbú, nas proximidades da Fonte da Gambôa.

A irmandade de São Benedito já atuava em Paranaguá desde o século XVII e estava sediada na igreja Matriz, com o nome de Nossa Senhora do Rosário dos Pretos. Posteriormente a Irmandade ficou sediada, em data desconhecida, na igreja das Mercês, o que pode ter ocorrido após a saída dos jesuítas, que utilizaram a igreja das Mercês, enquanto o edifício do Colégio estava em fase final de construção. (VIEIRA DOS SANTOS, 2001)

No ano de 1783, a Irmandade reunida na igreja Matriz, fez os acertos com o mestre pedreiro Matias Gomes, "[...] para dar começo às obras da nova capela de S. Benedito, conforme o risco que ele apresentou da mesma igreja, sacristia e campanário, ajustando a Irmandade com ele de a fazer a dita obra, por empreitada [...]".(VIEIRA DOS SANTOS, 2001, p. 174)

Também ficaram acertados com Matias Gomes, os materiais para a obra, que seria dividido com a Irmandade que daria parte das pedras, cantaria e cal. Existe um indício de que parte da estrutura da antiga igreja das Mercês fosse aproveitada na obra da igreja de São Benedito, quando Vieira dos Santos (2001, p.174) cita que a Irmandade "[...] daria mais em adjutores [ajuda] as paredes velhas que estavam junto à capela". O que poderia ser lido como o aproveitamento do material destas paredes, ou da própria parede, para a nova construção. Existe a possibilidade de 
que algumas das paredes da igreja de São Benedito (Figura 24 e Figura 25) possam ser as antigas estruturas da igreja das Mercês, do começo do século XVIII.

Vieira dos Santos (2001, p.174) descreve essa igreja da seguinte forma:

[...] feita de cantaria ao gosto mais moderno, com altura proporcionada à sua largura, seu frontispício não é desairoso, sua porta principal é larga com os umbrais de cantaria lavrada, bem como as duas portas travessas e duas janelas do coro; sua sacristia é pequena, mais airosa. Ornam esta igreja dois altares, o mor em que está colocada a imagem de São Benedito, orago da igreja e da Irmandade, e outra imagem antiga de Nossa Senhora do Rosário dos Pretos; o seu recatubo é feito à moderna, bem como a tribuna e o forro da capela-mor é pintado com gravuras e flores e quatro grandes anjos nos 4 ângulos dele. O outro altar colateral da parte do evangelho, nele está colocada a antiqüíssima imagem de Nossa Senhora das Mercês, que esteve na demolida capela da Ilha da Cotinga.

Seu frontispício "à moderna" é semelhante à igreja da Ordem Terceira de São Francisco das Chagas: temos o frontão sinuoso, o mesmo desenho do óculo central, as duas janelas superiores, a porta principal e os cunhais em cantaria, que foram rebocados em intervenções recentes. Mas no caso da igreja da Ordem este trabalho é mais apurado, nas aplicações em cantaria, tanto das janelas como das cimalhas mais delgadas.

Na igreja de São Benedito, como também ocorreu na igreja da Ordem, a torre sineira foi construída posteriormente, no século XIX. No caso da última a torre foi finalizada em 1862. Segundo a notícia do jornal Commercio do Paraná5:

Devido aos esforços do digno thesoureiro da irmandade de S. Benedicto, o Sr. José Gonsalves Lobo, se acha concluída a torre. O Sr. Francisco José de Souza e sua Exm. ${ }^{\text {a }}$ Sra. como juíza da festa vindoura, franquearão a sua bolsa para coadjuvação de uma obra tão meritória.

\footnotetext{
${ }^{5}$ Commercio do Paraná. A Torre de S. Benedicto. Commercio do Paraná, 15 nov. 1862, p 1.
} 

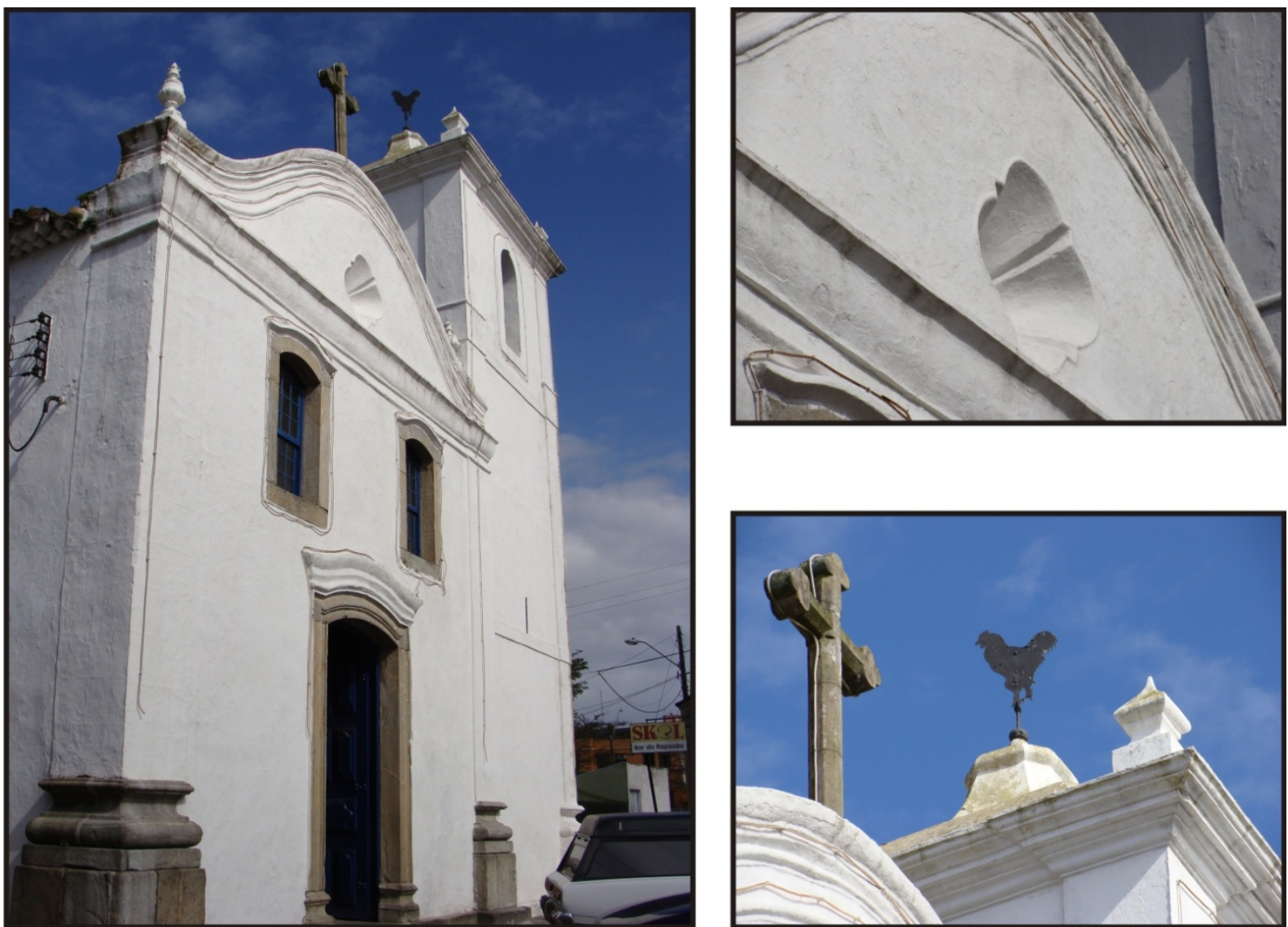

Figura 24. A igreja de São Benedito e alguns de seus detalhes.

Fonte: Acervo do autor, 2009.
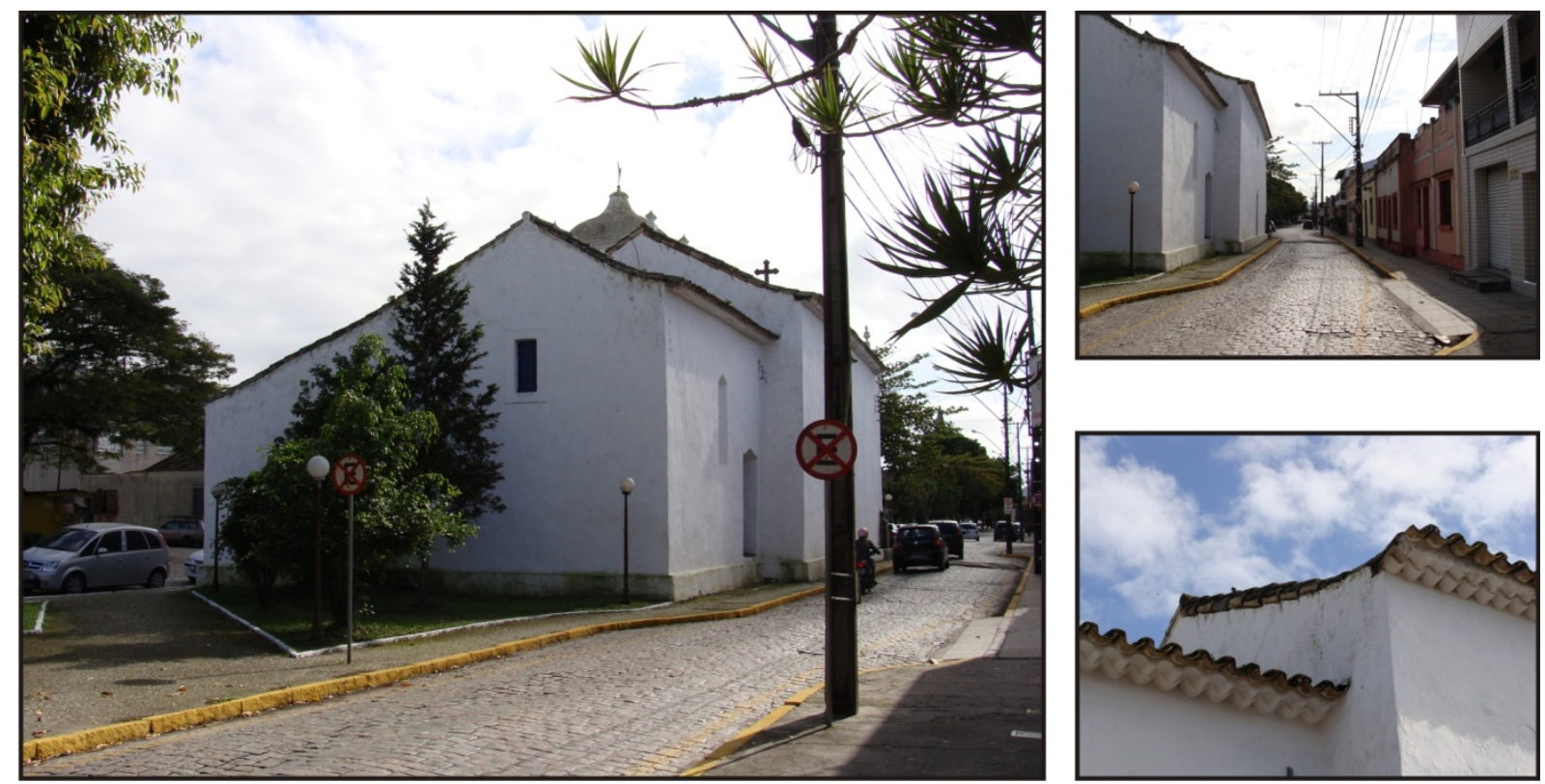

Figura 25. Fundos da igreja de São Benedito.

Fonte: Acervo do autor, 2009.
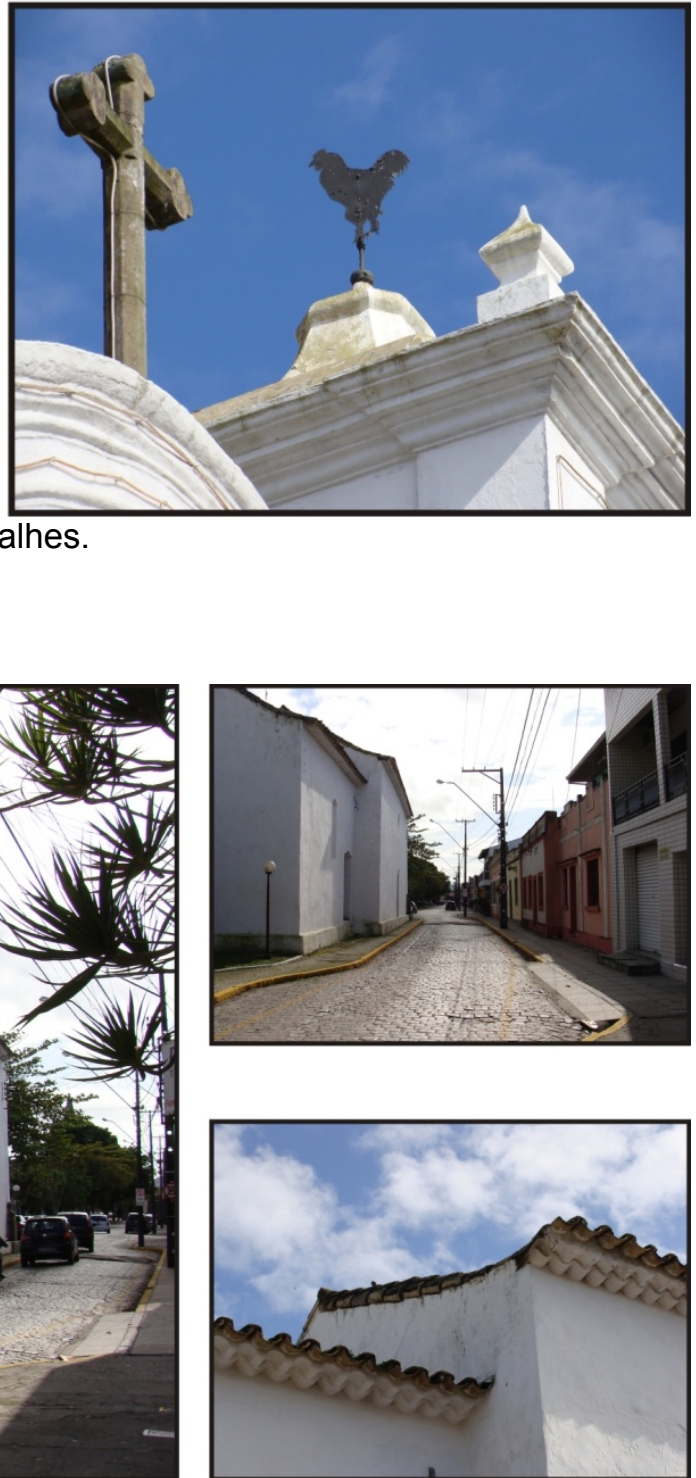


\subsubsection{A igreja Matriz}

A solução plástica aplicada na igreja da Ordem Terceira e na de São Benedito, influenciadas pelo barroco, foi também utilizada em escala maior nas reformas da igreja Matriz, a primeira construída na vila de Paranaguá. A solução barroca foi aplicada nessa fachada, que possui um frontão sinuoso, da mesma forma que as fachadas das igrejas de São Benedito e da Ordem Terceira, e o mesmo desenho de óculo. Já os pináculos, que margeiam as duas extremidades desta igreja, são semelhantes aos encontrados na igreja da Ordem.

É possível que a configuração predominante no frontispício da igreja Matriz (Figura 26), seja do período anterior ou posterior à construção da igreja da Ordem Terceira. Algumas características semelhantes podem ser observadas entre essas duas igrejas, além dos pináculos e do óculo quase idênticos, temos também semelhanças no desenho do frontão curvo que é mais acentuado e mais alto, como também é o caso da igreja da Ordem. Na de São Benedito, a curvatura do frontão é mais tênue. Outra característica semelhante são as cimalhas que delineiam o frontão, sendo uma de maior dimensão na borda e outra interna ao corpo do elemento, acompanhando sua curvatura.

Mais alguns dados sobre a igreja podem ser retirados da descrição de Vieira dos Santos no seguinte trecho:

Esta antiga igreja foi feita de pedra de cantaria e alvenaria tem de frente 70 palmos de largura e de 140 a 150 palmos de comprimento, o interior do corpo da igreja he de 60 palmos de largura e da porta principal ao Arco cruzeiro 110, e o restante da capella mor. O frontispício no seu exterior, feita ao gosto antigo he despido de ornatos d' architectura, contem somente a porta principal, alta e boa largura, três janellas rasgadas no lugar do côro para darem claridade o arremate do frontispício, he hua elevação arrendondada e a cruz em cima e dois esses que finalizão no cimo das paredes lateraes, estas são algua couza baixas em proporção ao 
comprimento da igreja não tem tribunas e sim duas frestas em cada hua a darem claridade ao corpo da igreja, como igualmente há na capella mór outras duas frestas envidraçadas na parede e do lado do Evangelho. (VIEIRA DOS SANTOS, 1850, p.38)
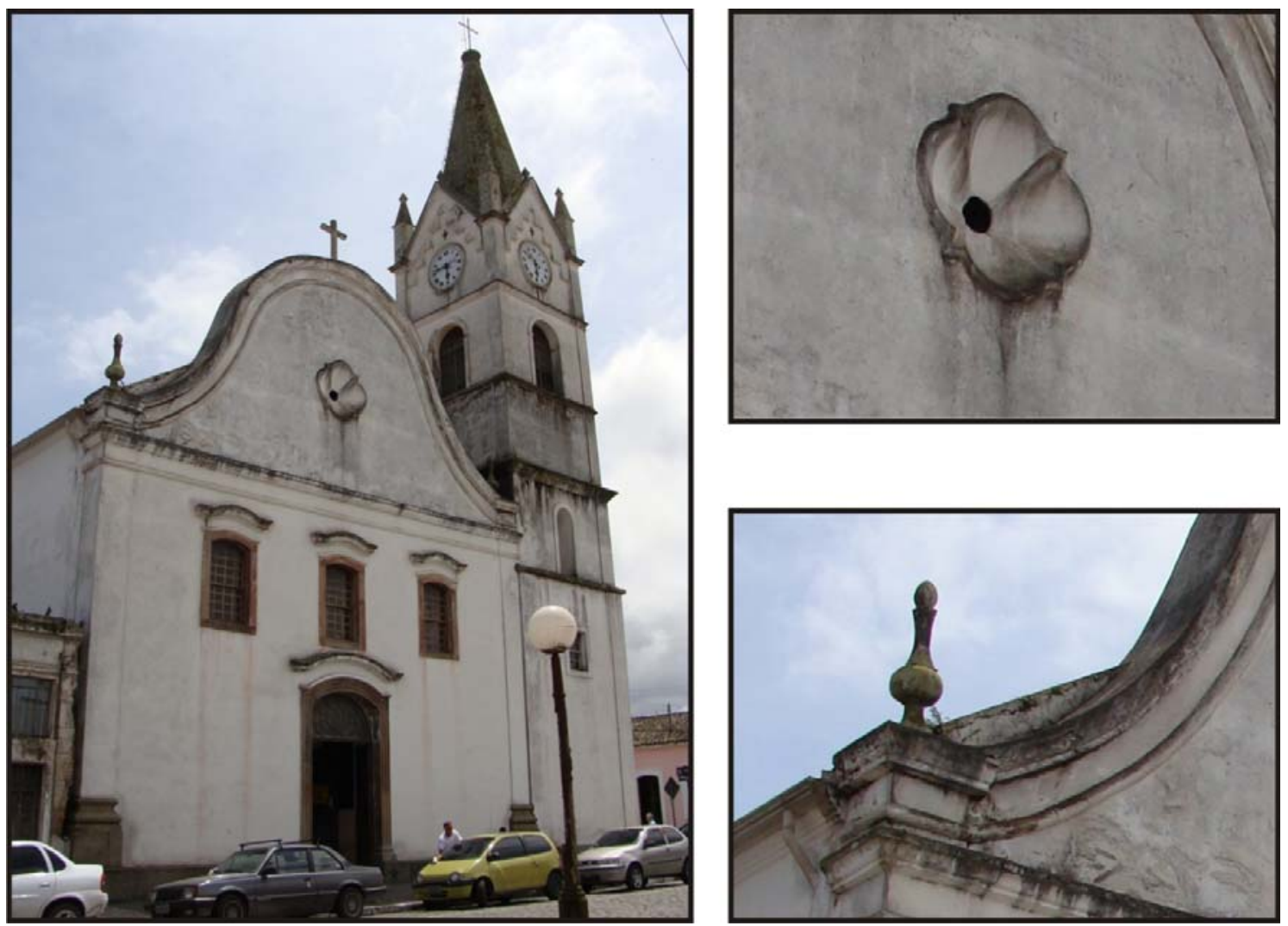

Figura 26. Matriz de Paranaguá.

Fonte: Acervo do autor, 2009.

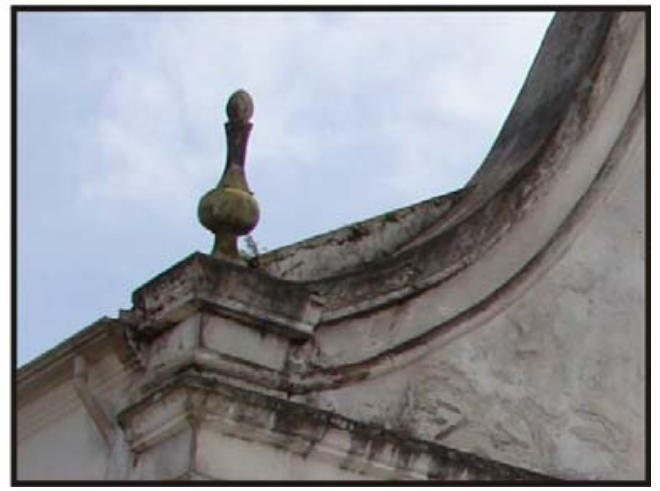

Desta descrição surge uma dúvida: Vieira dos Santos considera a fachada deste edifício "feita ao gosto antigo", poderíamos concluir que ele descrevia uma antiga configuração da Matriz, mas depois tratando de seu frontão, o autor relata que ele possuía a forma de "dois esses que finalizam no cimo das paredes laterais", referência ao frontão barroco ainda existente na fachada da igreja.

Mas quando o mesmo autor descreve as igrejas da Ordem Terceira e de São Benedito, ele considera estas fachadas de "gosto mais moderno", mas as duas são semelhantes à fachada da igreja Matriz. Qual seria o motivo desta consideração? Um engano de Vieira dos Santos? 
A Matriz adquiriu em suas reformas características barrocas antes da igreja da Ordem? Ou a igreja da Ordem foi uma fonte plástica para a reforma da igreja Matriz? Vieira dos Santos (2001) relata que desde 1661 foram encontrados nos autos do Conselho dados sobre reformas da igreja, a segunda grande reforma ocorreu em 1723 e 1733, sem especificações do que foi executado.

Em 1741 "[...] se fez o conserto nela e a Câmara tratou de a mandar forrar, cuja obra foi arrematada pelo mestre carpinteiro João da Silva, pela quantia de $500 \$$ mil réis; e então se fez novo encaibramento, retificação em toda a igreja." (VIEIRA DOS SANTOS, 2001, p. 43)

Outros dados relatam sobre um novo encaibramento geral, no corpo da igreja em 1804. Em 1839, foi reedificada a capela-mor, e nenhuma das referências encontradas comenta-se sobre reformas ou alterações na fachada deste edifício.

A desproporção da igreja Matriz em relação ao seu campanário pode ser identificada em uma das únicas fotografias (Figura 27) em que a torre sineira aparece em seu aspecto original, mais baixa que o frontão. A imagem de 1890 demonstra que existia a divergência destes dois elementos, e isto só seria corrigido no começo do século $X X$, quando a torre sofreu um aumento e perdeu suas características, com a aplicação de uma cobertura triangular em forma de agulha.

Vieira dos Santos (2001, p. 46, vol.II) escreveu como se configurava o campanário em 1850: "A torre deste templo é de baixa altura e pouca excede às paredes do corpo da igreja feita ao gosto antigo, arrematada por uma abóboda e três sineiras, todas de pedra de cantaria lavrada e nelas 3 sinos [...]."

Portanto podemos afirmar que a fachada da igreja Matriz carrega características de meados do século XVIII, quando são construídas igrejas de influência barroca na vila de Paranaguá. 


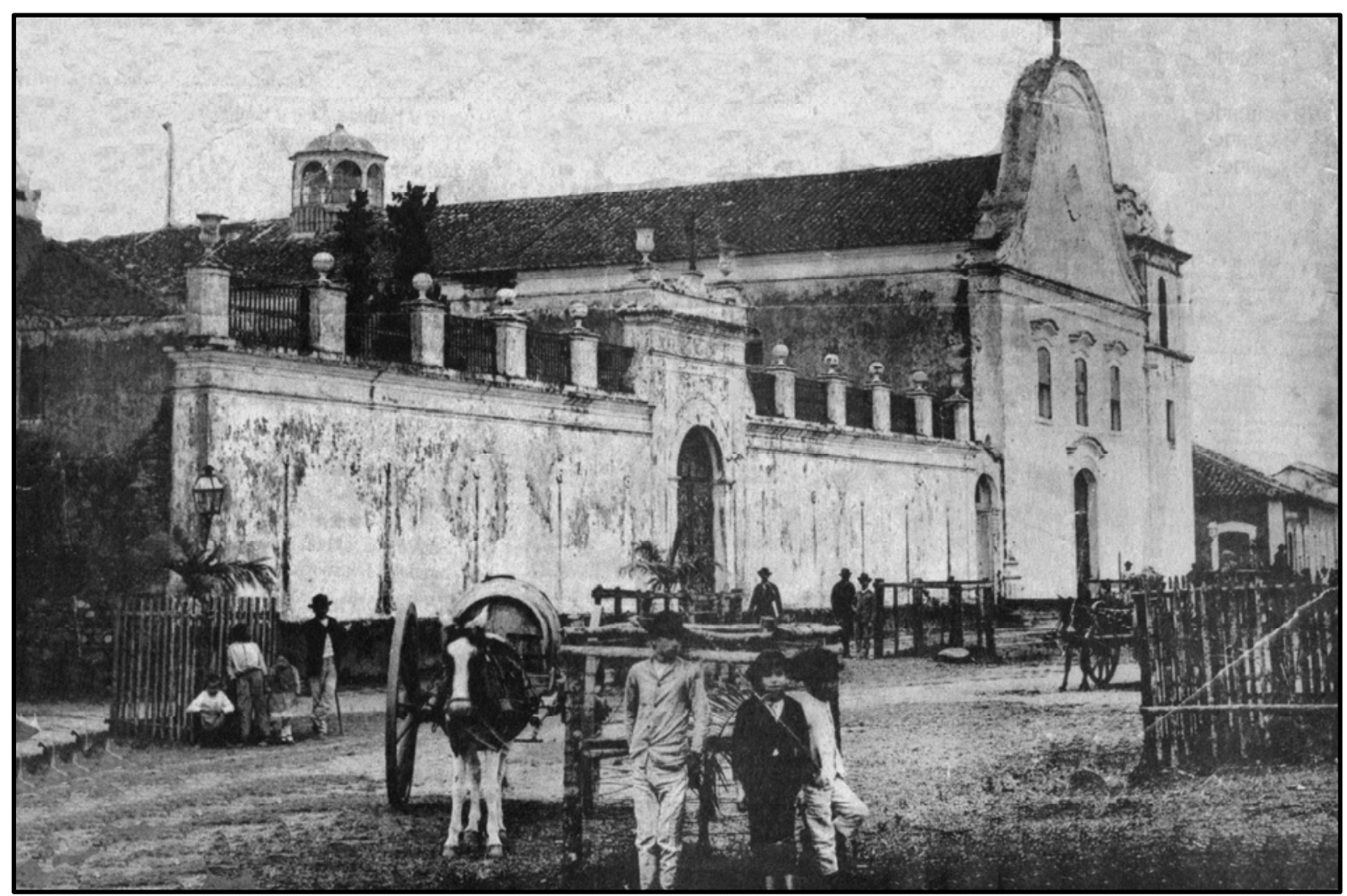

Figura 27. A Matriz nos anos de 1890.

Fonte: Instituto Histórico e Geográfico de Paranaguá

Neste processo de urbanização da vila de Paranaguá no século XVIII, temos como fatos importantes a formação do vilarejo no continente, ainda no século anterior, e posteriormente a Correição realizada em 1720 que delineou o crescimento de Paranaguá durante aquele século.

As suas igrejas, em grande parte construídas naquele período, determinaram em conjunto com as normativas estabelecidas pelo Ouvidor, a direção pela qual Paranaguá cresceu até o final do século XIX, sendo este o momento definitivo em que se estabeleceu a ocupação do rio Itiberê e a inserção do porto dentro deste vilarejo, tornando-se elemento importante nas dinâmicas urbanas da Paranaguá oitocentista. 


\subsection{CONSTRUÇÕES CIVIS NA VILA DE PARANAGUÁ}

As construções edificadas na vila de Paranaguá, entre os séculos XVII e XVIII, são identificadas a partir de dois momentos distintos; momentos nos quais caracterizamos através das análises in loco. Essa análise partiu dos métodos construtivos empregados nos edifícios da vila, que sofreram uma mudança a partir das determinações do Ouvidor Rafael Pires Pardinho. No capítulo anterior, discutimos a vinda do Ouvidor à Paranaguá e de sua Correição. Em um dos tópicos desse documento, Pardinho relatou sobre o grande número de residências construídas em pau-a-pique, pois a ilha da Cotinga, fonte de materiais de construção, estava sob posse de um proprietário particular, impedindo a entrada dos habitantes da vila. Portanto, através desses relatos, temos a Paranaguá do início do século XVIII, caracterizada por construções em pau-a-pique.

O único remanescente desta técnica construtiva, que encontramos atualmente na cidade de Paranaguá, é uma casa de esquina com telhas de capa e canal e janelas em canga de madeira (Figura 28 e Figura 29), localizada na rua Antônio Vieira dos Santos, antiga Rua do Fogo, ou seja a primeira rua da vila. Em algumas lacunas desta construção é possível perceber como foi executada a obra, sendo utilizados esteios de madeira e varas de taquara amarradas com cipó, material muito comum na região (Figura 30 e Figura 31). O barro está misturado com a cal, resultante da trituração dos sambaquis, que podem ser identificadas em pequenas amostras encontradas no local, contendo pedaços de conchas misturadas ao barro das vedações. 


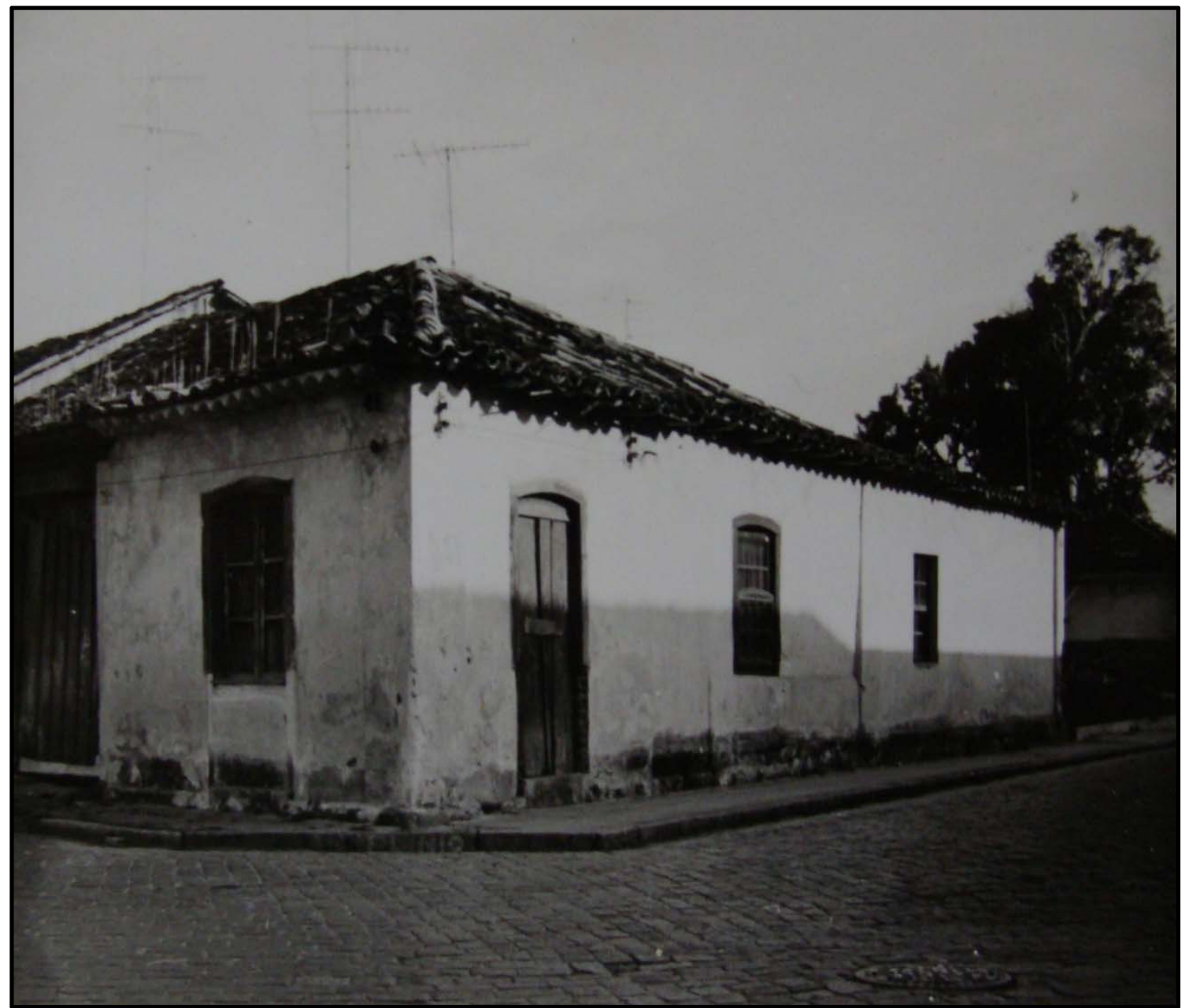

Figura 28. A casa de pau-a-pique em 1966, vista da rua Vieira dos Santos. Fonte: Kava, 1966; Acervo da Coordenadoria do Patrimônio Cultural do Estado do Paraná.
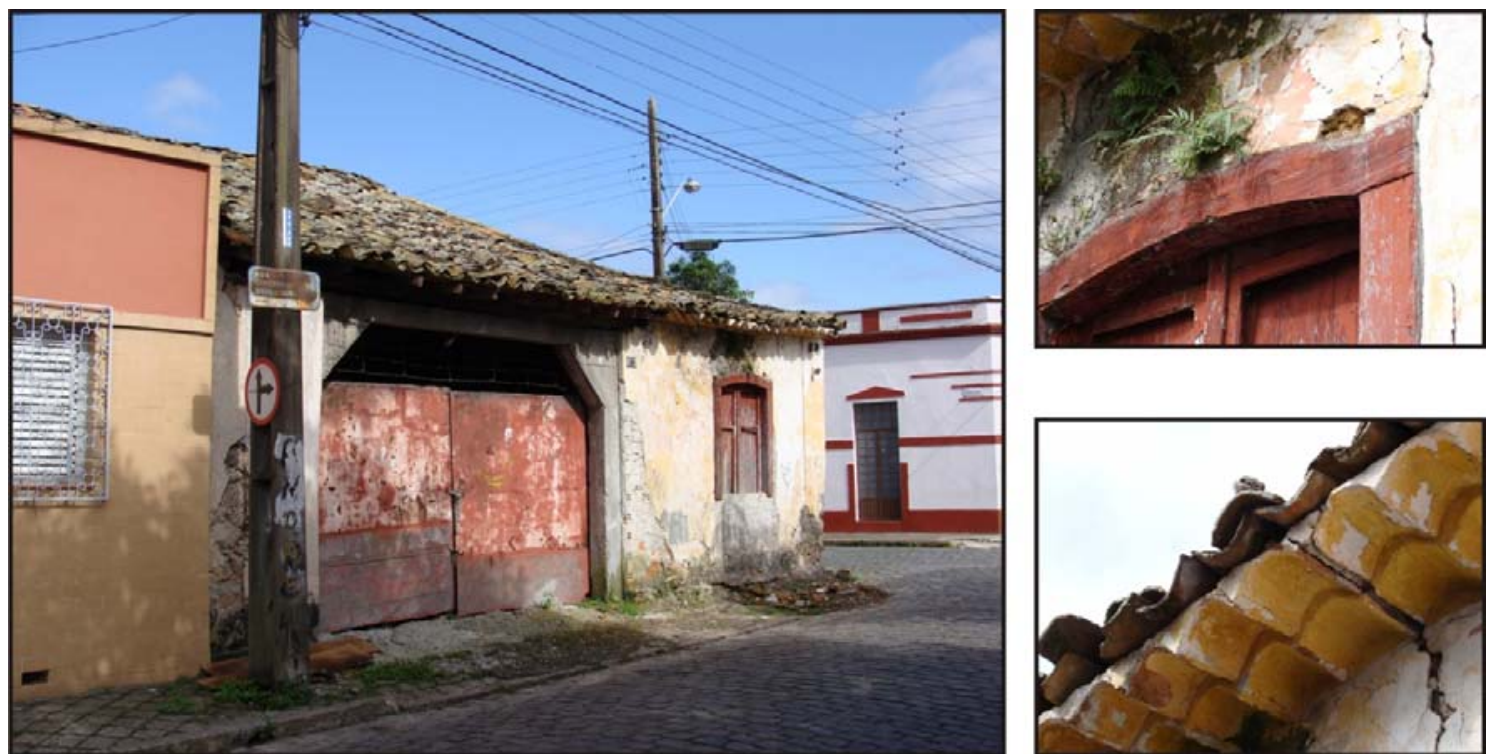

Figura 29. Último remanescente de construção em pau-a-pique, localizado na rua Vieira dos Santos, nota-se as vergas em madeira e o detalhe da beira seveira.

Fonte: Acervo do autor, 2009. 

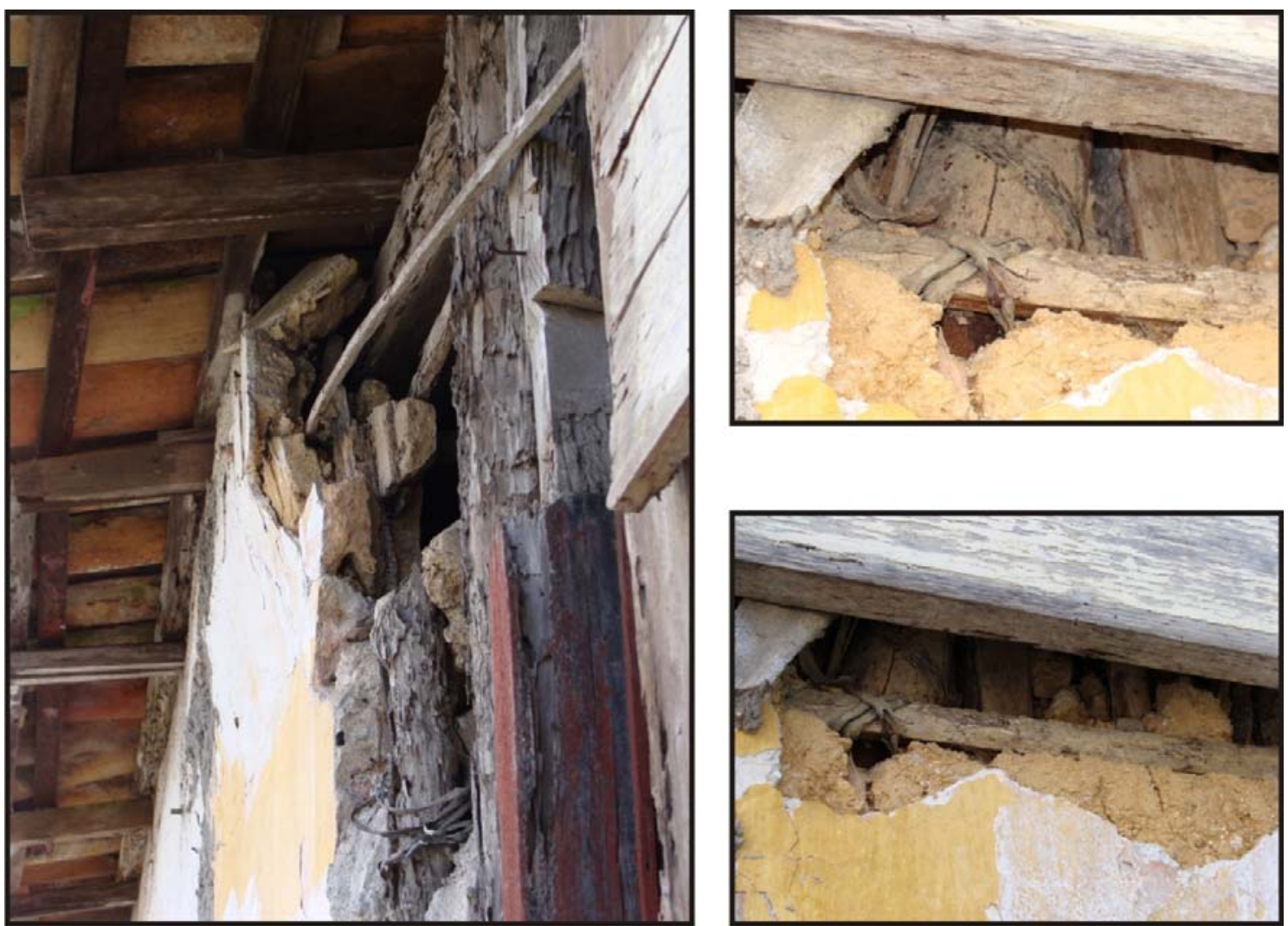

Figura 30. Lacunas existentes na casa localizada na rua Vieira dos Santos, em detalhe a amarração das taquaras com cipó.

Fonte: Acervo do autor, 2009.

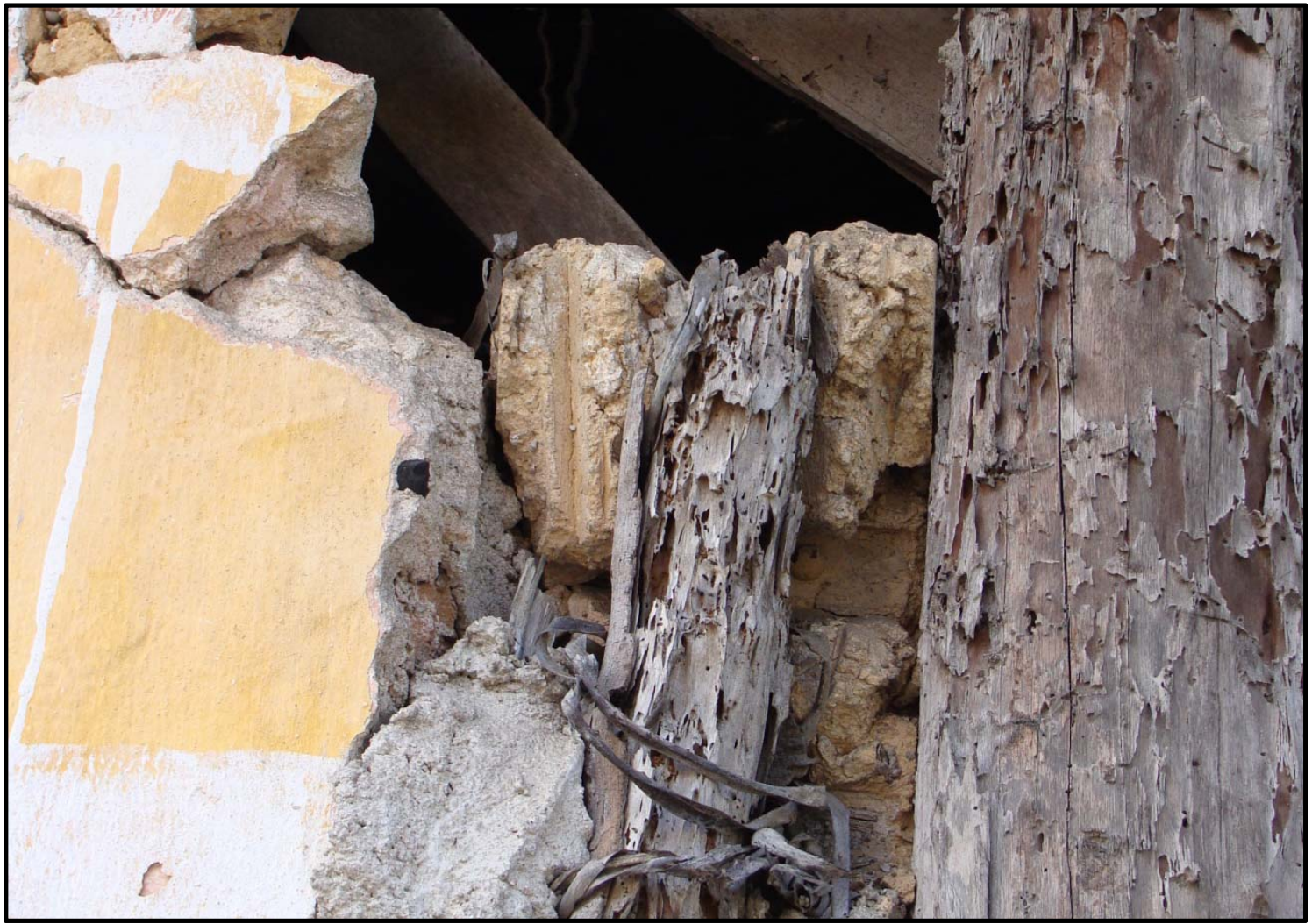

Figura 31. Detalhe da amarração das taquaras e da massa de argila. Fonte: Acervo do autor, 2009. 
Após a construção da trama em taquara e madeira, "[...] é o barro jogado e apertado sobre ela, trabalho que se faz, apenas com as mãos, sem o auxílio de qualquer ferramenta, o que tornou este sistema conhecido pelo nome de pescoção, tapona ou sopapo." (VASCONCELLOS, 1979, p. 45).

Apesar dos distintos métodos construtivos, essas residências de pau-a-pique se assemelham, nas suas fachadas, as construções de pedra, encontradas na cidade. Observa-se, no caso dessa residência, que ela possui verga curva em madeira, com desenho semelhante aos quadros das construções em pedra, assim como o beiral com beira-seveira que projeta-se à frente da casa, comum nos dois métodos construtivos.

Com a mudança nos aspectos construtivos, principalmente após as determinações de Pardinho, percebemos a utilização da pedra na estrutura das residências. Em análises realizadas no local, observamos que as estruturas em pedra eram unidas através de uma mistura de cal, obtida através da trituração de conchas retiradas dos sambaquis com a argila da ilha da Cotinga, semelhante à massa utilizada nas construções de pau-a-pique. Esse material foi utilizado não só como argamassa para estruturar as vedações, ligando as pedras, mas também como reboco, que posteriormente era caiado. Esses aspectos construtivos podem ser observados em antigas construções, através de suas lacunas ou em edifícios em ruínas, atualmente encontrados na cidade de Paranaguá.

Com a predominância na utilização da pedra nos processos construtivos da vila de Paranaguá, foi possível encontrar outra diferença entre essas estruturas. Essa diferença localiza-se nos quadros de portas e janelas, que possuem diferentes métodos construtivos. Uma das técnicas veio através da utilização da cantaria e a outra com a utilização do tijolo maciço. Nota-se que as construções mais relevantes 
da vila: sobrados e edifícios religiosos, foram construídos com portas e janelas possuindo seus quadros em cantaria, enquanto a maior parte das edificações parnanguaras possui seus quadros de portas e janelas empregados com tijolos maciços.

$\mathrm{Na}$ utilização da cantaria em construções parnanguaras, temos em um primeiro momento, essas estruturas entalhadas como peças autônomas, caracterizadas por vergas retas, que formavam blocos maciços de pedra. Os blocos eram assentados da seguinte forma: as vergas possuíam a largura da janela e em suas extremidades eram ligadas aos umbrais que descarregavam os esforços ao peitoril, método também empregado em estruturas de madeira. Percebe-se um aspecto peculiar na obra dos jesuítas, logo abaixo das janelas encontra-se uma grande laje de pedra (Figura 32), unida com o peitoril, que possibilita a colocação das conversadeiras na parte interna dos rasgos dos vãos das janelas, este recurso, denominado janela com avental, pode ser observado no claustro do colégio e poderia ter sido utilizado nas construções civis encontradas na vila.

No caso das residências desse período, que podemos considerar até a metade do século XVIII, as portas e janelas são constituídas por pedras de seção quadrada assentadas para formar o quadro, de forma simples sem nenhum tipo de entalhe decorativo. Pouquíssimos sobrados são encontrados com estas características na cidade de Paranaguá. Um exemplo está situado na esquina das ruas Pecego Junior e Professor Cleto (Figura 33). Este sobrado pode ser contemporâneo ao Colégio dos Jesuítas, possui baixa altura, cunhal em cantaria com trabalho apurado (Figura 34), e portas e janelas em estrutura de pedra, que aparentemente são de granito. 


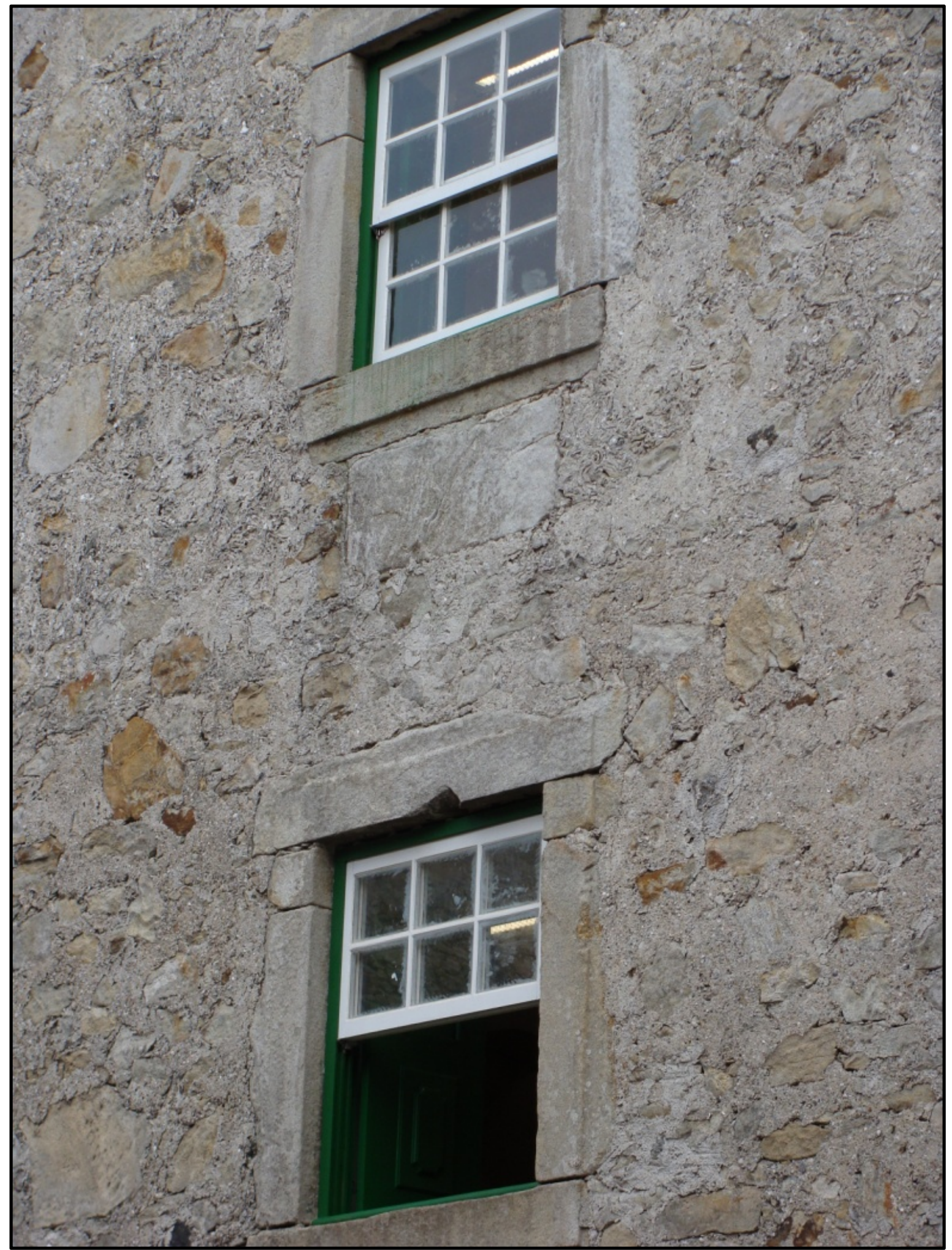

Figura 32. Quadro de janela em pedra situado no claustro do Colégio, observa-se abaixo do peitoril a laje de pedra, também denominada janela com avental.

Fonte: Acervo do autor, 2009. 

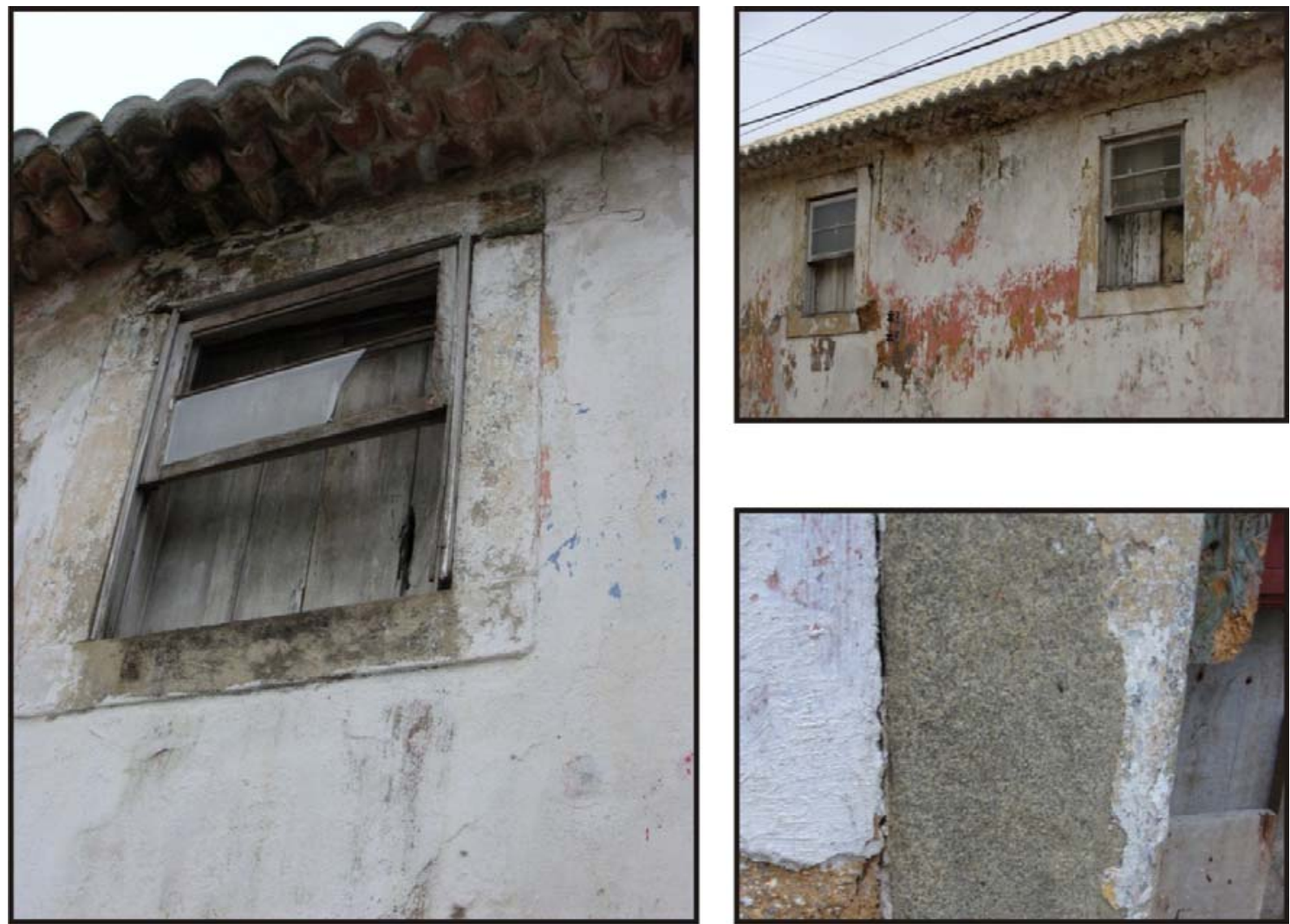

Figura 33. Sobrado situado na rua Pecego Junior, detalhe de sua janela em cantaria, semelhante à encontrada no Colégio dos Jesuítas.

Fonte: Acervo do autor, 2009.
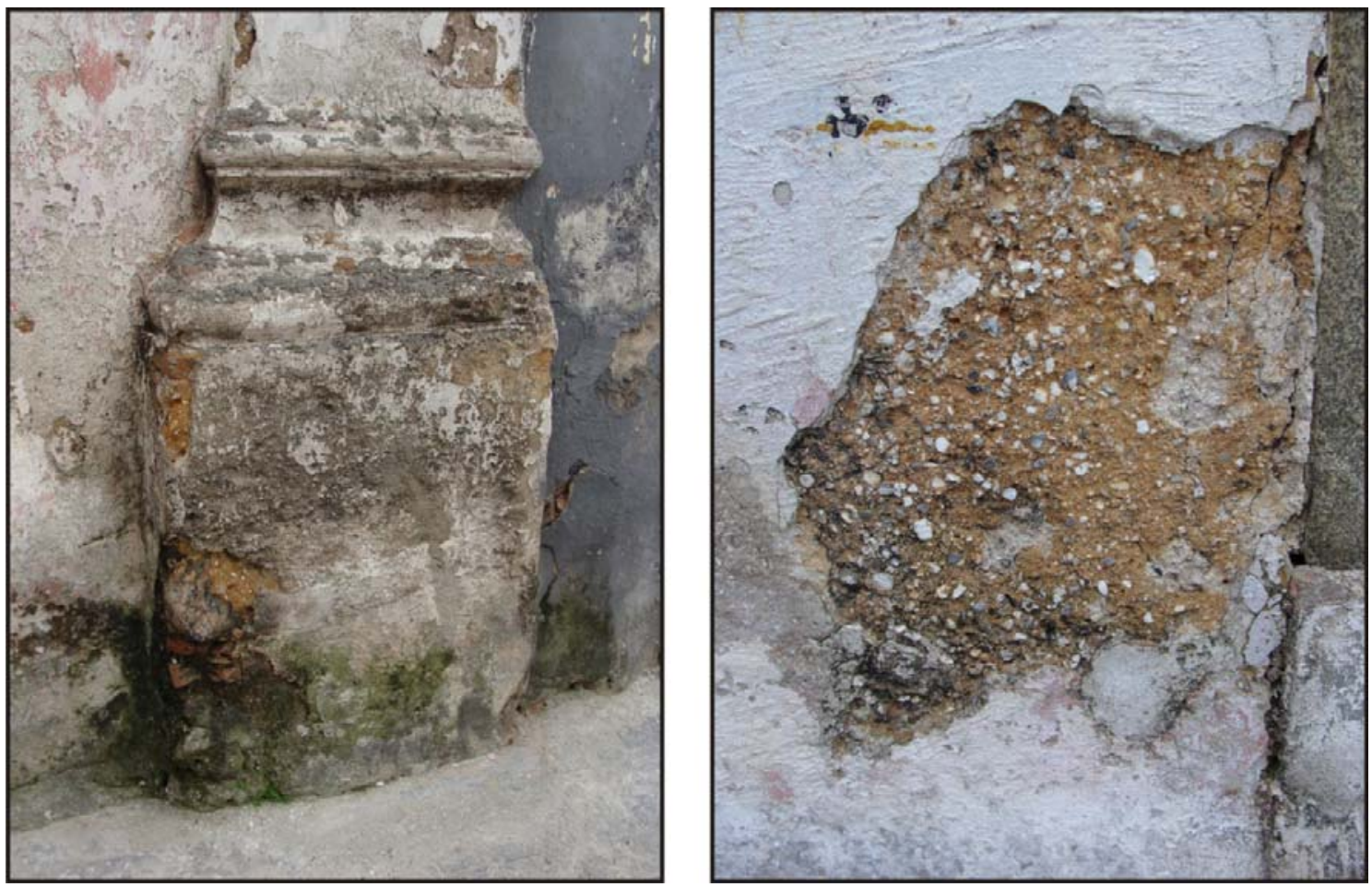

Figura 34. Detalhe do cunhal em cantaria e do revestimento em argila e cal, encontrado no sobrado da rua Pecego Junior.

Fonte: Acervo do autor, 2009. 
Após a metade do século XVIII, observa-se a utilização das portas e janelas em canga ou verga arqueada $^{6}$, possível influência pombalina e de Alpoim e suas construções em Minas Gerais, como o Palácio dos Governadores (LEMOS, CORONA, 1972), e a tendência do maior dimensionamento dessas estruturas. Apesar disso, as técnicas construtivas são mantidas. Exemplos dessas mudanças são o sobrado e a casa existentes no largo da Matriz (Figura 35), estes dois edifícios, provavelmente, formavam um único corpo térreo ou duas casas térreas independentes. Percebe-se no sobrado que, os quadros inferiores são em cantaria e os superiores imitam seu desenho, através da aplicação do revestimento de massa que cobre a estrutura das vergas e umbrais (Figura 36), indicando que esses quadros foram construídos com tijolos maciços.

Percebemos pelas visitas ao local, que a utilização dos tijolos maciços, nas estruturas dos vãos de portas e janelas, foi a técnica mais difundida na vila de Paranaguá. Sua utilização no enquadramento dos vãos possibilitou a amarração dessa estrutura, trazendo o mesmo efeito estrutural das peças de cantaria. Esses tijolos são encontrados em diversas residências do período Colonial em Paranaguá, e somente utilizados nas estruturas dos quadros, não sendo aplicadas nas estruturas das paredes, provavelmente pelo alto custo deste material no período.

Durante os levantamentos realizados na cidade de Paranaguá, encontramos duas tipologias de tijolos: a primeira possui semelhança com o tijolo de adobe, de tom amarelado, mas que deve ter sofrido algum processo de cozimento. Sua espessura é de 2,5 centímetros e sua dimensão é de aproximadamente $15 \times 13$ centímetros, ocorrendo variações.

\footnotetext{
6 "Em meados do século XVIII e no início do século XIX, as casas passaram a apresentar janelas e portas com vergas arqueadas e sobrevergas, isto é, elementos decorativos acima das peças de arremate superior de portas e janelas. (REIS FILHO, 2004, p. 46)
} 


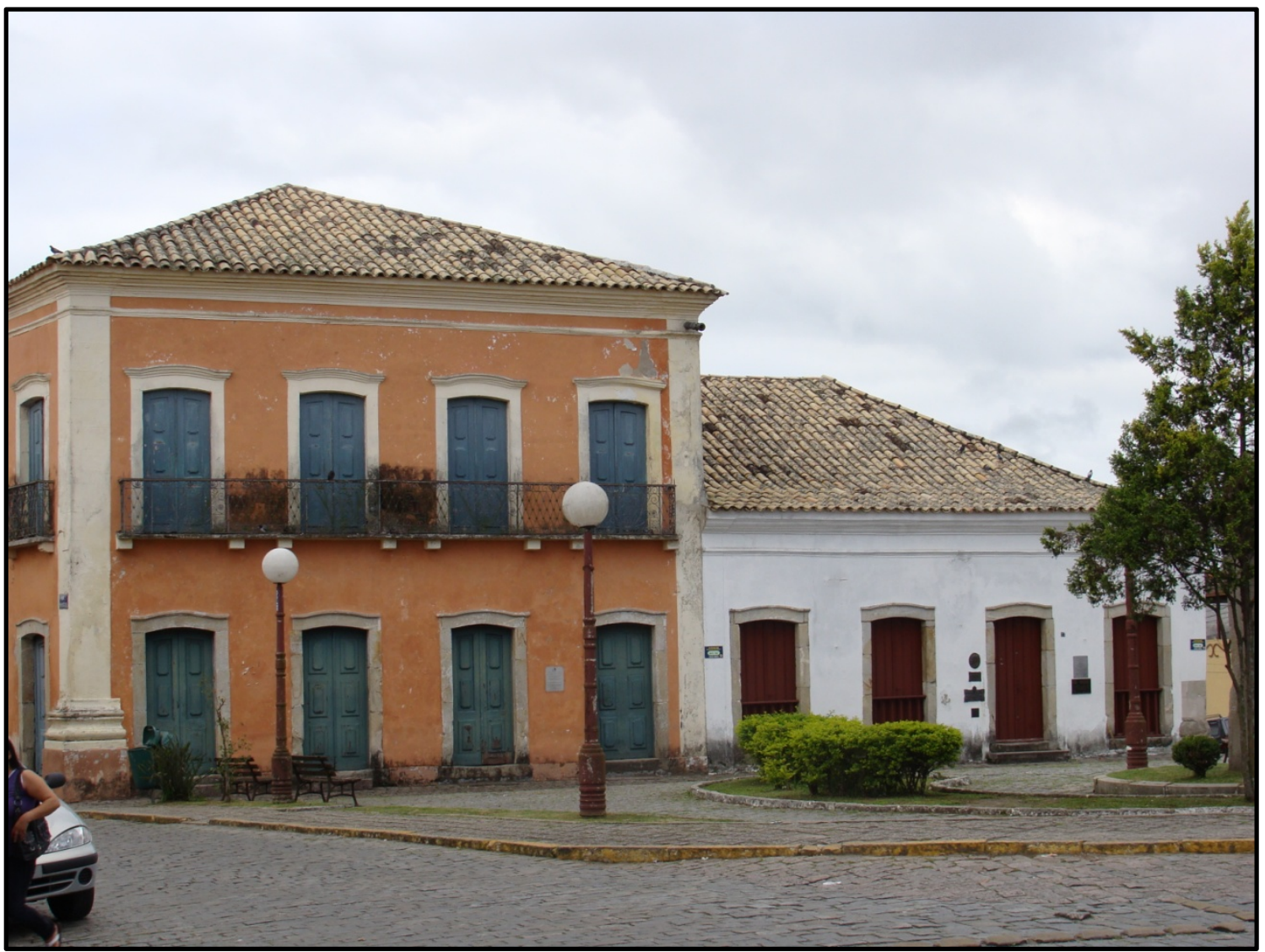

Figura 35. Casas situadas no largo da Matriz.

Fonte: Acervo do autor, 2009.
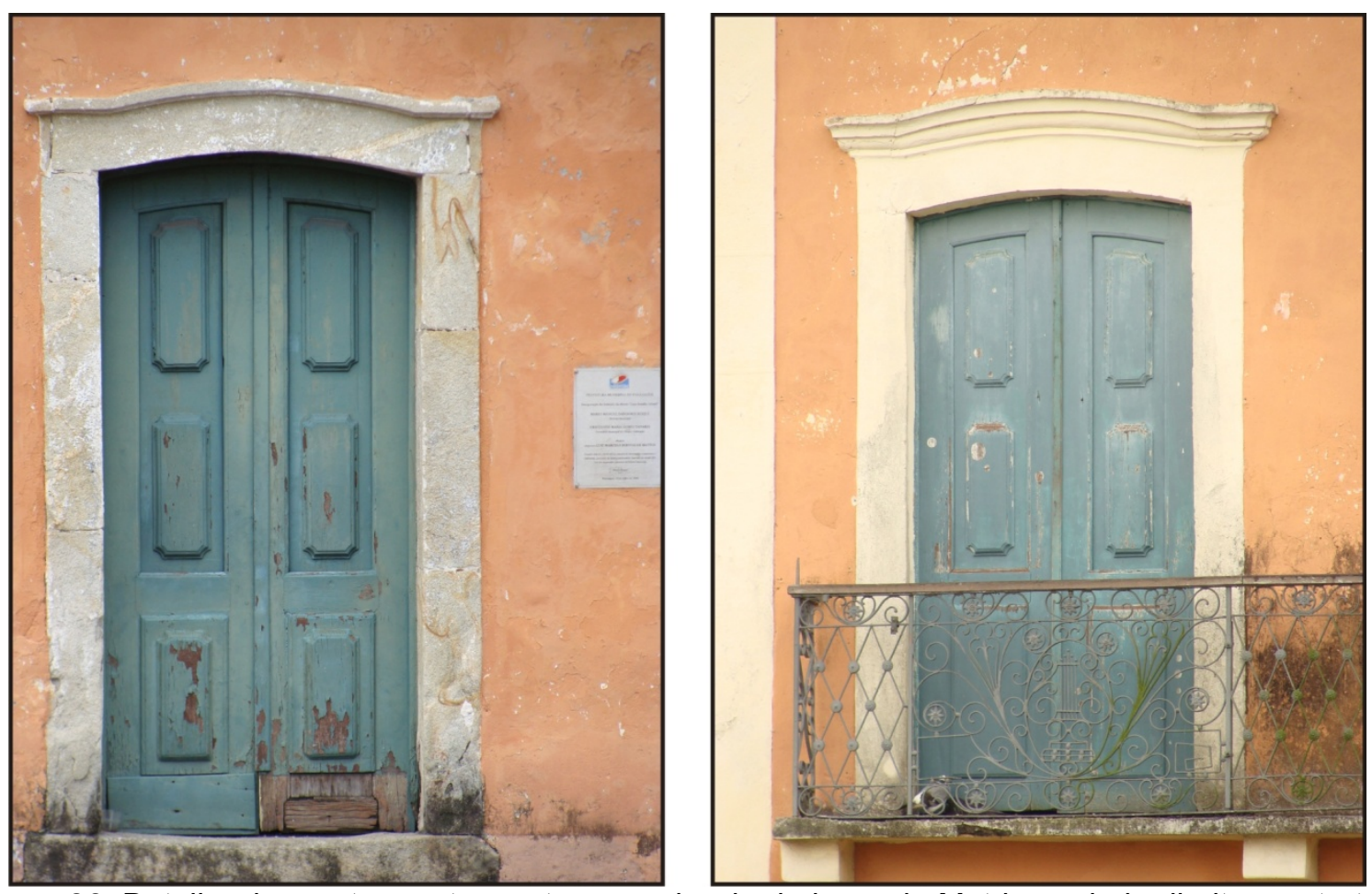

Figura 36. Detalhe das portas pertencentes ao sobrado do largo da Matriz, ao lado direito a estrutura de cantaria e ao lado esquerdo a estrutura provavelmente de tijolos.

Fonte: Acervo do autor, 2009. 
Esse tijolo possui boa rigidez e não desintegra com facilidade, aparentemente é uma mistura de argila e conchas trituradas que passou por um processo de cozimento, devido à sua rigidez. Esse material foi encontrado em uma das ruínas da rua Vieira dos Santos, a antiga rua do Fogo (Figura 37).

Provavelmente, foram as primeiras experiências com esse material na vila de Paranaguá. Portanto, os tijolos concorriam com as estruturas de cantaria, que poderiam ser recursos mais difíceis de serem obtidos, provavelmente pela dificuldade no entalhe dessas rochas, já que o granito é bastante comum naquela região ${ }^{7}$ e foi o material mais difundido nas construções das alvenarias. Percebe-se nas estruturas do Colégio dos Jesuítas, que os blocos de granito foram entalhados de modo rústico, não possuindo regularidade. Em uma das janelas do Colégio, notase a utilização de uma verga maior que a estrutura dos umbrais, este fato ilustra os indícios da falta de estrutura técnica para a confecção dessas peças (Figura 38).

Outra possibilidade é colocada por Ronald Paleare e Eloir Paleare (1973, p. 132), em seu estudo sobre a cidade de Paranaguá. De acordo com os autores:

Causa estranheza o fato de ter sido escolhido o granito, de mais difícil trabalho por lascar em curva côncava em vez do dolomito, encontrado em jazidas a poucos quilômetros da cidade, de mais fácil trabalho e lascagem plano e perfeita. A única razão para a escolha do granito em vez do dolomito, é o desconhecimento das jazidas e das propriedades do mesmo.

\footnotetext{
7 O litoral é constituído, em sua maior parte, por plagioclásiognaisses do Arqueano e granitos instrusivos do Neo-Précambriano e mais recentes. Os complexos mais antigos, fortemente dobrados, são orientados rumo $\mathrm{N} 60^{\circ}$ a $70^{\circ} \mathrm{E}$. Todavia, rochas algonquianas como quartzitos, itabiritos, filitos e calcários também participam da constituição geológica, aflorando principalmente na parte norte do litoral, no curso inferior do rio Itaqui e ao norte de Guaraqueçaba até a região limítrofe com o Estado de São Paulo. (MAACK, 1968, p. 299).
} 

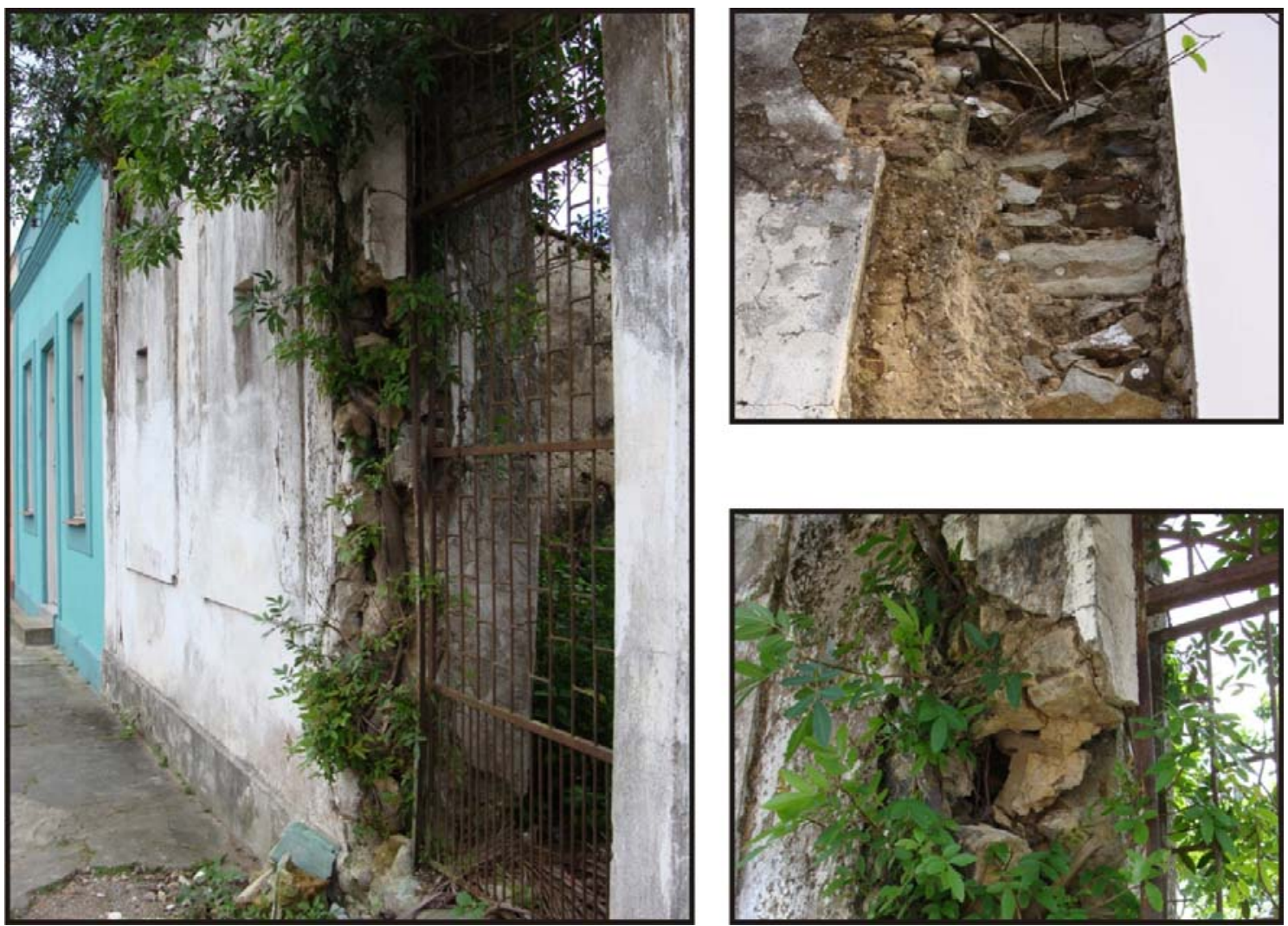

Figura 37. Ruína na rua Vieira dos Santos, onde foi encontrado o tijolo de tonalidade amarela nos quadros dos vãos da estrutura.

Fonte: Acervo do autor, 2009.
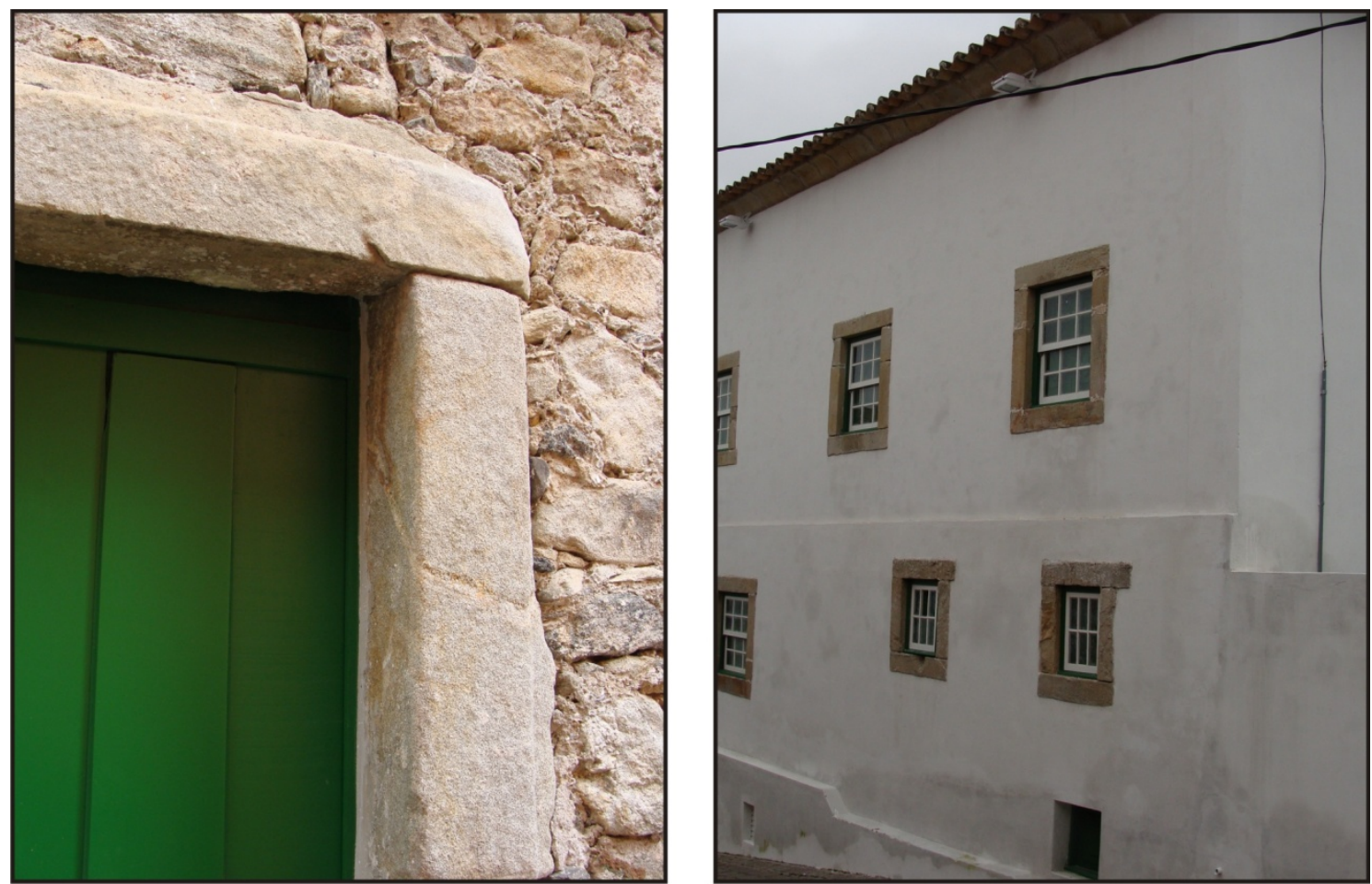

Figura 38. Detalhe de uma das portas do Colégio dos Jesuítas, percebe-se a rusticidade no entalhe da cantaria, ao lado um das janelas deste edifício com a verga desalinhada.

Fonte: Acervo do autor, 2009. 
Com a difusão do tijolo nessas construções, a técnica de confecção desse material foi se aprimorando. O segundo tipo de tijolo, encontrado em Paranaguá, tem semelhança nas dimensões com o tijolo de tom amarelado, comentado anteriormente. Nesse caso, o tijolo caracteriza-se pelo tom mais avermelhado, indício de que o material também passou pelo processo de cozimento, aparentemente de forma semelhante ao tijolo atual. Encontramos esse componente na maior parte das construções de Paranaguá: dentre as quais uma casa na rua Marechal Deodoro (Figura 39), antiga rua do Ouvidor, que está com suas paredes expostas, sem a presença de nenhum tipo de revestimento.

A aplicação construtiva dos dois tipos de tijolos é semelhante, são colocados para estruturar os quadros de portas e janelas. No caso das ombreiras, os tijolos são empilhados um em cima do outro, intercalados por uma argamassa, resultante da mistura de argila e cal obtida através da trituração das conchas. Nas vergas, o método é o mesmo, só que no sentido horizontal, ocorrendo uma pequena inclinação da fileira nas duas extremidades para formar a curva que caracterizará o vão. A estrutura de pedra das paredes margeia as vergas, umbrais e peitoril, auxiliando na estruturação dos tijolos. Depois de concluída a construção, estas fileiras são rebocadas, criando o desenho semelhante às vergas e umbrais em cantaria (Figura 39, Figura 40 e Figura 41).

A difusão desse método construtivo, não ocorreu somente no litoral, mas também foi encontrada serra acima, por exemplo, na ruína da igreja de São Francisco, localizada no Centro Histórico de Curitiba. 

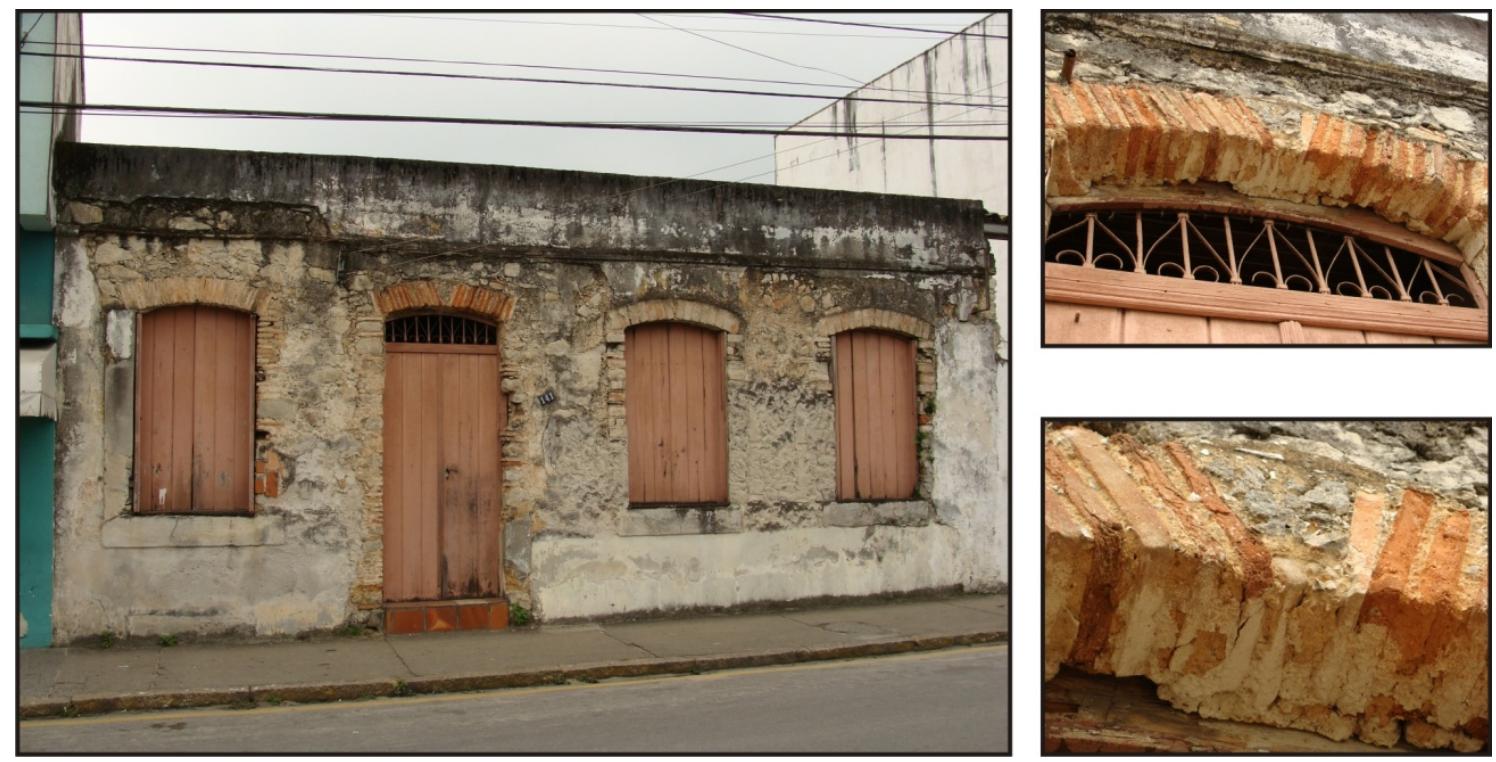

Figura 39. Casa na rua Marechal Deodoro, onde é possível perceber os tijolos assentados nas estruturas dos vãos.

Fonte: Acervo do autor, 2009.
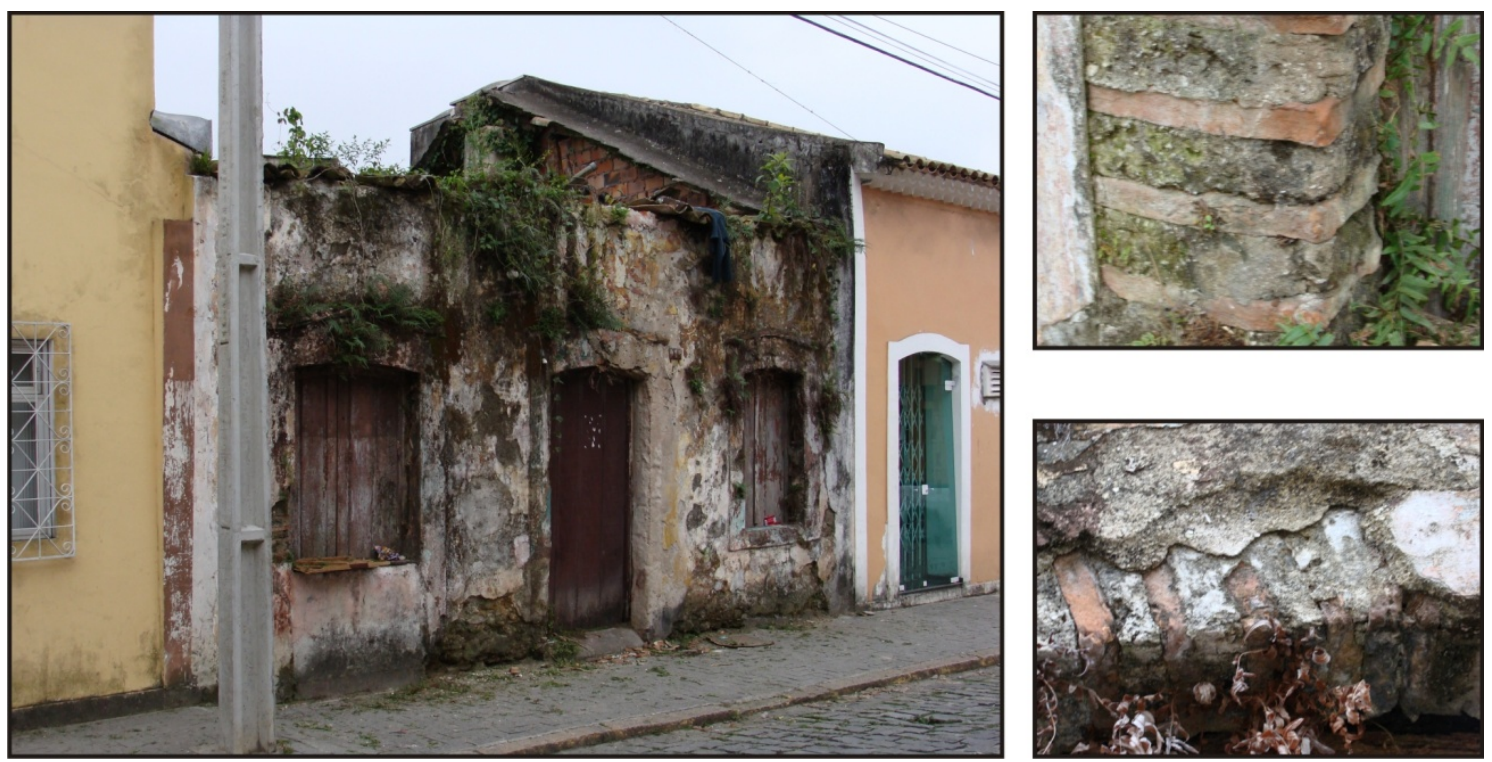

Figura 40. Ruína na rua Faria Sobrinho,no detalhe a utilização da técnica de tijolos nas estruturas de portas e janelas.

Fonte: Acervo do autor, 2009. 


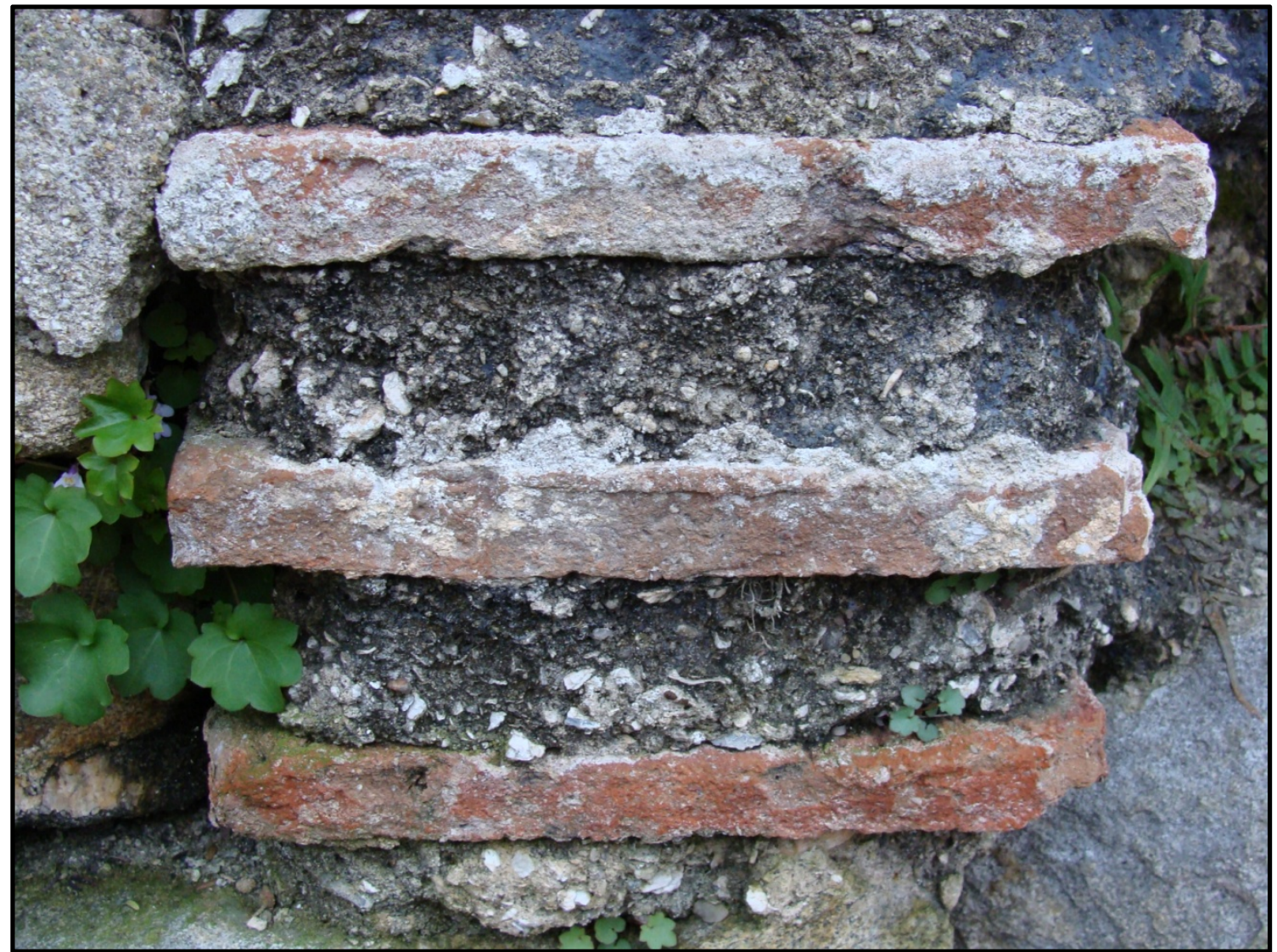

Figura 41. Outro exemplo da aplicação dos tijolos nas estruturas dos vãos, agora na rua Pecego Junior.

Fonte: Acervo do autor, 2009.
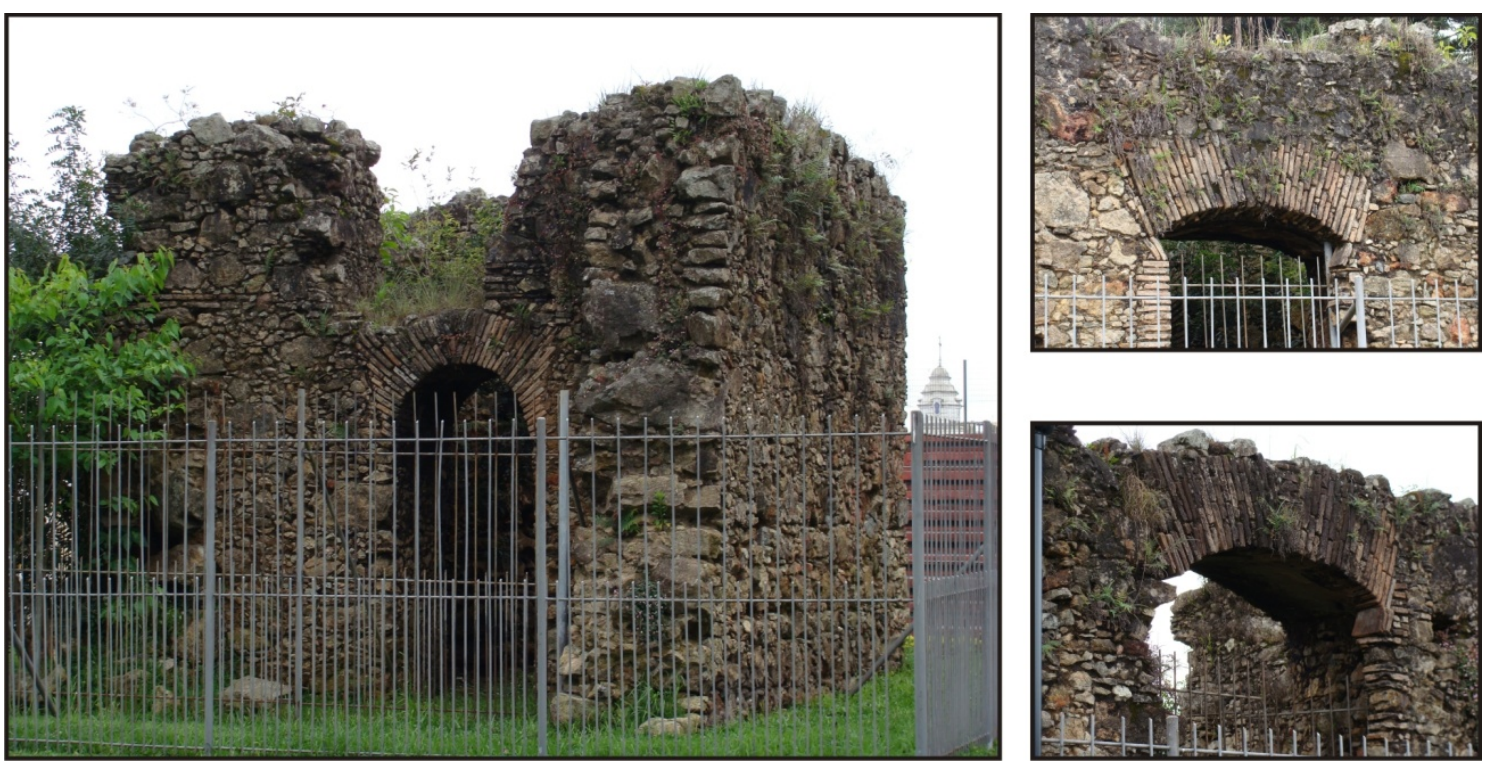

Figura 42. Ruínas da igreja de São Francisco em Curitiba e detalhe das arcadas em tijolo maciço. Fonte: Acervo do autor, 2009. 
Essa igreja, de 1811, nunca foi concluída, restando apenas parte de sua estrutura, suas arcadas são constituídas por tijolos, sendo nesse caso, em duas fileiras, provavelmente pelo tamanho dos arcos e pelo peso a ser suportado (Figura 42).

Essa técnica de utilização do tijolo, também ocorreu na região das Minas Gerais, como comentam Ávila, Gontijo e Machado (1980, p. 89):

Nas vilas e cidades mineiras do período colonial, o tijolo veio a substituir a taipa e o adobe nas estruturas das paredes. Seu emprego, pelo alto custo, limitava-se, de início, a pisos, abóbadas, arcos, etc., tendo sido introduzido em Ouro Preto na construção do Palácio dos Governadores (1741/1747) e também nas obras das torres da Igreja do Carmo.

Portanto, temos o tijolo nas estruturas dos quadros de portas e janelas e as pedras nas estruturas de paredes, como materiais mais empregados na Paranaguá do século XVIII e início do XIX. Quanto aos edifícios da cidade, observamos que as construções, de uma maneira geral, possuem estruturas de portas e janelas em canga, ou seja, construções posteriores à metade do século XVIII, muitas das quais alteradas com o passar do tempo. Através de antigas fotografias, poderemos analisar alguns dos aspectos das construções predominantes no século XVIII, como por exemplo, os balcões e sacadas, que eram construídos em madeira e sustentados por estruturas de pedras, os cachorros. Quanto aos balcões, não existem mais resquícios de estruturas em madeira, apenas uma fotografia (Figura 43), provavelmente do começo do século $X X$, ilustra essa característica em um sobrado localizado nas ruas Faria Sobrinho e Marechal Alberto de Abreu.

No conjunto, de forma geral, as construções térreas eram unidas umas as outras, construções em estrutura de pedra e seus telhados em duas águas, projetando seus beirais para frente das paredes das fachadas. 


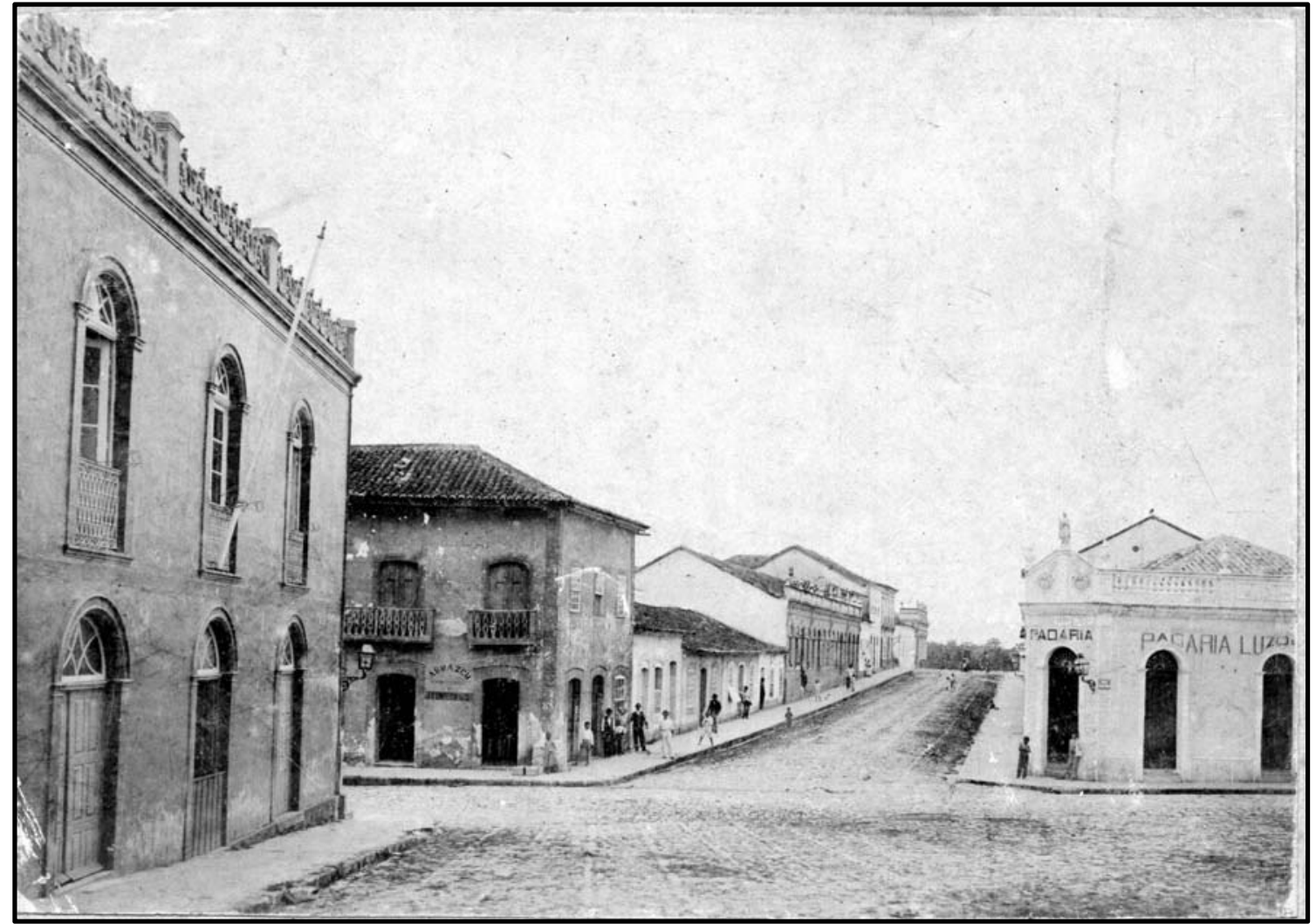

Figura 43. Fotografia do começo do século XX, na rua Faria Sobrinho, em que se observa o sobrado com sacada de madeira.

Fonte: IHGP.

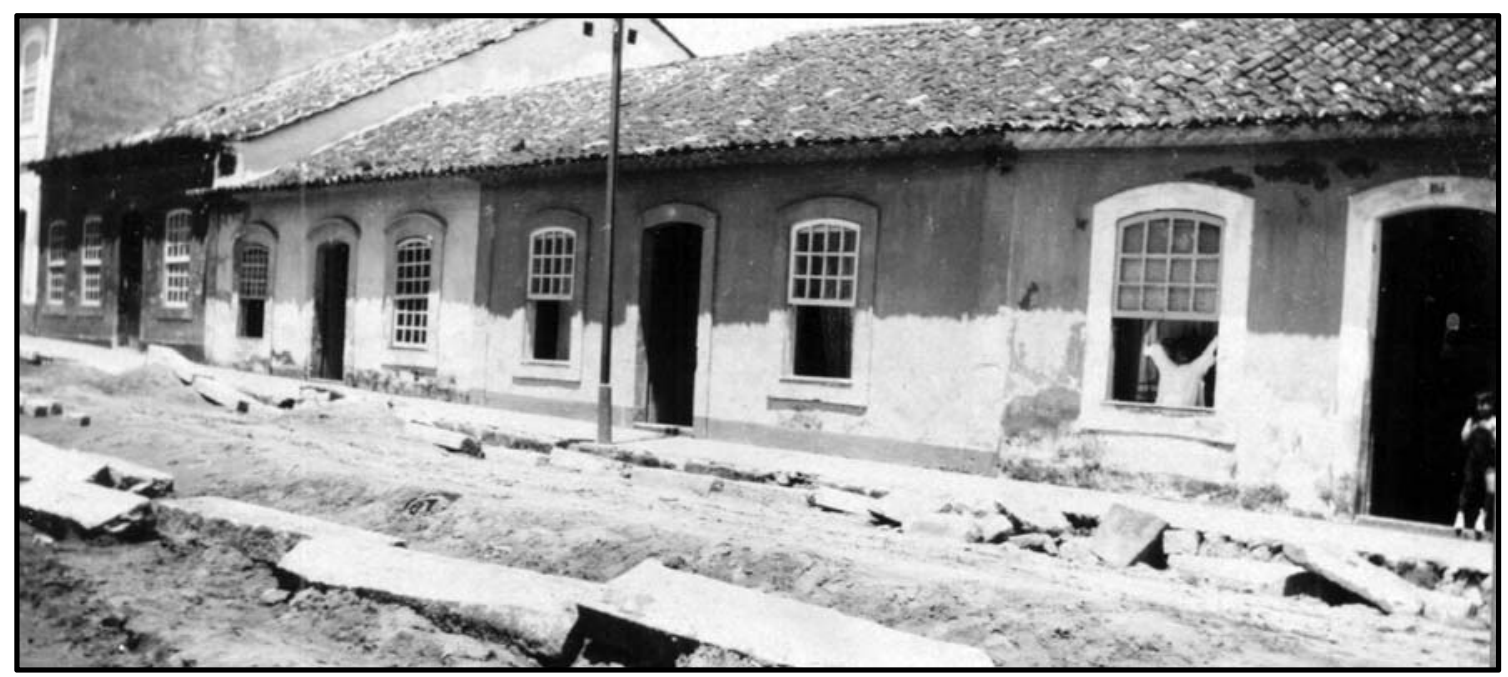

Figura 44. Casas na rua Marechal Alberto de Abreu, com suas portas e janelas em canga. Fonte: IHGP. 
Em relação às aberturas, o comum era uma porta central, rodeada por uma janela em cada lateral, variando em algumas estruturas, como uma porta central e duas janelas de um lado e uma do outro, características comuns das construções da Paranaguá oitocentista (Figura 44).

Em uma fotografia da rua XV de Novembro, antiga rua da Ordem e da Cadeia, percebemos os sobrados mais comuns encontrados na cidade, nota-se ao lado esquerdo da imagem dois sobrados com suas portas e janelas em verga e sobreverga, são provavelmente do final do século XVIII. Esses sobrados possuem sacadas de ferro, e altura maior se compararmos com o sobrado situado ao mesmo lado, no fundo, localizado na esquina da rua.

Suas portas e janelas são em canga, e por isso esse edifício pode ser da metade do século XVIII e ao lado direito percebemos uma casa, com portas e janelas de verga e sobreverga, assim como o sobrado ao seu lado, que possui sua sacada sustentada pelos cachorros em pedra.

Sobrados mais antigos estão localizados na rua Conselheiro Sinimbú, antiga rua da Fonte, como por exemplo, os dois edifícios contíguos existentes no começo dessa via ao lado da igreja Matriz. São construções de baixa altura com vergas retas nas portas e janelas, semelhantes à Casa de Câmara e Cadeia (Figura 46), o que possibilita indicar o período de construção desses edifícios, anteriores à metade do século XVIII. Outras construções semelhantes, podem ser observadas em fotografias da rua da Fonte (Figura 47 e Figura 48), como as do primeiro plano ao lado direito, localizadas ao lado da Matriz e do lado esquerdo ao fundo. 


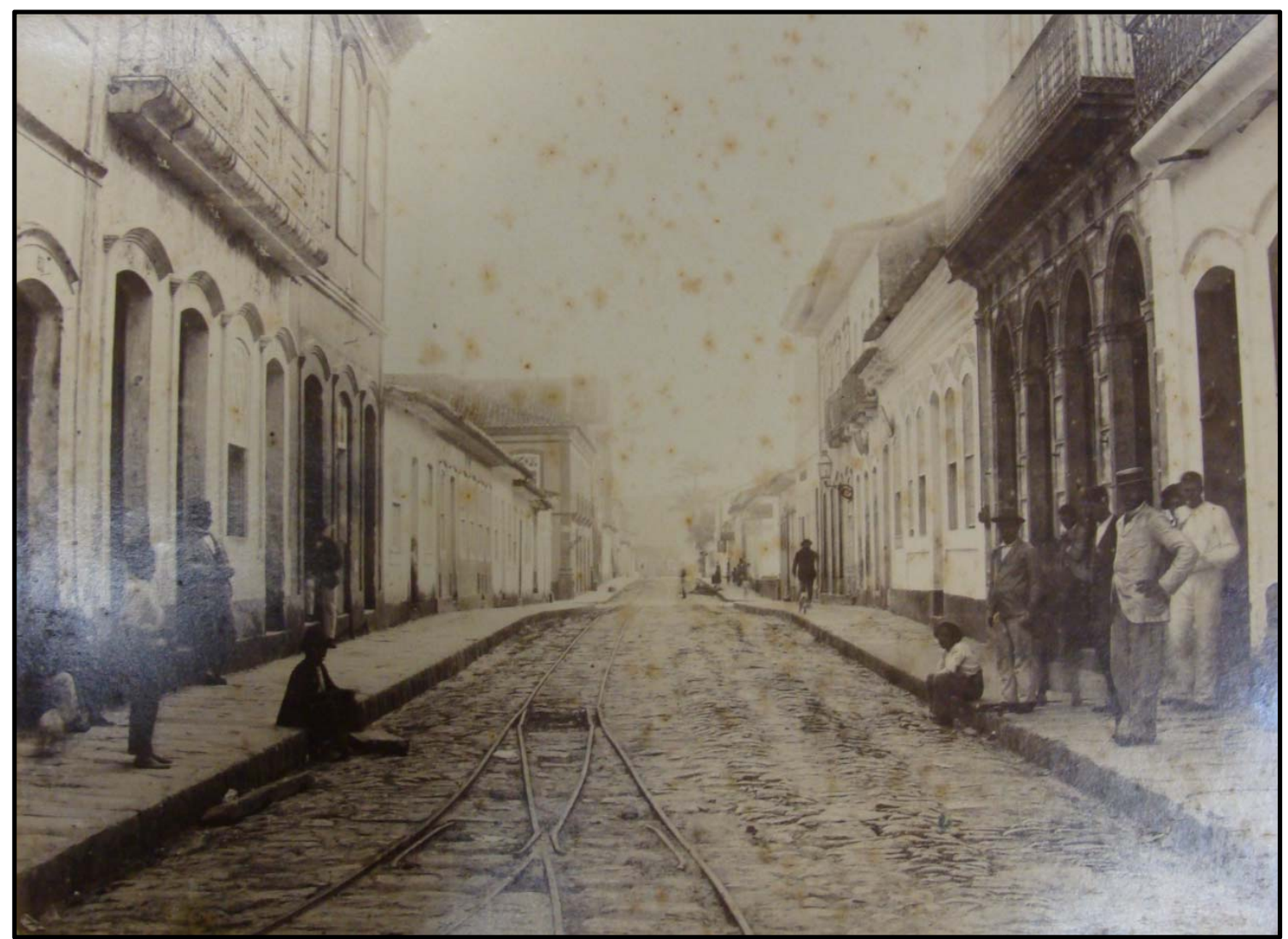

Figura 45. Rua XV de Novembro em 1900, área em que predominaram sobrados e casas do século XVIII.

Fonte: Acervo Fotográfico do Museu Paranaense.

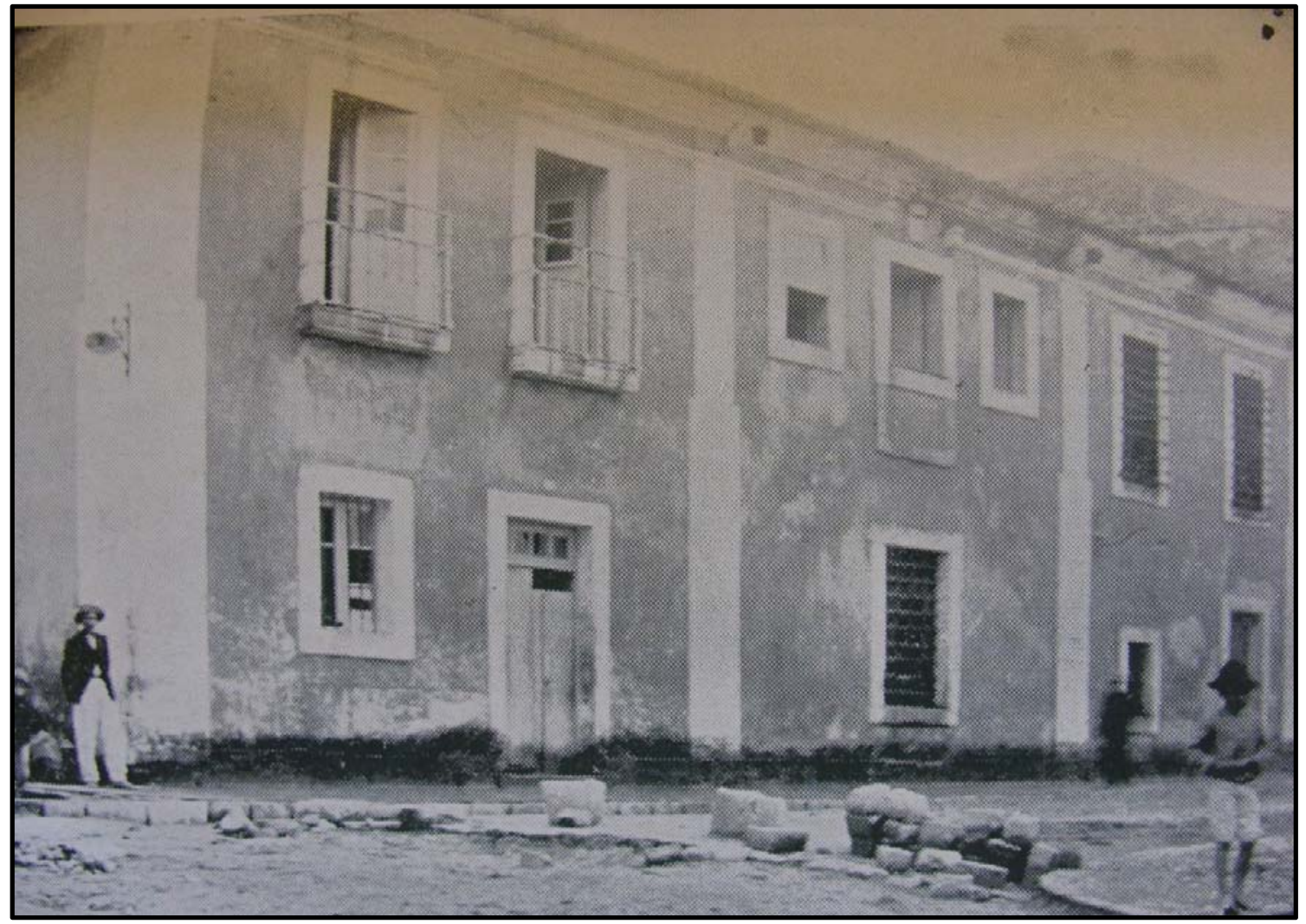

Figura 46. A Casa de Câmara e Cadeia de Paranaguá, em fins do século XIX.

Fonte: Revista O Itiberê, n³9/41, anno IV, setembro de 1922. 


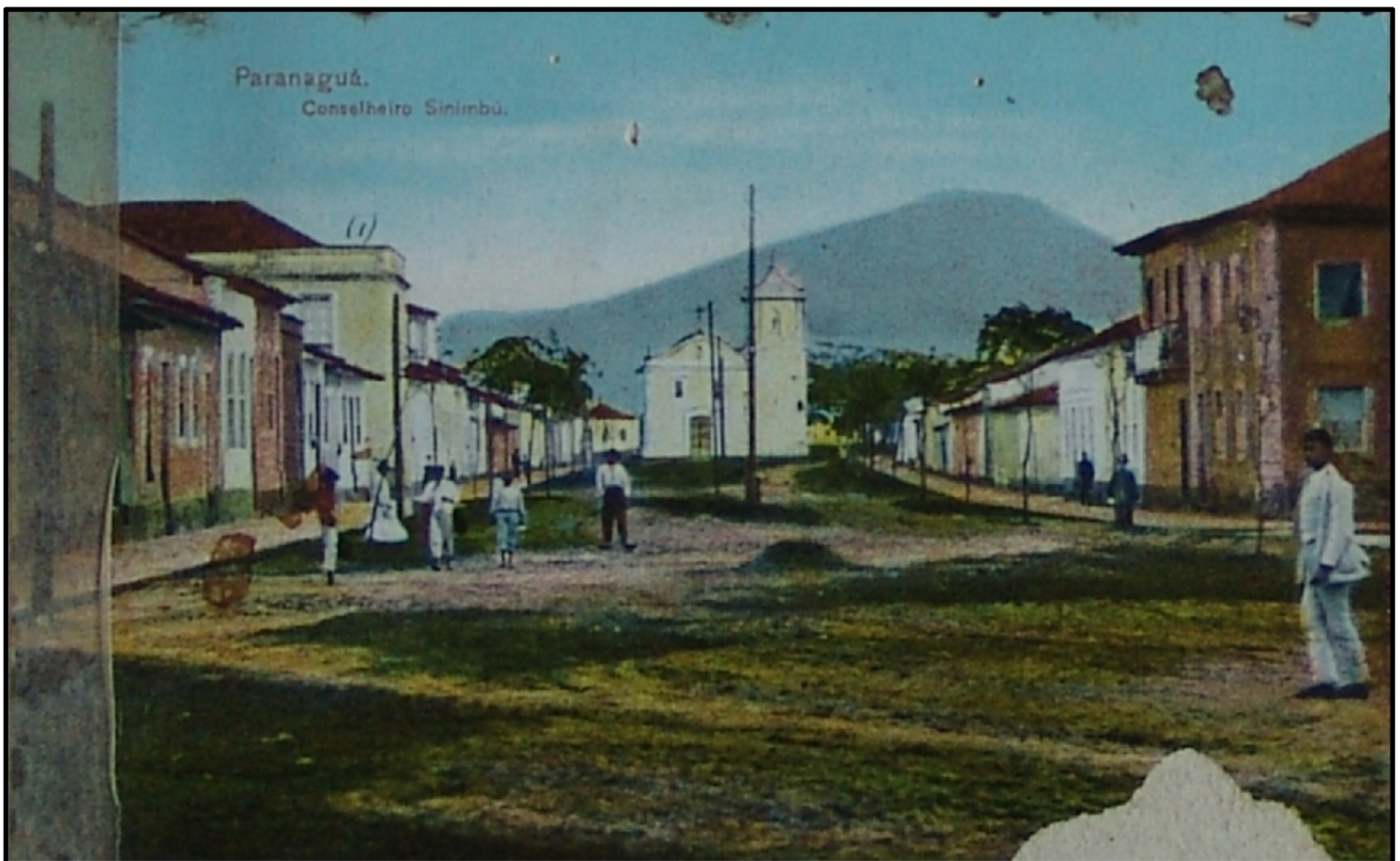

Figura 47. Rua Conselheiro Sinimbú, antiga rua da Fonte, começo do século XX, observa-se os sobrados localizados no lado direito e no lado esquerdo, ao fundo.

Fonte: Álbum José Lobo.

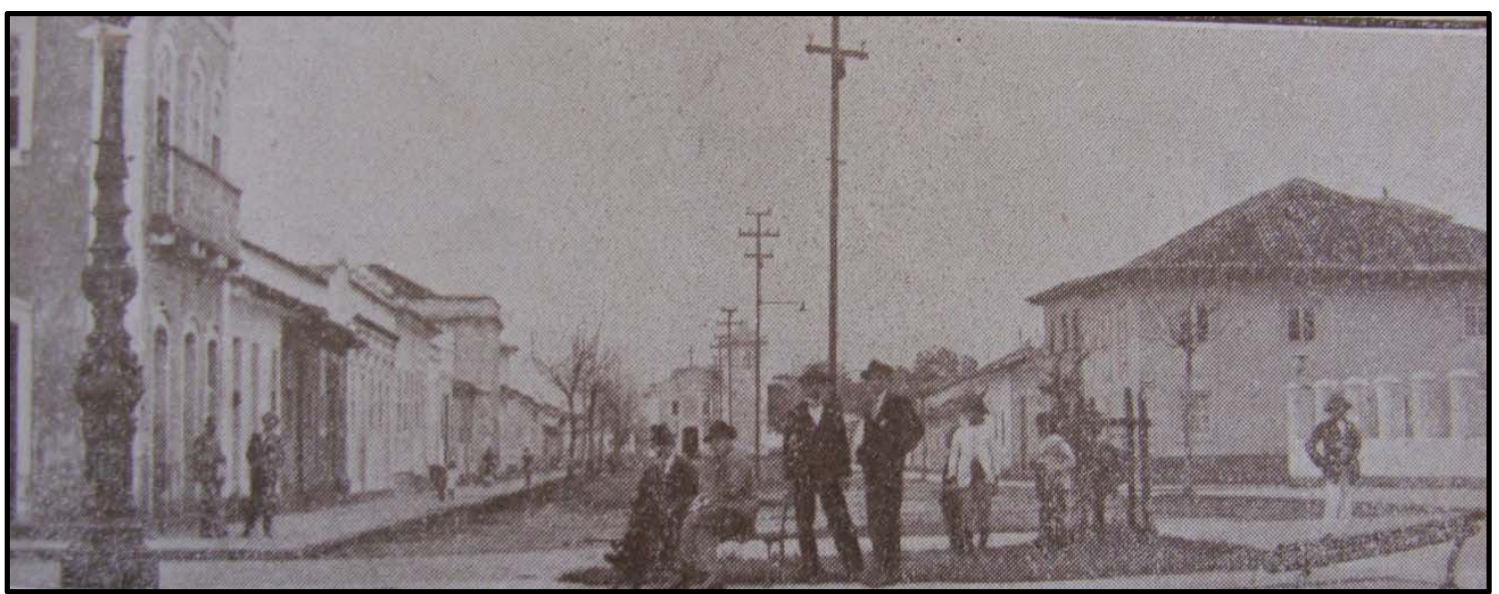

Figura 48. Rua Conselheiro Sinimbú, vista a partir do largo da Matriz em 1922.

Fonte: Revista O Itiberê. n³9/41, anno IV, setembro de 1922 
Observamos através de uma análise geral, que a Paranaguá do século XVIII e início do século XIX, foi caracterizada por casas e sobrados edificados em pedra e possuindo em suas fachadas portas e janelas em canga. Percebemos que construções com essas características predominaram na cidade e algumas estão preservadas até os dias atuais. Essas construções possuem beirais pequenos, pois não existia a necessidade de proteção das paredes contra a chuva e com isso foi possível a aplicação da beira-seveira, abaixo dos beirais, elemento difundido em grande parte das construções desse período.

A partir da segunda metade do século XIX, os sobrados aumentaram de altura e também nas medidas de portas e janelas. São construções em que diminuem os cheios e aumentam os vazios, e mudarão completamente a antiga configuração das construções, trazendo à tona a propagação das influências européias e o advento do Ecletismo. 


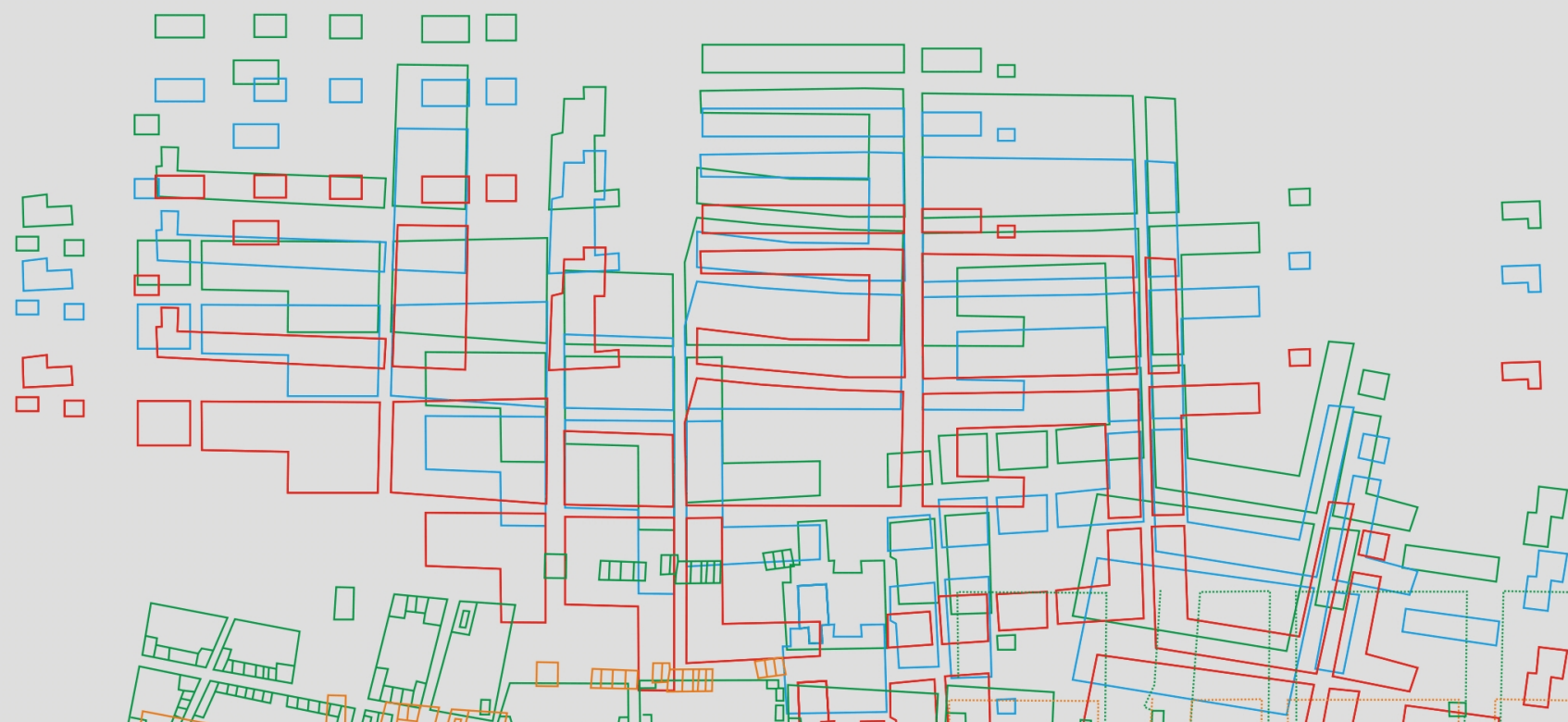

而务

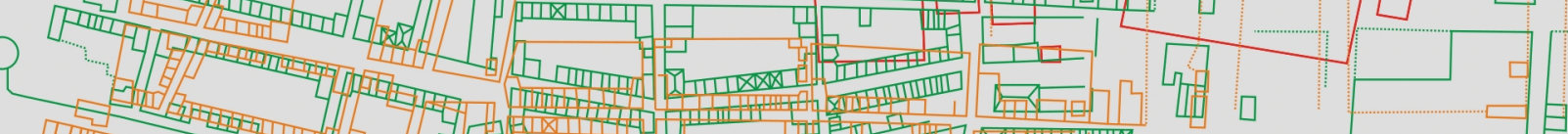

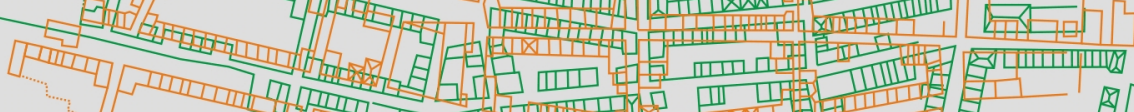
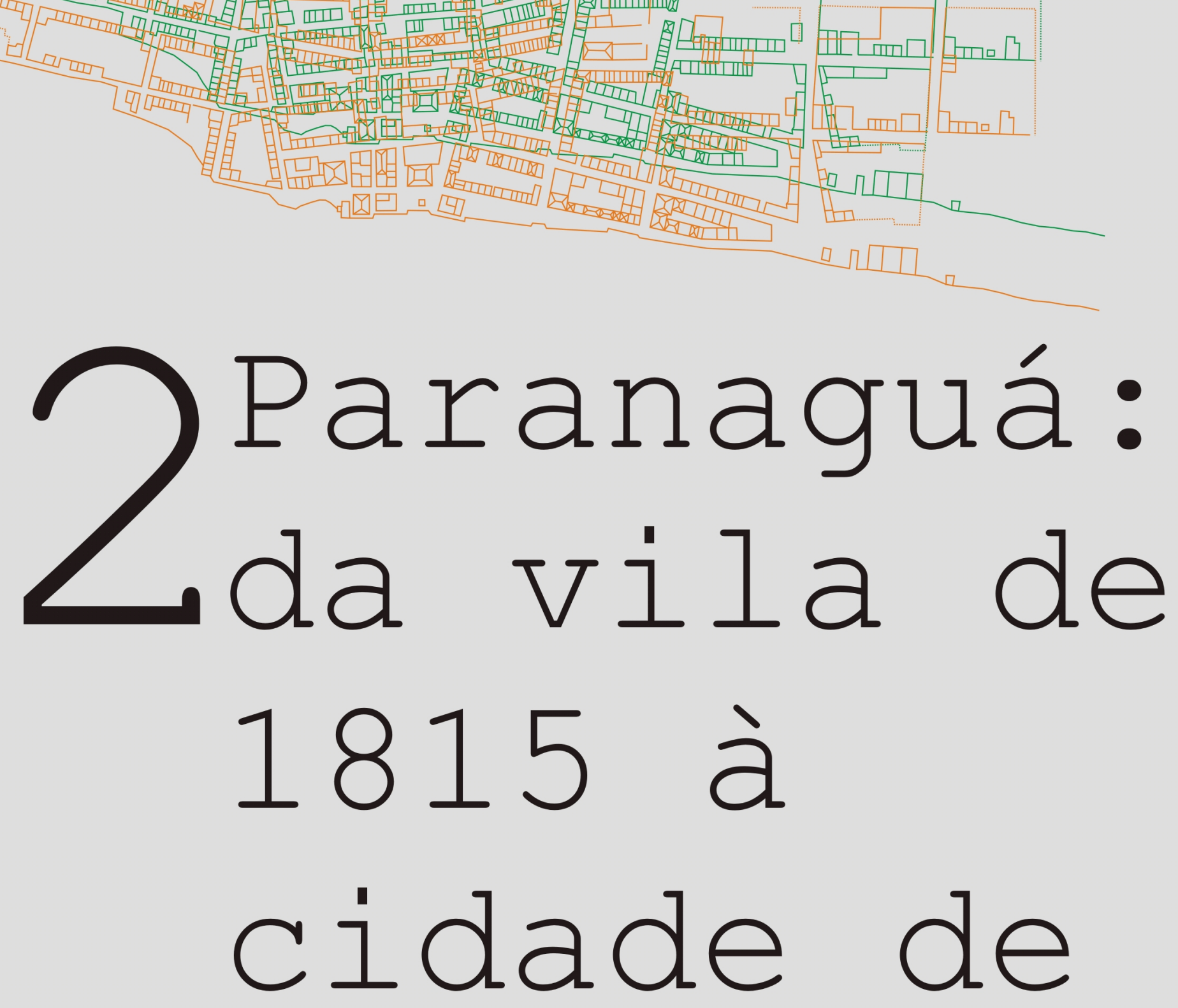

1895 



\section{PARANAGUÁ: DA VILA DE 1815 À CIDADE DE 1895}

O século XIX foi o momento determinante nas transformações urbanas e arquitetônicas de Paranaguá, principalmente pelas mudanças econômicas e políticas, que definiram sua importância como ponto exportador de produtos, dentre

os quais a erva-mate e a madeira. A erva-mate foi o artigo que desenvolveu a economia paranaense naquele período, auxiliando nas mudanças políticas e estruturais, como a elevação de Paranaguá a categoria de cidade em 1842, a formação da Província do Paraná em 1853, a chegada da ferrovia e a transferência de seu porto, do rio Itiberê para a baía de Paranaguá.

Para compreender as transformações urbanas de Paranaguá e sua relação com o desenvolvimento econômico paranaense, partiremos da análise de dois mapas, que serão parte dos pontos iniciais no desenvolvimento desse capítulo, que discutirá Paranaguá durante o século XIX. Esses mapas representam a vila em 1815 e a cidade em 1895, dois extremos temporais que direcionarão no entendimento de como a vila, e depois cidade se comportou durante o século XIX. Esses extremos nos mostram a vila, antes da chegada da erva-mate, ainda arraigada a estrutura do Período Colonial e depois, a cidade em fins do século XIX, com a chegada da ferrovia e a erva-mate incorporada como produto importante na exportação. 


\subsection{PARANAGUÁ EM DOIS MAPAS}

Dois extremos no tempo, um mapa do início e outro ao final do século XIX, dois documentos cartográficos que analisamos para buscar informações de como se comportou o traçado urbano de Paranaguá. O mapa de 1815 (Figura 49), intitulado Planta Topographica da Villa de Paranaguá, de autoria do Engenheiro Militar Capitão João da Costa Ferreira, possibilita entender de que forma se configurava a vila de Paranaguá, no início do século XIX, mas também nos três últimos decênios do século XVIII. Pois constata-se pelas descrições de viajantes desse período, que não ocorreram consideráveis transformações em sua estrutura, desde as correições do Ouvidor Rafael Pires Pardinho em 1720.

Quanto ao mapa de 1895 (Figura 50), não existem informações sobre sua autoria, somente a indicação de que é uma cópia do mapa original, localizado em uma instituição não identificada no documento, devido à precariedade na sua reprodução, já que o original dessa cópia não foi encontrado em nenhum acervo. Provavelmente foi um mapa executado pela prefeitura da cidade ou algum órgão governamental, como planta de situação.

Antes de qualquer análise sobre os mapas, devemos considerar alguns aspectos: primeiramente, no caso do mapa de 1815, não existe uma precisão sobre o número de construções existentes na vila, já que o mapa está configurado em quadras, sem especificação dos limites dos lotes ou qualquer indicação das construções, o que não possibilita garantir que estas quadras estivessem completamente ocupadas por casas e outros edifícios. 


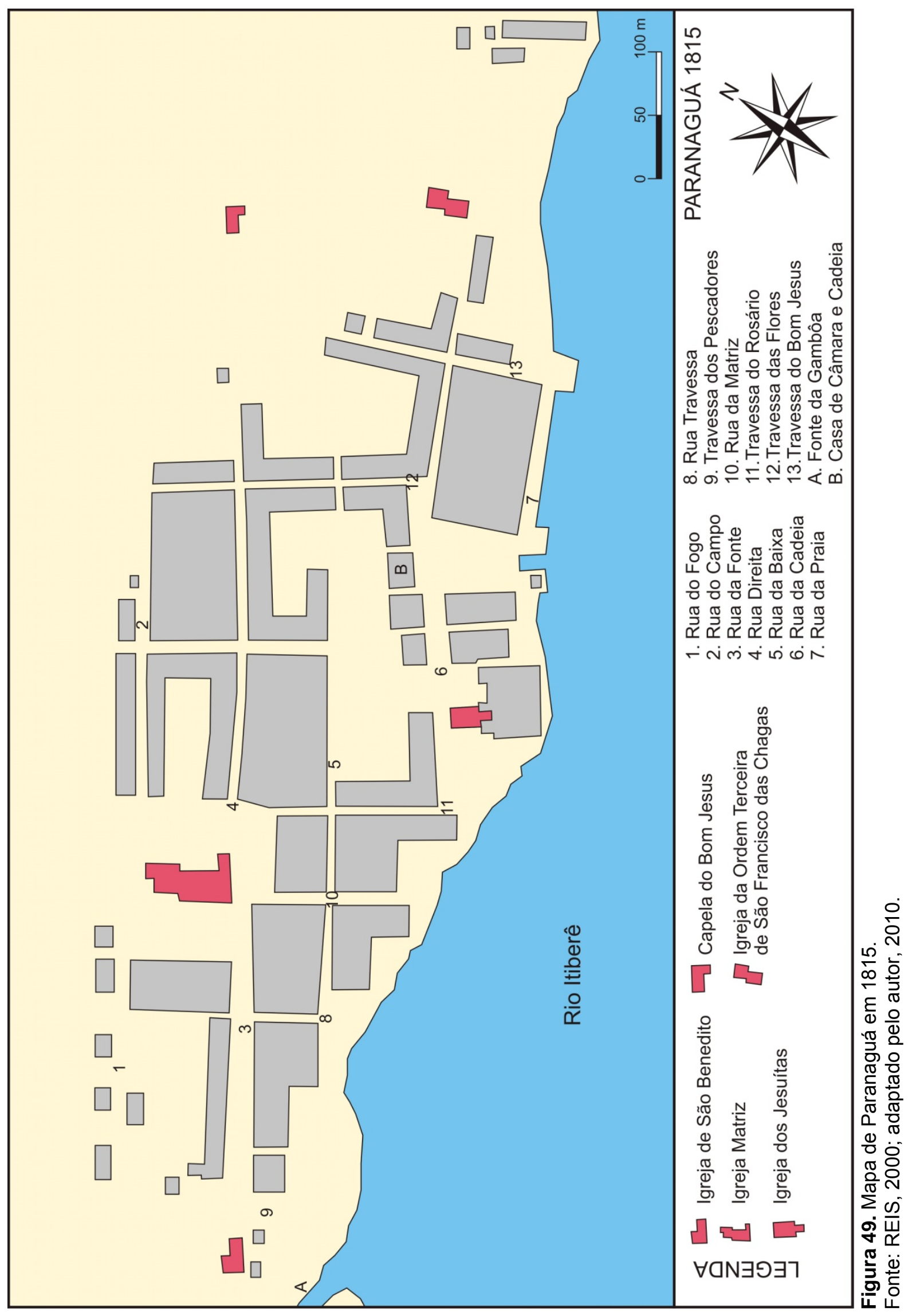




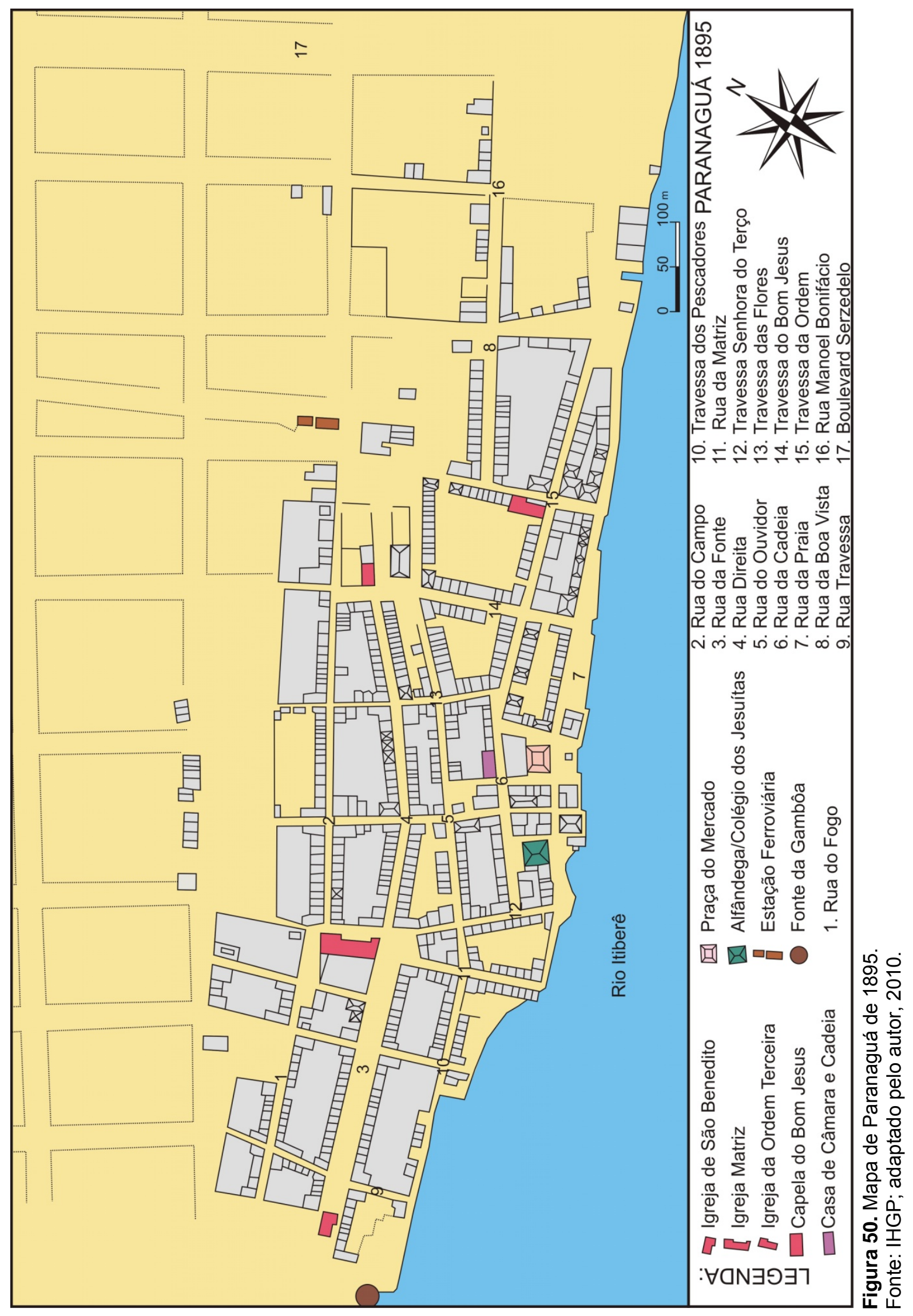


A legenda no mapa indica somente as igrejas e capelas locais, não referenciando outros pontos relevantes, como o pelourinho, a casa de Câmara e Cadeia e a fonte da Gambôa. No mapa de 1895, estão apontadas as igrejas e capelas, como no documento anterior, sinalizados com a cruz. Uma característica importante é que suas quadras estão divididas em lotes, que podem indicar as áreas ocupadas e os sobrados existentes, representados com o desenho de suas coberturas.

A vila, em 1815, ainda carregava características do século anterior, tanto em suas construções como na estrutura urbana. Ela estava delimitada ao noroeste pelos fundos da igreja Matriz, ao sudeste pelo Colégio dos Jesuítas, ao nordeste pela capela do Bom Jesus e igreja da Ordem Terceira, afastadas da maior concentração urbana, e ao sudoeste pela igreja de São Benedito e fonte da Gambôa.

Um aspecto geral da cidade neste começo de século pode ser retirado das descrições que o viajante francês Auguste de Saint - Hilaire fez em sua visita à cidade. Saint - Hilaire percorreu grande parte do que hoje é o Estado do Paraná e antes de chegar à Paranaguá, o viajante esteve em Curitiba, sede da Comarca, e posteriormente se deslocou ao litoral.

A vila, de acordo com o viajante, possuía casas aparentemente bem cuidadas, onde a grande maioria estava configurada com um pavimento. Sobre a estrutura desses edifícios, ele coloca: "Quando se chega à Paranaguá, vindo do interior, onde a maioria das casas das vilas e arraiais são feitas de barro. O que chama a nossa atenção é ver todas as casas e todos os prédios públicos feitos em pedra." (HILAIRE, 1995, p.150) 
Quando Hilaire comentou sobre as construções em pedra, observamos que, nesse período, a maioria das obras já era edificada dessa forma, ao contrário do que ocorreu na visita do Ouvidor Pardinho em 1720, em que observou grande parte das construções em pau-a-pique, devido ao problema sobre a propriedade da ilha da Cotinga. Certamente, na época da visita de Saint-Hilaire, ainda existiam algumas construções em barro na vila, mas não foram percebidas pelo viajante, provavelmente por ser de fato uma minoria naquela época.

O viajante considera Paranaguá, "[...] certamente uma das mais bonitas que já visitei desde a minha chegada ao Brasil, mas o calor ali é quase tão forte quanto no Rio de Janeiro." (HILAIRE, 1995, p.154). Neste mesmo trecho ele relata sobre o problema do abastecimento de água, dizendo que, "[...] a água que se bebe, fornecida por uma fonte distante das casas algumas centenas de passos, extremamente medíocre." (HILAIRE, 1995, p.154).

Era uma vila pequena, rodeada por uma bela paisagem natural ao seu redor, constituída por cursos d’água e pela baía, tendo ao seu fundo a Serra do Mar, visto que Paranaguá sempre foi comentada pelos viajantes, principalmente por seus aspectos naturais, que impressionavam à quem pelo mar chegava ao porto.

Quanto ao traçado das ruas, Hilaire considerou as vias paralelas ao rio Itiberê largas, bem alinhadas e não pavimentadas, "[...] no entanto elas jamais se mostram barrentas, já que o terreno é muito arenoso." (HILAIRE, 1995, p.150). O alinhamento das vias pode ser percebido no mapa de 1815, apesar de existirem algumas fora dessas características, como a rua Direita e a rua da Cadeia, mas a maioria das ruas tem um traçado quase retilíneo, principalmente as de menor dimensão.

Durante o século XIX, a cidade continuará limitada ao noroeste, pelos fundos da igreja Matriz, em que poucas construções ultrapassavam esse limite, também a 
cidade não passou ao sudoeste, pela igreja de São Benedito. Esse crescimento é percebido na direção nordeste, já que a cidade, em 1895, engloba as igrejas da Ordem e Bom Jesus e a ultrapassa, chegando à proximidade da foz do rio Itiberê.

Com o desenvolvimento econômico propiciado pela exportação da erva-mate, a partir de 1820, quando chegou à vila o comerciante argentino Francisco de Alzagaray, deu início a uma nova fase no desenvolvimento de Paranaguá. Como existia a falta da erva paraguaia em Buenos Aires, devido ao bloqueio econômico paraguaio, Alzagaray então instalou em Paranaguá a primeira fábrica de beneficiamento de mate, que depois seria introduzido no mercado argentino. (WESTPHALEN, 1972)

Este bloqueio econômico foi resultante da proibição, em 1813, pelo ditador Francia, do Paraguai, da exportação de erva-mate para os consumidores da Argentina e Uruguai ${ }^{8}$. Dessa forma, os comerciantes dessas regiões, prejudicados pelo ato de Francia, decidiram buscar novos mercados do produto em outras localidades. (WACHOWICZ, 2001).

A exportação da erva-mate se desenvolveu a partir da independência brasileira, e teve grande importância no comércio paranaense, nas palavras de Westphalen, a erva mate, "[...] torna-se o principal produto da exportação paranaense em todo o século XIX." (WESTPHALEN, 1972, p.40)

O crescimento da exportação do mate no Paraná contribuiu para o desenvolvimento de Paranaguá, resultando em 1842 na elevação da vila à categoria de Cidade. O cronista Vieira dos Santos relatou através de uma carta enviada pela

\footnotetext{
8 "Porém, sob o governo de Francia, as remessas de erva foram escasseando em decorrência das medidas restritivas impostas ao país. A falta de erva em Buenos Aires ocasionava alta de preços que só ao Paraguai beneficiava, de tal maneira que cansados os comerciantes argentinos desse encarecimento excessivo, logo substituíram a erva no Paraguai e das Missões, de tal maneira que, face as demandas crescentes, aumentou rapidamente no Brasil o número de estabelecimentos destinados à produção da erva-mate." (WESTPHALEN, 1998, p.235).
} 
Câmara Municipal de Paranaguá ao Presidente da Província de São Paulo, a situação na qual se encontrava a recém criada cidade. Em um trecho observa-se:

O comércio que anteriormente se tinha conservado em estreito círculo, há anos já tem tomado não pequenos desenvolvimentos, pois que tem sido tal o seu progresso que tem quadruplicado o número das transações; geralmente ele se estende a todos os objetos que no país se comerceia; porém especialmente os gêneros que ocupam grande parte dos habitantes deste Município em cuja indústria empregam seus capitais, são a erva de mate, aguardente, exportação de madeiras, etc ..., sendo entre todos estes a erva mate, o de mais importância, porquanto este gênero ocupa quase dois terços dos capitais em giro, tendo chegado a grande perfeição sua produção e fabrico; este produto é peculiar da Comarca, não demanda em sua nascença o trabalho aturado do produtor, nem o emprego demorado do capital, porquanto a natureza pródiga fornece a matéria-prima em abundância, cuja fonte é inesgotável. (CÂMARA DE PARANAGUÁ, 1843 apud VIEIRA DOS SANTOS, 2001, p. 317318)

Após a elevação à cidade, temos uma pequena descrição sobre Paranaguá, realizada por Salvador José Correia Coelho, em 1844. Esse autor descreve sua viagem de São Paulo, onde morava, até a Lapa, sua cidade natal. De passagem pela cidade litorânea, Coelho (1995, p. 67) comenta alguns de seus aspectos:

Paranaguá - é cidade pequena, porém muito comerciante: seu comércio de cabotagem e com o estrangeiro é em grande escala. Exporta madeira bruta, arroz, erva mate, etc., é enfim o empório da província do Paraná, porque é seu principal porto marítimo

Uma das ruas de Paranaguá lhe chama a atenção pela forma em que se configura e também por seu nome:

Há na cidade uma rua que fica na parte posterior de outra cujos quintais ai fecham seus muros; é designada pelo povo "rua de traz... dos outros" na sociedade polida é chamada "rua de traz dos outros" esta última qualificação envolve um feliz pensamento elíptico. (COELHO, 1995, p.68)

Quanto aos edifícios de Paranaguá, José Correia Coelho (1995, p.68) comenta que: "As construções da cidade são vulgares, mas de pedra e cal; não há gosto arquitetônico e atende-se exclusivamente a solidez." $\mathrm{Na}$ realidade, o autor 
escreveu este texto em 1860, sobre a sua viagem de 1844. Portanto, quando relatou sobre a falta de gosto arquitetônico, provavelmente se refere às novas influências européias, que já estavam consolidadas na sede do Império, a cidade do Rio de Janeiro.

José Correia considera Paranaguá o empório comercial do Paraná, graças a seu porto que também influenciou no direcionamento do crescimento da cidade. Paranaguá possui, no sentido nordeste, o direcionamento principal de seu crescimento, concentrando parte das construções e mantendo a proximidade com o rio Itiberê. Um dos fatores que direcionaram este desenvolvimento foi o porto de Paranaguá, localizado nas margens daquele rio. Observamos no mapa de 1815 alguns trapiches localizados nas proximidades do Colégio dos Jesuítas, indo até o início da rua Alberto de Abreu, antiga travessa do Bom Jesus. Ao fim do século, a cidade se expandia na direção da foz do Itiberê, acompanhando os trapiches do porto que já se desenvolviam até o final da rua da Cadeia.

Nessa região onde está situado o porto de Paranaguá, foi formada a rua da Praia, que se transformou em importante via comercial e alfandegária, onde circulavam na metade do século XIX, produtos de diversas partes do Brasil e do mundo. Em 1850, são encontrados nessa via, estaleiros, armazéns, e a Alfândega da cidade, no antigo Colégio dos Jesuítas, onde "[...] há ali um trapiche sobre o mar com um guindaste para desembarcar as fazendas das embarcações e irem ao despacho da alfândega, e nele se embarcarem as que são exportadas [...]", nessa rua também são encontradas, "[...] duas boas ferrarias, carpintarias, lojas de 
fazendas, de armazéns de bebidas e massames ${ }^{9}$; as casas todas têm boa vista por estarem com a frente para o mar." (VIEIRA DOS SANTOS, 2001, p.14, Vol.I).

Naquele período, já se consolidava a exportação de erva-mate pelo porto parnanguara. O viajante Daniel Kidder relata suas impressões sobre a cidade na metade do século XIX:

Eu também fui á terra. Paranaguá é uma linda e asseada cidade, - um pouco em decadência, pensei à princípio; mas a segunda inspeção mostrou-me que não fizera justiça ao único porto do Paraná. Esta cidade tem cerca de três mil habitantes, e exporta anualmente um milhão de dólares de erva mate. O mate é a folha seca e a haste nova de uma espécie de planta que é colhida no interior e trazida para o litoral em pêlos de couro cru, muito apertadamente amarrados, sendo aqui embarcada para as Repúblicas hispano-americanas. (KIDDER and FLETCHER, p.15, 1941)

Uma cidade pequena, mas comercialmente ativa na visão de Kidder e também na de Johan Jakob Von Tschudi, que esteve na cidade em 1860. Em sua visita, a descreveu da seguinte forma:

"Apesar de pequena, Paranaguá é uma bela localidade, com casas vistosas, ruas regulares, e praças públicas agradáveis. Dá impressão de serem bem situados os seus moradores. Pelas ruas há muita movimentação, tudo indicando uma vida comercial ativa e, de fato, Paranaguá é também uma cidade comercial muito importante. Seu principal artigo de exportação é o chá do Paraguai (erva-mate), destinada principalmente para o Chile. Já tem acontecido, ao mesmo tempo, encontrarem-se 18 navios na baía, todos carregando erva-mate para o Chile. Essa erva é também exportada para Buenos Aires e Montevidéu. (TSCHUDI, 1860 apud TREVISAN, 2002, p. 58).

A rua da Praia era o principal ponto concentrador de estabelecimentos comerciais no ano de $1863^{10}$, possuindo 40 num total de 133 estabelecimentos em toda a cidade, ou seja $30 \%$ do comércio de Paranaguá estava concentrado nas

\footnotetext{
9 "Leito de pedras argamassadas com cimento, ou betume, nas cisternas ou obras semelhantes." (LEMOS; CORONA, 1972, p. 315)

${ }^{10}$ De acordo com a "Estatística da cidade de Paranaguá da província do Paraná do anno de 1862" publicado no jornal Commercio do Paraná, $n^{\circ} 58$ de 7 de janeiro de 1863.
} 
margens do rio Itiberê, isto já na metade do século. Por isso, temos nesse período, a rua da Praia com o maior número de sobrados na cidade, em conjunto com a rua da Ordem. Era a necessidade de ocupar essas áreas importantes comercialmente e que estavam próximas ao porto de Paranaguá. Essa característica pode ser analisada através de uma aquarela do ano de 1874 (Figura 51), de autoria desconhecida, que retrata a cidade de Paranaguá através do rio Itiberê. Nesse período, a rua da Praia estava totalmente ocupada, com suas casas e sobrados; pela gravura pode-se observar a inserção da igreja da Ordem dentro da cidade e o desenvolvimento de Paranaguá para a região da foz do Itiberê, que estava em parte ocupada naquele período, principalmente na rua da Boa Vista em que se encontra o Palacete Nácar e em alguns estaleiros que já existiam anteriormente.

Isto se mantém ao findar do século XIX, como pode ser observado em duas fotografias, uma de aproximadamente 1890 e outra de 1900 (Figura 52), com a alta concentração de sobrados, principalmente na rua da Praia. Apesar da transferência do porto para a região da baía de Paranaguá, a rua da Praia se manterá por muito tempo ainda como área de embarque e desembarque de mercadorias, observamos na imagem de 1900, no antigo Colégio dos Jesuítas, uma construção de madeira que funcionava como trapiche da Alfândega, sediada naquele edifício.

Pela fotografia de 1890, ao lado direito, percebemos que a cidade se mantinha limitada pelas proximidades com rua da Boa Vista, em que estão localizados alguns estaleiros, portanto a cidade mantinha-se concentrada naquela região, na qual eram oferecidos os serviços essenciais para a vida cotidiana parnaguara: o comércio, o porto, o abastecimento de água das fontes, a vida política e religiosa, atividades que coexistiam naquele espaço, nas margens do Itiberê. 


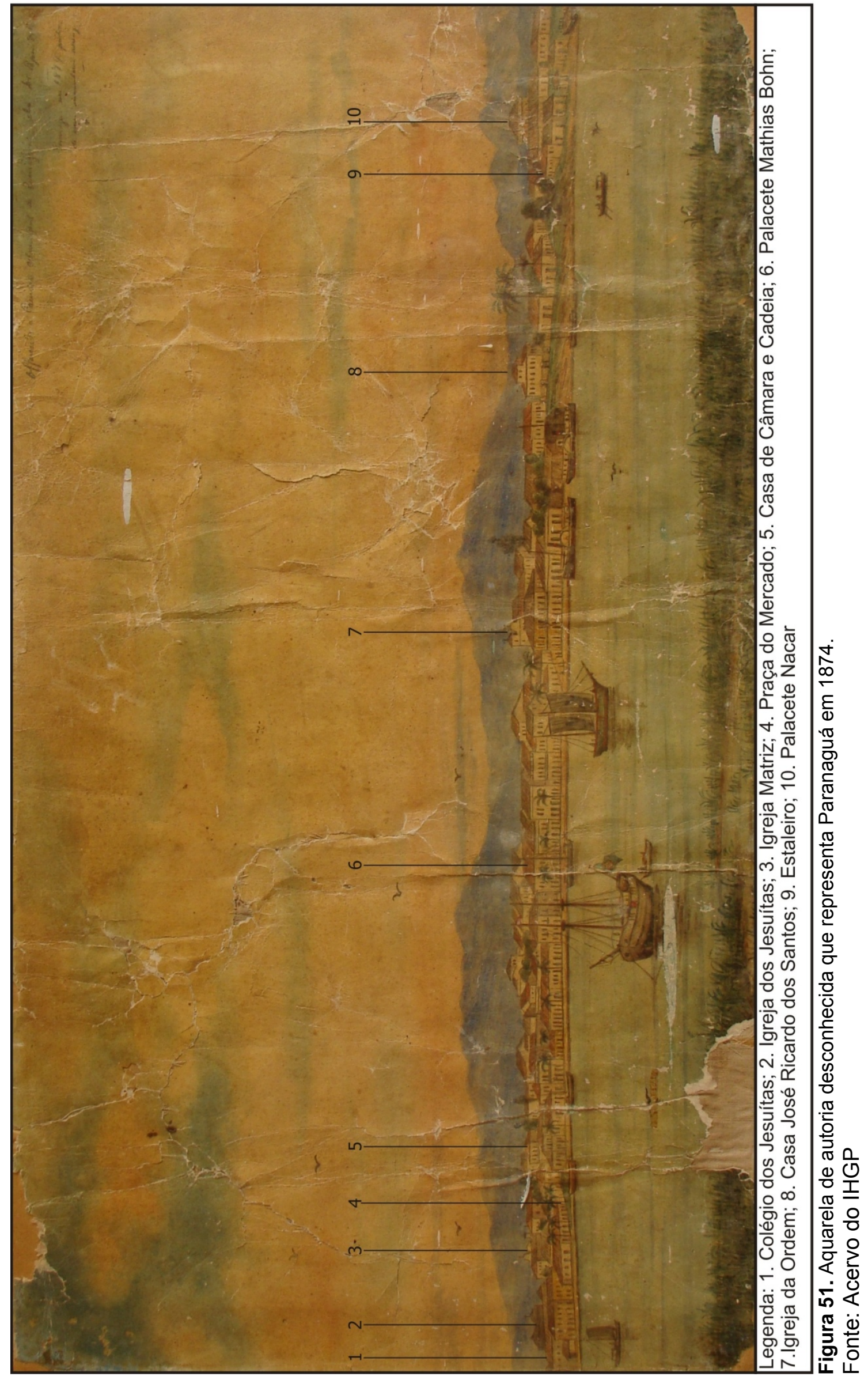



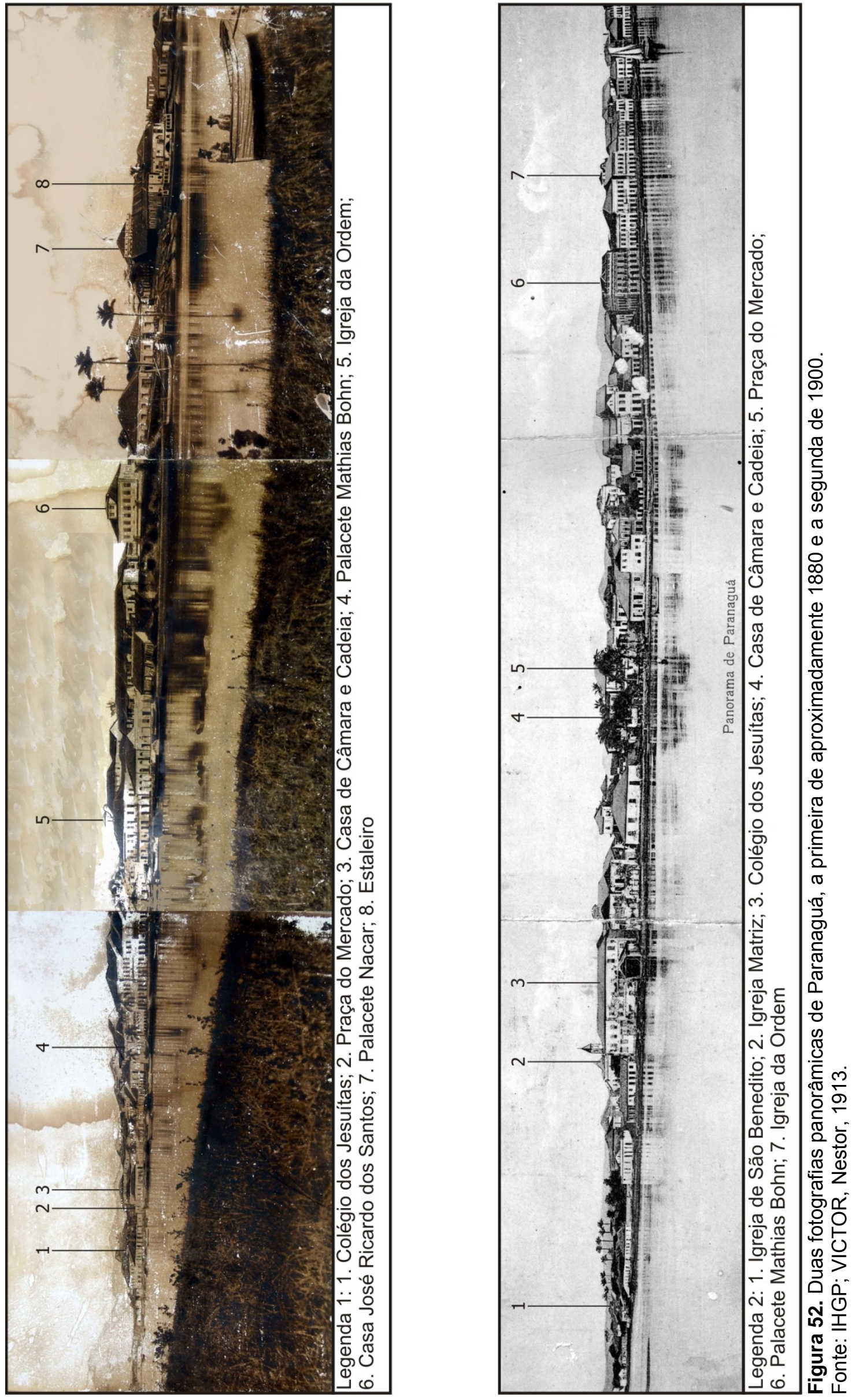
Na rua da Cadeia e da Ordem, situava-se a sede política e administrativa da cidade, e também a antiga Casa de Fundição de Ouro, esta via teve um crescimento expressivo no século XIX, devido a sua proximidade com o rio Itiberê e com a sede política. Paralela à rua da Praia, agora ela ultrapassa os limites da igreja da Ordem, transformando-se em uma via comercial, com grande número de sobrados, possuindo "[...] lojas de fazendas, armazéns de molhados, de comissões, boticas, vendas, lojas de alfaiates, sapateiros e tamanqueiros." (VIEIRA DOS SANTOS, 2001, p. 15).

Temos durante o século XIX a consolidação do eixo entre as igrejas de São Benedito, Matriz e Capela do Bom Jesus, ou seja, nas ruas da Gambôa e Direita. A rua Direita que começava ao lado da Matriz, em 1895, já está finalizando à frente da Capela do Bom Jesus (Figura 53), para isso, a rua teve que se curvar entre a igreja Matriz (Figura 54) e a do Bom Jesus, criando a perspectiva dos dois edifícios. Segundo Vieira dos Santos (2001), essa rua era ocupada por casas térreas, e que possuíam em sua construção materiais importados da Europa, como móveis e tapetes, além de vasos para a área externa, portanto uma rua ocupada por moradores de rendas consideráveis. A rua Direita, em muitas cidades brasileiras, se configurava desse modo: ligando um ponto importante à outro. De acordo com Murillo Marx (1980, p. 45):

Seu nome, agora pitoresco, é apropriado à função que tinham noutros tempos. Ligar, levar de um ponto importante a outro, quase sempre dum pátio ou duma construção religiosa a outra. Assim, em São Paulo a rua direita levava o transeunte da Sé direto à igreja de Santo Antônio, e vice-eversa. E no Rio, do mosteiro de São Bento à irmandade da Misericórdia.

Outra via que utilizava os recursos da perspectiva, para valorizar um edifício, foi a rua da Matriz, aberta por determinação do Ouvidor Pardinho. 


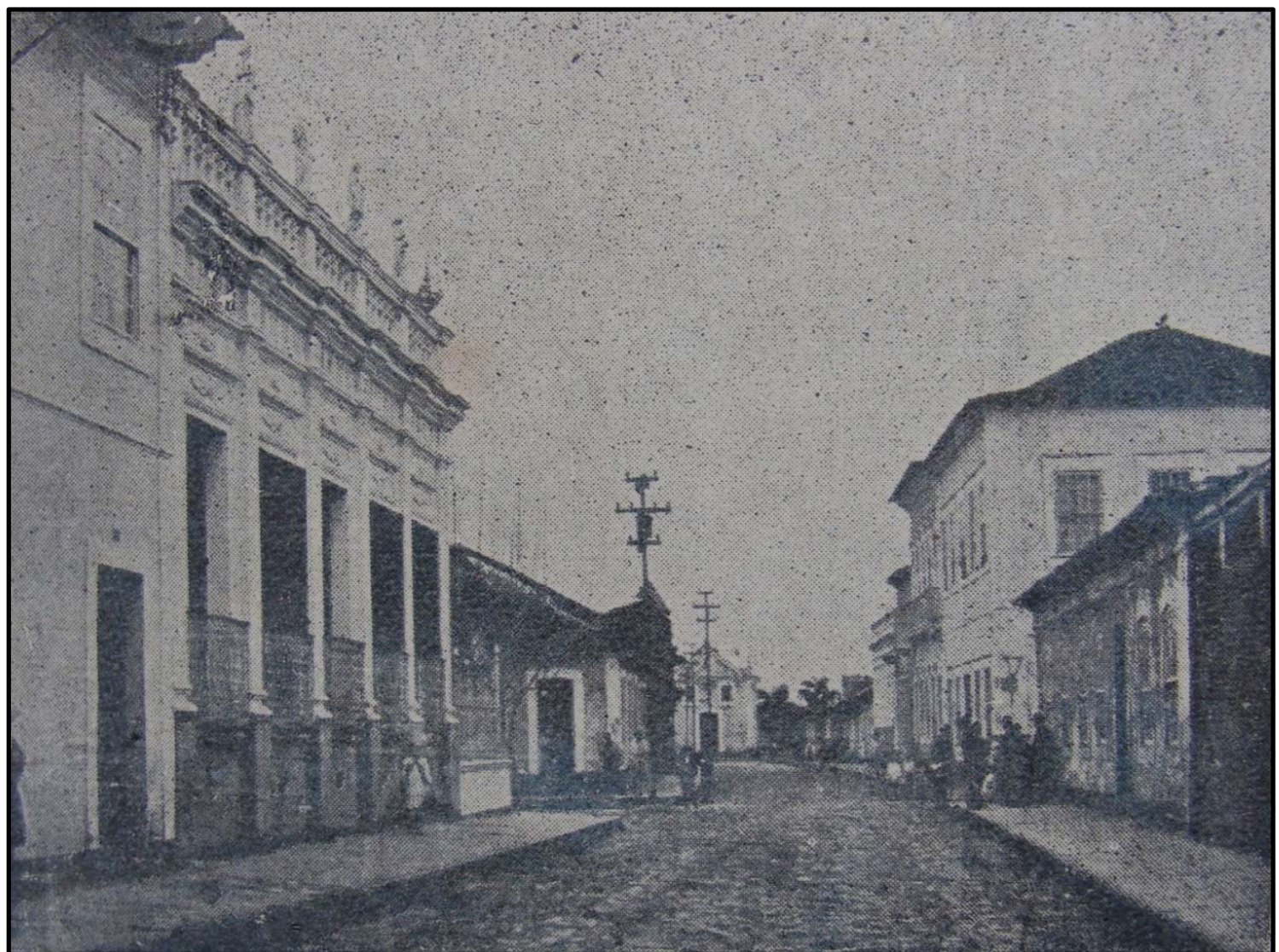

Figura 53. A visão da igreja do Bom Jesus a partir da rua Direita, em 1920, a rua converge a perspectiva para este templo.

Fonte: Revista O Itiberê, n¹1, março de 1920

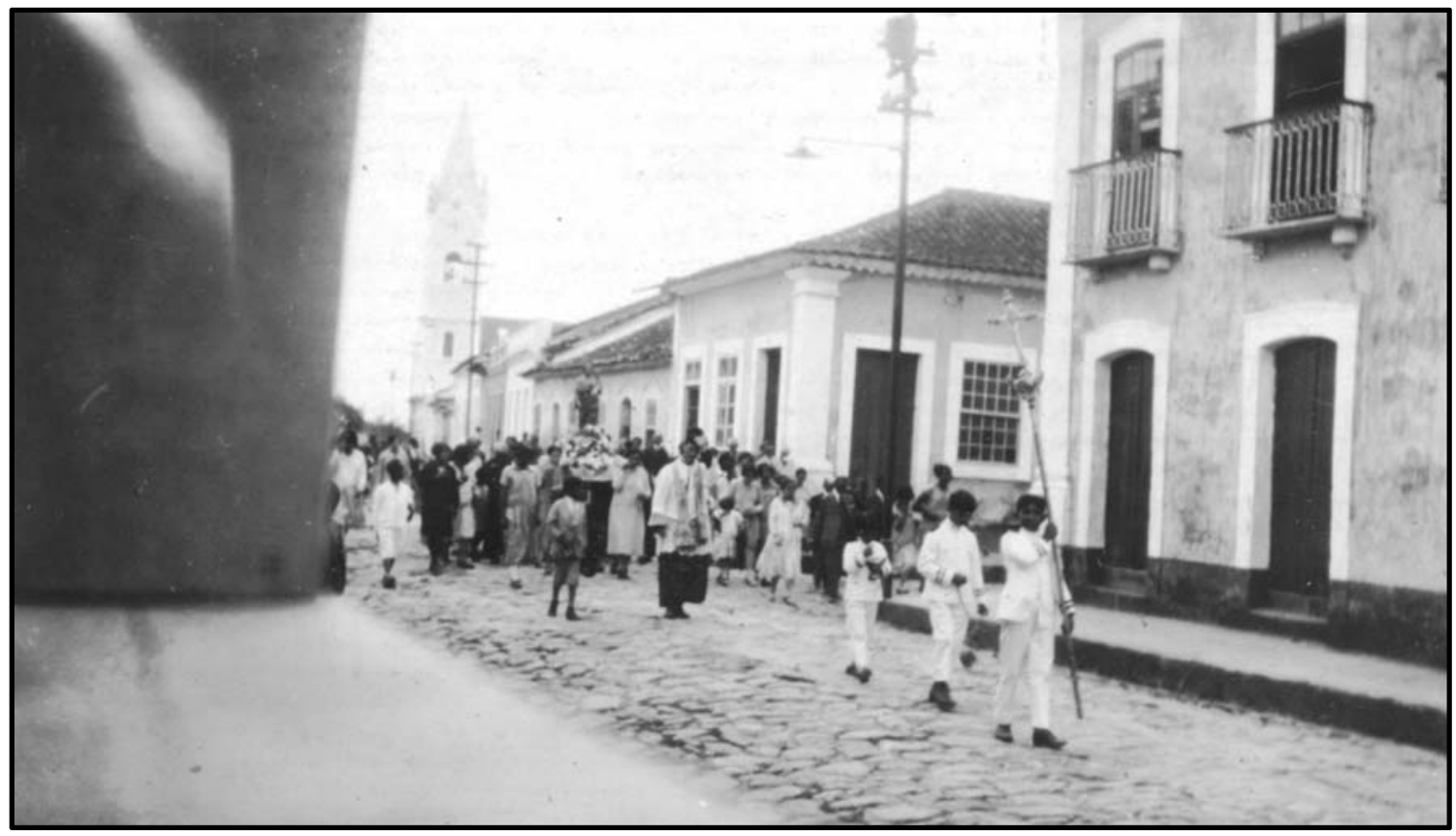

Figura 54.Uma procissão passa pela rua Direita em 1927, ao fundo o campanário da igreja Matriz. Fonte: IHGP 
Percebemos no mapa de 1815, que sua correição já surtia efeito, a rua estava ocupada desde a igreja até a margem do rio Itiberê. Nessa mesma região foi aberta a travessa da Senhora do Terço (Figura 55), atual rua Professor Cleto, que não existia em 1815, mas que em 1895 já estava totalmente ocupada, o que pode indicar que foi aberta pouco tempo depois do primeiro mapa, sendo citada em 1850 por Vieira dos Santos. Essa travessa também direcionava a visão para a Matriz, na direção do campanário. Assim como a rua da Matriz, ela tem início no largo da igreja e finaliza no Itiberê, ao lado do Colégio dos Jesuítas.

Já aos fundos da Casa de Câmara e Cadeia, área ainda desocupada no começo do século XIX, ao findar daquele século, está quase em sua totalidade ocupada. Naquele edifício se manteria a Câmara de Paranaguá, após a sua elevação à cidade em 1842. Conhecida como rua da Baixa, ou rua do Meio, pois estava no centro da vila, foi posteriormente denominada rua do Ouvidor. Ela iniciava nas proximidades da fonte da Gambôa e finalizava defronte à sede do primeiro Clube Literário, ao lado da igreja do Bom Jesus. Segundo Vieira dos Santos (2001), era uma via comercial com casas de negócios de fazendas secas, armazéns e tabernas.

Não só ocorreu a consolidação da ocupação de ruas já existentes na cidade, como também surgiram algumas vias na região que se expandiu, ou seja, à nordeste de Paranaguá, em direção à foz do Itiberê. Temos ali a abertura da rua da Boa Vista (Figura 56), possuindo essa denominação por situar-se em uma área mais alta, com vista para a região costeira. A rua começa nos fundos da igreja da Ordem e será ocupada por grandes casarões ecléticos, dentre os quais o do Visconde de Nácar e a do Coronel João Guilherme Guimarães. 

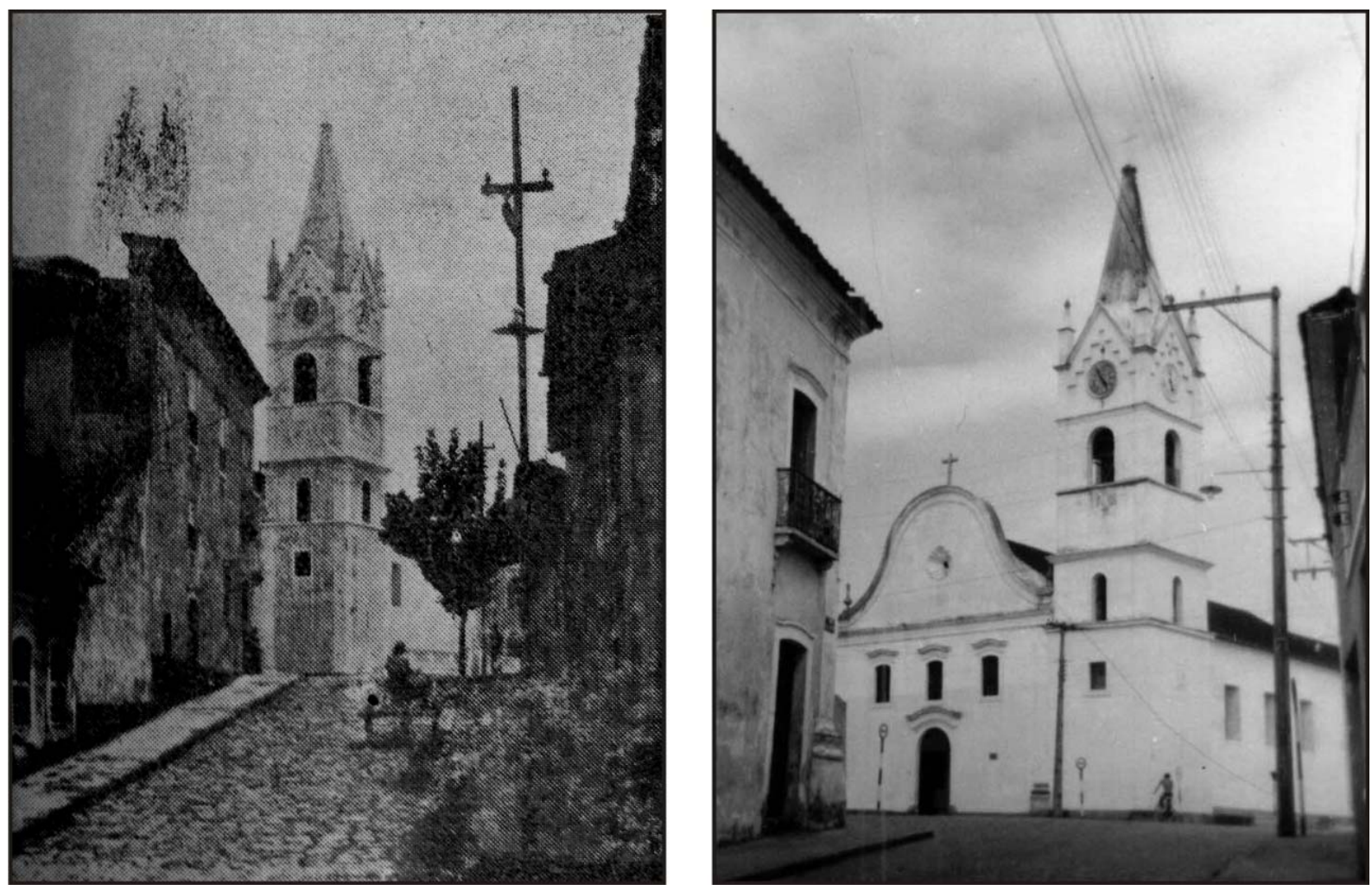

Figura 55. Dois aspectos da rua Senhora do Terço, a da esquerda do começo do século XX e a seguinte da década de 60 do mesmo século.

Fonte: Revista Itiberê, n 112, agosto de 1928/lHGP

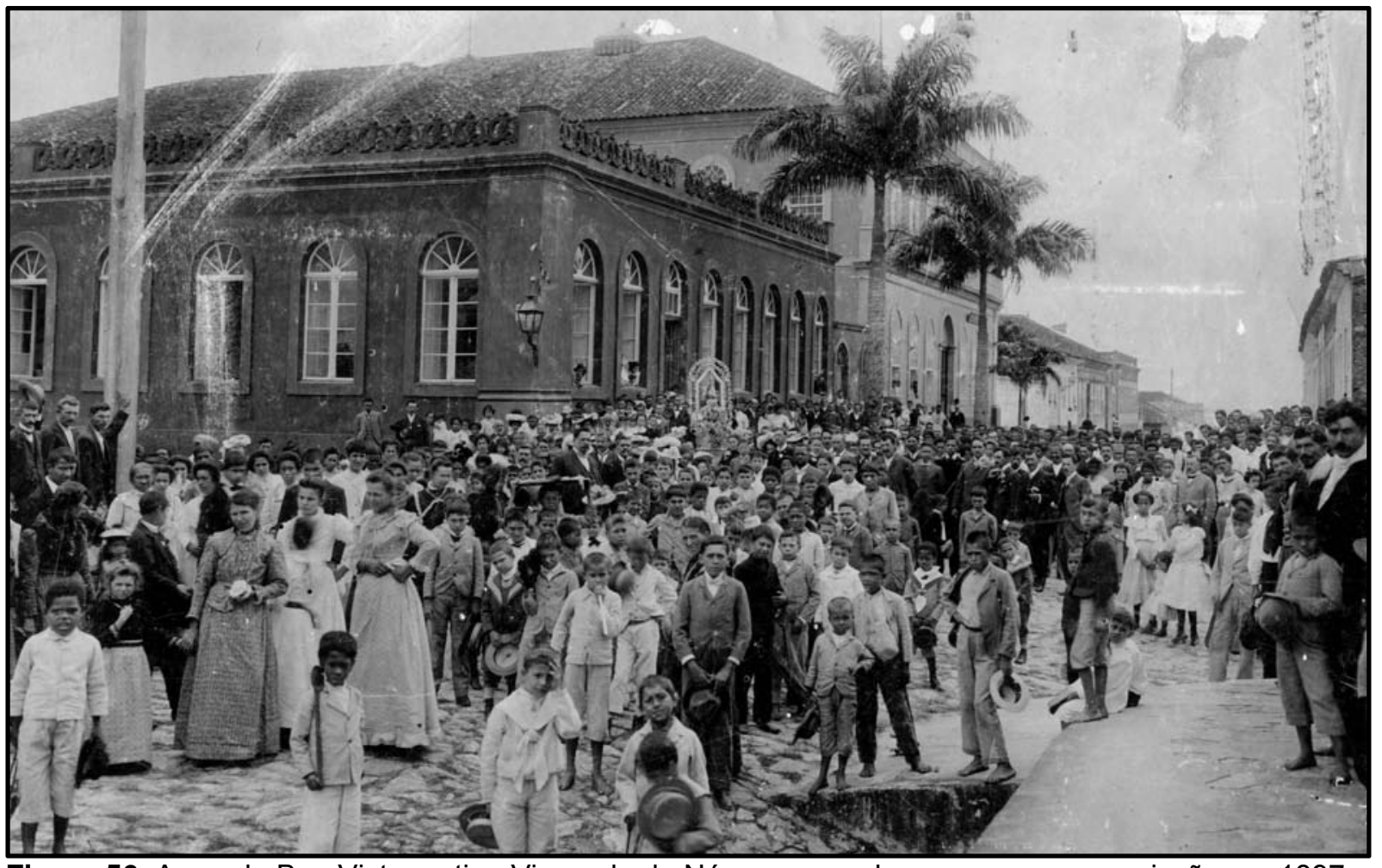

Figura 56. A rua da Boa Vista, antiga Visconde de Nácar, por onde passava uma procissão em 1897. Fonte: Álbum de José Lobo. 
Através destes dois mapas observamos que a cidade expandiu sua área urbana, pelo prolongamento das ruas já existentes, como a rua da Praia, Ordem, Direita e do Campo, direcionando-se para a região nordeste. Esse prolongamento das vias inseriu as igrejas, que na época de sua construção estavam afastadas da antiga vila, como a capela do Bom Jesus e igreja da Ordem.

Em linhas gerais, temos no sentido paralelo ao rio Itiberê, cinco eixos principais: rua do Fogo/rua do Campo, rua da Gambôa/rua Direita, rua do Ouvidor, rua da Cadeia e da Ordem, e finalmente a rua da Praia; estas são as ruas de maior comprimento e que caracterizam o sentido longitudinal desta formação urbana, isso acontece na vila de 1815 (Figura 57) e na cidade de 1895 (Figura 58). Já as vias de menor dimensão, denominadas travessas, são perpendiculares ao Itiberê e cortam as ruas, grande parte delas inicia-se na rua da Praia e finaliza na rua do Fogo/Campo.

A vila em 1815, no sentido perpendicular ao rio, limita-se pela rua Travessa, que passa em frente à igreja de São Benedito, e termina na travessa do Bom Jesus. Em 1895, a cidade de Paranaguá se mantém limitada à travessa do Bom Jesus, mas na direção nordeste seu limite vai até a atual rua Manoel Bonifácio. No sentido paralelo ao rio, temos o limite da área atrás da Matriz que compete a rua do Fogo/Campo e em outro extremo o limite natural do território, ou seja, o Itiberê. Estas características são mantidas ao final do século XIX, possuindo os mesmos limites. Portanto a expansão de Paranaguá se deu nas áreas vazias, localizadas ao centro da vila, como aos fundos da Casa de Câmara e Cadeia e no prolongamento das vias já existentes, o que aparentemente demonstra um crescimento pouco expressivo, a cidade se manteve concentrada próxima ao Itiberê e de seu porto, mas não se desenvolveu totalmente. 


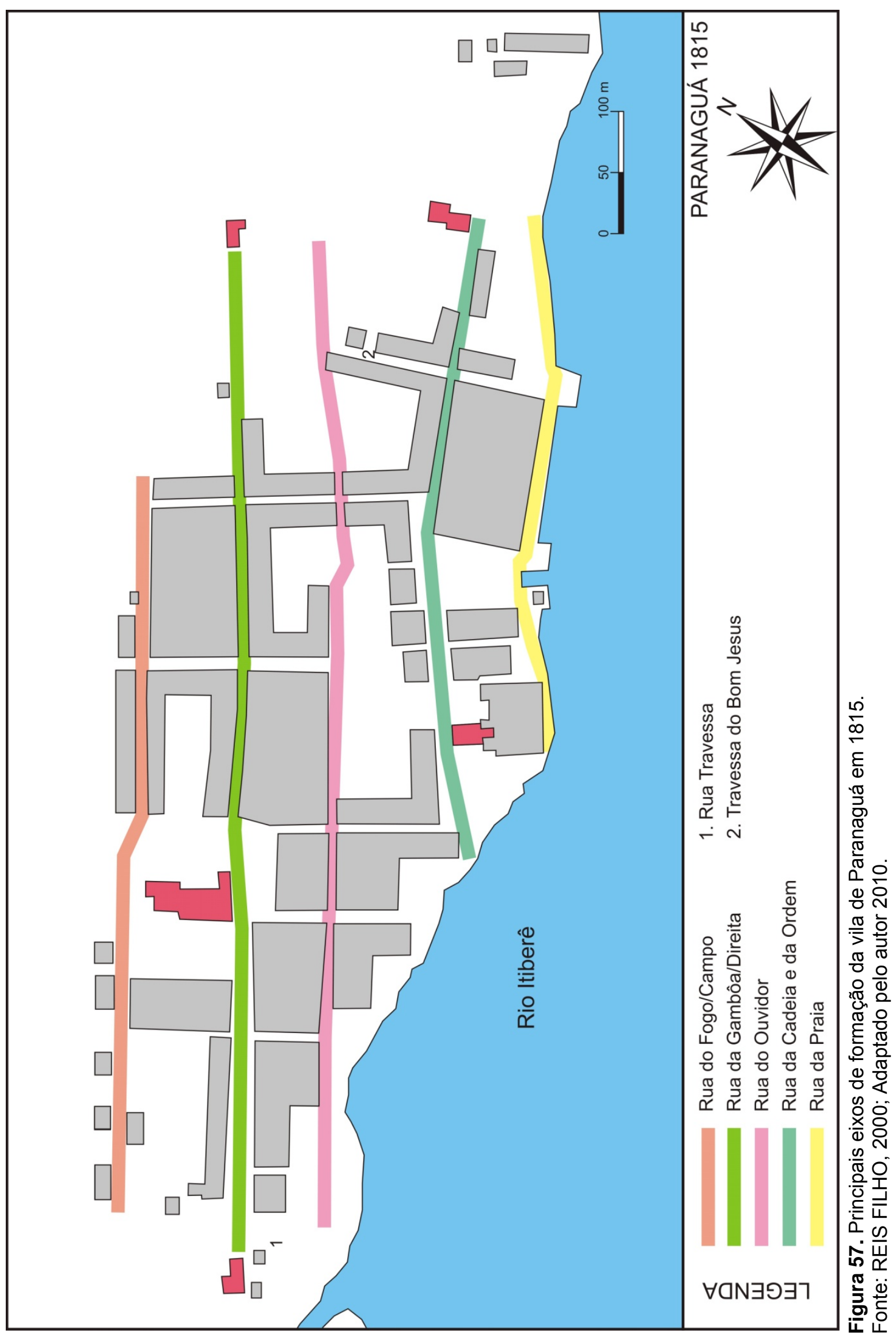




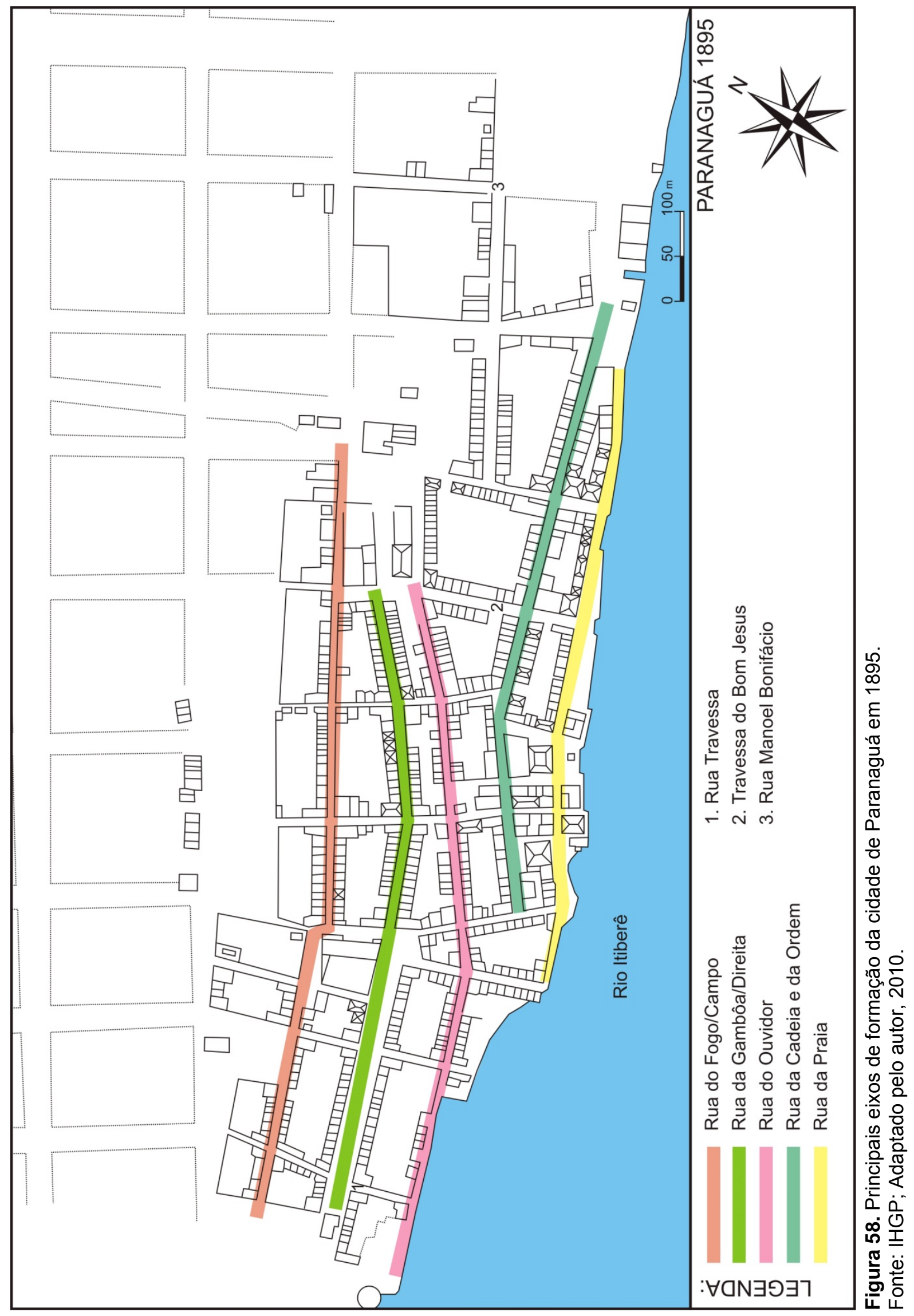


Se analisarmos em valores populacionais, através de informações coletadas por viajantes, cronistas locais, jornais e relatórios provinciais, será possível complementar a análise acima descrita. Não serão valores precisos, mas trarão uma luz sobre o comportamento populacional de Paranaguá, durante o século XIX.

Vieira dos Santos (2001), coloca que Paranaguá, em 1785 possuía uma população aproximada de 3.427 habitantes, já em 1820 o viajante Auguste de SaintHilaire (1998) descreve a vila com 5.000 moradores e em 1838 com 8.891 pessoas. Voltando a Vieira dos Santos (2001), este coloca que no ano de 1849 a cidade contava com 6.155 pessoas, uma queda ao compararmos com os valores colocados por Hilaire. Os dados de Vieira dos Santos são considerados os mais aproximados, pois em um levantamento oficial realizado pela Província do Paraná em 1854, contido no Relatório do Presidente Zacarias de Góes e Vasconcellos, temos o número de 6.533 pessoas, ou seja, um pequeno crescimento em cinco anos.

Pouco tempo depois, em outro relatório Provincial, do Presidente André Augusto Fleury (1866), temos os levantamentos populacionais de Paranaguá que resultam em uma população de 8.063 habitantes. Com o findar do século XIX, temos pelo Almanach, editado por Romário Martins (1900) em 1900, os seguintes dados: em 1890 temos Paranaguá com 11.794 habitantes e dez anos depois a população diminui para 10.152.

Observamos que o crescimento urbano de Paranaguá, até o final do século XIX (Tabela 1) não foi de grandes proporções. Curitiba depois de se tornar capital, contava com uma população de 6.791 habitantes (GÓES E VASCONCELLOS, 1854), quase o mesmo número que Paranaguá. Ao final do século, a capital da província contava com uma população de mais de 50.000 pessoas, grande diferença 
se compararmos com a cidade litorânea, que também foi preterida para ser a capital da nova província.

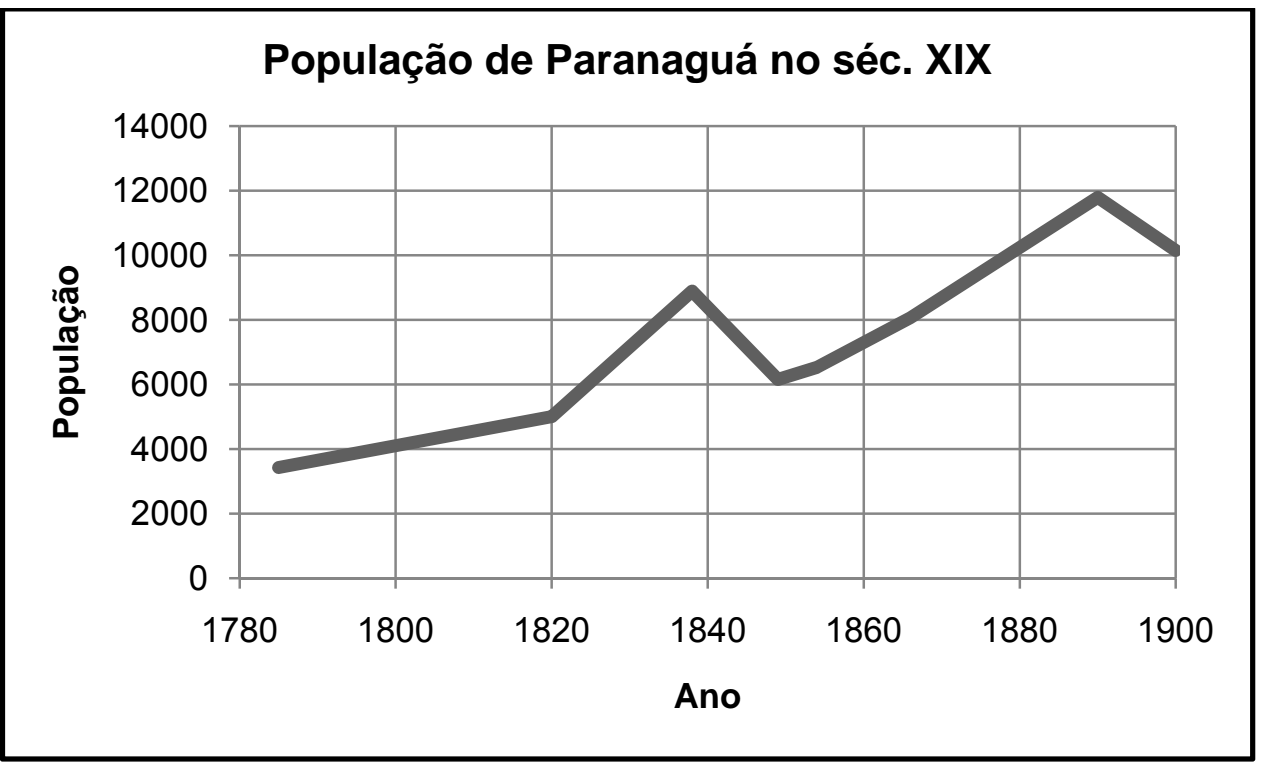

Tabela 1. População de Paranaguá no século XIX, baseando-se em dados coletados em diversas publicações.

Fonte: VIEIRA DOS SANTOS, 2001; SAINT-HILAIRE, 1998; GOES E VASCONCELLOS, 1854; FLEURY, 1866, MARTINS, 1900 /Adaptado pelo autor, 2010.

A cidade em fins de século pode ser descrita por alguns viajantes que lá estiveram nesse período, um deles é Paul Walle, que relatou Paranaguá da seguinte forma:

La vieille ville portugaise a un aspect calme et mélancolique de ville de province, mais nullemente désagréable ; il y existe même quelques belles constructions, entre autres, la Municipalité et les habitations de riches négotiants ou fonctionnaires. Nous avons été supris de voir l'exiguité de la gare du chemin de fer du Parana ; quand il y a affluence à l'arrivée ou au départ des trains, beaucoup de personnes doivent rester dehors; les magasins sont tellement petits que les expéditeurs se voient refuser leurs marchandises jusqu'á ce qu'il y ait de la place. Le tout est trés insuffisant et nuit considérablement au trafic de la ligne. Paranagua n'a guére plus de 6.000 habitants; cette ville ne se développera qu'en s'agrandissant vers Porto de Agua, et ce, lorsqu'on se sera décidé à améliorer le port, qui est un des meilleurs de la cóte. ${ }^{11}$ (WALLE, s/d, p.294)

\footnotetext{
${ }^{11}$ A velha vila portuguesa tem um aspecto calmo e melancólico de cidade provinciana, mas não de forma desagradável; existem algumas belas construções, entre outras, a Prefeitura, e as residências dos ricos negociantes ou funcionários. Ficamos surpresos de ver como é pequena a estação da estrada de ferro do Paraná; quando acontecem a chegada e partida dos trens, muitas pessoas ficam
} 
Koseritz, no seguinte trecho de suas descrições sobre Paranaguá em 1883:

As ruas são pavimentadas e mostram em sua maioria largas e belas calçadas, mas são abundantemente cobertas de capim, pois Paranaguá é uma cidade pouco povoada, quase deserta. Andei ruas inteiras nas quais não vi viv'alma. A cidade não é pequena, é maior que Antonina, mas foi visivelmente projetada antigamente para proporções muito maiores do que realmente alcançou. (KOSERITZ, 1980, p. 124)

Próximo da passagem do século XIX para o XX, esteve na cidade Émile de

Saint - Denis, que a descreve da seguinte forma:

Le coup d'oeil de la ville est charmant, la premiére impression est bonne, trés bonne meme. Sur les quais, les maisons sont bien ranges et coquettes... je vois du bord meme, avec mes jumelles l'Hôtel do Commercio, qui sera ma résidence, j'aperçois quelques villas et quelques palacètes (petits palais), qui me paraissent de fort bom goût. ${ }^{12}$ (SAINTDENIS, 1898, p. 65-66)

Temos aqui três descrições de diferentes viajantes, em períodos muito próximos, as duas primeiras nos mostram uma Paranaguá pouco povoada e abandonada, uma cidade provinciana nas impressões de Paul Walle, a estrada de ferro já estava instalada, mas a estação de Paranaguá não supria as necessidades daquele período. Em outro relato de Koseritz, este constata o grande número de consulados em Paranaguá, muito mais do que na capital Curitiba: "Há um exagero de consulados em Paranaguá; em cada rua se vê um escudo consular e às vezes dois e três em uma só casa. Ao contrário parece que em Curitiba, que é a capital, não há nenhum cônsul, coisa realmente extraordinária" (KOSERITZ, 1980, p. 125).

para fora, as lojas são tão pequenas que os carregadores recusam-se a carregar seus bens até que haja espaço. Tudo é insuficiente e prejudica a estrada de ferro. Paranaguá possui pouco mais de 6.000 habitantes; esta cidade só se desenvolverá quando o Porto d' Agua se desenvolver, e isso, quando alguém decidir melhorar este porto, que é um dos melhores da costa. (Tradução do autor)

$12 \mathrm{O}$ visual da cidade é encantador, a primeira impressão e boa, muito boa mesmo. Sobre o cais, as casas são bem arrumadas e charmosas... Eu vejo a bordo, com meus binóculos do Hotel do Commercio, que é minha moradia, eu vi algumas moradias e alguns palacetes (pequenos palácios), que aparentam ter muito bom gosto. (Tradução do autor) 
Mesmo com estas impressões, Paranaguá era uma cidade que possuía diversas organizações importantes para a época, no Almanach de 1888 temos uma lista de instituições e de comércio da cidade, como telégrafo elétrico e ótico, o Clube Literário, o Clube Republicano, lojas importadoras, perfumarias, tipografia, confeitarias e padarias, representando um conjunto de serviços que em muitas cidades não existia. (BARROS, 1887).

Para explicar o motivo do escasso número de habitantes na cidade, Koseritz (1980, p. 125) tem uma teoria:

Paranaguá é cidade de pequena povoação principalmente por causa das suas más condições higiênicas, e estas não podem melhorar enquanto a maré baixa descobrir no Itaberé uma grande extensão de lama fedorenta, sobre a qual dardejam os raios do sol sub - tropical.

O contato com o porto contribuiu para estes aspectos, as lojas importadoras, o comércio de exportação, os consulados, são efeitos dessa influência. A cidade contava com um pequeno público consumidor de produtos e serviços, principalmente aqueles que estavam ligados à exportação da erva-mate, e que possuíam recursos para financiar esse consumo. Três grandes exportadores se destacavam em 1888: Caetano Gomes Henriques, Ildefonso P. Corrêa e o Visconde de Nácar ${ }^{13}$.

Apesar da pequena população, o dinheiro circulante era muito grande, na metade do século XIX isto já era percebido por Kidder, que se impressiona com o consumo de erva-mate pelos povos sul-americanos e os rendimentos desse consumo:

Essa substância, tão pouco conhecida fora da América do Sul, forma em verdade a principal beberagem refrigerante dos hispano-americanos ao sul do equador, e milhões de dólares são anualmente gastos em Buenos Aires, Bolívia, Perú e Chile no seu consumo. Esta cidade de Paranaguá,

\footnotetext{
${ }^{13}$ De acordo com o Almanak Administrativo, Mercantil e Industrial da Província do Paraná, para o Anno de 1888. Organizado por José Ferreira de Barros.
} 
com apenas cerca de três mil habitantes, exporta cada ano mate no valor quase de um milhão de dólares. (KIDDER and FLETCHER, 1941, p.22)

Mas o que motivou o crescimento populacional de Curitiba e por que ela se tornou tão populosa se a compararmos com a cidade de Paranaguá? Primeiramente, temos em 1853 a formação da Província do Paraná, resultante de sua separação da Província de São Paulo. A economia ervateira foi determinante nessa separação, dando maior independência a jovem província, que agora se desenvolveria sem a interseção do governo paulista.

Portanto:

\begin{abstract}
"durante essa fase, os desejos de liberdade política estão diretamente ligados à necessidade de expansão comercial. Era, portanto, imperativa a emancipação da $5^{\text {a }}$ Comarca de São Paulo a fim de que ela alcançasse mais rápido e diretamente o seu progresso econômico." (SANTOS, 2001, p.43)
\end{abstract}

Com o decreto de criação da Província do Paraná, foi despertado entre os habitantes das duas principais cidades, agora paranaenses, uma grande dúvida: qual cidade sediaria a capital do Paraná, Paranaguá ou Curitiba? Primeiramente, ocorreu a nomeação do Presidente: Dr. Zacarias de Góes e Vasconcelos, que chegou à Paranaguá para sua posse em 1853. Cabia a ele a decisão sobre a nova capital.

A cidade de Curitiba foi escolhida para sediar a nova capital da jovem província, de acordo com Wilson Martins (1999), a justificativa de Vasconcellos para essa preferência era aparentemente a necessidade do desenvolvimento daquela região. Segundo Martins, o presidente justificou essa ação da seguinte forma: Curitiba era ponto mais central do que qualquer cidade litorânea, ele considerava o município mais populoso, também colocou que existia a falta de cultura e progresso das cidades de "serra-acima", Curitiba ficava próxima a regiões ainda desocupadas 
como Guarapuava e Palmas, e por fim o clima curitibano, considerado salubre, pois era semelhante ao europeu.

Mas outras considerações também devem ser relevadas, a partir do século XVIII, foram formados dois partidos políticos que no próximo século estariam em constantes conflitos. Curitiba sediou o Partido Liberal, composto pelos fazendeiros curitibanos e dos Campos Gerais, já em Paranaguá, foi formado o Partido Conservador, constituído por comerciantes e industriais da erva-mate. A primeira disputa de interesses entre os dois partidos ocorreu em 1812, com a transferência da sede da Comarca de Paranaguá para Curitiba, sendo esta a primeira grande derrota parnanguara, depois disso o fortalecimento dos fazendeiros e comerciantes de mulas do interior pesou na decisão para a criação da capital curitibana. (PEREIRA; SANTOS, 2000).

Em outro aspecto, a cidade de Curitiba recebeu grande parte dos imigrantes que chegaram à nova província, principalmente após o desenvolvimento da exploração da erva-mate, de acordo com Samuel Guimarães da Costa (1988, p. 86):

Por outro lado, a erva-mate teve uma participação importante na fixação das colônias de neo-europeus, principalmente italianos, poloneses e ucranianos, oriundos da grande imigração estrangeira iniciada em fins do século passado, assegurando a sobrevivência de muitas delas que, de outro modo, dadas as reduzidas dimensões do mercado interno, teriam certamente fracassado.

Grande parte da mão de obra da economia ervateira estava presente nas primeiras fases após a coleta da erva-mate. Depois de cortados os galhos, os ramos são colocados sobre o fogo, em um processo denominado "sapeco", posteriormente a erva passa por uma segunda secagem em fogo indireto e o material é triturado. Após esse processo, a erva-mate era transportada aos engenhos de beneficiamento 
e exportada, através do porto de Paranaguá, aos países cisplatinos. (DA COSTA, 1995).

Nas palavras de Dennison de Oliveira (2001, p. 26):

Numa primeira etapa de seu processo de produção, o mate requeria mão de obra abundante e barata, ainda que pouca ou nenhuma qualificação fosse necessária. No processo da colheita, as folhas da erva, nativa dos campos do Paraná, eram cortadas e amarradas para envio ao local de beneficiamento. No estágio seguinte, as folhas eram torradas e moídas em engenhos movidos a energia hidráulica ou animal. Finalmente, o pó assim obtido era socado dentro de sacos e enviado para a comercialização.

A mão de obra estava concentrada nos arredores da capital paranaense e foi o local que atraiu parte dos imigrantes externos e internos, segundo Sérgio Odilon Nadalin (2001, p. 77 ):

Foi na região de Curitiba que melhor se desenvolveu a atividade colonizadora, compreendendo o estabelecimento de alemães e suíços, italianos e poloneses, secundados em importância por franceses, ingleses e escandinavos. O ponto de referência da presença imigrante no primeiro planalto paranaense situa-se entre 1850 e 1859. Neste momento, iniciavase o fluxo maior da remigração de imigrantes de idioma alemão para Curitiba, oriundos da Colônia Dona Francisca (Joinville), no norte de Santa Catarina.

Portanto, temos a imigração como um dos fatores de desenvolvimento populacional de Curitiba, aliado à própria criação da capital. Já Paranaguá, se mantinha como centro exportador e de comércio, que remetia através de seu porto as produções advindas de "serra-acima", possuindo uma economia desenvolvida, mas que não se refletia na cidade. Paranaguá manteve as diretrizes de seu traçado colonial, através do prolongamento das vias já existentes, o crescimento ocorreu nestas vias prolongadas e também nas áreas vazias encontradas dentro da estrutura urbana da antiga vila. Utilizando uma das definições sobre o desenvolvimento de São Paulo no século XVII, por Nestor Goulart ${ }^{14}$ e aproveitando-

\footnotetext{
${ }^{14}$ Sobre o desenvolvimento da Vila de São Paulo, ver REIS FILHO, Nestor Goulart. São Paulo: Vila, Cidade, Metrópole. São Paulo: Takano, 2004.
} 
a para este caso, Paranaguá, no século XIX, foi uma cidade que "cresceu quase sem crescer", ou seja, se desenvolveu, mas sem ser explicitamente observada nos mapas e no crescimento da população. A vila "pequena, mas comerciante", descrita pelos viajantes, analisada nos mapas, dados econômicos e populacionais nos mostram esses aspectos.

Sendo assim, Paranaguá sediou uma elite ervateira e escravocrata, que mantinha para si a apropriação daquele espaço, obtendo lucros, mas não desenvolvendo a população. Uma economia ainda presa ao sistema escravista, que lucrava com o tráfico de escravos e tornando a cidade um centro dessas atividades, provocando na metade do século um incidente diplomático que afetou as relações entre Brasil e Inglaterra ${ }^{15}$.

A própria política ainda muito conservadora e saudosista, mantêm certas tradições, mesmo após a República. Uma fotografia que chama bastante atenção (Figura 60), foi encontrada no álbum do Prefeito José Lobo, ela retrata um conjunto de quadros colocados no Salão Nobre (sala de sessões) da Prefeitura de Paranaguá (Figura 59), no começo do século XX. Existe um quadro mais alto e outros cinco abaixo dessa imagem principal. A imagem principal era a de D. Pedro II e abaixo dela está a dos Presidentes Campos Salles, Wenceslau Brás, Epitácio Pessoa, Marechal Hermes e Rodrigues Alves. Temos a imagem de D. Pedro II como a principal daquele conjunto, ainda representando o poder máximo para grande parte dos cidadãos parnanguaras, pertencentes a uma sociedade que possivelmente se via perdida sem o imperador dominando suas vidas.

\footnotetext{
${ }^{15} \mathrm{Em} 1846$ o Parlamento inglês aprovou uma lei que autorizava à sua marinha a considerar navios negreiros como piratas, sendo possível sua apreensão e julgamento. Este controle estava concentrado nos mares brasileiros e um dos casos mais importantes ocorreu em Paranaguá, com a troca de tiros entre os cidadãos e este navio inglês que queria interceptar um navio negreiro, 0 acontecimento ficou conhecido como Combate do Cormorant. (FAUSTO, 2001, MARTINS, 1995).
} 


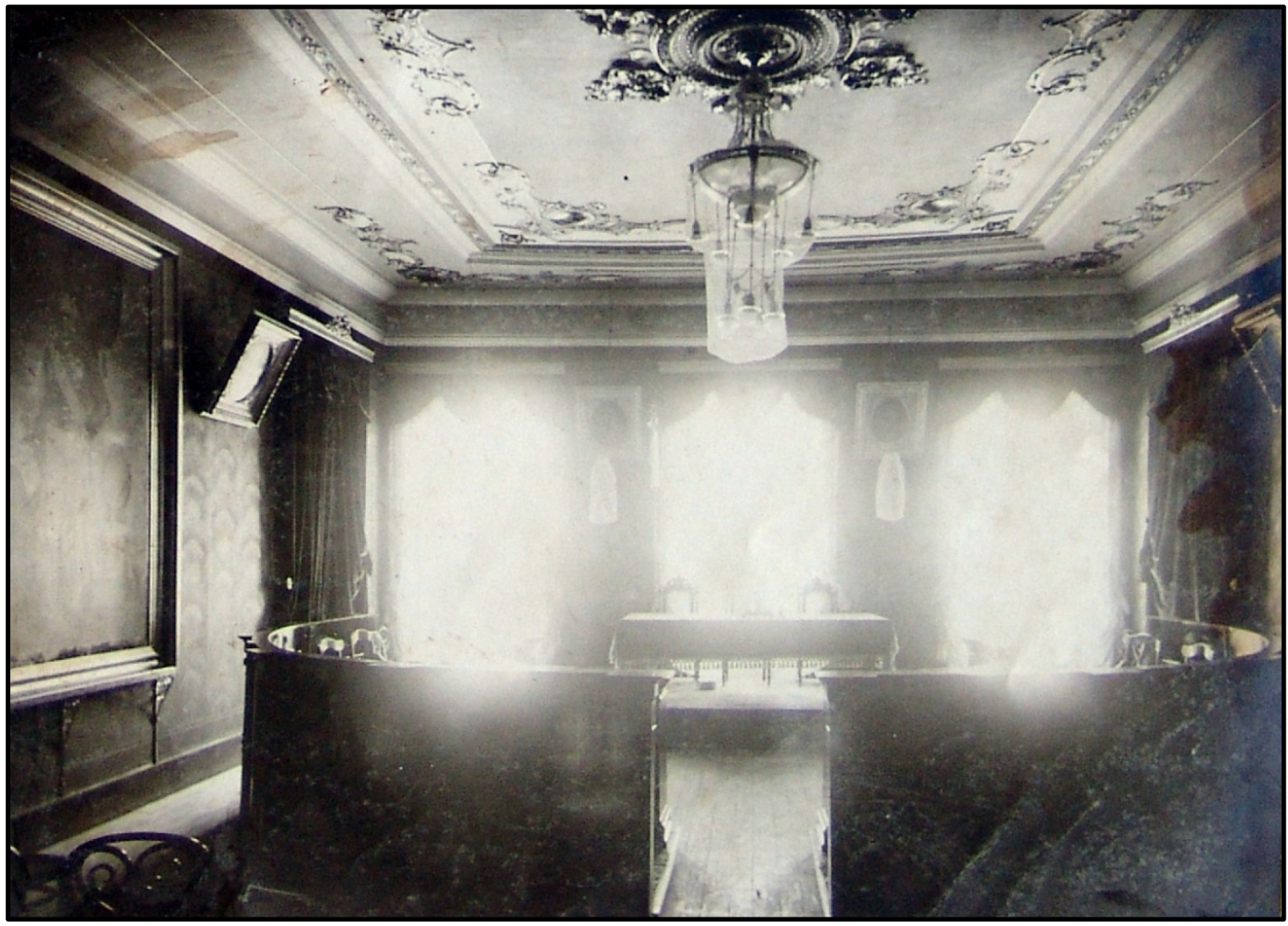

Figura 59. Salão Nobre da Prefeitura Municipal de Paranaguá, começo do século XX Fonte: Álbum de José Lobo

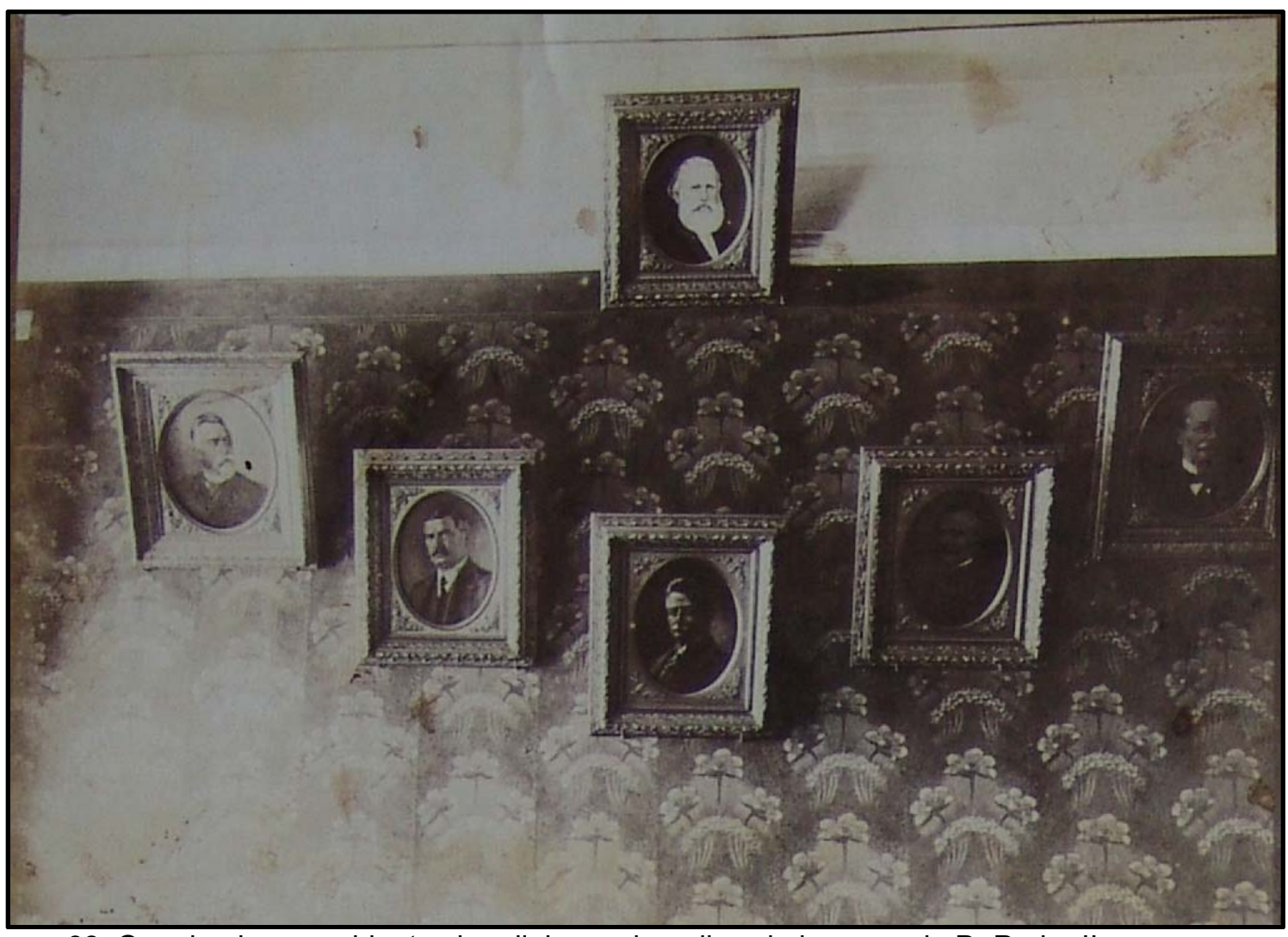

Figura 60. Os primeiros presidentes brasileiros sob o olhar da imagem de D. Pedro II. Fonte: Álbum de José Lobo 
2.2. CEMITÉRIO, MERCADO, POSTURAS: AS PREOCUPAÇÕES SANITÁRIAS NA CIDADE DE PARANAGUÁ.

No século XIX, foram marcantes os estudos relacionados à higiene das cidades. No Brasil, um dos pioneiros foi o médico Manuel Maurício Rebouças, que em 1831, escreveu um relatório sobre os métodos de sepultamentos ocorridos no interior das igrejas. Baseando-se na literatura médica francesa, Rebouças considerava o método um perigo à saúde, já que os gases resultantes da decomposição dos corpos exalavam no interior dos templos, o que possibilitava a contaminação daqueles que freqüentavam esses ambientes. Portanto, o estudioso propõe certas medidas para evitar essa tradição, acabando com estes sepultamentos e criando-se cemitérios a céu aberto, longe das cidades, de fontes de água e fora da rota dos ventos. Este estudo e outros anteriormente divulgados, também relatavam sobre o problema, o que interessaram aos legisladores, culminando na alteração das leis relacionadas ao tema nas reformas liberais de D. Pedro I em 1828. (REIS, 2008)

Esses estudos, normas e procedimentos serão propagados por todo o Brasil, no caso de Paranaguá, em 1850, já existiam críticas quanto aos enterramentos no interior das igrejas, principalmente na Matriz. Vieira dos Santos descreveu como se configurava a distribuição dos túmulos no interior da igreja, onde seu piso foi dividido, no ano de 1756, em três áreas distintas:

A primeira do presbitério ao arco do cruzeiro com vinte sepulturas, em duas ordens, onde não se enterra pessoa alguma salvo se for eclesiástico. A segunda divisão é do arco do cruzeiro às grades da comunhão, em três ordens, em trinta sepulturas [...] a terceira divisão é das grades da comunhão à porta principal que contém 135 sepulturas divididas em nove 
ordens de quinze cada uma, sendo o total de todas que tem neste templo: 185 sepulturas [...] (VIEIRA DOS SANTOS, 2001, p.45).

A descrição colocada por Vieira dos Santos demonstra a hierarquia existente nos sepultamentos ali realizados. No caso de Paranaguá, as sepulturas mais próximas ao altar eram exclusivas dos sacerdotes, sendo que as outras divisões eram destinadas às irmandades e aos que delas faziam parte.

Portanto, a posição dos túmulos dentro da igreja vinha de acordo com a posição social de quem ali era enterrado, sendo as mais próximas do altar aos que possuíam melhor situação e as que estavam próximas ao adro os de menor prestígio. (REIS, 2008). Essa tradição, comum em todo o Brasil, possuía um simbolismo importante para aqueles que freqüentavam as igrejas. De acordo com José Reis (2008, p.124-125):

A igreja representava uma espécie de portal do Paraíso. Ao mesmo tempo era o lugar perfeito e desejável para se aguardar a ressurreição no dia do Juízo Final, uma concepção amplamente difundida no mundo católico desde a Idade Média.

Mas, no século XIX, as igrejas mais antigas já não supriam a quantidade de mortos enterrados em suas estruturas e já causavam problemas sanitários que preocupavam os médicos da época. Em Paranaguá, Vieira dos Santos relatou em seus escritos sobre os problemas dos enterramentos na igreja Matriz. Pelos seus cálculos, ele sugere que estivessem enterrados mais de 45.000 corpos nessa igreja:

[...] depositados sempre num mesmo terreno, já se vê que esse não pode ter mais vigor a saciar a ardente fome de desfazer carne humana; as contínuas exalações que evapora esta terra devem necessariamente formar muitos gases pela decomposição destas substâncias pútridas, continuamente atraídas pelo ar atmosférico, estas substâncias indizíveis e insalubres encerradas quase sempre dentro do recinto do templo a maior parte do dia fechado, não podem estes eflúvios serem saudáveis à espécie vivente [...] (VIEIRA DOS SANTOS, 2001, p. 45). 
A idéia da contaminação pelos gases provenientes da decomposição dos corpos foi, em grande parte, divulgada no Brasil, pela Sociedade de Medicina do Rio de Janeiro, que relatava os efeitos que os miasmas, ou os gases provenientes da decomposição, causavam nas pessoas que freqüentavam as igrejas, que vão de desmaios, até a morte. O próprio olfato deveria ser mais intolerante, acostumado ao cheiro de putrefação, isto agora deveria ser evitado de forma a evitar o contágio (REIS, 2008).

Esses métodos de enterramento, cada vez mais eram alvos de críticas em todo o Império, onde as primeiras determinações sobre a implantação de cemitérios externos, nas cidades, foi organizada através da lei de 1828 que criou as Câmaras Municipais e também estabeleceu a organização destes locais de sepultamento. (VIEIRA DOS SANTOS, 2001). Em Paranaguá isso não foi diferente, na metade do século XIX foi ordenada a construção de um cemitério, na área urbana da cidade, ao lado da igreja Matriz.

Observa-se que a lei só foi aplicada efetivamente 20 anos depois das determinações imperiais. Provavelmente, com o método de enterramento nas igrejas, ainda arraigado às tradições, a idéia de implantar um cemitério em local afastado da cidade era uma medida impopular. Portanto, implantando-se este cemitério ao lado da principal igreja da cidade, seria uma forma mais atenuante de se estabelecer novos padrões para o sepultamento dos habitantes, sem que estes perdessem a proximidade com o edifício religioso.

Em Paranaguá, o início das obras do novo cemitério, aconteceu em janeiro de 1850, onde foi delineado o terreno e a construção de um muro em toda sua volta. Em sua configuração final, o campo santo estava cercado por um muro de pedra, onde em sua face principal esse muro era encimado por oito pequenos pilares que o 
arrematavam em conjunto com o gradil de ferro e sobre cada pilastra estava um vaso de flor. (VIEIRA DOS SANTOS, 2001).

A hierarquia social existente nos antigos métodos de sepultamentos, não foi perdida com a mudança no espaço, pelas descrições de Vieira dos Santos (2001), existiam duas entradas na fachada principal do novo cemitério de Paranaguá, uma maior ao centro do muro, era em arco pleno e possuía logo acima uma parede mais alta, encimada por dois vasos e a cruz cristã (Figura 27), indicando ser este o acesso principal ao cemitério. Essa entrada estava destinada à chegada dos funerais mais faustosos, ou seja, daqueles que possuíam condições de executá-lo. Já para aqueles que não tinham a mesma condição, os funerais mais simples, sem toda a pompa e circunstância, existia outro acesso, na lateral direita do cemitério, na divisa com a Matriz, onde havia uma porta menor e mais acanhada.

Quanto à sua distribuição interna, existiam no total 114 catacumbas, divididas em 72 para adultos, 18 para menores e 24 para recém-nascidos, os espaços para os últimos eram localizados nas paredes internas do cemitério. No centro do terreno, estava localizado um octógono, configurando-se como um altar, para as últimas homenagens aos mortos, que também era destinado ao sepultamento de recémnascidos. (VIEIRA DOS SANTOS, 2001).

Apesar da mudança significativa no espaço de sepultamentos, em prol da melhoria da saúde dos católicos, a implantação destes cemitérios nas áreas urbanas, acabou tornando-se alvo de críticas do primeiro presidente da Província do Paraná em seu relatório anual. A importância da discussão fez com que nesse relatório, o assunto cemitério recebesse grande destaque, tornando-se um dos capítulos daquele texto. 
Primeiramente o presidente Zacarias de Góes e Vasconcellos, critica o antigo procedimento dos sepultamentos em igrejas:

A religião, não menos que a hygiene, oppôe-se ao reprovado costume de se enterrarem nos templos cadáveres humanos; mas tal he a força dos hábitos e dos abusos, que ás vezes o medo pode fazer inclinar-se a balança em favor da razão e da experiência." (GÓES E VASCONCELLOS, 1854, p.52).

O presidente também discute casos semelhantes, da implantação do campo santo ao lado de igrejas, existentes em outras cidades litorâneas como Morretes e Antonina. Segundo Vasconcellos (1854, p. 52):

Forão, e são ainda, esses cemitérios obras imperfeitas e, por assim dizer, provisórias, e basta considerar que são elles annexos ás igrejas em Morretes, Antonina, e mesmo em Paranaguá onde de três que há, hum pertencente a irmandade de S. Francisco da Penitência, e dous públicos, só hum destes está collocado fora da povoação, a saber, o da irmandade junto a igreja de $\mathrm{S}$. Francisco, hum dos dous públicos annexo á matriz, e outro fora do recinto da cidade. (GÓES E VASCONCELLOS, 1854, p.52).

Pelo relatório provincial, em 1854 existiam três cemitérios na cidade de Paranaguá: um deles, o primeiro, estava na lateral da igreja Matriz, o outro na igreja de São Francisco da Penitência, ou seja, na igreja da Ordem Terceira. No caso da igreja da Ordem, em sua lateral, observamos a existência de uma pequena área, onde estão algumas lápides que datam das décadas de 60 e 70 do século XIX, um cemitério em que estão sepultados membros de sua irmandade, devido ao exíguo espaço no qual estão contidos e pela própria definição de Zacarias de Góes e Vasconcellos no relatório citado anteriormente, que considera público o cemitério na área externa da cidade e o da Matriz.

Em 1858, com a publicação do Código de Posturas de Paranaguá, ficou estabelecido em um dos itens desse documento a proibição de sepulturas no interior das igrejas, definindo que a partir daquele momento, esses enterros deveriam ser realizados no cemitério da Ressurreição. 
Mas, tudo indica que o início da implantação de um cemitério definitivo na área externa da cidade ocorrerá a partir dos anos 60 do século XIX e se desenrolará durante décadas. As primeiras ações de implantação do campo santo são encontradas no relatório do Presidente Antônio Barbosa Nogueira, onde a Câmara de Paranaguá solicitou "[...] a construção de um cemitério extra-muros [...]", fora da concentração urbana, e a "[...] transferência do portão de ferro e portadas de pedra do antigo para o novo cemitério." (NOGUEIRA, 1863, p. 57-58). Seria a transferência dos materiais do antigo cemitério, ao lado da Matriz, para esse instalado na área externa da cidade.

A mudança no local dos enterramentos já era indicada em periódicos da época, como em mensagem colocada no jornal parnanguara, Commercio do Paraná, que diz: "Quem tiver ossos de seus defuntos no cemitério da matriz queira mandar tirar até o dia 30 do corrente, do contrario serão enterrados todos juntos. 0 fiscal Manoel Gonsalves Guimarães."16

Mas, quanto às condições do novo cemitério:

Tivemos occasião de ir ao cemitério publico, e avista do abandono e desleixo em que o encontramos não podemos deixar de dizer duas palavras, afim de ver se ellas chegarão a despertar do somno da indolência em que jaz aquelle a quem compete zelar pelo cemitério Os túmulos que ali se achão estão mettidos no meio do matto, devido ao pouco ou nenhum cuidado de mandarem carpir o terreno, o que se podia conseguir com dois dias de serviço.

A tumba ou caixão da fábrica se acha atirado no chão, exposto ao rigor do tempo! Se não tiver occasião de ser occupado, alli apodrecerá. ${ }^{17}$

Em 1864, ainda se mantinham as mesmas condições precárias do cemitério público: "Consta-nos que o cemitério do Palmital se acha em muito mao estado. Os animaes pastão dentro delle a sua vontade como se estivessem em um campo

\footnotetext{
${ }^{16}$ Commercio do Paraná. Annuncios. Commercio do Paraná. Paranaguá, 27 dez. 1862, p. 2.

${ }^{17}$ Commercio do Paraná. Cemitério. Commercio do Paraná. Paranaguá, 31 jan. 1863, p. 1
} 
aberto."18 Portanto, nem o cercamento fora feito nesse novo cemitério, era um espaço aberto sem possuir a manutenção necessária e provavelmente ninguém aceitaria velar e enterrar seus mortos em um local como aquele.

Em 1880, o estado daquele local continuava da mesma forma e o jornal curitibano Dezenove de Dezembro, publicou a seguinte informação sobre a situação e o descaso no tratamento desse campo santo:

S. Ex o Sr. Dr. Presidente da província tendo verificado, por ocasião de sua viajem ao littoral, o máo estado do cemitério da cidade de Paranaguá, pois o cerco existente e que é de madeira, acha-se de tal modo estragado, que não offerece o necessário amparo e não veda a entrada de animaes $[\ldots] .{ }^{19}$

O mesmo jornal ainda coloca que foi nomeada uma comissão, composta por nomes como o Visconde de Nácar, o vigário da cidade, o delegado e outros que tinham a função de arrecadar doações em prol das reformas deste cemitério. Segundo Ferreira Junior (190?), estas doações continuaram em 1883, onde outra comissão foi nomeada para arrecadar fundos para a construção do cemitério.

No mesmo ano, foi apresentado à Câmara de Paranaguá o projeto e o orçamento do novo cemitério, oferecido gratuitamente pelo "arquiteto civil" Antônio Arzua dos Santos. Em novembro de 1883, "Foi contractada a factura do Cemitério por 11:000\$000, com Antonio Arzua dos Santos." (FERREIRA JUNIOR, 190?, p. 68)

No início de 1884, foi então realizada a cerimônia de abertura dos trabalhos, com a construção do muro e a colocação do portão, o cemitério estava na região do Palmital e ainda era denominado Cemitério da Ressurreição. Finalmente em 7 de janeiro de 1886: "Foi recebido pela respectiva Comissão de Obras Públicas, o Cemitério da Ressurreição, visto achar-se concluída a sua factura, de conformidade com o contracto." (FERREIRA JUNIOR, 1903).

\footnotetext{
${ }^{18}$ Commercio do Paraná. Cemitério. Commercio do Paraná. Paranaguá, 23 de julho de 1864, p. 1.

${ }^{19}$ Dezenove de Dezembro. Cemitério de Paranaguá. Dezenove de Dezembro. Curitiba, 23 de out. de 1880 , p. 3.
} 
De uma área abandonada sem nenhuma proteção, até a construção de muros e a inauguração oficial do cemitério, foram quase trinta anos. Só em 1896, no Código de Posturas, publicaram-se as normas para esse local, agora denominado Cemitério do Carmo. Este seria o único cemitério da cidade, pois na relação de despesas da Câmara Municipal, para o ano de $1897^{20}$, o único cemitério que consta nesses documentos é o Cemitério do Carmo.

Em seu interior, de acordo com as posturas de 1896, o cemitério estava dividido em "[...] quadros ou quadrilongos, como melhor convier, separados pelas ruas necessárias que terão largura não menor de vinte palmos." Onde "as ruas serão bordadas de arvoredos próprios" (PARANAGUÁ, 1896, p. 113). Especifica-se a construção de uma capela e de salas para cadáveres que não pudessem ser enterrados no mesmo dia em que entraram no cemitério. Em casos de dúvidas no diagnóstico de morte, a norma definia uma sala para estes casos, onde: "[...] bem assim com todos os arranjos e apparelhos necessários para a vigília e observação dos corpos de pessoas mortas repentinamente, até manifestarem signaes de princípio de decomposição." (PARANAGUÁ, 1896, p. 113). Uma forma de evitar o sepultamento de pessoas ainda vivas.

Quanto às preocupações sanitárias, esse código especifica a profundidade das covas, não sendo menores que 7 palmos, e os caixões deveriam ser em madeira, revestidos com folhas de chumbo, provavelmente para evitar a contaminação do solo. As covas poderiam ser renovadas após sete anos do primeiro enterro, para isso as ossadas deveriam ser enterradas no mesmo lugar, mas abaixo dos sete palmos e acima disso outro corpo poderia ser sepultado. (PARANAGUÁ, 1896).

\footnotetext{
${ }^{20}$ PARANAGUÁ. Lei no 34 de 22 de outubro de 1896 - Lei de Orçamento. Paranaguá: [s.n.], 1896.
} 
As posturas municipais organizaram a estrutura do cemitério, nomeando um administrador e um coveiro, também estabelecendo a criação de um livro que catalogava todos que ali estavam enterrados. As covas sem lápides ou outro tipo de indicação, teriam um número para que fossem localizadas. A implantação definitiva do cemitério em Paranaguá, até que se chegasse a um sistema desejável, passou à partir da metade do século XIX, por um lento processo de transformação. Do interior das igrejas para a área externa, ao lado da Matriz, o cemitério ainda estava situado no convívio do dia a dia, dos eventos litúrgicos e não longe do "portal do paraíso".

Enquanto não eram resolvidos os problemas para a transferência definitiva da necrópole para a região extramuros, os habitantes se conformavam em enterrá-los em sua proximidade, dentro da cidade. Apenas no final do século XIX, com a construção de um local apropriado, essa mudança pôde ocorrer. O atraso nessa mudança pode ter sido motivado pela contrariedade das pessoas em mudar suas tradições, ou no descaso do governo, postergando a construção definitiva de um cemitério externo na cidade de Paranaguá.

Outro edifício urbano que terá uma organização administrativa, preocupandose com as questões de higiene será a Praça do Mercado. A construção desse edifício em Paranaguá, ocorreu através da solicitação de sua Câmara ao recém criado Governo Provincial do Paraná, em que, [...] lembra a urgente necessidade de huma praça de mercado, e de hum matadouro regular." A instalação desse edifício tem por finalidade, organizar os vendedores de produtos agrícolas para que pudessem expor [...] à venda aos consumidores da cidade, e, no caso de os não venderem promptamente, achem, mediante hum módico aluguel, quartos para guardal-os até dispor delles [...] (GÓES E VASCONCELLOS, 1854, p. 49). 
Paranaguá contava, no ano da criação da Província do Paraná (1853), com uma população ${ }^{21}$ de aproximadamente 6.533 pessoas, dentre as quais 1.274 eram escravos, enquanto a capital Curitiba, possuía 6.791 habitantes. Observa-se a pequena diferença populacional entre as duas cidades, sendo estas as mais povoadas da jovem província e as primeiras a receberem o edifício do mercado.

Após a solicitação, pela Câmara de Paranaguá, para a construção da praça do mercado, ocorreu a concessão do dinheiro em 1856, sendo que, a solenidade de lançamento da Pedra Fundamental do Mercado aconteceu em dezembro de 1857, marcada por grandes festividades e a colocação de três pedras que simbolizavam os acessos principais ao novo edifício. (FERREIRA JUNIOR, 1903)

A obra foi concluída em 1859, "[...] faltando-lhe os portões de ferro, mandados vir do Rio de Janeiro." (MATTOS, 1859, p.30). O mercado de Paranaguá foi construído antes do mercado da capital da Província, que nesta época iniciava as obras de seu edifício e de São Paulo ${ }^{22}$, que teria seu primeiro mercado em 1867 , cuja obra foi autorizada pelo governo provincial no ano em que Paranaguá inaugurava o seu espaço comercial. Em 29 de setembro de 1859, foi inaugurada a Praça do Mercado com a presença de autoridades e da população, ocorrendo a entrega das chaves aos locatários das casinhas e posteriormente:

[...]o empreiteiro Ursulino José da Silva, que havia preparado nas varandas do lado do sul, uma meza decentemente arranjada e guarnecida de doces e liquidos finos, adequados a actos semelhantes, obsequiou os concurrentes, convidando-os a tomarem um copo d' água do poço do Mercado, o que sendo unanimemente acceito, com gosto e enthusiasmo todos se chegaram á meza e utilizaram-se do que n'ella havia disposto com o maior aceio e ordem que se observa em todo o Edifício. (FERREIRA JUNIOR, 1903: 32-33)

\footnotetext{
${ }^{21}$ Segundo dados publicados no Relatório do Presidente da Província do Paraná, de 15 de julho de 1854.

22 Segundo Reis Filho (1994).
} 
Ursulino José da Silva foi uma figura marcante na Paranaguá da metade do século XIX, sendo responsável por algumas das obras construídas na cidade naquele período. Poucos documentos relatam sobre este construtor, sendo encontrado seu nome em algumas notícias de jornais e atas da câmara, que mencionam sobre a sua responsabilidade na execução de obras, no papel de empreiteiro, como na edificação da torre da igreja de São Benedito, nas reformas da igreja Matriz e na Praça do Mercado.

Com a construção da Praça do Mercado, temos aqui a consolidação da rua da Praia, margeando o Itiberê, como importante via comercial e alfandegária da cidade, onde circulavam na metade do século XIX, produtos de diversas partes do Brasil e do mundo e provavelmente pode ter influenciado na escolha desse local para sediar o mercado de Paranaguá.

A praça do mercado foi uma das primeiras obras com características Neoclássicas em Paranaguá, apesar de sua simplicidade, o edifício contém elementos pouco utilizados na época de sua construção (Figura 61 e Figura 62). Ele se constitui de uma planta quadrada em que as pequenas lojas estão localizadas em seu entorno, abrindo-se ao interior, onde existia um pátio e ao centro deste pátio estava uma pequena fonte de água, que servia para a limpeza do local. Sua fachada era simples, marcada pelos três acessos, um em cada face. Esses acessos eram encimados por pequenos frontões triangulares, e as três portas eram em arco pleno, assim como também as janelas que circundavam todo o edifício, essas aberturas continham grades em ferro que foram forjadas no Rio de Janeiro. O mercado era coroado por uma platibanda, marcada pelo friso superior e inferior, que ocultava a cobertura e emoldurava os frontões. 

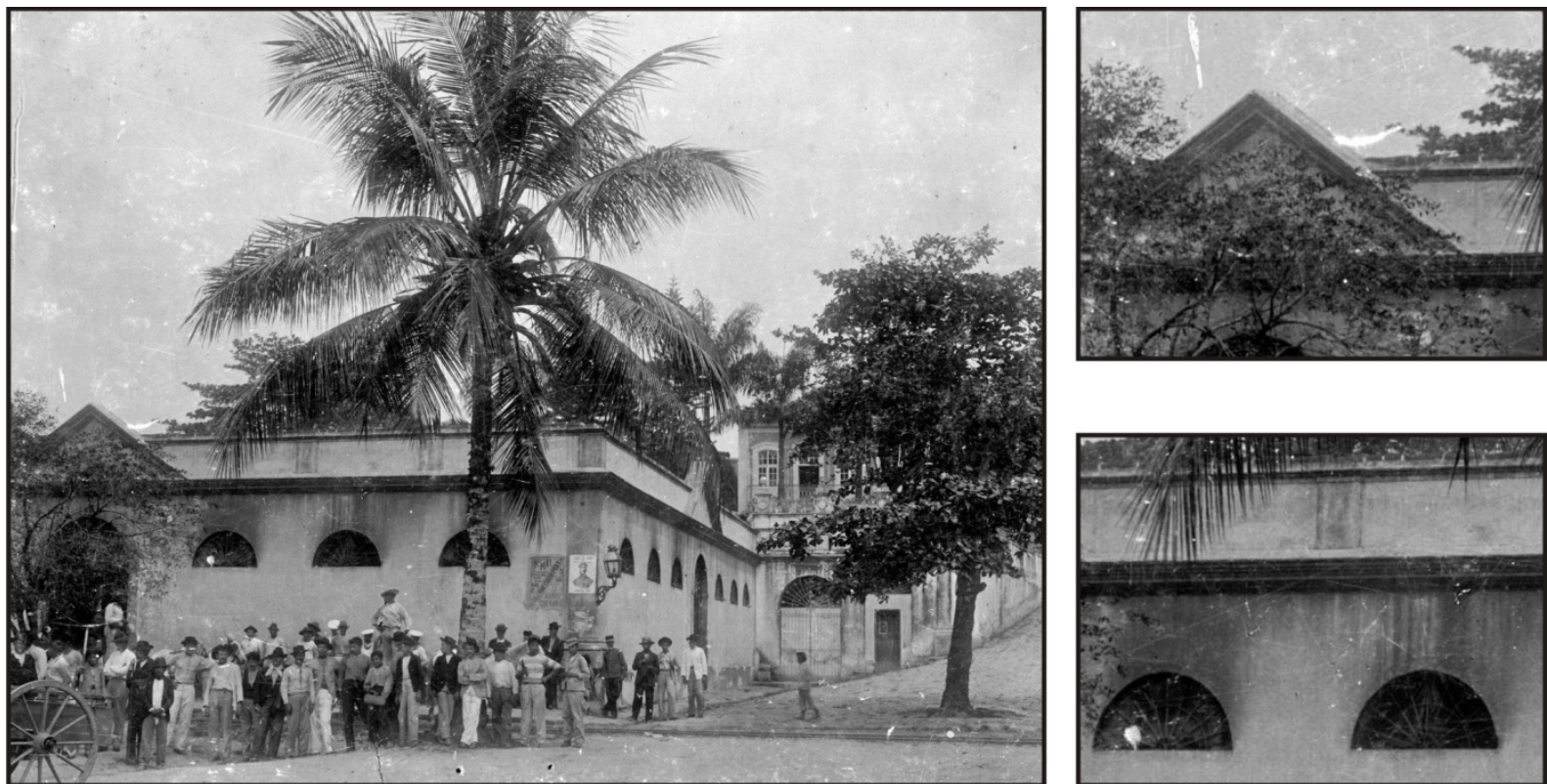

Figura 61. A Praça do Mercado em fins do século XIX

Fonte: IHGP.
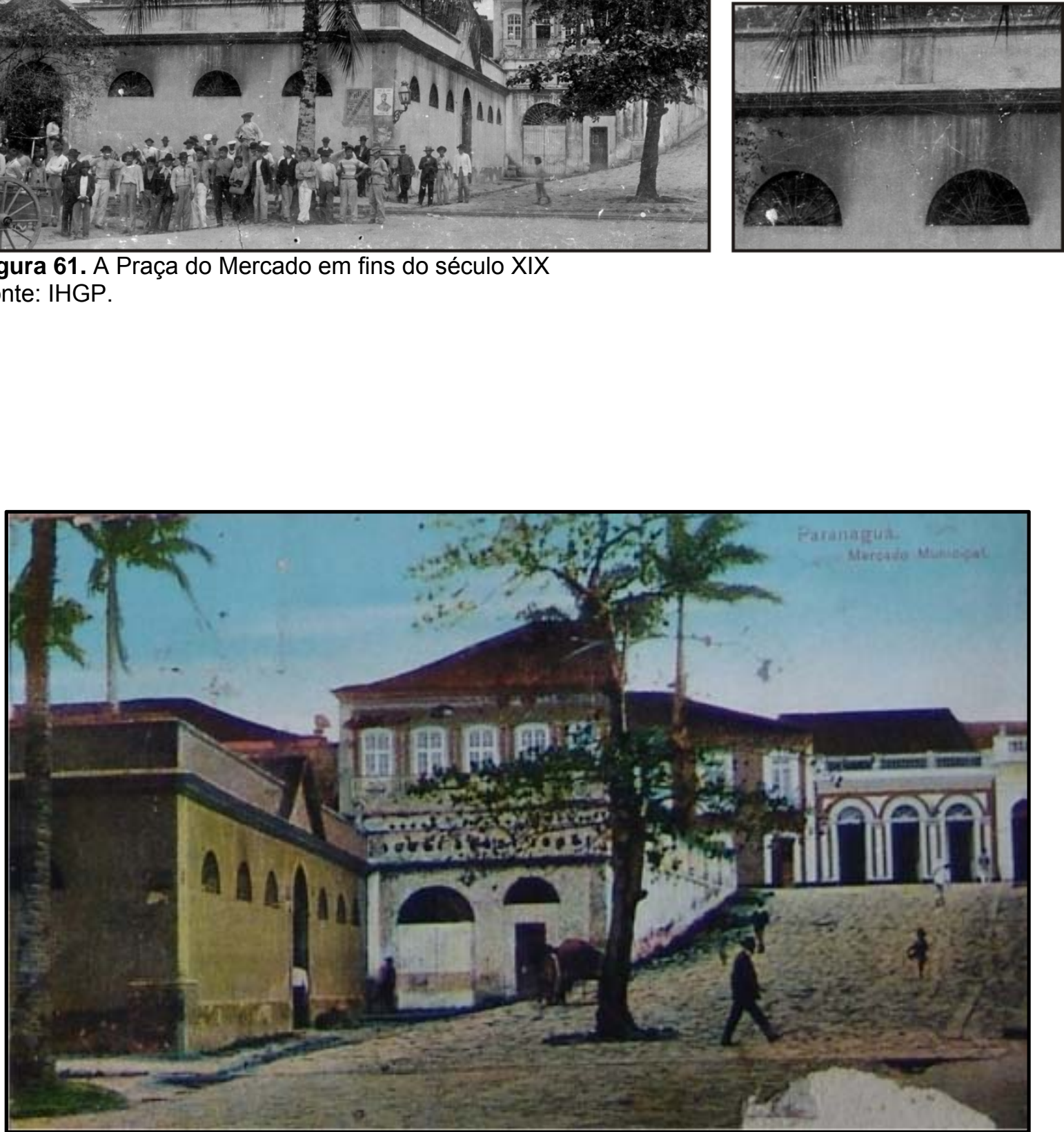

Figura 62. A lateral da Praça do Mercado e ao fundo, do lado esquerdo, pode ser observada parte do telhado da antiga Casa de Câmara e Cadeia de Paranaguá, começo do século XX.

Fonte: Álbum José Lobo. 
Após a construção da Praça do Mercado, nas margens do rio Itiberê, uma novidade na cidade de Paranaguá, foi estabelecida a administração e nomeados os funcionários desse edifício, através de certas regras implantadas para o seu funcionamento. Essas leis estão contidas nos Códigos de Posturas da cidade, e englobam questões de higiene, organização das casinhas de venda, impostos a serem cobrados, dentre outros aspectos. Uma dessas normas pertence ao Código de Posturas de 1877, intitulado "Regulamento da Praça de Mercado de Paranaguá".

Segundo o regulamento, a Praça do Mercado é

[...] logar desta cidade, com edifício apropriado, aonde devem ser expostos a venda os gêneros próprios de quitanda, a carne verde, e peixe e toda a qualidade de pescado para alimentação que diariamente se consome; os quaes deverão ser collocados nelle, segundo as suas divisões, em casinhas, bancos, vãos de columnas e centros da praça na forma determinada neste regulamento. (PARANAGUÁ, 1877, p. 33)

Os produtos, a serem vendidos no interior do mercado, foram organizados através de sua setorização, temos em uma sequência de casinhas a exclusividade da venda de carne verde, sendo que os animais deveriam ser esquartejados somente no Matadouro Municipal, seu sangue enterrado e a carne transportada até o mercado em "[...] carros perfeitamente fechados, de forma que não venham a vista" (PARANAGUÁ, 1877p. 22). Já os pescados e mariscos deveriam ficar em outro conjunto de casinhas, sendo que os produtos frescos seriam vendidos somente no dia, apenas os pescados secos ou salgados não seguiam essa regra. Outra área de venda eram os vãos de colunas, alugados para as quitandeiras, onde cada vão era o espaço destinado para uma vendedora (PARANAGUÁ, 1877).

Posteriormente, em 1887, foi construído um chalet de madeira, [...] destinado à venda do pescado" (FERREIRA JUNIOR, 1903: 3), localizado defronte à praça do mercado. 


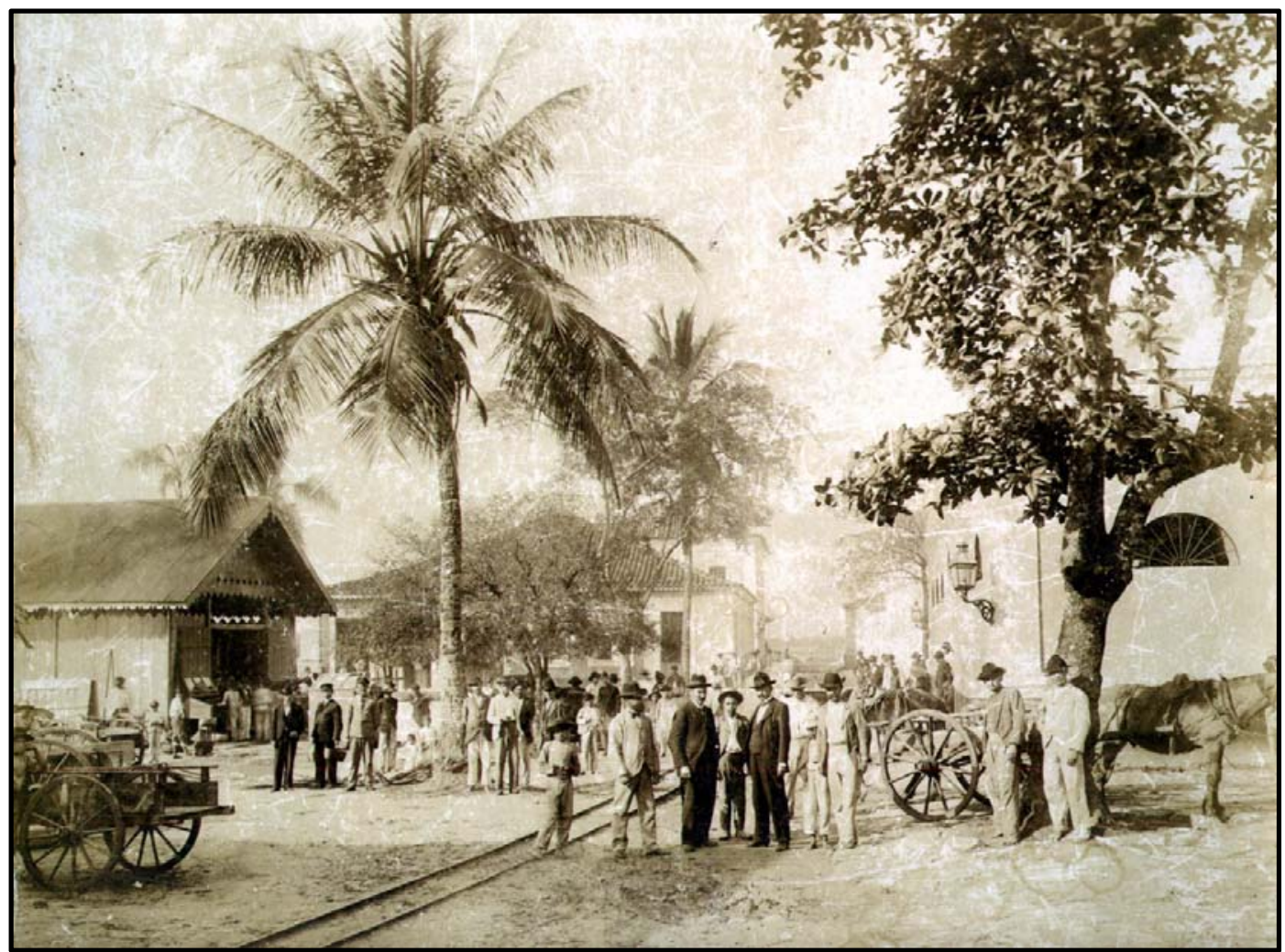

Figura 63. Em meio aos populares, observa-se do lado direito da fotografia, de fins do século XIX, o mercado com suas janelas em arco e no lado esquerdo está o chalé de pescados em pleno funcionamento.

Fonte: IHGP

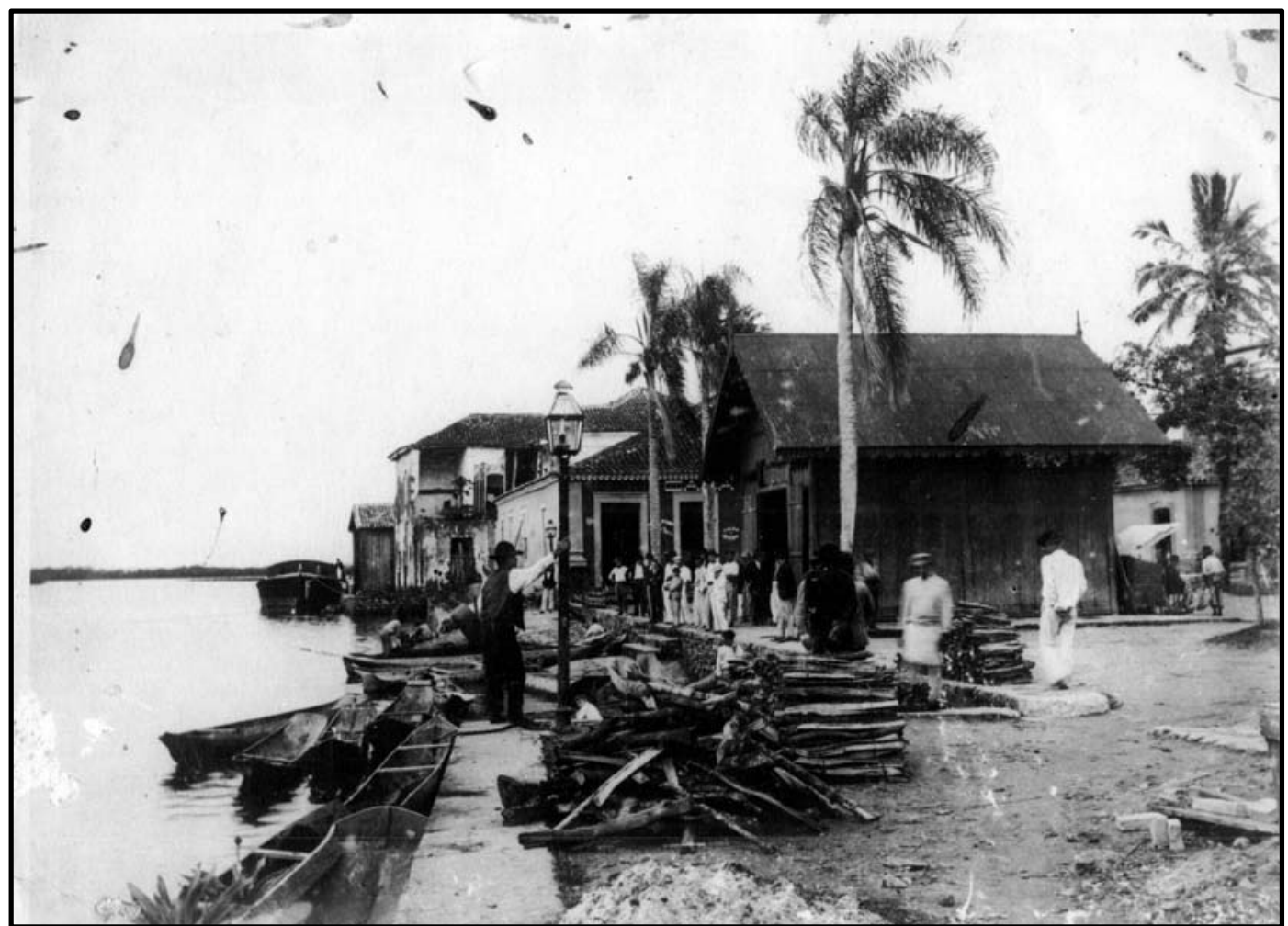

Figura 64. Defronte ao chalet dos pescados, o rio Itiberê, onde estão atracados os barcos dos pescadores que já entregaram a coleta do dia, fins do século XIX.

Fonte: IHGP 
Esse pequeno edifício pode ser visto em algumas fotografias daquele período (Figura 63 e Figura 64), no qual se observa o trabalho na estrutura de madeira, com elementos vazados, lambrequins e telhas metálicas, possivelmente influenciado pela arquitetura do norte da Europa.

Uma descrição sobre o edifício do mercado é do viajante Émille de SaintDenis, de aproximadamente 20 anos após sua construção. O autor comenta sobre o pátio interno e o seu funcionamento, destacando as áreas setorizadas dos produtos e a movimentação de pessoas e mercadorias:

Le marché de Paranaguá est un grand bàtiment carré divise em quatre parties: poissonnerie, boucherie, épicerie, legumes, etc., et mercerie.

Ce bàtiment est spacieux. Prope et bien entretenu, au milieu une Fontaine coule toute la journée dans un basin de granit.

Devant le marché est un débarcadére ou une trentaine de pirogues remplies de poissons et de legumes; les bateliers s'em disputent l'accès avec dês jurons de nègres assez semblabes à ceux de nos maraichers ou poissonniers. (SAINT-DENIS, 1898, p. 108-113) ${ }^{23}$

Até uma fonte de água foi instalada no interior da praça para seu uso exclusivo, na limpeza e no abastecimento das casinhas comerciais, ou seja, o mercado já possuía sua própria fonte de água, algo novo em uma cidade que não tinha água encanada em suas edificações e onde o abastecimento das casas e outros edifícios eram feitos através de algumas fontes de uso público.

Para controlar o uso da fonte, aplicar as normas e fiscalizar as condições sanitárias, o Mercado possuía uma figura importante, chamado de Guarda da Praça. Esse funcionário era nomeado pela Câmara da cidade e tinha a função de executar as normas estabelecidas pelas Posturas e de receber os impostos a serem pagos

\footnotetext{
23 "O mercado de Paranaguá é um grande edifício quadrado dividido em quatro segmentos: peixaria, açougue, mercearia, vegetais, etc., e armarinho.

O edifício é espaçoso, limpo e bem mantido, em seu centro uma fonte d'água jorra todos os dias em uma base de granito.

Em frente ao mercado está um píer com trinta canoas cheias de peixes e de vegetais, os barqueiros disputam a entrada com palavrões de negros semelhantes aos nossos vendedores de hortaliças e peixeiros." (Tradução do autor)
} 
pelos mercadores. O guarda abria e fechava os portões, organizava os vendedores em suas casinhas, verificava a limpeza do interior e do exterior do edifício, organizava a coleta dos impostos e controlava os horários de entrada e saída de pessoas do local.

Este controle exercido pelo Guarda da Praça, também o beneficiava em negócios ilegais. No ano de 1862, o jornal Commércio do Paraná ${ }^{24}$ denunciou que esse funcionário comprava grandes quantidades de produtos para o seu próprio comércio, situação proibida pelas normas estabelecidas nas Posturas e assim tornando-se alvo de críticas pela imprensa local.

Quanto aos artigos comercializados no mercado, temos nesse período, grande parte deles advindos de outras regiões do Brasil e da América do Sul, já que pouca coisa era produzida no litoral, onde a economia local estava voltada à exportação da erva-mate e na extração da madeira. Parte da população era direcionada a trabalhar nesses setores, deixando as plantações de alimentos para um segundo plano. Críticas sobre essa exclusividade na produção e na exportação da erva-mate são encontradas nos comentários de Demétrio Acácio Fernandes da Cruz: "Ao presente, á exepção da herva mate e da madeira, tudo o mais é importado por esta mesma cidade, cuja agricultura foi outr'ora tão florescente; acrescendo a este triste quadro a carestia dos fretes e a exorbitância dos mesmos, autorisada pelo monopólio." (CRUZ, 1863, p. 117-118) Rocha Pombo, no início do século XX, também comenta sobre este assunto, relatando que mesmo em uma região de solo fértil, os habitantes são obrigados a "importar desde a maior parte dos cereais

\footnotetext{
24 "O guarda da praça do mercado tem comprado gêneros em porção para seu negócio, pergunto: pode elle fazer isso quando as posturas da camara prohibem completamente? Tanto mais quando esse empregado devia ser o primeiro a dar o exemplo?

Que diz o Snr. Fiscal, neste cazo não quer se comprometter, ou fecha os olhos para não ver?

Esperamos que esta simples pergunta será sufficiente para correcção deste abuso, do contrario voltará a imprensa." (O Vigilante. Praça do Mercado. Commercio do Paraná, Paranaguá, 1 mar. 1862, p. 4).
} 
indispensáveis ao consumo geral até a carne do Rio Grande e do Prata". (POMBO, 1980, p. 93).

Era muito mais cômodo para os trabalhadores paranaenses ocuparem-se da extração de erva-mate, que não exigia grandes processos para o seu beneficiamento, do que trabalharem em plantações de alimentos que despendiam mais tempo e mão de obra, visto também que a espécie era comum em toda a região sul do Paraná (WESTPHALEN, 1998). O cultivo da erva-mate era muito mais simples e sua rentabilidade maior.

A importação dos produtos agrícolas para o comércio local foi, em grande parte, realizado através do porto de Paranaguá, situado nas proximidades do mercado, na região da rua da Praia. Observa-se nos relatórios de importação, destacados nos jornais da cidade na década de $1860^{25}$, a chegada de artigos como a carne-seca vinda de Montevidéu, o couro de Minas Gerais, o feijão, a farinha de trigo, o arroz, o toucinho, o açúcar, a banha de porco, o bacalhau e o café, dentre os mais citados naquele período.

O arroz, o feijão e as carnes eram itens importantes na alimentação da população brasileira do século XIX. O viajante Bigg-Wither em uma visita à cidade de Antonina, no litoral paranaense, na década de 1870, descreveu sobre um dos jantares servidos no hotel em que estava hospedado:

"Quase duas horas depois de dado o pedido, posta uma longa mesa para vinte pessoas, que rangia sob o peso dos pratos de carne cozida, frango, arroz e feijão preto, enquanto uma fila de garrafas, algumas com o conhecido rótulo de Bass and Co., enfeitava o centro e em cuja cabeceira o Sr. Pascoal fazia as honras da casa, dentro da boa moda antiga." (BIGGWITHER, 1974, p. 64)

Segundo outro viajante, o americano Daniel Kidder, o prato mais apreciado por brasileiros e estrangeiros nos jantares, geralmente servido às duas da tarde era:

\footnotetext{
${ }^{25}$ Levantados no jornal Commercio do Paraná, da década de 1860.
} 
[...] feijão, (feijão preto do país) misturado com carne seca e toucinho. Farinha é espalhada por cima, ou, preparada como uma pasta espessa. Essa farinha é o pão para milhões de pessoas, e é o principal alimento dos pretos em todo o país, que a consideram como prejudicada em seu paladar quando comida sem os dedos." (KIDDER; FLETCHER, 1941, p. 191-192, Vol. 1)

Além do consumo de produtos agrícolas, temos naquele período, algumas vendas contendo artigos industrializados, que geralmente eram importados de países europeus. Em jornais de Paranaguá, da década de 1860, encontramos anúncios que divulgam produtos como: sutaches de lã (espécie de trança de seda), perfumaria, toalhas de linho, agulhas de tricô, pós da china para os dentes, tintura de arnica e outros. Quanto aos alimentos, eram trazidos ao comércio as manteigas inglesas, queijos do reino, vinho do Porto, cerveja inglesa e a banha de Baltimore. ${ }^{26}$

Os produtos importados eram sinais dos novos costumes implantados na corte brasileira, em que a influência da culinária européia e o interesse em comercializar esses artigos, beneficiaram o aumento do seu consumo. Esse aumento foi resultante da divulgação desses alimentos e produtos pelos jornais da época, da chegada dos imigrantes ao Brasil que trouxeram, além da mão de obra, suas tradições alimentares. (ALENCASTRO; RENAUX, 2008). Em fins do século XIX, os paulistas já se habituavam aos novos costumes alimentares, introduzindo em seu cardápio verduras e legumes, massas e salsicharia, os italianos vendiam os miúdos, comprados no matadouro e os alemães, gelo e cerveja, outras famílias cultivavam frutas européias adaptando-as ao clima brasileiro. (REIS FILHO, 1994)

Apesar da comercialização de produtos importados, alguns desses artigos poderiam ser produzidos na região, o que não ocorria, causando estranheza aos viajantes que passavam pelo Paraná naquele período. Mesmo a capital da Província

\footnotetext{
${ }^{26}$ COMMERcio do PARANÁ. Largo da Praça do Mercado. Commercio do Paraná, Paranaguá, nº 88, p. 4, 5 de
} setembro de 1863 
estava sujeita a estes problemas, como relata Robert Avé-Lallemant em 1870, aproximadamente: "Em Curitiba, capital de uma Província célebre pela sua criação de gado, sempre encontrei manteiga velha e mesmo rançosa, aliás recebida da Inglaterra. O queijo que vi era da Holanda. O leite às vezes é um artigo caro; às vezes não se encontravam ovos e mesmo a carne é cara" (Avé-Lallemant, 1980, p. 283).

O mercado, em grande parte, foi responsável pela divulgação destes produtos industrializados, sendo que esses edifícios foram estabelecidos em cidades que não possuíam plantações de alimentos em suas proximidades. Segundo Murillo Marx (1980, p. 81-82):

Geralmente de banda e na borda da cidade, vieram os mercados enriquecer o cenário existente com prédios singelos de madeira ou de alvenaria, com simples coberturas ou pátios fechados, com construções mais audaciosas a introduzir entre os materiais empregados o ferro e o vidro. São todos símbolo da ação reguladora do Estado e da sua responsabilidade para com o abastecimento de uma gente citadina, que não planta o que come.

Quanto ao controle do Estado sobre o abastecimento de alimentos, isso pode ser observado nas posturas municipais de Paranaguá, onde em épocas de escassez de produtos, o Guarda da Praça controlaria a sua venda de forma proporcional ao número de clientes, para que a maioria pudesse adquirir os alimentos necessários. (PARANAGUÁ, 1877).

A concentração comercial em um único edifício possibilitou ao Estado, não só o controle sobre os alimentos a serem vendidos, mas também na cobrança dos impostos desses produtos; já que era possível levantar de forma mais precisa o número de transações e cobrar as taxas sobre as mercadorias vendidas. Temos aqui, portanto, uma fiscalização mais minuciosa do que nas vendas espalhadas pela cidade e também dos escravos de ganho, que pelas ruas vendiam seus produtos 
aos moradores e eram proibidos de entrar no interior do mercado. Além do aluguel das casinhas e vãos, são cobrados dos vendedores, taxas sobre os produtos, impostos sobre as licenças anuais para o comércio, taxas para aferição de balanças, pesos e medidas e os alvarás para a abertura de vendas no mercado.

Em uma tabela de orçamentos do município de Paranaguá, estão especificados os rendimentos do mercado, constando o aluguel dos quartos e dos espaços das quitandeiras estabelecidas nos vãos das colunas, de produtos como o toucinho, a banha, a carne, os pescados, os queijos, os cereais, as batatas, a farinha, dentre os principais. Temos como resultante da arrecadação do mercado, especificados para o ano de 1896, o valor de 117:700\$000, enquanto as licenças anuais sobre o comércio, escritórios, consultórios e outros estabelecimentos da cidade, resultavam em uma arrecadação de 95:000\$000 (PARANAGUÁ, 1896). No ano de 1902 (Tabela 2), data em que essas informações estavam mais detalhadas, a arrecadação desse estabelecimento já concorria com os impostos do cais do porto, dos gêneros negociados no município, das licenças anuais e do imposto predial, ou seja, o mercado era uma fonte importante de arrecadação de impostos para Paranaguá.

Até a própria localização do edifício, defronte à Câmara da cidade, aumentou ainda mais o controle sobre a Praça do Mercado, que rendia consideráveis lucros em impostos ao município e, portanto, era necessária a fiscalização diária do guarda da praça e de outros funcionários da cidade, para que todos os rendimentos fossem arrecadados. O local da instalação da Praça do Mercado era conveniente ao município, já que de um lado estava o poder público, a Câmara e Cadeia, que fiscalizava e arrecadava os impostos e de outro o porto de Paranaguá e o rio ltiberê de onde chegavam as mercadorias para o seu abastecimento. 


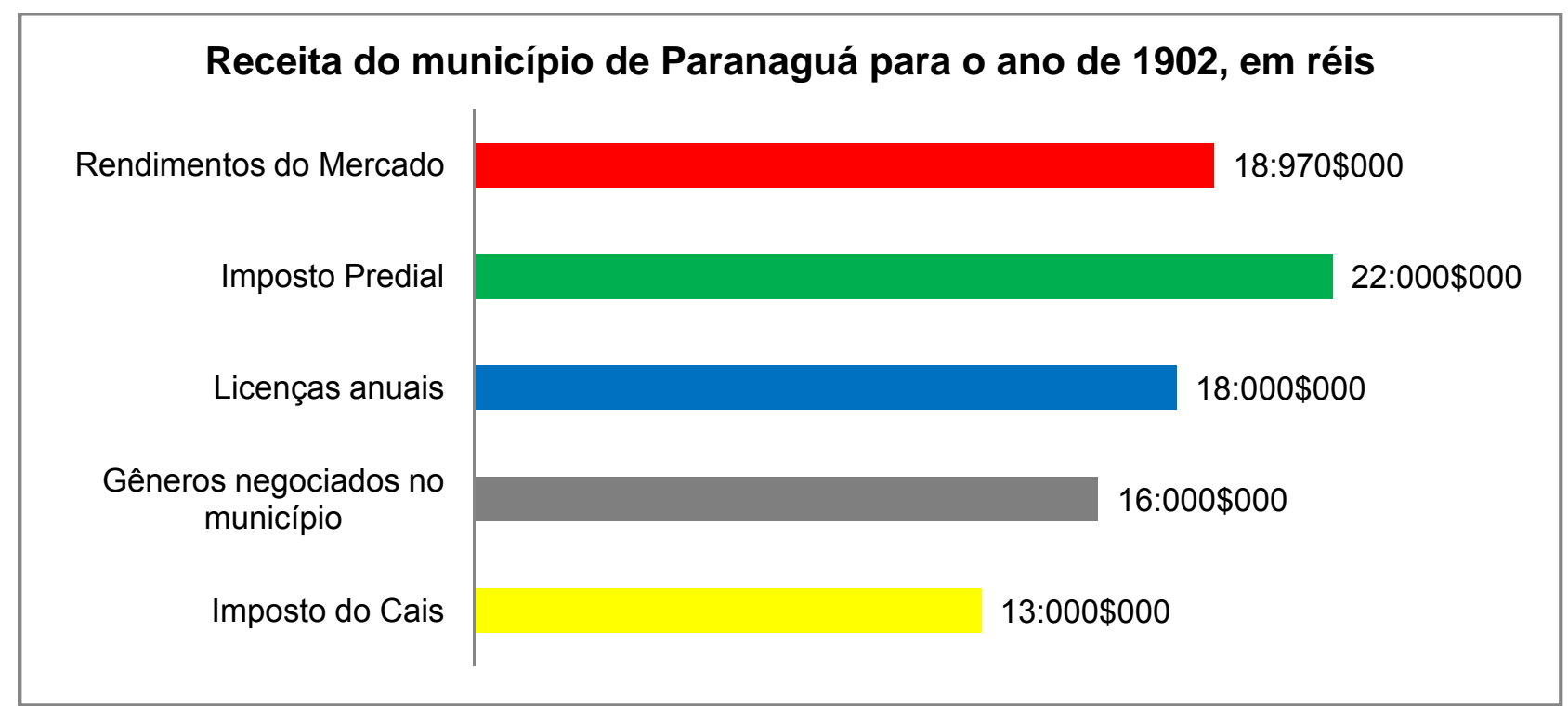

Tabela 2. Principais receitas do município de Paranaguá, para o ano de 1902.

Fonte: Leis da Câmara Municipal de Paranaguá, 1902.

A introdução da Praça do Mercado, na cidade de Paranaguá, deu início a organização do seu comércio, concentrando em um mesmo espaço opções de vendas de produtos a serem consumidos pela população local, distribuídos de forma setorizada, em que cada tipo de artigo estava concentrado em um conjunto de casinhas comerciais. Esta organização espacial se fundamentava nos regulamentos introduzidos através dos Códigos de Posturas da cidade, que traziam as normas para o funcionamento do mercado e as exigências nos padrões de higiene e aceio desse ambiente.

As posturas não só regulavam a salubridade das construções públicas, mas também estavam direcionadas para as residências e ao comércio da cidade. Nas construções residenciais, as posturas de 1858, regulamentavam sobre as águas servidas e na limpeza dos quintais, onde estava proibido: "O que lançar águas infectas, lixos ou immundicias no quintal, área, ou cano de sua propriedade, que aliás devem ser conservados limpos, será multado em vinte mil réis." (PROVÍNCIA DO PARANÁ, 1858). 
As posturas desse período enfocavam, principalmente, na limpeza externa das casas e dos terrenos, como por exemplo, os moradores eram obrigados a manterem limpos os fundos dos terrenos e as testadas, indo até o meio da rua, ou seja, a varrição de ruas e calçadas era de responsabilidade do morador. E se o morador possuísse casa defronte a alguma praça, essa área de varrição era maior, chegando a uma área da praça para cada um deles. As fontes eram também alvo das posturas, em um dos itens intitulado "Polícia das Fontes", são proibidas a lavagem de roupas nas fontes de beber água, assim como a vinda de animais, impedindo a contaminação destes mananciais.

Já nas Posturas publicadas em 1877, são mantidas as leis que proíbem a liberação de águas servidas na frente das casas, nos quintais e pátios. As casas deveriam possuir um sistema de canos que liberava a água das chuvas, não permitindo que invadissem as calçadas. Em um dos artigos, ficou estabelecida a proibição da passagem desses canos pelo terreno dos vizinhos, para que estas águas pudessem ser jogadas nas ruas: "Art. 45. Os proprietários de prédios urbanos devem providenciar que as águas de seus pateos ou quintaes não passem para os de seus vizinhos dando-Ihe esgoto para a superfície das ruas. Ao contraventor multa de 10\$000." (PARANAGUÁ, 1877)

Portanto, as águas servidas das casas e comércios de Paranaguá eram jogadas nas ruas, em muitos casos ainda não pavimentadas, apenas exigindo-se dos proprietários a construção das calçadas, mas proibindo-se [...] dar esgoto ás águas fluviaes das áreas ou quintaes dos prédios urbanos por cano superior ás calçadas dos passeios." (PARANAGUÁ, 1877).

Nesse Código de 1877, foi mantida a Polícia das Fontes, proibindo as lavagens de qualquer tipo, bem como a entrada de animais para ali beberem água. 
Mas a partir dessa norma, foi incluída a nomeação de um fiscal, que controlaria a limpeza e os outros cuidados necessários a manutenção das fontes.

Em 1893, foi implantado um novo Código de Posturas, nele também estão contidas leis relacionadas à limpeza das ruas e outros aspectos. Mantinha-se a lei de 1858 , de que cada proprietário deveria manter a testada de sua casa limpa, mas agora a limpeza chegava até a sarjeta e não mais contando com parte da rua, como na lei anterior. Continuam as proibições quanto ao despejo de águas servidas nas ruas, mas contendo agora uma definição mais detalhada sobre a sua retirada, de acordo com a lei: “Art. 39. É prohibido lançarem-se materiais excrementícias nas ruas, largos, pateos e em lugares próximos as fontes e vertentes, ou conservaremse cloacas junto as mesmas sob penna de 10\$000." (PARANAGUÁ, 1893, p. 26).

O Código de 1893 possui um capítulo intitulado Da Hygiene e Salubridade Pública, demonstrando a preocupação cada vez maior com as questões de saúde na cidade. Nesse Código, estão contidas novas especificações sobre limpeza e normas de saúde, ao contrário dos outros códigos que possuem leis mais generalizadas e com poucas definições.

Possui o referido Código, por exemplo, artigos que especificam lugares apropriados para a lavagem de roupas hospitalares e também locais para os animais beberem água. Nos dois casos, esses pontos seriam posteriores aos locais de coleta de água pela população, evitando assim o seu contato com as "águas servidas". No caso das roupas hospitalares, estas deveriam:

Antes de se fazer a lavagem de taes roupas, principalmente as dos hospitaes dos variolosos ou doentes de qualquer moléstia eruptiva contagiosa ou não, serão primeiramente n' aquelles estabelecimentos ou casas a que pertenção, passadas em água quente e potassa, fazendo-se o transporte das mesmas com toda a cautela necessária, em saccos ou carroças fechadas. (PARANAGUÁ, 1893, p. 33). 
As posturas também estabelecem a coleta do lixo, visto que as carroças para essa função deveriam ser "[...] hermeticamente fechadas afim de não produzir exhalação fétida." (PARANAGUÁ, 1893, p. 34). A coleta seria realizada da seguinte maneira: o condutor da carroça tocaria a buzina nas esquinas e nos meios de quadra para que os moradores levassem o lixo, sendo que o horário das coletas era das 6 a 7 horas da manhã durante o verão, e das 7 as 8 da manhã nos meses mais frios. E se o morador não enviasse o lixo todos os dias, ele seria multado.

São as primeiras experimentações de coleta do lixo na cidade de Paranaguá, e pela rigorosidade nas regras, exigindo-se a retirada diária dos detritos, a população deveria se habituar aos novos costumes, armazenando o lixo para que em um momento do dia, fosse entregue ao carroceiro, evitando o despejo do material nas ruas ou queimado nos quintais, o que também estava proibido no referido Código.

A própria questão do cheiro, antes tão tolerada pelos habitantes acostumados aos odores nos interiores das igrejas, resultantes dos corpos em decomposição, ou do esgoto coletado pelos escravos em seus tigres, vai se alterando com o findar do século XIX. Observa-se, por exemplo, que a partir da inserção dessas novas leis ocorre uma mudança em relação a estes costumes, como no caso da coleta do lixo, que exigia o acondicionamento do material em locais fechados, para evitar a "exhalação fétida", indício de alteração nos costumes da população brasileira daquele período, agora mais intolerante aos odores

As normas de higiene também serão refletidas no comércio local, nesse código são definidas leis que se preocupam com a limpeza dos ambientes, principalmente em locais de muita aglomeração. Por exemplo, a lei determinava a caiação dos ambientes internos uma vez ao ano, para sua desinfecção. Exige-se a 
manutenção da limpeza em padarias, confeitarias, cafés e outras casas onde eram vendidos comestíveis. São novos estabelecimentos que surgiam à partir do final do século XIX e que comercializavam alimentos já prontos para o consumo.

Outra novidade nesta Postura são normas referentes a pequenas fábricas, oficinas e curtumes, em que ocorre a preocupação de separar esses estabelecimentos do conjunto urbano. De acordo com a lei:

É prohibido estabelecerem dentro da cidade fábricas de sabão, azeite, óleos, velas de sebo, distilação e outras que pela qualidade de matérias primas e seus productos e combustível empregados, ou por outro motivo, exhalem vapores que tornem nociva a atmosphera, a pureza das águas potáveis ou incommodem a visinhança. (PARANAGUÁ, 1893, p. 35)

Essas indústrias traziam riscos de incêndio, poluição das águas dentre outros problemas, por isso deveriam ser instaladas em áreas distantes da cidade. Ao final do século XIX, essas medidas já eram aplicadas em Paranaguá, separando a área industrial das residências e do comércio da cidade.

De uma maneira geral, as leis sanitárias foram, cada vez mais, ampliando sua área de influência, de pequenas alterações no escoamento das águas e dos usos das fontes, chegando à coleta do lixo e na separação de áreas industriais do conjunto urbano. Nas leis de 1858, são destacados os artigos relacionados à limpeza das ruas e quintais e na eliminação das águas servidas, nas posturas de 1877 se mantêm algumas das leis do antigo código, mas é acrescentada a regulamentação do uso das fontes públicas, que eram as áreas de abastecimento da cidade. Com o findar do século, ocorreu um aumento considerável nas leis sanitárias onde estão especificados, de forma mais precisa, as proibições e os artigos.

Na Postura de 1893, já são definidos a coleta do lixo, padrões de higiene em estabelecimentos comerciais, principalmente os que vendiam alimentos, também na limpeza de hospitais e na especificação de pontos para a lavagem de materiais que 
poderiam ser fontes de contaminação e por fim a separação das áreas nocivas ao conjunto urbano, como as pequenas indústrias e curtumes, exigindo a sua instalação em locais afastados da cidade.

A partir da metade do século, cada vez mais são observadas preocupações referentes à higiene. As posturas primeiramente enfocam as residências e se direcionam ao comércio, ao fim do século XIX foram as indústrias e o conjunto urbano, não só pontualmente, mas em todo o espaço construído. Eram novas preocupações de uma cidade que se transformava, a partir da metade do século XIX, com a introdução de exigências para o melhoramento de sua estrutura urbana. 


\subsection{CONSTRUÇÕES AO GOSTO MODERNO}

A Paranaguá, da metade do século XIX, teve transformações significativas em sua estrutura. Novas preocupações com a saúde e a aplicação dos Códigos de Posturas, transformaram aos poucos a forma de morar e de viver na cidade. Assim, retornamos a um autor comentado nos capítulos anteriores, que relatou sobre essas mudanças em seus escritos, este autor é Antônio Vieira dos Santos.

Sobre a descrição geral da cidade, Vieira dos Santos (2001, p. 13) diz que:

A cidade de Paranaguá está situada num terreno plano; seus edifícios são quase todos de pedra de cantaria; tem muitas casas térreas airosas e feitas ao gosto moderno e envidraçadas. As de sobrado (à exceção das antigas) são também feitas à moderna, imitando no exterior as das Cidades. No ano de 1810 se contavam na Cidade só 12 moradas de casas de sobrado, inclusos algumas de sótãos; no ano de 1845 havia 45 moradas e presentemente tem 48.

A cidade contava com grande parte de suas construções edificadas em alvenaria de pedra, mas já era notada pelo autor a diferença entre as residências mais antigas e os seus contemporâneos, as denominando, "feitas ao gosto moderno". Mas como se caracterizavam as construções "à moderna"? Em uma das descrições do autor, observa-se:

$1^{\text {a }}$ a do Comendador Joaquim Américo Guimarães, feita à moderna no exterior com sacadas de grades de ferro envidraçadas elegantemente mostrando uma aparatosa perspectiva, adjunta com a $2^{\mathrm{a}}$ morada assobradada do mesmo Comendador, arrematada por uma formosa sotéia circulada e avarandada com um gradil de ferro e ajardinado com riquíssimos vasos que mandou buscar na Europa, onde plantou lindas flores e sendo ladrilhada a mesma sotéia com mármores diferentes; apresenta um alegrete que serve de recreio à sua família e de aformoseamento à mesma rua, não falando no grandioso asseio do interior de magníficas salas, acobertadas de tapetes e adornadas com as mais ricas mobílias; estas famosas propriedades consta importaram em mais de 30 contos de réis; [...] (VIEIRA DOS SANTOS, 2001, p.16) 
Temos como elementos de destaque em sua descrição: as sacadas, com grades de ferro, as janelas envidraçadas, a sóteia ${ }^{27}$, um tipo de terraço, os vasos importados, os jardins e o cultivo de flores e o alegrete ${ }^{28}$, características que diferenciavam as novas residências das demais que existiam na cidade naquele período.

Algumas já se configuravam com portões laterais, algo novo na implantação das construções da época, como a encontrada no final da rua da Ordem, atual XV de novembro, Vieira dos Santos a descreve da seguinte forma:

O magnífico palacete (assim denominado) meio assobradado, com bastantes janelas de peitoril, elegantemente envidraçadas, tendo um pátio ao lado, fechado por um portão, e na entrada de um formoso pórtico para o mesmo palacete, tem um escadório de cantaria lavrada em ordem circular, que faz realçar a beleza deste edifício; em cima tem um grandioso sótão com a vista para a Cotinga e baías; além dela o interior desse palacete tanto as portas, como os umbrais e janelas são feitas de cedro, araribá e outras madeiras de diversas cores, que envernizadas mostram sua beleza; foram mandadas fazer pelo bom gosto que tinha o cidadão paranaguense José Ricardo dos Santos, proprietário dos bergantins Cacique e Caboclo e hoje pertencentes aquelas propriedades a seus herdeiros [...] (VIEIRA DOS SANTOS, 2001, p. 14, grifo nosso)

A fotografia de fins de século (Figura 65) nos mostra que as construções contemporâneas à Vieira dos Santos ainda estavam ligadas aos preceitos construtivos do período Colonial, janelas com vergas em canga, a camarinha, a estrutura de pedra e o conjunto em si. Mas alguns aspectos peculiares podem ser observados, primeiro, essa residência possuía afastamento nas duas laterais e o nível do piso dessa construção está elevado em relação à rua, o que poderia configurar uso de porão, além do grande número de janelas em sua fachada e de sua porta principal em arco pleno (Figura 66).

\footnotetext{
27 "Cobertura plana e horizontal de uma construção, geralmente ladrilhada, que serve de local para se tomar sol. Eirado, açoteia, mirante." (LEMOS ; CORONA, 1972, p. 431).

${ }^{28}$ Termo de pouco uso que designa as pequenas divisões quadrangulares de pedra, tijolo ou madeira, cheias de terra, nas quais se cultivam flores e que eram colocadas nos jardins ou nas varandas e que por alegrarem a vista, tomaram esse nome. (LEMOS; CORONA, 1972, p. 29)
} 


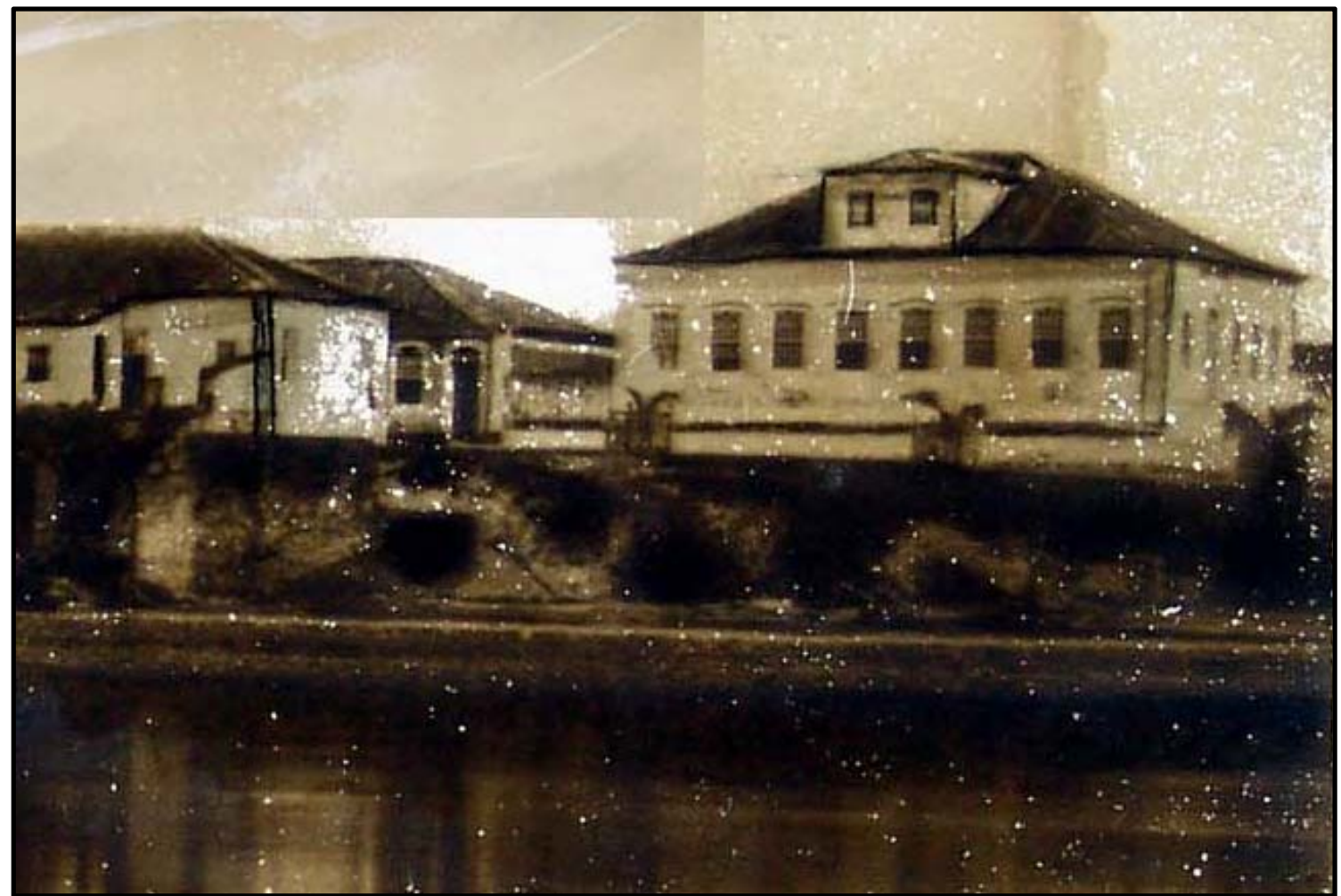

Figura 65. A residência descrita por Vieira dos Santos, final do século XIX. Fonte: Instituto Histórico e Geográfico de Paranaguá.

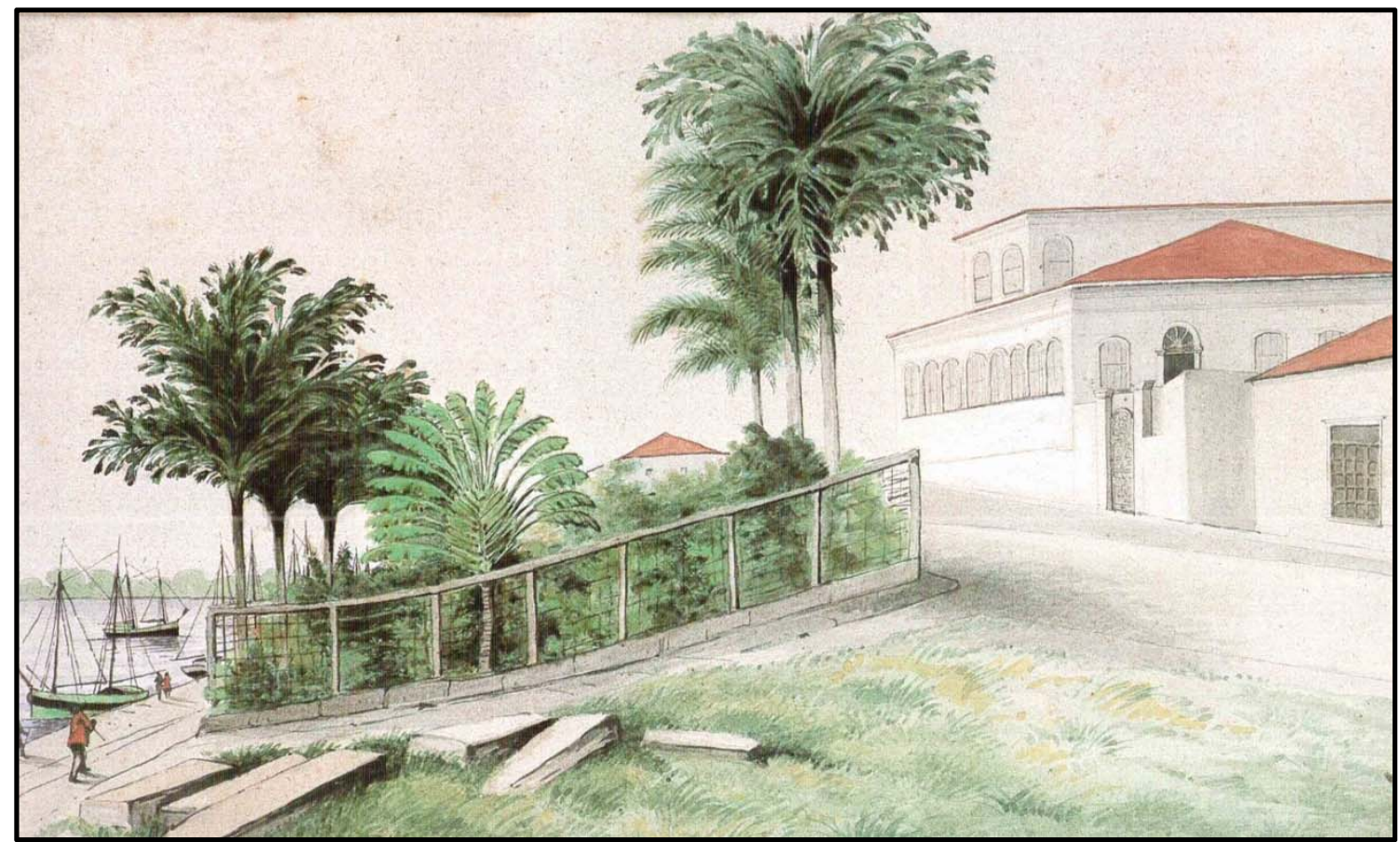

Figura 66. Nesta aquarela de William Michaud, de 1890, percebe-se a lateral desta residência com sua porta principal em arco pleno.

Fonte: Pintores da Paisagem Paranaense. 
Esse tipo de residência é um exemplo dessa transição entre as construções comuns no período Colonial e as renovações que ocorreram a partir da metade do século XIX em Paranaguá, com introdução do Ecletismo.

Essas pequenas mudanças não só eram refletidas no espaço externo, mas também na decoração dos ambientes, o consumo de objetos importados para as residências, cada vez mais se ampliava. Em anúncio de leilões, publicados no jornal Commercio do Paraná, de 1863, são descritos os seguintes objetos de uma residência: "[...] uma rica mobília de jacarandá com tampos de mármore, pianos, candelabros, vazos, serpintinas, tapetes, escarradeiras de porcellana dourada, mesa elástica para jantar, guarda roupa, toilet guarnecido de mármore, lavatório, etc."29

Primeiramente, as influências do Ecletismo vieram através dos móveis e dos objetos decorativos, com as mobílias cada vez mais especializadas e na decoração das paredes, com papéis e pinturas. A necessidade de mudanças no corpo externo das construções veio posteriormente, principalmente por aqueles que dominavam o campo econômico da cidade, como os exportadores de erva-mate em Paranaguá, que construíram seus palacetes ecléticos para assim, simbolizar seu status dentro do núcleo urbano, de forma a demonstrar seu alto poder aquisitivo.

As novas construções que surgiam na Paranaguá da metade do século XIX e comentadas com destaque por Vieira dos Santos, obedeciam ao Código de Posturas estabelecido pela Câmara Municipal, em que, de acordo com o autor, "as modernas que se vão levantando são feitas na competente altura que a Câmara estabeleceu em suas posturas." (VIEIRA DOS SANTOS, 2001, p.18)

As posturas mais antigas encontradas nos arquivos, datam do ano de 1858, posteriormente à criação da província do Paraná e das descrições de Vieira dos

\footnotetext{
${ }^{29}$ Commercio do Paraná. Leilão. Commercio do Paraná, 7 de jan. de 1863.
} 
Santos. Em um manuscrito, que relata os fatos mais importantes da Câmara Municipal de Paranaguá, foi encontrada a seguinte informação em agosto de 1855: "[...] foi offerecido um código de posturas, a qual foi approvado." (FERREIRA JÚNIOR, 1903, p. 17-18). O código de 1855 não foi localizado nos arquivos pesquisados. Mas, o código de 1855 pode ter sido publicado em 1858 nas Colleções das Leis, Decretos, Regulamentos e Deliberações do Governo da Província do Paraná, que editou além do código de Paranaguá, o de cidades como Morretes, Antonina e da capital Curitiba.

Dentre as diversas determinações encontradas nesse Código de 1858, algumas interferem na configuração usual das edificações daquele período, como o Artigo 50 que diz: "He proibido edificar propriedades com rotulas, postigos, cancellas, balcões, portas, e janellas de abrir para fora." (PROVÍNCIA DO PARANÁ, 1858, p. 51). São medidas que eliminaram alguns dos elementos característicos das construções do século XVIII em prol da circulação dos pedestres nas calçadas. De acordo com José do Amaral Lapa (1996, p. 62-63):

Surgem então as calçadas, que, como dissemos, têm entre as suas finalidades a de serem reservadas só para o uso dos pedestres, naturalmente livres e cidadãos.

Sobre esses espaços reservados, rentes às moradias e estabelecimentos, cuida-se então de proibir janelas que abrissem para fora, fossem rótulas, cancelas, postigos, caixilhos e gelosias, para não prejudicar os passantes.

Quanto às alturas das edificações, ficou definido neste código da seguinte forma:

Art. 162: As casas térreas terão 18 pés de altura, da face superior das soleiras ao respaldo das paredes, que recebem os frechaes.

Podem, porém, os proprietários elevarem a altura até 20 palmos, ou mais, especialmente em ladeiras, para uniformidades.

Art. 163: Nas casas de sobrado a altura do primeiro pavimento será de dezoito a vinte palmos; da face superior das soleiras, á do vigamento; no segundo pavimento de dezessete a dezenove; e nos mais decrescerá sempre meio palmo. (PROVÍNCIA DO PARANÁ, 1858, p. 63) 
Portanto, as alturas para casas térreas variavam de no mínimo 5,94 metros até 6,6 metros ou mais, em casos especiais. No caso das casas de sobrado, essa altura variava de 11,55 metros até 12,87 metros. São os padrões encontrados para as residências desse período, alturas maiores do que as edificações mais antigas; que nas palavras de Vieira dos Santos (2001, p.18), sobre estas edificações, comenta:

[...] do mesmo lado se acham dois pequenos e baixos sobrados que pela perspectiva de um gosto gótico antiquário parece foram feitas nos princípios da criação da vila ou antes de 1660, porquanto sua baixa altura pouco excedente às casas térreas modernas [...]

As medidas também influíram nas aberturas de portas e janelas; as portas deveriam ter de 13 a 15 palmos $(2,86$ a 3,3 m) de altura e de largura 5 a 6,5 palmos (1,1 a $1,43 \mathrm{~m})$, com ombreiras não ultrapassando 10 polegadas $(27,5 \mathrm{~cm})$. No caso das janelas existia a diferença de medidas entre as casas térreas e as de sobrado, na primeira, os peitoris deveriam ter de 5 a 7 palmos de altura (1,1 a 1,54 m), e sua altura deveria ser de 8 a 9 palmos (1,76 a 1,98 m). Nas casas de sobrado, o peitoril tinha como medida 4,5 palmos $(0,99 \mathrm{~m})$, com a altura da janela variando entre $8,5 \mathrm{a}$ 9,5 palmos (1,87 a 2,09 m). (PROVÍNCIA DO PARANÁ, 1858).

Nesse período, temos a construção da primeira residência, ainda no alinhamento da calçada, mas totalmente identificada com o ecletismo classicizante em Paranaguá. O Palacete do Visconde de Nácar é um edifício de grandes dimensões, imponente, rigidamente simétrico, construído entre os anos de 1850 e 1860, por um dos maiores exportadores de erva-mate da Província do Paraná.

A propagação do Ecletismo foi marcante no século XIX, mesmo São Paulo, com sua proximidade com o Rio de Janeiro só conheceru estas novidades após 1850, como comenta Carlos Lemos (1987, p. 72): "Desde os anos finais do século 
XVIII até 1850, São Paulo praticamente não conheceu nenhuma novidade arquitetônica." O autor ainda considera como uma das primeiras expressões do estilo, a residência da família Gavião, retratada por Militão de Azevedo em 1860, como sendo a primeira construção de inspiração neoclássica de São Paulo. Construída aparentemente de alvenaria de tijolos, percebida em uma fotografia, através da umidade em sua platibanda. (LEMOS, 1987).

A difusão do Ecletismo, perdurou durante o século XIX e teve sua maior atuação ao fim daquele século, em que grande parte das construções eram edificadas dessa forma, de acordo com Alberto Souza (1994, p. 108-109):

Ao nosso entender, com o deslocamento do centro do Império Português para o Brasil, no começo do século XIX, iniciou-se um gradual processo de transformação da arquitetura produzida em nosso país, que iria alterar substancialmente a fisionomia arquitetônica de muitos dos nossos principais centros urbanos. Tal processo, desencadeado com a implantação no Rio de Janeiro e em Salvador de uns poucos edifícios de feição distinta daquela das construções da época colonial, alimentando em seguida pelo ensino formal de arquitetura ministrado pela Academia Imperial de Belas Artes e fortalecido ao mesmo tempo pela atuação no Brasil de arquitetos e engenheiros estrangeiros de formação classicista, alcançaria sua consolidação na década de 1840, quando a nova arquitetura por ele engedrada atingiria sua idade adulta, ganhando características próprias e definidas e seus primeiros edifícios de indiscutível qualidade. A partir desse momento, e até os anos 1880, essa nova arquitetura se difundiria pelo país, predominando sobre as demais linguagens que seriam praticadas na mesma época.

No caso do Palacete Visconde de Nácar, são encontradas informações sobre sua construção nas atas da Câmara de Paranaguá do ano de 1858, relatando sobre um eclipse solar ocorrido na cidade. Nesse evento, estiveram presentes o Diretor do Observatório Astronômico Imperial do Rio de Janeiro e uma comissão científica do Observatório Astronômico Imperial de Paris, além de outros estudiosos. (FERREIRA JUNIOR, 190?, p.25-26)

De acordo com o depoimento sobre o eclipse temos: 
O Conselheiro Mello e Capitães Nunes e Galvão, hóspedes do Commendador Manoel Antônio Guimarães, habitavam seu novo Palácio, ainda em conclusão, na rua da Boa Vista, apropozito preferido pela Commissão, pela commodidade para as observações da noite, que eram feitas no alto e centro do terreno em que Manoel José Correia tem começadas as paredes para uma casa. (FERREIRA JUNIOR, 190?, p.2526, grifo nosso)

Através do relato sobre o eclipse em Paranaguá, podemos observar que a data que consta na platibanda do Palacete, não é o ano de término da construção, já que em 1858 (Figura 67) o edifício ainda estava em obras, sendo já habitado por seu proprietário, Manoel Antônio Guimarães, futuro Visconde de Nácar e seus hóspedes. A data pode referenciar o início da construção do edifício, já que em dois anos a obra ainda se encontrava em andamento.

O edifício deve ter impressionado os habitantes de Paranaguá, devido as suas grandes proporções e suas características tanto externas como internas. Sua fachada possui na parte superior sete janelas em arco pleno, na parte inferior são seis janelas, sendo que ao centro do edifício está colocada a grande porta (Figura 68), de acesso principal da casa arrematado com bandeira em arco pleno. Temos aqui a utilização do espaço inferior como parte da residência e não para fins comerciais, como era comum nos sobrados daquele período.

As vergas e umbrais de portas e janelas receberam um bom trabalho de entalhe em granito aparente em tons de cinza e preto (Figura 69), suas esquadrias são em madeira e a grande sacada corrida na área superior percorre a fachada de um extremo ao outro. Na composição geral da fachada, temos as duas pilastras em cada canto do edifício e mais duas no corpo central, que estão configuradas no pavimento superior, as cornijas dessas pilastras estão decoradas por um relevo de flor, motivo encontrado também em outras construções de Paranaguá. 

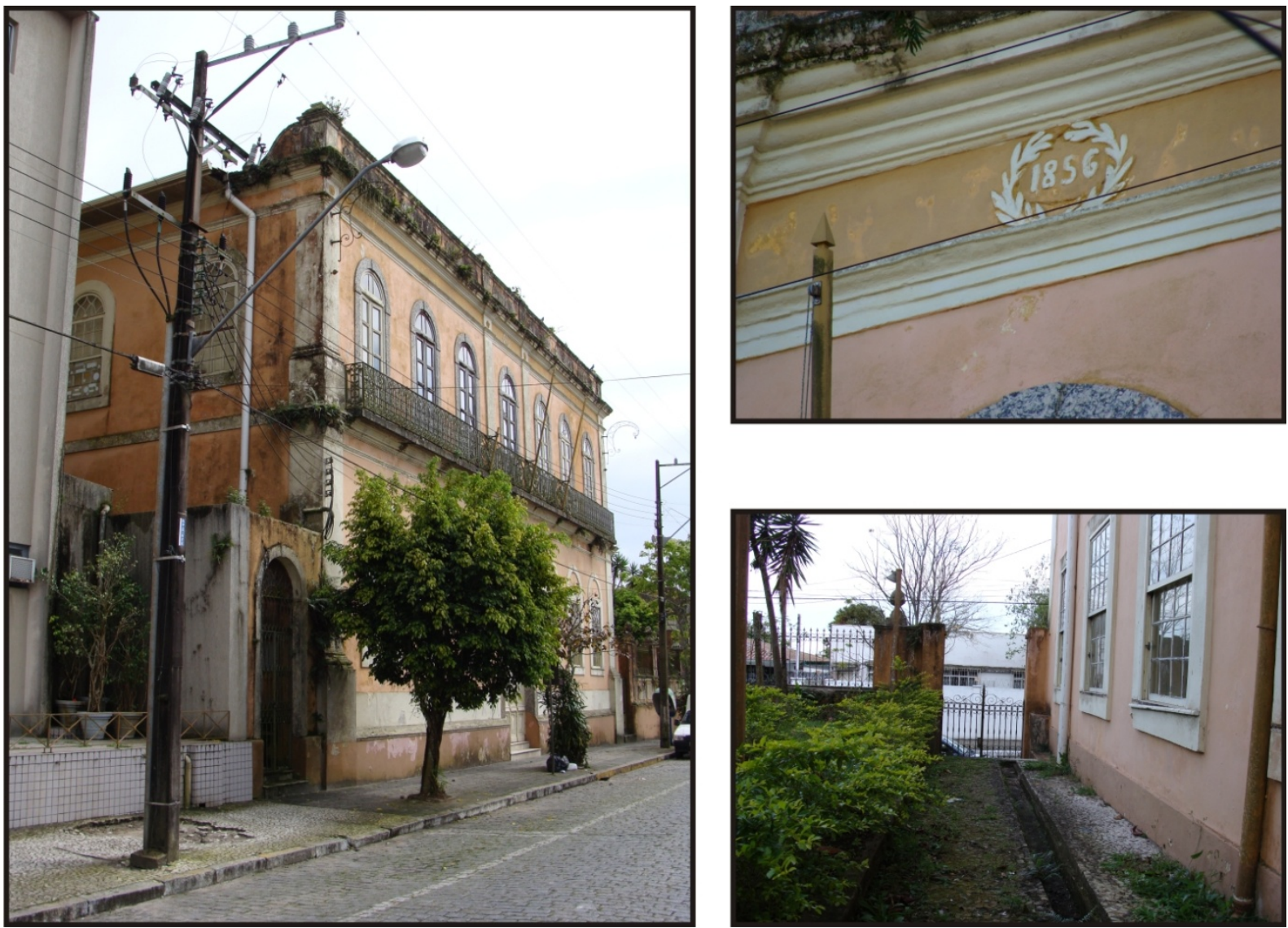

Figura 67. O Palacete Visconde de Nácar, no quadro superior direito a data colocada em sua platibanda, no quadro inferior o jardim lateral.

Fonte: Acervo do autor, 2009.
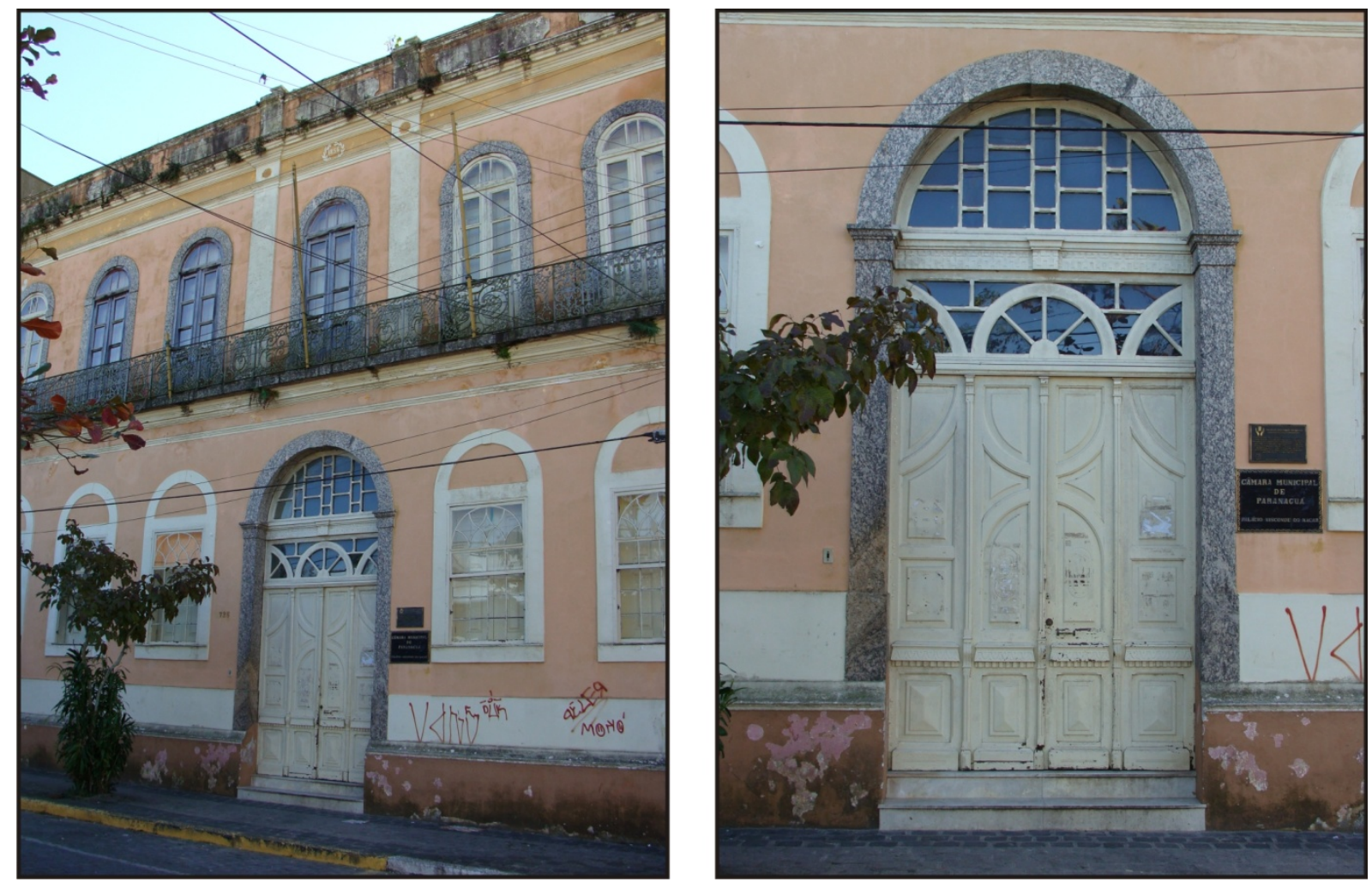

Figura 68. Fachada do Palacete Nácar e seu acesso principal.

Fonte: Acervo do autor, 2009.

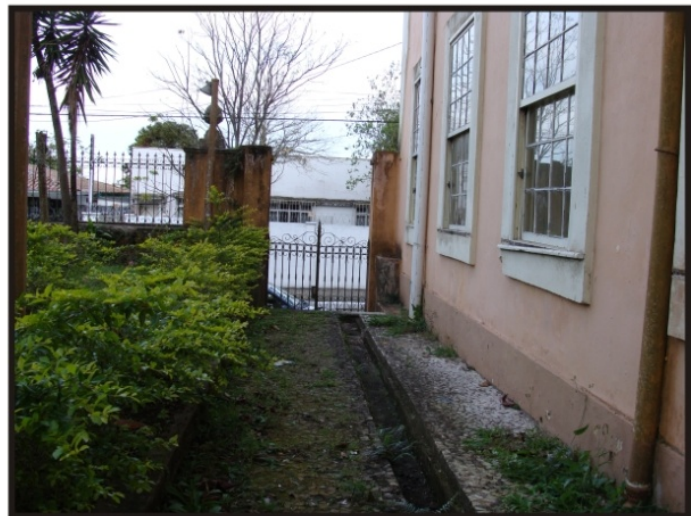



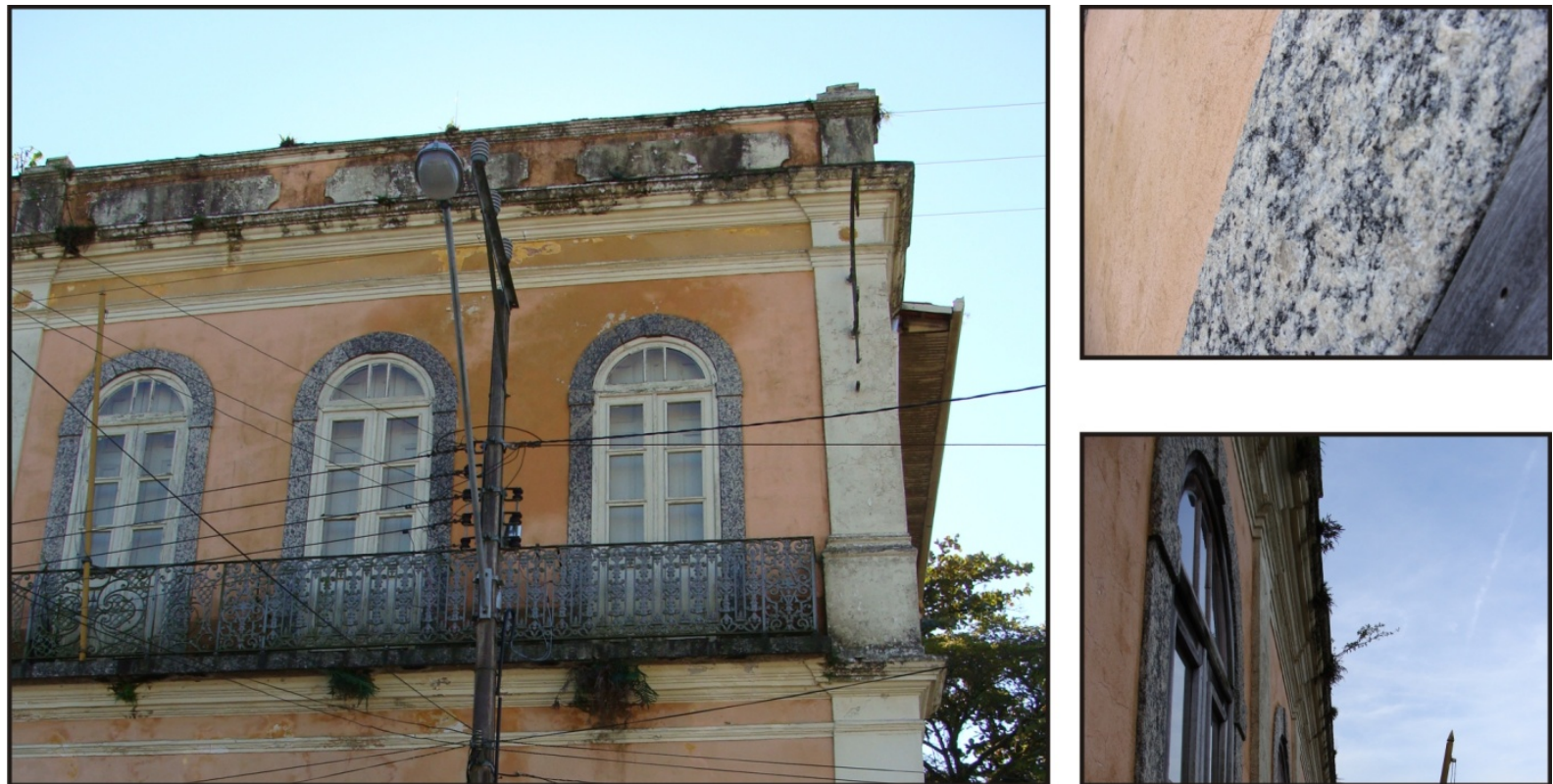

Figura 69. Detalhes das aberturas do edifício.

Fonte: Acervo do autor, 2009.
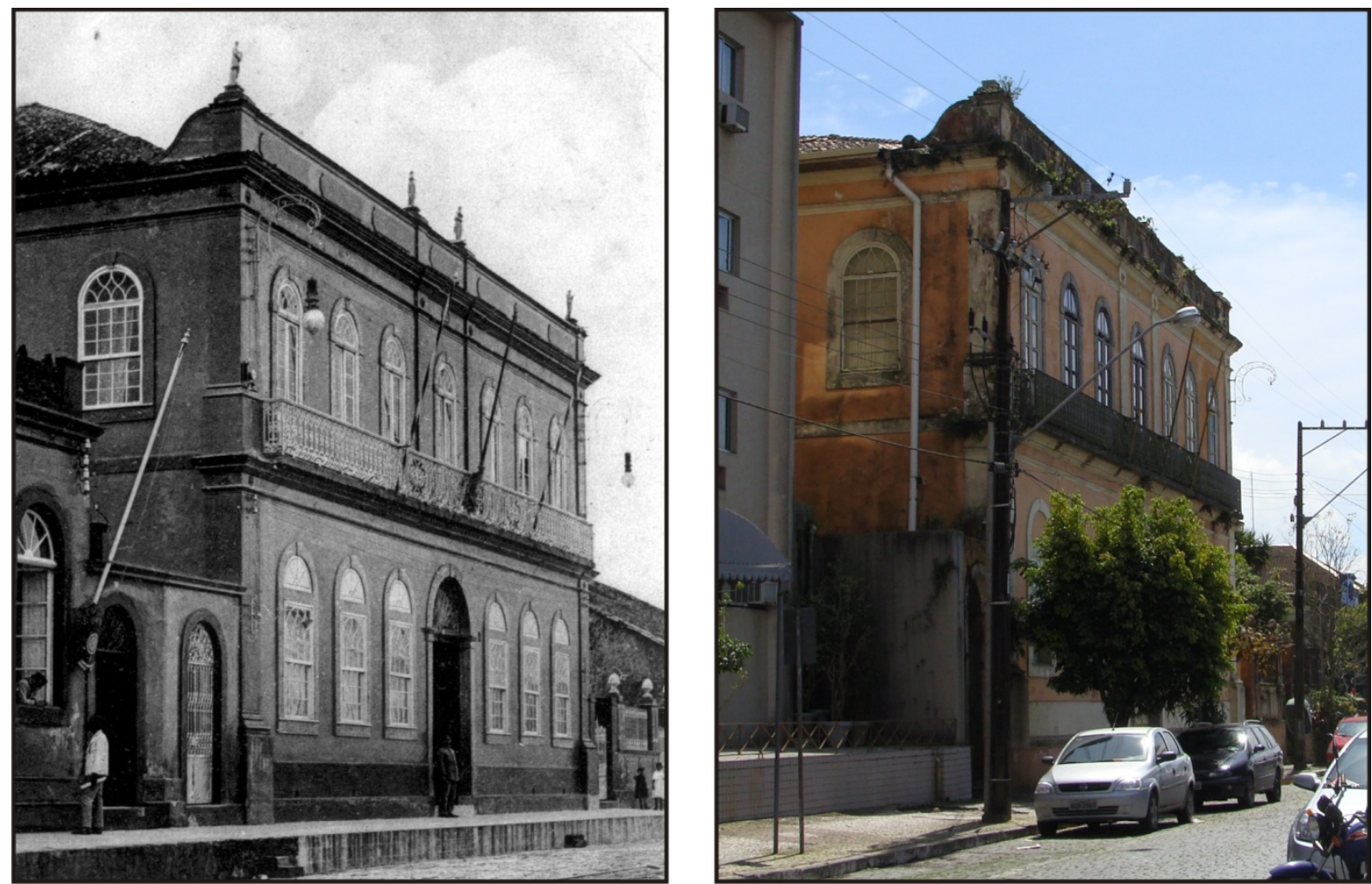

Figura 70. O Palacete Nácar no começo do século XX, e no início do XXI.

Fonte: Instituto Histórico e Geográfico de Paranaguá/Acervo do autor, 2009. 
As cimalhas foram aplicadas no pavimento inferior, no superior e na platibanda, que possui em seu centro a data de 1856 , envolto em dois ramos e quatro figuras femininas, representando as estações do ano. O prédio era originalmente coberto com telhas do tipo capa e canal e sua estrutura é de alvenaria de pedra. O que se observa nesse palacete é que alguns métodos construtivos ainda se conservavam da mesma forma que nas construções da maior parte do século XVIII, mas possuindo inovações em relação aos materiais, como o vidro, os elementos decorativos, o jardim lateral e as grandes proporções do edifício. 0 edifício está sobre o alinhamento da rua (Figura 70), possuindo recuos nas duas laterais, em que um deles dá acesso aos fundos do terreno e o maior é resultante da construção de um jardim lateral (Figura 71), onde estão contidos dois bancos embrechados com conchas que formam as iniciais de seu proprietário (Figura 72).

A composição de influência clássica aplicada no Brasil é comentada por Reis Filho (1978, p. 117) no seguinte trecho:

A arquitetura elaborada sob a influência da Academia era caracterizada pela clareza construtiva e simplicidade de formas. Apenas alguns elementos construtivos como cornijas e platibandas eram explorados como recursos formais. Em geral, as linhas básicas da composição eram marcadas por pilastras, sobre as quais, nas platibandas, dispunham-se objetos de louça do Porto, como compoteiras ou figuras representando as quatro estações do ano, os continentes, as virtudes etc. As paredes, de pedra ou de tijolo, eram revestidas e pintadas de cores suaves, como branco, rosa, amarelo ou azul-pastel e sobre esse fundo se destacavam janelas e portas, enquadradas em pedra aparelhada e arrematadas em arco pleno, em cujas bandeiras dispunham-se rosáceas mais ou menos complicadas, com vidros coloridos

Sobre a residência do Visconde, temos uma pequena descrição dos anos 70 do século XIX, das impressões do viajante francês Émille de Saint-Denis, que foi hóspede do Visconde de Nácar e assim descreveu sua propriedade: 

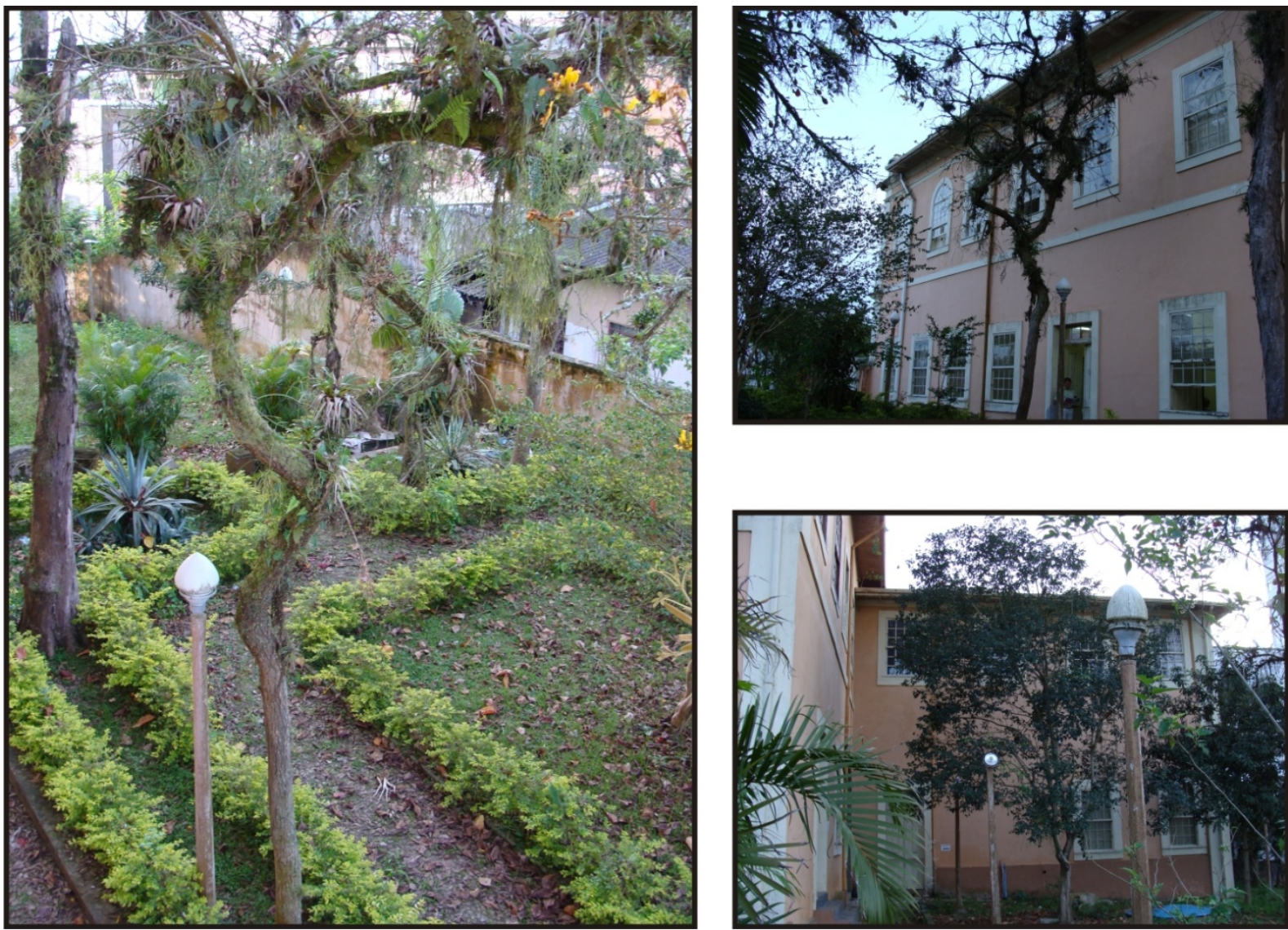

Figura 71. O grande jardim lateral do palacete Nácar.

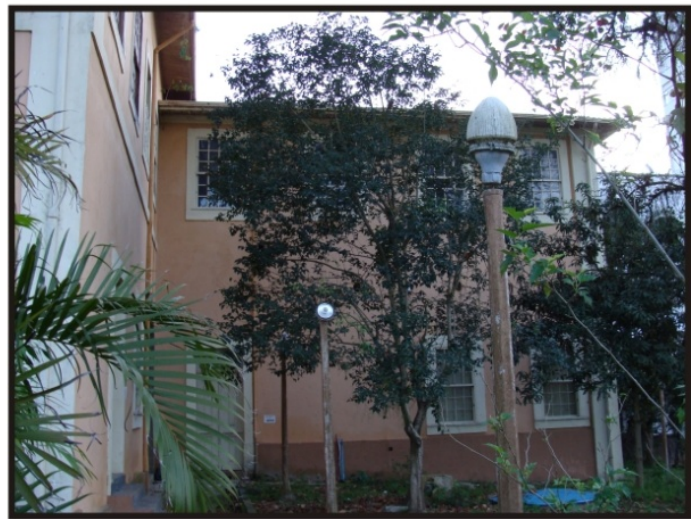
Fonte: Acervo do autor, 2009.
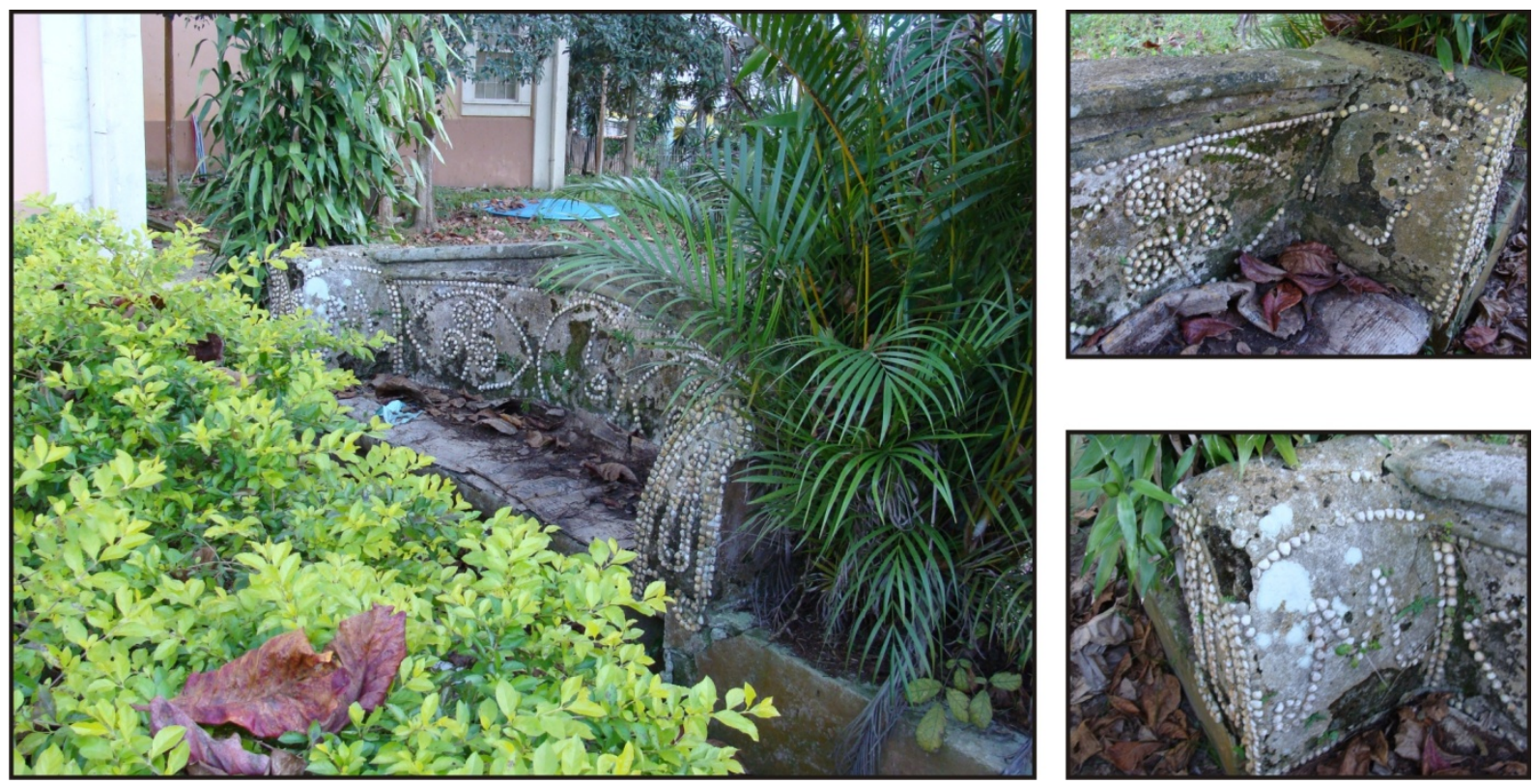

Figura 72. Os bancos do jardim embrechados com conchas, que formam o nome do prorietário.

Fonte: Acervo do autor, 2009 
Je fus introduit dans un grand vestibule attenant à un magnifique jardin couvert ou vérandah! ... et fis passer ma carte. Le fils du baron, un charmant jeune homme, vint aussitôt au devant de moi et me salua par ces mots : "Nous vous attendions dès hier, et vous prions de nous excuser de n' avoir pas pu vous retrouver dans la foule ; mon pére sera bien heureux de vous voir! Veuillez entrer. ${ }^{30}$ (SAINT-DENIS, 1898, p.92-93)

\section{Em outro trecho sobre uma festa dada por Nacar, o autor comenta:}

Les salons du Baron étaient illuminés à giorno, des lanternes vénitiennes dans les arbres, des globes dans les allés du jardin, des torches à l'entrée, tout était du plus grand effet, et les invités se pressaient sur la terrasse causant et fumant toujours ces cigarrettes de paille, cigarros, qui paraissent indispensables aux Brésiliens ! ${ }^{31}$ (SAINT-DENIS, 1898, p. 102-103)

Este edifício se destacava na paisagem parnanguara, principalmente para aqueles que chegavam à cidade pelo rio Itiberê, assim como descreveu o alemão Carl Von Koseritz em 1883 (1980, p. 22):

Admirei, de bordo, o grandioso palácio do visconde de Nacar, que se apresentava como um gigante entre anões e observei pelo binóculo os edifícios da estrada de ferro, que foi construída num ponto em que os maiores navios do mundo podem ancorar, desde que, bem entendido, eles tenham conseguido transpor, são e salvos, a perigosa barra de Paranaguá.

As influências européias na arquitetura também serão refletidas nos costumes e no modo de vida da população, o jornal Commercio do Paraná, da década de 1860 (Figura 73), publica anúncios que relatam a chegada de um dentista alemão que estava se estabelecendo na cidade, de retratos tirados pelo sistema de ambrotipo a fumo e coloridos, tinturaria, o ensino de meninas pela "Madama Jessica James", que voltava da Europa e ensinaria às alunas “[...] Geographia, História, Bordados, e

\footnotetext{
${ }^{30}$ Fui conduzido a um grande salão ao lado de um magnífico jardim coberto ou avarandado e entreguei minha carta. O filho do Barão, um rapaz encantador imediatamente veio ao meu encontro e me cumprimentou dizendo: "Esperávamos você ontem e nos desculpamos por não ter the encontrado no meio da multidão, meu pai ficará feliz em vê-lo! Por favor, siga-me. (Traduzido pelo autor)

${ }^{31}$ Os salões do Barão estavam iluminados à giorno, lanternas venezianas nas árvores, globos nos caminhos do jardim, tochas na entrada, era tudo com grande efeito, os convidados se espremiam no terrasso conversando e fumando sempre os cigarretes de palha, cigarros, que parecem indispensáveis aos brasileiros! (Traduzido pelo autor).
} 

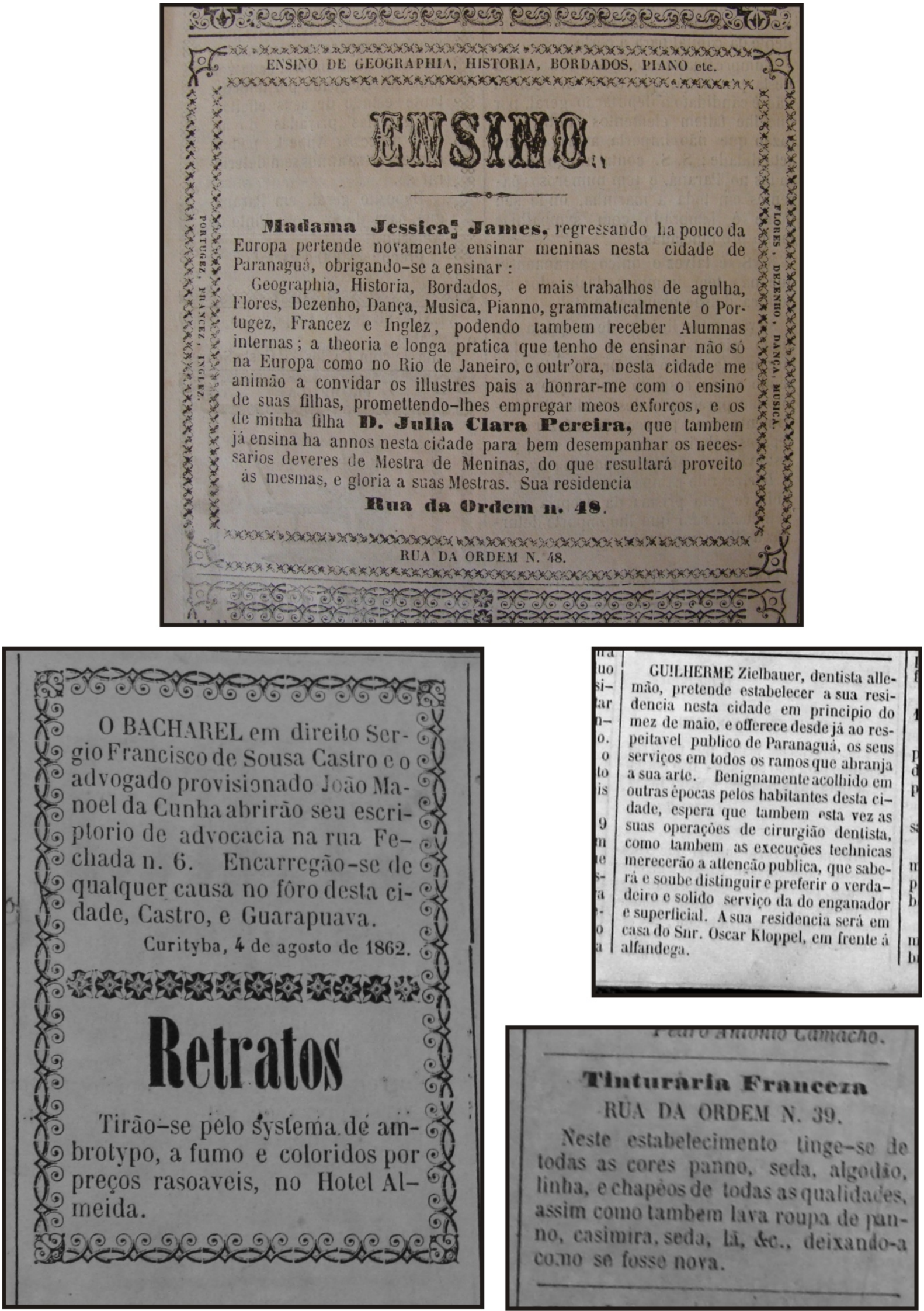

Figura 73. Anúncios encontrados no jornal Commercio do Paraná da década de 1860.

Fonte: Jornais Commercio do Paraná, 5 de set. de 1863, 30 ago. 1862, 29 mar. 1862, 27 set. de 1862. 
mais trabalhos de agulha, Flores, Dezenho, Dança, Música, pianno, grammaticalmente o Portuguez, Francez e Inglez [...]"

Nesse conjunto de novos costumes e principalmente influenciados pela cultura européia, foram se desenvolvendo as novas construções presentes em Paranaguá, principalmente a partir da metade do século XIX, e muito se deve aos novos materiais que vinham de outras nações e adentravam na cidade através de seu porto, que se mantinha nas margens do rio Itiberê.

Com o Código de Posturas de 1877, criaram-se novas determinações para o delineamento dos terrenos sendo que: "Art. 19: Os terrenos urbanos concedidos por carta de data, nunca poderão ter menos de sete metros de frente, salvo caso de total impossibilidade por causa de extensão e necessidade de aformoseamento da cidade." (PARANAGUÁ, 1877, p. 9). Já são exigências para as novas necessidades de construção, para residências mais amplas com maior número de aberturas e da utilização de jardins laterais. Anteriormente a configuração dos lotes caracterizavase por sua estreiteza, com construções unidas uma as outras, não possuindo recuo lateral.

No caso das alturas das edificações, as casas térreas deveriam possuir 4 metros de altura e as de sobrado 8 metros, permitindo-se alturas maiores. Portas deveriam possuir altura de 3 metros por 1,30 de largura e janelas com largura e alturas proporcionais. (PARANAGUÁ, 1877). Essas dimensões implantadas para as edificações no ano de 1877, são menores que as estabelecidas no Código de 1858. Preocupações quanto ao conjunto urbano também são especificadas nesse Código, como o seguinte:

Art. 35: Quem tiver quintal com frente para a rua, praça ou campo é obrigado a fazer improrogavelmente no prazo de um anno aformoseando com porta e janela como se fora frente de casa, elevando na altura determinada na presente postura sendo alinhado na forma dos arts. $28 \mathrm{e}$ 
29. O contraventor pagará a multa de $20 \$ 000$. Não se comprehendem nestas disposições as casas ajardinadas na frente que poderá ser enumeradas até a altura conveniente para receber gradil de ferro.

Quanto ao código de Postura de 1893, este surge com novas definições sobre a abertura de ruas e também de seus dimensionamentos, de acordo com o Artigo $1^{\circ}$ : "Todas as ruas que se abrirem nesta cidade ou em outras povoações do município terão a largura de 20 metros as praças e largos serão quadrados quanto o terreno permitir." (PARANAGUÁ, 1893, p.19). Já os terrenos das novas ruas, não poderiam ultrapassar a medida de 25 por 50 metros.

O Código de 1858, estabelecia a largura de 60 palmos, aproximadamente 13 metros e no de 1877 não são especificadas medidas, a preocupação maior com leis sobre o traçado urbano de Paranaguá, são encontrados neste último código do século XIX.

Algo que não foi alterado nestes três períodos, foi de que as construções, não poderiam se afastar dos arruamentos determinados pela Câmara, significando que os edifícios não poderiam utilizar o recuo frontal, tendo sempre suas casas alinhadas aos limites da frente do terreno. Sobre as alturas especificadas temos:

Art II: A altura dos edifícios e dos seus differentes pavimentos, bem como as dimensões exteriores das portas e janellas que se abrirem serão reguladas pelo padrão seguinte: 5 metros para o primeiro pavimento (sem contar a soleira) 4, $88 \mathrm{~m}$ para o segundo e 4,56 para o terceiro. Ao todo 14 , $44 \mathrm{~m}$. estas alturas serão as mínimas e podem variar para um edifício de 3 pavimentos até 17 metros de altura. As janellas terão $2,20 \mathrm{~m}$ sobre $1,20 \mathrm{~m}$ de largura sem contar as hombreiras vergas e peitoris as vergas das portas devem acompanhar o nível das janellas. (PARANAGUÁ, 1893, p.21).

É neste artigo que pela primeira vez está configurada a obrigatoriedade da construção do porão alto, pela lei: "O assoalho do primeiro pavimento deverá ficar pelo menos 0,50 m superior ao terreno." (PARANAGUÁ, 1893, p.21). Significando 
que o piso inferior deveria estar elevado em relação à rua e assim configurando o porão alto.

No caso das alturas dos edifícios, especificados no Código de Posturas de 1893, são maiores do que os estabelecidos em 1877 e com medidas semelhantes às determinadas em 1855. Portanto, as medidas, estabelecidas para as construções na metade do século, foram reduzidas no Código de 1877 e aumentadas no Código de 1893.

No código de 1877 e de 1893, os proprietários de imóveis são obrigados a pavimentar as calçadas após o término de suas obras, na largura de 2,22 m, o prazo para esta exigência diminui entre as duas posturas de 6 meses para 3 em 1893. O que demonstra, pela diminuição do prazo, a importância das calçadas na configuração dos passeios nesse período.

Nessa nova lei, mantinham-se as proibições de se construir janelas que abrissem para fora, rótulas e sacadas de madeira, e indicavam novos elementos obrigatórios nas obras, como as calhas: "Art. 16: Nos prédios que se forem edificando ou reedificando haverá canos no interior das paredes para receberem dos telhados ou terraços as águas fluviaes para as levarem por baixo das calçadas até as sargetas." (PARANAGUÁ, 1893, p.21).

Foi estabelecida a arborização da cidade de Paranaguá, por determinação da Câmara que "[...] promoverá a arborização dos pateos, largos e ruas em que por sua largura, for isso possível. No plantio dessas arvores procurar-se -há aquellas que forem de grande duração e que sejam frondosas, preferindo as que não crescem muito.“ (PARANAGUÁ, 1893, p.30-31)

Em conjunto com estas novas leis, também foram ampliados os recursos construtivos, o emprego do tijolo, a maior utilização do vidro, as telhas francesas, 
vão formando em Paranaguá um novo conjunto de construções. A chegada da ferrovia à partir de 1880, também influenciou neste aspecto, trazendo as estruturas metálicas e os materiais importados para a edificação de suas estações.

Exemplos de construções ecléticas desse período, como a da família Veiga, edificada em alvenaria de tijolos, foi durante algum tempo a moradia do pintor paranaense Alfredo Andersen ${ }^{32}$. Localizada no fim da rua Visconde de Nácar, está implantada no alinhamento frontal do terreno e possui as duas laterais recuadas, onde estão localizados dois grandes portões com escadarias, marcando a simetria do edifício. Por uma imagem de fins do século XIX ou início do século XX (Figura 74), nota-se que esta residência, provavelmente sediou o consulado argentino, devido à bandeira e o pequeno brasão em sua fachada, infelizmente não foram encontradas mais informações sobre este aspecto.

Essa residência (Figura 75) possui grandes aberturas em verga reta e sua fachada é marcada pelos balcões em ferro trabalhado, as pilastras possuem pseudo-capitéis do tipo coríntio e sua platibanda é arrematada em forma de balaustrada. Na parte superior do edifício, não foi aplicado nenhum tipo de ornamento, como compoteiras ou estátuas, as compoteiras são encontradas nos dois portões de acesso à casa.

Um detalhe peculiar encontrado nessa residência é a decoração das vergas das portas e janelas. Além da cimalha, existe em cada extremo um perfil de rosto humano (Figura 76), de um homem com bigodes, um elemento decorativo único em Paranaguá.

\footnotetext{
${ }^{32}$ Pintor norueguês, viveu no fim do século XIX, por cinco anos em Paranaguá, depois se radicou em Curitiba onde fundou uma escola particular de desenho e pintura. Andersen tornou-se um dos mais importantes pintores paranaenses, retratando aspectos deste Estado, como o transporte e beneficiamento da erva-mate, os pinheiros e conhecidas paisagens paranaenses como as Sete Quedas, o litoral e também Paranaguá. (PARANÁ, 2005).
} 


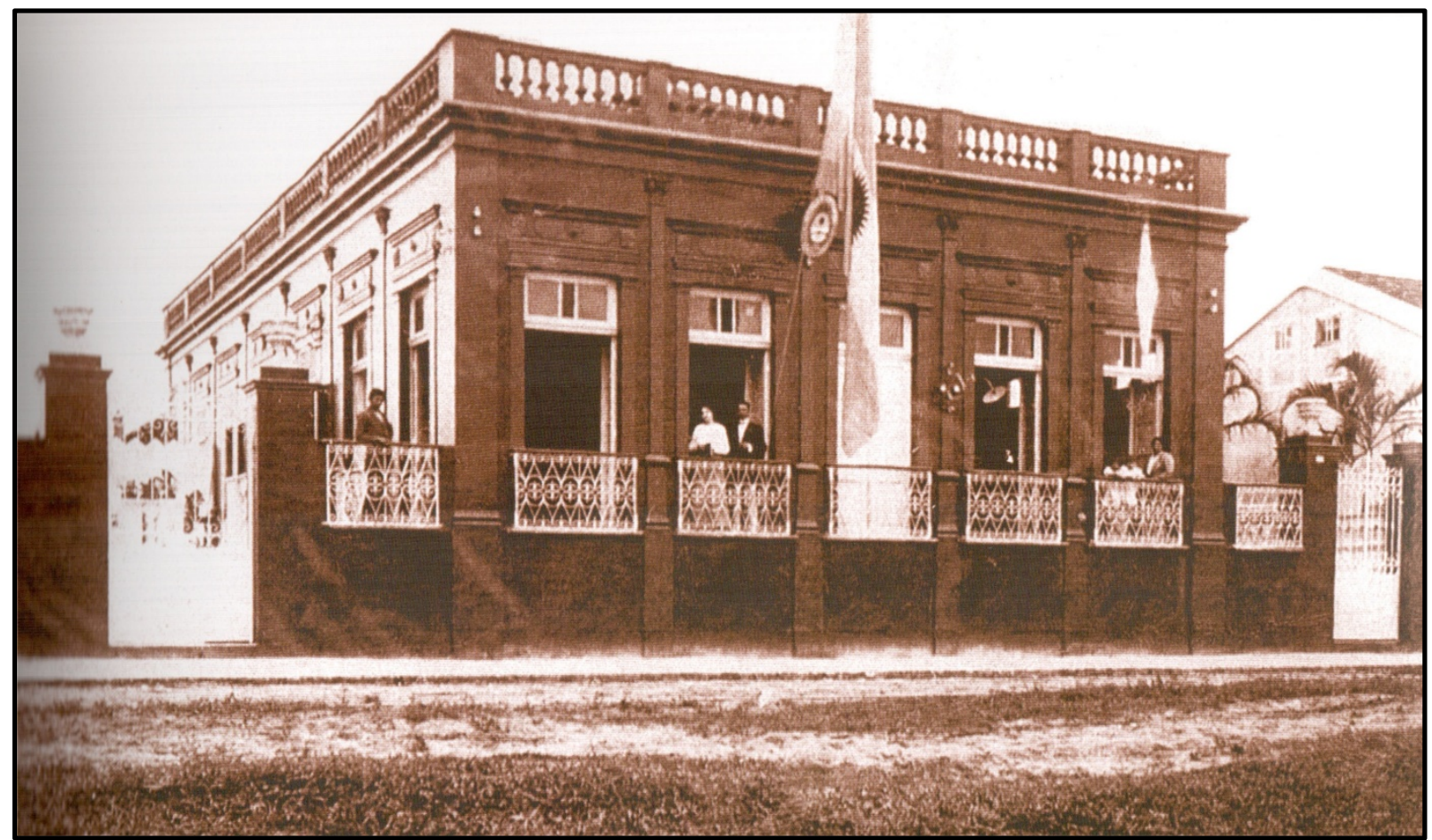

Figura 74. A residência Veiga em fins do século XIX ou início do XX, nota-se a simetria do edifício através dos dois grandes portões em suas laterais.

Fonte: PARANÁ, 2007.
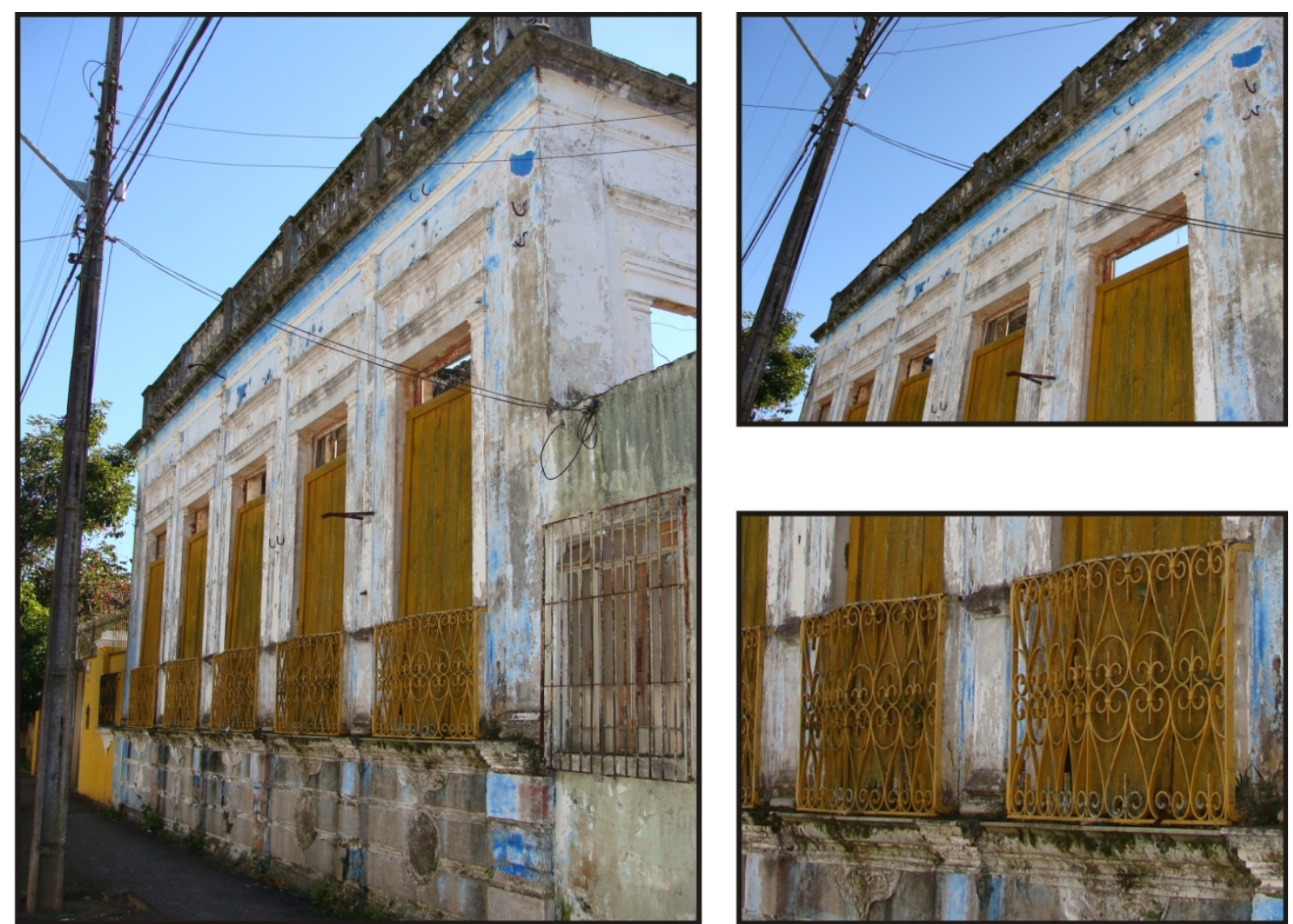

Figura 75. A residência da família Veiga em seu estado atual, com a eliminação dos portões laterais.

Fonte: Acervo do autor, 2009.

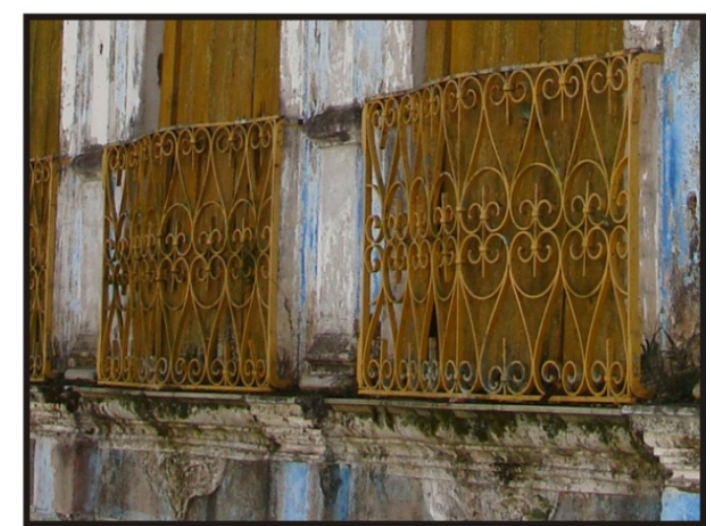



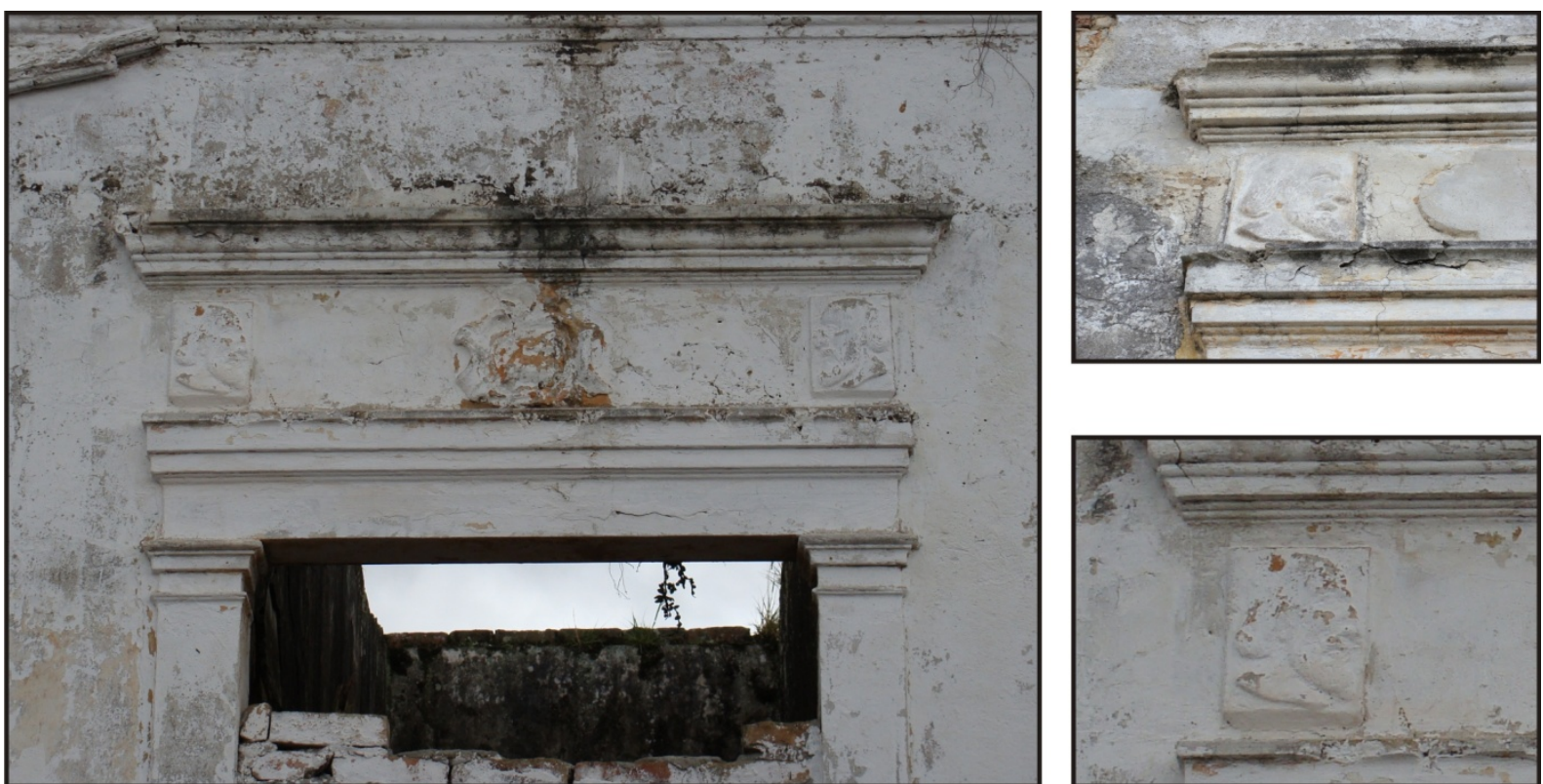

Figura 76. O perfil humano existente na fachada da residência Veiga.

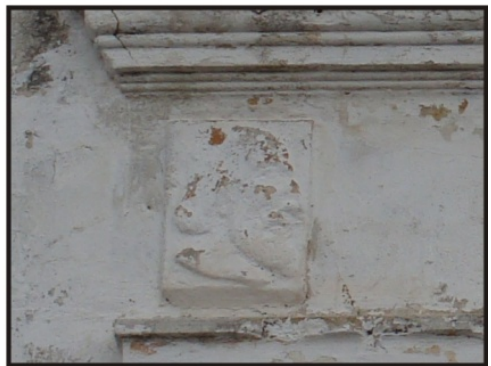
Fonte: Acervo do autor, 2009.

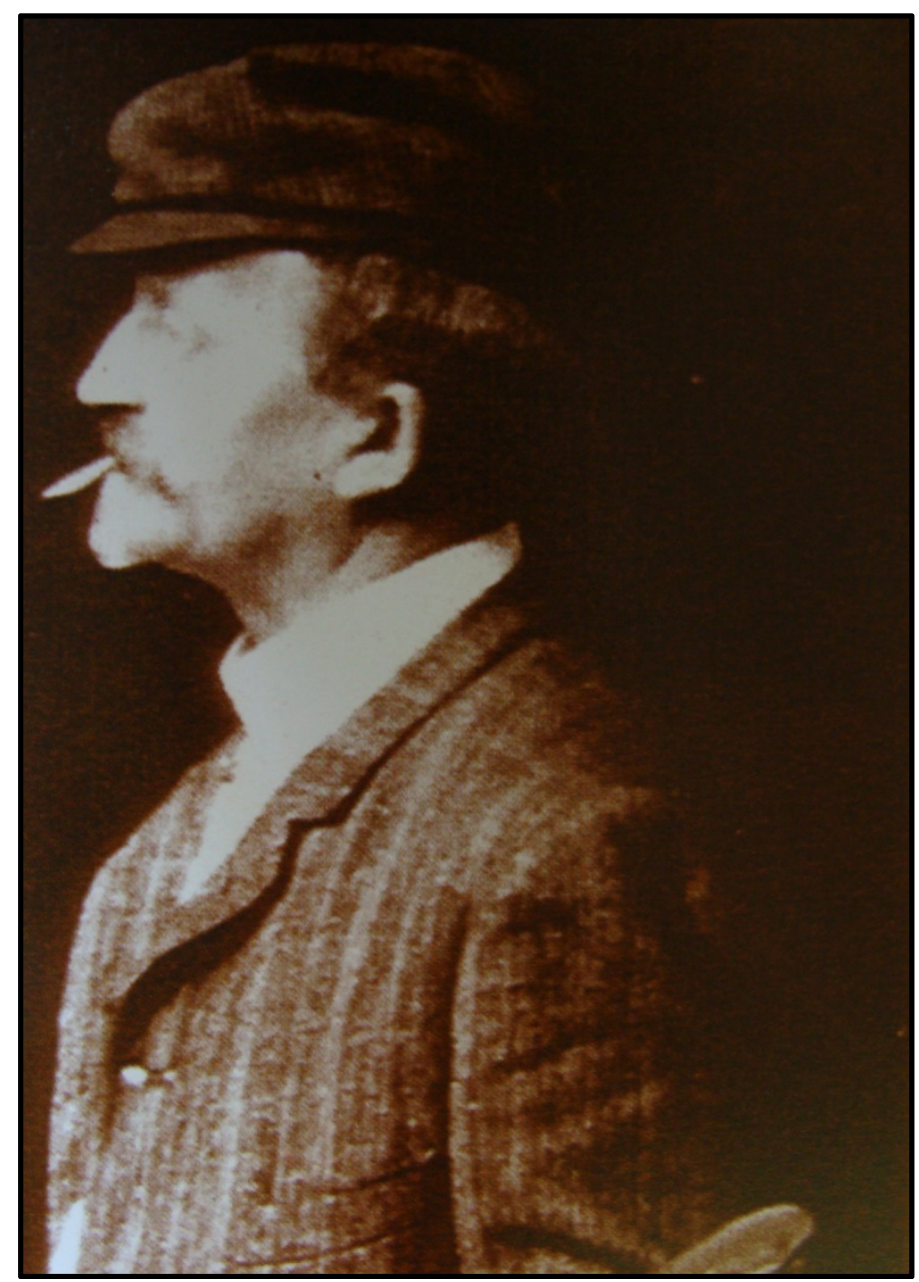

Figura 77. Perfil de Alfredo Andersen, provavelmente década de 1920. Fonte: PARANÁ, 2007. 
Uma explicação dada por um dos membros do IHGP, o Sr. José Maria Faria de Freitas (informação pessoal) ${ }^{33}$ é que este perfil seria o do pintor Alfredo Andersen (Figura 77), para marcar sua estada nessa residência nos fins do século XIX. O artista foi responsável pelas pinturas dos afrescos no interior da residência (Figura 78), na década de 1890, perdidas em função da situação em que se encontra a casa nos dias de hoje.

Quanto à sua construção, ela possui fundação em tijolos construídos em forma de arcada, criando um porão (Figura 79). Somente as paredes externas da fundação do edifício foram construídas em pedra, uma forma de estabilizar toda a estrutura (Figura 80). Todas as paredes das divisões internas e externas foram construídas em tijolos, já o reboco utilizado é semelhante ao que existia desde os tempos da Colônia, uma espécie de argila misturado com o cal de ostras (Figura 81), o que significa que sua utilização ainda era muito recorrente durante o século XIX.

Temos aqui uma das construções mais expressivas do final do século XIX, em Paranaguá, pela importância histórica e também por sua composição estética, de forma simplificada, mas com muita expressividade, por sua escala e composição, revelando em sua estrutura, além dos aspectos estéticos, seus aspectos construtivos e de implantação nesse terreno.

Nessa mesma técnica construtiva, temos a propriedade de João Guilherme Guimarães (Figura 82 e Figura 83), provavelmente contemporânea a anteriormente descrita. Essa residência possui um grande jardim lateral, com janelas em verga reta, venezianas e duas escadas laterais que levam ao pavimento superior. Sua construção em tijolos configura-se no alinhamento da rua e possui afastamento nas duas laterais, em que uma delas resulta em um grande jardim.

\footnotetext{
${ }^{33}$ Informação fornecida por José Maria Faria de Freitas em Paranaguá, em 2009.
} 


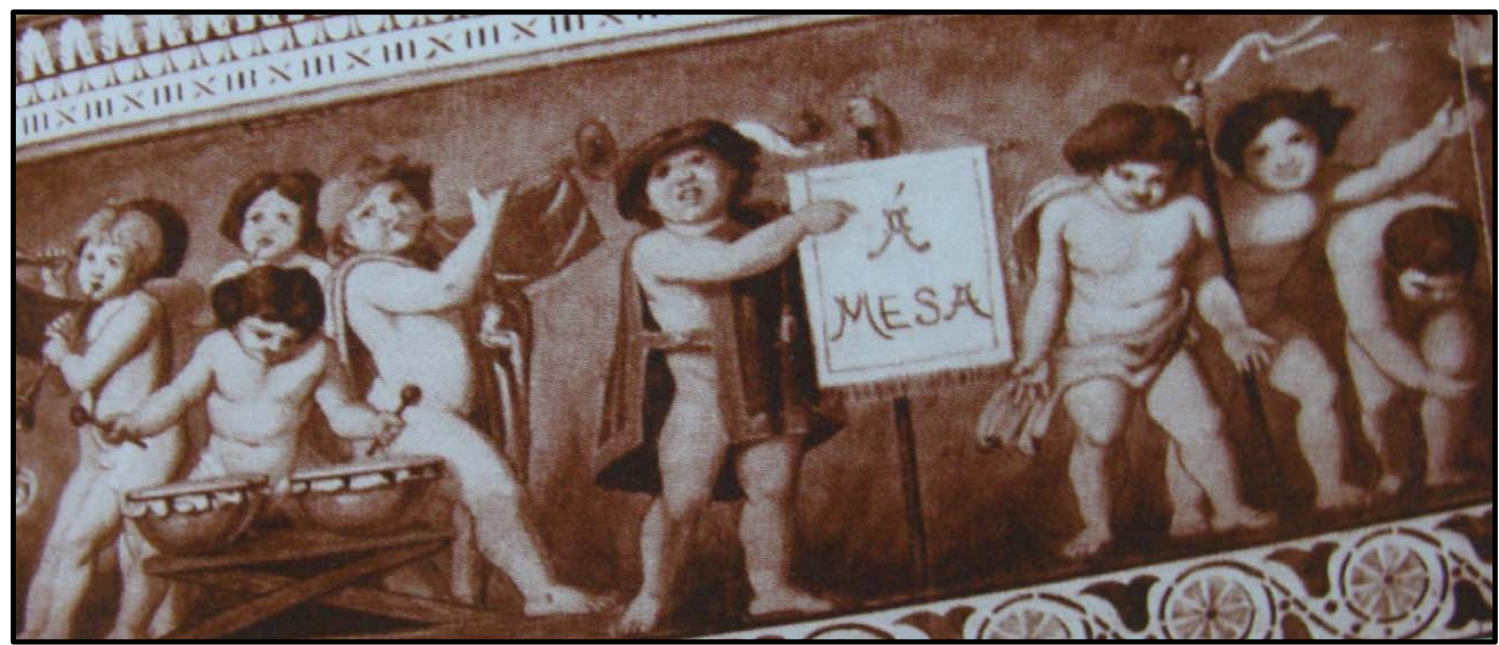

Figura 78. Um dos frisos decorativos localizados na sala de jantar, de autoria de Alfredo Andersen. Fonte: PARANÁ, 2007.
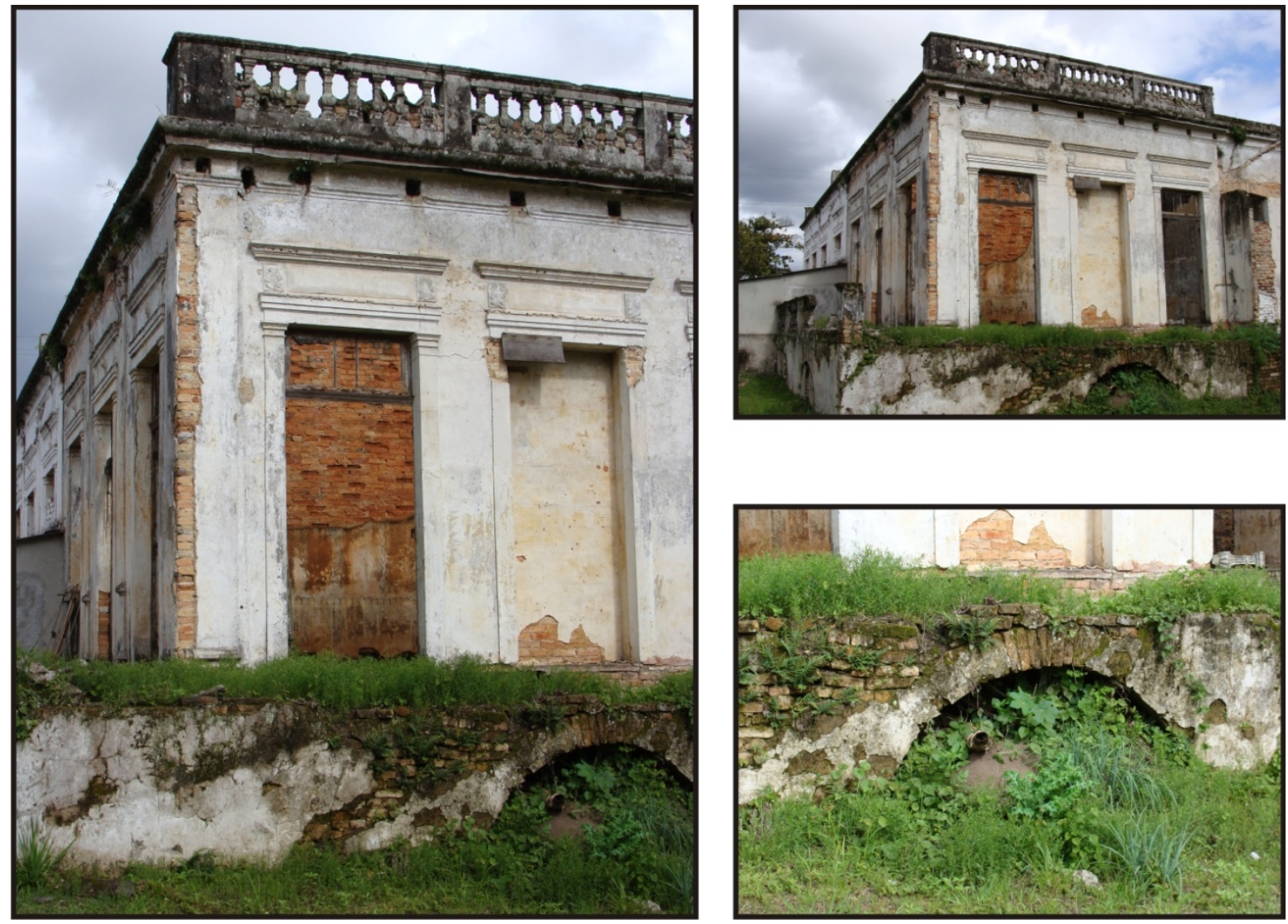

Figura 79. Fundos da residência Veiga e detalhe de uma das arcadas de sua estrutura.

Fonte: Acervo do autor, 2009.

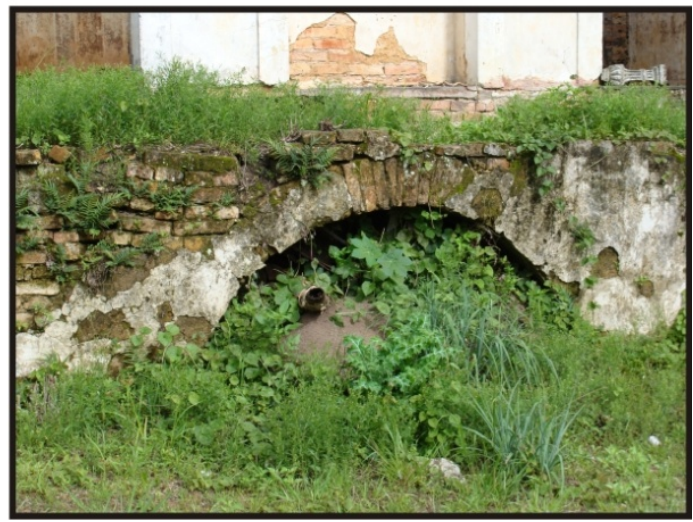



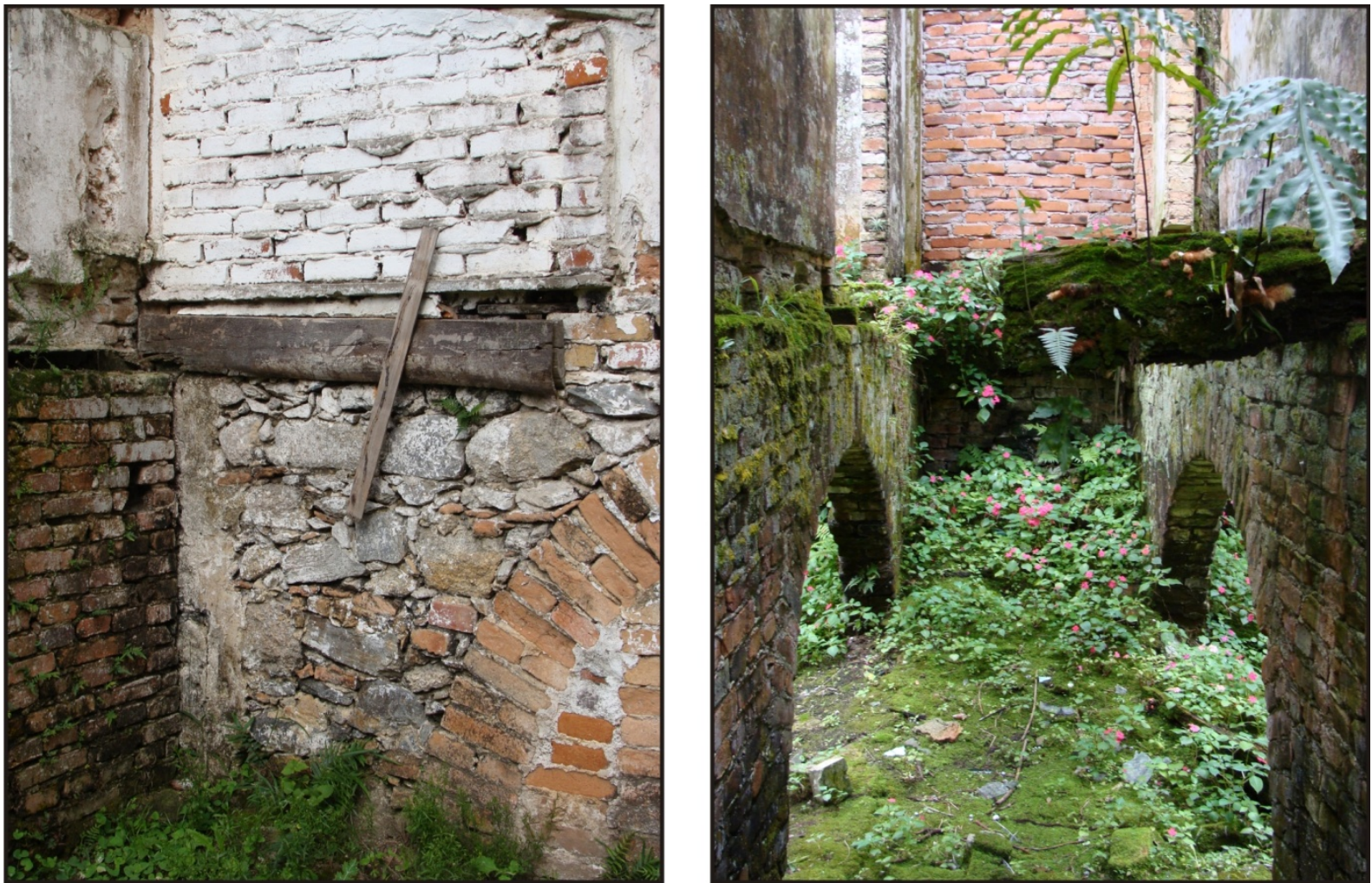

Figura 80. As arcadas em tijolos maciços e as fundações externas em pedra da residência Veiga. Fonte: Acervo do autor, 2009.
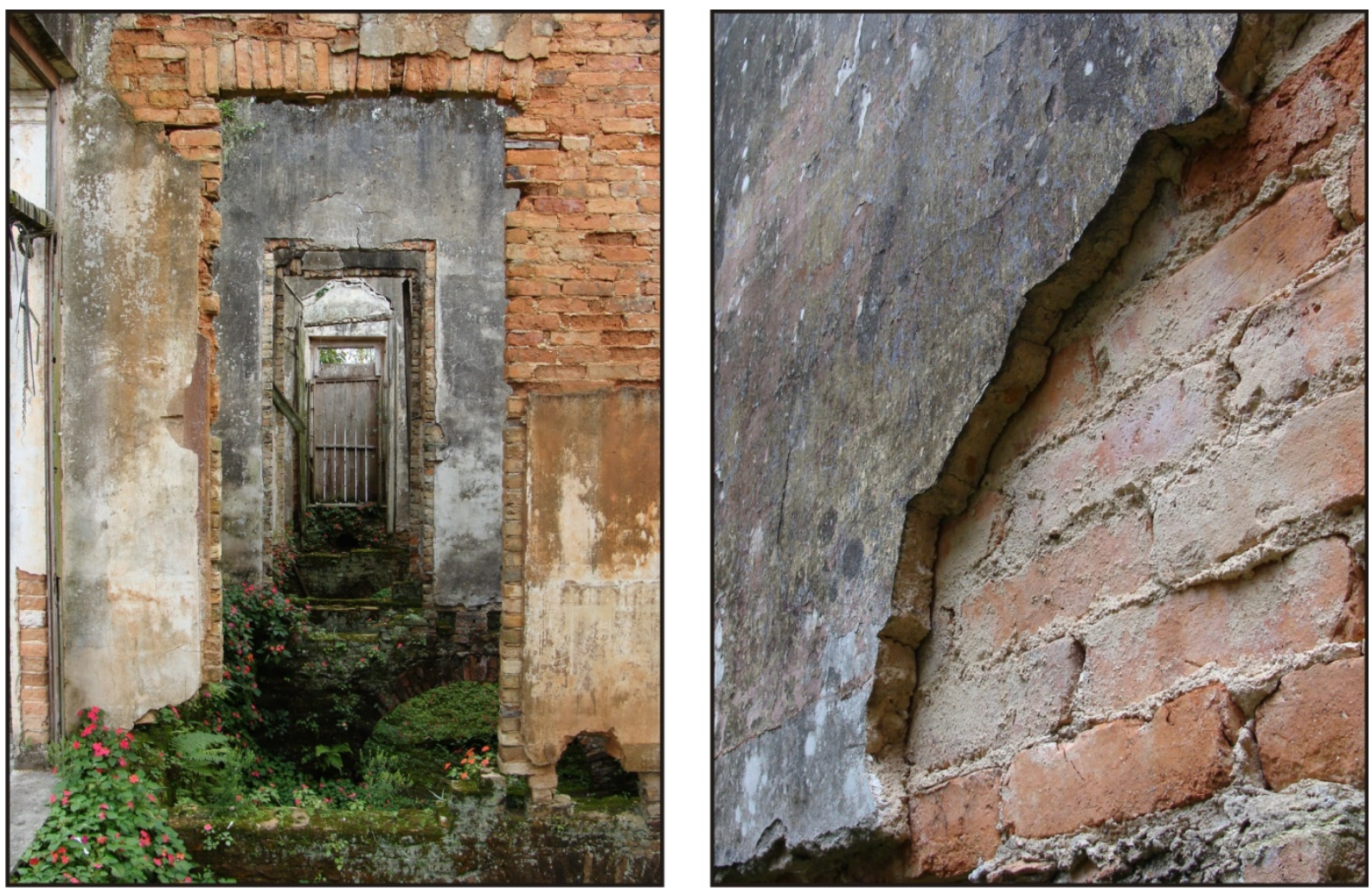

Figura 81. As paredes em tijolo maciço e o detalhe do reboco muito espesso da residência Veiga. Fonte: Acervo do autor, 2009. 


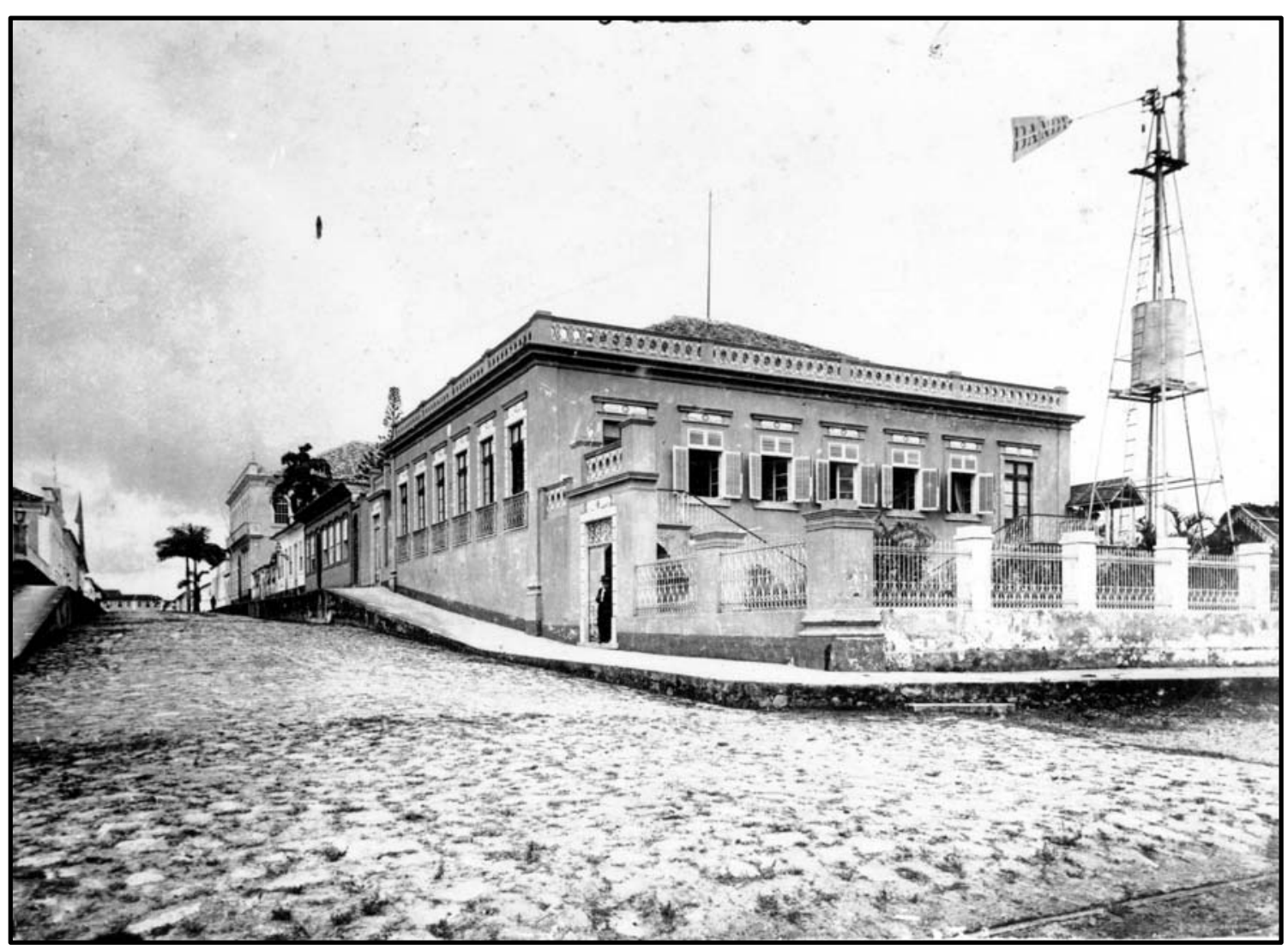

Figura 82. A residência do Coronel João Guilherme Guimarães, início do século XX. Fonte: Instituto Histórico e Geográfico de Paranaguá

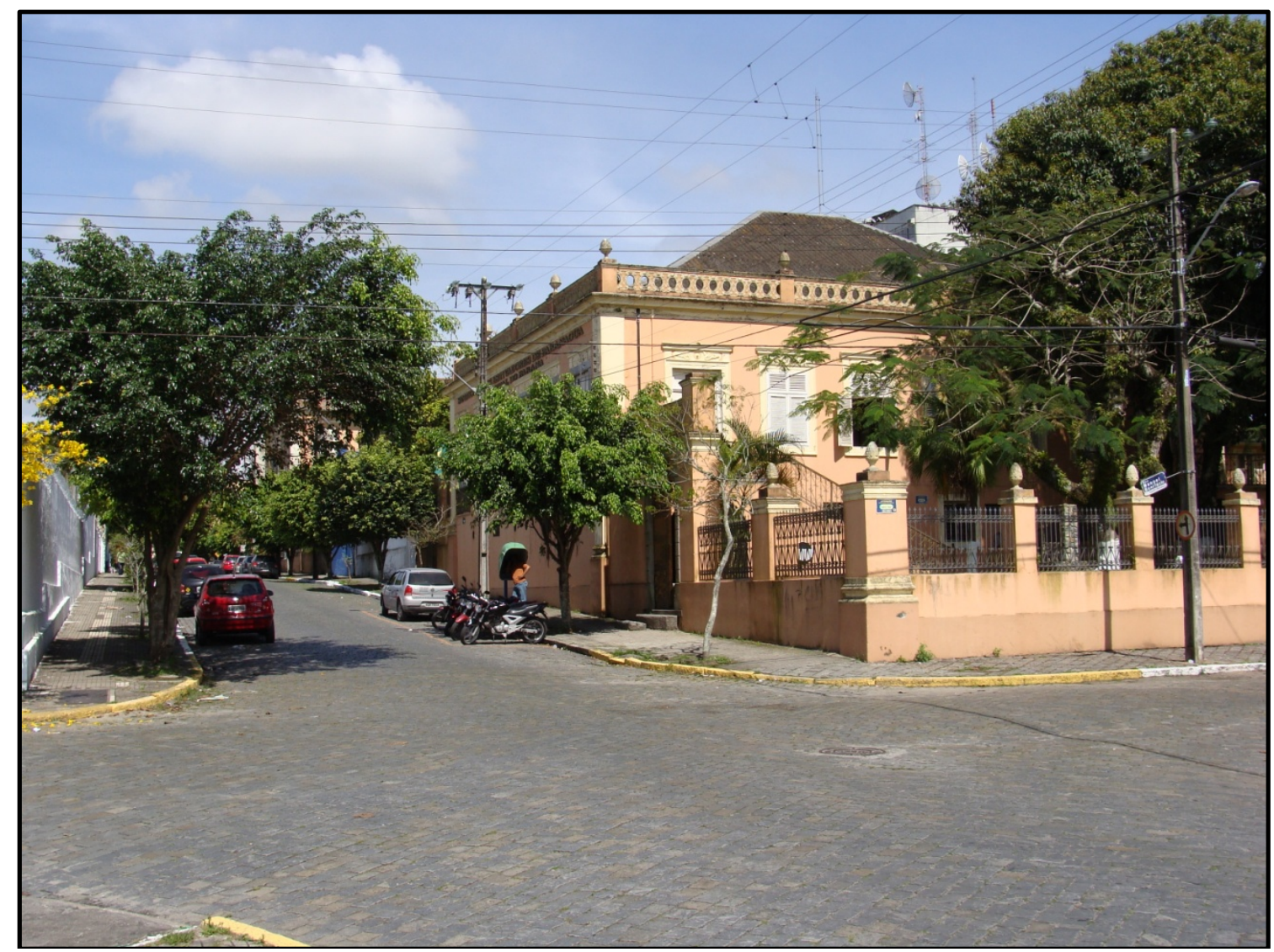

Figura 83. A residência João Guilherme Guimarães em 2009.

Fonte: Acervo do autor, 2009. 
Em outra residência encontrada na rua XV de Novembro, temos a aplicação de azulejos em sua fachada (Figura 84). Os azulejos em tons de azul decoravam todo o conjunto, apenas se diferenciando na platibanda. As vergas das portas são em granito, semelhantes às da casa do Visconde de Nácar, mas com um desenho mais aprimorado. Não foram encontradas informações de sua construção, mas deve ser de poucos anos após a construção do palacete Nácar, pela semelhança em alguns detalhes, como nos arcos das portas e no desenho da platibanda.

Outro edifício com azulejos em sua fachada, também está localizado na rua XV de Novembro, possuindo características de um chalet (Figura 85), seu exterior é ornamentado com azulejos azuis e marrons, suas portas e janelas são em arco pleno. As portas e janelas do andar superior possuem sacadas em púlpito, seu telhado de duas águas projetava-se para frente, ultrapassando os beirais das casas mais antigas, como na imagem de 1897 da rua XV de Novembro (Figura 86).

A ornamentação, principalmente das platibandas, serão recursos muito utilizados nesse período em Paranaguá, as mais comuns eram as imagens femininas, as compoteiras, os pináculos, as pinhas e os balaústres. As antigas fotografias da cidade revelam essas características, ruas como a antiga Direita (Figura 87), já demonstra em fins do século XIX a competição entre os beirais coloniais e as construções ecléticas, como os dois edifícios ornamentados com estátuas femininas em contraponto com o pequeno sobrado que os separam.

Também temos neste período, a construção de uma casa conhecida atualmente como residência Elfrida Lobo (Figura 88). Essa casa situa-se em uma das esquinas da rua Dr. Leocádio, próxima aos fundos da igreja Matriz. 

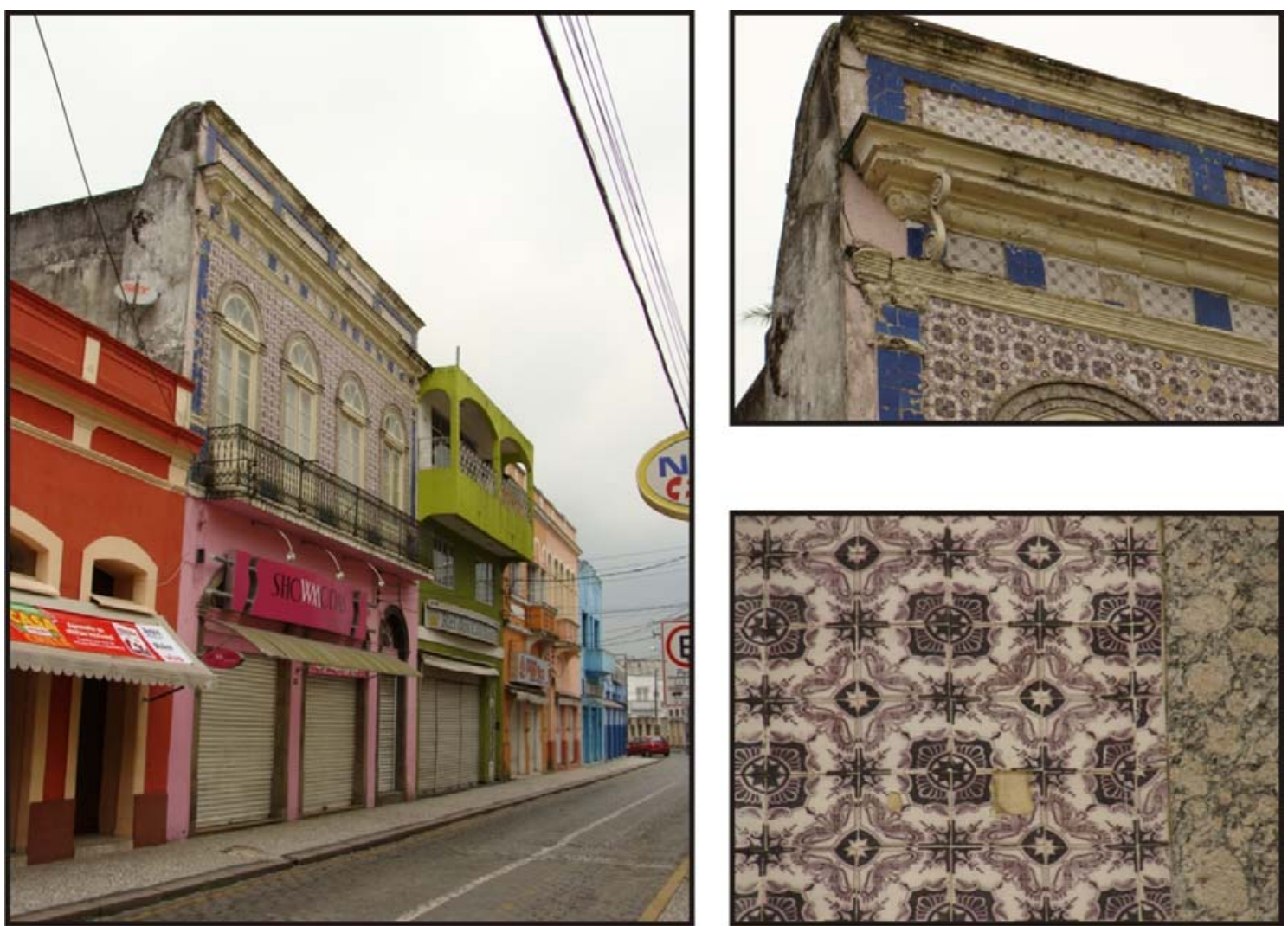

Figura 84. A casa azulejada situada na rua XV de Novembro.

Fonte: Acervo do autor, 2009
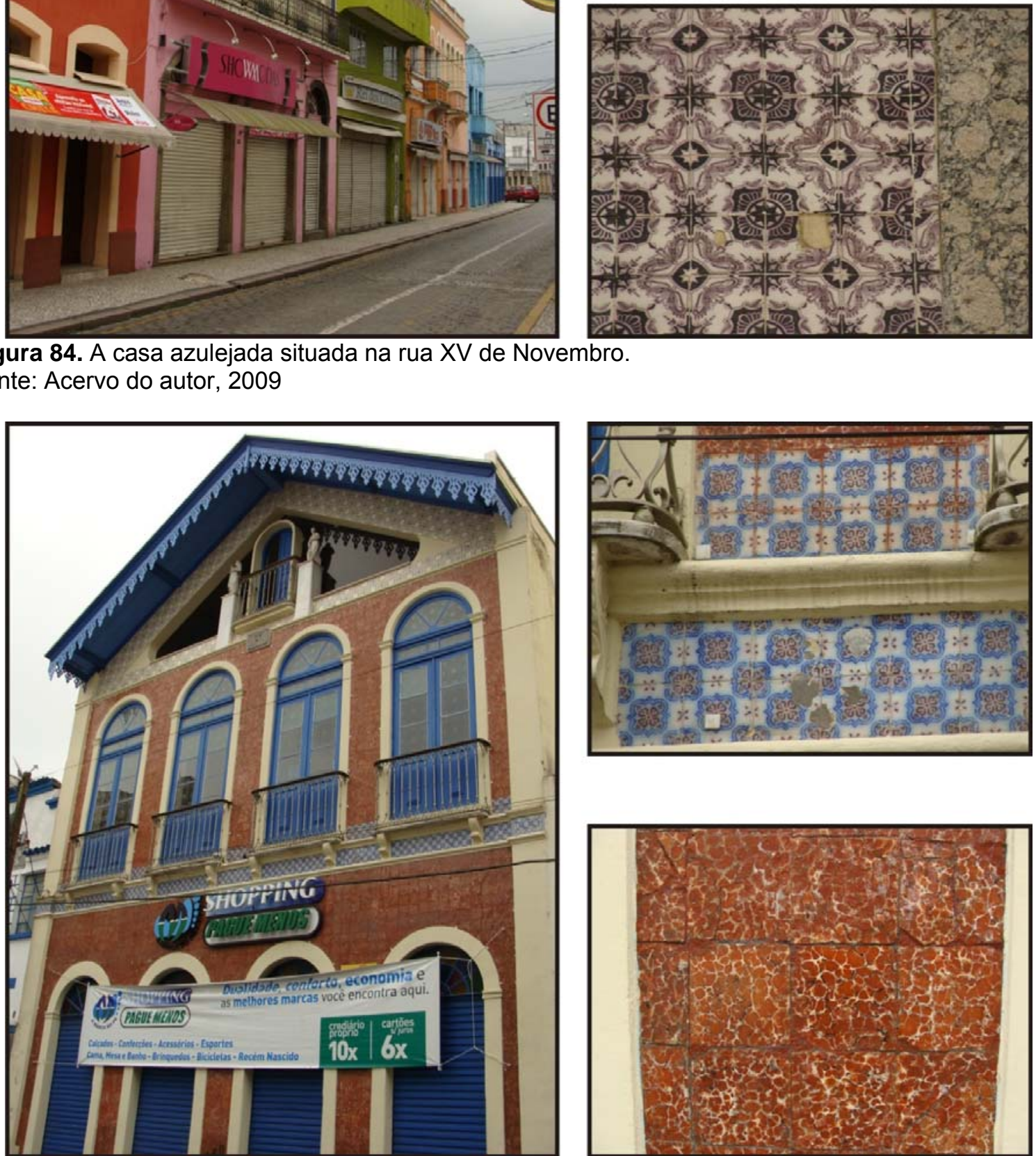

Figura 85. O Chalet azulejado na rua XV de Novembro.

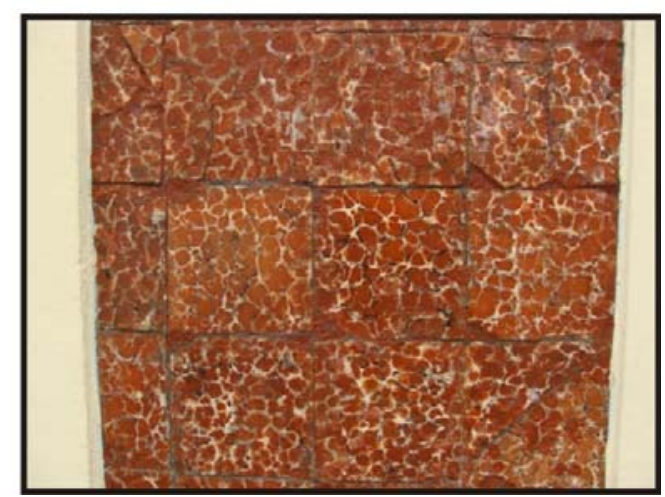

Fonte: Acervo do autor, 2009. 


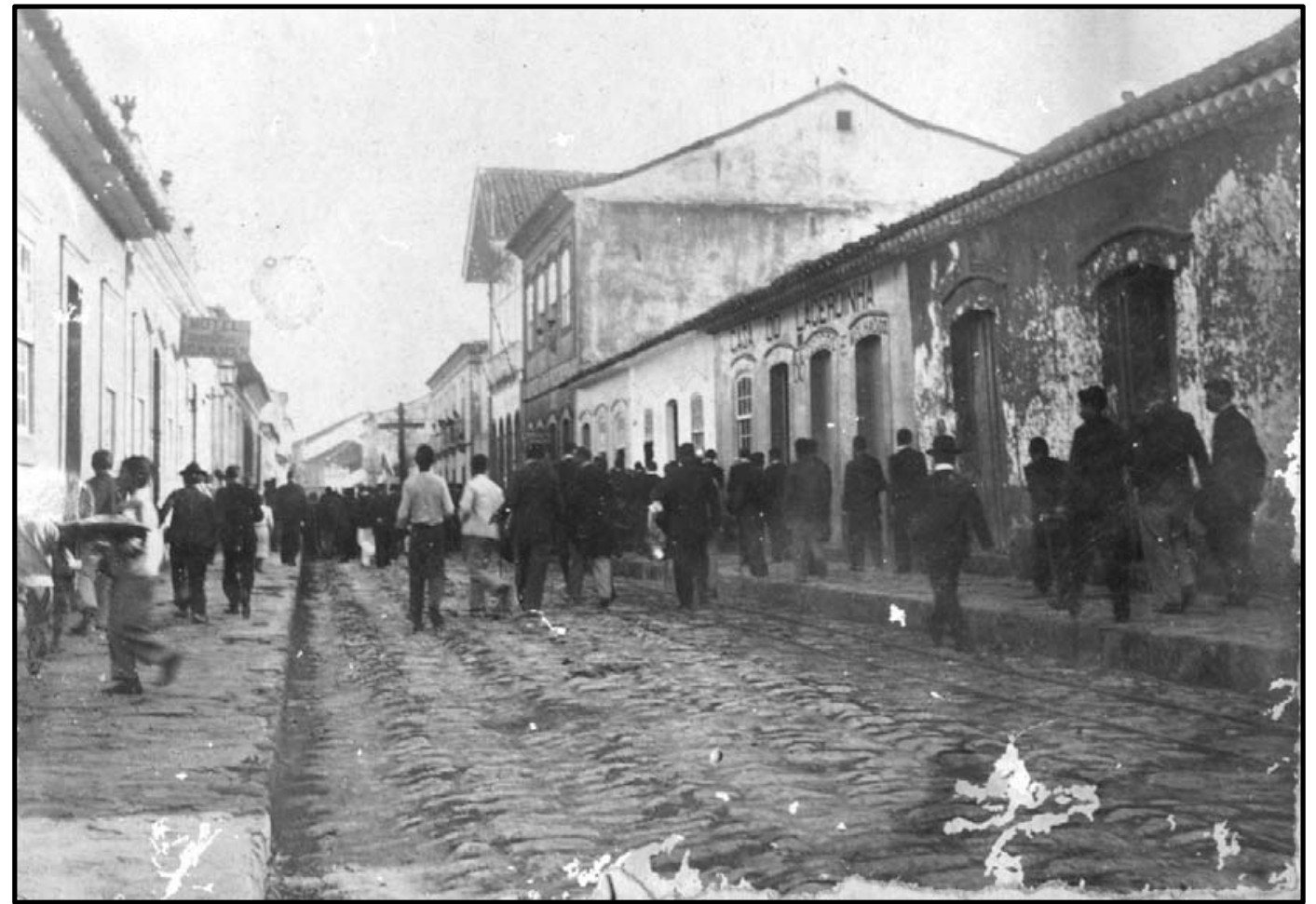

Figura 86. A rua XV de Novembro em 1897, no lado direito ao fundo está o chalet azulejado. Fonte: IHGP.

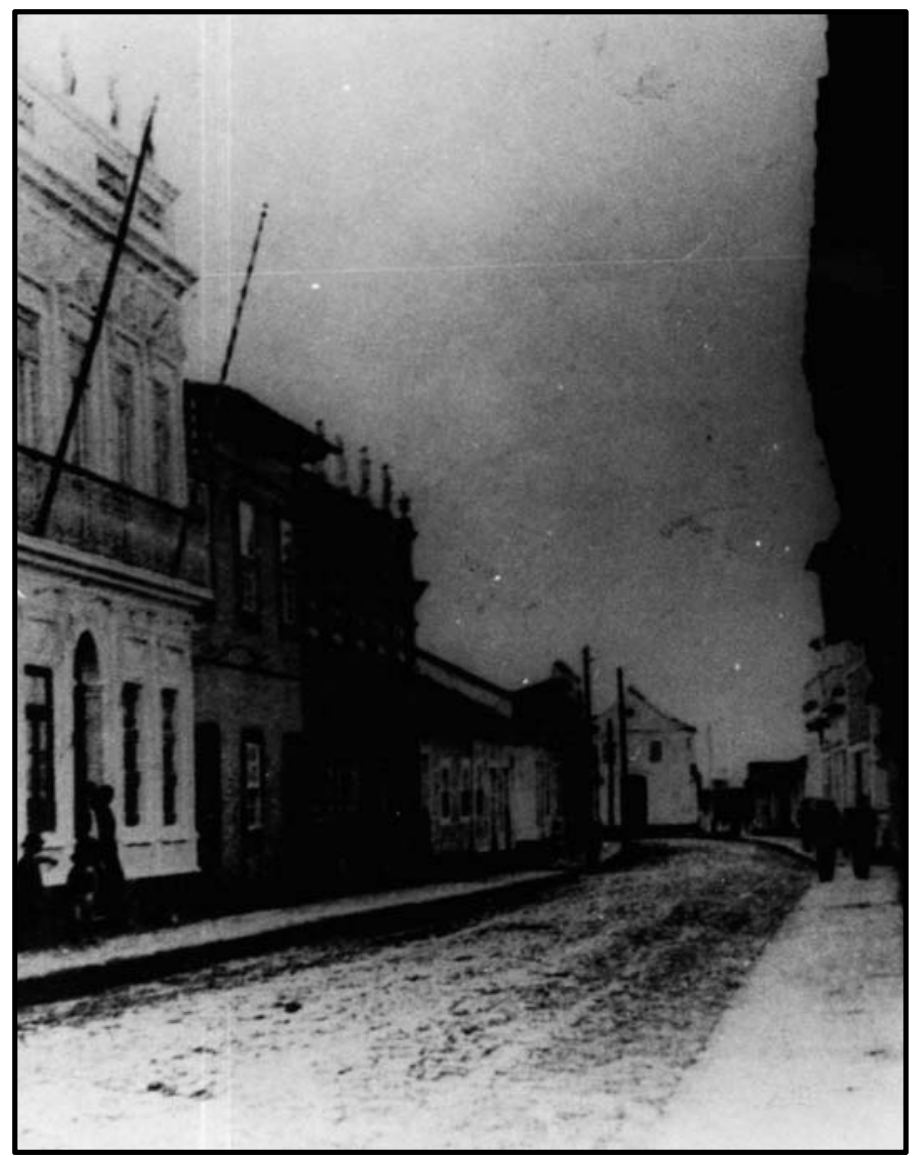

Figura 87. A rua Direita em fins do século XIX, observa-se a disputa entre os beirais coloniais e as platibandas ecléticas.

Fonte: IHGP 
Sua profusão de ornamentos a caracteriza como mais uma residência vinculada ao Ecletismo. Essa construção também se configura no alinhamento do terreno, sendo que existem duas entradas laterais em cada extremo do edifício, na qual uma delas vai para um pequeno jardim (Figura 89) e além dos dois acessos, ainda existe uma entrada principal, voltada para a rua.

Suas portas são em arco pleno e todas possuem balcões, já que a residência está configurada em um patamar elevado em relação à rua, pois existe o porão que é ventilado por um óculo que fica debaixo de cada balcão. As paredes externas deste porão são decoradas com bossagens, com saliências que avançam e apóiam as pilastras com frisos e capitéis jônicos. As cimalhas são decoradas com folhas de acanto, assim como o arremate da platibanda é muito peculiar (Figura 90). Ainda na decoração da platibanda são aplicadas pinhas, que também se repetem nos portões de acesso.

No seu interior, destacam-se as grandes aberturas que ventilam e iluminam os ambientes (Figura 91), ao fundo do edifício, na parte do jardim (Figura 92), existem pisos hidráulicos coloridos, provavelmente importados. Estes ladrilhos hidráulicos também são encontrados no interior de um tipo de apêndice da construção (Figura 93), que poderia ser o quarto dos empregados, esse apêndice possui lambrequins em madeira e em sua frente está o jardim com canteiros sinuosos, feitos em tijolos e embrechados com conchas.

Outra residência encontrada em Paranaguá do período do Ecletismo, é o Palacete Mathias Bohn, neste caso localizado na rua da Praia. Esse Palacete foi resultado da reforma de um antigo casarão do período Colonial que se situava em uma das esquinas daquela rua. 

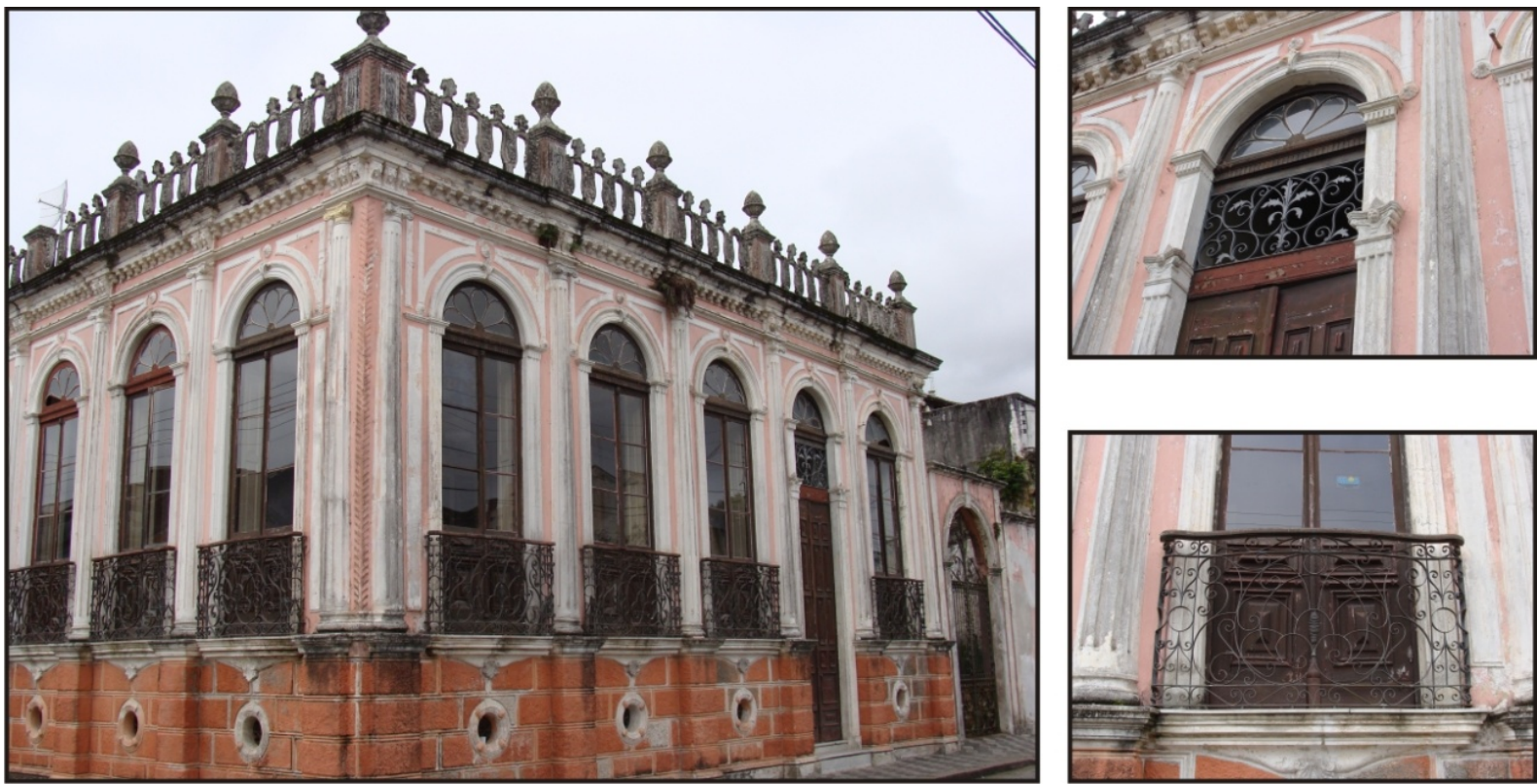

Figura 88. A residência Elfrida Lobo. Fonte: Acervo do autor, 2009.
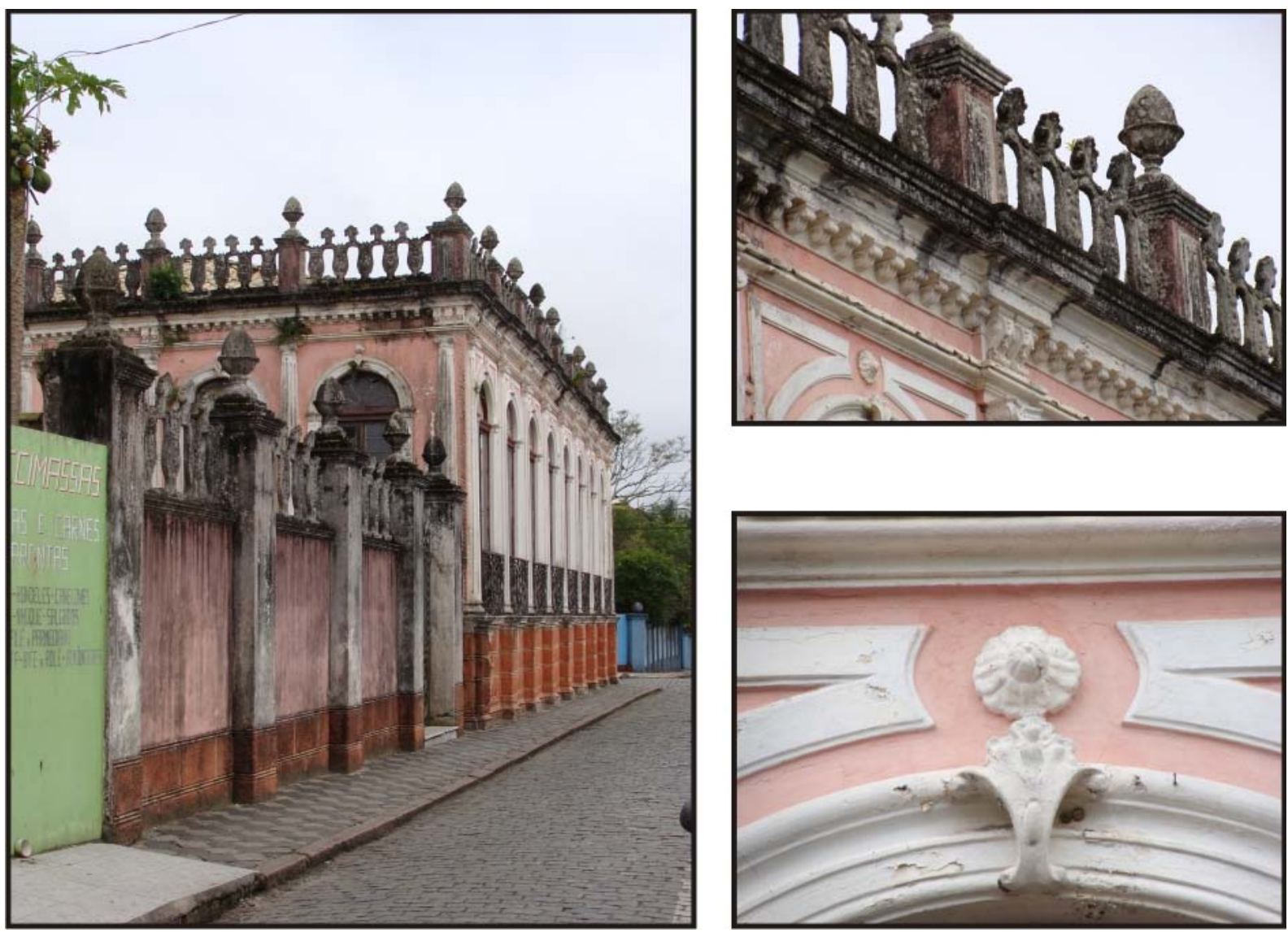

Figura 89. Acesso para o jardim lateral e alguns detalhes da residência Elfrida Lobo.

Fonte: Acervo do autor, 2009.
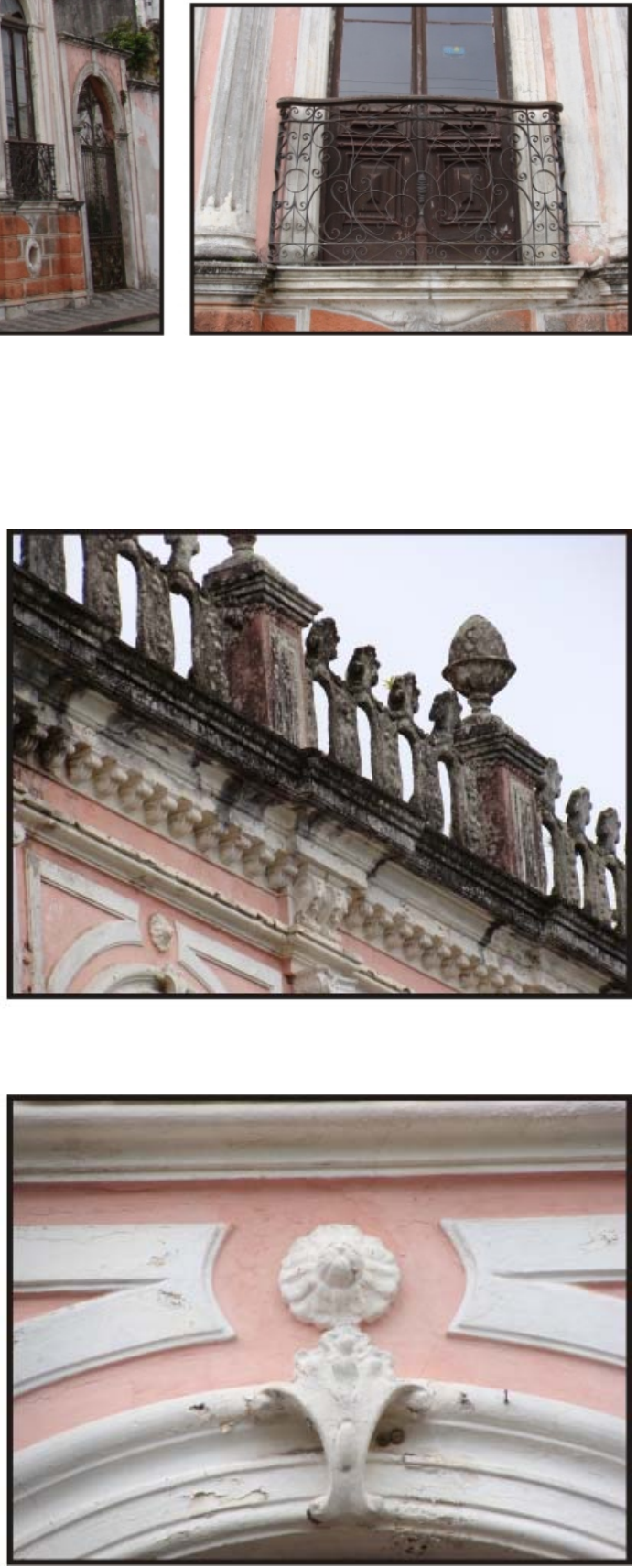

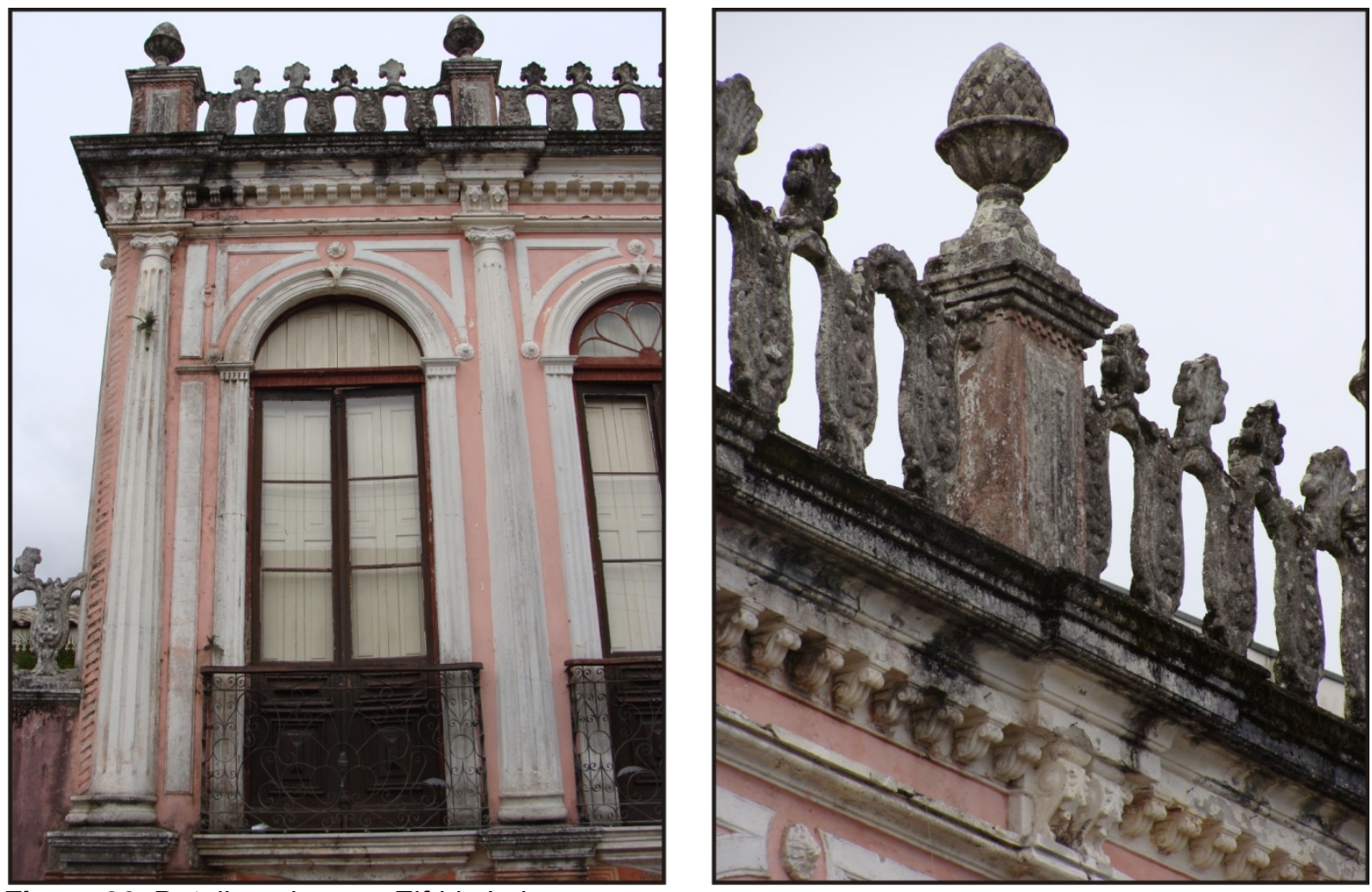

Figura 90. Detalhes da casa Elfrida Lobo.

Fonte: Acervo do autor, 2009.
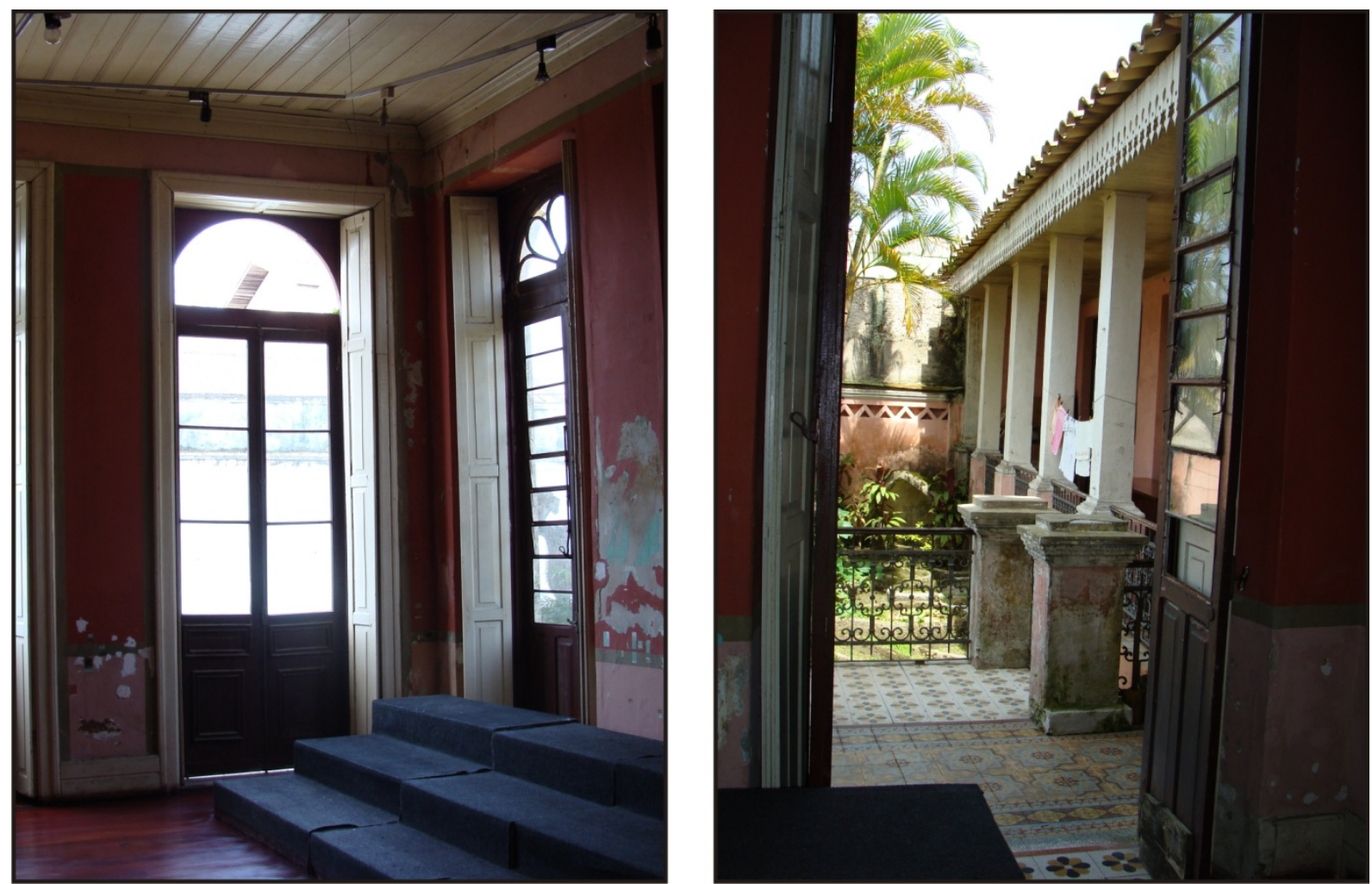

Figura 91. Interior da casa Elfrida Lobo e o acesso ao jardim.

Fonte: Acervo do autor, 2009. 

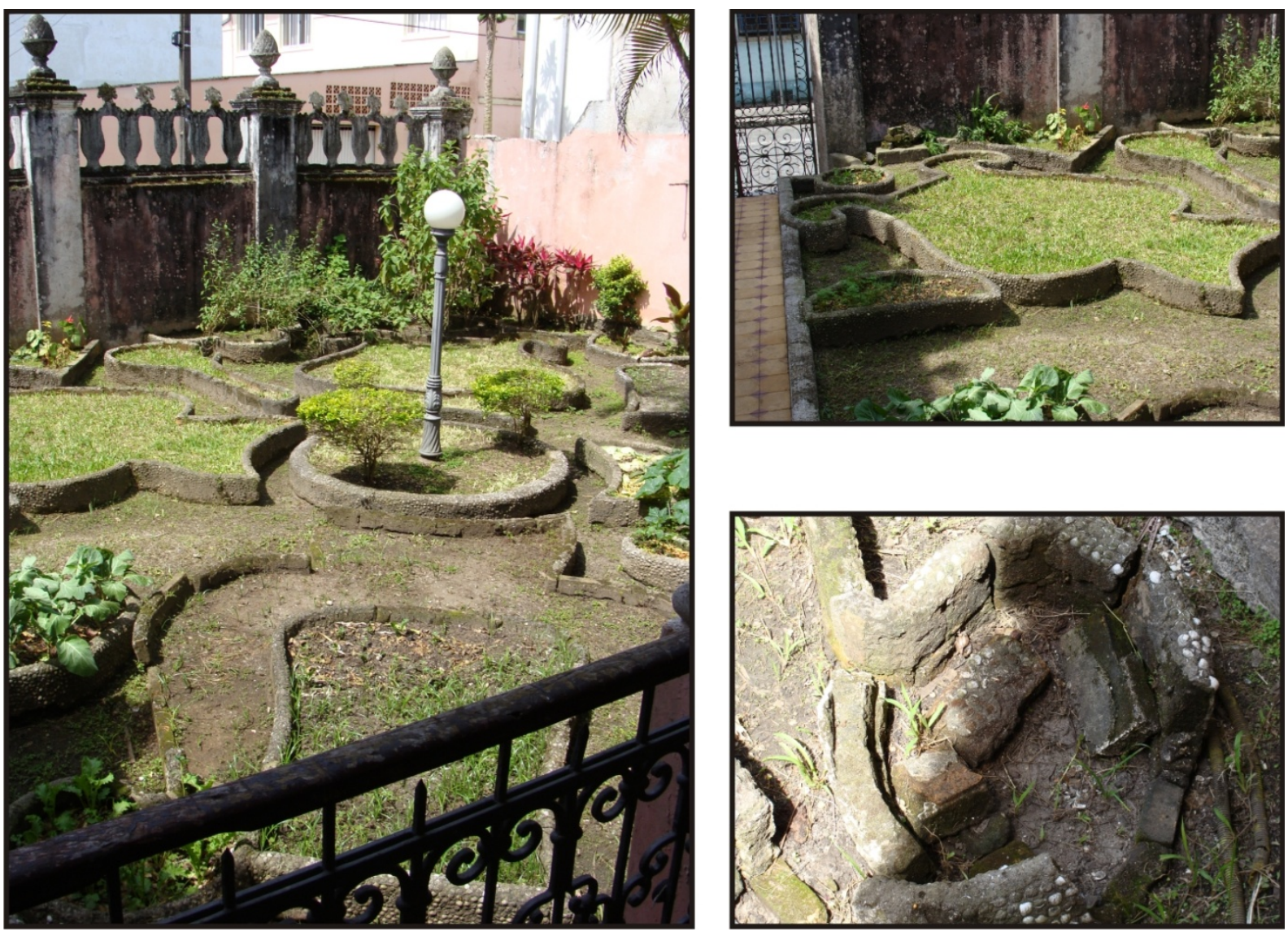

Figura 92. Aspecto do jardim lateral da residência Elfrida Lobo.

Fonte: Acervo do autor, 2009.
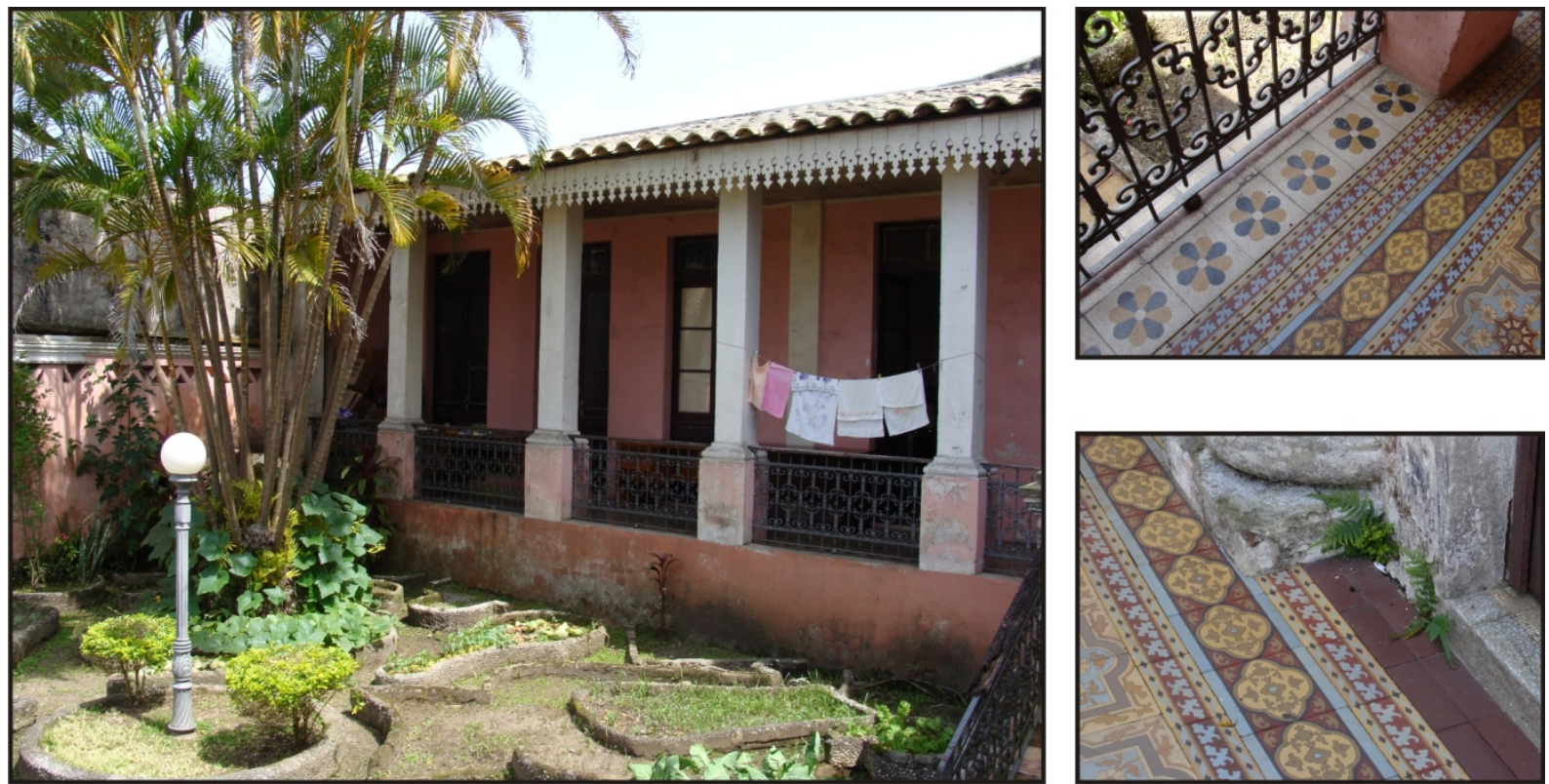

Figura 93. O anexo da casa Elfrida Lobo e o detalhe dos pisos hidráulicos.

Fonte: Acervo do autor, 2009. 
Ainda são encontradas fotografias do casarão original (Figura 94), sua reforma o transformou completamente, restando apenas a estrutura de pedra. Nessa reforma, o Palacete ganhou novas decorações tanto externas como internas (Figura 95, Figura 96 e Figura 98). Sua fachada possui portas em arco pleno no pavimento inferior e verga reta no pavimento superior, na parte inferior foram aplicadas bossagens, enquanto no andar superior são aplicados elementos decorativos como figuras femininas, cabeças de leões, arranjo de flores e na balaustrada da platibanda também existem compoteiras e imagens femininas.

$\mathrm{Na}$ parte inferior, abaixo dos balcões, encontram-se elementos que remetem ao mar, como as cimalhas em formas de ondas e as figuras mitológicas de um tipo de Netuno, estas figuras ampliam ainda mais os detalhes dessa construção. Em uma das esquinas do edifício, em seu cunhal, existe um brasão com as letras MB, ou seja, o nome de seu proprietário (Figura 97). Seu interior era decorado com pinturas murais e aplicação de elementos como pilastras e molduras (Figura 98).

Não só os grandes casarões foram reformados, mas também é possível encontrar, pequenas casas na cidade que se adaptaram aos novos valores estéticos da construção. Em consulta na Prefeitura de Paranaguá, foi possível identificar no começo do século $X X$, um grande número de pequenas reformas em casas do período Colonial para se adaptarem aos novos padrões.

As formas mais comuns de adaptação são a aplicação de ornamentos nas platibandas dos edifícios, retirando os antigos beirais (Figura 99). Estes beirais foram substituídos por calhas para as águas pluviais, estabelecidos pelas posturas de 1893. As aplicações dos elementos decorativos comuns à época, de alguma forma valorizavam a construção e descartavam a imagem considerada ultrapassada, existente nas construções mais antigas. 

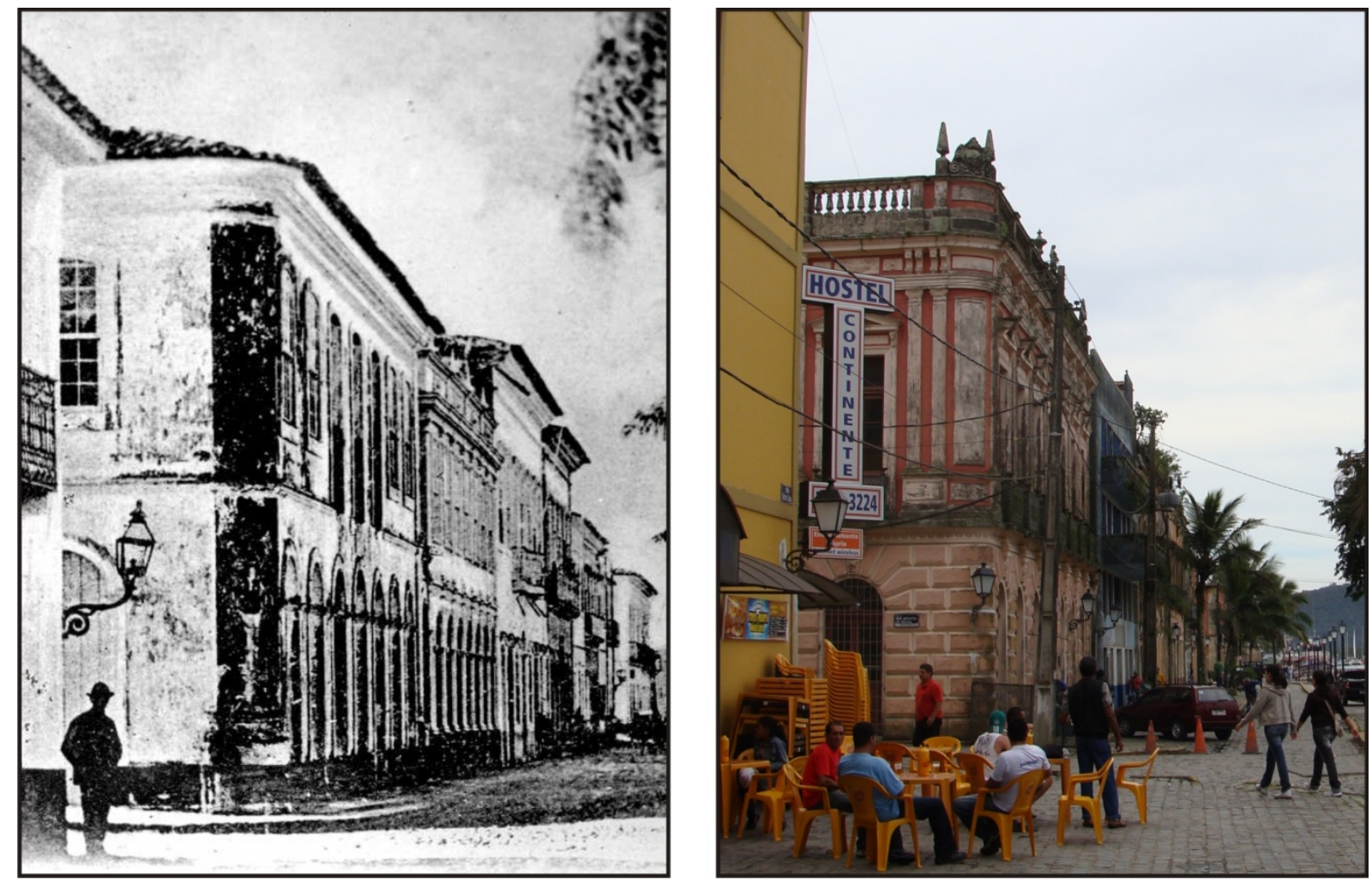

Figura 94. O casarão em fins do século XIX e o aspecto atual do Palacete Mathias Bohn.

Fonte: Instituto Histórico e Geográfico de Paranaguá, Acervo do autor, 2009
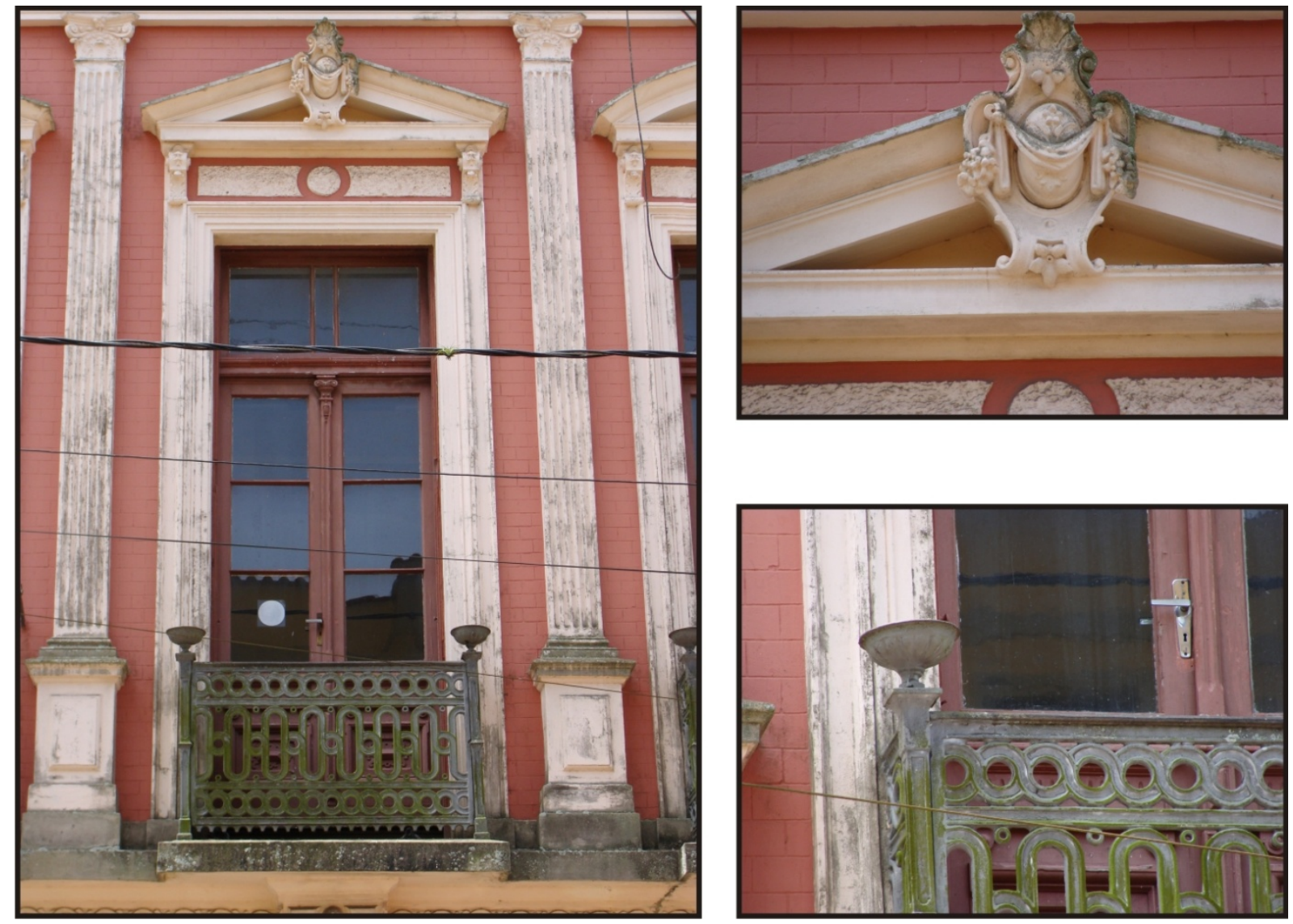

Figura 95. Detalhes do Palacete Bohn.

Fonte: Acervo do autor, 2009.

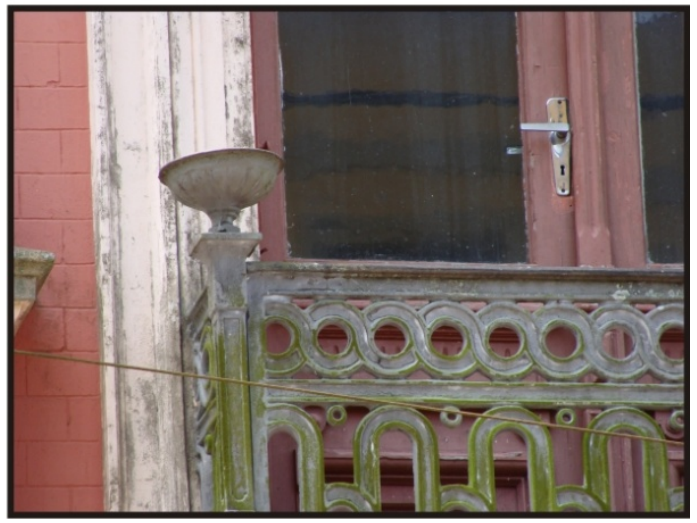



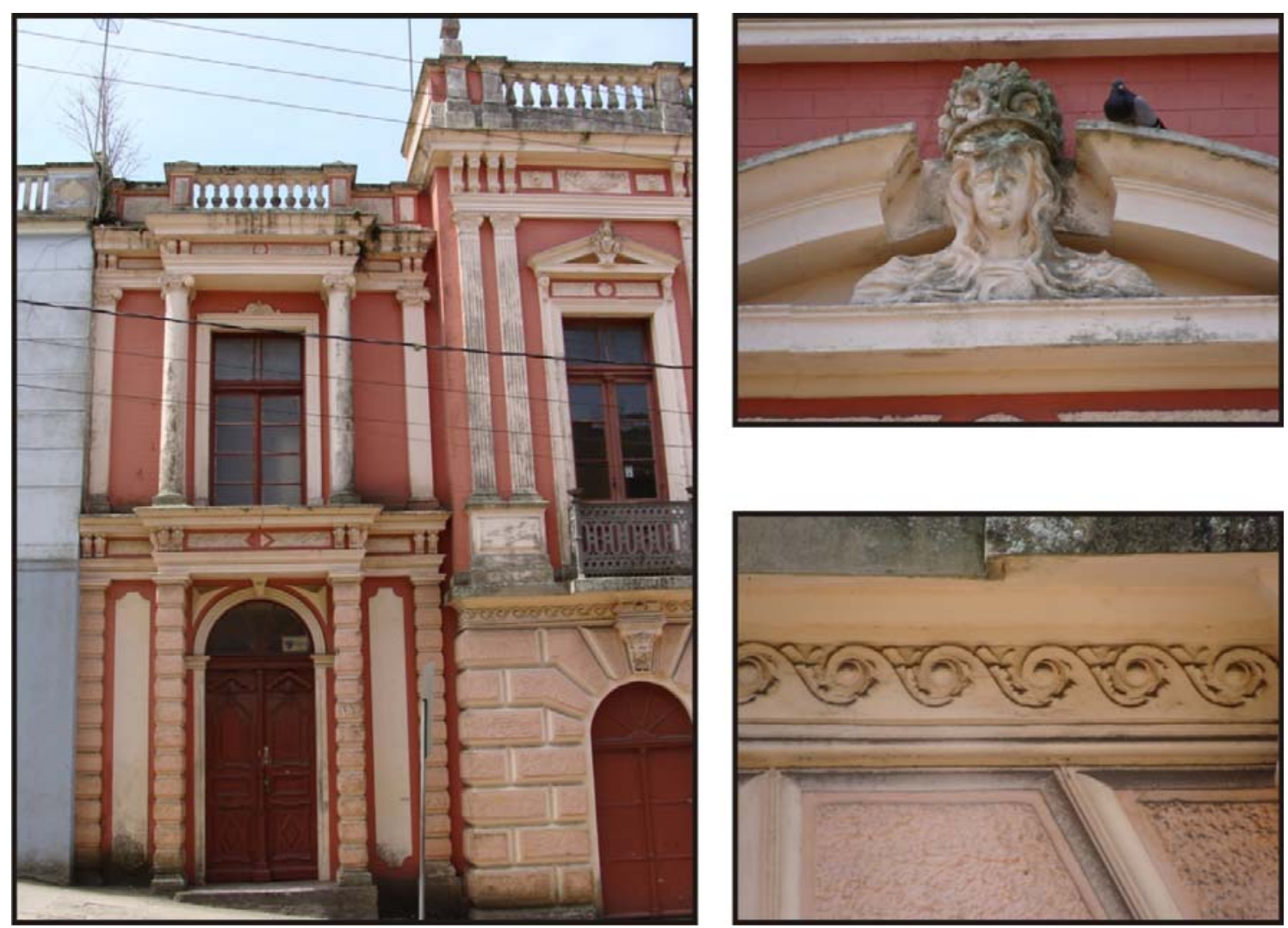

Figura 96. O acesso lateral do Palacete Bohn e seus detalhes, como o rosto feminino, acima das portas superiores e o friso com meandros, abaixo das sacadas de púlpito.

Fonte: Acervo do autor, 2009.
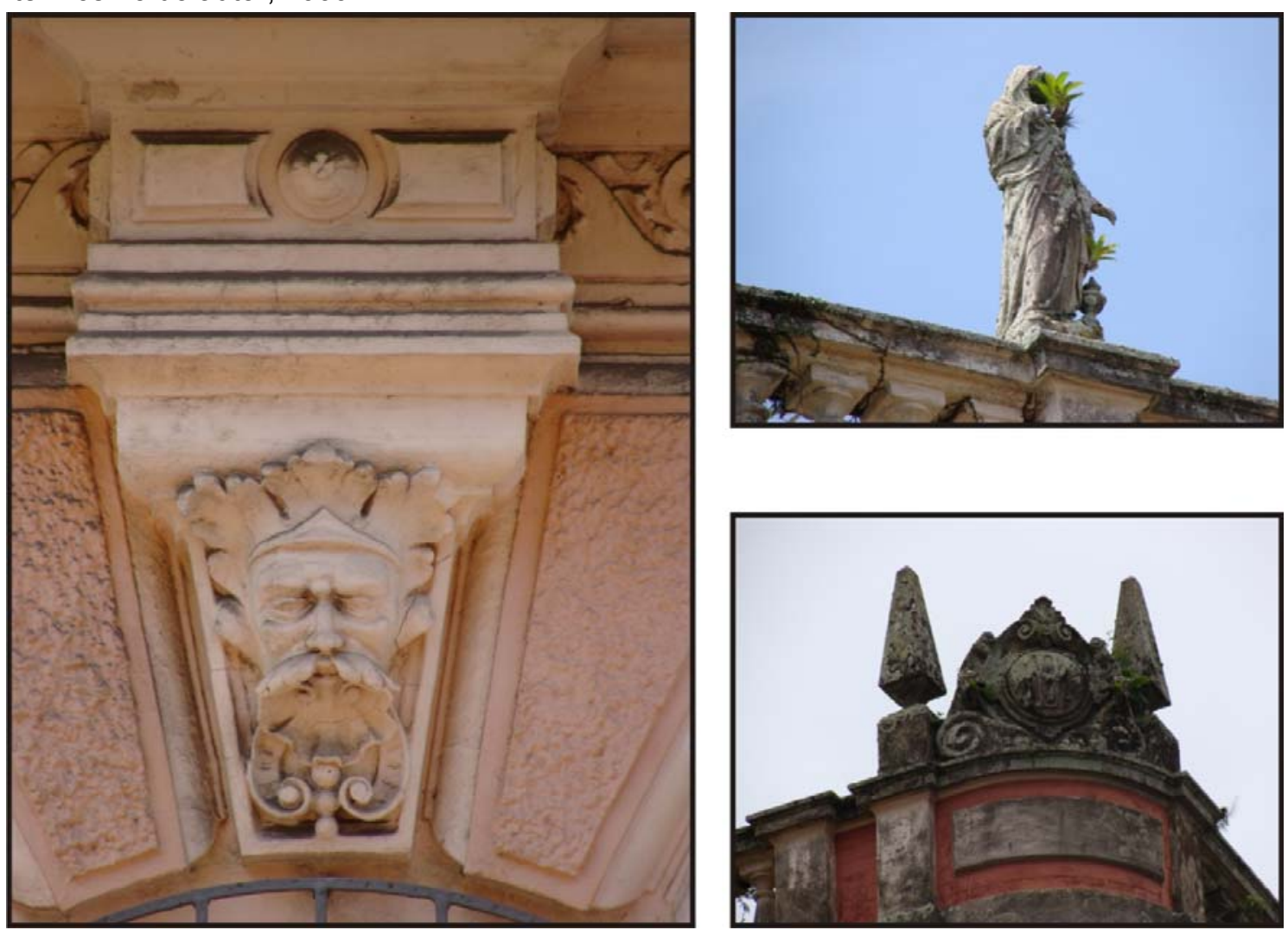

Figura 97. Mais alguns detalhes do Palacete Mathias Bohn, em destaque a figura de Netuno, no canto superior a figura feminina, representando uma das estações do ano, no canto inferior direito as iniciais do proprietário.

Fonte: Acervo do autor, 2009. 

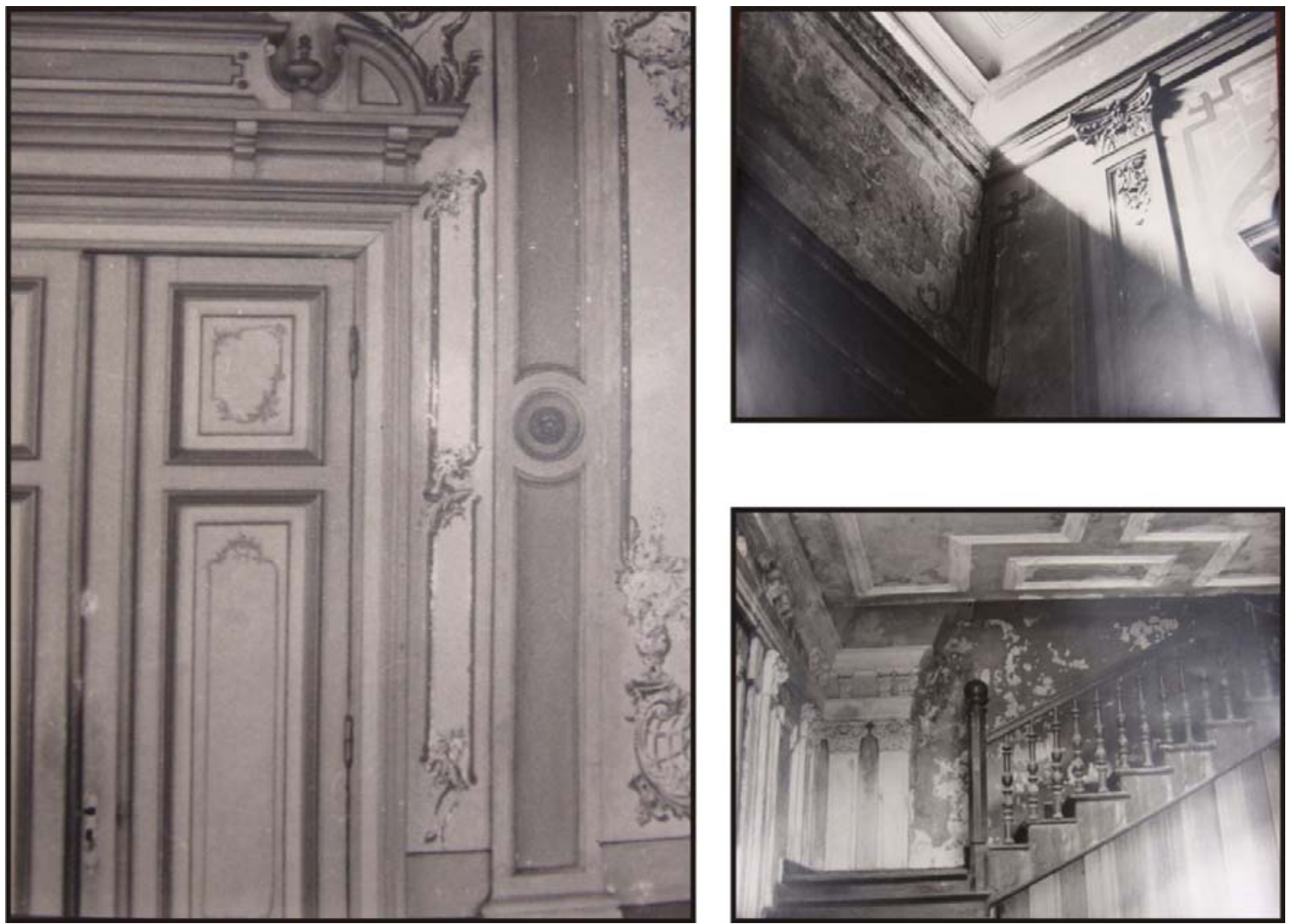

Figura 98. Interior do Palacete Mathias Bohn em 1962.

Fonte: Synval Stocehero, Acervo do Museu Paranaense.

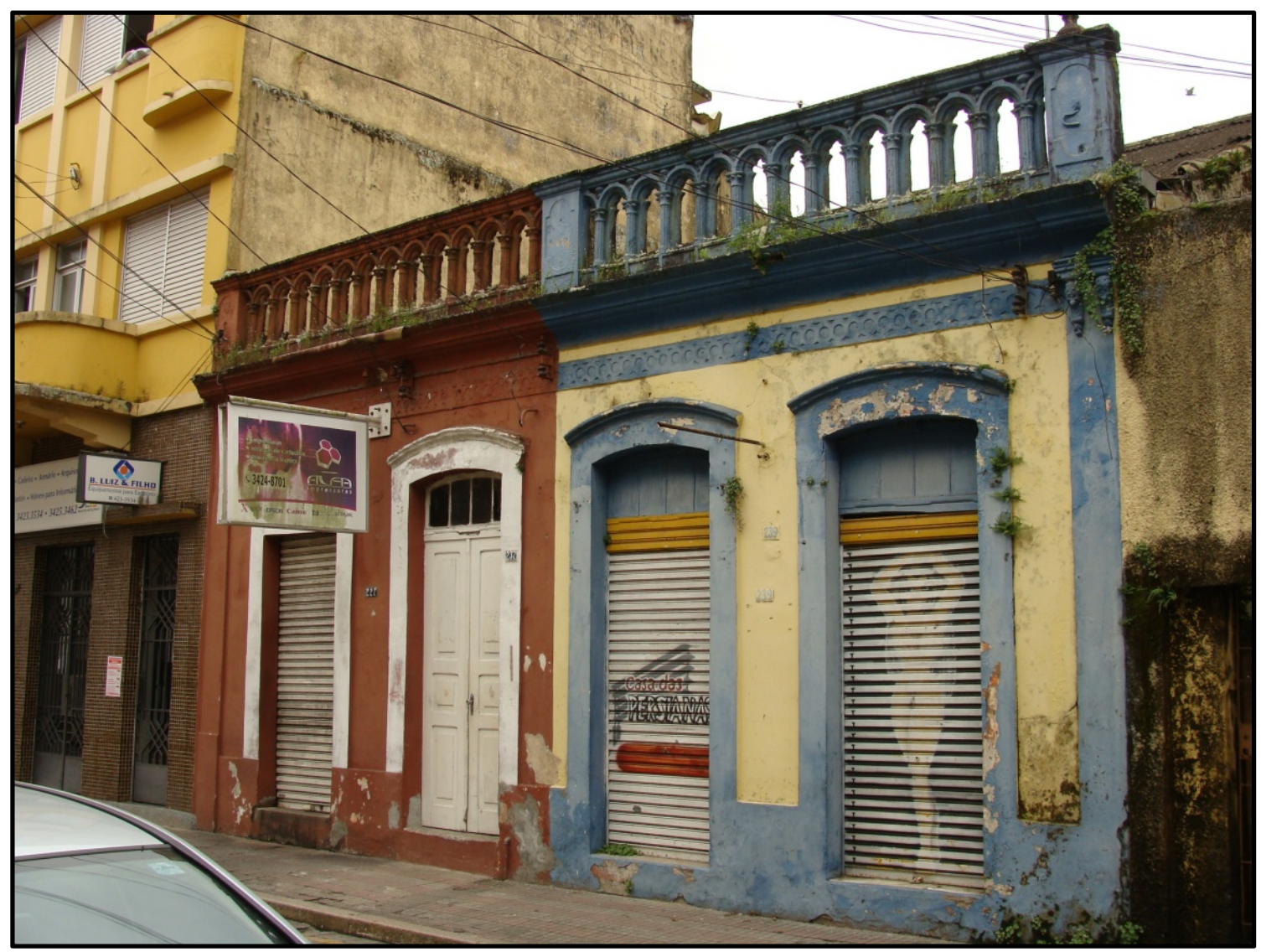

Figura 99. Exemplo de adaptação de construção do período Colonial, na rua Mal. Deodoro. Fonte: Acervo do autor, 2009. 
As posturas de Paranaguá definiram as características arquitetônicas das construções a partir da metade do século XIX, mais do que no traçado urbano ainda ligado ao período Colonial. Temos nas posturas, a normatização de medidas que padronizaram grande parte das novas residências construídas na cidade, delineando as fachadas em volumes alinhados nas ruas parnanguaras.

Com o passar dos anos, ocorreu o acréscimo de leis nessas posturas, principalmente em relação às preocupações sanitárias e de especificações na construção dos edifícios dentro desse quadro urbano. Portanto, a construção dessa paisagem parnanguara será uniformizada pelas posturas, até hoje observada em seu conjunto.

Essas construções, assim como os palacetes ecléticos, constituem símbolos do "[...] processo civilizador, sendo o espaço independente do estilo de arquitetura. Esse tipo de residência, definiu-se com a República, com a instituição da higiene pública e a separação dos papeis masculinos e femininos." (HOMEM, 1996, p. 247).

Nas palavras de Mário Maestri, temos uma sociedade estruturalmente desigual, mas que prezava pelo ordenamento de suas construções:

Portanto, inicialmente, as normas estabelecidas pelas municipalidades almejaram que as residências fossem levantadas, de forma ordenada, ao longo de ruas retas, com o mesmo nivelamento e a mesma altura. Insistiase também em que as aberturas das fachadas possuíssem as mesmas dimensões. Como já vimos, nessa sociedade estruturalmente desigual em sua formação social, a uniformidade das construções era um objetivo claramente perseguido. (MAESTRI, 2001, p. 124). 


\subsection{A CIDADE E O PORTO D. PEDRO II}

O porto de Paranaguá se consolidou durante o século XIX, como principal fonte de rendas da cidade. Sua estrutura e localização se mantinham da mesma forma que no século XVIII, mas com o aumento na circulação de produtos e o maior dimensionamento dos navios, resultaram no surgimento de problemas nessa antiga estrutura, refletindo-se tanto em seu espaço físico, como no assoreamento do rio Itiberê.

Nos anos de 1860, constatavam-se problemas antigos no porto de Paranaguá (Figura 100 e Figura 101), principalmente no assoreamento do rio Itiberê, impedindo a chegada de grandes navios à cidade. Esses problemas eram encontrados no início do cais, nas proximidades da igreja Matriz, onde já eram observados alguns bancos de areia, como descreveu Demétrio Acácio Fernandes da Cruz (1863, p.117):

O porto tem bom surgidouro, as embarcações podem atracar ao caes, onde há fundo bastante, apezar das correntes terem-o prejudicado consideravelmente, e tanto, que hoje se vêm muitíssimos bancos de área, onde outr'ora era fundeadouro para as grandes galeras, que largavam âncora em frente à Matriz e Fonte Grande (ponta extrema da cidade pelo lado do continente).

Também são encontrados jornais do período, como o Commercio do Paraná, que traziam notícias de capa sobre o entrave:

O nosso bello e excellente porto vae-se de dia em dia arruinado. Os bancos de arêa que estorvão a navegação, tem tomado proporções enormes.

Correndo na direcção de N. a S. tem estreitado por força tal, que o reduzio a um canal de oitenta braças mais ou menos de extenção. ${ }^{34}$

\footnotetext{
${ }^{34}$ Commercio do Paraná. Melhoramentos do Porto de Paranaguá. Commercio do Paraná, Paranaguá, 25 jan. 1862, p. 3.
} 


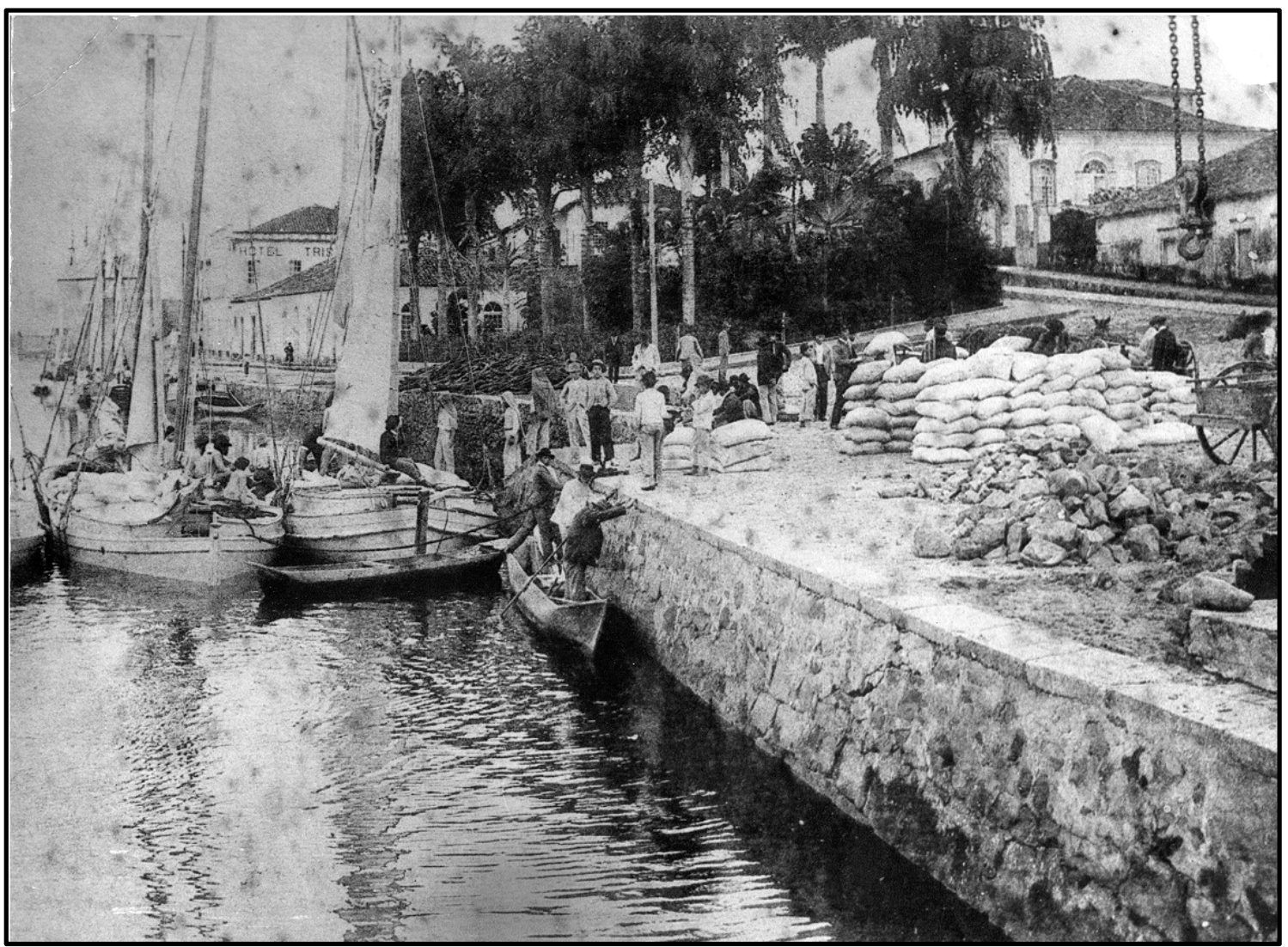

Figura 100. Atividade portuária no rio Itiberê, em fins do século XIX.

Fonte: Associação dos Portos do Paraná (APPA).

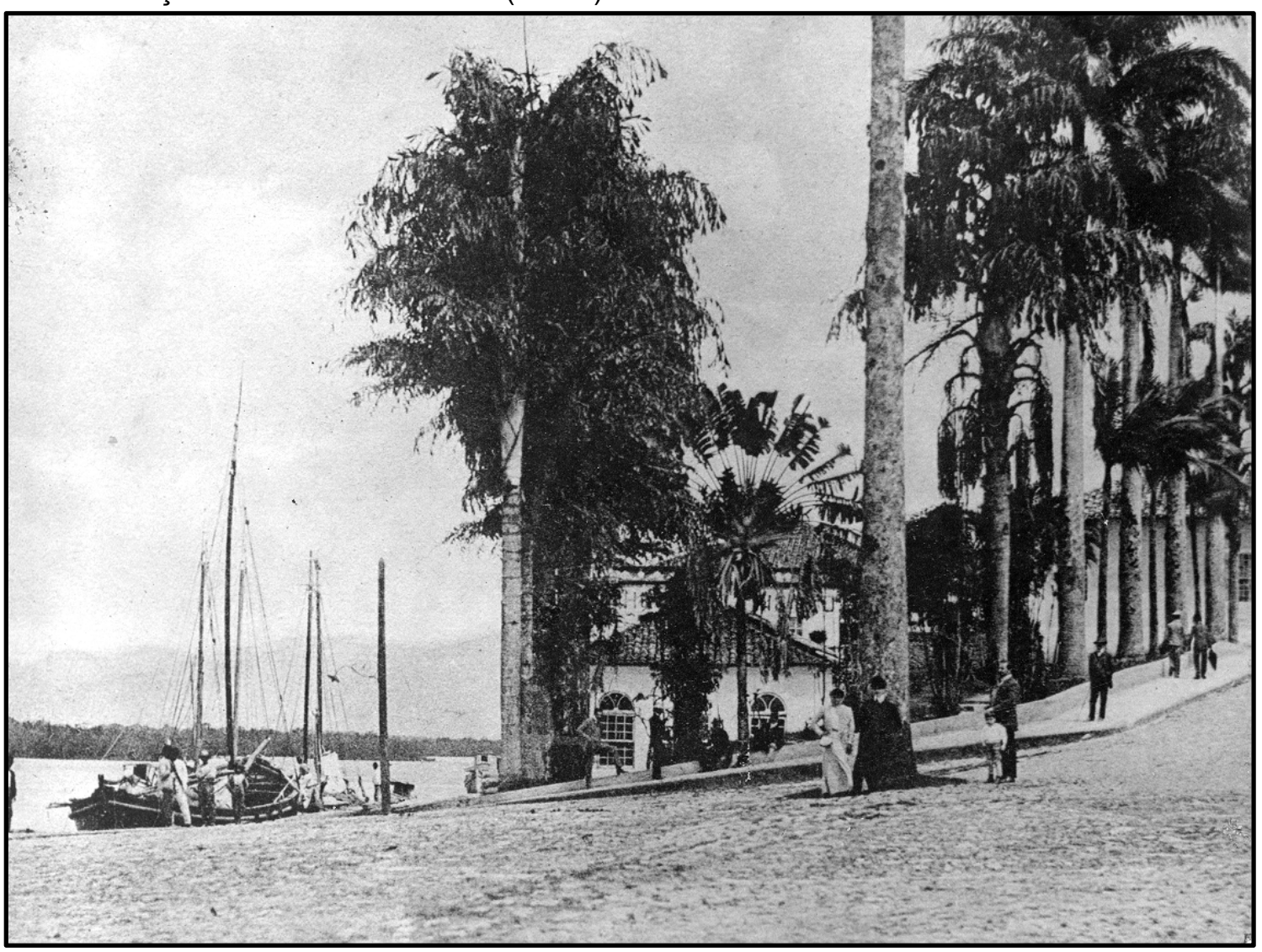

Figura 101. Região do porto no Itiberê, ao fim da rua da Cadeia e da Ordem, fins do século XIX. Fonte: APPA. 
A conseqüência do estado crítico do porto é grande prejuízo commercial, pelos estorvos insuperáveis que põem a navegação, ainda mesmo de exígua tonelagem; pelas repetidas varações, avarias, e perda considerável de tempo que sem duvida é um capital precioso no jogo das indústrias. ${ }^{35}$

O Presidente da Província, Antônio Nogueira constatou que a movimentação de carga e descarga de mercadorias no porto de Paranaguá, só ocorria nas horas de maré alta, possibilitando a aproximação dos grandes navios: "[...] seu estado de obstrução encontra o serviço interno e das capatazias o maior embaraço, tornandose preciso esperar-se a enchente das marés para ter logar a descarga das mercadorias destinadas aos armazéns." (NOGUEIRA, 1863, p.38).

Para sanar os problemas provocados pelo assoreamento e consequentemente a dificuldade na circulação de grandes navios, foi proposta pela Câmara Municipal de Paranaguá, em 1868, a escavação do leito do rio:

A camara suppõe que este mal é devido aos desmoronamentos de barrancas á margem do rio e á corrente de áreas levadas pelas agoas que a elle vão ter.

Com uma barca de excavação, diz a camara, se removeriam estes males, e com um estudo serio dos rios cujo curso póde ser aproveitado para mais aprofundar o porto, e economisar as voltas que dão os moradores de suas margens, muito lucrariam o município, a província e o paíz, porque se abririam horisontes ricos para a emigração que nos procura. (ARAÚJO, 1868, p.34)

A mudança de local e o melhoramento do porto de Paranaguá só foram executados a partir da proposta para a construção da Estrada de Ferro do Paraná. O primeiro plano desta estrada se constituía de uma linha entre Curitiba e o porto de Antonina, situado na Baía de Paranaguá. O porto de Antonina levava vantagem por estar localizado em mar aberto e não nas margens de um rio como o atracadouro parnanguara.

${ }^{35}$ Commércio do Paraná. Melhoramento do Porto. Commercio do Paraná, Paranaguá, 30 ago. 1862, p. 1. 
Nesse período era concluída a primeira estrada pavimentada, ligando o interior ao litoral: a estrada da Graciosa, concluída em 1873, marcando um período de "renascimento econômico", nas palavras de Rocha Pombo. Nesta fase, o tráfego na estrada era intenso, onde "centenas de carroças eram permanentemente empregadas na condução de cargas entre o interior e os entrepostos marítimos". (POMBO, 1980,p.91). Outro fato importante é que muitas famílias implantaram-se nas margens desta estrada, formando algumas povoações, dentre as quais a de imigrantes alemães e italianos. (POMBO, 1980)

A própria construção da estrada da Graciosa foi realizada com mão de obra imigrante. Em sua visita ao Brasil, o viajante Robert Avé-Lallemant descreve suas impressões sobre a construção da Graciosa e sobre os alemães que ali trabalhavam:

Depois de ter estudado cuidadosamente o terreno, o referido engenheiro fez um novo traçado na extensão de treze léguas, do mar até Curitiba, para uma cômoda estrada de rodagem para o planalto, mediante cuja extensão ficará aberta ao tráfego toda uma Província. Para esse fim foram destinados seiscentos contos, o que equivale a 480.000 táleres prussianos. No momento de minha passagem estavam em atividade 170 trabalhadores, entre os quais 54 alemães; cada um recebe 1 mil-réis e a comida e contudo faltam trabalhadores. Falta ainda mais o pronto pagamento do dinheiro; se não me engano, há meses os trabalhadores tem salários atrasados a receber. (AVÉ-LALLEMANT, 1980, p. 288-289)

Essa mão de obra também será utilizada na construção da estrada de ferro, mas antes, analisaremos as propostas apresentadas sobre a ligação entre a capital e o litoral paranaense. Em 1871, foi elaborado pelo Engenheiro Antonio Rebouças, um estudo sobre a construção da estrada de ferro, ligando a capital Curitiba até a cidade de Antonina, no litoral da província. A linha seria dividida em três partes, serra, serra abaixo e serra acima, ligaria o litoral ao interior da Província. (LISBOA, 1872). O relatório de Rebouças foi concluído em 1872, apresentando “[...] os 
respectivos estudos, plantas e orçamento; e é de se esperar que, depois de organisada a companhia e dentro do prazo marcado, comecem os trabalhos desta importante via de communicação." (GUIMARÃES, 1873, p.7).

Em 1872, foi apresentada a proposta de autoria de Pedro Alloys Scherer, José Gonçalves Pecego Junior e José Maria da Silva Lemos, da transferência do porto de Paranaguá para a região denominada Enseada do Gato, ou seja, na baía de Paranaguá, ao mesmo tempo em que eram iniciadas as obras de uma pequena estrada de ferro, ligando Paranaguá a Morretes, cidade localizada próxima à serra do mar, através daquele ponto do novo porto. (ABRANCHES, 1874).

Mas, em 1874, o Engenheiro Antônio Rebouças, responsável pela construção da linha entre Antonina e Curitiba, faleceu e sua concessão foi perdida. Com isso, foi nomeada uma comissão para analisar em qual porto a linha da estrada de Ferro do Paraná, receberia o início desta linha. (MORGENSTERN, 1985, p. 8)

O trabalho intitulado "Relatório sobre os Portos de Pedro II e Antonina" de 1875, discute qual das duas áreas era o ponto inicial da ferrovia, ligando o litoral à Curitiba. O documento descreve a baía de Paranaguá e os dois entrepostos marítimos, discutindo as vantagens e desvantagens de cada um deles. De acordo com o Relatório:

A commissão não póde vacillar na escolha entre os dous portos que disputam a preferência para servir de origem, á primeira e principal estrada de ferro da província, e em indicar o porto projectado em frente ao ancoradouro de franquia da cidade de Paranaguá, e ao qual a camara municipal dessa cidade deu o nome de porto D. Pedro $2^{\circ}$, como o que melhor satisfaz ao fim que se tem em vista. (IMPÉRIO DO BRASIL, 1875, p. 20)

Em 1875, por decreto do Governo Imperial, foi autorizada a construção da estrada de ferro, ligando Paranaguá a Curitiba e os melhoramentos a serem realizados no novo porto, instalado na baía. Foi dada a concessão à Pecego Junior 
e José Maria da Silva Lemos, responsáveis pela mudança do porto em 1872. Com essa concessão, foram nomeados os engenheiros que estudariam o melhor traçado para unir estas duas cidades, sendo que a primeira seção ligando Paranaguá a Morretes já possuía relatório. (LINS, 1876). Em 1879, os sócios entregaram a concessão para a "Compagnie Générale de Chemins de Fér Bresiliens”, responsável pela construção da estrada de ferro. (MARAVALHAS, 1904).

A partir de 1874, o Porto d' Água passou a se chamar Porto D. Pedro II. (FERREIRA JUNIOR, 190?). Em 1880, com a implantação do Porto D. Pedro II, foram:

"[...] alinhados os quarteirões para a edificação urbana no Porto Pedro II, foram dadas as seguintes denominações ás quatro primeiras ruas:

Cinco de Junho

Primeiro de Junho

Conselheiro Correia

Conselheiro Costa Pereira "(FERREIRA JUNIOR, 190?, p.64)

Seria o início da ocupação dessa região próxima ao novo porto, com o traçado de vias e o atrativo econômico de sua instalação, agora localizado na baía de Paranaguá. A linha entre Paranaguá e Morretes foi inaugurada em novembro de 1883, e a linha entre Morretes e Curitiba foi inaugurada em fevereiro de 1885. (MARAVALHAS, 1904).

Para dar início às obras da estrada de ferro, pela Compagnie Générale de Chemins de Fer, esteve presente na Província o Imperador D. Pedro II. Quando da chegada do monarca, ocorreram diversos festejos (VIANA, 1980?). No Jornal Dezenove de Dezembro de 1880, foi publicado o seguinte telegrama:

SS.MM. chegaram ás 5 e um quarto da tarde, embarcaram no ancoradouro da Cutinga e desembarcaram nesta cidade ás 6 e meia. Muito regosijo no desembarque, haviam de 900 á 1000 pessoas. O temporal de chuva felizmente cessou. ${ }^{36}$

\footnotetext{
${ }^{36}$ Dezenove de Dezembro. Noticiário. Dezenove de Dezembro, Curitiba, 19 de maio de 1880, p.3.
} 
O cortejo visitou algumas cidades do litoral, Curitiba e o interior, posteriormente voltou à Paranaguá, a fim de inaugurar os trabalhos da Estrada de Ferro e de sua primeira estação:

Feito o desembarque no vapor "Marumby" seguiram logo SS.MM. acompanhados de sua comitiva e immenso sequito de povo, no delyrio das manifestações, para o sítio da primeira estação urbana da estrada de ferro, afim de ter logar logo a respectiva inauguração.

Ahi, n'um pavilhão elegante e vistosamente enfeitado da variegadas bandeiras, teve logar, na Augusta presença de suas Magestades, a benção da $1^{\text {a }}$ pedra, que foi depois conduzida para seu logar por S.M. o Imperador, Exm. Ministro da agricultura, Exm. Presidente da Província, e Presidente da camara municipal.

O concurso de povo que era então imenso, vivas, foguetes, musicas, tudo concorreu para fazer brilhantíssima a solemnidade, exprimindo de modo mais eloqüente os votos da população, não só dessa cidade, como de toda a província, pela realisação de tão desejado e grande melhoramento.

Concluída a importante solemnidade, dirigiram-se Suas Magestades para o palacete do Sr. Barão de Nacar, onde jantaram. ${ }^{37}$

Com a instalação da Estrada de Ferro do Paraná, ligando Paranaguá à capital da Província, criou-se uma melhor comunicação entre estas duas importantes cidades, causando uma nova transformação não só na urbanização de Paranaguá, mas também em suas construções, a começar pela própria estação de cargas e de passageiros.

A construção das duas estações da Estrada de Ferro do Paraná ocorreu de forma quase simultânea, de acordo com o relatório do engenheiro Christiano Ottoni Junior, de 1881, no qual apresenta a situação das obras naquele período. Segundo Ottoni Junior (1881, p. 13), no Porto D. Pedro II, "[...] o edifício destinado aos viajantes ficou a bem dizer concluído, faltando somente a pintura das portas e janellas e a construção da plataforma de embarque." Enquanto a estação de Paranaguá, "Acha-se este edifício quasi concluído, faltando apenas a collocação das portas e janellas." (OTTONI JUNIOR, 1881, p. 15).

${ }^{37}$ Dezenove de Dezembro. Viagem Imperial. Dezenove de Dezembro, Curitiba, 9 de junho de 1880, p. 1. 
A estação do Porto D. Pedro II, foi concluída no ano de 1882. De acordo com o Presidente Carlos Augusto de Carvalho (1882, p. 46):

Na do Porto D. Pedro II ficou acabado o edifício de viajantes e uma das plataformas.

Concluiu-se o armazém de mercadorias annexo a esta estação, assim como a respectiva plataforma de embarque.

Terminou-se também o depósito de locomotivas destinado a abrigar quatro destes vehiculos, e bem assim a construcção do reservatório de água destinada a servir á alimentação das mesmas.

Essa estação (Figura 102) foi construída segundo os preceitos do Ecletismo, principalmente através da utilização de materiais importados, como telhas e estruturas em ferro. Poucas fotografias desse edifício, demolido nos anos de 1980, foram encontradas, para auxiliar no estudo de sua configuração.

Segundo o relatório do engenheiro Ottoni Junior (1881, p. 12), a estação está configurada em três edifícios distintos: "Compõe-se esta de três edifícios: um para viajantes e bagagens, outro para armazém de mercadorias e o terceiro para depósito de locomotivas. Foram também construídas as paredes circulares de alvenaria de tijolo que supportam o reservatório d' água."

Sua fachada está dividida em três partes, sendo que a parte central se projeta para frente em relação ao plano principal do edifício, esta parte que se destaca é marcada por um frontão triangular e uma cobertura em duas águas, nessa mesma parte se encontram três portas em arco pleno, os acessos principais.

De acordo com descrição de Ottoni Junior (1881, p.13):

Este edifício, com área de 25 metros de comprimento sobre 8 de largura, é collocado lateralmente á linha e contém largo vestíbulo ligado por passagem directa, que divide o edifício ao meio; plataforma coberta de 50 metros de comprimento; diversas peças, formadas por paredes divisórias de tijolo, destinados ao serviço administrativo da estação, despacho de bagagens, compra de bilhetes, e escriptorio; salas de espera de $1^{\mathrm{a}}$ e de $2^{\mathrm{a}}$ classe e uma peça reservada. Nos dous extremos da plataforma estão em construcção dous pavilhões, um dos quaes tem de servir para guardar utensílios e outro para latrinas. Este edifício está sendo construído, 
conforme o primeiro projecto proposto e approvado, salvo quanto às fundações.

Nas duas laterais do edifício, recuados em relação ao acesso principal, estão duas janelas em arco pleno, cada uma em um lado do edifício, também são encontrados nos cantos da estação, pilastras que ajudam na ornamentação e na simetria na qual o edifício busca como proposta. Essa obra é coberta "[...] de telhas francezas chatas; as paredes exteriores são de pedra e medem $0,45 \mathrm{~m}$ de espessura, e as interiores de tijolo de 0, 30 m." (OTTONI JUNIOR, 1881, p.13), as telhas francesas foram fabricadas em Marselha, como exemplar existente no acervo museológico do IHGP (Figura 103). Também temos as plataformas em estrutura metálica, uma novidade para a cidade de Paranaguá, mas mesmo assim algumas técnicas construtivas se mantinham, como a utilização da pedra nas paredes externas do edifício, provavelmente o tijolo ainda era um recurso mais dispendioso, utilizado somente nas divisões internas das construções.

Quanto aos outros edifícios desse conjunto, são encontrados o armazém de mercadorias e o depósito de locomotivas, construído em alvenaria de tijolos e com abrigo para quatro locomotivas. Percebemos o descaso da companhia quanto aos sistemas empregados nestas construções, tornando-se alvos de críticas pelo Engenheiro Ottoni (1881). As fundações destes edifícios foram feitas em madeira, numa região de grande umidade, o que poderia provocar a deterioração do material. Outras críticas referem-se ao vigamento de madeira para sustentação da cobertura do depósito de locomotivas, ao invés de estruturas metálicas como fora recomendado pelo projeto. 


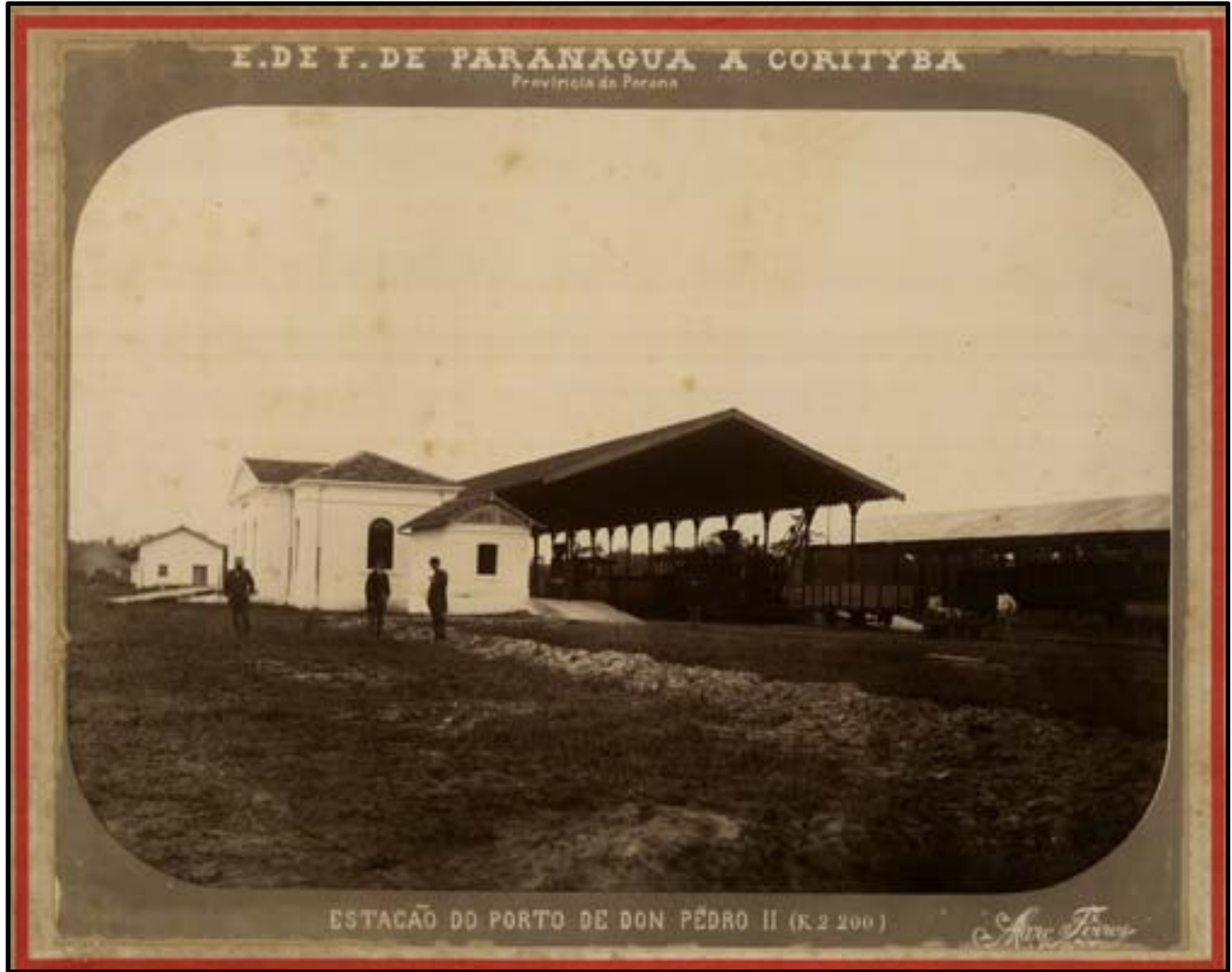

Figura 102. A estação do Porto D. Pedro em 1880.

Fonte: Biblioteca Nacional.

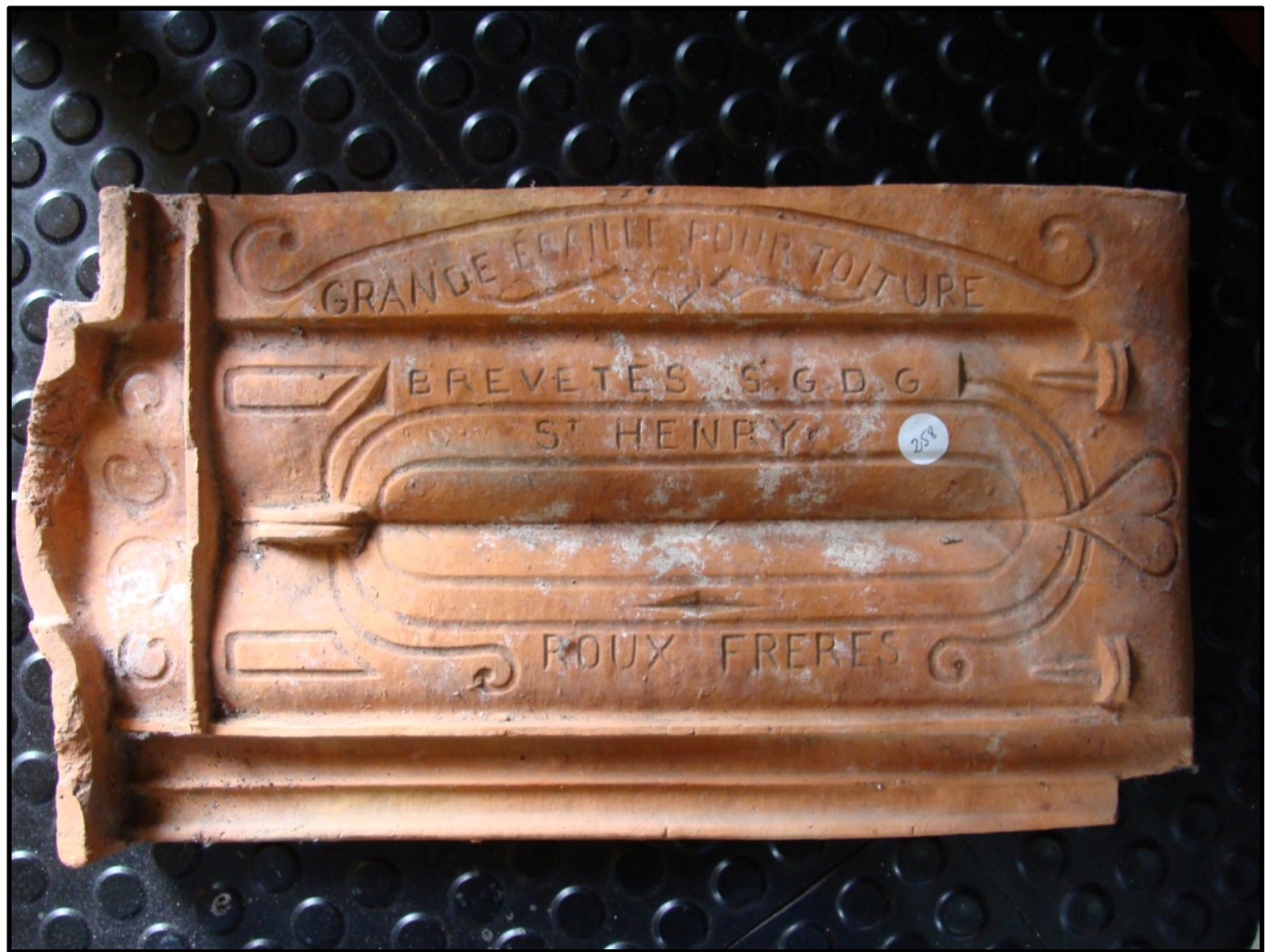

Figura 103. Telha Francesa encontrada nas ruínas da estação do Porto D. Pedro II. Fonte: Acervo do Instituto Histórico e Geográfico de Paranaguá. 
No armazém foram construídas escadas e plataformas de madeira e o engenheiro também criticou a falta de uniformidade nas portas e janelas desse edifício. São indícios de que a empresa não se preocupou com a construção das estações, o que poderia explicar a simplicidade quanto ao projeto arquitetônico e ao espaço exíguo que elas ofereciam.

A estação de passageiros, bagagens e mercadorias de Paranaguá, está localizada na região de expansão da cidade, nas proximidades da igreja do Bom Jesus, e ao fim da rua Dr. Leocádio, antiga rua do Campo, área que se consolidará a partir do final do século XIX e início de século XX (Figura 104). Localizada dentro da cidade de Paranaguá, onde está o início da linha, esta estação possui semelhanças com a estação do Porto D. Pedro II, ela também se caracterizava por um pequeno frontão triangular que marca o acesso principal. Esse acesso se dá por três portas em arco pleno e junto com o frontão, avançam na fachada, criando o destaque na parte central do edifício, de forma muito semelhante à estação do Porto D. Pedro II.

Em seu interior existia uma sala armazém, um vestíbulo transversal, uma sala de espera ou gabinete de toilette, um escritório e a plataforma, todos esses itens inseridos em um único edifício, o que causava certos transtornos nas chegadas e saídas de passageiros, como descreveu Paul Walle ${ }^{38}$ anteriormente sobre a sua espera por um trem na estação de Paranaguá.

Nas extremidades do edifício, de cada lado situa-se uma janela também em arco pleno, já nas faces laterais (Figura 105, Figura 106 e Figura 109), encontram-se duas janelas em verga reta, com dimensões semelhantes as das janelas da fachada principal. Quanto aos elementos decorativos, encontramos bossagens nos cantos do prédio e molduras nas janelas.

\footnotetext{
${ }^{38}$ Ver página 138-139.
} 


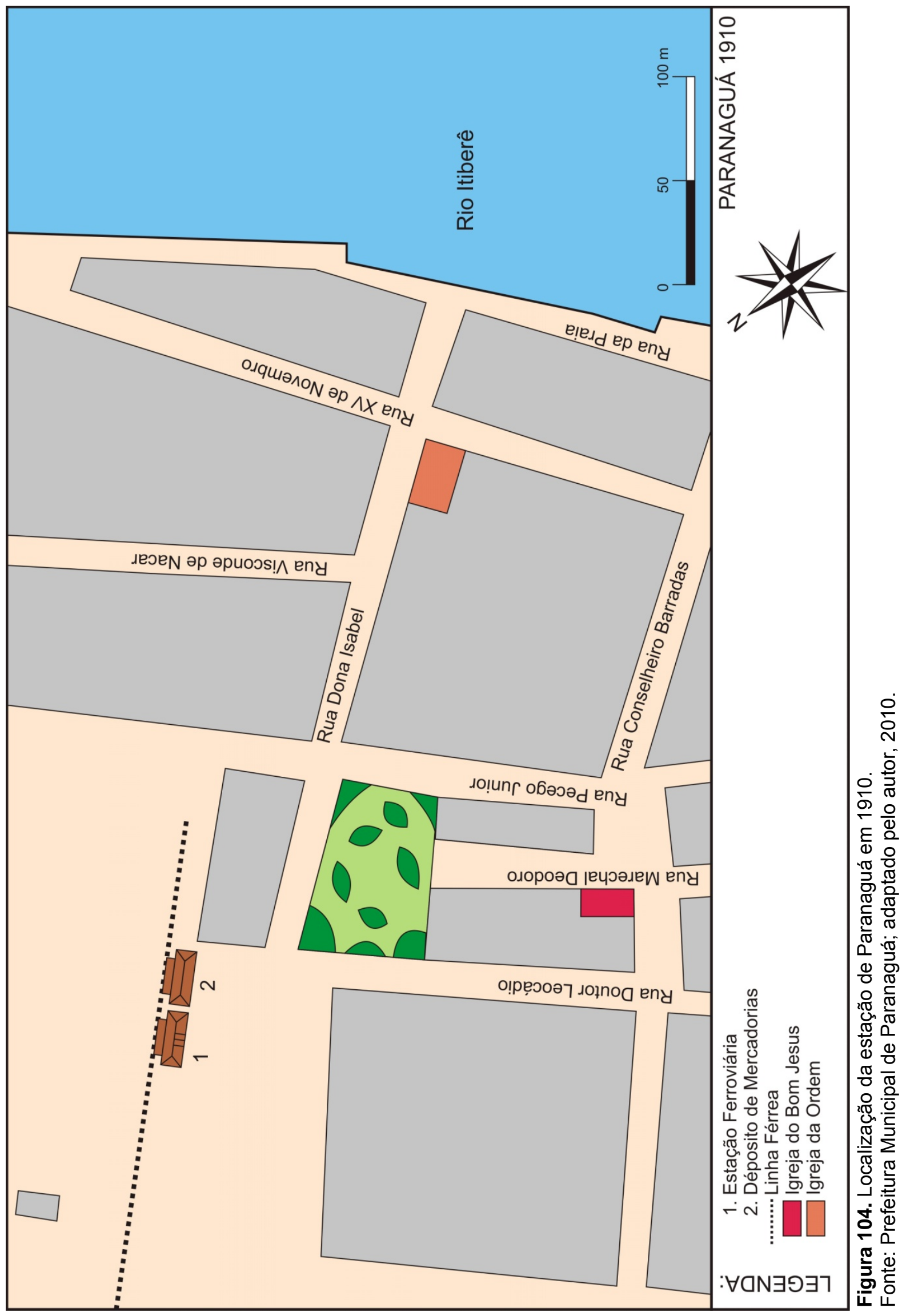


Ao fundo do edifício está a plataforma de embarque, em estrutura de ferro fundido com cobertura em telha cerâmica francesa, nota-se que na construção original existiam lambrequins na cobertura da plataforma, como visto na imagem de Marc Ferrez, em 1884 (Figura 107). Nessa fachada, estão cinco portas em verga reta e o piso faz a ligação entre o prédio da estação de embarque e o depósito que na imagem de Marc Ferrez não existia, pois um pequeno prédio, naquele local, estava em fase de demolição.

Esse indício também é encontrado no relatório do Engenheiro Ottoni, em seu relato ele coloca que no projeto original da estação de Paranaguá só existia um edifício. Apesar disso, havia a exigência do Governo Provincial para que esta estação possuísse o serviço de mercadorias, algo que a Companhia não concordava. A empresa considerava a estação do Porto D. Pedro II a principal e por ela deveriam transitar as mercadorias que saíam e chegavam dos navios, mas de acordo com Ottoni (1881, p. 16):

Muito longo seria refazer o histórico de toda a controvérsia havida sobre a diposição a adoptar nesta estação, a qual consistia em saber si a estação seria ou não destinada ao despacho e recepção de mercadorias, visto achar-se a dous kilometros apenas da estação principal; semelhante questão prendia-se a uma outra, a do systema de trafego que melhor conviria estabelecer entre dous pontos tão próximos um do outro. Pelo Aviso supramencionado n. 21 de 3 de maio do anno findo ella elucidada no sentido de servir a estação principal, a do Porto D. Pedro II, para despacho e recepção das mercadorias de exportação e importação que tiverem de transitar pela ferro-via, destinadas ou provenientes do exterior e localidades do interior da província servidas pela mesma estrada, e a estação de Paranaguá para o serviço das mercadorias exportadas e importadas por esta cidade.

Portanto, a construção do depósito de mercadorias ocorreu depois de 1884 , quando a estação já estava em funcionamento (Figura 108). 


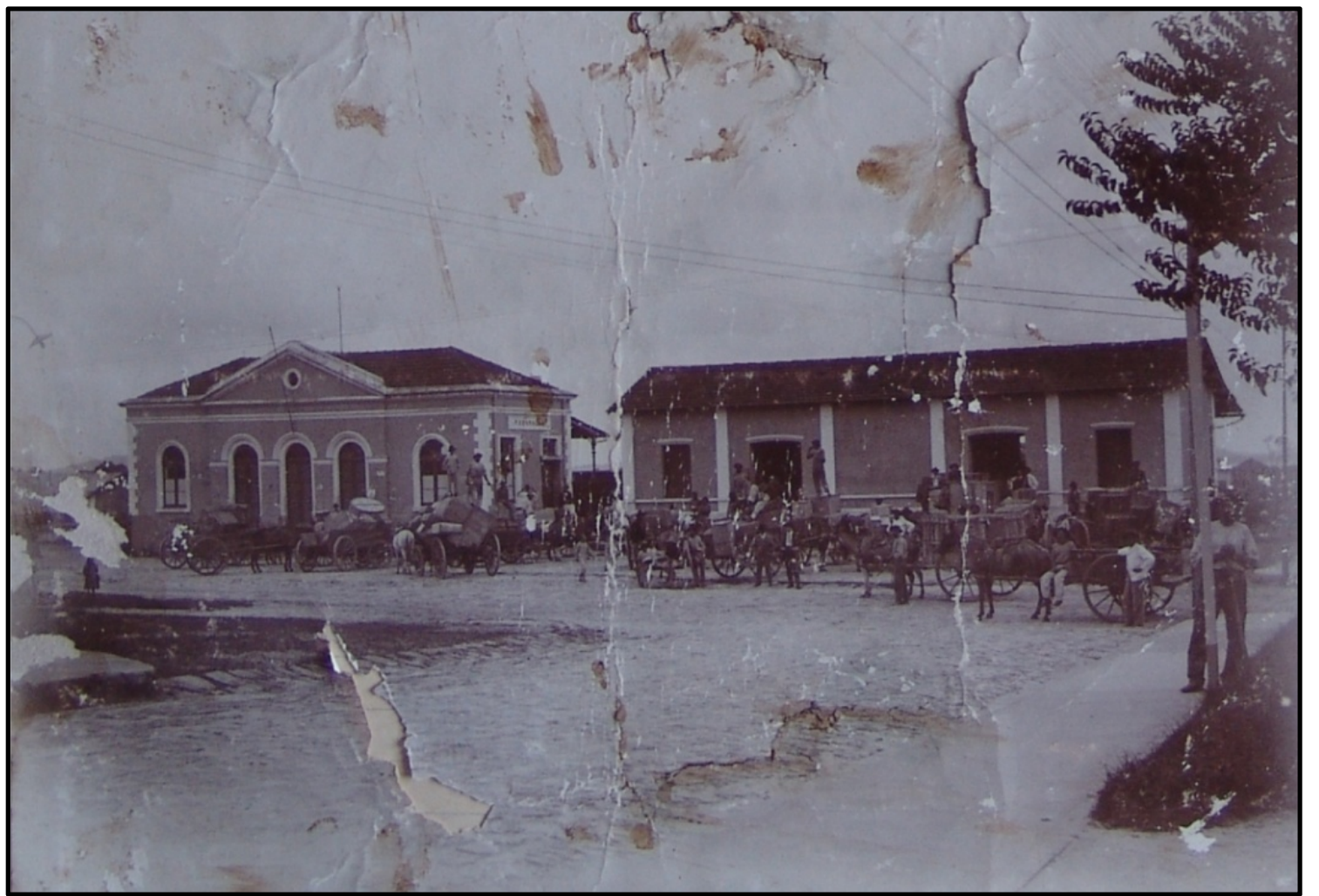

Figura 105. A estação ferroviária da cidade e o depósito de mercadorias, nos fins do século XIX. Fonte: Álbum particular do Prefeito José Lobo.

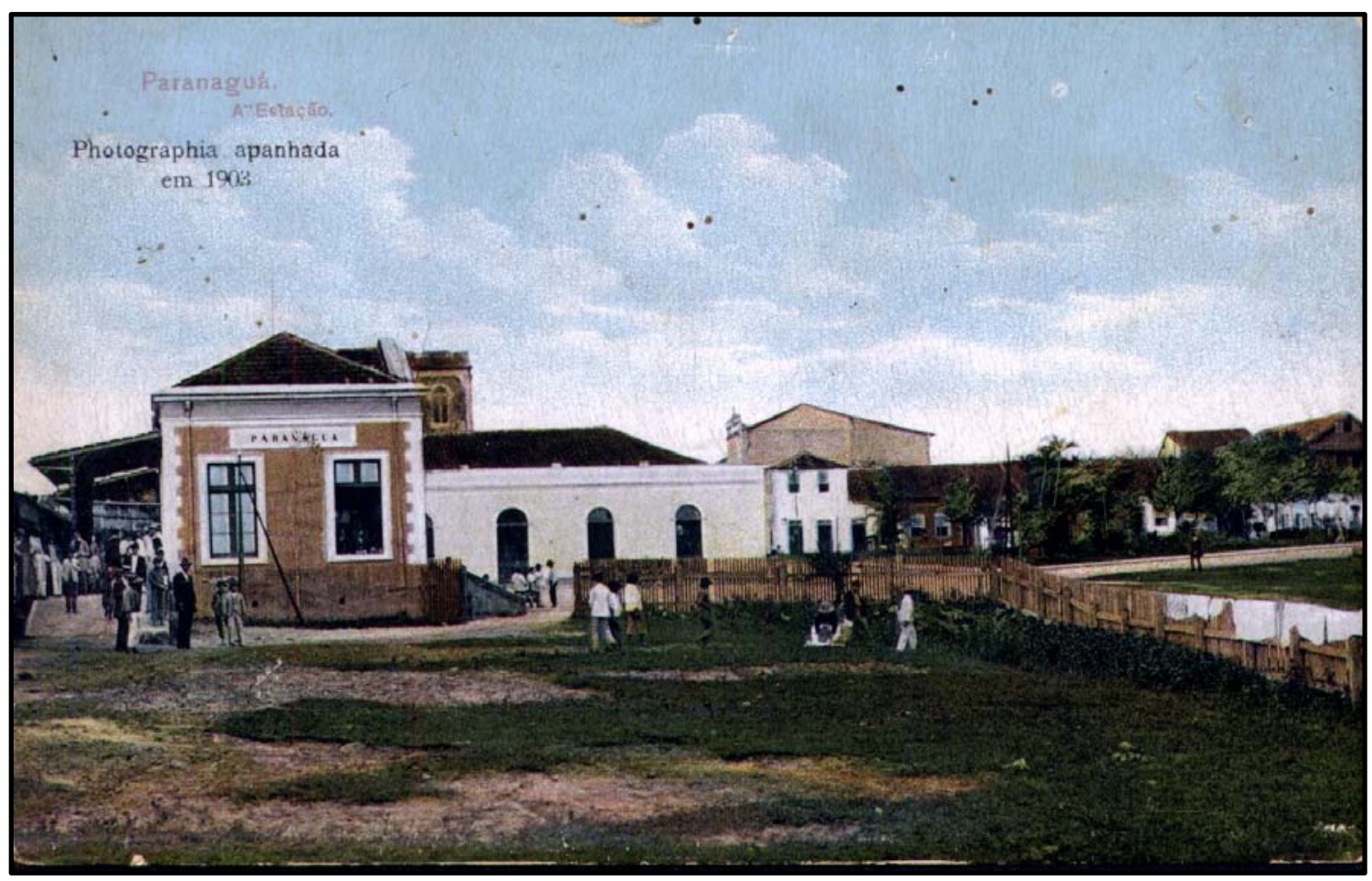

Figura 106. Postal colorido da estação de Paranaguá, em 1903.

Fonte: Instituto Histórico e Geográfico de Paranaguá. 


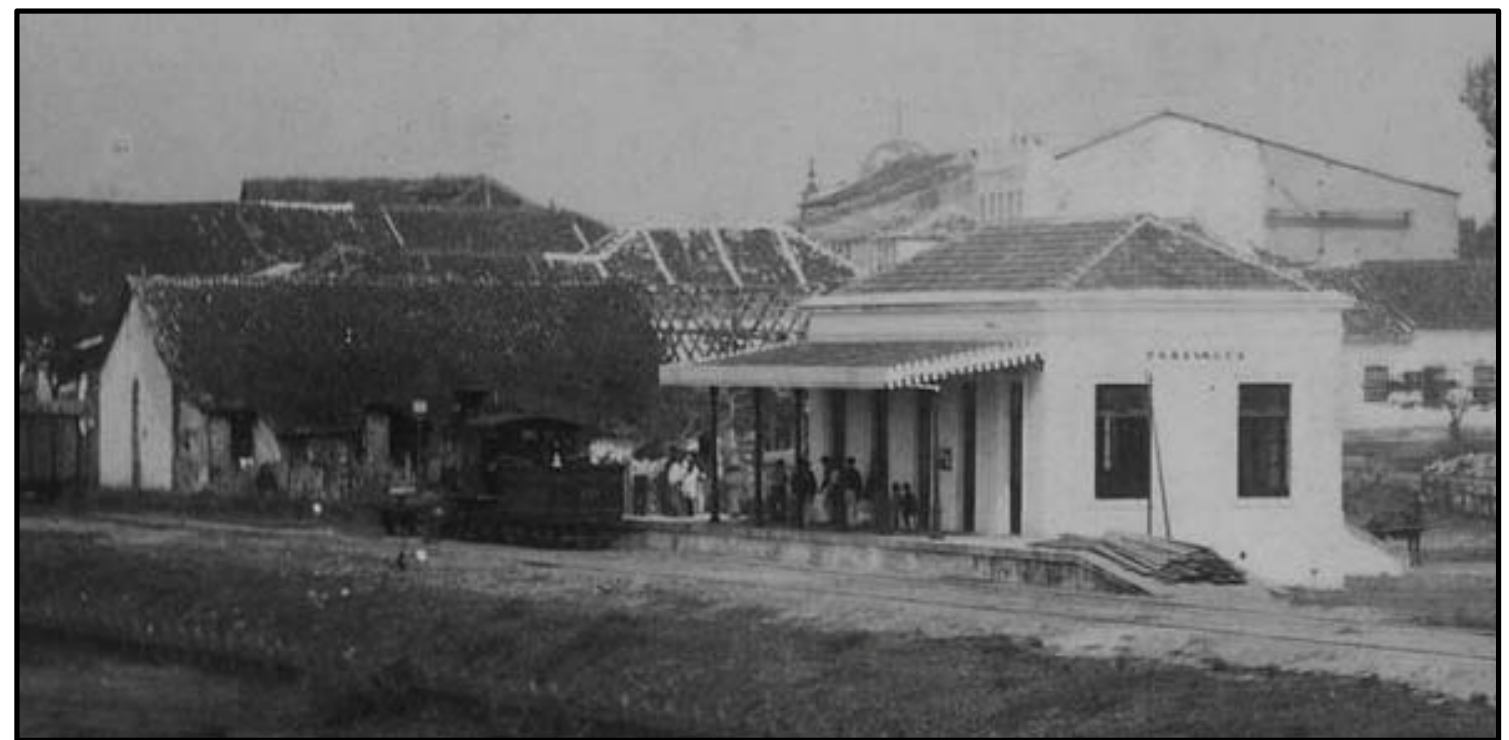

Figura 107. A estação em 1884, fotografada por Marc Ferrez e ao lado o pequeno edifício em demolição para dar lugar ao depósito de mercadorias.

Fonte: Biblioteca Nacional.

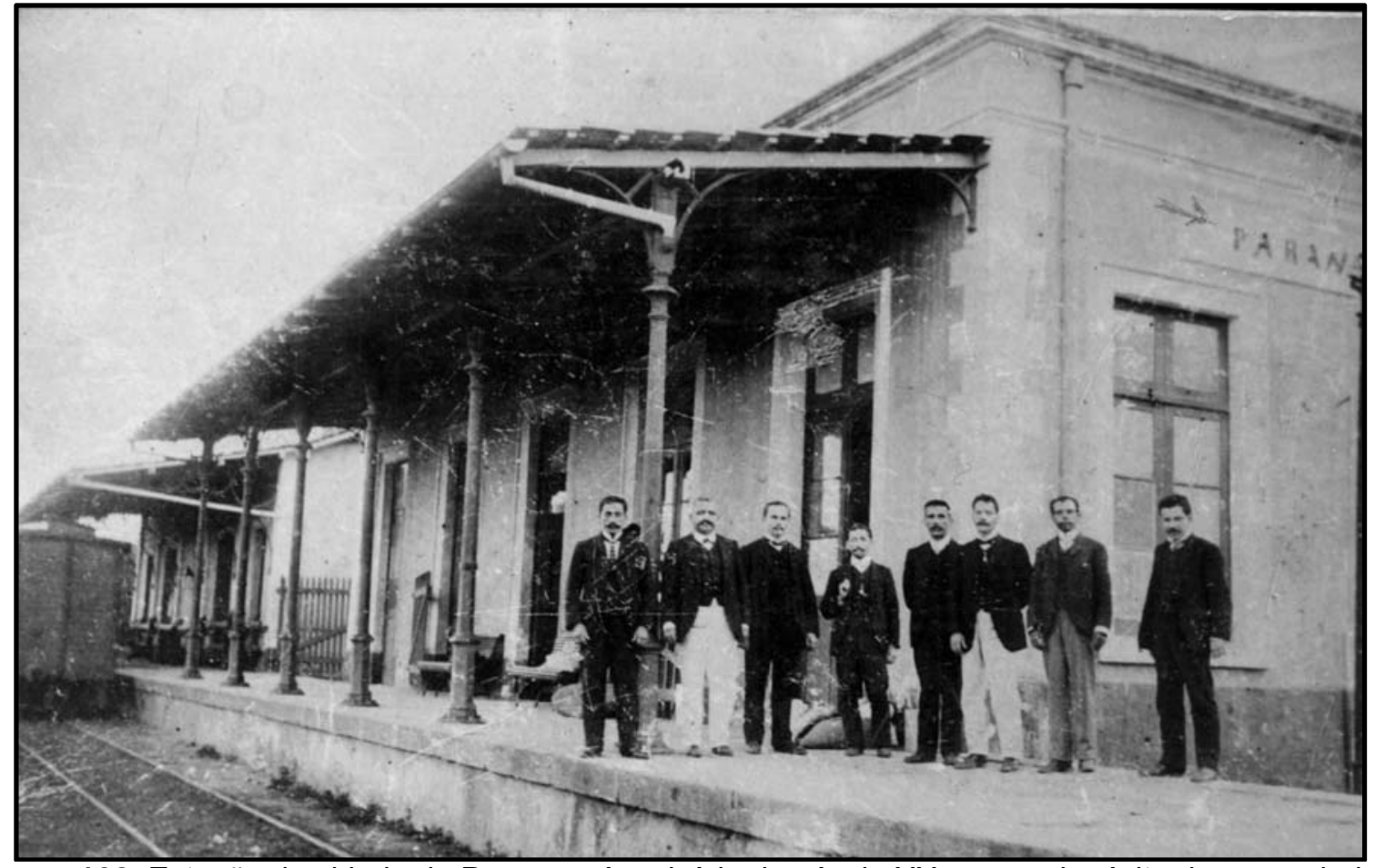

Figura 108. Estação da cidade de Paranaguá no início do século XX, com o depósito de mercadorias já construído. Fonte: IHGP 
Este fato demonstra que existia dificuldade em se chegar ao porto D. Pedro II, apesar da distância de apenas 2 kilômetros entre as estações, resultando na construção do depósito ao lado da estação de Paranaguá, que provavelmente possuía maior movimentação de passageiros do que a estação do porto D. Pedro II, por estar dentro da cidade.(Figura 109 e Figura 110).

A construção da ferrovia trouxe às cidades, novas estruturas, que não só se diferenciavam em seus elementos construtivos, mas também no programa de necessidades, com a construção de armazéns, depósitos, oficinas e as estações de passageiros:

Estas edificações deviam responder a programas e exigências até então desconhecidos, reunindo em um conjunto de edifícios funções bastante diversas entre si, além de ter que resolver todas as questões referentes à circulação de passageiros e mercadorias. (KÜHL, 1998, p.58)

Todo o material, utilizado na construção da Estrada de Ferro do Paraná, veio através dos grandes navios que, advindos principalmente da Europa, adentraram o Porto de Paranaguá, são materiais para a construção das pontes (Figura 111 e Figura 112), produzida pela empresa Atéliers de la Dyle de Louvain, na Bélgica, as telhas francesas para os edifícios, chegando até as locomotivas, construídas pela Société de Construction de Batignolles, sediada em Paris, como descrito neste trecho:

[...] trilhos, pontes de ferro, reservatórios de folhas de ferro, gyradores, apparelhos de mudanças de linha, signaes, carros de viajantes, vagonetes, guindastes, balanças de pesar vagões, etc. transportados pelos navios Tetens e Jonas, chegando em março ao porto D. Pedro II, e pelo vapor Pio da companhia do Pacífico, vindo directamente da Europa ao mesmo porto, onde chegou no mez de maio seguinte com carregamento de 4.000 toneladas.

Nos mezes de julho e agosto ahi aportaram também os navios Alcedo e Solide que carregavam a quantidade restante de trilhos de aço para toda a linha, quatro locomotivas, todo o material telegráphico para a primeira secção, como também as machinas perfuratrizes do systema Ingersoll que têm de ser utilisadas para a perfuração do tunnel de Roça-Nova no alto da Serra; trazendo igualmente o navio Ellida 100.000 telhas francezas 


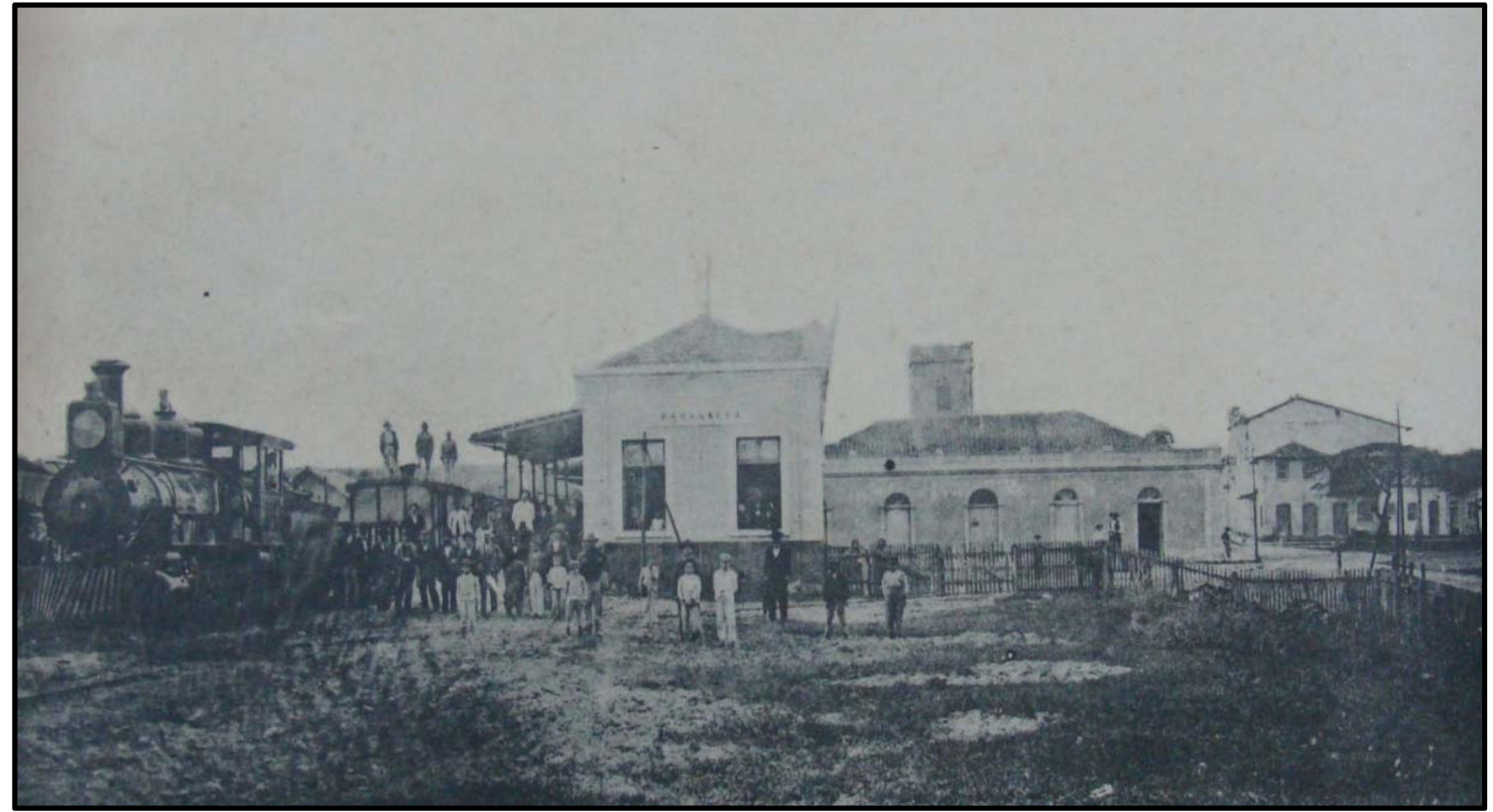

Figura 109. A estação de Paranaguá no início do século XX.

Fonte: Estrada de Ferro do Paraná.

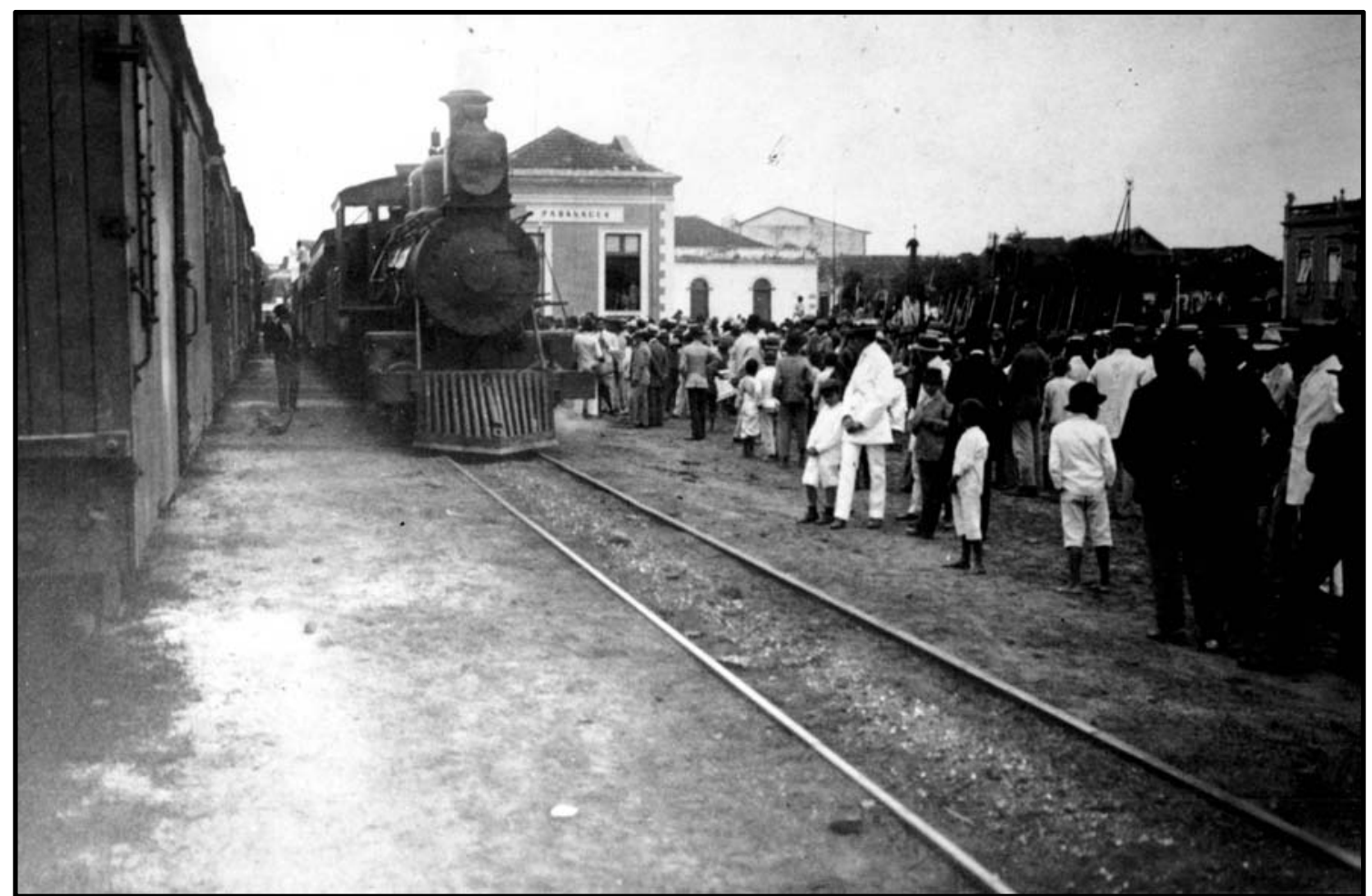

Figura 110. Grande movimentação de pessoas na chegada do trem à estação de Paranaguá, início do século XX.

Fonte: IHGP. 


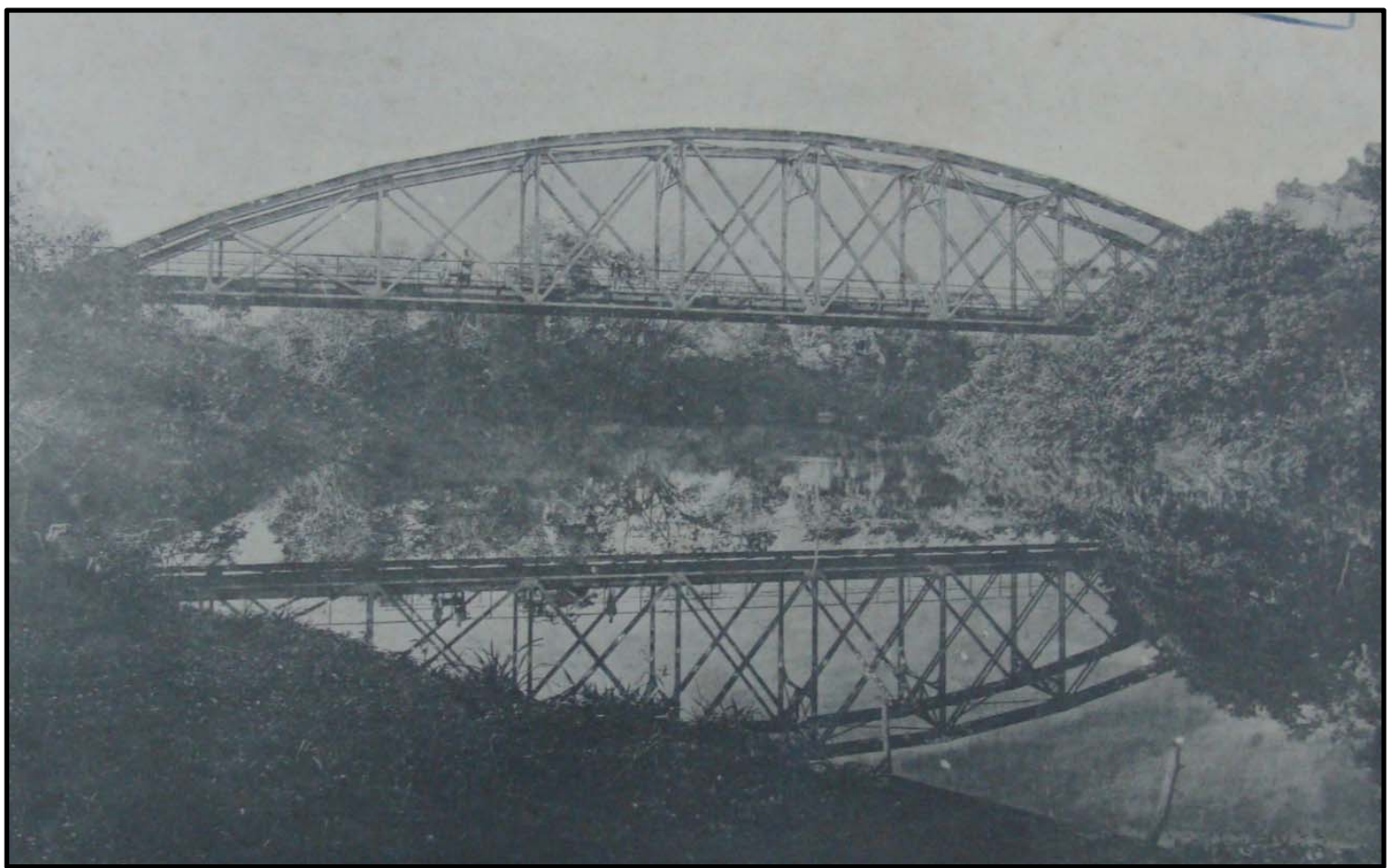

Figura 111. Ponte metálica entre as cidades de Morretes e Antonina, fins do século XIX. Fonte: Álbum da Estrada de Ferro do Paraná.

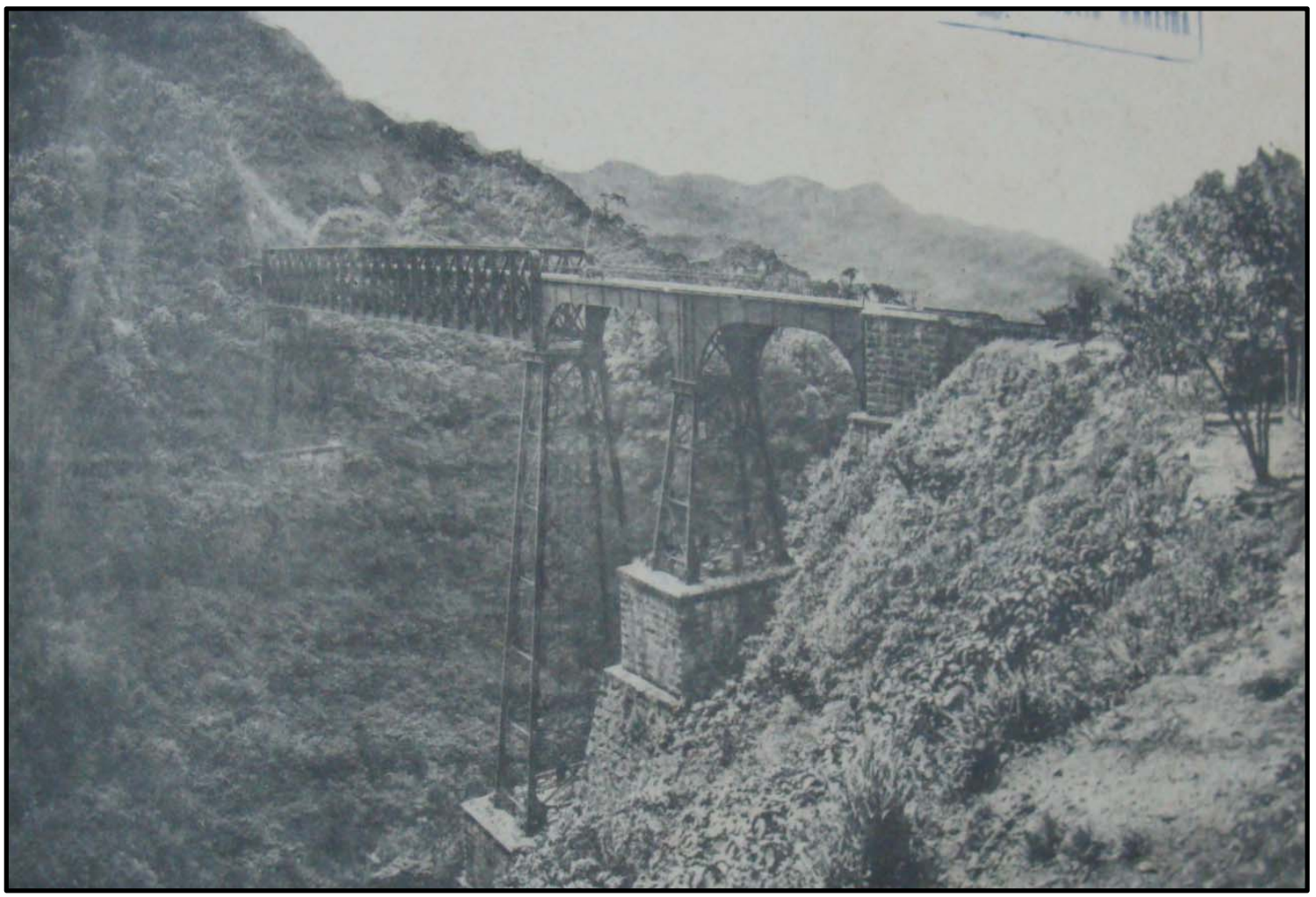

Figura 112. Estruturas metálicas provenientes da Bélgica, como a ponte São João, fins do século XIX.

Fonte: Álbum da Estrada de Ferro do Paraná. 
destinadas ás cobertas dos edifícios da estrada, estações, etc, etc., as quaes foram descarregadas no mez de dezembro do anno findo. (OTTONI, 1881, p. 20-21).

Também foi importante a mão de obra imigrante na construção da ferrovia, são encontrados jornais da época que traziam anúncios bilíngües, conclamando trabalhadores para a Estrada de Ferro. Um desses, encontrado no Dezenove de Dezembro de 1882 (Figura 113), foi escrito em português e alemão, em busca daqueles que trabalhassem com a madeira. Esse período foi marcado pela entrada de imigrantes na Província do Paraná, segundo Nadalin (2001, p. 78):

A demanda agora seria repartida pela necessidade de mão-de-obra para a construção, principalmente de estradas de ferro e linhas telegráficas. Como a iniciativa estatal havia se esgotado, adotaram-se medidas para estimular a organização de sociedades privadas de imigração, cujo trabalho mostrou-se muito "eficiente e variado". Atuaram fazendo bastante publicidade, em virtude da qual, realizada da mesma forma pelas companhias concessionárias para a construção de ferrovias, conseguiram resultado favorável.

Não só alemães, mas também portugueses e italianos participaram dessa construção, e que durante as obras, sofreram alguns acidentes de trabalho:

A 14 de julho, por occasião do assentamento da superstructura Metallica da ponte sobre o rio Jacarehy, occorreu fracturar uma perna o trabalhador italiano Antonio Ferrari. No mesmo dia o súbdito portuguez Antonio Carneiro, no momento de engatar um vagão de lastro, foi comprimido entre dous carros, resultando-lhe algumas contusões. Estes accidentes foram casuaes, tendo sido delles prevenidas as autoridades locaes. (OTTONI JUNIOR, 1881, p.26).

Com a construção da Estrada de Ferro, e a implantação do porto na região da baía de Paranaguá, criou-se um grande vazio entre a cidade e o novo porto (Figura 114). As primeiras ações para a integração destas duas áreas ocorreu em 1893, em que: 


\section{t IIIIU11Cios.}

\section{Distrala de ferro do Raraná}

Precisa-se trabalhadores em madeira, falqueijadores e serradores; dirigir-se aus encarregados-Athanagildo Curdeiro dos Santos em Piraquara e Antunio Evangelista no Pinheirinho da barreira du Itupava

\section{Cisen}

Tuechtige Holzbeschlaejer gegen guten Lohn, eveden gesucht.

In Piraquara bei Athanagildo Cordeiro dos Santos.

No Pinheirinho da barreira do Itupava bei Antonio Evangelista.

Figura 113. Anúncio bilingue encontrado no jornal Dezenove de Dezembro de 1882.

Fonte: Dezenove de Dezembro, 3 de maio de 1882. 
"Foi offerecida a Camara Municipal, a planta geral da cidade, pelo Doutor Tobias Tell Martins Moscoso. Digno Engenheiro Director das Obras da Alfândega d' esta Cidade; em virtude do que, foi- Ihe consignado, na acta da presente sessão, um voto de louvor e agradecimento." (FERREIRA JUNIOR, 190?, p.7).

Não foram encontrados documentos desse levantamento. Este levantamento serviu de base para a proposta de urbanização da área desocupada, existente entre a cidade de Paranaguá e o Porto D. Pedro II. O estudo foi elaborado pelo Engenheiro Tobias Martins e pelo Engenheiro do Município Virgílio Ricardo dos Santos. A proposta cria uma nova avenida, denominada Boulevard Serzedello. Segundo o Engenheiro Martins: "Na qualidade de Engenheiro Director das obras d' Alfandega, procurei o meio de conciliar os interesses do commercio com os do Fisco, isto é, unindo esta cidade com o Porto d' Água, por uma extensa rua, na direcção da recta [...]" (FERREIRA JUNIOR, 190?, p.8).

Sobre essa ligação entre o porto e a cidade, o Engenheiro descreve: "Segundo o traçado, tem esta rua 1910 metros e pela sua construção e seus detalhes será um perfeito Boulevard, com todos os melhoramentos modernos." (FERREIRA JUNIOR, 190?).

Os lotes dessa avenida seriam de grandes dimensões, na qual:

"[...] todas as casas serem de chácara, em que a Câmara reservará para si o domínio dos terrenos, na distância de 5 metros da rua, mas dará aos proprietários confinantes ou limitrophes, o uso e gozo perpétuo, para o seu ajardinamento, como só é com os da Praia de Bota-Fogo, no Rio de Janeiro." (FERREIRA JUNIOR, 190?).

Outros detalhes especificados são, a instalação de postes com iluminação à gás ou elétrica, calçadas de 5 metros de largura, e nas margens da avenida seriam plantadas árvores de 8,33 em 8,33 metros, "[...]para que a entrada central de cada chácara que tem 25 metros de frente, fique livre com a rua." (FERREIRA JUNIOR, 190?, p. 9-10). 


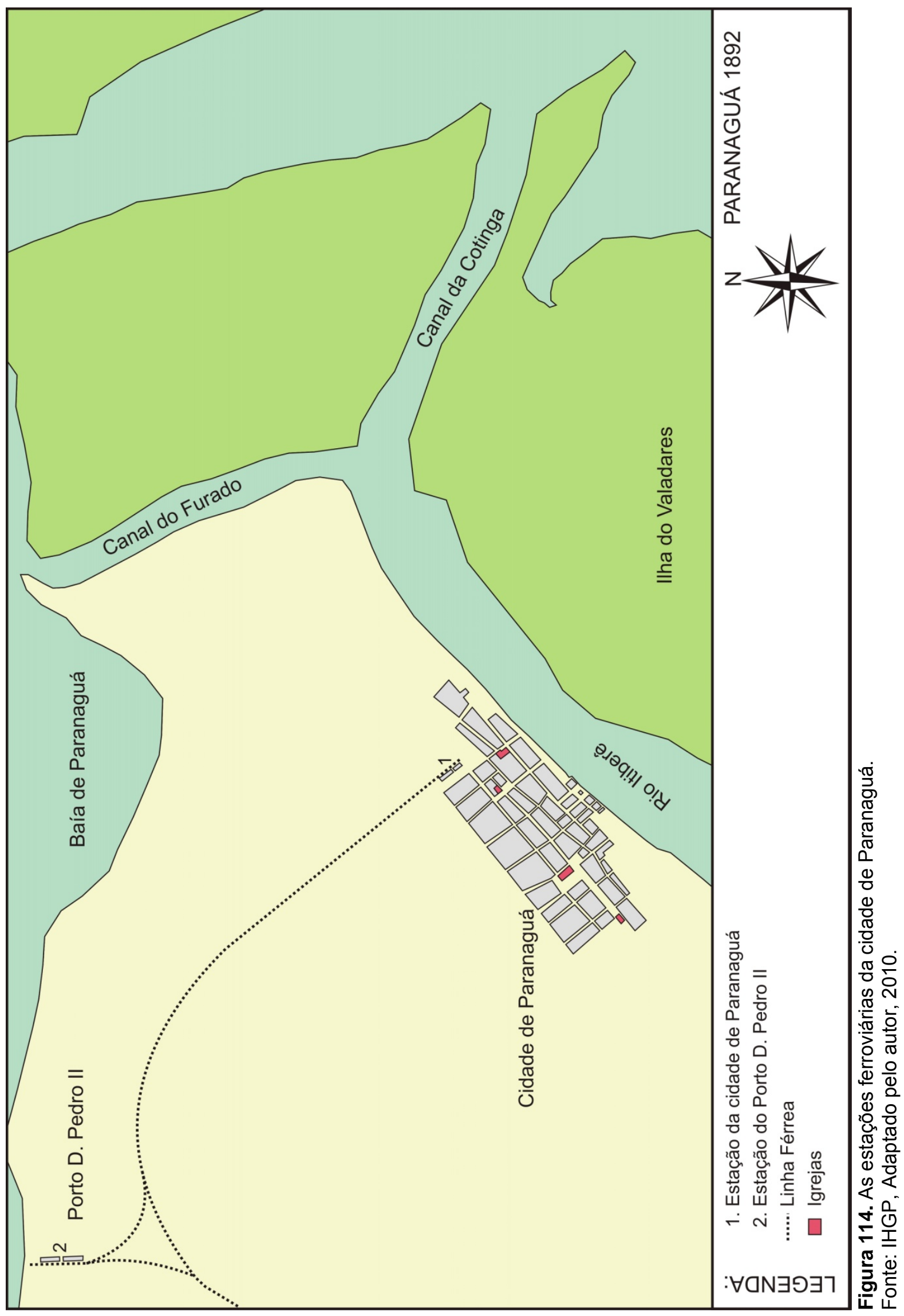


Nesse relatório, os engenheiros também especificam a construção de duas praças, uma nas margens do Itiberê, na entrada da nova rua:

[...] tendo à margem do rio, um largo mirante, na altura de 2 metros, que será calçado a mármore ou mosaico, com uma balaustrada dupla de cantaria, sendo a subida por 2 escadas, traçadas no sentido de combinação de curvas. Esta praça será arborizada, com a mesma ordem e distância no Boulevard, terá bancos de madeira de lei, sobre pés de ferro fundido, dando um aspecto de prazer e conforto ao visitante.

Os botes e pequenas embarcações, poderão ali atracar: o que será de bom effeito, com uma escada de pedra, de um e outro lado, na direcção das ruas. (FERREIRA JUNIOR, 190?, p. 10).

E no outro extremo dessa rua:

A Praça Ubaldino será de um outro effeito, ficará em frente ao edifício d' Alfândega: procura apresentar o gosto do bosque, da mata, do carramanchão e da gruta, em que devem repousar ou descançar aquelles que forem d'este porto nos tempos quentes, quando as sombras das arvores mitigam os ardores do calmoso dia. (FERREIRA JUNIOR, 190?, p. 10-11)

Essa imagem bucólica, criada nas duas praças, nos mostra a preocupação em transformar áreas urbanas em espaços para a contemplação, localizadas no início e ao fim desse boulevard, remetendo às influências do urbanismo francês, principalmente nas reformas colocadas pelo Barão de Haussmann, nas largas avenidas que convergem à um ponto focal, uma praça.

Essas propostas de urbanização marcam um período em que, nas palavras de Heliana Salgueiro (2001, p.143), "o belo caminha lado a lado com a noção do útil", ou seja, a modernização do espaço sem perder a preocupação com a estética; construção de largas avenidas arborizadas para a circulação, e ao seu fim a criação de praças que encerram a perspectiva, dessa forma aliando essas duas idéias.

De acordo com Salgueiro (2001, p. 156):

A primeira medida (a arborização), preconizada por Reynaud, é típica do urbanismo de regularização do século XIX e encontrará seu apogeu na Paris haussmanniana, enquanto a segunda (o parque) segue a tradição pitoresca, inserindo-se habilmente na planta, graças a seu contorno geométrico. 
Portanto, o Boulevard Serzedelo seria limitado em seus dois extremos pela Praça João Guilherme nas margens do rio Itiberê e pela Praça Ubaldino, defronte a nova Alfândega de Paranaguá, no porto D. Pedro II. Além do prédio da Alfândega, consta nesse relatório a construção do $5^{\circ}$ Distrito dos Portos Marítimos e a Repartição de Imigração, com hospedaria e Agência Oficial de Colonização. (FERREIRA JUNIOR, 190?).

Consta neste relatório, que a Alfândega seria construída no Porto D. Pedro II, já os outros edifícios, seriam instalados em duas quadras ao sul da Praça do Mercado, ou seja, na região da rua da Praia. Essas informações demonstram que a referida via mantinha o funcionamento do porto, apesar dos problemas com assoreamento do rio Itiberê e a exigüidade de espaços para a ampliação portuária. Apesar destes problemas, surgiu a proposta para o novo Paço Municipal, ao lado da Praça João Guilherme, refletindo a importância que a área do rio Itiberê mantinha dentro da cidade de Paranaguá. Apesar da proposta de mudança da sede da prefeitura, isto não foi concretizado, pois somente em 1910, o prefeito Caetano Munhoz da Rocha comprou o Palacete Nácar, para ali ser sediada a prefeitura municipal.

Parte dessa proposta pode ser observada no mapa de 1893, analisado anteriormente. Apesar de não existirem indicações documentais sobre essa hipótese, analisando o mapa, observamos certas relações com a proposta do Engenheiro Tobias Martins. As novas áreas estabelecidas pelo engenheiro estão indicadas nessa planta através de linhas pontilhadas, por exemplo, o boulevard Serzedello, situado nas proximidades da foz do Itiberê. O mapa não indica as praças citadas no projeto, mas já cria um traçado regular de quadras nas áreas vazias entre 
a cidade e o porto. Essas quadras possuem grandes dimensões se comparadas com o traçado original da cidade de Paranaguá.

O início das obras deste projeto ocorreu em março de 1893 com:

[...] a inauguração official dos trabalhos da "Praça João Guilherme" do "Boulevard Serzedello" e da "Praça Ubaldino", de conformidade com o Plano Geral e condições elaboradas pelo Engenheiro Director das obras d'Alfandega d'esta Cidade, Tobias Tell Martins Moscoso e Agrimensor, servindo de Engenheiro Municipal Virgilio Ricardo dos Santos, approvado em sessão de quinze do corrente. (FERREIRA JUNIOR, 190?, p.13)

Durante as obras ocorreu o falecimento do Engenheiro Tobias Martins e nas atas da Câmara de Paranaguá, consta que o prefeito, em 1893, [...] communicou haver contractado a abertura do projectado Boulevard Serzedello. (FERREIRA JUNIOR, 190?, p.16). O Boulevar provavelmente não foi finalizado, pois não se encontram documentos que relatem sobre a inauguração ou qualquer descrição desta via.

Além do projeto urbanístico do boulevard, a prefeitura iniciou o calçamento de várias ruas da cidade, constatada pelos dados das atas da Câmara de Paranaguá. Temos assim, o calçamento da rua Visconde de Nácar em 1880 (FERREIRA JUNIOR, 190?), via que concentraria parte da elite parnanguara, em que foram construídas importantes residências como a do próprio Visconde e a residência do Coronel João Guilherme Guimarães.

Também foram calçadas a rua Sete de Setembro em 1883, parte da rua Silva Lemos, atual Desembargador Hugo Simas e da rua do Ipiranga em 1887. Um ano depois foi feito o calçamento da rua da Praia, e em 1889 foi a rua da Imperatriz, atual Marechal Deodoro. Com a República, em 1890, foram calçadas as ruas do Rosário, Pecego Junior, Paysandú, Rodrigo Silva (parte da atual General Carneiro) e 
Ipiranga; em 1892, foram feitos os trabalhos na ladeira do Bom Jesus.(FERREIRA JUNIOR, 190?)

Percebemos que a cidade, até o findar do século XIX, manteve-se concentrada na região do rio Itiberê, enquanto sua área de rocio permanecia vazia; a implantação da Estrada de Ferro e a construção de duas estações, uma no Porto D. Pedro e outra na cidade, influenciaram nesta expansão, principalmente por facilitar o transporte entre as duas regiões.

Apesar desta ligação através da ferrovia, notamos em antigas fotografias, que o porto de Paranaguá, nas margens do Itiberê, permaneceu em funcionamento até o segundo decênio do século XX, as fotografias apresentam navios atracados, principalmente na região ao fim da rua da Praia (Figura 115 e Figura 116), nas proximidades da foz do Itiberê e além disso, nesse período ainda estava em funcionamento no antigo Colégio, a Alfândega foi transferida para a região do porto D. Pedro II, apenas em 1911. Portanto, a mudança apesar de ter se iniciado na década de 80 do século XIX, vai se estender por aproximadamente 40 anos até a definitiva transferência para o porto da baía de Paranaguá.

A linha de bondes ligando as duas regiões foi inaugurada em 1893:

Teve lugar, n'esta data, a inauguração do tráfego da linha de bonds de propriedade da Empreza de Transportes Paranaguense, levada a effeito devido aos grandes exforços empregados pelo preclaro cidadão João Eugenio Gonsalves Marques, Director Gerente da mesma Empreza. $\mathrm{O}$ acto revistio-se da maior solemnidade, em que realçou grandemente o enthusiasmo da população. (FERREIRA JUNIOR, 190?, p. 16)

Os primeiros bondes eram à tração animal (Figura 117 e Figura 118) e ligavam estes dois extremos da cidade, foi o primeiro transporte coletivo de Paranaguá e possibilitou aos cidadãos, conhecerem uma parte da cidade que antes não possuíam contato. 


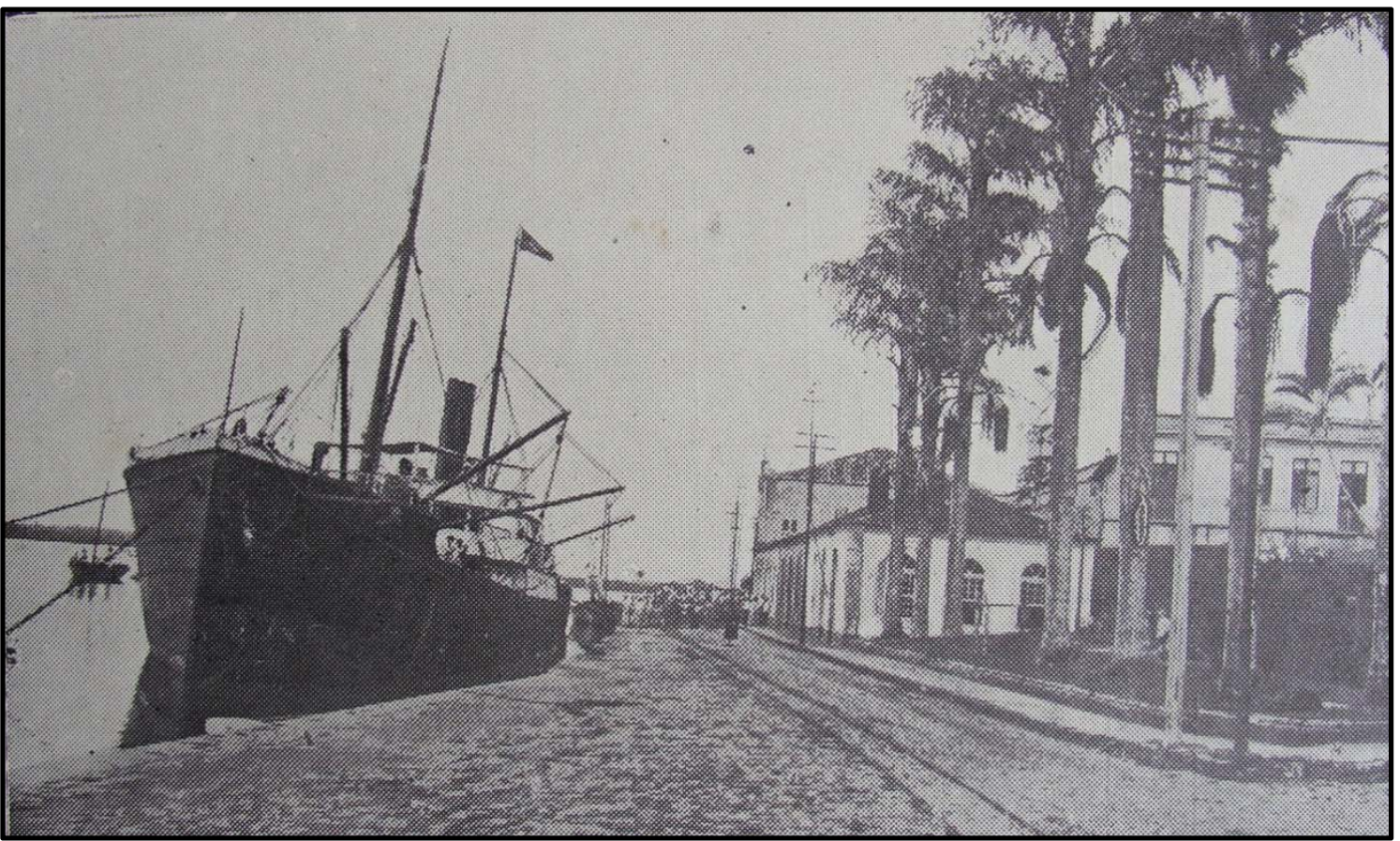

Figura 115. Defronte às construções que margeiam o Itiberê, este navio está atracado para desembarcar um carregamento de sal, começo do século XX

Fonte: Revista O Itiberê, n¹3, anno 1, maio de 1920.

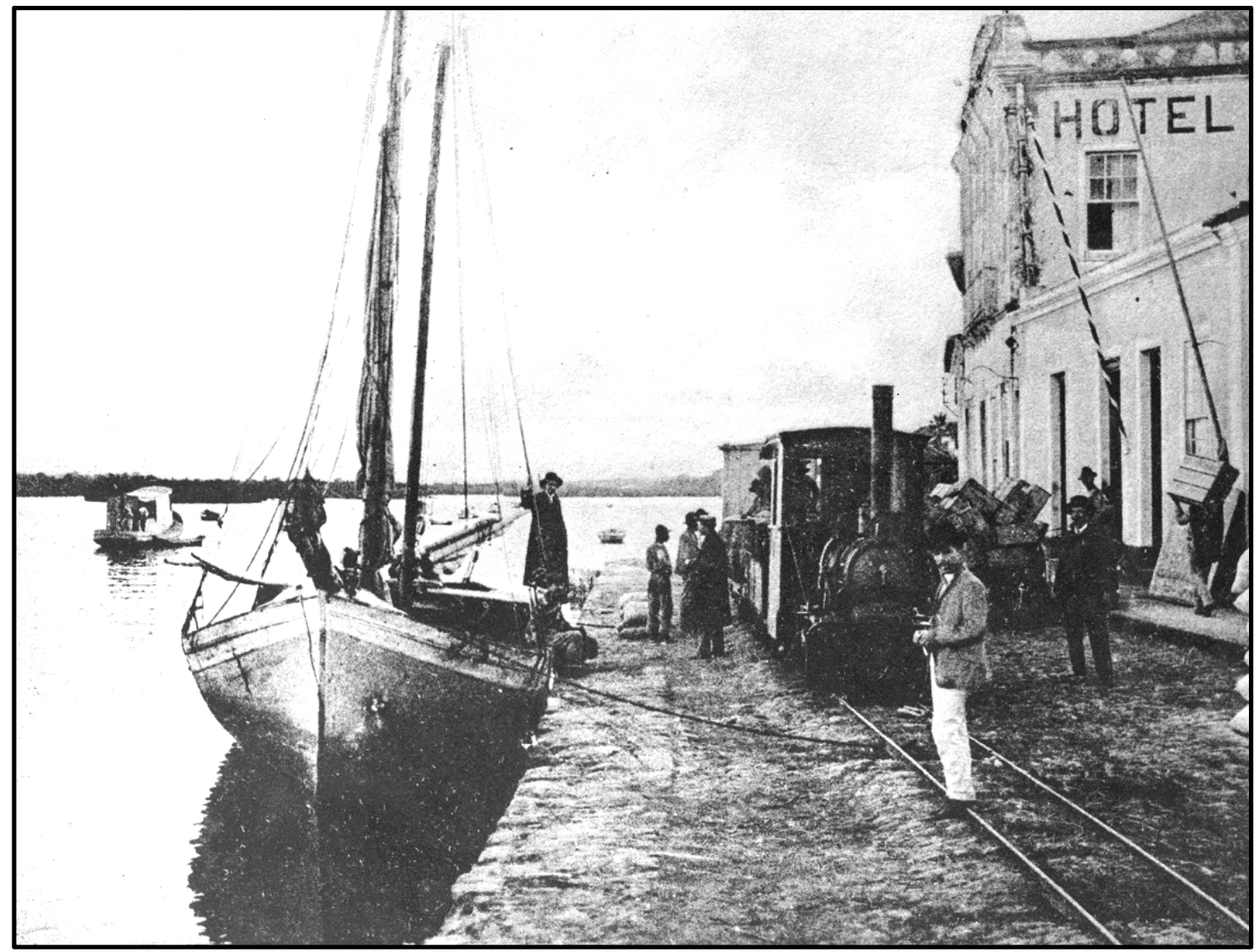

Figura 116. Este pequeno trem ligava a Alfândega do Itiberê ao porto D. Pedro II, início do século XX. Fonte: APPA. 


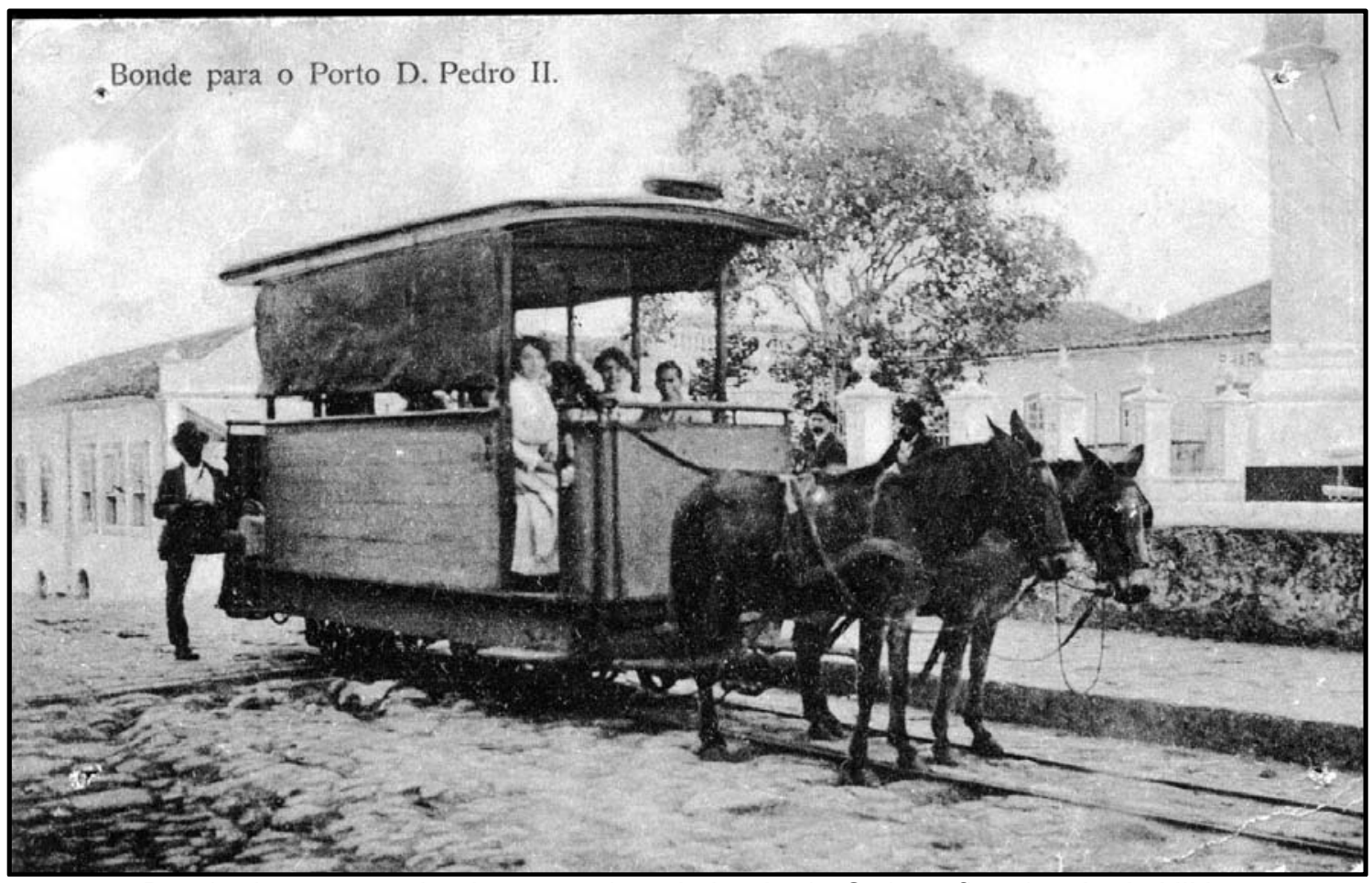

Figura 117. Bonde de tração animal, passando pela igreja da Ordem, fins do século XIX. Fonte: IHGP

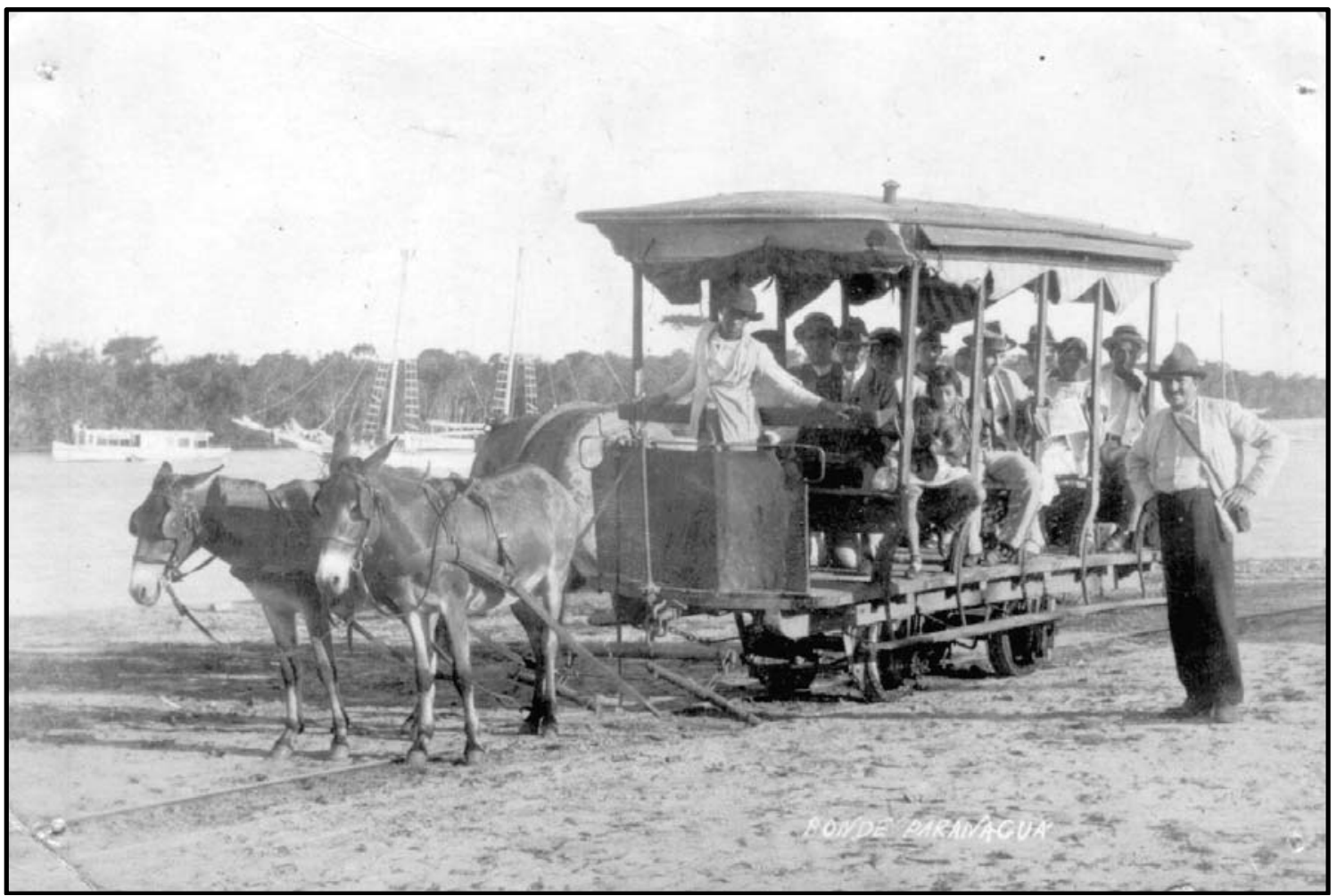

Figura 118. Bonde provavelmente nas margens do Itiberê, início do século $X X$ Fonte: IHGP 
Essa população habitava a área da antiga vila, nas margens do Itiberê, o bonde, "[...] já era um poderoso índice de urbanização, transformação tecnológica e ampliação do espaço público" (SEVCENKO, 2008, p. 527). São ações como essas que possibilitaram a ampliação do traçado da cidade, complementando-se com a instalação do serviço de água e esgotos, que ocorreria apenas no começo do século $\mathrm{XX}$.

Mas ainda no final do século XIX, foi encontrada uma proposta para a instalação de energia elétrica, rede de água e esgotos na cidade de Paranaguá, a pedido do prefeito João Guilherme Guimarães. Segundo ata da Câmara Municipal:

Foi tomado conhecimento de uma proposta de Müller, relativamente aos melhoramentos de abastecimento d' água, collocação de esgotos e luz electrica, acompanhada do parecer informativo que a pedido do cidadão Prefeito, deu o illustre engenheiro Dr. Furtado de Mendonça; cuja proposta deixou de ser acceita, em virtude do seus preços pouco vantajosos; conforme se verá do parecer abaixo, cujas condições não foram acceitas pelos proponentes. (FERREIRA JUNIOR, 190?, p.24)

Em 1901, foi solicitada a instalação de uma pequena usina de energia elétrica, a ser construída pela firma de Carlos O. Barreto. No ano de 1903, ela foi inaugurada:

A hora determinada o Cidadão Prefeito dirigio-se à Usina de Luz electrica, que ao chegar ao seu destino, vio-se acompanhado de grande massa popular.

O Snr. Coronel Theodorico Julio dos Santos e com elle o povo, tomam ingresso na casa das machinas e ahi S. Exa. Com as mãos sobre a alavanca illuminativa, proferio emocionante discurso de congratulações ao povo Paranaguense, vendo n'aquelle momento tão solemne e tão grato para si; coroados os seus urgentes esforços, entregando luz electrica aos seus habitantes.

Indiscreptível o enthusiasmo popular em suas expansões de agradecimentos e applausos com que victoriaram as últimas palavras do orador.

Fiat lux! E a luz se fez clara, brilhante e completa. (FERREIRA JUNIOR, 190 ?, p. 50).

Ao findar do século XIX, temos as últimas intervenções urbanísticas daquele período, que definiram o traçado da cidade durante o século XX. Desde as ações de 
Pardinho em 1720, não foram propostas idéias gerais de urbanização, apenas em 1890, com a ligação entre a cidade e o porto D. Pedro. Foram encontradas propostas urbanas de maior porte apenas no começo do século $X X$, com os melhoramentos urbanos propostos por Caetano Munhoz Da Rocha, seguindo, talvez influências de Pereira Passos para o Rio de Janeiro.

A chegada da ferrovia traçou o destino do porto de Paranaguá na região da baía, onde foi instalada uma das estações de trem, dessa forma o transporte entre o litoral e o interior foi beneficiado, ampliando as exportações de madeira e erva-mate, contribuindo para o desenvolvimento da capital Curitiba, dando maior mobilidade a esses habitantes e também aos de Paranaguá.

Segundo Cacilda Teixeira da Costa:

Em muitos aspectos a estrada de ferro mudou a face das cidades, introduziu os diferentes aspectos da vida moderna, e chegou a transformar as noções de tempo, de pressa, de pontualidade, de hora certa e valor comercial do tempo. O "horário do trem" se sobrepôs à hora local, solar e relativa, dada pela igreja. As diferenças de minutos passaram a ser importantes e, nas cidades maiores, as torres das estações introduziram relógios marcando a hora exata, conceito até então injustificado. "Perder o trem" tornou-se expressão de incompetência e ridículo. (TEIXEIRA DA COSTA, 2001, p.123)

Dessa forma, a cidade conheceu em fins do século novidades que alteraram o modo de vida de seus habitantes - a ferrovia, a eletricidade, padarias, confeitarias, o mercado, o novo cemitério, os novos materiais construtivos, o novo porto, são exemplos destas mudanças que transformaram definitivamente a condição dessa população ávida por novidades, mas ainda relutante em certos aspectos.

São mudanças que se refletiram no século $X X$ e influenciaram no desenvolvimento urbano de Paranaguá e de suas construções, portanto o século XIX é de suma relevância nas próximas transformações que ocorreram tanto na habitação como no desenvolvimento da cidade. A própria relação entre as pessoas 
se torna mais complexa, são novos padrões de moda, de literatura, de educação, símbolos de uma população que prezava pelos costumes europeus e gostaria de aplicá-los ao seu local de morada, isto também se refletiu nas residências, com a chegada dos materiais importados e as influências externas de uma nova cidade que se abria para a chegada de um novo século: o século $X X$.

Ao início do século XX, Paranaguá passou por uma grande reforma urbana, orquestrada pelo prefeito Caetano Munhoz da Rocha, que reformou edifícios públicos, como o antigo mercado, remodelou praças, abriu novas ruas e implantou o primeiro sistema de água e esgotos da cidade. Além disso, o porto D. Pedro II se consolidou na baía de Paranaguá e a partir de 1935, quando são encerradas as obras do novo cais, temos uma nova fase de funcionamento dessa estrutura portuária, transportando além da erva-mate e da madeira, o ouro verde: o café. Durante a primeira metade do século $X X$, Paranaguá consolidou sua estrutura portuária, principalmente pelo aumento nas exportações do café, produzido no norte paranaense. 

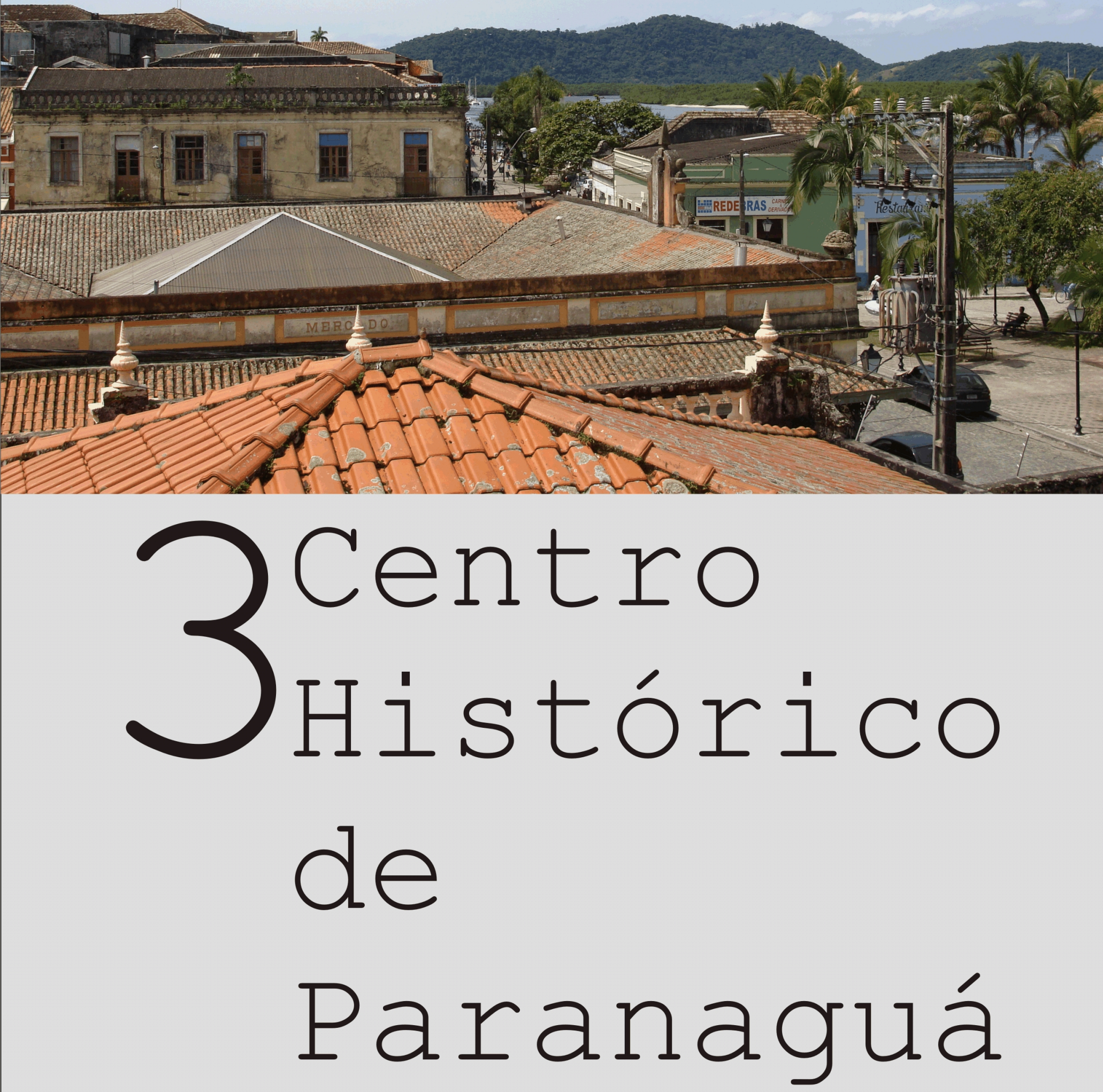



\section{CENTRO HISTÓRICO DE PARANAGUÁ.}

A partir do estudo, apresentado anteriormente sobre as transformações urbanas e arquitetônicas de Paranaguá dos séculos XVIII a XIX, é possível neste momento, avaliar o Centro Histórico da cidade nos dias de hoje, de um conjunto que sobreviveu, ao seu modo, durante os três últimos séculos. Pretendemos elaborar uma análise sobre a eficiência das ações de preservação estabelecidas no município e, a partir dessa análise, contribuir com o entendimento sobre a preservação de Paranaguá, trazendo à luz as edificações sobreviventes e o seu traçado urbano.

É importante compreendermos como a vila, e depois cidade de Paranaguá, desenvolveu-se durante o século XVIII e XIX. E a partir disso, analisar a cidade em sua configuração atual, buscando remanescentes que identifiquem suas marcas do passado, que fazem parte da memória da cidade. Essa análise pretende auxiliar no entendimento e na valorização do importante conjunto urbano, na formação do Estado do Paraná e do Brasil. Posteriormente, apresentamos um roteiro de visita, baseado na proposta do livro Atlas de Centros Históricos no Brasil, que dá sugestão aos visitantes, resultante de pesquisas históricas como esta, e assim possibilite a leitura e a compreensão de algumas cidades a partir de análises urbanas e arquitetônicas.

Portanto, pretendemos contribuir, através deste estudo, com os órgãos de preservação, com vistas a ampliar a discussão sobre as ações atuais de conservação e restauro, apresentando análises que podem ajudar na formação de novas propostas de ação patrimonial sobre o Centro Histórico de Paranaguá. 


\subsection{COMPREENDER PARA PRESERVAR}

A cidade de Paranaguá sofreu durante o século $X X$, transformações em sua estrutura urbana. Apesar disso, parte de seu traçado colonial se manteve preservado, tornando-se área do Centro Histórico, reconhecido na década de 1990. Esta análise partirá do Plano Diretor de Paranaguá, instituído em 1998, e que contém a lei de preservação do Centro Histórico, ainda em vigor. Esta lei será discutida, para que possamos sugerir novas contribuições, com a finalidade de aprimorar os mecanismos de preservação do conjunto urbano de Paranaguá.

Em 1998, foi aprovado o novo Plano Diretor do município de Paranaguá, que possui entre algumas decisões, a delimitação de seu Centro Histórico ${ }^{39}$, agora estabelecida como lei municipal. São definidas através deste Plano, três áreas distintas de proteção: o Setor Histórico Tombado, no qual está situado o conjunto urbano que deve ser preservado; a Área Envoltória, que como o próprio nome já diz, circunda o Setor Histórico e tem a função de "[...] proteger a visibilidade dos bens tombados na cidade." (PARANAGUÁ, 1998, p. 6); e a Zona de Proteção do Setor Histórico, que consiste na transição entre a Área Envoltória e a Zona Residencial 1.

No mapa, a poligonal do Setor Histórico, que se configura em um eixo, foi definida da seguinte forma: o primeiro ponto situa-se na rua Vieira dos Santos, antiga rua do Fogo, cruzando com a rua Mestre Leopoldino, depois se encaminha pelo sentido sudeste até encontrar a rua Conselheiro Sinimbú, antiga rua da Gambôa, direcionando-se ao eixo da rua Padre Albino, onde está o ponto 2, a partir

\footnotetext{
${ }^{39}$ Tombamento Estadual: Processo n 017/90. Inscrição n¹09. Data: 22/12/1990. (PARANÁ, 2006, p. 377).
} 
daí esta linha segue novamente a rua Mestre Leopoldino, no sentido sudoeste até alcançar a rua Pecego Junior, antiga rua do Meio, onde se definiu o ponto 3.

A linha se mantêm na rua Pecego Junior, no sentido nordeste até o eixo da rua João Régis, antiga Rua da Matriz, definindo o ponto 4, deste ponto segue no sentido sudeste até o eixo da rua João Estevão, onde está o ponto 5, encaminhando-se em seu eixo no sentido nordeste até a rua Professor Cleto, antiga travessa Senhora do Terço, onde está o ponto 6. Deste ponto se vai ao sentido leste-sudeste por 150 metros até o rio Itiberê, onde está o ponto 7 , deste ponto se segue o rio até o eixo da rua Princesa Isabel, onde está o ponto 8 , a partir daí segue-se esta via no sentido noroeste até o cruzamento com a rua Visconde de Nácar, antiga rua da Boa Vista, onde está o ponto 9, deste ponto encaminhando-se por esta rua na direção nordeste até o eixo da rua Manoel Bonifácio, está o ponto 10, a partir daí volta-se para a direção sudoeste até a rua Presciliano Corrêa, no qual está o ponto 11, depois segue no sentido sudeste por esta rua, até a rua XV de Novembro, antiga rua da Câmara e Cadeia, localizando-se o ponto 12, deste ponto a poligonal se encaminha por esta via no sentido sudoeste até encontrar a rua Professor Cleto, marcando o ponto 13, deste local segue no sentido oeste-noroeste até a rua Vieira dos Santos no ponto 14 e a partir daí segue no sentido sudoeste até o ponto inicial para o fechamento da poligonal. (PARANAGUÁ, 1998)

Qualquer tipo de alteração, (reforma, construções, recuperação, ampliação) referente à área do Setor Histórico, tanto urbanística (paisagismo, mobiliário, infraestrutura) quanto particular (residências, comércio), deve passar por análise da Curadoria do Patrimônio Histórico e Artístico do Estado e pela Prefeitura Municipal de Paranaguá. Além da delimitação do Setor Histórico, consta na lei municipal a classificação dos edifícios existentes neste setor, do Grau 1 ao 4, definindo a escala 
de alterações que poderão ser executadas nas restaurações, reformas e até nas demolições:

GP1: com grau de proteção rigorosa, os edifícios possuem importância histórica e/ou arquitetônica, seus aspectos originais deverão ser mantidos integralmente e são permitidas intervenções que venham recuperar as suas características originais e modificações internas tão somente aquelas destinadas à melhoria de habitabilidade.

GP2: Grau de proteção rigorosa, diz respeito aos edifícios com importância histórica e/ ou arquitetônica relevantes para o conjunto urbano, os quais, porém, sofreram, no decorrer do tempo, alterações de maior significação que restitua a concepção originais. Deverão ser mantidos integralmente os aspectos originais remanescentes de sua concepção, sendo permitidas intervenções que venham a recuperar suas características originais e modificações internas tão somente aquelas destinadas à melhoria de habitabilidade.

GP3: Unidade de acompanhamento. São os edifícios que se caracterizam como unidades de acompanhamento devendo ser mantidas a sua volumetria, podendo receber intervenções internas ou externamente, de modo a harmonizá-los ao conjunto urbano.

GP4: Unidades que poderão ser substituídas integralmente, obedecendo, para as novas edificações, as normas aqui estabelecidas. (PARANAGUA, 1998, p. 18-19)

A classificação, estabelecida pela Prefeitura está identificada em um mapa do

Setor Histórico (Figura 119) no qual os edifícios dispostos nessa escala são apresentados através de cores distintas, cada uma indicando um grau de proteção.

Fora dessa classificação, encontram-se as construções com registros individuais, seja Estadual ou Federal. No mapa também consta o eixo de tombamento e os setores descritos anteriormente. Nesse conjunto de obras temos a Fonte d' Água ${ }^{40}$, a igreja de São Benedito ${ }^{41}$, a Matriz $^{42}$, duas residências defronte à Matriz ${ }^{43}, 0$ Colégio dos Jesuítas ${ }^{44}$, a igreja da $\operatorname{Ordem}^{45}$ e o Palacete Visconde de Nácar ${ }^{46}$.

\footnotetext{
${ }^{40}$ Tombamento Estadual: Processo n 222-04/64. Inscrição n4. Data: 26/01/1964. (PARANÁ, 2006, p. 332).

${ }^{41}$ Tombamento Estadual: Processo $n^{\circ}$ 002, Inscrição $n^{\circ}$ 222-02/62. Data: 04/11/1962. Tombamento Federal: Processo n 455-T. Inscrição n 403. Data: 03/08/1967. (PARANÁ, 2006, p. 342).

${ }^{42}$ Tombamento Estadual: Processo no 18/67. Inscrição n¹8. Data: 20/10/1967. (PARANÁ, 2006, p. 346).

${ }^{43}$ Tombamento Estadual: Processo no 40/72, Inscrição n 39. Data: 11/08/1972. (PARANÁ, 2006, p. 326)

${ }^{44}$ Tombamento Estadual: Processo ${ }^{\circ} 38 / 72$, Inscrição n ${ }^{\circ} 37$. Data: 01/03/1972. Tombamento Federal: Processos no 101-T e 155-T. Inscrição nº 59 e 105. Data: 24/05/1938. (PARANÁ, 2006, p. 320).

${ }^{45}$ Tombamento Estadual: Processo $n^{\circ} 222-01 / 62$, Inscrição $n^{\circ} 1$. Data: 04/11/1962. Tombamento Federal: Processo n 455-T. Inscrição n 391. Data: 27/02/1967. (PARANÁ, 2006, p. 340).

${ }^{46}$ Tombamento Estadual: Processo n 016/66. Inscrição n¹6. Data: 22/12/1966. (PARANÁ, 2006, p. 360).
} 


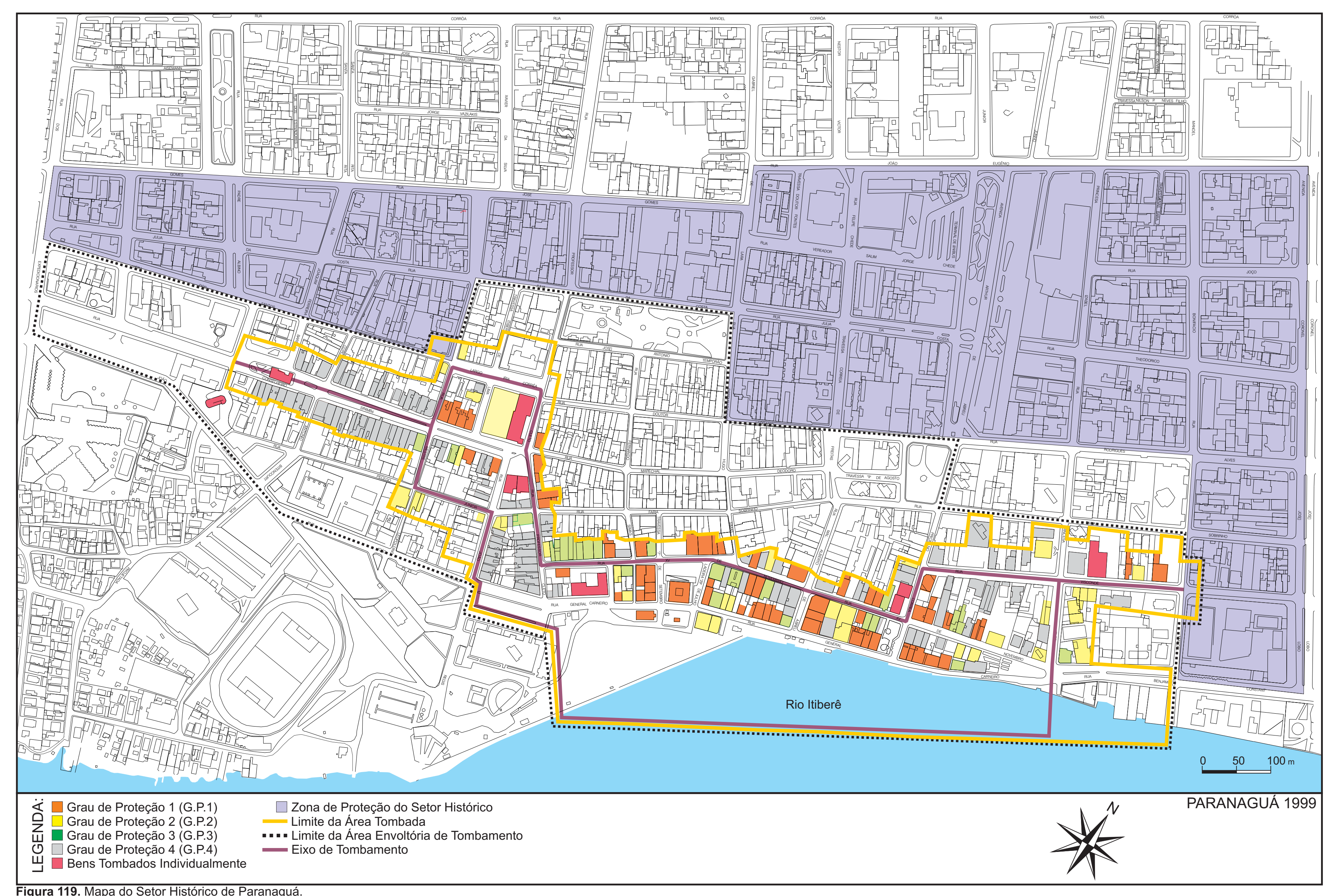

Figura 119. Mapa do Setor Histórico de Paranaguá.
Fonte: Prefeitura Municipal de Paranaguá, 1999/ Adaptado pelo autor, 2010. 

Não constam no mapa a Casa Elfrida $\operatorname{Lobo}^{47}$ e a Estação Ferroviária ${ }^{48}$, apesar de possuírem registros individuais.

Quanto aos edifícios classificados no mapa do Setor Histórico, temos pelo Grau de Proteção 1, ou seja, aqueles que possuem importância arquitetônica e histórica, possibilitando a recuperação de suas características originais: a Praça do Mercado, o Palacete Mathias Bohn, algumas edificações na rua da Praia, a casa do coronel João Guilherme Guimarães e algumas residências no largo da Matriz. Quanto ao Grau de Proteção 2, temos construções importantes para o conjunto urbano, que já sofreram algum tipo de alteração em suas características originais, possibilitando sua restituição, neste caso encontram-se algumas residências na rua Pecego Junior, o edifício ao lado da igreja Matriz e outras pequenas construções ao longo desta área. Pelo Grau de Proteção 3, definidos como unidades de acompanhamento, em que devem ser preservadas a volumetria, possibilitando alterações internas e externas, são encontradas grande parte das construções do Setor Histórico, classificadas desta forma, como as inseridas na rua XV de Novembro. Por fim, o Grau 4, que pela definição possibilita a substituição integral do edifício, chama nossa atenção o grande conjunto de construções existentes na rua Conselheiro Sinimbú, uma das vias mais antigas da cidade, também temos outro conjunto, na mesma situação, localizado na rua Professor Cleto e João Régis e outra concentração na rua Visconde de Nácar.

Após compreender como se desenvolveu a vila e depois cidade durante os séculos XVIII e XIX, é possível analisar de que forma, esse sistema, aplicado pela Prefeitura de Paranaguá e pelo Governo do Estado, é eficiente no propósito de preservar o importante conjunto urbano que manteve em seu traçado as feições

\footnotetext{
${ }^{47}$ Tombamento Estadual: Processo n 021/90. Inscrição n¹20. Data: 08/11/1999. (PARANÁ, 2006, p. 324).

${ }^{48}$ Tombamento Estadual: Processo n 011/90. Inscrição n¹08. Data: 14/12/1990. (PARANÁ, 2006, p. 329).
} 
dessa cidade nos séculos XVIII e XIX. Primeiramente enfocando na rua Conselheiro Sinimbú, que foi, em conjunto com a rua do Fogo, o núcleo urbano inicial de Paranaguá, após a transferência do povoado da ilha da Cotinga para o continente.

Analisando o mapa do Setor Histórico de Paranaguá, mais precisamente nas proximidades da igreja de São Benedito, observa-se um grande conjunto de construções dos dois lados desta via, indicado com o Grau de Proteção mais baixo. Esse eixo vai da igreja até a rua Mestre Romão, contando com aproximadamente 38 construções que podem ser demolidas integralmente, desde que, respeitando as leis de volumetria estabelecidas pela prefeitura. Mas, considerando a rua um eixo importantíssimo na formação da Paranaguá setecentista, algumas construções ali existentes possuem relevância, a ponto de não se justificar esta classificação estabelecida.

Nesta rua, encontram-se construções do século XVIII, já alteradas, mas que ainda revelam suas características originais. Temos um conjunto ao lado da igreja de São Benedito, no qual se observam as aberturas em verga reta e a baixa altura. Dentre elas uma se destaca: possui janelas e portas desalinhadas (Figura 120) e está implantada um pouco à frente das construções lindeiras, é possível, apesar das mudanças na cobertura e na instalação de uma platibanda, que esta seja uma construção da vila do século XVIII, isto também é observado no mapa de 1815 , em que na lateral da igreja de São Benedito identificam-se duas construções separadas e uma delas está mais à frente do que a outra; mais uma evidência que possibilita classificá-la como parte desta ocupação inicial nas proximidades da fonte da Gambôa, a poucos metros deste local. Podemos considerar que a casa em discussão é a mesma dos registros do século XVIII, conforme visto anteriormente. 


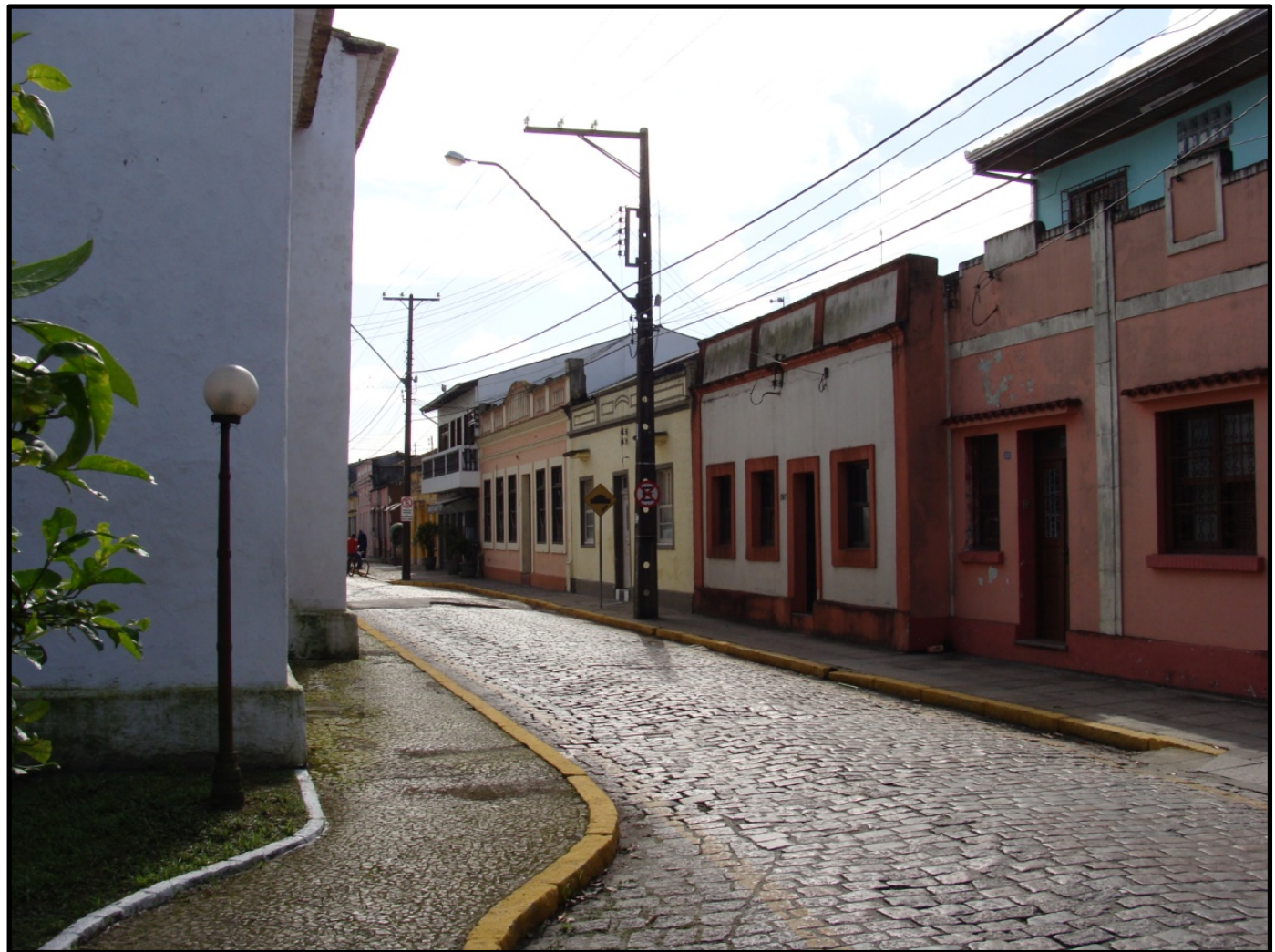

Figura 120. Construções na lateral da igreja de São Benedito, em que se permite a demolição. Fonte: Acervo do autor, 2009.

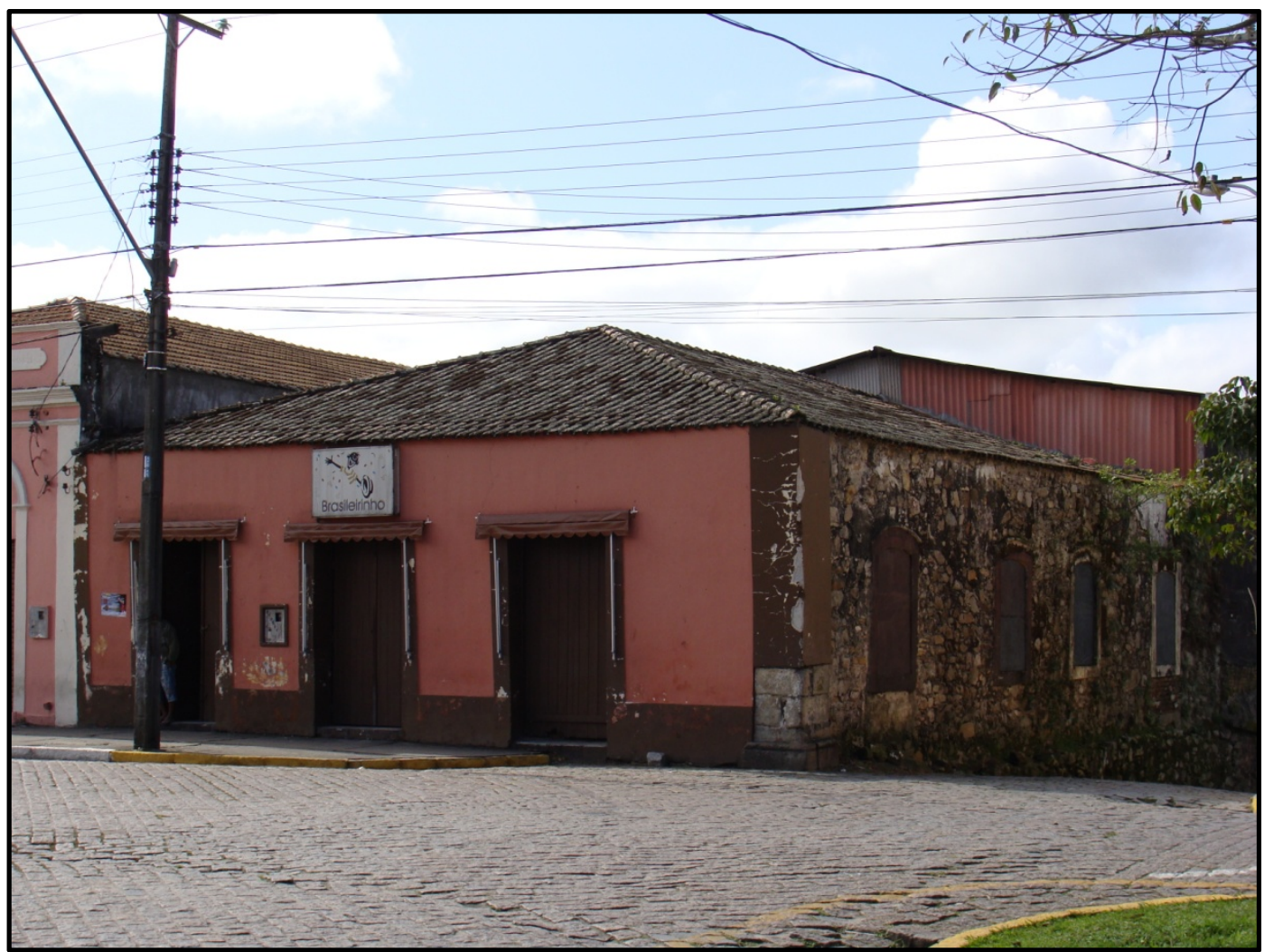

Figura 121. Casa térrea situada na esquina da rua Sinimbú com Antonio Bittencourt, em que se permite a demolição.

Fonte: Acervo do autor, 2009. 
Caminhando um pouco mais à frente, na esquina da rua Sinimbú com a Coronel Antonio Bitencourt, temos outra construção do século XVIII ou início do XIX: uma casa térrea (Figura 121), que possui cunhal em cantaria, na qual se observa sua parede lateral em pedra e barro, sem nenhum tipo de reboco. Essa é outra construção que pode ser demolida, de acordo com a atual lei municipal, e que não recomendamos tal ato. Outra casa sob o mesmo risco é bem peculiar pela sua baixa altura (Figura 122), provavelmente da metade do século XVIII. Esta construção é a mais baixa desta rua, se não for a de todo o Centro Histórico, e mereceria uma intervenção significativa em sua estrutura, com vistas a manter seu valor tipológico e urbano.

Assim, como as construções deste período, também existem casas e sobrados do final do século XIX e início do século XX sob a mesma ameaça. Algumas são adaptações das construções de séculos anteriores, reformadas e alteradas para configurar-se à nova estética da época, com a adição de elementos decorativos, como a platibanda. De uma maneira geral, se observamos o conjunto da rua Conselheiro Sinimbú, nota-se a volumetria e distribuição dos lotes de forma a aproveitar ao máximo a área de ocupação(Figura 123): são lotes estreitos, que formam esse conjunto de construções delgadas, que podem ser observadas no mapa de 1815 e também nos dias atuais.

Nesta mesma rua, existem apenas seis construções com Grau de Proteção 1, dentre as quais um conjunto de dois sobrados contíguos (Figura 124), que possuem altura mais baixa se comparados a outros sobrados, encontrados na cidade. Este conjunto, possivelmente classificado como obras do século XVIII, ainda apresenta algumas de suas características originais, apesar das alterações nas aberturas e no telhado. 


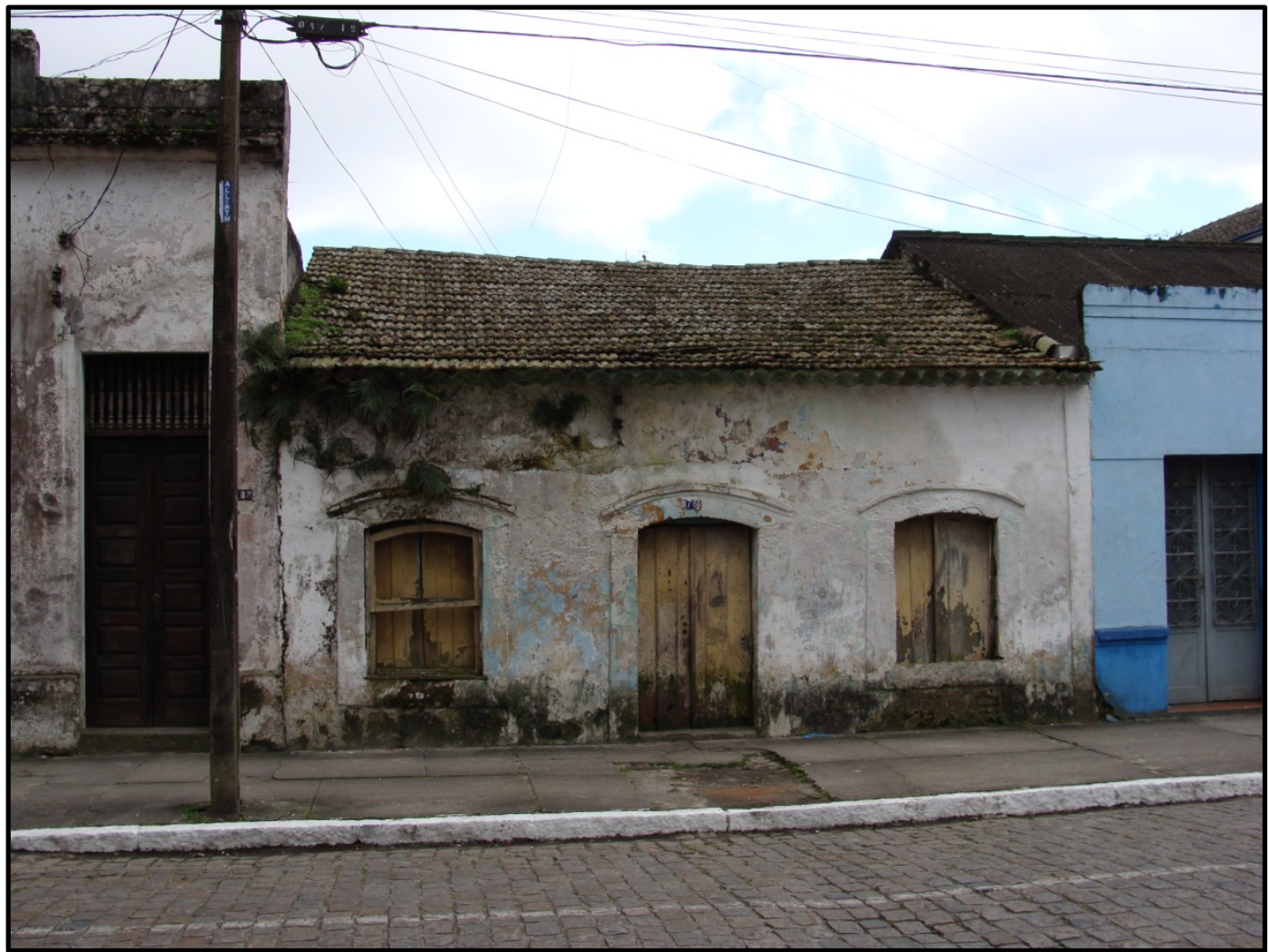

Figura 122. Pequena casa localizada na rua Conselheiro Sinimbú. Fonte: Acervo do autor, 2009.

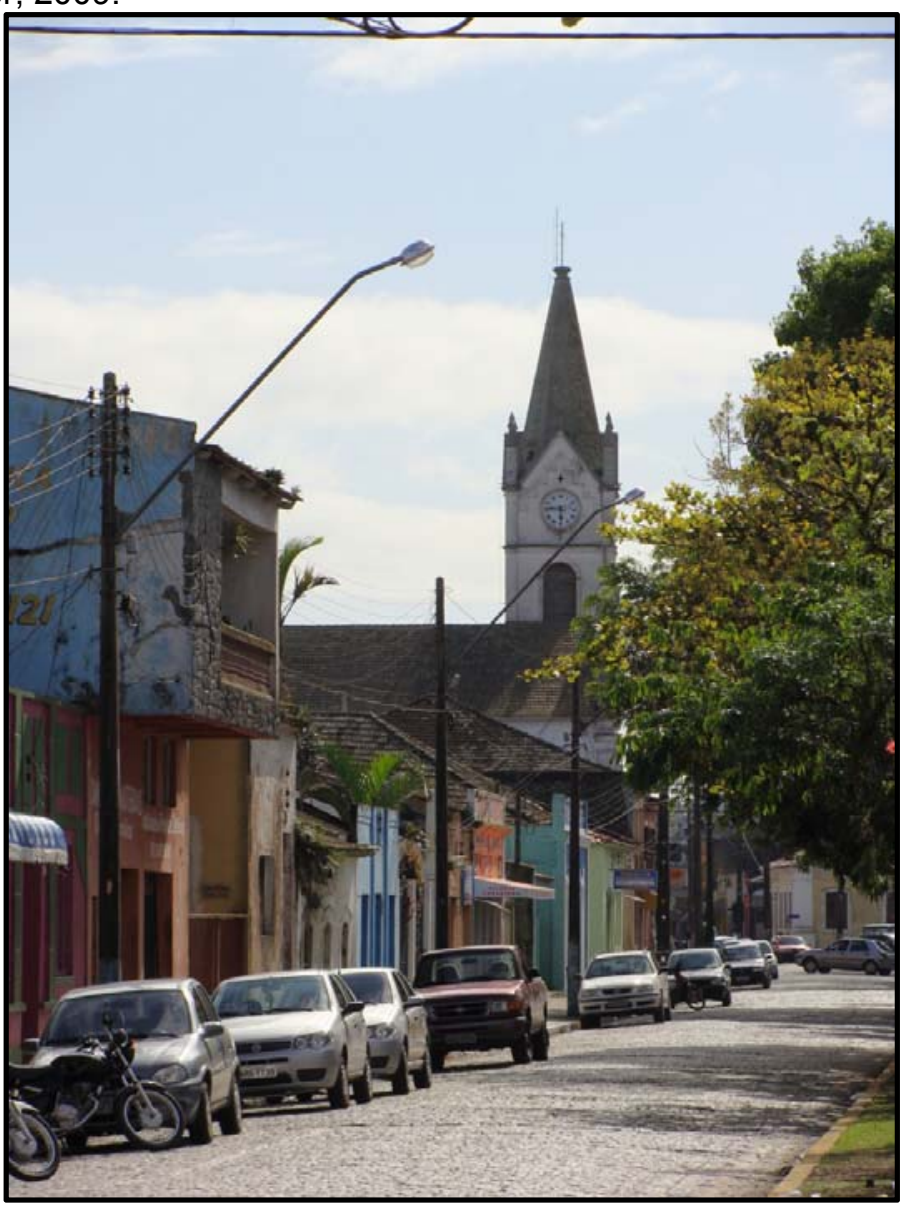

Figura 123. Conjunto de construções localizadas na rua Conselheiro Sinimbú. Fonte: Acervo do autor, 2009. 


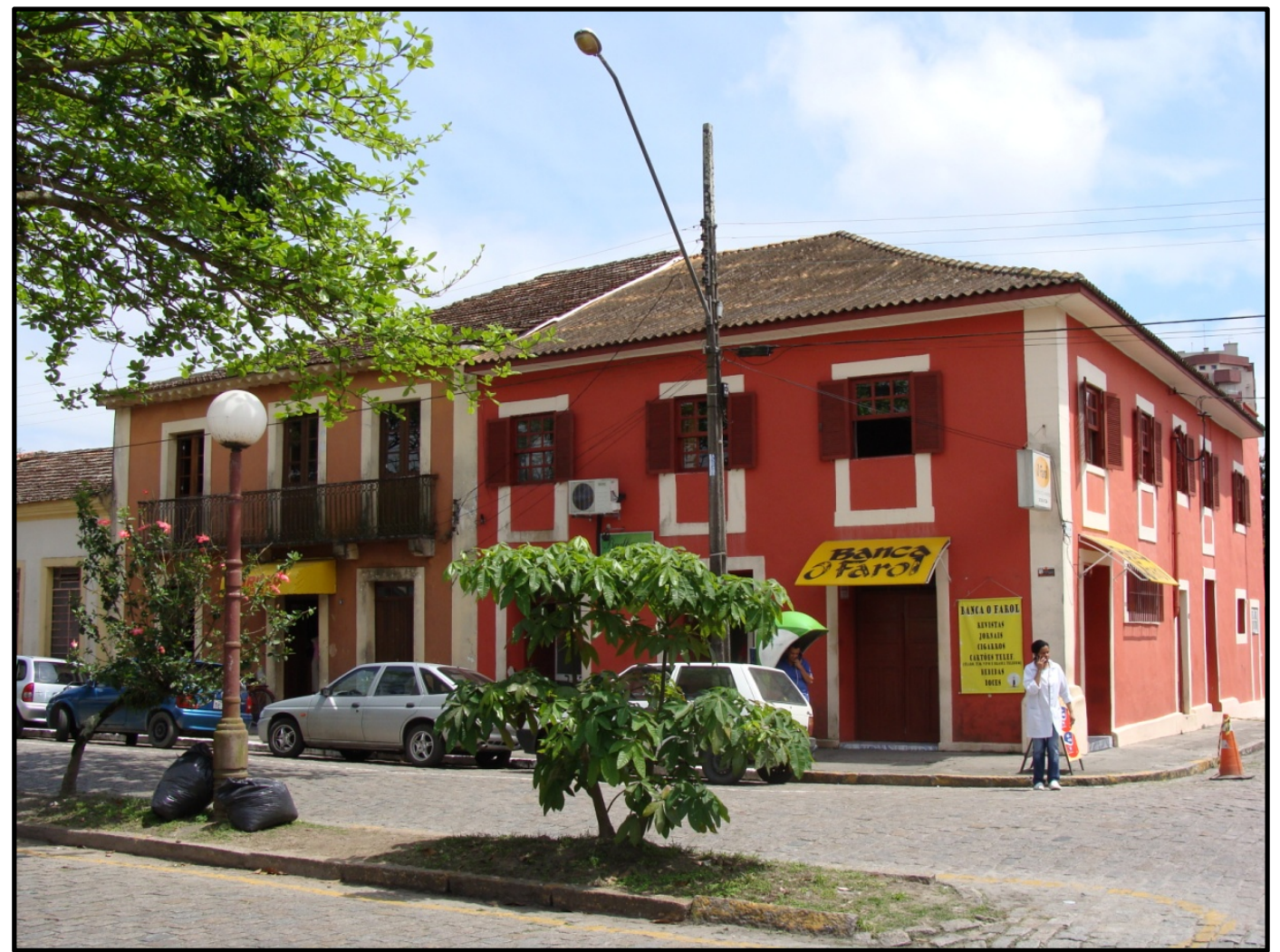

Figura 124. Conjunto de sobrados baixos na rua Sinimbú.

Fonte: Acervo do autor, 2009.

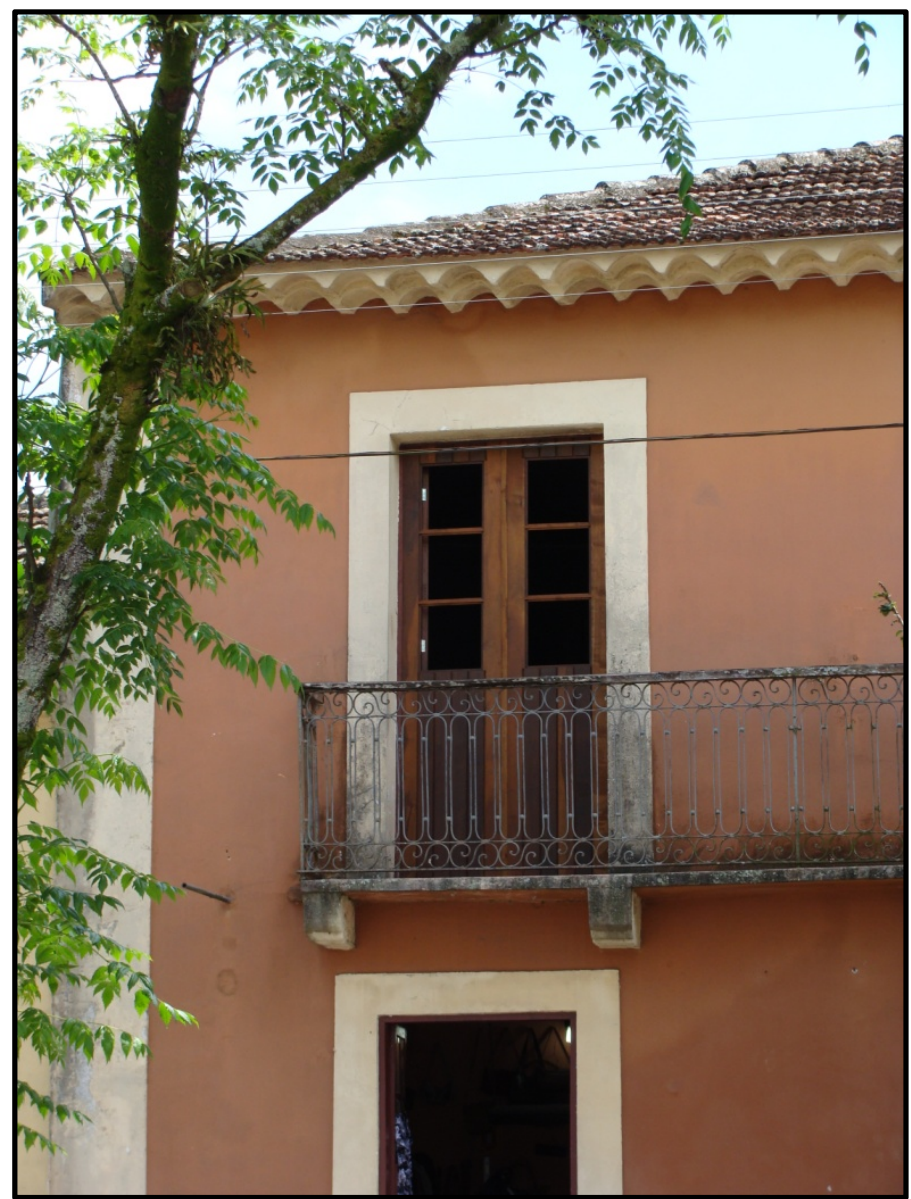

Figura 125. Cachorros em pedra do sobrado localizado na rua Sinimbú.

Fonte: Acervo do autor, 2009. 
São construções semelhantes às descritas por Vieira dos Santos, de baixa altura e que contrastavam com as novas casas térreas, mais altas, que começavam a ser construídas naquele período. Outra peculiaridade encontrada no sobrado que possui sacada, é o fato de sua estrutura ainda ser sustentada pelos cachorros em pedra (Figura 125), uma das únicas a preservar esta característica, em Paranaguá.

Continuando com a mesma preocupação, em relação as primeiras vias formadoras da cidade de Paranaguá, analisaremos agora a situação em que se encontra a rua do Fogo, atual Vieira dos Santos (Figura 126). Nessa via não existe nenhum tipo de classificação das construções, ou seja, nenhum tipo de grau de proteção é ali encontrado. Parte dela já não possui construções configuradas originalmente, mas ainda é possível identificar alguns resquícios desta ocupação. Existe um conjunto de casas de aberturas em verga reta, sendo que uma delas está em ruínas (Figura 127) e que revelam aspectos de sua configuração durante o século XVIII. Essas construções, apesar de alteradas, são semelhantes às encontradas próximas à igreja de São Benedito e podem até ser contemporâneas. São construções simples em que uma porta é ladeada por uma janela de cada lado, as vergas e umbrais destas aberturas foram construídas em tijolos, conforme identificado em uma das ruínas desta rua.

Nesta mesma via, encontra-se uma residência que consideramos importante dentro da formação de Paranaguá no século XVIII, o único exemplar de construção em pau-a-pique (Figura 128 e Figura 129) encontrado na cidade, possivelmente contemporânea à vinda do Ouvidor Pardinho em 1720, que constatou o grande número de construções deste tipo na pequena vila. 


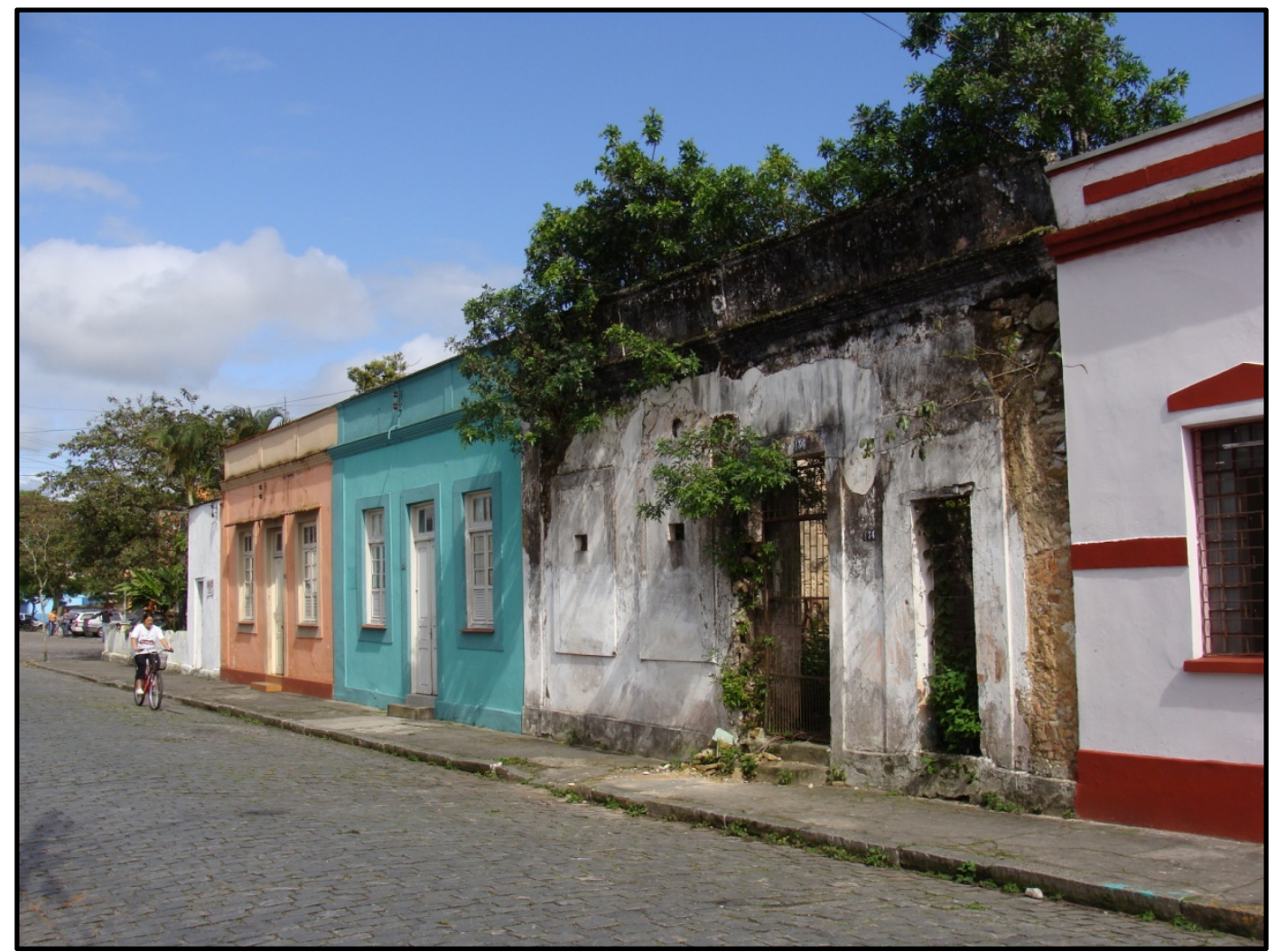

Figura 126. Construções encontradas na rua do Fogo, atual Vieira dos Santos. Fonte: Acervo do autor, 2009.

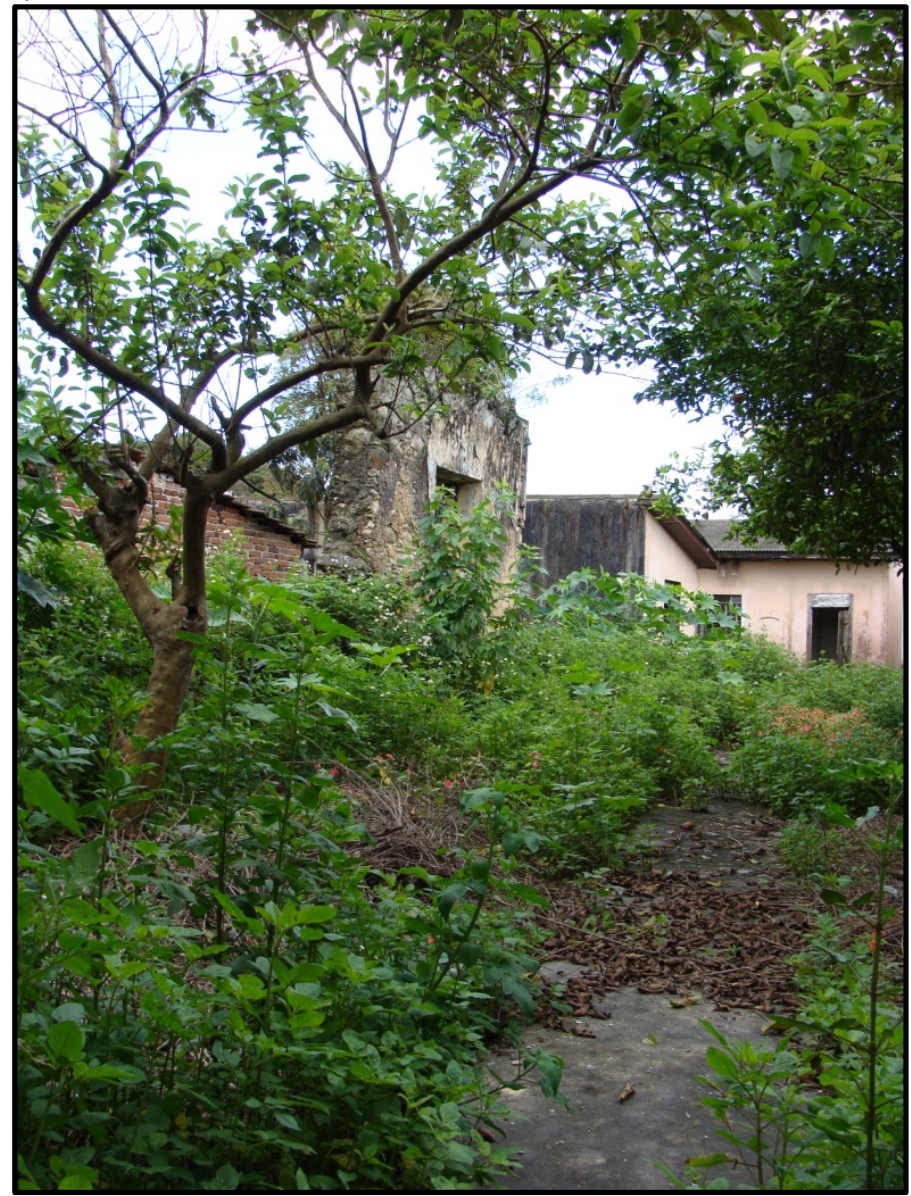

Figura 127. Ruínas encontradas na rua Vieira dos Santos.

Fonte: Acervo do autor, 2009. 


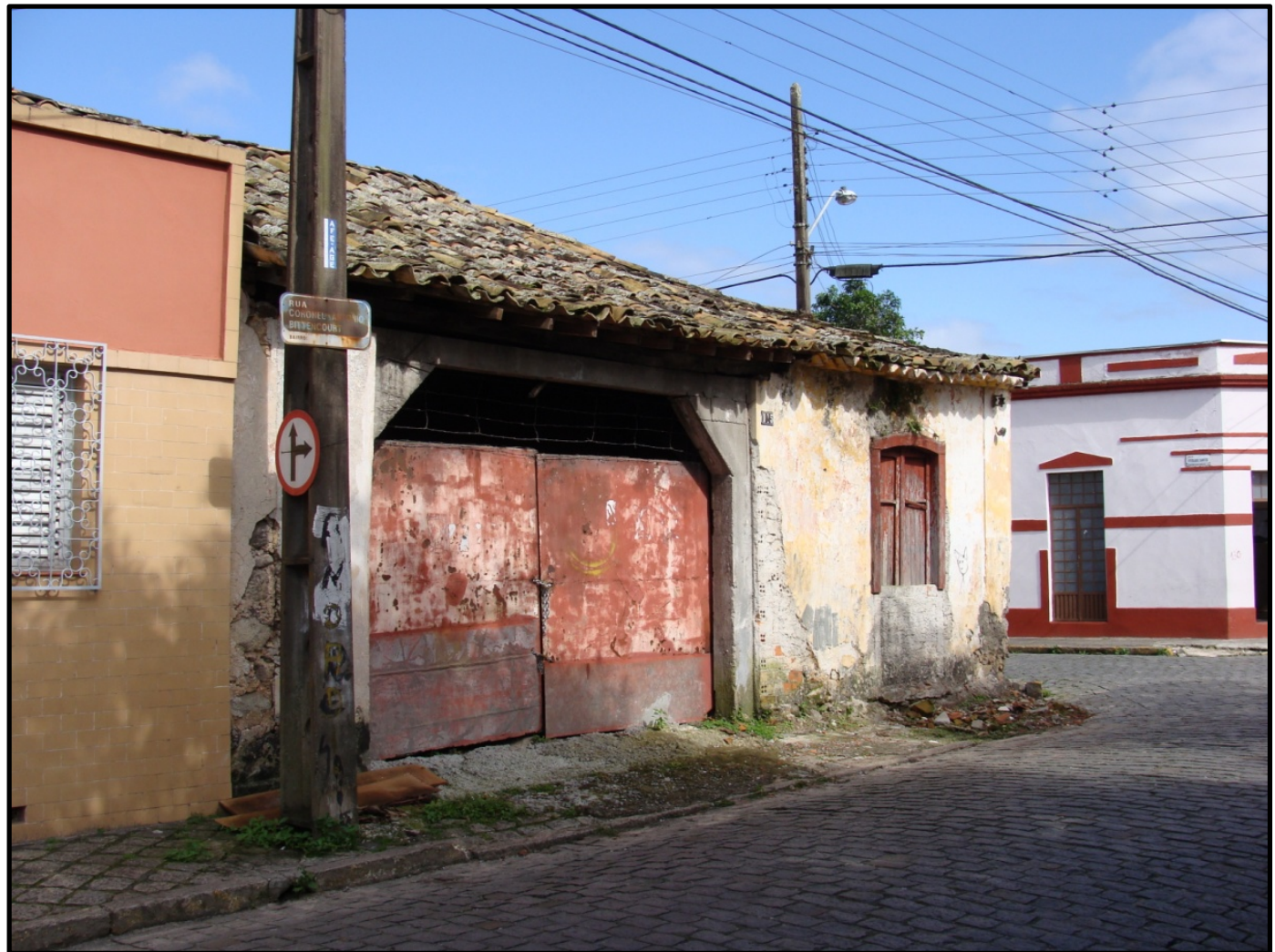

Figura 128. A última casa de pau-a-pique de Paranaguá, vista da rua Cel. Antonio Bitencourt. Fonte: Acervo do autor, 2009.

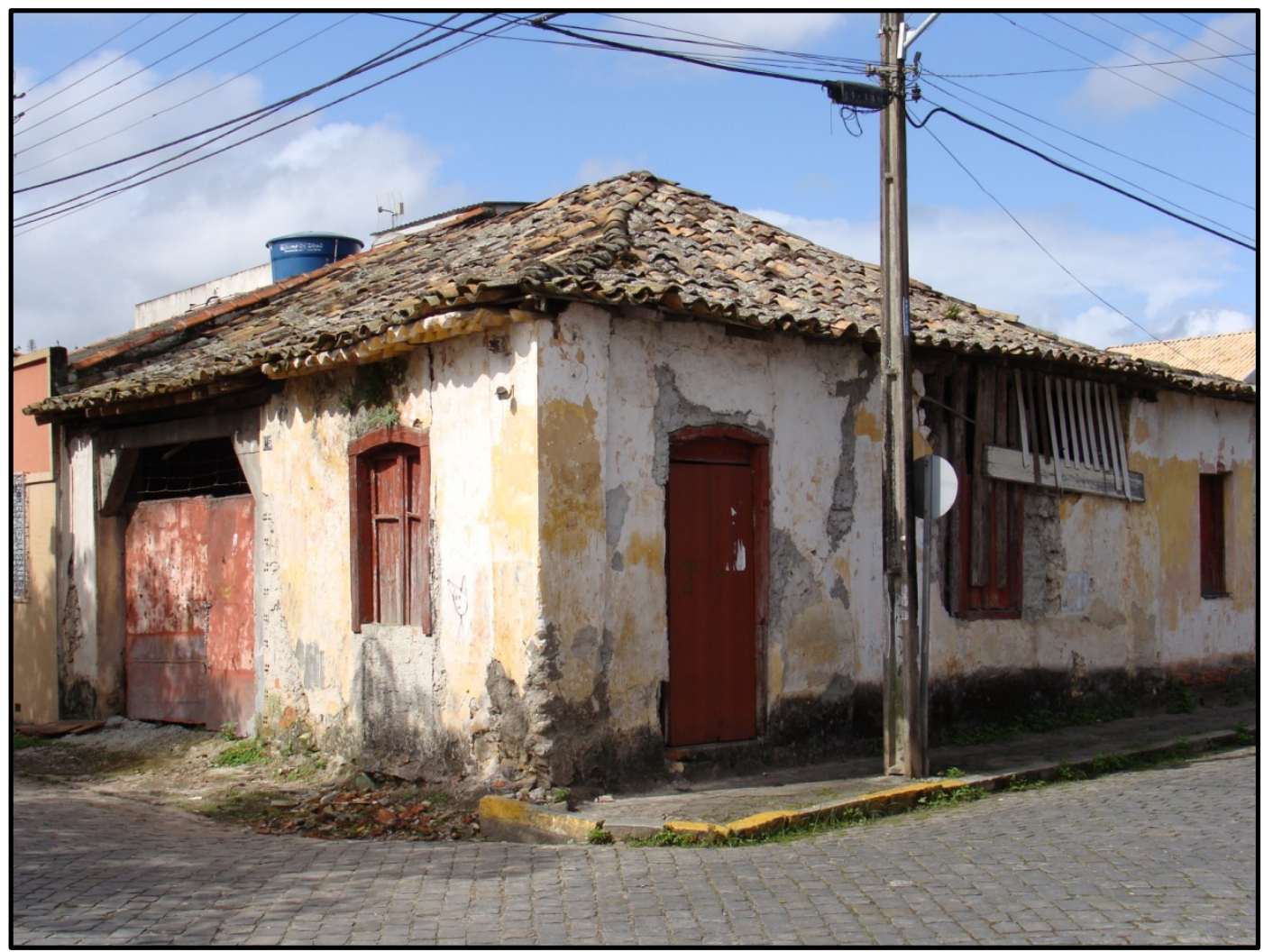

Figura 129. A casa de pau-a-pique, vista da rua Vieira dos Santos.

Fonte: Acervo do autor, 2009. 
Esta residência está localizada na esquina das ruas Vieira dos Santos com a Coronel Antonio Bitencourt e traz em sua estrutura características daquele período, como suas janelas em verga de canga feitas em madeira e o antigo telhado em capa e canal, ainda sobrevivendo às intempéries. Hoje, esta propriedade particular se encontra em abandono. Apesar de estar um pouco alterada, carrega parte de suas características originais, sendo necessária sua recuperação.

Nas proximidades da igreja Matriz, temos o largo de mesmo nome, em que se encontram duas residências (Figura 130), sendo que, uma delas é térrea e a outra um sobrado. Hoje sediam Centros Culturais e são tombadas pelo Estado do Paraná. A casa térrea era residência de duas importantes figuras da cidade, o compositor Brasílio Itiberê e seu irmão Itiberê da Cunha. Ao lado desta residência, está a via aberta por Pardinho em sua estada na vila: a rua da Matriz (Figura 131), que direciona a visão para esta igreja, e ainda é reconhecível no traçado urbano de Paranaguá. Esta via remanescente apesar de sua importância e preservação não tem seu aspecto histórico reconhecido pela população.

Outra via que cria perspectiva para a igreja Matriz é a rua Senhora do Terço, atual Professor Cleto (Figura 132). Ali se encontra um sobrado do qual restou apenas a fachada (Figura 133). Sua estrutura demonstra que este edifício pode ser contemporâneo ou anterior ao Colégio dos Jesuítas. Percebe-se que nas construções civis, quase a totalidade das estruturas de portas e janelas foram feitas com o tijolo maciço. Neste edifício, as estruturas de portas e janelas foram construídas em pedra, semelhantes às encontradas no Colégio. A altura desta edificação é mais baixa do que os outros sobrados da cidade e que pode revelá-lo como contemporâneo a outras construções encontradas na rua Sinimbú, comentadas anteriormente. 


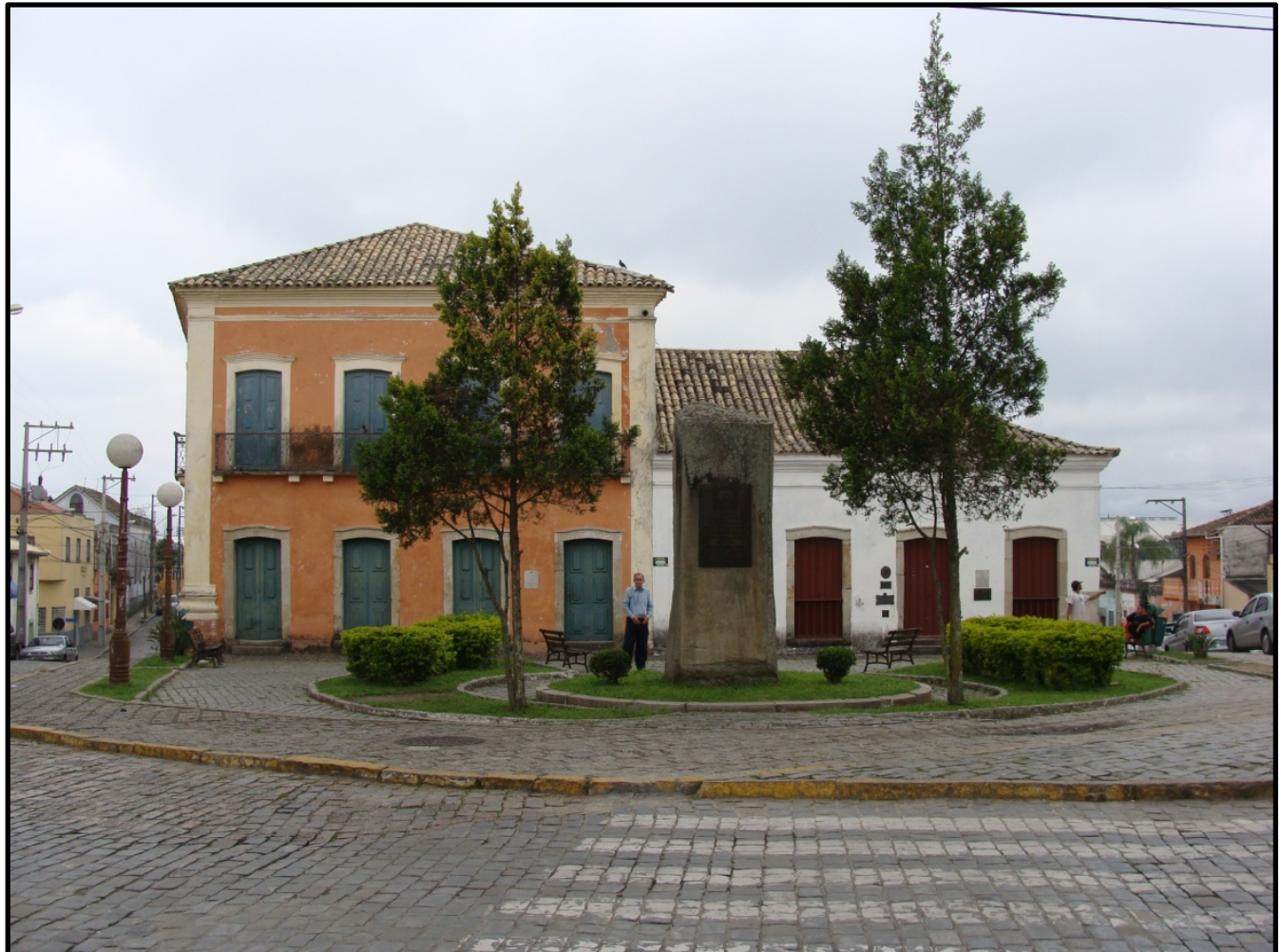

Figura 130. Largo da Matriz, do lado direito a casa de Brasílio Itiberê e a rua da Matriz, do lado esquerdo o sobrado e a rua Senhora do Terço.

Fonte: Acervo do autor, 2009.

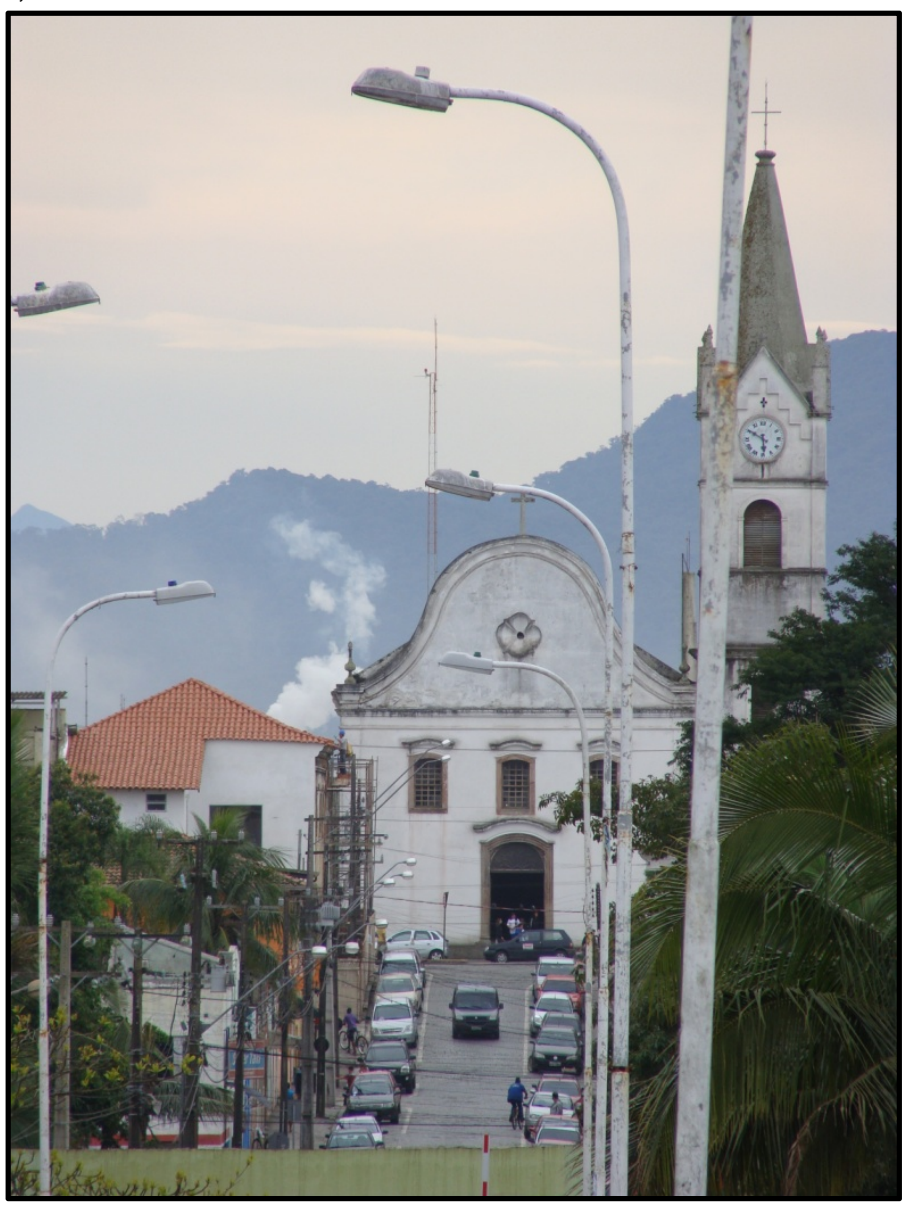

Figura 131. Perspectiva da rua João Régis, antiga rua da Matriz. Fonte: Acervo do autor, 2009. 


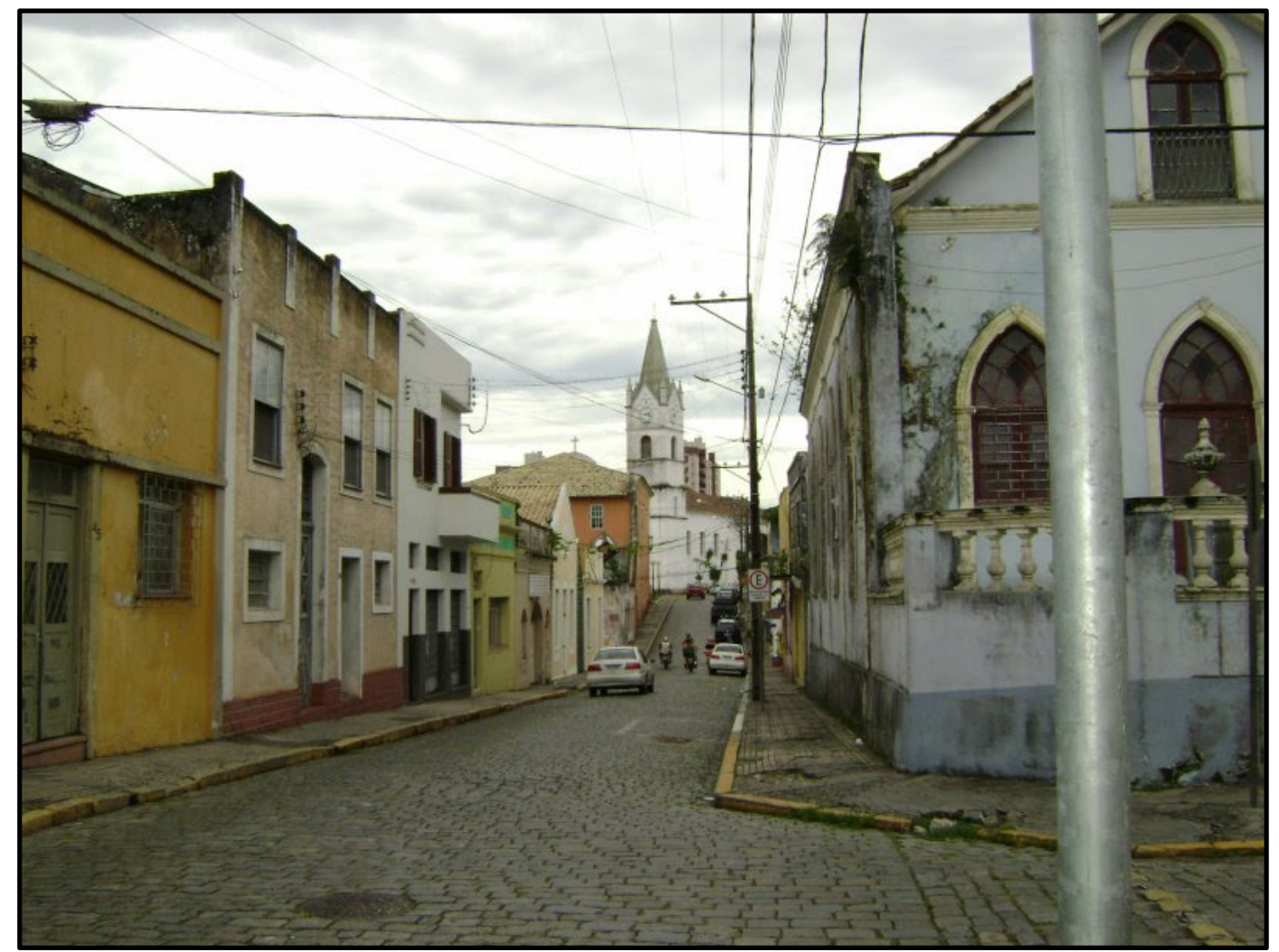

Figura 132. Perspectiva da rua Professor Cleto, antiga rua Senhora do Terço. Fonte: Acervo do autor, 2009.

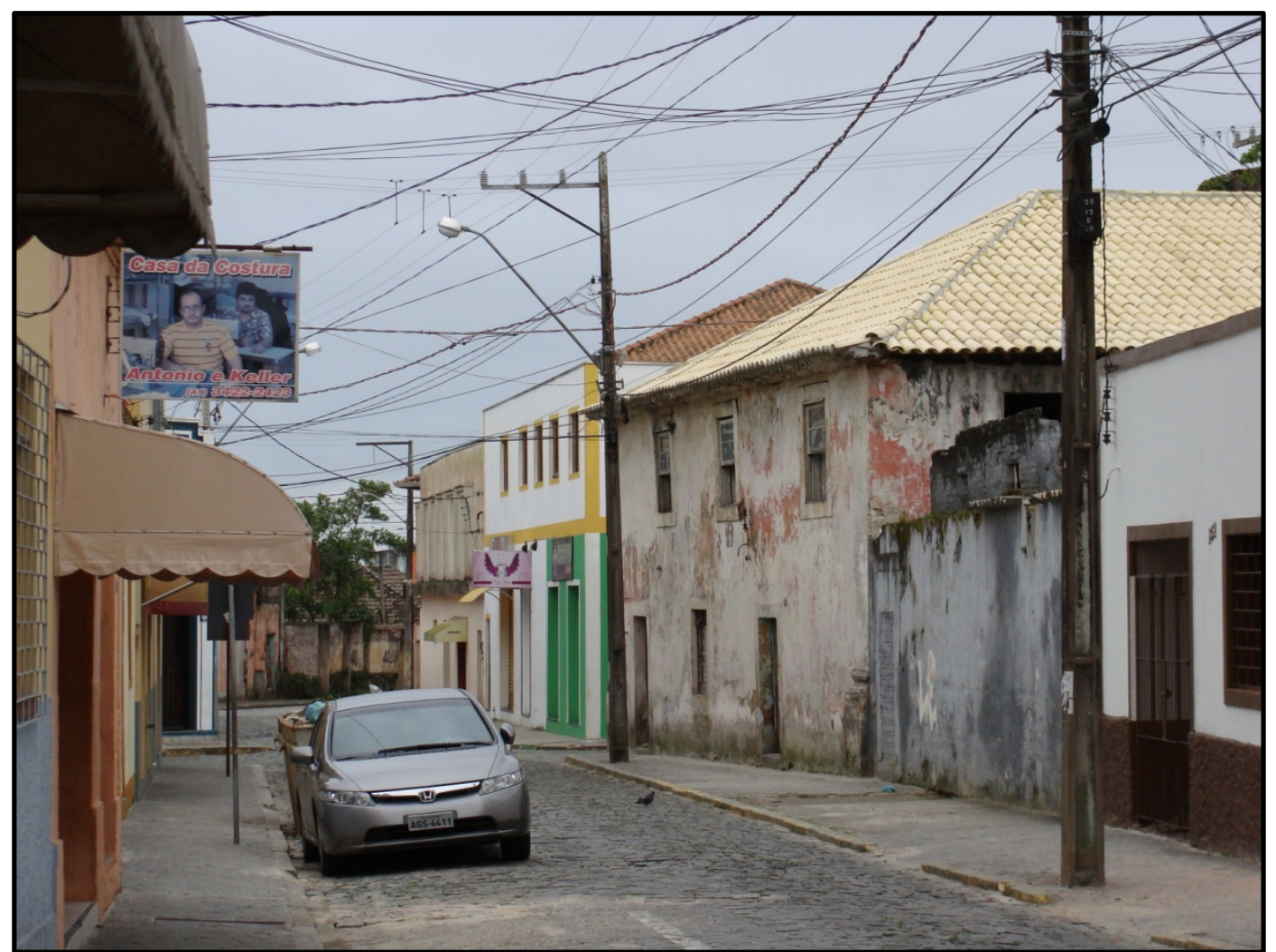

Figura 133. Antigo sobrado de esquina existente entre as ruas Faria Sobrinho e Professor Cleto. Fonte: Acervo do autor, 2009. 
O edifício está classificado com o Grau de Proteção 1, mas o que se observa em uma recente reforma, realizada no telhado e em parte de sua fachada, é o pouco cuidado do proprietário com a preservação da residência e a pouca vigilância por parte do governo.

As antigas telhas que cobriam esse sobrado foram retiradas para dar lugar a uma nova estrutura de telhado (Figura 133), que Ihe dá um aspecto inadequado. $\mathrm{O}$ telhado de coloração muito clara se destaca em relação ao corpo do edifício, com sujidades e degradações, além disso, a beira-seveira (Figura 134) desta construção foi refeita com argamassa, sem o devido conhecimento técnico. O interior continua em ruínas(Figura 135), mas felizmente o construtor não interferiu na estrutura da fachada, que permanece, degradada.

Deslocando-nos em direção a rua Princesa Izabel (Figura 136), nas proximidades do rio Itiberê, encontramos outra construção que possivelmente é anterior à metade do século XVIII, e poderia ser um dos antigos estaleiros (Figura 137) situados nas margens do rio. Esta construção ainda possui suas aberturas em verga reta e está classificada com o Grau 2, contendo características originais ainda preservadas e com parte de sua estrutura aparente. É necessária uma intervenção que possa preservar as características ainda sobreviventes no edifício.

Nas proximidades dessa mesma rua, localiza-se a rua Visconde de Nácar, antiga Boa Vista. Aí encontramos o Palacete do Visconde, que possui tombamento Estadual. Ao fim desta rua, encontra-se outra residência comentada na pesquisa, em que viveu o pintor paranaense Alfredo Andersen. Essa construção não possui nenhum tipo de classificação, e está fora da área tombada, localizando-se na área envoltória. 


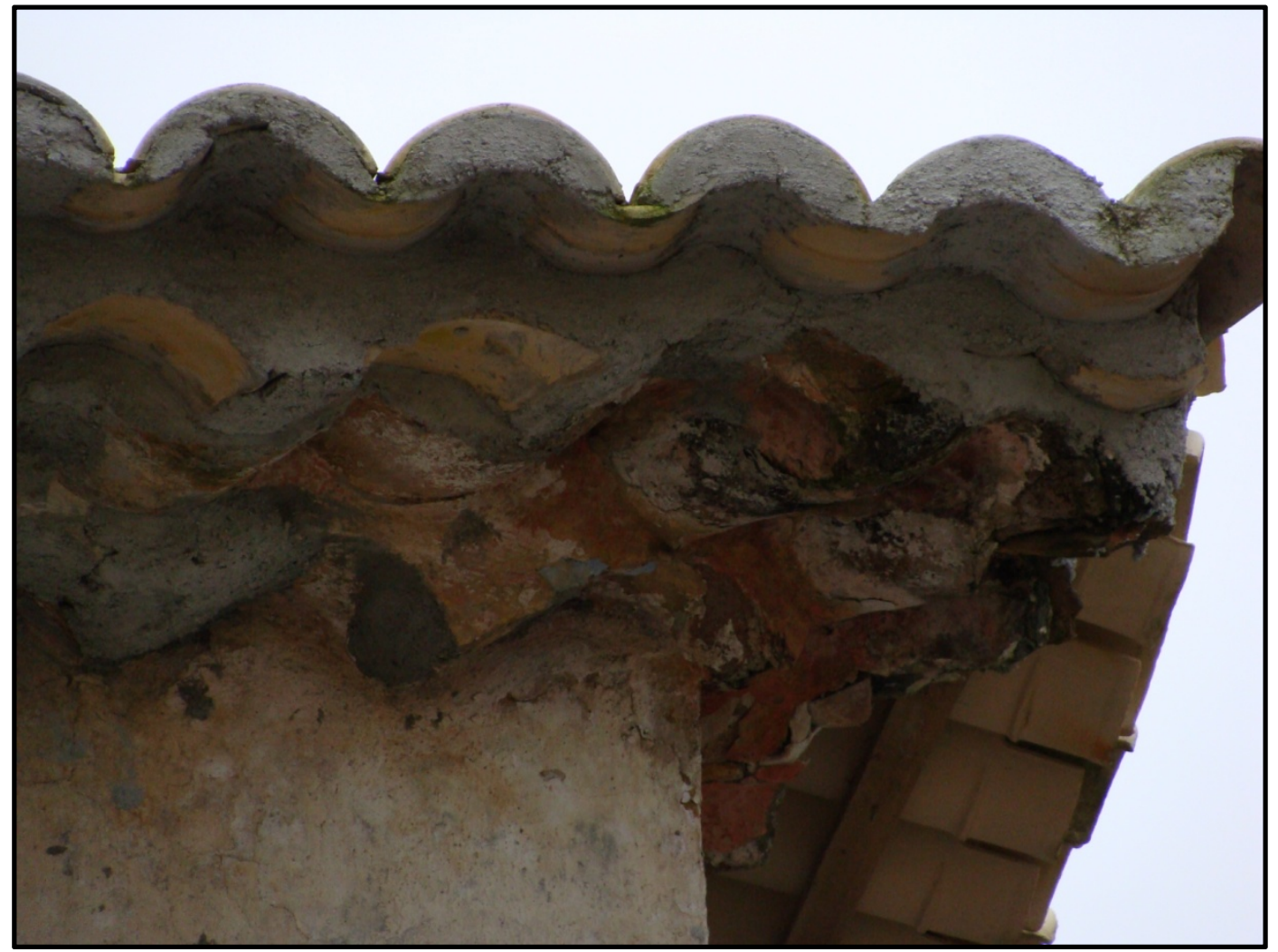

Figura 134. Detalhe da beira-seveira, reconstituída no sobrado da rua Professor Cleto. Fonte: Acervo do autor, 2009.

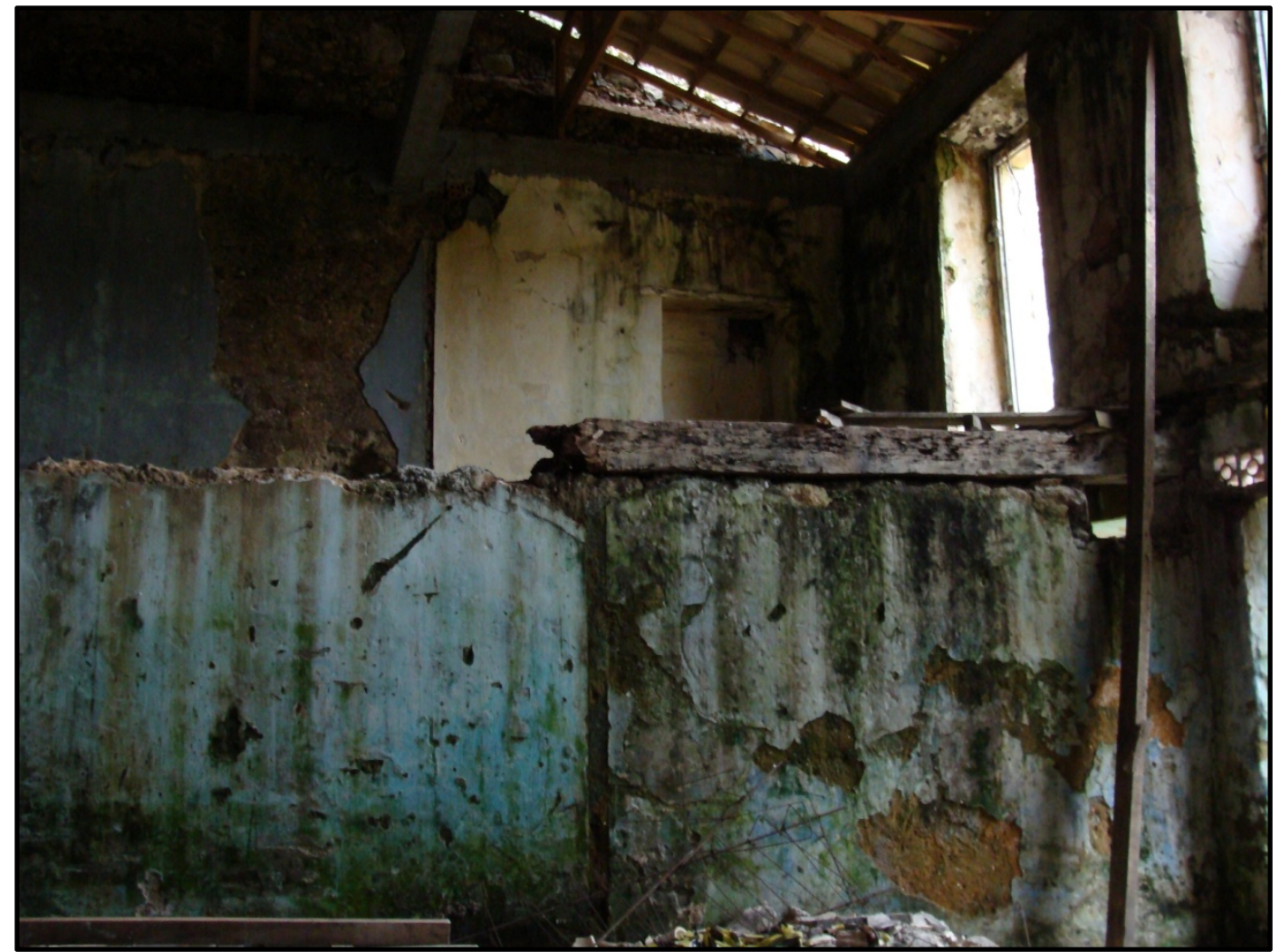

Figura 135. Interior do sobrado localizado na rua Professor Cleto.

Fonte: Acervo do autor, 2009. 


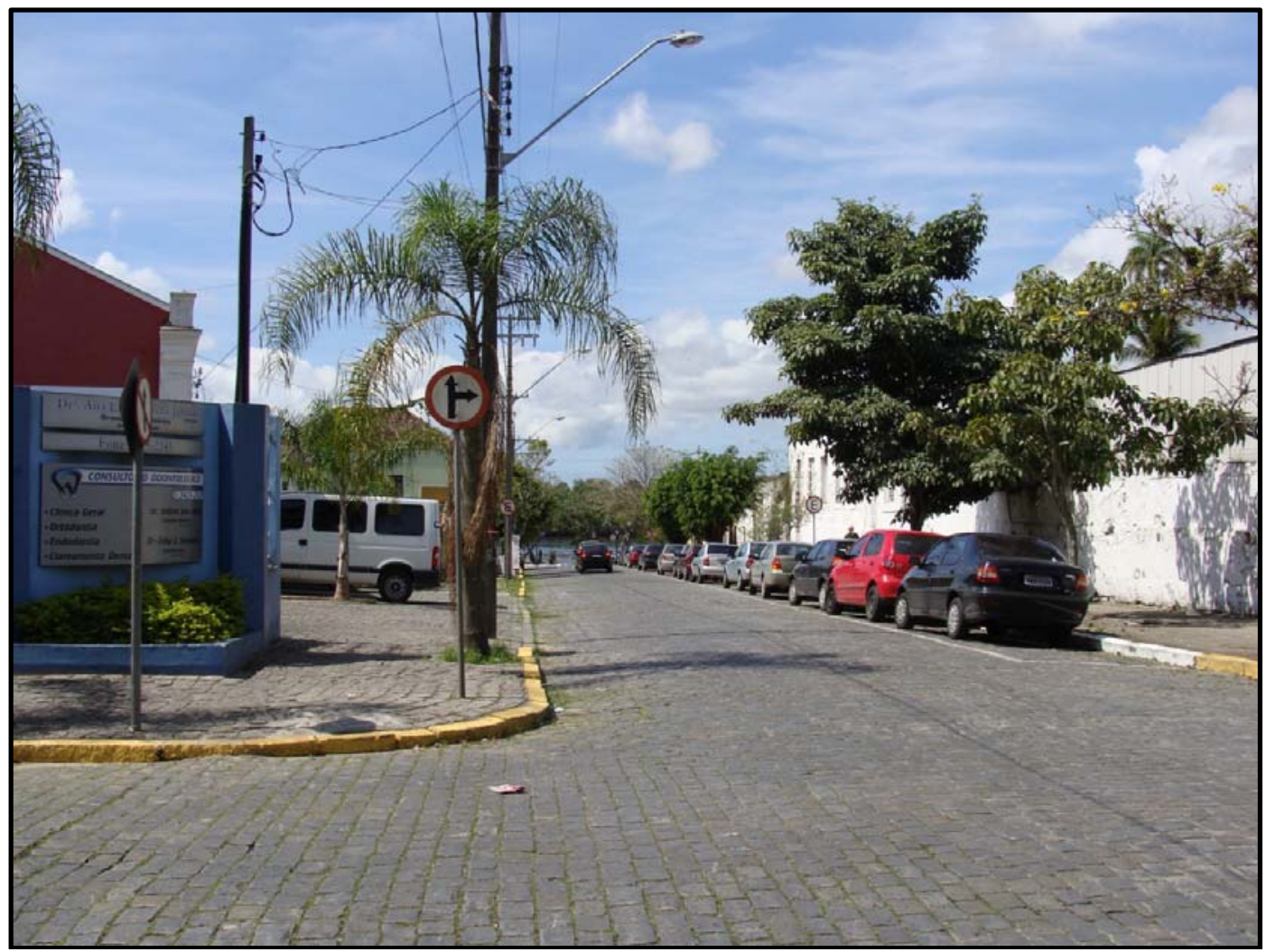

Figura 136. Rua Princesa Isabel, em branco ao lado direito o antigo estaleiro. Fonte: Acervo do autor, 2009.

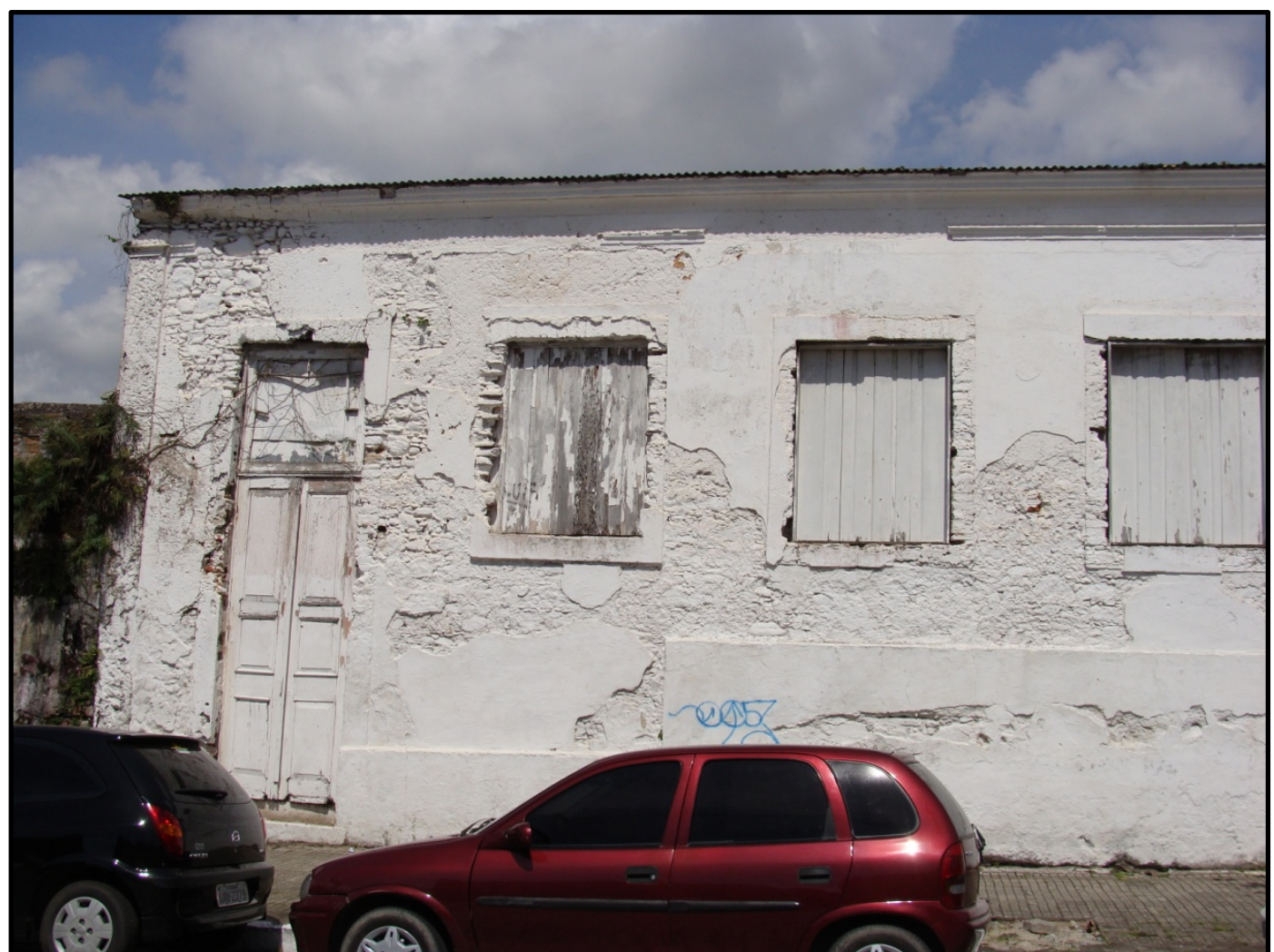

Figura 137. O estaleiro da rua Princesa Isabel e suas janelas e portas com umbrais e vergas de tijolos maciços.

Fonte: Acervo do autor, 2009. 
Através das imagens apresentadas anteriormente, observamos que sua situação é de ruína, apesar do fato de que a estrutura e as paredes manterem-se preservadas, o que possibilita uma intervenção que recupere o edifício para possíveis novas utilizações.

No caso da rua da Praia, importante via para o turismo local, temos grande parte do conjunto de casas e sobrados classificados com o grau mais rigoroso estabelecido pela Prefeitura de Paranaguá. Apenas duas construções podem ser demolidas - no início da via existe uma construção possivelmente dos anos 70 ou 80 do século $X X$, assim como o último edifício deste conjunto que também é aparentemente do mesmo período. São encontradas nesta via construções em estado de ruína (Figura 138 e Figura 139), sem nenhuma ação para a sua preservação, em grande parte delas, restam apenas as fachadas, sem qualquer tipo de contenção das estruturas, criando riscos para os transeuntes que circulam diariamente pela rua da Praia. Porque não recuperá-las e integrá-las ao contexto do conjunto urbano? São espaços ociosos que poderiam ser utilizados a partir de novas estruturas que fornecessem serviços aos moradores e turistas.

Apesar dessa situação, esta via possui construções que já sofreram alguma restauração. São utilizadas atualmente para o comércio voltado ao turismo e restaurantes, revelando a importância dada às ações de preservação nessa via. Nela se concentram pontos turísticos importantes, como o Colégio dos Jesuítas, que passou recentemente por restauração, o antigo mercado da cidade, pequenos trapiches onde se encontram barcos para o passeio na baía e o conjunto de sobrados descritos anteriormente.

A rua da Praia foi uma via comercial muito importante para a cidade, principalmente pelo funcionamento do Porto de Paranaguá. 


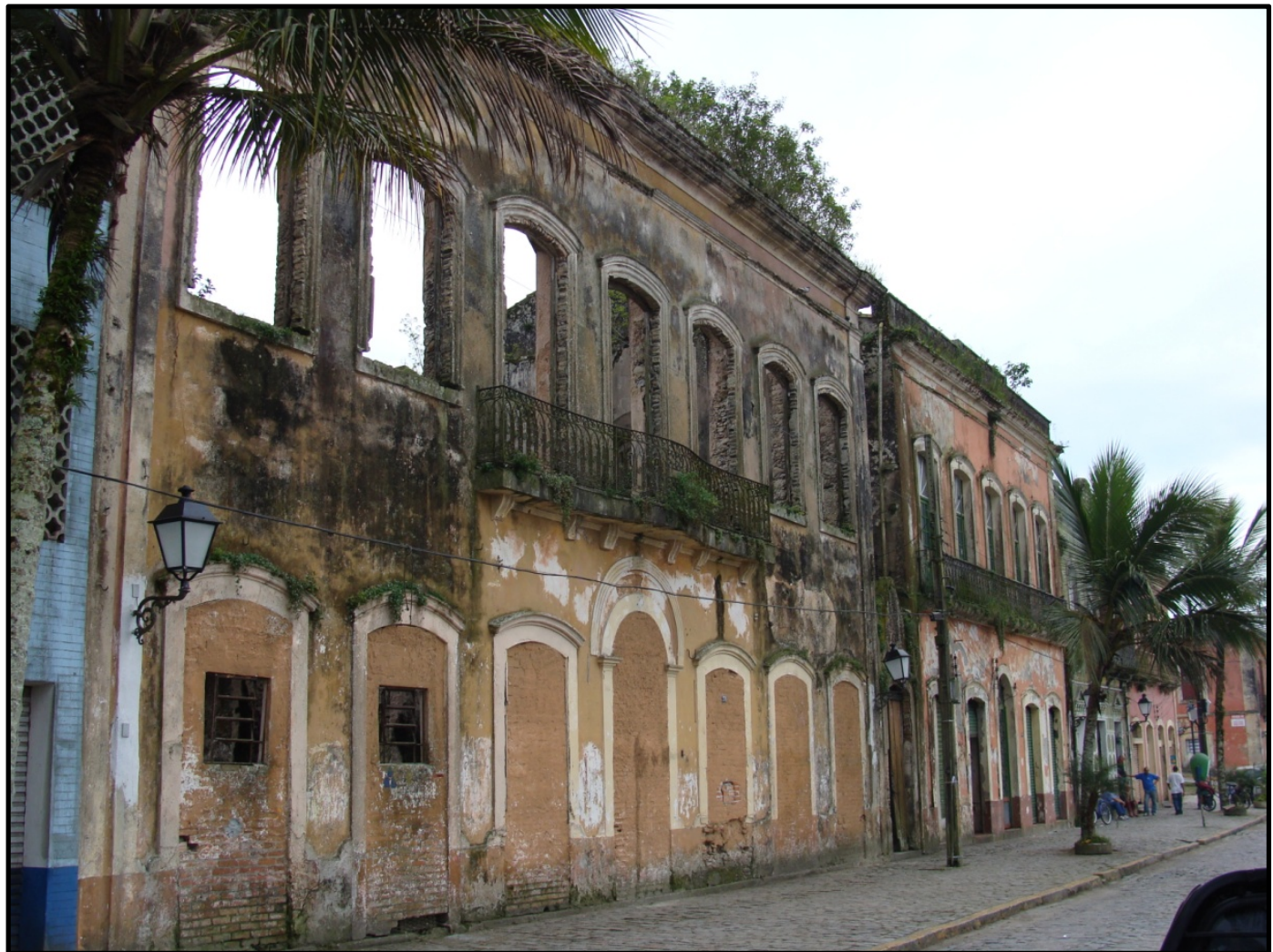

Figura 138. Sobrado localizado na rua da Praia, restando apenas sua fachada. Fonte: Acervo do autor, 2009.

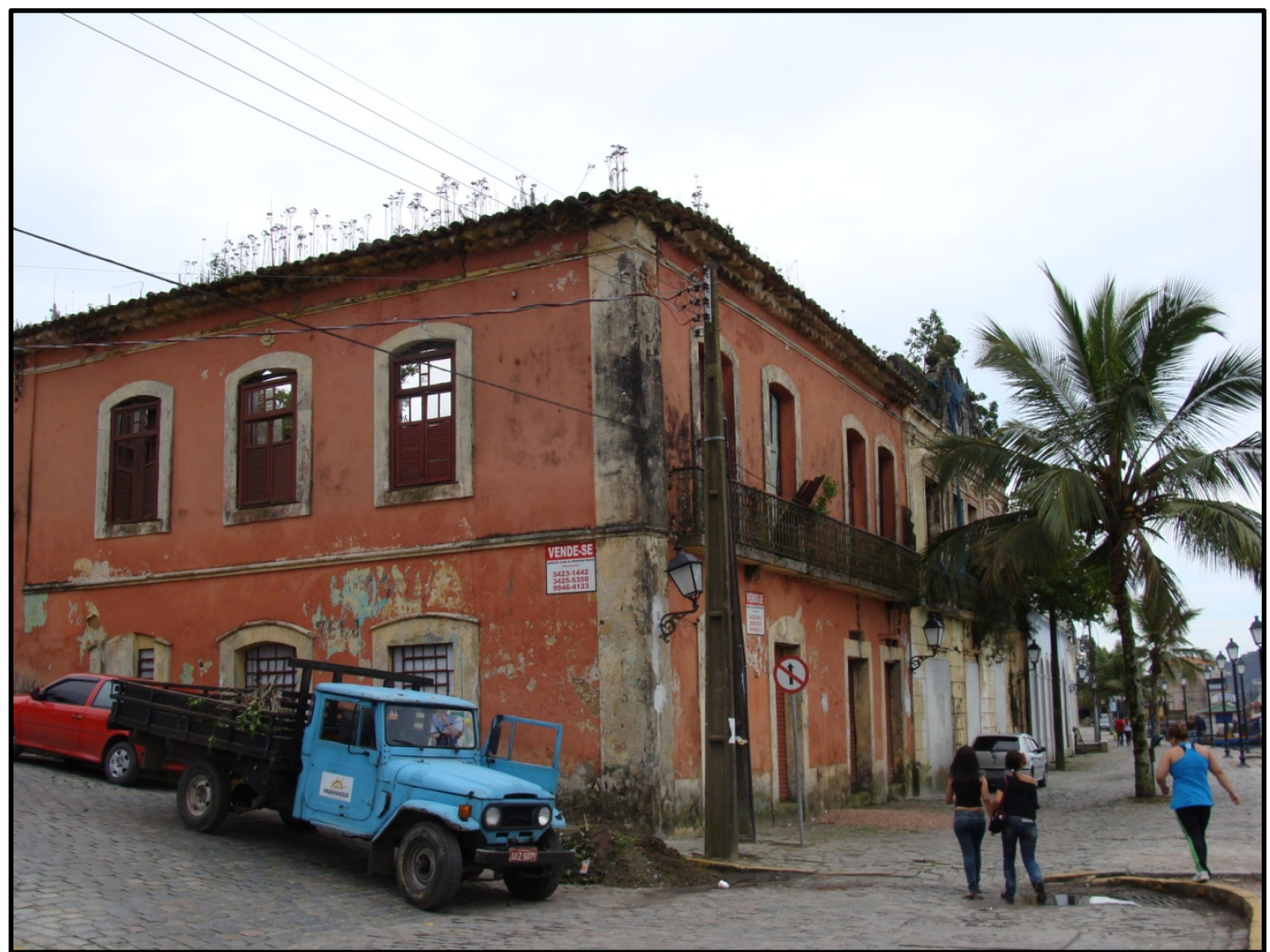

Figura 139. Ruínas de dois sobrados, localizados na rua da Praia, esquina com a rua Presciliano Correa.

Fonte: Acervo do autor, 2009. 
Percebemos atualmente, a falta de evidências desse antigo porto naquela região, elemento importante na vida cotidiana parnanguara até o começo do século $X X$, e que poderia ser mais explicitado. Ao final da referida rua, apenas resta um pequena grua (Figura 140 e Figura 141), aparentemente isolada do conjunto de casarios, que poderia ser integrado à este conjunto, possibilitando evidenciar as atividades portuárias que fizeram parte do cotidiano de Paranaguá, às margens do rio ltiberê.

De uma maneira geral, percebemos que a área de tombamento do Centro Histórico de Paranaguá é muito restrita e ainda vinculada aos principais edifícios, sem dar a devida importância ao traçado urbano da cidade. Temos a delimitação deste setor através das construções e não pelas vias. Assim, parte de ruas importantes na formação da cidade, como a rua Marechal Deodoro (Direita), rua Faria Sobrinho (Ouvidor), rua Vieira dos Santos (Fogo), rua Doutor Leocádio (do Campo), dentre as principais neste conjunto, fazem parte da área envoltória e não da área tombada. É imprescindível, pelos órgãos competentes, que ocorra maior preocupação com o traçado urbano, pois preserva parte das características de formação da vila durante o século XVIII e XIX, e, portanto, são fontes para compreender o desenvolvimento de Paranaguá em seus primórdios.

Como já foi analisado anteriormente, existem cinco eixos principais na formação da cidade: rua do Fogo/Campo, atual Vieira dos Santos/Doutor Leocádio, a rua da Gambôa/Direita, hoje rua Conselheiro Sinimbú/Marechal Deodoro, rua do Meio ou do Ouvidor, atual Pecego Junior/Faria Sobrinho, a rua da Cadeia e da Ordem, atual XV de Novembro e por fim a rua da Praia, atual General Carneiro (Figura 142). Esses eixos foram importantes no desenvolvimento de Paranaguá, durante os séculos XVIII e XIX e poderiam ser relevantes no momento de reconfigurar esta nova delimitação do Centro Histórico da cidade. 


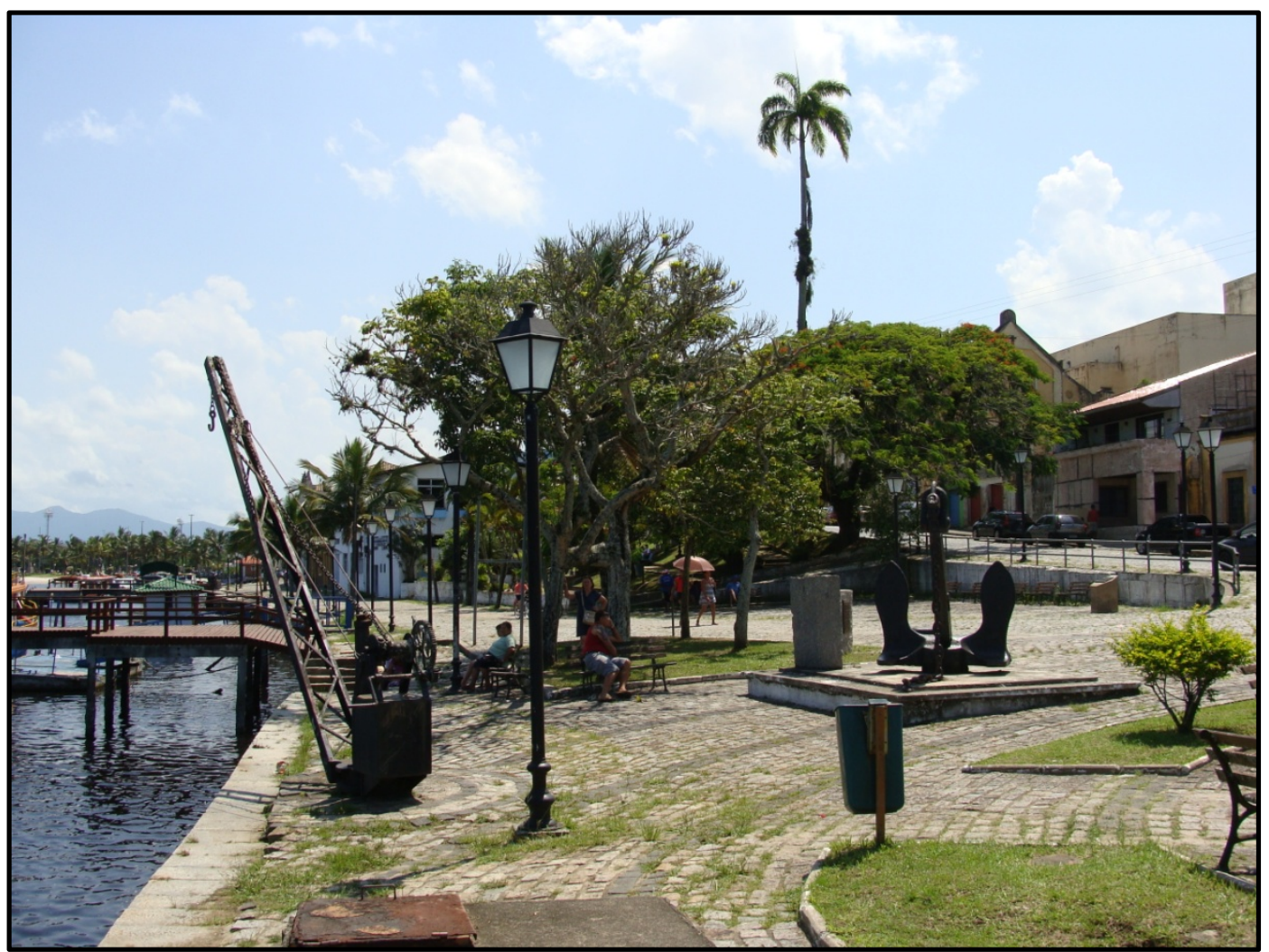

Figura 140. Grua existente no final da rua da Praia.

Fonte: Acervo do autor, 2011.

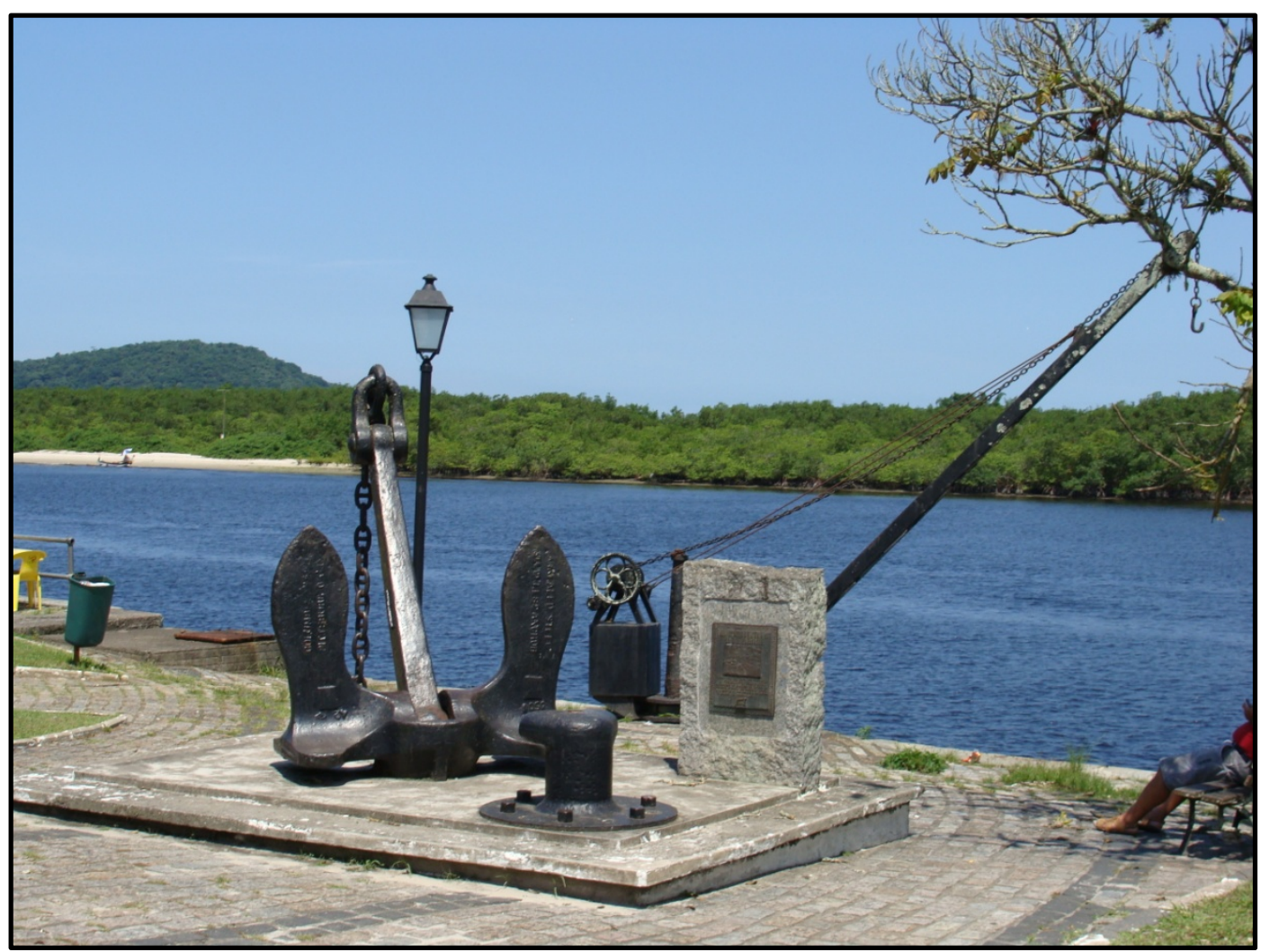

Figura 141. Em primeiro plano uma âncora com placa comemorativa de aniversário da cidade e ao fundo a antiga grua.

Fonte: Acervo do autor, 2011. 


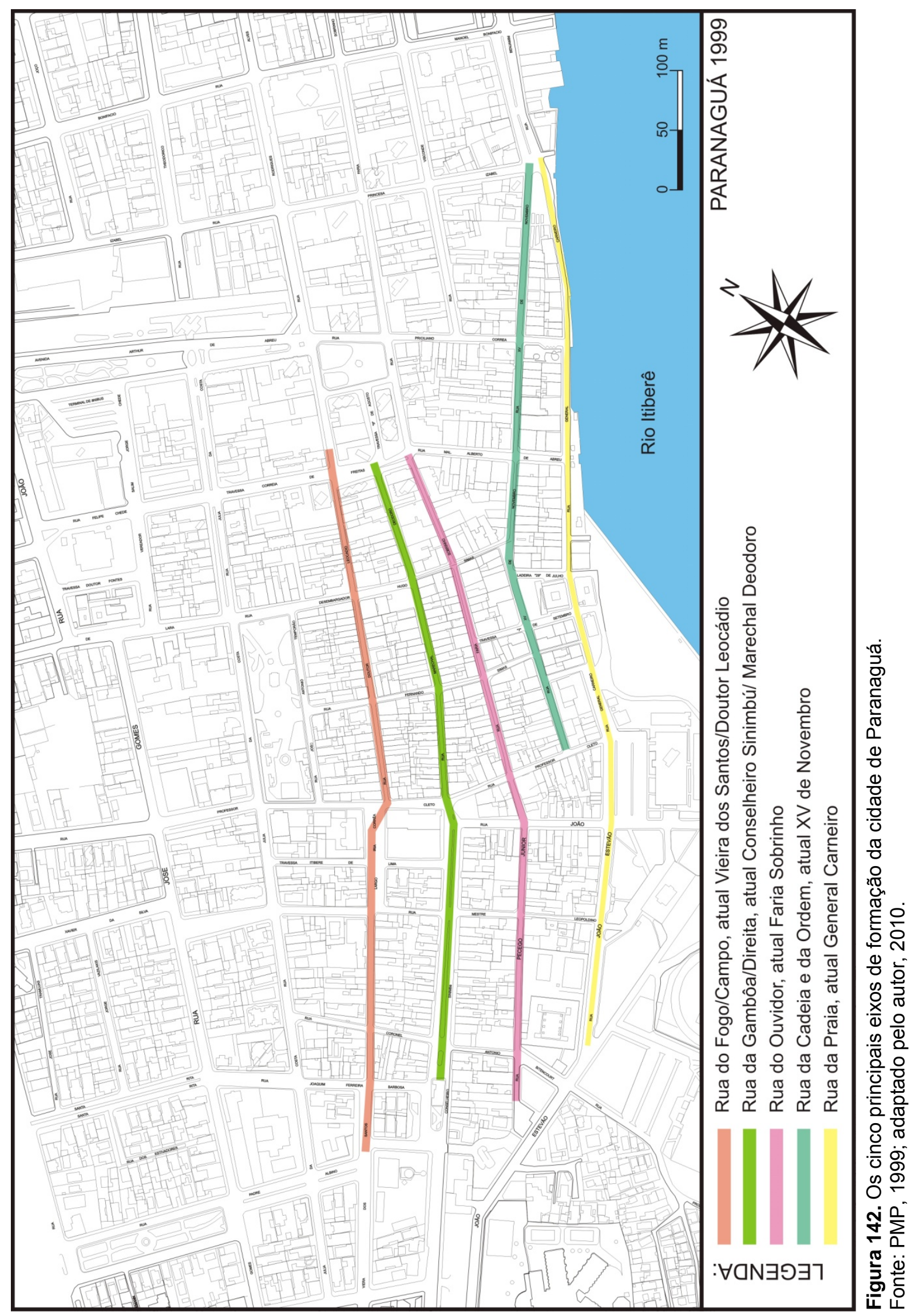


Ao invés de um eixo de tombamento, como consta no mapa desta área, deveria se utilizar cinco eixos, apontados neste estudo como os principais na formação da vila e depois cidade de Paranaguá.

A partir destes cinco eixos, poderíamos formular novas propostas de preservação desse conjunto, criando roteiros de turismo que possibilitariam compreender melhor a cidade e seu contexto de desenvolvimento. Este roteiro deveria ser acompanhado por um grande número de informações sobre a cidade, não apenas sobre seu conjunto urbano, mas também sobre suas manifestações populares que marcam as tradições e preservam a memória parnanguara, integrando o patrimônio material e imaterial. Observamos que grande parte dos turistas e visitantes que vão à Paranaguá se concentram nas regiões mais conhecidas da cidade, como a rua da Praia. Ficam esquecidas áreas importantes como a rua Conselheiro Sinimbú, a Visconde de Nácar e a rua Vieira dos Santos, devido a falta de informações sobre estes conjuntos e sua importância na formação da cidade.

Um ponto positivo é que o Centro Histórico se mantêm como centro comercial, onde também existem algumas habitações. O município deveria efetuar ações de apoio aos interessados em viver nessa região; quanto ao comércio, este deveria tirar maior proveito em relação à preservação do conjunto histórico, criando novas diretrizes para a instalação de estabelecimentos nessa área, de forma a integrar aquilo que já existe, aos novos usos que podem ser possibilitados através da restauração. Ali, são mantidos os vínculos comerciais originais, construídos desde a chegada do Ouvidor Pardinho e do desenvolvimento do porto de Paranaguá, na região da rua da Praia. O Centro Histórico da cidade é o centro comercial, financeiro e político. Lá estão concentradas as lojas, os bancos e a sede 
da prefeitura o que indica a manutenção dos mesmos usos nessa estrutura do período colonial.

De acordo com a Carta de Veneza, um novo uso, incorporado a antigas construções, pode favorecer a conservação desses edifícios:

A conservação de monumentos é sempre favorecia quando se atribui a esses monumentos função útil à sociedade, utilização essa que não pode alterar a disposição dos elementos que os compõe nem seu ambiente. É pois, dentro desses limites que devem ser concebidas e podem ser autorizadas as reformas exigidas pela evolução dos usos e costumes. (CARTA DE VENEZA, 1964, p. 2)

A própria reintegração de edifícios, de alguma forma descaracterizada aos aspectos originais, como pregam as leis estabelecidas pela Prefeitura de Paranaguá, principalmente nas classificações de Grau 1 e 2, são discutíveis. Será justificável, uma estrutura em que apenas sua fachada ficou preservada, ser reintegrada de forma a retornar às suas características originais? Ou reformas que ocorreram principalmente nos fins do século XIX e início do século XX, com a adição de platibandas, por exemplo, em estruturas coloniais poderão ser retiradas a fim de que estas construções possam se assemelhar ao que foram originalmente?

Se analisarmos como testemunhos de um processo de transformação, estas alterações deveriam ser mantidas, assim como é desnecessário o caráter de reversibilidade e retorno a um passado do qual na maioria das vezes não conhecemos plenamente a configuração. Segundo Cesare Brandi, o estudo do processo de criação e das transformações ao longo do tempo também são fundamentais para o conhecimento da obra e para nortear a tomada de decisão em um processo de restauração. E, o mais importante, nunca "presumir nem o tempo como reversível, nem a abolição da história". Ou seja, é necessário respeitar as 
mudanças posteriores pelas quais a obra passou, desde que não comprometam sua estética. (BRANDI, 2005, p.61).

De acordo com a Conferência de Nara (2000, p.321), realizada em 1994:

O conhecimento e a compreensão dos levantamentos de dados a respeito da originalidade dos bens, assim como de suas transformações ao longo do tempo, tanto em termos de patrimônio cultural quanto de seu significado, constituem requisitos básicos para que se tenha acesso a todos os aspectos da autenticidade.

Outro fator importante é que se a obra não apresenta uma unidade, e com o passar do tempo, elementos se perderam, existe a necessidade de recompor a unidade, mesmo não existindo as partes faltantes. Isto possibilitaria uma anastilose (recomposição da parte original com as peças originais). Mesmo não existindo essa alternativa, deve ocorrer a integração, possibilitando seu reconhecimento. Assim Brandi nos explica essa possibilidade, em seus princípios:

O primeiro é que a integração deverá ser sempre reconhecível; mas sem que por isso se venha a infringir a própria unidade que se visa a reconstruir. Desse modo, a integração deverá ser invisível a distância de que a obra de arte deve ser observada, mas reconhecível de imediato, e sem necessidade de instrumentos especiais, quando se chega a uma visão mais aproximada (BRANDI, 2005, p.47).

A partir das questões acima apresentadas, dois exemplos, no caso de Paranaguá, podem ser considerados. O primeiro é uma construção localizada ao fim da rua XV de Novembro. Essa pequena casa apresenta uma peculiar adaptação da estrutura do Período Colonial às necessidades advindas dos Códigos de Posturas municipais e a nova estética do Ecletismo. Neste caso ainda se mantêm as portas, características de sua origem, com vergas em canga. No entanto, essa estrutura passou por reformas, possivelmente ao final do século XIX, em que foram adicionados um friso decorativo em sua fachada e uma platibanda, na qual podem 
ter sido instalados os encanamentos pluviais. Esse pequeno edifício é testemunho de adaptações durante sua construção, e o "retorno" a suas "características originais" não pode ser justificada, pois são as marcas de suas transformações ao longo do tempo.

O outro exemplo refere-se a um sobrado localizado no largo da Matriz, denominado casa Dacheux, que passou nesses últimos anos por um processo de restauração encabeçado pelo IPHAN. Nesse caso restavam apenas as suas duas fachadas voltadas para a igreja. Para o processo de restauração, foi refeita a estrutura interna dessa edificação, com a construção de um novo telhado (Figura 143), semelhante ao original, e refeita a parede dos fundos desse edifício (Figura 144), como encontrado em algumas imagens do começo do século XX. Dessa forma, esta restauração foi realizada para reintegrar o edifício em suas características originais, sendo que os processos de transformação desta construção, sua ruínas, foram descartados, dando um novo aspecto ao edifício.

Seria apropriada esta forma de restauração? Será que estas intervenções são reconhecíveis à quem a primeira vista a vê? A própria pintura da fachada, realizada no ano de 2010, causa um grande impacto à quem observa o conjunto, foram aplicadas cores muito fortes, que transformaram um edifício construído há dois séculos atrás, em aparentemente, uma construção dotada de poucos anos de existência (Figura 145).

Os procedimentos de restauração devem ser claros, possibilitando seu reconhecimento, de forma a respeitar os processos de transformação pelo qual o edifício passou até o momento de sua restauração. Segundo Beatriz Küll (2006, p.33-34): 


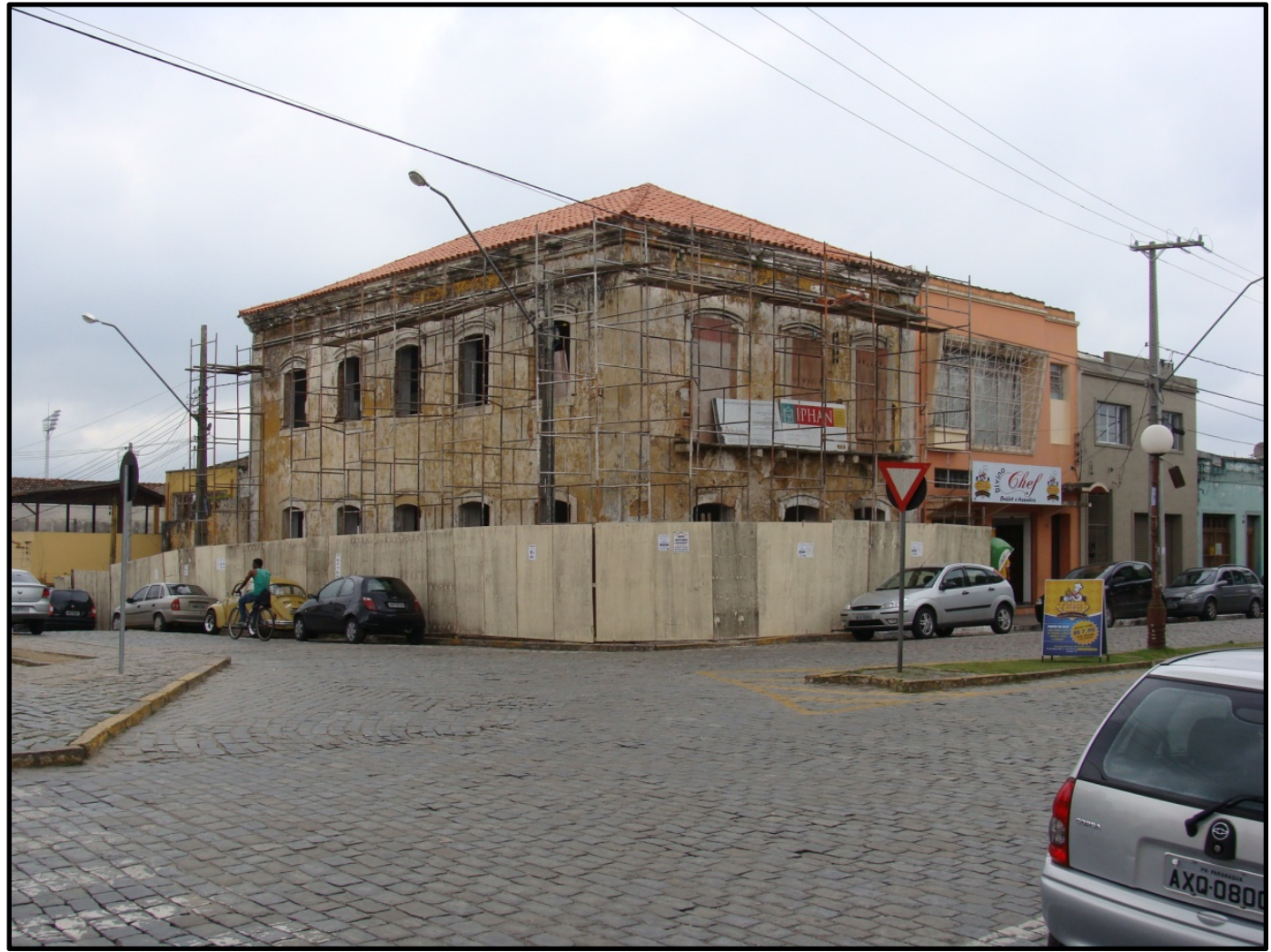

Figura 143. Casa Dacheux, localizada no largo da Matriz, em processo de restauração pelo IPHAN. Fonte: Acervo do autor, 2009.

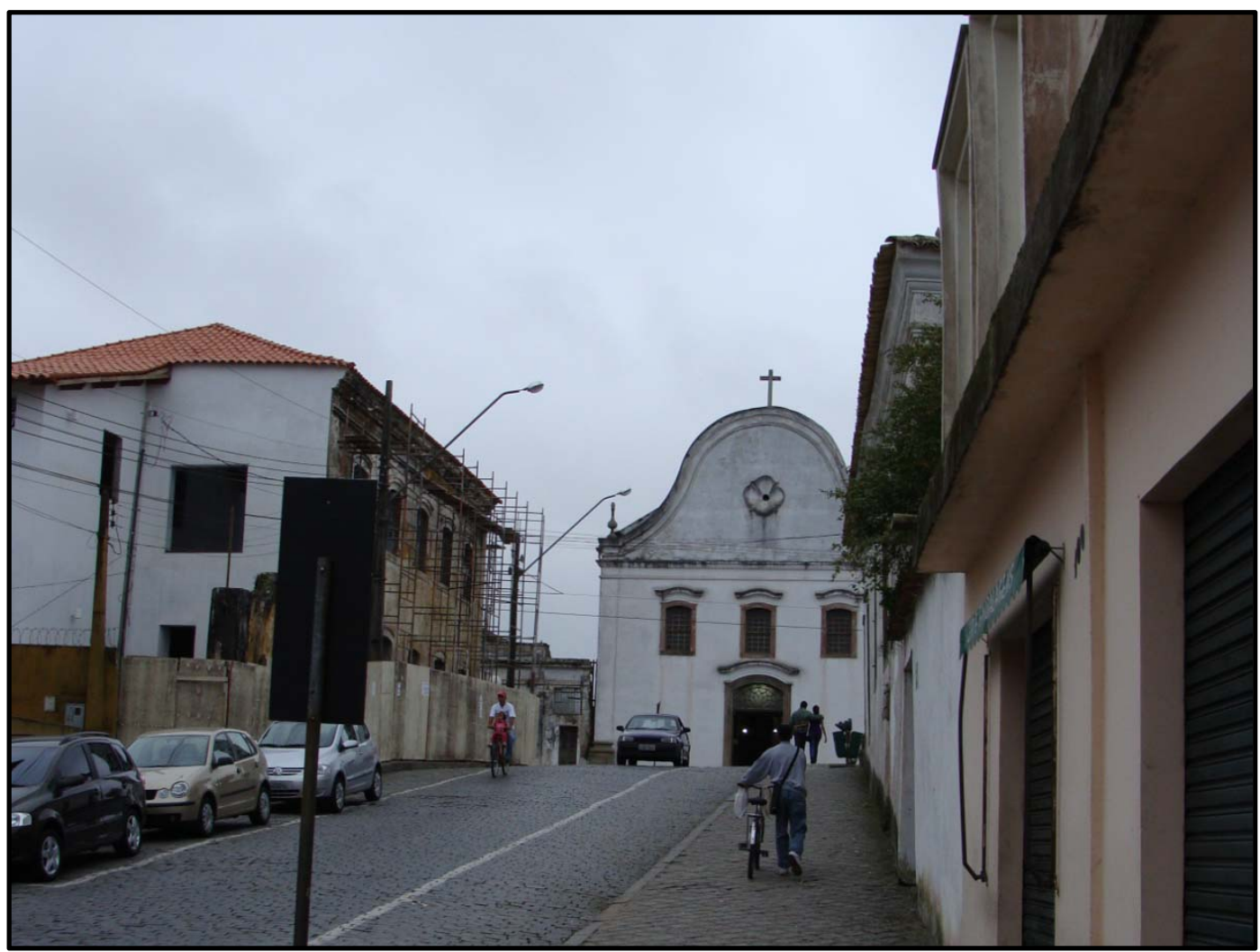

Figura 144. Ao lado esquerdo, os fundos da casa Dacheux, com a nova parede refeita no restauro realizado pelo IPHAN.

Fonte: Acervo do autor, 2009. 


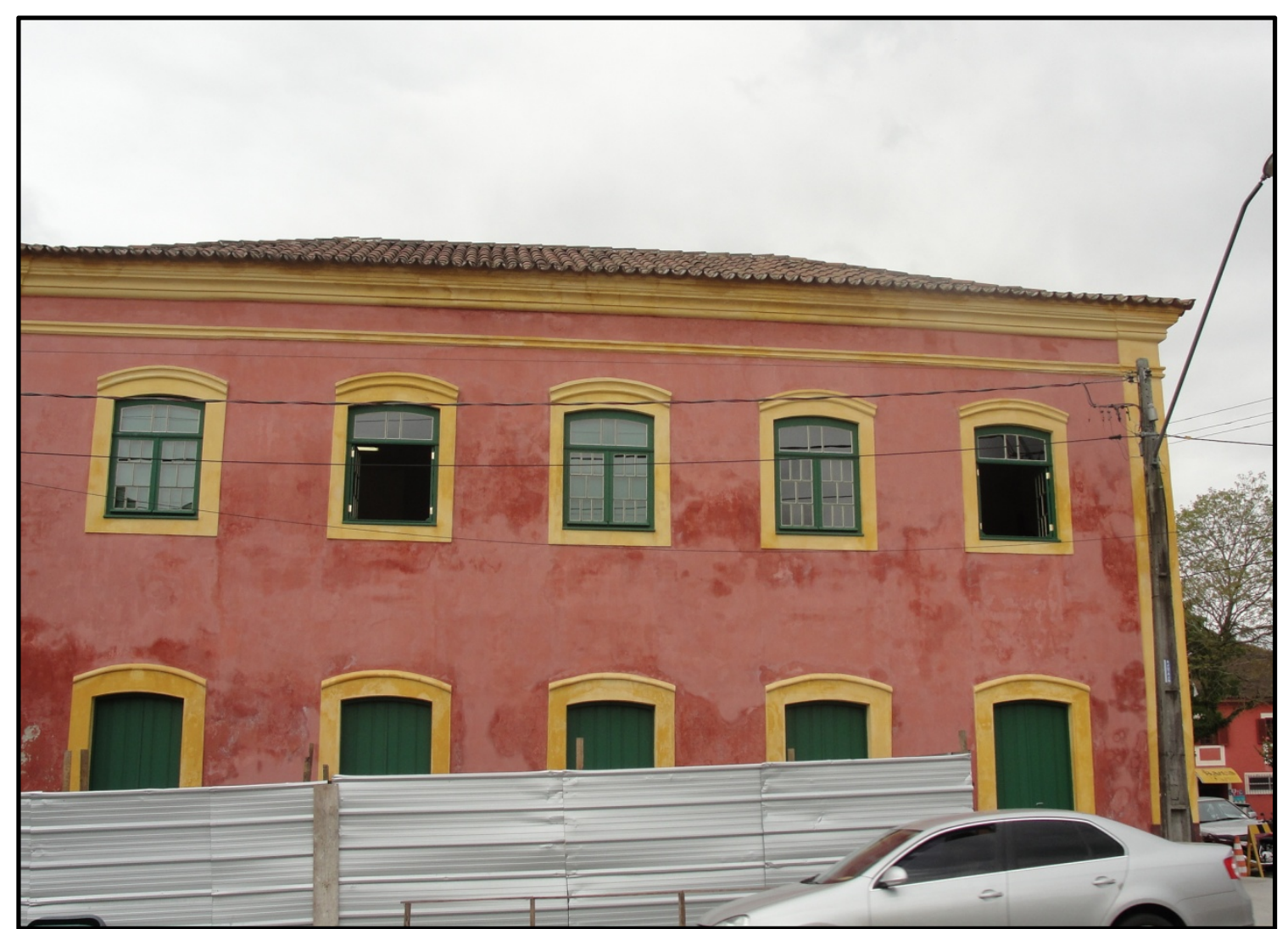

Figura 145. Aspecto da casa Dacheux, vista da rua João Régis, antiga da Matriz, após a nova pintura.

Fonte: JABUR, Simone Sartori, 2010.

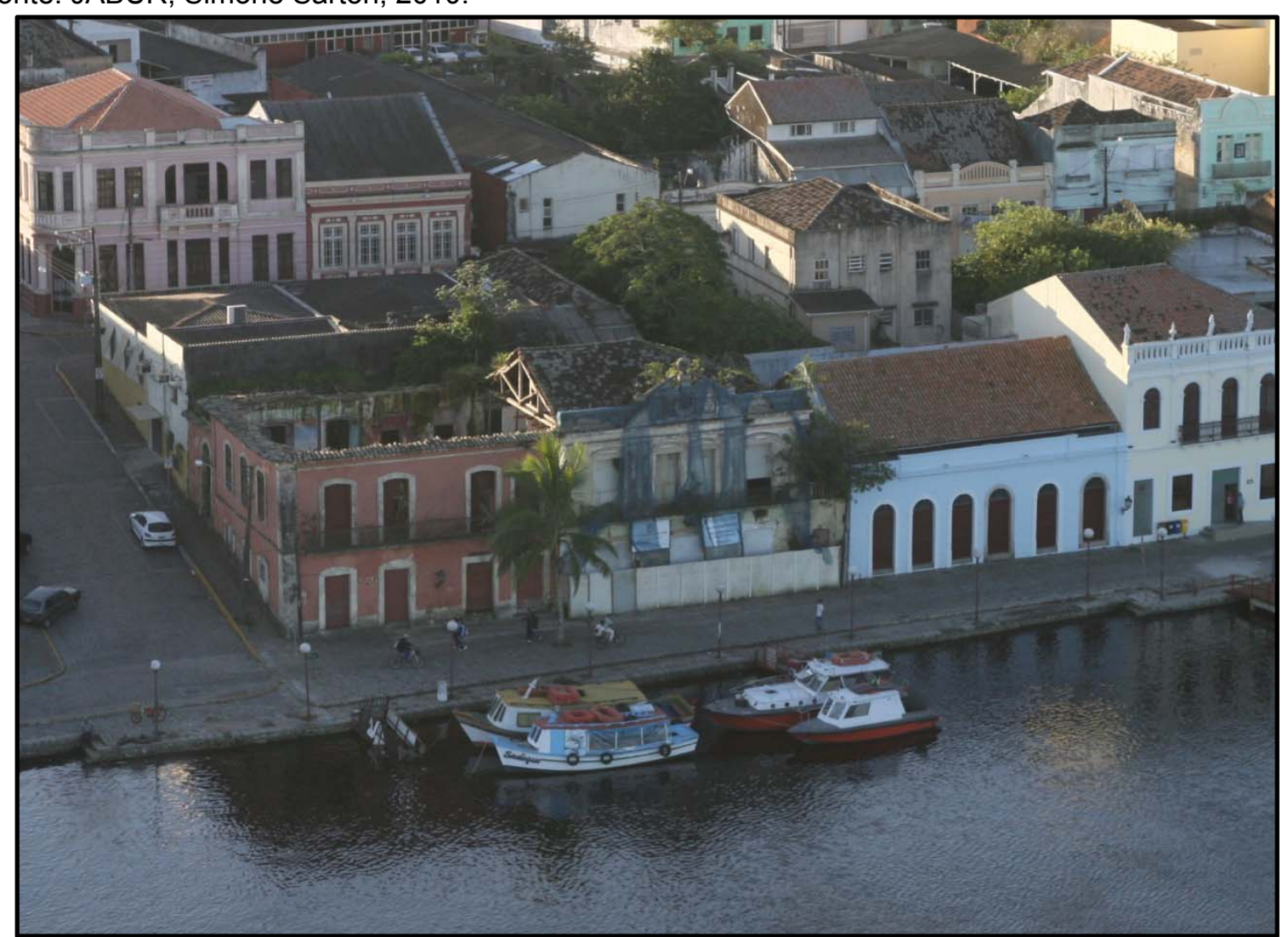

Figura 146. Ruínas encontradas na rua da Praia, as duas casas da esquina sofrem o risco de desmoronamento.

Fonte: LEAL, Rodrigo; APPA, 2009. 
A preservação é um legítimo ato de respeito pelo passado, que, alicerçado no reconhecimento da obra de arte e de seu transformar no decorrer do tempo, insere-se no tempo presente. Deve sempre ser ato de reinterpretação do presente, em que se propõe, de maneira socialmente e culturalmente responsável, uma renovada forma de se relacionar com um monumento histórico, voltado para sua transmissão para as próximas gerações da melhor maneira possível e, portanto, uma ação que mantém sempre o futuro no horizonte de suas reflexões.

Percorrendo as vias de Paranaguá, é possível perceber um grande número de casas e sobrados, dos quais restam apenas as fachadas (Figura 146), como a da casa Dacheux. Percebemos uma tendência a se criar um cenário somente de fachadas originais, sem se preocupar com os recursos arquitetônicos utilizados nos ambientes internos. A própria reconstrução é uma forma recorrente na cidade, apenas com a intenção de reedificar a cobertura, mas com ambientes internos desproporcionais em relação ao corpo do edifício, exemplos podem ser vistos na rua da Praia, principalmente naquelas construções com fins comerciais.

Outro caso que encontramos na cidade, são as lacunas existentes em algumas áreas deste conjunto urbano, como o grande vazio, localizado no terreno onde foi edificada a Casa de Câmara e Cadeia (Figura 147 e Figura 148), no século XVIII, e demolida dois séculos depois, para dar lugar a um edifício que também foi demolido na metade do século XX. Qual seria a solução para resolver este problema em um local tão importante historicamente? Não existem informações, para os que visitam Paranaguá, sobre a localização deste edifício, nem de que forma se configurava.

Outra marca considerável na cidade, foi a demolição da igreja do Bom Jesus, ao fim da antiga rua Direita (Figura 149), que perdeu a perspectiva antes criada por este monumento e agora dando lugar a um posto de gasolina, já abandonado (Figura 150). São áreas mal ocupadas e que necessitariam de ações governamentais para de alguma forma sanar estes problemas. 


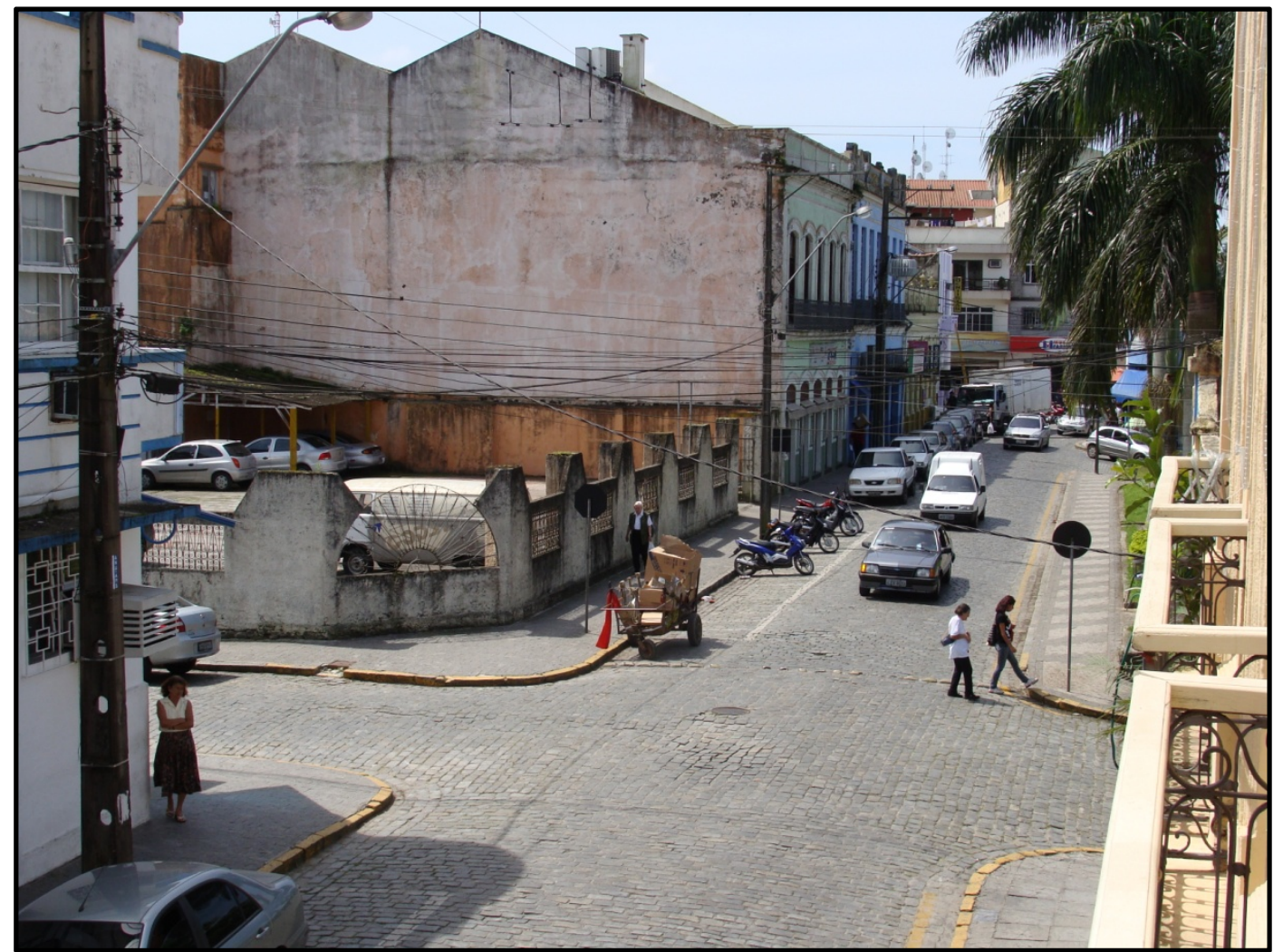

Figura 147. O grande vazio existente onde um dia esteve situada a casa de Câmara e Cadeia de Paranaguá.

Fonte: Acervo do autor, 2009.

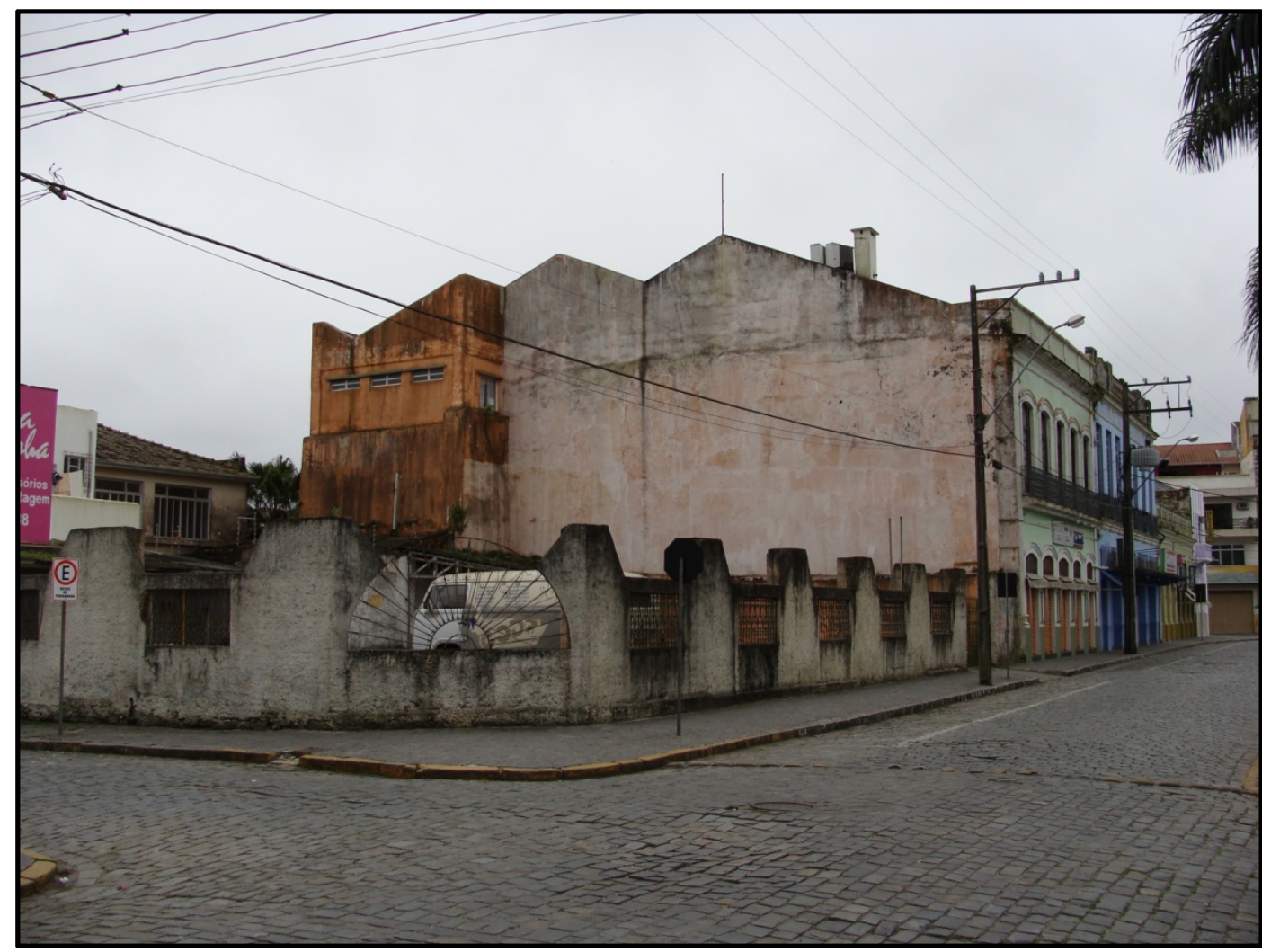

Figura 148. Neste local esteve construída a casa de Câmara e Cadeia de Paranaguá, demolida no começo do século XX.

Fonte: Acervo do autor, 2009. 


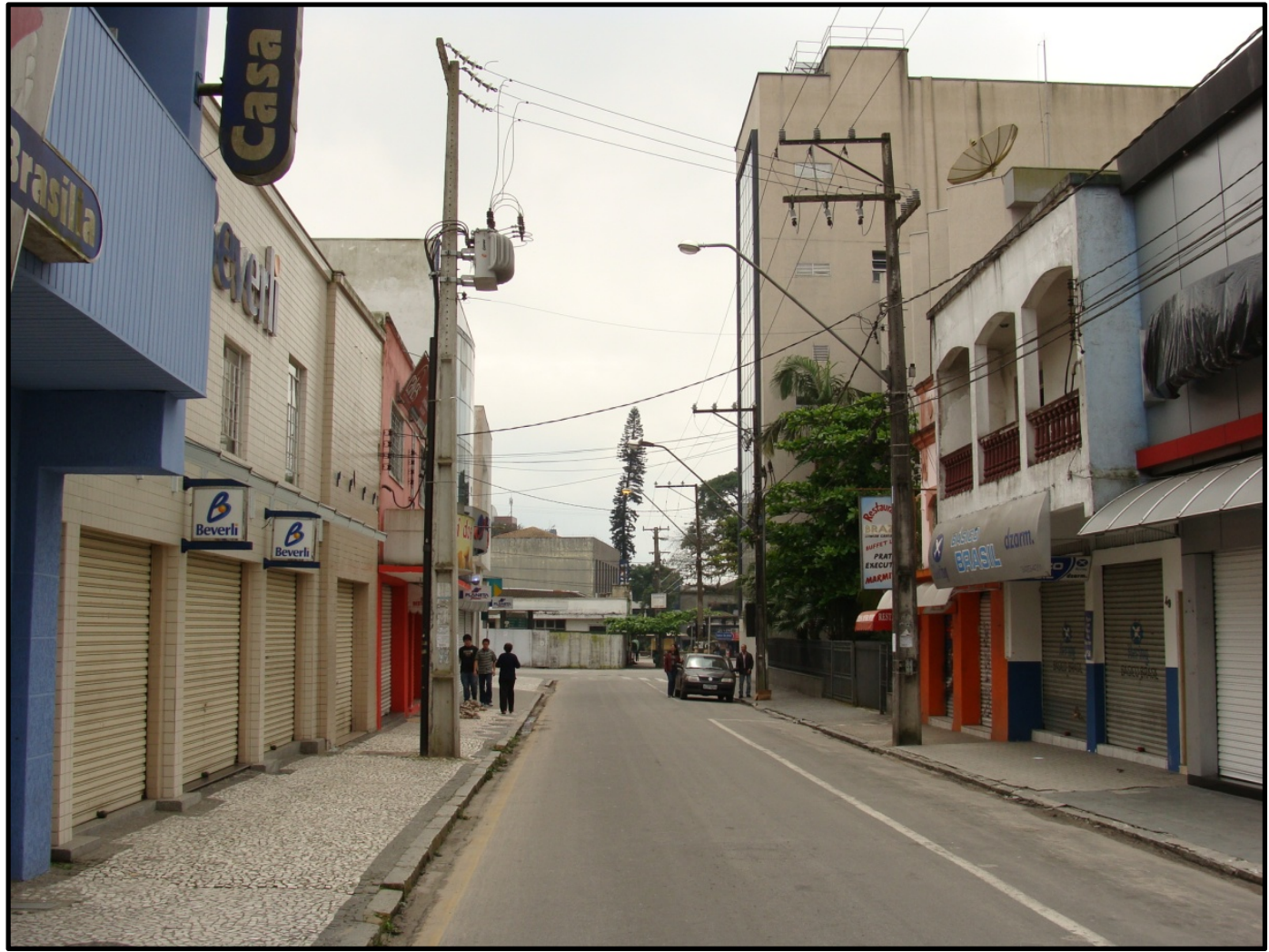

Figura 149. Visão da antiga rua Direita e logo à frente o vazio produzido pela demolição da igreja do Bom Jesus.

Fonte: Acervo do autor, 2009.

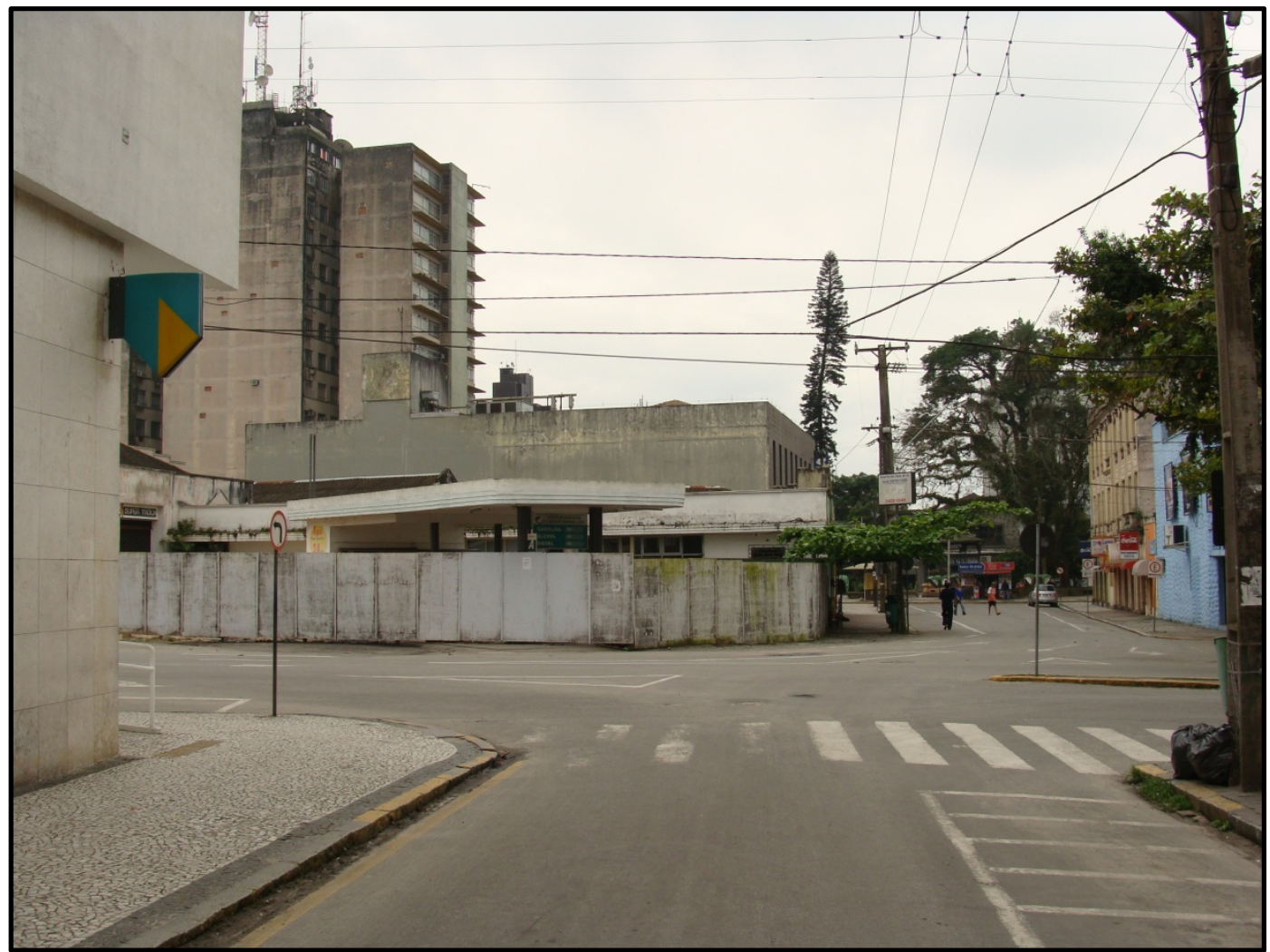

Figura 150. No espaço deste posto de gasolina esteve construída a igreja do Bom Jesus. Fonte: Acervo do autor, 2009. 
A reconstrução desses edifícios é algo inadequado? Resultaria em um falso histórico? Uma construção que se basearia em documentos e fotografias sem a certeza de sua veracidade, de acordo com Brandi (2005, p.89): "O adágio nostálgico “Como era, onde estava" é a negação do próprio princípio da restauração, é uma ofensa à história e um ultraje à Estética, colocando o tempo como reversível e a obra de arte como reproduzível à vontade".

É necessária uma ampla discussão nesse sentido, para que possam ser evitadas reconstruções do tipo falso histórico. Até o presente momento não são cogitadas, estas possibilidades e tampouco qualquer solução para o problema destas lacunas no Centro Histórico de Paranaguá. Estas "cicatrizes" necessitam ser estudadas para uma melhor reintegração destes espaços, dando a importância necessária ao conjunto que fez parte da formação de Paranaguá e assim trazer a população e aos visitantes melhores informações sobre estes monumentos.

No caso do tratamento das lacunas, devem ser analisadas as possibilidades de ocupação dos espaços que atrapalham a leitura do conjunto urbano, e que possam ser identificáveis. Para Odete Dourado (2003, p.13):

Assim, o monumento deverá ser construído com base nos dados espaciais oferecidos pela própria obra de arte - a cidade - no sentido de ressarcir a sua condição de inteireza. Dessa maneira, deve-se construir um edifício no lugar do antigo casarão, mas não o casarão perdido. Só assim o novo edifício, proposto naturalmente em linguagem contemporânea, deverá então restaurar toda a cidade comprometida e a ela fará jus.

Desta forma poderemos solucionar parte do problema da leitura urbana desse conjunto, mas no caso de Paranaguá, no espaço onde esteve o edifício da Casa de Câmara e Cadeia, como identificá-lo através de uma nova construção e consequentemente integrá-lo a cidade? Uma possível solução está na utilização de mídias virtuais para a reconstrução de áreas perdidas, que poderiam ser sediadas 
nesse novo edifício, ampliando o número de informações para aqueles que visitam a cidade e também seus moradores.

A identificação de intervenções em monumentos e no conjunto urbano deve ser explícita e fazer parte de seu processo de existência. Uma ação que será revelada e não ocultada, pois estas ações farão parte daquele conjunto e de sua recuperação. De acordo com Odete Dourado (2003, p. 11):

Conservar, ou, melhor ainda, restaurar, não significa e nem pode significar "congelar" o monumento, ou fazê-lo voltar, através de soluções artificiosas, "ao seu antigo estado". A intervenção restaurativa incorpora-se ao monumento, passando a fazer parte da sua história e, portanto, da sua transmissão no tempo. Como tal, deverá trazer, inexoravelmente, as marcas da época em que foi executada, sem desrespeitar as duas instâncias de que gozam as obras de arte: as que dizem respeito à estética e à história.

Outro problema, encontrado na cidade, refere-se à manutenção dos edifícios já restaurados, importante para que não sejam necessárias novas intervenções em sua estrutura. Em Paranaguá, apenas 10 anos separam a situação de recuperação de seu Centro Histórico, do estado em que se encontra grande parte deste conjunto atualmente; havendo a necessidade de uma nova intervenção. Hoje, são encontrados na cidade de Paranaguá, edifícios como o Palacete Mathias Bohn, restaurado no final da década de 90 , do século $X X$, e que hoje está em risco de ruína, também encontramos em situação de descaso, a Praça do Mercado, o Palacete Visconde de Nácar. Também devem ocorrer ações em pequenas construções que são importantes no contexto urbano, como a casa de pau-a-pique, algumas construções da rua Conselheiro Sinimbú, da rua Vieira dos Santos, do sobrado na esquina das ruas Faria Sobrinho com a Professor Cleto, como muitos outros existentes na cidade.

Infelizmente, a mudança na continuidade da gestão pública e a diminuição nas ações de preservação podem ser fatores deste descaso. Para tanto, é 
necessária a criação de diretrizes para a manutenção dos edifícios públicos e particulares, de forma a evitar a necessidade de futuras grandes intervenções. A preservação não está ligada somente aos processos de restauração, mas a grande resposta se encontra na própria manutenção destas construções públicas e privadas. Assim como está definida na Carta de Veneza (1964, p.2): “A conservação de monumentos impõe, antes de tudo, perseverança em sua manutenção."

Também se percebe a falta de discussões e estudos sobre o restauro urbano, a falta de clareza conceitual que possibilite efetuar as ações de preservação. As idéias são muito abrangentes e passíveis de interpretações errôneas. Segundo Ana Barbosa, em análise sobre as intervenções realizadas na cidade de Serro, em Minas Gerais:

Não há clareza conceitual; o que se observa são propostas de embelezamento, tratamento de fachadas, criação de cenários, visando retorno financeiro, com a ilusão de uma indústria do turismo (sem um coerente planejamento), e não um sólido e adequado posicionamento diante da obra, respeitando sua autenticidade, com vista à sua transmissão para o futuro, (como podemos observar a partir dos preceitos brandianos). (BARBOSA, 2007, p. 281).

É preciso efetivar as ações de preservação, assim como inserir a população nestes atos para compreender a sua identidade com este conjunto. Não somente são necessárias as restaurações, mas também a aplicação de educação patrimonial para a população e os turistas, revelando aos moradores sua própria identidade. Que possam dar maior importância às antigas estruturas e também exigir a conservação delas, não apenas das construções mais importantes, mas também das pequenas que constituem grande parte do conjunto.

Kevin Lynch (1999, p. 247), considera que as coisas antigas são conservadas “[...] não pelo seu valor próprio, nem numa tentativa quixotesca de parar a mudança, mas para melhor transmitir um sentido de história." Uma forma de resgatar o 
passado sem que isto atrapalhe as transformações do presente e o encaminhar ao futuro. As ações de preservação não podem ser decididas de forma unilateral, mas possibilitar a participação e o envolvimento da população. Formando equipes com diversos especialistas, para que sejam preservados não só edifícios que possuem importância para as classes dominantes, ou os envolvidos com interesses políticos, mas também daqueles que convivem com a cidade no dia a dia.

Existe a necessidade de manter elementos que tornam a cidade mais humana, garantindo a permanência das características de certas áreas e auxiliando na compreensão deste conjunto, são características que se mantêm e dão identidade à cidade e a seus habitantes. São elementos que simbolizam a relação entre a cidade e sua população, caracterizando-se como referenciais urbanos, que ao se tornarem ausentes, fazem com que o cidadão não encontre mais seu lugar na cidade e não reconheça seu ambiente. (FONTĖS et al., 1986).

A cidade é constantemente passível de transformações e isto deve ser entendido dentro do Centro Histórico, ele não pode ser um espaço congelado no tempo, mas como um espaço de mudanças, desde que não agridam sua composição e integridade. Lembremos do que Milton Santos coloca sobre o espaço: resultante de um conjunto de ações para sua criação, deste modo, com o passar do tempo, estas ações vão se adaptando aos antigos espaços, e estes também sofrem um processo de transformação, apesar disso, ainda podem restar marcas de um tempo passado, testemunho de uma época importante ou não na construção da cidade. Se analisarmos as considerações de Milton Santos (2004, p. 173) sobre o espaço, poderemos complementar este entendimento:

O espaço portanto é um testemunho, ele testemunha um momento de um modo de produção pela memória do espaço construído, das coisas fixadas na paisagem criada. Assim o espaço é uma forma, uma forma durável, que não se desfaz paralelamente à mudança de processos; ao contrário, 
alguns processos se adaptam às formas pré-existentes enquanto que outros criam novas formas para se inserir dentro delas.

Em uma análise sobre as normas de preservação urbana no Brasil, Marcia Sant'Anna (1995, p. 250), coloca a seguinte questão sobre os Centros Históricos brasileiros:

A nosso ver, a política de preservação e as operações de conservação de áreas urbanas não apresentam em geral bons resultados porque desconsideram o caráter pluridimensional e a natureza mutável do fenômeno urbano. Em outras palavras, porque o querem como um objeto estático em todas as suas dimensões - formal, documental, social, econômica, simbólica, funcional e vivencial - e também no seu tecido social. As regras patrimoniais tratam a área urbana - patrimônio ainda de modo museológico e sem considerar que, mesmo quando parte de sua materialidade é preservada, ela cresce e muda constantemente. Isso deveria implicar, pelo menos, a revisão periódica dos instrumentos de oficialização e normalização de critérios de intervenção.

As leis de preservação do Centro Histórico de Paranaguá necessitam de revisão e alteração. A delimitação desta área não pode ser algo estático, pois através de novas pesquisas sobre a cidade concorrem para seu entendimento, estas alterações deveriam ocorrer, baseando-se nos trabalhos científicos apresentados. Tais contribuições ampliam o conhecimento sobre a cidade e beneficiam o entendimento de seu desenvolvimento, trazendo novas sugestões para a preservação e principalmente atuando na conscientização da população sobre seu patrimônio.

Segundo Lynch (1999, p. 247):

O perito em conservação, o residente ou o trabalhador podem entrar em diálogo, para o qual cada um contribui com a sua própria percepção do local. Neste processo, cada um deles acaba por vislumbrar um significado mais profundo, por sentir uma continuidade mais forte.

A cidade necessita de constantes interpretações para poder preservar o que ainda existe e desta forma evitar grandes perdas, é necessária uma preocupação 
maior com as pequenas construções da cidade e não somente com os monumentos mais importantes, valorizando as habitações que fazem parte deste contexto urbano, pois também são testemunhos de um passado ainda preservado na cidade de Paranaguá, basta apenas enfatizar a sua importância aos olhos da população e dos órgãos públicos. 


\subsection{CONHECENDO PARANAGUÁ ATRAVÉS DE UM ROTEIRO DE VISITA}

Seguindo os principais elementos da discussão aqui apresentadas, criamos uma proposta de roteiro para visita em Paranaguá, que se baseia na história de seu crescimento urbano, desde a formação da vila, até o findar do século XIX. O roteiro é uma sugestão para que as organizações de preservação e a Prefeitura Municipal trabalharem com a sociedade local, sendo um recurso dentre outros a serem aplicados dentro das atividades de educação patrimonial, afim de que todos possam melhor compreender, o desenvolvimento da cidade de Paranaguá e dessa forma contribuir em parte na noção de preservação do patrimônio, e, o mais importante, discutir as diretrizes para o seu desenvolvimento futuro.

O roteiro tem por base a publicação intitulada Atlas de Centros Históricos do Brasil, em que foram analisadas, por diversos autores, cidades que possuem seus Centros Históricos tombados pelo IPHAN. Partindo de uma análise urbana sobre estas cidades, a publicação apresenta posteriormente uma sugestão de roteiro de visita, com a função de aplicar os estudos sobre as cidades neste roteiro de fácil compreensão.

Esta ação poderá levar o conhecimento acadêmico para toda população interessada em Paranaguá. Uma atividade que contribuirá para o entendimento mais amplo da formação da cidade, já que será realizada no espaço deste estudo, ou seja, a cidade de Paranaguá. O processo histórico de desenvolvimento urbano poderá ser clarificado através da proposta desse roteiro e, portanto, incentivar o interesse dos parnanguaras por este patrimônio, que em 2009 foi tombado pelo Instituto do Patrimônio Histórico e Artístico Nacional (IPHAN). 
É imprescindível conhecer a cidade, necessário aos cidadãos que a habitam, uma forma de criar vínculos com este patrimônio e dar fomento às ações de preservação, não apenas pelas instituições governamentais, mas também pela população local, que poderia sugerir e questionar as atividades preservacionistas. Mas para isso é necessário conhecê-la, e aqui apresentamos uma proposta.

Este roteiro de visita (Figura 151) se baseará na evolução urbana da cidade e de suas construções. O passeio se encaminha de acordo com o crescimento de Paranaguá, criando uma sugestão de roteiro para conhecer seu Centro Histórico. A partir da perspectiva sugerida, descreveremos esse roteiro. O itinerário inicia-se no largo da Matriz, região que consideramos o início da vila, neste local encontra-se a igreja Matriz (Ponto 1), construção que passou por constantes reformas, mas que ainda possui características do século XVIII, como pode ser observado em sua fachada, visto que o grande espaço interior já foi desfigurado por diversas alterações em sua nave e altar. Ao lado da igreja, localiza-se a área em que estava situado o primeiro cemitério público da cidade, edificado em 1850.

Nas imediações da igreja Matriz, provavelmente foi edificada a primeira Casa de Câmara e Cadeia e o Pelourinho, neste local são encontradas residências provavelmente de fins do século XVIII, como a casa Itiberê, e o sobrado ao lado, que concentram espaços culturais (Ponto 2). Estas construções possuem vergas e umbrais em cantaria, e suas portas e janelas são em canga. No largo também encontramos a casa Dacheux (Ponto 3), sobrado que passa por restauração para tornar-se um centro gastronômico, formando um conjunto de construções importantes que retratam parte das características da vila em fins do setecento.

Do largo da Matriz, nos encaminhamos para a rua rua João Régis, antiga rua da Matriz, e deste ponto é possível observar o frontispício da igreja (Ponto 4). O 
recurso de perspectiva para o referido templo foi intencional, já que a rua, aberta por determinação do Ouvidor Rafael Pires Pardinho, tinha o objetivo de possibilitar a melhor visualização da Matriz. Deste local, adentramos a rua Pecego Junior, antiga rua da Baixa ou do Meio, que possuía este nome devido a seu traçado, pois cortava a vila na metade e foi, por determinação do Ouvidor, pavimentada ainda no século XVIII. Esta via possui pequenas casas já alteradas, mas que trazem marcas de seu passado setecentista, como as portas em verga de canga e as beiras-seveiras.

Seguindo em frente, pela rua Pecego Junior, temos em seu final, a primeira construção pública da cidade, a fonte d’Água (Ponto 5), local importante na formação da vila de Paranaguá, pois foi sua fonte de abastecimento de água até o primeiro decênio do século $X X$, e atraiu, no início da ocupação desta região, parte das construções da vila. A fonte também serviu para as aguadas dos navios que atracavam na região, quando a margem do Itiberê chegava em sua proximidade, como pode ser observada nos antigos mapas de Paranaguá.

Passando pela lateral da fonte, entramos em uma pequena rua (Figura 152), o próximo ponto, a igreja de São Benedito (Figura 153), local onde esteve edificada a igreja das Mercês (Ponto 6), que se encontrava na ilha da Cotinga e foi, em 1699, reconstruída neste ponto. O interior da igreja de São Benedito está preservado, constituindo-se pelo altar e talhas em madeira, datados do século XIX, e a imagem de São Benedito. Na lateral da igreja, existem algumas construções que fazem parte do desenvolvimento inicial da vila, e que foram reformadas, adquirindo platibandas, mas que carregam algumas características de séculos anteriores, indicando como se configuravam as construções civis no período Colonial. 


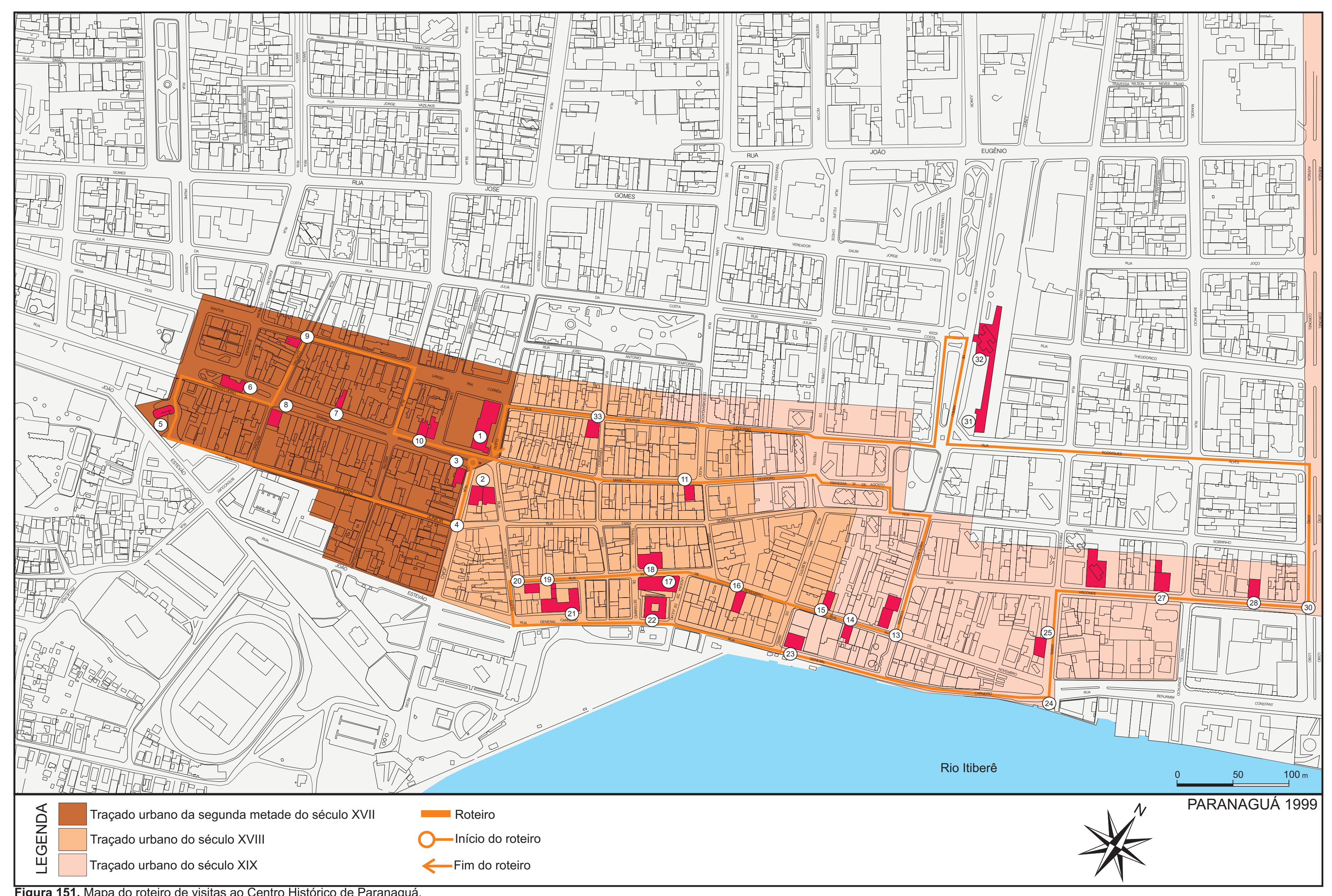

Figura 151. Mapa do roteiro de visitas ao Centro Histórico de Paranaguá. 



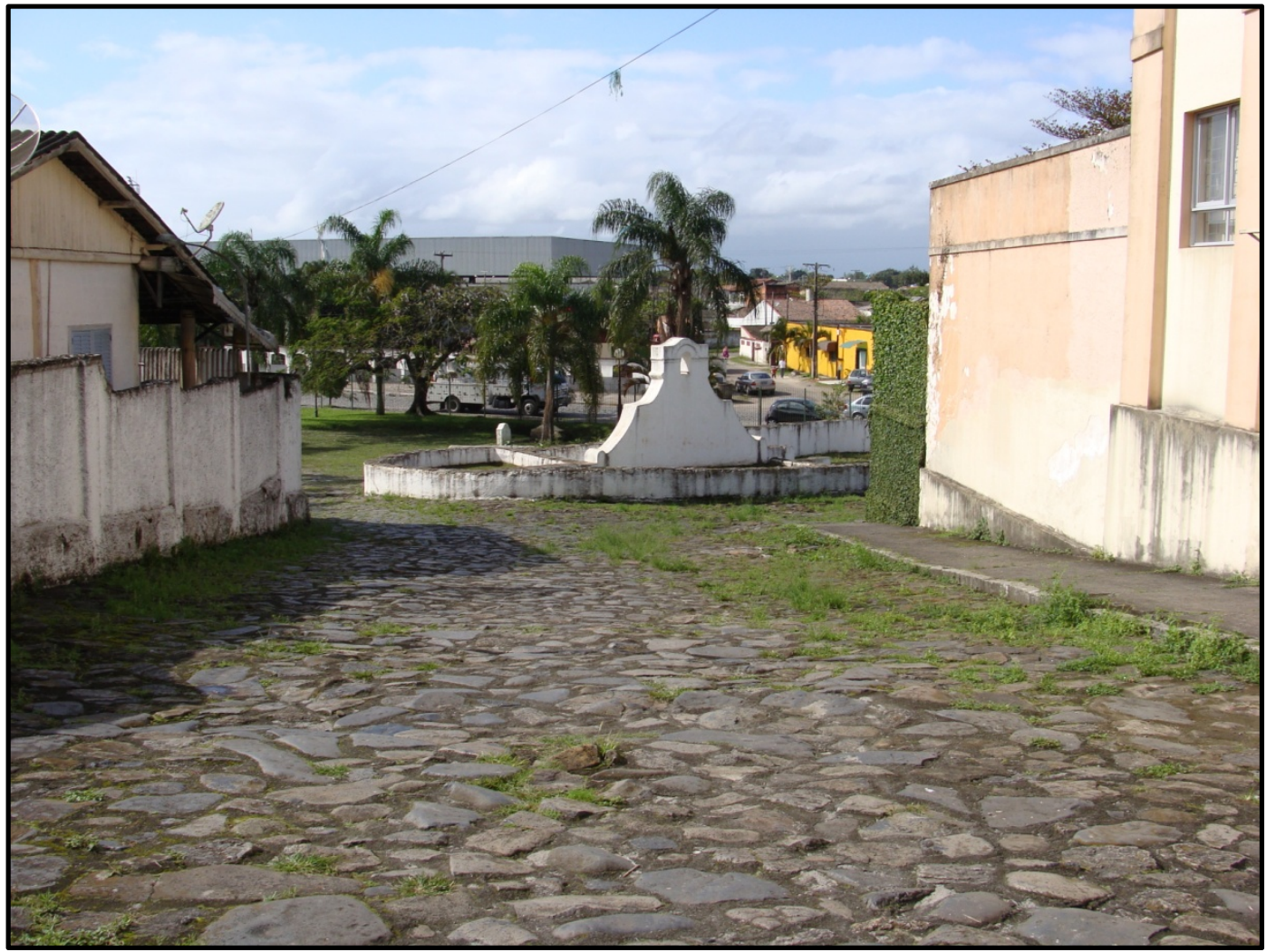

Figura 152. Ladeira que liga a fonte d'Água aos fundos da igreja de São Benedito. Fonte: Acervo do autor, 2009.

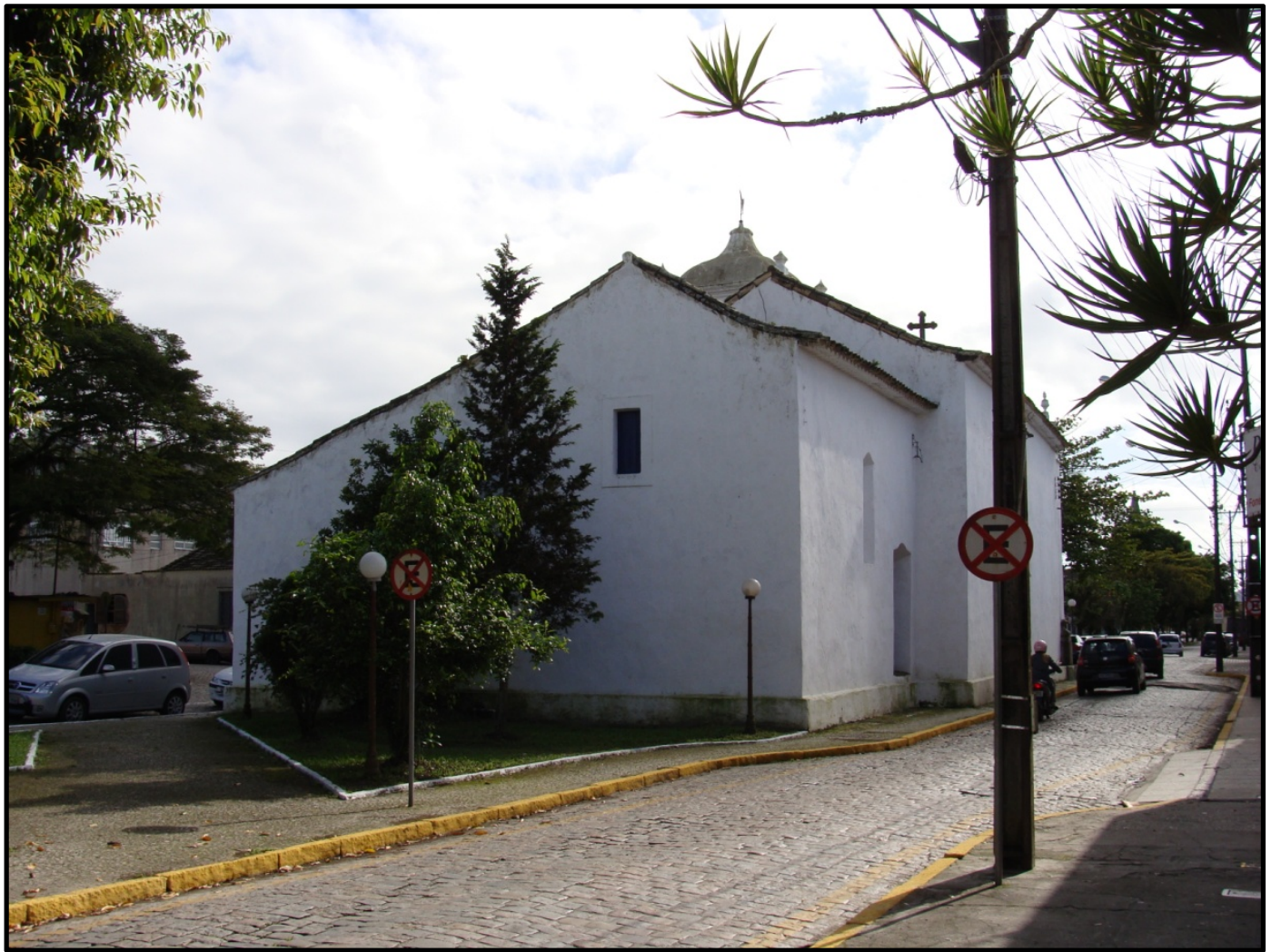

Figura 153. Fundos da igreja de São Benedito.

Fonte: Acervo do autor, 2009. 
Em frente à igreja de São Benedito, temos a rua Conselheiro Sinimbú, antiga rua da Fonte, esta via formava o eixo inicial da vila de Paranaguá, e atualmente contém construções que passaram por reformas durante o século $X I X$ e $X X$, existindo ainda algumas edificações do século XVIII, como a casa de baixa altura (Ponto 7) e a casa de esquina com sua parede de pedra e seu cunhal de cantaria (Ponto 8). Esta rua forma um interessante conjunto de construções civis que mantiveram parte das características do período colonial, mas que sofreram no século XIX e XX, algumas reformas, é um conjunto testemunho dos processos de transformação da cidade de Paranaguá. A partir da igreja de São Benedito é possível visualizar a igreja Matriz, neste eixo que também faz parte a antiga igreja do Bom Jesus, que se localizava ao fim da rua Direita.

Continuando a caminhada, viramos à esquerda na rua Joaquim Ferreira Barbosa, e seguimos em frente, chegando na rua Antonio Vieira dos Santos, antiga rua do Fogo, esta é a primeira via da cidade e possui algumas ruínas de antigas habitações. Na esquina destas duas ruas, encontramos a última construção de paua-pique da cidade (Ponto 9), provavelmente contemporânea a vinda do Ouvidor Rafael Pires Pardinho a Paranaguá, em 1720. A construção mantém as características originais, possibilitando ser reconhecida em sua construção, até mesmo a técnica construtiva poderá ser visualizada em algumas lacunas, encontradas em sua fachada.

Seguindo o trajeto pela antiga rua do Fogo, chegamos a rua Mestre Leopoldino e depois nos encaminhamos na direção da rua Conselheiro Sinimbú, deste ponto é possível visualizar ao fim da rua, a igreja de São Benedito e no sentido oposto o largo da Matriz. Nos dois lados desta via, são encontrados alguns 
sobrados, provavelmente do século XVIII, já alterados, no qual um deles possui ainda sua sacada corrida, sustentada por cachorros em pedra (Ponto 10).

Da rua Conselheiro Sinimbú, seguiremos em direção a rua Marechal Deodoro, antigamente conhecida como rua Direita, esta via em conjunto com a Sinimbú, formava um eixo de três igrejas, iniciando na igreja de São Benedito, passando pela igreja Matriz e finalizando na igreja do Bom Jesus. A rua Direita, mantêm seu traçado original, em que a rua curva-se para chegar à frente da igreja do Bom Jesus, finalizando a perspectiva. As construções da rua Marechal Deodoro (Figura 154) já foram bastante alteradas, são encontrados poucos edifícios do século XVIII e ecléticos. Uma das residências, que poderemos destacar, pode ser observada por seus aspectos construtivos, pois suas paredes não possuem reboco e revelam características construtivas de grande parte das residências do século XVIII e XIX, principalmente em relação as paredes de pedra e as vergas e umbrais de portas e janelas feitas com tijolos maciços (Ponto 11).

Ao fim desta via, encontra-se um grande largo, em que um dia esteve construída a igreja do Bom Jesus (Ponto 12), demolida no começo do século XX para dar lugar a um posto de gasolina, que atualmente está desativado. Esta região apresenta uma grande lacuna que cria um problema para o restauro urbano, pela perda irreparável de um monumento que em conjunto com esta via criava uma unidade perspéctica, perdida após a demolição.

Continuando na rua Marechal Deodoro, encaminhamo-nos para a rua Presciliano Correa (Figura 155), antiga travessa da Ordem, direcionando-se para o rio Itiberê. 


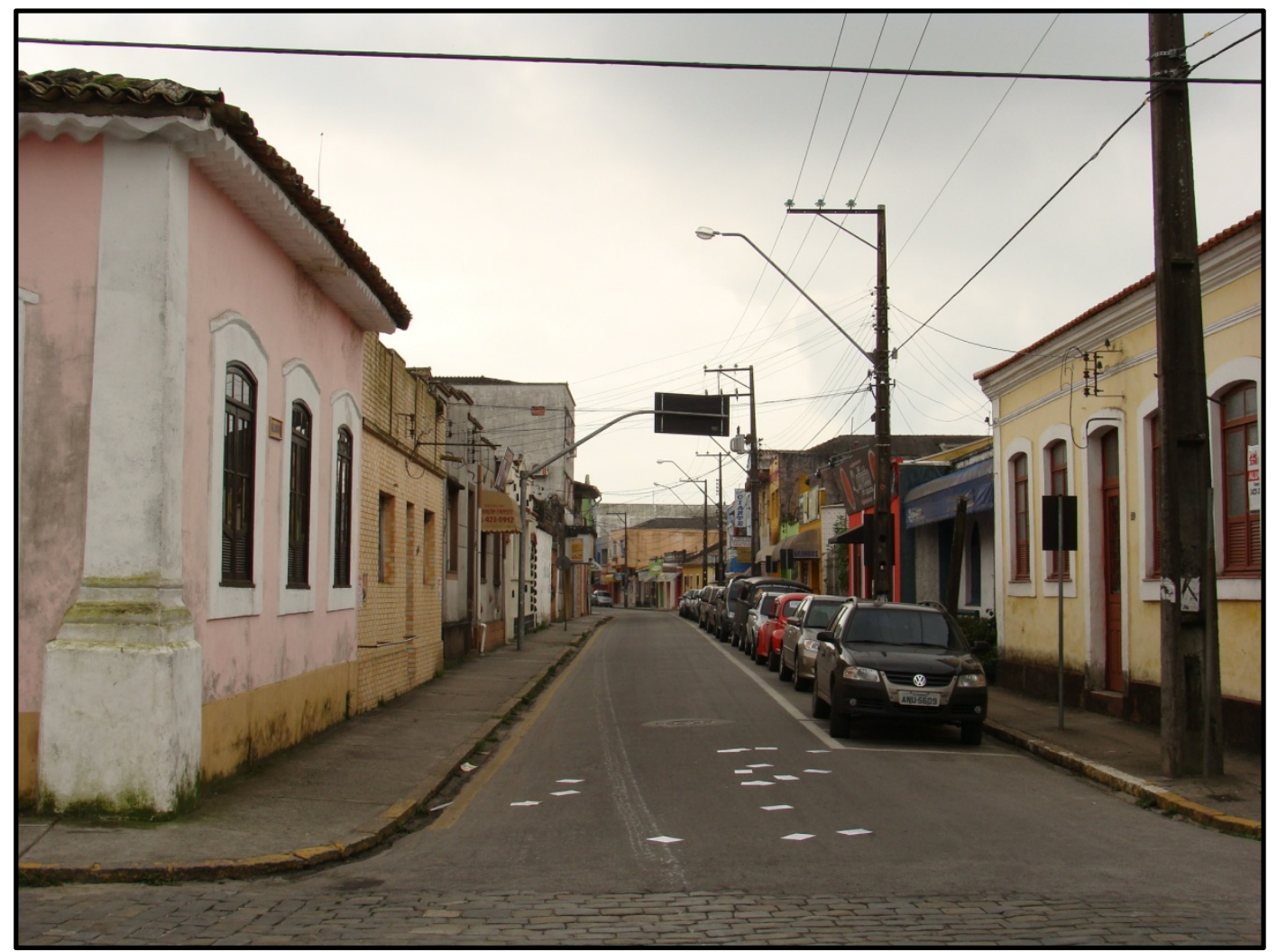

Figura 154. Início da rua Marechal Dedodoro, antiga rua Direita.

Fonte: Acervo do autor, 2009.

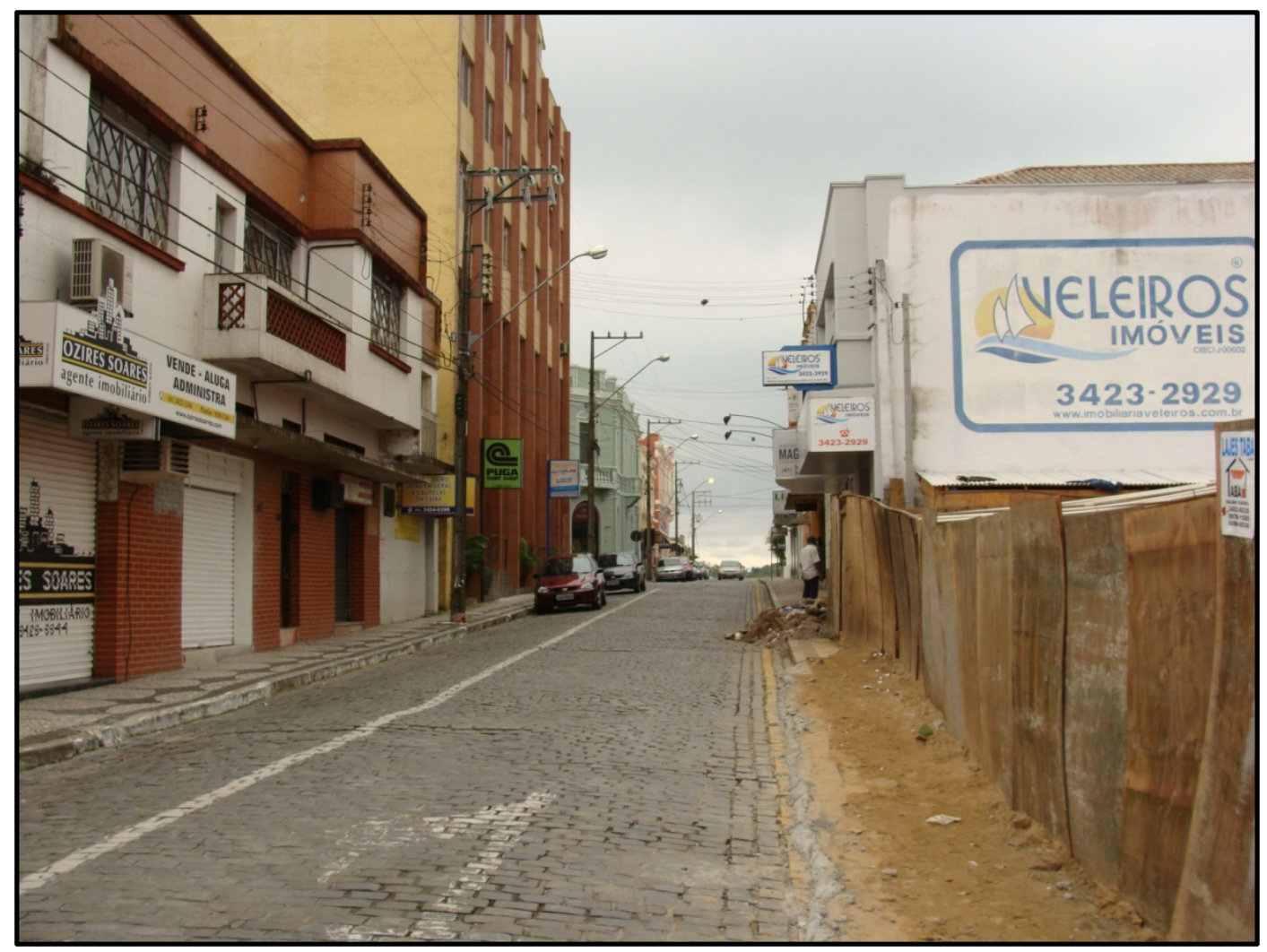

Figura 155. Rua Prisciliano Correa, antiga travessa da Ordem.

Fonte: Acervo do autor, 2009. 
Quando chegamos na rua XV de Novembro, visualizamos a igreja da Ordem (Ponto 13), uma das mais representativas da cidade, esta igreja localiza-se fora do eixo dos três templos anteriores, seu interior foi destruído em um incêndio, mas, ainda é possível observar sua estrutura, e na lateral o pequeno cemitério de sua irmandade. Continuando na rua XV de Novembro, antiga rua da Ordem e da Cadeia, é possível reconhecer construções civis reformadas no século XIX, como a pequena casa com portas em verga de canga em que foi adicionado o friso e a platibanda (Ponto 14) e construções Ecléticas, com seus porões altos. Esta via possui um número maior de edificações antigas do que a rua Marechal Deodoro, grande parte delas posteriores à metade do século XIX.

Nesta rua situam-se os sobrados azulejados, o primeiro semelhante à um chalet (Ponto 15), possui toda fachada coberta com azulejos marrons e azuis, assim como mais a frente encontramos outro sobrado do tipo. Esse, provavelmente da metade do século XIX, possui a fachada encoberta pelos azulejos azuis no pavimento superior. Em contrapartida, o pavimento inferior foi alterado, mas pode ser observado o trabalho na cantaria das janelas superiores e o desenho de frisos e platibanda (Ponto 16). Encontramos, também nesta via, algumas construções do século XVIII.

Seguindo em frente, deparamo-nos com um ponto importante na formação da vila de Paranaguá, o largo do Pelourinho (Ponto 17), lá se encontra uma réplica deste símbolo da justiça em uma pequena praça, onde antes fora o largo. Defronte ao Pelourinho está o local que foi instalado, por determinação do Ouvidor Pardinho, a Casa de Câmara e Cadeia de Paranaguá (Ponto 18), hoje apenas restando um espaço vazio, problemático para o entendimento da cidade. Foi a partir da instalação deste espaço público que a vila iniciou seu desenvolvimento para as margens do 
Itiberê e para o sítio da ribanceira. Continuando em frente, encontramos mais algumas construções ecléticas, uma antiga residência e dois sobrados que provavelmente eram antigas construções coloniais, reformadas no início do século $\mathrm{XX}$.

Ao fim desta via encontramos os fundos do Colégio dos Jesuítas, onde agora funciona o Museu de Arqueologia e Etnografia de Paranaguá, administrado pela Universidade Federal do Paraná, o acesso ao museu se dá pelos fundos, em um anexo contemporâneo, construído recentemente (Figura 156) (Ponto 19), e ao lado desse bloco de vidro encontramos o local da antiga igreja dos Jesuítas, demolida em fins do século XIX. Ainda é possível visualizar o arco cruzeiro da antiga igreja (Figura 157), ao lado está o Instituto Histórico e Geográfico de Paranaguá (Ponto 20), instalado no edifício de uma antiga escola, lá se encontra um pequeno museu relacionado à cidade, com peças do cotidiano, imagens sacras e objetos do porto, além do Pelourinho original. Este espaço torna-se interessante ao visitante no reconhecimento da organização da vida parnanguara, principalmente no século XIX.

Na esquina do IHGP, é possível observar a igreja Matriz, pela rua Professor Cleto, antiga rua Senhora do Terço, aberta no século XIX, provavelmente para criar outra perspectiva para a Matriz, nesta via descemos em direção ao Itiberê e viramos a esquerda, adentrando a rua da Praia, e já visualizamos o Colégio dos Jesuítas (Ponto 21), a maior construção do século XVIII, e que faz parte deste conjunto preservado nas margens do Itiberê, local em que funcionou o porto de Paranaguá. 


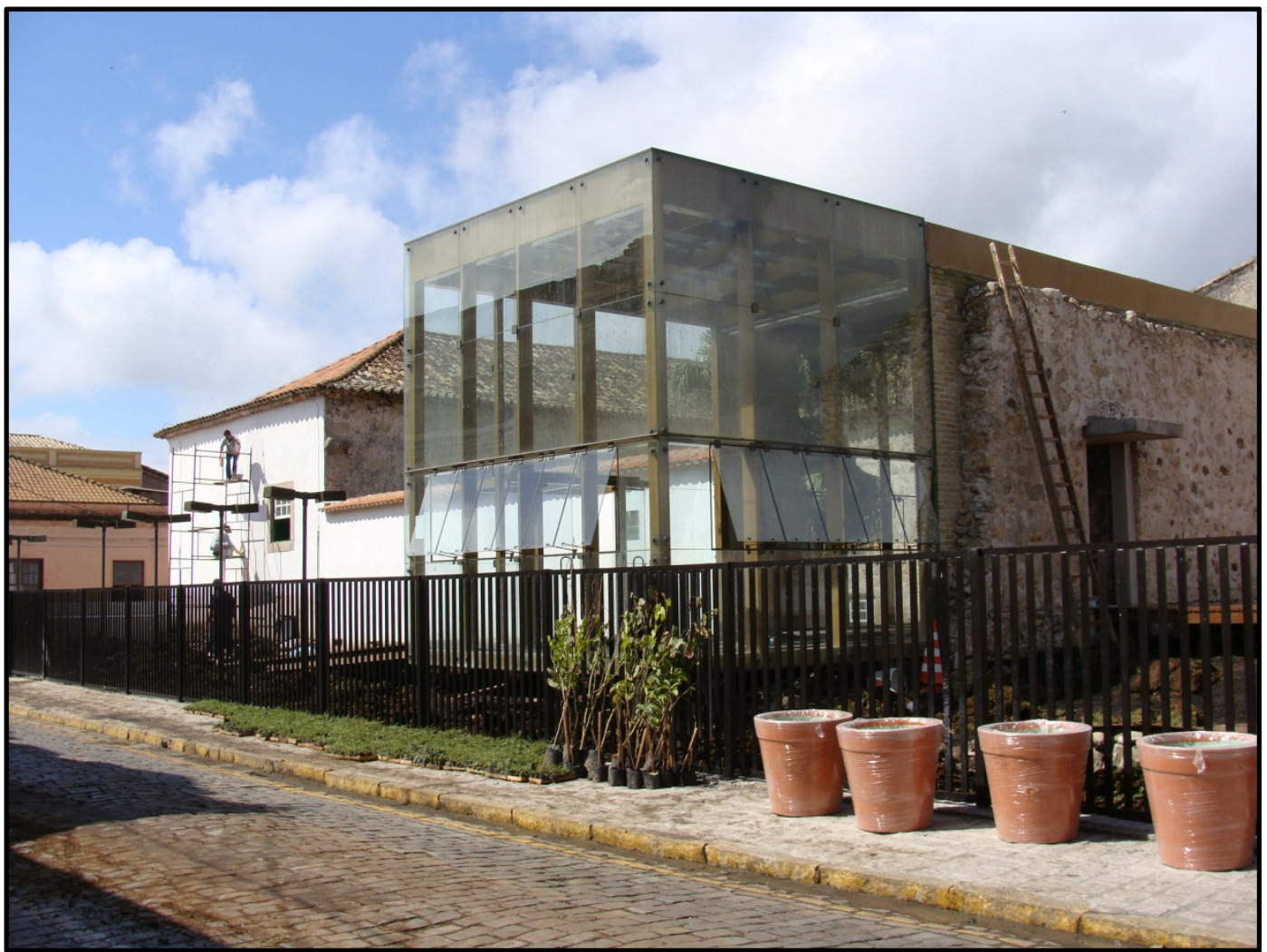

Figura 156. Esta construção contemporânea é o acesso principal ao Museu de Arqueologia e Entografia de Paranaguá, situado na rua XV de Novembro.

Fonte: Acervo do autor, 2009.

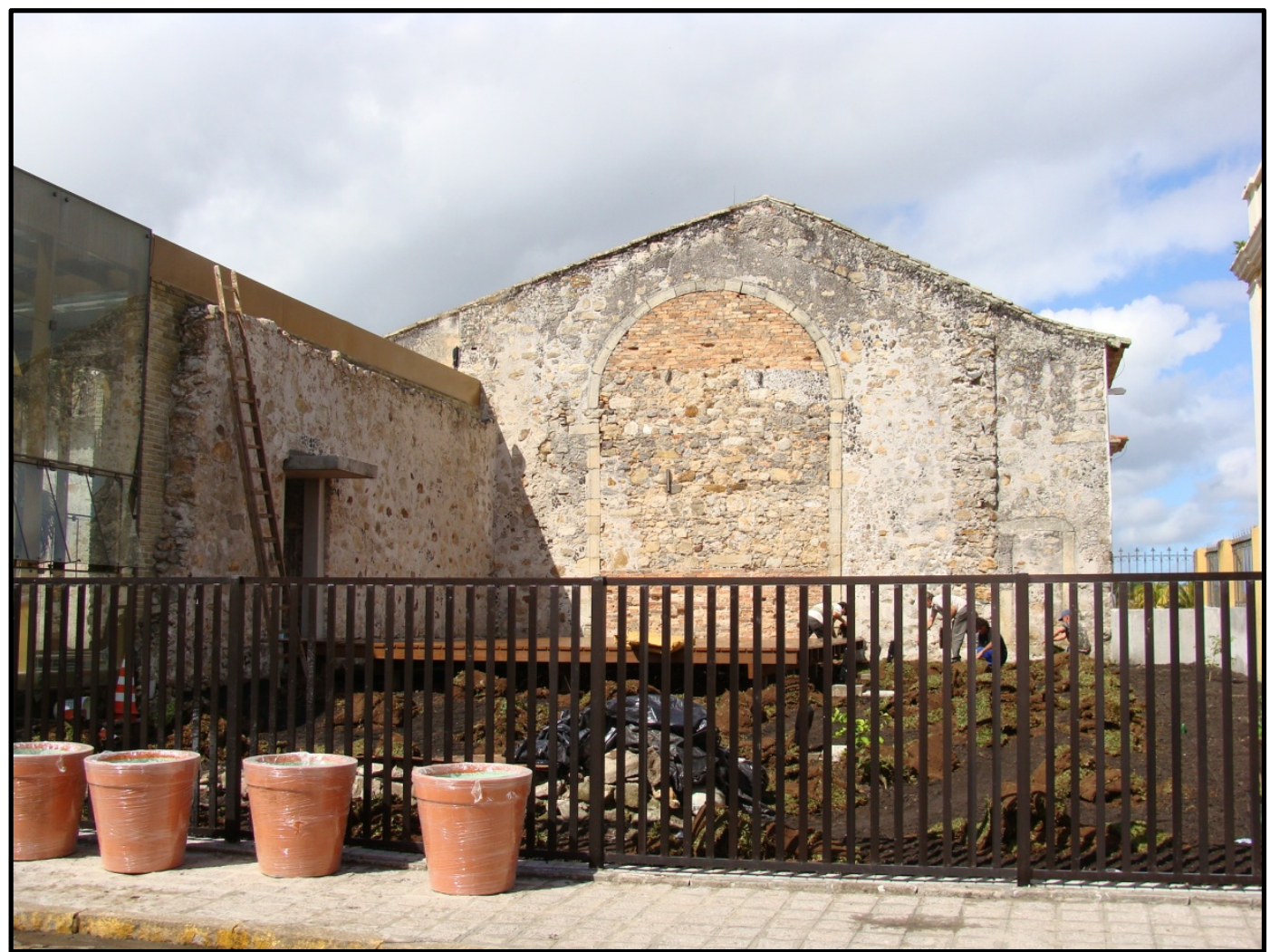

Figura 157. Local onde estava situada a igreja dos Jesuítas, ao fundo observa-se o arco cruzeiro. Fonte: Acervo do autor, 2009. 
A partir do Colégio dos Jesuítas, encaminhamo-nos em direção à Praça do Mercado (Ponto 22), importante local na consolidação comercial da rua da Praia. Construído na metade do século XIX, este edifício foi reformado na administração de Caetano Munhoz da Rocha, no começo do século XX (Figura 158), dando-lhe o aspecto Eclético, conservando ainda o volume do antigo edifício, assim como o pátio interno. Hoje o Mercado funciona com um conjunto de pequenos restaurantes, onde também ocorrem apresentações de fandango, dança típica desta região. Continuando pela rua da Praia (Figura 159), vamos observando o conjunto de casas e sobrados do século XVIII e XIX, dentre os quais alguns reformados. Para estabelecer os preceitos do Ecletismo, podemos destacar o palacete Mathias Bohn (Ponto 23), antigo sobrado do período Colonial, reformado em fins do século XIX, e outros sobrados com estas características. São edifícios construídos em frente ao antigo Porto e grande parte deles possuía fins comercias, em função da entrada e saída de mercadorias por este entreposto marítimo.

A partir da construção da Casa de Câmara e Cadeia na região do sítio da ribanceira, inicia-se a ocupação da área, que em conjunto com o porto, foi se desenvolvendo nas margens do Itiberê. Ao fim da rua da Praia, observa-se o último resquício do funcionamento do porto de Paranaguá nesta região, duas pequenas gruas (Ponto 24) que serviam para a colocação e retirada de mercadorias dos barcos que atracavam no local, são símbolos do desenvolvimento do porto nas margens do Itiberê. O porto contribuiu para o direcionamento do crescimento de Paranaguá, em direção à foz do rio e no desenvolvimento econômico da cidade. 


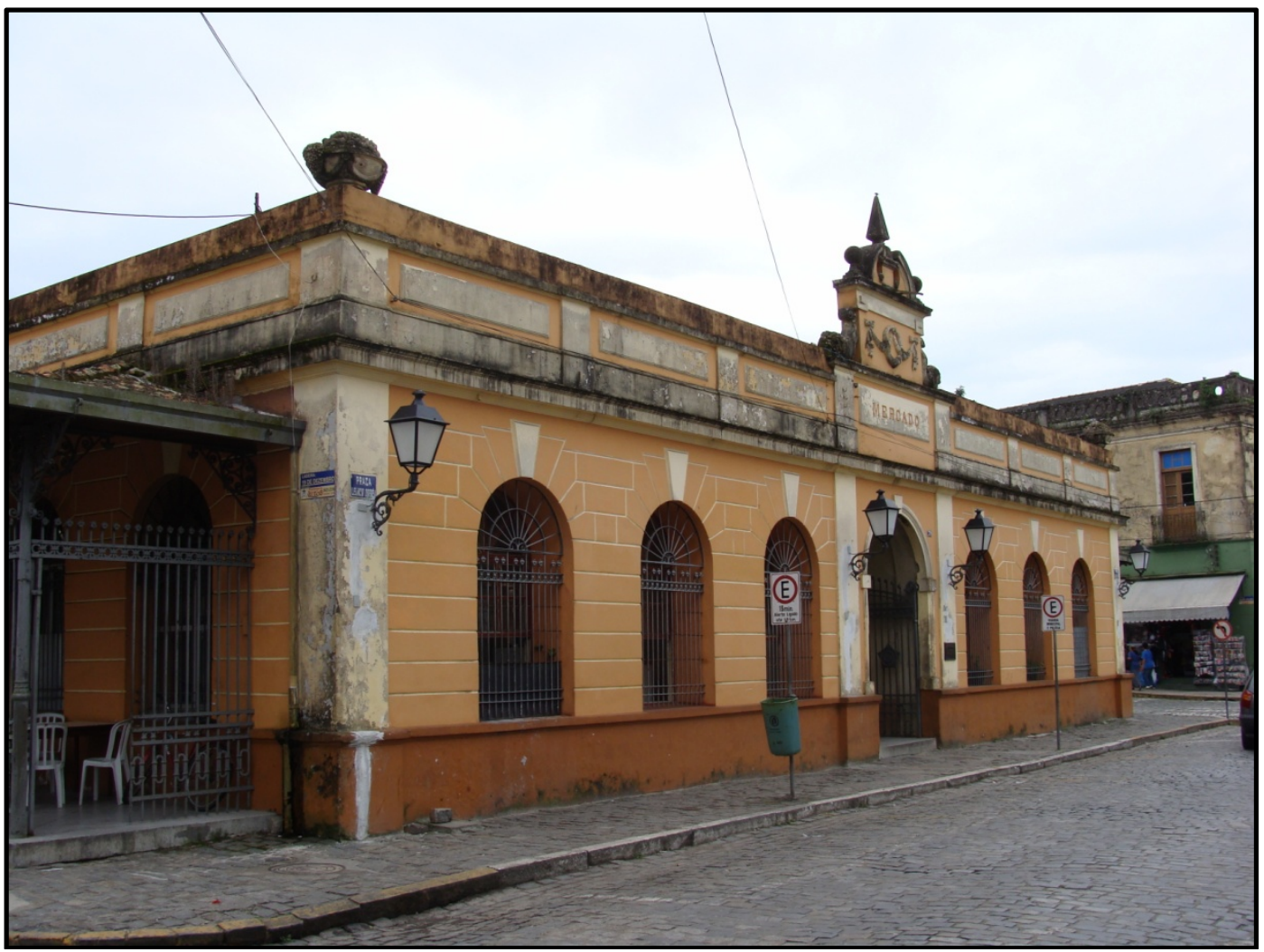

Figura 158. A Praça do Mercado, reformada no primeiro decênio do século XX, localizada na rua da Praia.

Fonte: Acervo do autor, 2009.

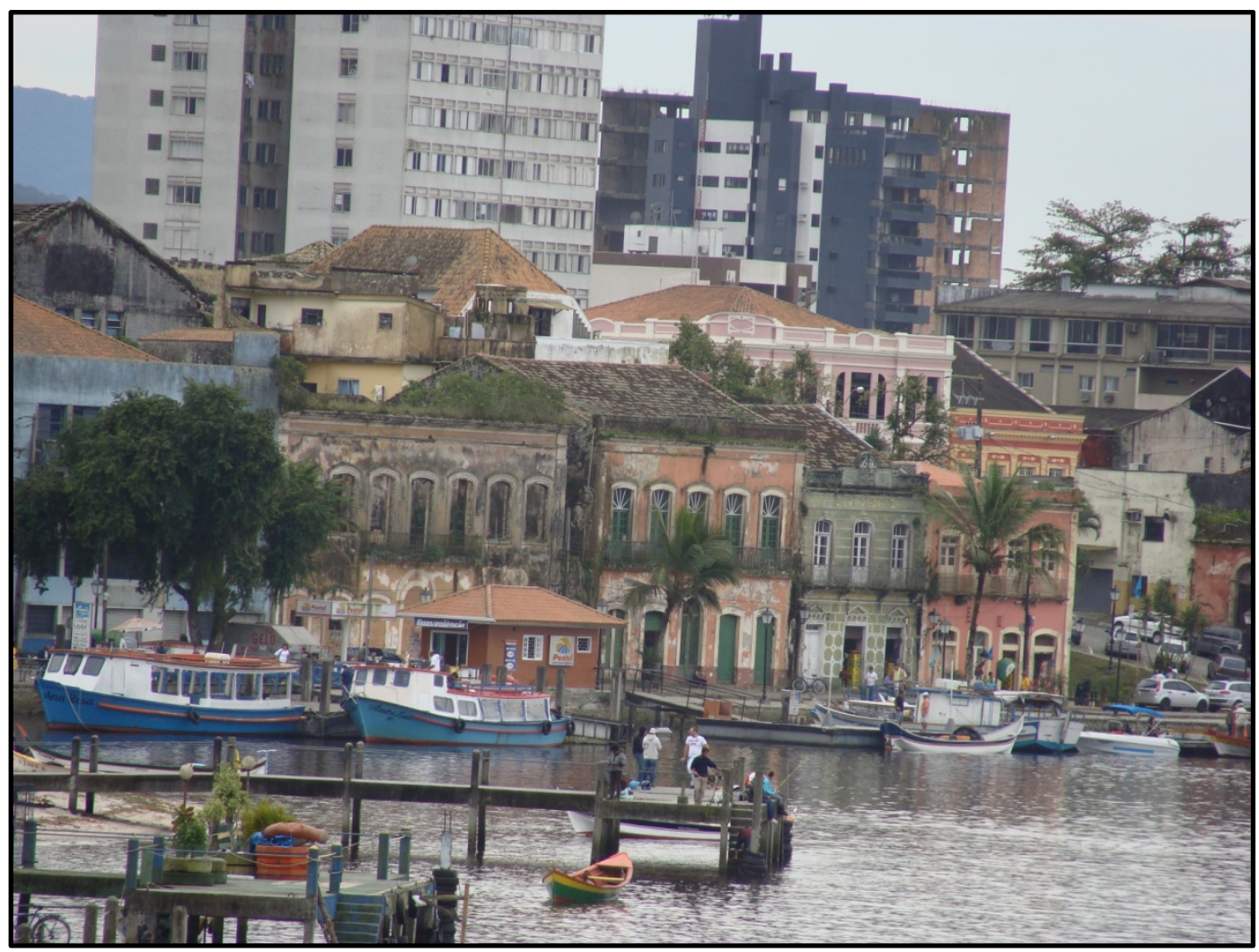

Figura 159. O rio Itiberê e parte do casario existente na rua da Praia.

Fonte: Acervo do autor, 2009. 
Adentrado a rua Princesa Izabel, encontramos no lado esquerdo, um pequeno edifício do século XVIII, que funcionava como estaleiro (Ponto 25), parte importante no desenvolvimento do Porto de Paranaguá. O local era utilizado para a manutenção e a construção dos barcos que navegavam pela região.

Continuando pela rua Princesa Izabel, chegamos à rua Visconde de Nácar, antiga rua da Boa Vista, local onde instalaram-se os grandes comerciantes de ervamate da cidade, produto que ampliou o comércio portuário paranaense e foi importante na formação da Província do Paraná. A via localiza-se nas proximidades do antigo porto e sedia residências como o Palacete Nácar (Ponto 26), uma das primeiras construções neoclássicas da cidade, que possui grandes proporções. É provavelmente a maior residência parnanguara do século XIX, também encontramos a casa de João Guilherme Guimarães (Ponto 27), residência representativa do Ecletismo e por fim logo à frente, a casa Veiga, construção de fins do século XIX, representativa daquele período, nesta casa viveu o pintor paranaense Alfredo Andersen e hoje encontra-se em ruínas (Ponto 28).

Continuando à frente, cruzamos com a Avenida Coronel José Lobo, onde se estabeleceu o antigo Boulevard Serzedello (Ponto 30), projetado em 1895, pelos engenheiros Tobias Martins e Virgilio Ricardo dos Santos, como proposta de ligação entre a cidade e o Porto D. Pedro II, o novo atracadouro, localizado na baía de Paranaguá. A grande avenida seria arborizada e reuniria chácaras ao seu redor, além de possuir em seus dois extremos, praças que não foram construídas. Hoje, esta avenida faz a ligação do centro da cidade ao porto de Paranaguá. Subindo a avenida, chegamos à rua Rodrigues Alves, e seguindo pela rua, logo a frente, encontramos a avenida que leva à estação ferroviária de Paranaguá, considerada o marco zero da estrada de ferro que liga o litoral à capital Curitiba. 
A estrada de ferro foi importante na transferência do porto para a baía de Paranaguá, sendo uma das condicionantes para a instalação da ferrovia nesta cidade, além da estação de Paranaguá, outra foi construída no porto, infelizmente demolida na década de 80 do século $X X$, para ampliação das áreas portuárias, portanto a estrada de ferro contribuiu para a ligação da cidade com o porto, em fins do século XIX e ao direcionamento da cidade para aquela região.

Da antiga estação de fins do século XIX, resta apenas um edifício (Ponto 31), que foi transformado em depósito, ainda é possível perceber a volumetria da antiga estação, recuperada recentemente, assim como a nova estação construída nos anos 20 do século $X X$, de proporções maiores que a antiga e com características Ecléticas (Ponto 32). Atualmente, ela recebe os passageiros que fazem o roteiro turístico entre Curitiba e Paranaguá. Da estação ferroviária, seguimos em frente pela rua Doutor Leocádio, antiga rua do Campo, que foi o limite para a região noroeste da cidade e até o século $\mathrm{XIX}$, eram áreas do rocio, estabelecidas pelo Ouvidor Pardinho.

A rua chega até os fundos da igreja Matriz e grande parte das antigas construções já não existe mais, mas poderemos destacar a casa Elfrida Lobo (Ponto 33), de fins do século XIX, ornamentada com as características do Ecletismo e conserva em seu interior aspectos originais, como o jardim lateral, o piso em madeira e os ladrilhos hidráulicos multicoloridos, encontrados aos fundos desta construção. Hoje a residência é sede da Associação dos Alcoólicos Anônimos, mas pode ser visitada, dependendo do dia. 


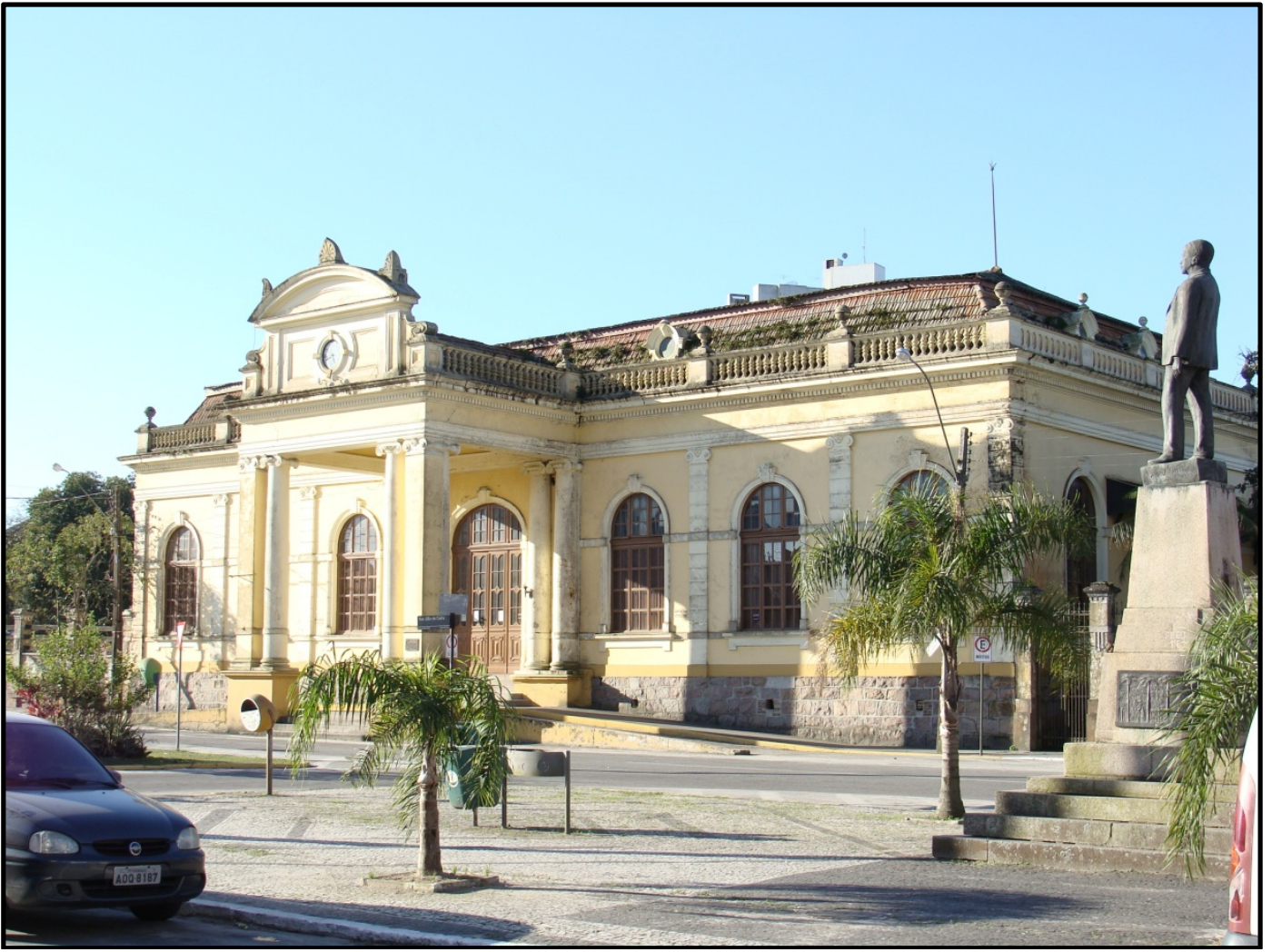

Figura 160. A estação de Paranaguá, construída nos anos 20 do século $X X$. Fonte: Acervo do autor, 2009.

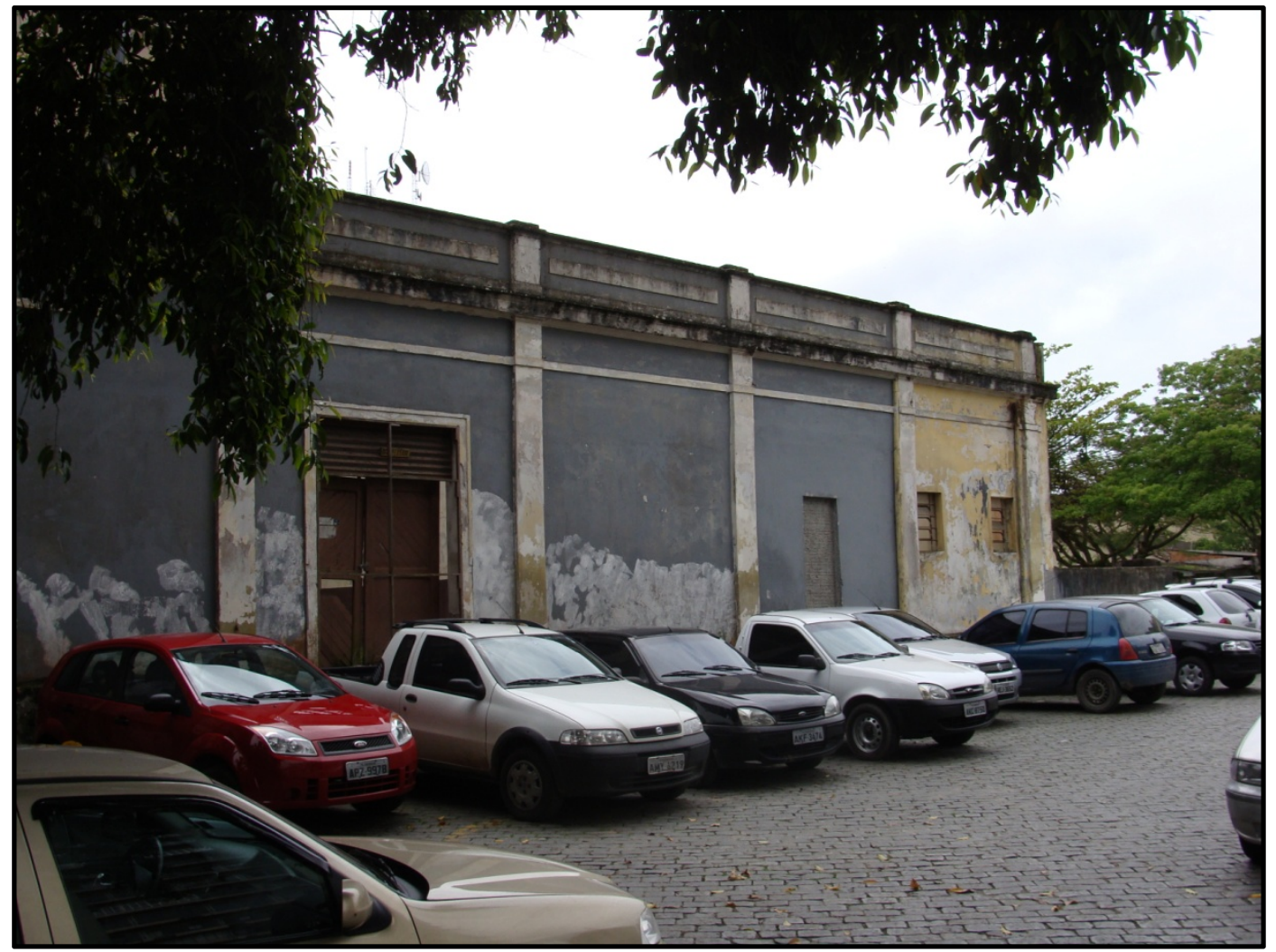

Figura 161. A Antiga estação de Paranaguá, que tornou-se depósito da nova estação e foi recuperada recentemente, servindo de posto de informações turísticas.

Fonte: Acervo do autor, 2009. 


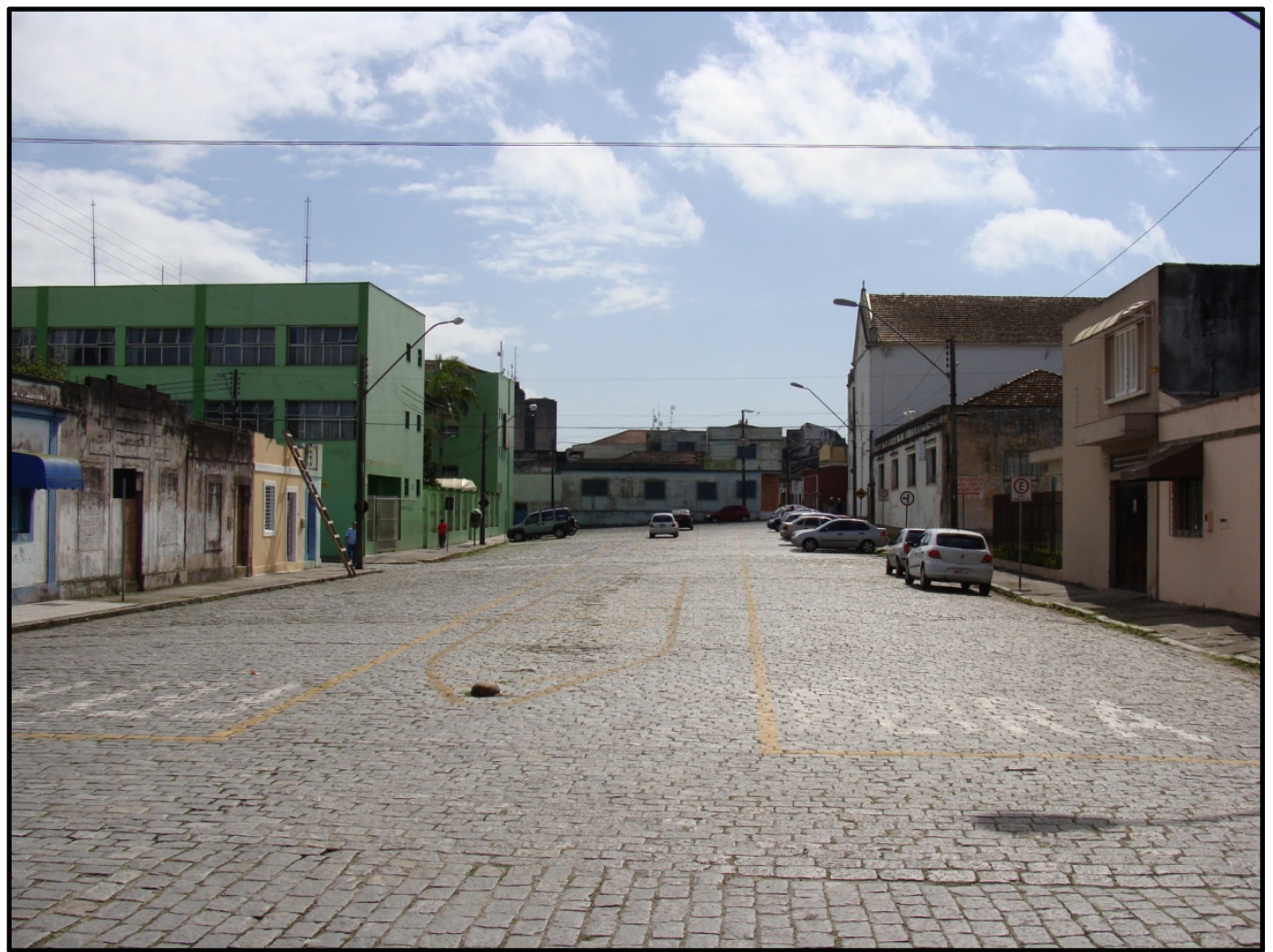

Figura 162. Os fundos da igreja Matriz.

Fonte: Acervo do autor, 2009.

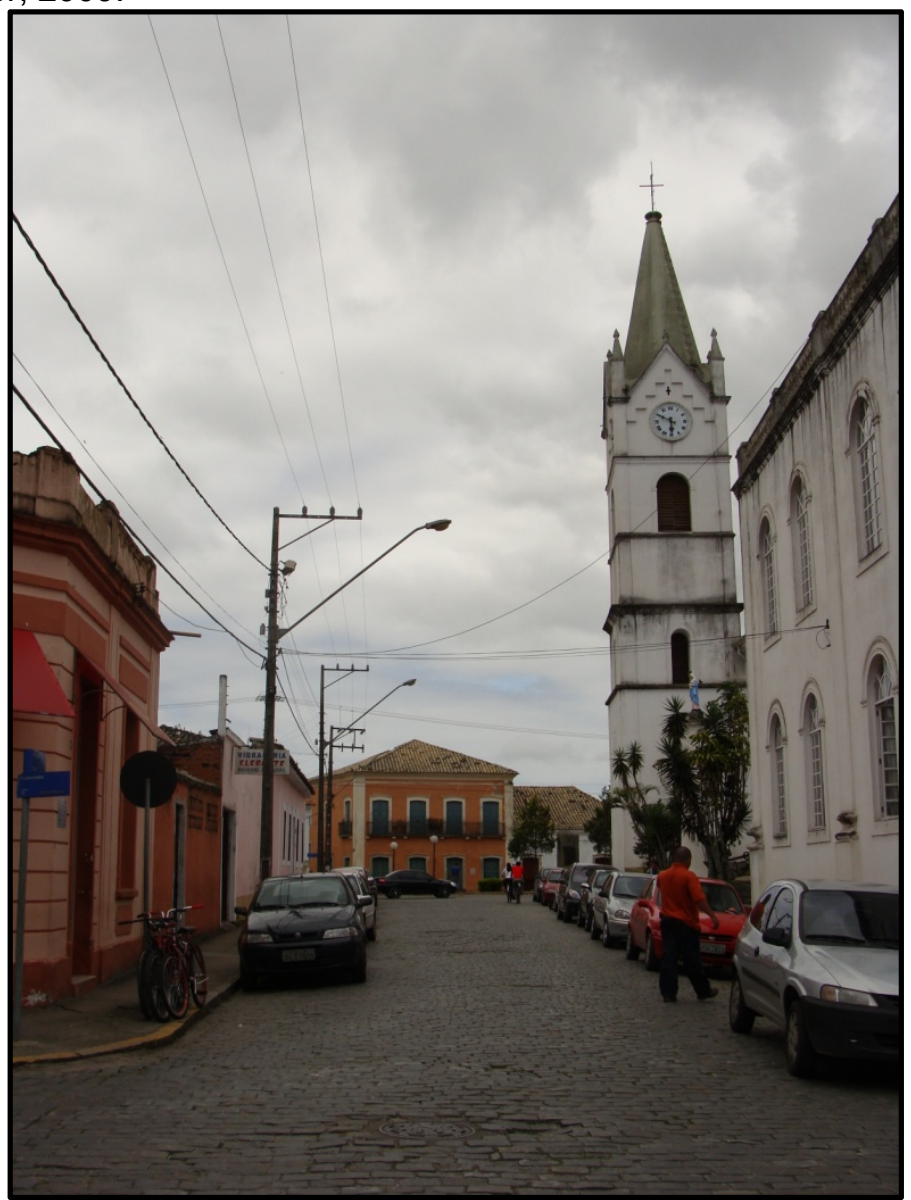

Figura 163. Rua Professor Cleto, ao lado da Matriz, ao fundo, as casas existentes no largo da Matriz. Fonte: Acervo do autor, 2009. 
Saindo desta residência encaminhamo-nos para o fim da rua Doutor Leocádio, visualizando os fundos da igreja Matriz (Figura 162), que possui um grande espaço, onde encontramos a primeira rua da cidade. Caminhando em direção à rua Professor Cleto (Figura 163), passamos pela lateral da igreja Matriz, possibilitando visualizar as duas casas existentes em seu largo, mais alguns passos e finalmente chegamos à este local, encerrando o passeio, já que regressamos ao ponto de partida.

Portanto, apresentamos aqui uma sugestão de roteiro, como exemplo de atividade para o reconhecimento do Centro Histórico de Paranaguá, tanto em relação a seu traçado urbano como de suas construções. E a partir deste roteiro, outras sugestões poderão surgir, enfocando, por exemplo, nos meios comerciais, nas ações do Ouvidor Pires Pardinho e no funcionamento do Porto de Paranaguá. Criando assim, diversas temáticas de passeios, que podem auxiliar na compreensão do desenvolvimento urbano e arquitetônico de Paranaguá, até os dias atuais. 


$$
\begin{aligned}
& \text { Paranagua } \\
& \text { devvila a } \\
& \text { cidade, do } \\
& \text { Itiberê a } \\
& \text { baía, de } \\
& \text { Pardinho à } \\
& \text { ferrovia }
\end{aligned}
$$



PARANAGUÁ DE VILA A CIDADE, DO ITIBERÊ A BAÍA, DE PARDINHO A FERROVIA.

Paranaguá representa, para o estudo urbano das cidades brasileiras, um exemplo de transformações embasadas em seus meios de produção, pois, assim como a vila e posteriormente a cidade, foi acompanhada pelo porto, que desde a busca do ouro, à exploração da erva-mate, foi essencial para o seu desenvolvimento.

A vila de Paranaguá, implantada no continente, após a ocupação inicial da ilha da Cotinga, teve a consolidação de sua ocupação através das ordens colocadas pelo Ouvidor Rafael Pires Pardinho, disciplinador do crescimento urbano da cidade naquele período. Se temos, Paranaguá ocupando as margens do rio Itiberê, e descentralizando sua concentração urbana inicial, nas proximidade da igreja Matriz e da fonte d'Água, de alguma forma isto foi graças às determinações deste Ouvidor, pois Pardinho representa o momento crucial na implantação da vila de Paranaguá, e estas determinações influenciarão em seu desenvolvimento no século XVIII e XIX.

A descentralização foi marcada pela construção da Casa de Câmara e Cadeia, na região do Sítio da Ribanceira e próxima a ela, o Colégio dos Jesuítas, a maior construção do período na vila. Estes dois elementos também serão fatores de atração, para o estabelecimento de outras edificações nessa região, formando um conjunto predominantemente comercial, em função do porto às margens do Itiberê.

As determinações do Ouvidor são um exemplo de diretrizes de organização da vila, não só na preocupação com a delimitação e ocupação de seu rossio, mas também na abertura de novas ruas, nas ações dos poderes locais e até no 
comportamento da população. Pardinho é definitivamente um marco na história urbana de Paranaguá, pois além das definições aplicadas pelo Ouvidor, a partir de suas correições, temos a organização do porto nas margens do Itiberê e o início de sua ligação com a vila. Portanto, temos a partir desse momento a convergência da estrutura portuária com a Paranaguá setecentista. Consideramos que a vila de Paranaguá, iniciou efetivamente sua ocupação continental, após a vinda de Pardinho, ou seja, suas determinações delinearam a ocupação urbana de Paranaguá, que antes concentrava-se afastada do Itiberê, na região mais alta da vila, e a partir das correições, toma o Itiberê como fonte de renda e como parte da vida cotidiana parnanguara.

Além das correições, outro elemento crucial nesta ocupação foram as igrejas, estes pontos de concentração urbana, também direcionaram o crescimento da vila no século XVIII e XIX, a partir do momento em que eram implantadas. Do eixo concentrador inicial entre as igrejas das Mercês e Matriz, ele se expande após a implantação da igreja do Bom Jesus em 1710, esta igreja delimita o fim do eixo, formado pelas ruas da Gambôa e Direita. As igrejas dos Jesuítas e da Ordem estavam fora do eixo e foram construídas depois da vinda do Ouvidor Pardinho, estão localizadas nas proximidades do rio Itiberê.

Com o findar do século XVIII, e a chegada do século XIX, a pequena vila passará por intensas transformações em suas construções, nos modos de vida e em sua economia. Temos a partir do segundo decênio do século XIX, a implantação do produto que marcará Paranaguá neste período, a erva-mate. Este produto definitivamente colocará a cidade como centro exportador e será fundamental para a criação da Província do Paraná e também para a elevação de Paranaguá a cidade, no ano de 1843. 
A erva-mate consolidou o comércio na rua da Praia, concentrando os estabelecimentos comerciais e de exportação, e que contribuiu para enriquecer os exportadores ervateiros e a construção de grandes residências na cidade, como símbolos de seu poderio. Estas construções foram influenciadas, primeiramente pelo Neoclássico, como o Palacete Nácar e posteriormente com o Ecletismo, como o Palacete Bohn, são edifícios construídos em função da erva-mate, assim como o café foi para os paulistanos, portanto, o Ecletismo que para São Paulo foi a expressão do café, em Paranaguá será expresso pela erva-mate.

Ao findar do século XIX, a cidade, visitada por diversos viajantes, não ultrapassou, no sentido ortogonal ao rio Itiberê, os limites estabelecidos por Pardinho, no século XVIII. Observamos que Paranaguá desenvolveu-se no sentido longitudinal, paralelo ao rio Itiberê, através de cinco eixos importantes, rua do Fogo/rua do Campo, rua da Gambôa/rua Direita, rua do Ouvidor, rua da Cadeia e da Ordem e por fim a rua da Praia. Grande parte do crescimento de Paranaguá ocorreu nestes eixos, ou seja, a cidade se concentrou nas proximidades de seu porto e de outros edifícios relevantes como: a Alfândega no antigo Colégio dos Jesuítas, a Casa de Câmara e Cadeia e a fonte d'Água, manancial de abastecimento de seus habitantes até o começo do século XX.

De acordo com ampliação do espaço portuário, nas margens do Itiberê, constatamos que a cidade acompanhou este crescimento, aumentando o comprimento dos eixos viários principais de desenvolvimento, até chegar ao limite natural, da foz do rio Itiberê. Portanto, o porto não só auxiliou economicamente a cidade de Paranaguá, mas também foi um ponto magnético de atração urbana, que assim como as águas do Itiberê, cresceu no sentido nascente-foz (Figura 164 e Figura 165). 


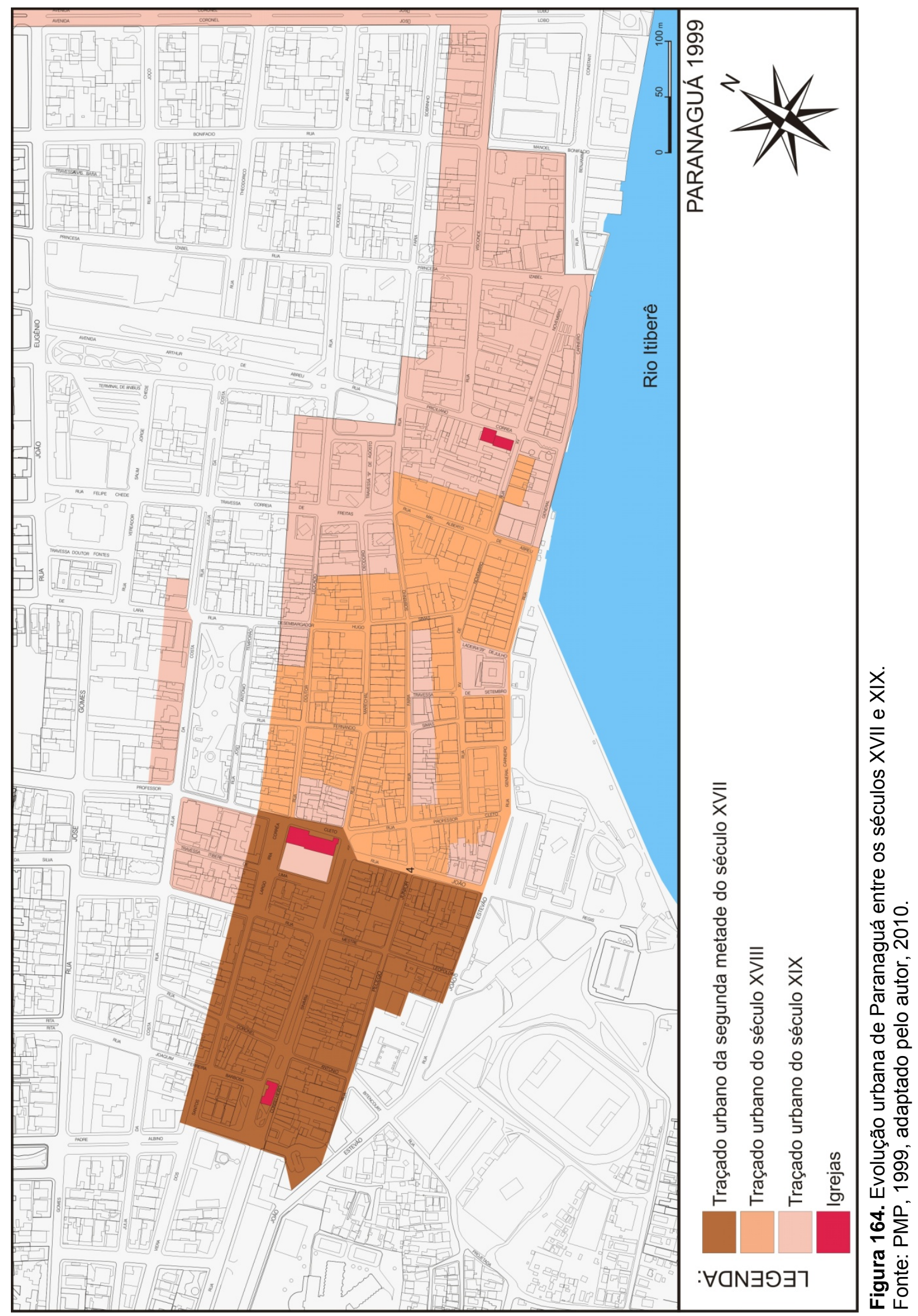




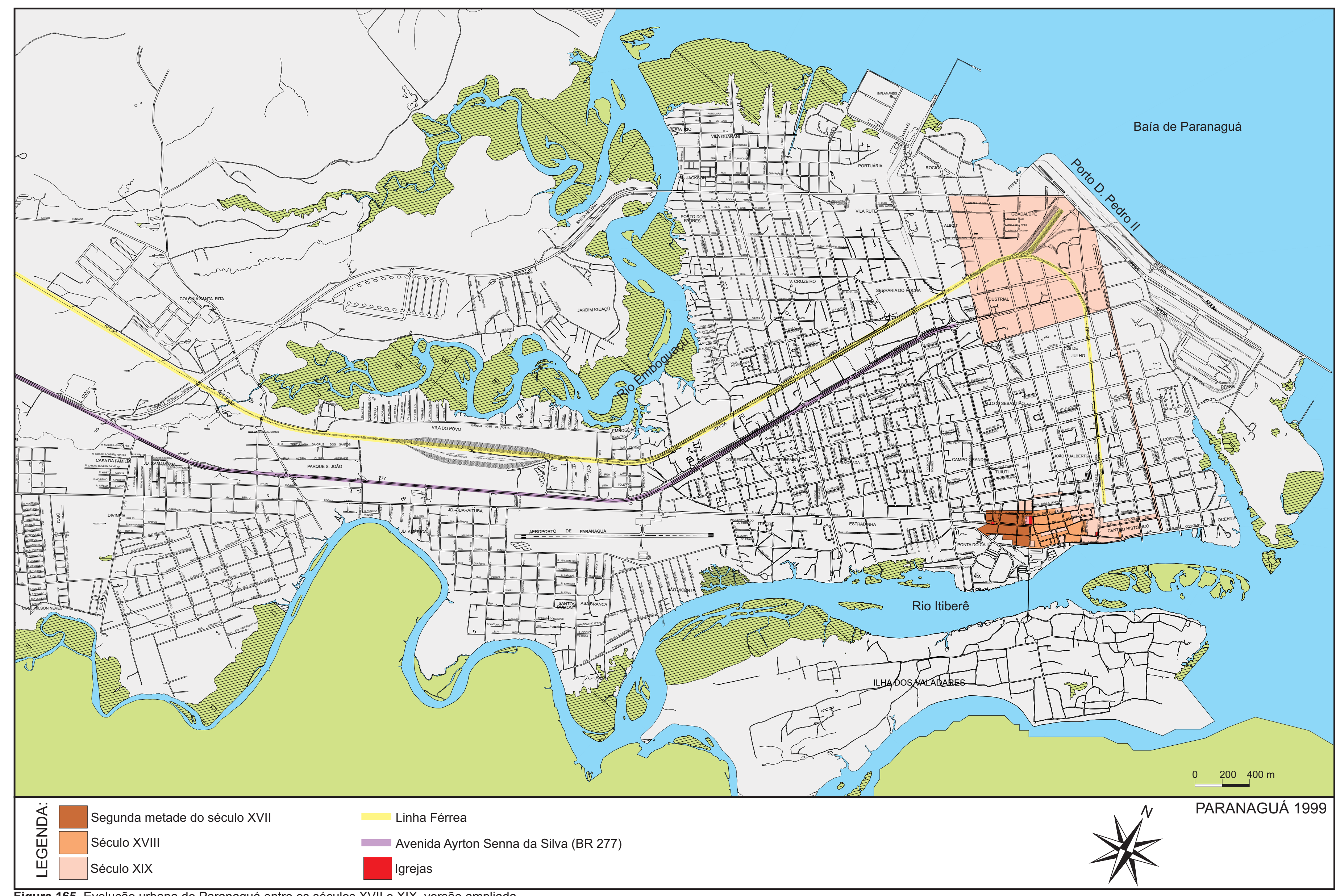

Figura 165. Evolução urbana de Paranaguá entre os séculos XVII e XIX, versão ampliada.

Fonte: PMP, 1999/ adaptado pelo autor, 2010. 

Mas com os problemas de assoreamento identificados em diversos documentos de época, e o interesse na implantação da Estrada de Ferro, iniciandose em Paranaguá, ocorreu a estratégia de mudança das atividades portuárias da margem esquerda do Itiberê para a baía de Paranaguá, na região noroeste deste território. Com a implantação das estações da Estrada de Ferro em Paranaguá, e o deslocamento do porto à baía, começou a partir deste momento o deslocamento do crescimento da cidade para a região ainda desocupada, entre Paranaguá e o novo porto. E a partir desta problemática, foi realizada a proposta para a urbanização deste território, através da criação de um Boulevard, influenciados pelas reformas haussmanianas em Paris, um novo elemento urbano, em uma cidade de traçados coloniais.

Foi uma cidade também marcada pelo tráfico negreiro, passando pela transição entre o Império e a criação da República, em conjunto com o fim da escravidão, provavelmente atordoada com tantas mudanças, uma cidade na visão dos viajantes "pequena, mas comerciante" que trazia em sua estrutura uma classe dominante escravista e exportadora de erva-mate, produto que utilizava pouca mão de obra para o seu beneficiamento e desta forma não necessitava de grandes tecnologias.

Mesmo com estas iniciativas para a ligação entre a cidade e o porto, a consolidação daquela região como área portuária só ocorrerá nos anos 30 do século XX, observamos que existiam a ausência de alguns elementos essenciais, que possibilitassem o desenvolvimento da cidade para fora de seus limites coloniais: primeiro o problema do abastecimento de água, as fontes estavam localizadas dentro da cidade e a construção de uma rede de abastecimento só ocorreu em 1916, na gestão de Caetano Munhoz da Rocha. Outro problema era o transporte 
público, inexistente naquele período, temos as primeiras iniciativas de bondes ligando estas duas regiões, apenas em 1893, portanto são problemáticas que de alguma forma retardaram o crescimento de Paranaguá para a direção de sua baía.

Enquanto estas ações não eram consolidadas, percebemos que a cidade mantinha-se concentrada nas margens do Itiberê, este rio foi, certamente importantíssimo na formação da cidade, como porta de entrada de mercadorias e de viajantes, dentre os quais aqueles que imortalizaram suas passagens pela cidade através das descrições, fundamentais para o entendimento de Paranaguá e de sua situação nos períodos de estudos. Além disso, as fotografias foram de suma importância, ilustrando dados colocados na pesquisa, trouxeram novas informações que em alguns casos os textos não apresentavam, são documentos importantes e por isso é necessária sua preservação e divulgação.

Paranaguá, ainda hoje "quase capital” do Paraná, possui em sua população um sentimento de perda e de decadência, observado em sua estrutura urbana atual, uma cidade do "quase lá", de construções remendadas, do pastiche, da ocupação desordenada, de seu Centro Histórico em decomposição, sobrevivendo à violência da especulação imobiliária. Uma cidade que acha ser o "berço da civilização paranaense", divulgada em placas e motivo de orgulho dos seus cidadãos. Mas que civilização é esta que pouco preserva seu passado? Paranaguá é a cidade do "dizem que", das incertezas em sua história, dos textos de memorialistas, da ocultação de eventos históricos, das suposições infundadas, são fatores que fazem parte de sua existência.

O porto que antes contribuíra para o desenvolvimento da cidade, agora a destrói, explora, não contribui para o município, causando enorme impacto. O porto de Paranaguá é uma peça autônoma no funcionamento da cidade, separado por 
grades e muros, o que antes era permeável agora possui acesso restrito, a cidade não tem mais a identidade com seu porto (Figura 166 e Figura 167).

Paranaguá não é apenas a cidade do Visconde de Nácar, da visita de D. Pedro II, ou das famílias, Correa, Guimarães, Lobo, mas também de toda a população que contribuiu para dar vida à este espaço urbano, são aquelas pequenas construções, os espaços públicos e seu traçado urbano que faziam parte do cotidiano parnanguara e que estão de certa forma esquecidos nos dias atuais.

Esperamos que esta pesquisa possa contribuir para o início de uma reflexão sobre a cidade e também de outras cidades do litoral paranaense, não podemos preservar apenas por preservar, é necessário entender e conhecer aquilo que será preservado. Paranaguá é uma cidade com infinitas possibilidades de desenvolvimento, não apenas no turismo, mas também para aqueles que lá habitam e convivem, é necessário ações organizadas que incentivem a valorização de seu Centro Histórico, não só pelo poder público, mas também por sua população, descobrindo qual o grau de identificação dos parnaguaras com sua cidade.

Portanto, esperamos contribuir para isso, sugerindo que outras pesquisas sobre a cidade possam ser realizadas, como sua situação no século $X X$, as ações de preservação de seu Centro Histórico, a identidade da população com esta cidade, os estudos sociológicos, novas pesquisas históricas, pois ainda existem muitos assuntos a serem desvendados não só em Paranaguá, mas em todo o litoral paranaense. Paranaguá é uma cidade que pode oferecer diversas leituras, esperamos que esta pesquisa seja o início de novas possibilidades de interpretação sobre a cidade e suas estruturas. 


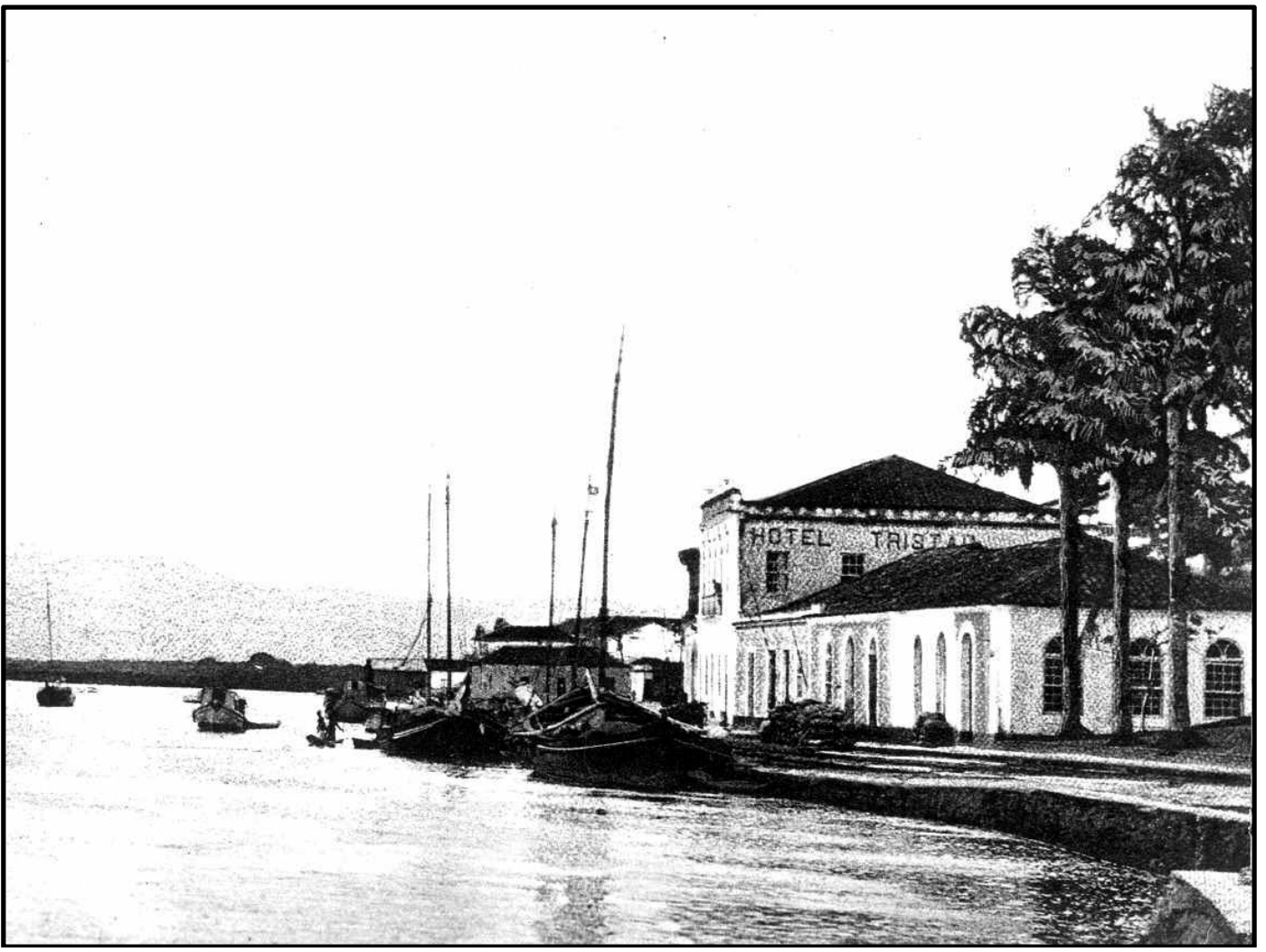

Figura 166. O porto do Itiberê possuía relações permeáveis com a cidade.

Fonte: IHGP.

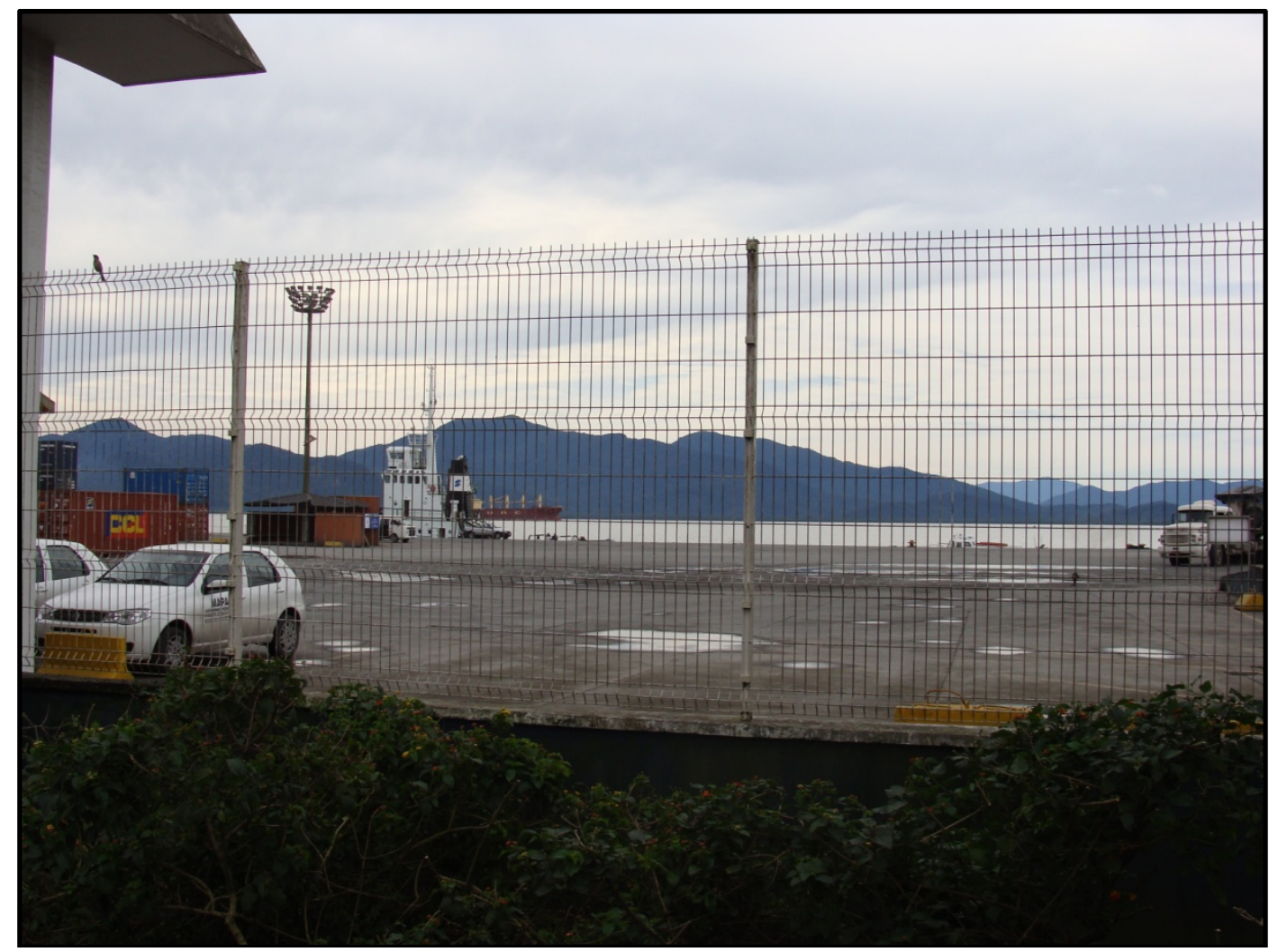

Figura 167. O Porto da baía de Paranaguá, separado da cidade por grades e muros. Fonte: Acervo do autor, 2009. 


\section{REFERÊNCIAS}

\section{BIBLIOGRAFIA}

ALENCASTRO, Luiz Felipe de; RENAUX, Maria Luiza. Caras e modos dos migrantes e imigrantes. In: NOVAIS, Fernando A. História da Vida Privada no Brasil. Vol. II. São Paulo: Companhia das Letras, 2008, 291- 336.

AVÉ-LALLEMANT, Robert. Viagens pelas províncias de Santa Catarina, Paraná e São Paulo. Belo Horizonte: Ed. Itatiaia, 1980.

ÁVILA, A.; GONTIJO; J. M. M.; MACHADO, R. G. Barroco Mineiro: Glossário de Arquitetura e Ornamentação. São Paulo: Cia. Melhoramentos de S. Paulo, 1980.

BARBOSA, Ana Aparecida. Uma Fresta na Neblina: Estudo da Possibilidade de Restauro Urbano do Serro. 2007. 289 f. Dissertação (Mestrado) - Departamento de Arquitetura e Urbanismo da Escola de Engenharia de São Carlos, Universidade de São Paulo, São Carlos, 2007.

BARRETO, Paulo Thedin. Casas de Câmara e Cadeia. In: FAUUSP e MEC-IPHAN. Arquitetura Oficial I. São Paulo: FAUUSP e MEC-IPHAN, 1978, 103-253.

BAZIN, Germain. A Arquitetura Religiosa Barroca no Brasil. Rio de Janeiro: Editora Record, s/d. Vol. I e II.

BIGG-WITHER, Thomas Plantagenet. Novo Caminho no Brasil meridional: a província do Paraná, três anos de vida em suas florestas e campos 1872/1875. Rio de Janeiro: J. Olympio, 1974.

BRANDI, Cesare. Teoria da Restauração. 2. ed. Cotia: Ateliê Editorial, 2005. 261p.

BURY, John. Arquitetura e Arte no Brasil Colonial. Brasília: IPHAN, MONUMENTA, 2006.

CARTA DE VENEZA. Carta de Veneza. 1964. Disponível em: www.iphan.gov.br; acesso em: 20/12/2010 
CODMAN, John. Ten Months in Brazil With Incidents of Voyages and Travels, Descriptions of Scenery and Character, Notices of Commerce and Productions, etc. Boston: Lee and Shepard. 1867. Disponível em: http//:www.googlebooks.com. Acesso em: 10 de janeiro de 2010.

COELHO, Salvador José Correia. Passeio à Minha Terra. Curitiba: Fundação Cultural, 1995.

CORONA, Eduardo; LEMOS, Carlos A. C. Dicionário da Arquitetura Brasileira.

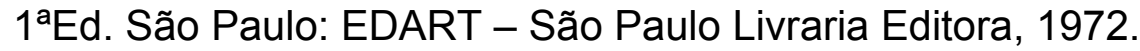

COSTA, Lucio. Arquitetura Jesuítica no Brasil. Revista do IPHAN, Rio de Janeiro, n 4, 1941.

DA COSTA, Samuel Guimarães. A Erva-Mate. Curitiba: Coleção Farol do Saber, 1995.

DA COSTA, Samuel Guimarães. O Último Capitão-Mor: 1782-1857. Paranaguá: Scientia e Labor, 1988.

DOURADO, Odete. Por um Restauro Urbano: novas edificações que restauram cidades monumentais. Revista RUA. N.8, p.8-13. Salvador: Programa de PósGraduação em Arquitetura e Urbanismo, UFBA, 2003.

FAUSTO, Boris. História do Brasil. 8ªEd. EDUSP: São Paulo. 2000.

FERREZ, Marc. Álbum da Estrada de Ferro do Paraná. 1884. Conjunto de Fotografias Sobre a Construção da Estrada de Ferro entre Curitiba e Paranaguá. Coleção D. Tereza Cristina Maria. Disponível em: www.bn.br/bndigital. Acesso em: 15 de junho de 2009

FOLHA DO LITORAL. Porto D. Pedro II completa 74 anos. Folha do Litoral. 17 mar. 2009, p. 16.

FONTĖS, Lúcia Helena, et al. Preservação e Desenvolvimento: As duas Faces de uma Moeda Urbana. Revista do Patrimônio Histórico e Artístico Nacional, Rio de Janeiro, $\mathrm{n}^{\circ}$ 21, p. 51-55, 1986. Disponível em: www.iphan.gov.br Acesso em: 5 de julho de 2010. 
HILAIRE, Saint, Auguste de. Viagem pela Comarca de Curitiba. Curitiba: Farol do Saber, 1995. 182p.

HOLANDA, Sergio Buarque de. A Época Colonial: Administração, Economia, Sociedade. Tomo I, Vol. 2. São Paulo: Difusão Européia do Livro, 1968.

HOMEM, Maria Cecília Naclércio. O Palacete paulistano e Outras Formas Urbanas de Morar da Elite Cafeeira: 1867 - 1918. São Paulo: Martins Fontes, 1996.

KIDDER, D. P. e FLETCHER, J.C. O Brasil e os Brasileiros (Esboço Histórico e Descritivo). Vol I e II. São Paulo: Companhia Editora Nacional. 1941.

KOSERITZ, Carl Von. Imagens do Brasil. Tradução Afonso Arinos de Melo Franco. Belo Horizonte: Ed. Itatiaia; São Paulo: Editora da Universidade de São Paulo, 1980.

KÜLL, Beatriz Mugayar. Arquitetura do Ferro e Arquitetura Ferroviária em São Paulo - Reflexões sobre a sua Preservação. São Paulo: Ateliê Editorial: Fapesp: Secretaria da Cultura, 1998.

KÜLL, Beatriz Mugayar.História e Ética na Conservação e Restauração de Monumentos Históricos. Revista CPC, São Paulo, v.1, n.1, p. 16-40, Nov. 2005-abr. 2006.

LEMOS, Carlos. O Ecletismo em São Paulo. In: FABRIS, Annateresa (Org.). Ecletismo na Arquitetura Brasileira. São Paulo: Nobel; Editora da Universidade de São Paulo, 1987.

LYNCH, Kevin. A Boa Forma da Cidade. Lisboa: Edições 70, 1999.

MAACK, Reinhard. Notas para a História, Geologia e Geografia de Paranaguá. In: Revista do Instituto Histórico, Geográfico e Etnográfico Paranaense, 1963, p 822.

MAESTRI, Mário. O Sobrado e o Cativo: A Arquitetura Urbana Erudita no Brasil Escravista - O Caso Gaúcho. Passo Fundo: UPF, 2001.

MARTINS, Romário. História do Paraná. Curitiba: Travessa dos Editores, 1995. 
MARTINS, Wilson. A Invenção do Paraná: Estudo sobre a Presidência Zacarias de Góes e Vasconcellos. Curitiba: Imprensa Oficial, 1999.

MARX, Murillo. Cidade Brasileira. São Paulo: Melhoramentos:EDUSP, 1980.

MARX, Murillo. Cidade no Brasil: Terra de Quem? São Paulo: Nobel:EDUSP. 1991.

MORGENSTERN, Algacyr. Porto de Paranaguá, Contribuição à História: Período: 1648/1935. Paranaguá: Imprensa Oficial, 1985.

NADALIN, Sergio Odilon. Paraná: Ocupação do Território, População e Migrações. Curitiba: SEED, 2001.

OLIVEIRA, Dennison. Urbanização e Industrialização no Paraná. Curitiba: SEED, 2001.

PARANÁ, Secretaria de Estado da Cultura. Espirais do Tempo: Bens Tombados do Paraná. Curitiba: Secretaria de Estado da Cultura, 2006.

PARANÁ. Secretaria de Estado da Cultura. Catálogo Museu Alfredo Andersen. Curitiba: Secretaria de Estado da Cultura, 2007.

PARANÁ. Secretaria de Estado da Cultura. Pintores da Paisagem Paranaense. Curitiba: Solar do Rosário, 2005.

PARANAGUÁ. Lei Complementar n 4, de 21 de janeiro de 1998. Paranaguá, 1998.

PEREIRA, Magnus Roberto de Mello; SANTOS, Antonio Cesar de Almeida. O Poder Local e a Cidade: A Câmara Municipal de Curitiba. Curitiba: Aos Quatro Ventos, 2000.

PESSOA, José; PICCINATO, Giorgio (Org). Atlas de Centros Históricos do Brasil. Rio de Janeiro: Casa da Palavra, 2007.

POMBO, José Francisco da Rocha. O Paraná no Centenário (1500-1900). $2^{\mathrm{a}}$ Ed. Curitiba: Secretaria da Cultura e do Esporte do Estado do Paraná, 1980. 
PRIORE, Mary del. Ritos da Vida Privada. In: NOVAIS, Fernando A. História da Vida Privada no Brasil. Vol. I. São Paulo: Companhia das Letras, 1998, 275-331.

REIS FILHO, Nestor Goulart. Evolução Urbana no Brasil. São Paulo: Editora da Universidade de São Paulo, 1968.

REIS FILHO, Nestor Goulart. Imagens de Vilas e Cidades do Brasil Colonial. São Paulo: EDUSP. 2001.

REIS FILHO, Nestor Goulart. Quadro da arquitetura no Brasil. 6. ed. São Paulo: Perspectiva, 1978.

REIS FILHO, Nestor Goulart. São Paulo - Vila, Cidade, Metrópole. São Paulo: Takano, 2004.

REIS FILHO, Nestor Goulart. São Paulo e Outras Cidades - Produção Social e Degradação dos Espaços Urbanos. São Paulo: Hucitec, 1994.

REIS, João José. O cotidiano da morte no Brasil oitocentista. In: NOVAIS, Fernando A. História da Vida Privada no Brasil. Vol. II. São Paulo: Companhia das Letras, 2008, 95 - 141.

SALGUEIRO, Heliana Angotti. O Pensamento Francês na Fundação de Belo Horizonte: Das Representações às Práticas. In: SALGUEIRO, Heliana Angotti (Org). Cidades Capitais do Século XIX Racionalidade, Cosmopolitismo e Transferência de Modelos. São Paulo: EDUSP, 2001.

SANT'ANNA, M. G. de. Da cidade-monumento à cidade-documento: a trajetória da norma de preservação de áreas urbanas no Brasil (1937-1990). Dissertação (mestrado) - Faculdade de Arquitetura e Urbanismo, Universidade Federal da Bahia, Salvador, 1995.

SANTOS, Carlos Antunes. Paraná: Vida Material, Vida Econômica. Curitiba: SEED, 2001.

SANTOS, Milton. Por uma Geografia Nova: Da Crítica da Geografia a uma Geografia Crítica. 6ª Ed. São Paulo: EDUSP, 2004.

SOUZA, Alberto. Arquitetura Neoclássica Brasileira: Um Reexame. São Paulo: PINI, 1994. 
TEIXEIRA DA COSTA, Cacilda. O Sonho e a Técnica: A Arquitetura de Ferro no Brasil. São Paulo: EDUSP, 2001

TREVISAN, Edilberto. Visitante Estrangeiros no Paraná: Tschudi, Platzmann, Fric, Helling - Vida e algum texto. Curitiba: Livraria do Chain Editora, 2002.

UNESCO-ICCROM e ICOMOS. Conferência de Nara. In: Instituto do Patrimônio Histórico e Artístico Nacional. Cartas Patrimoniais. $2^{a}$ Ed. Rio de Janeiro, 2000.

VAINFAS, Ronaldo (Org). Dicionário do Brasil Colonial (1500 - 1808). Rio de Janeiro: Objetiva, 2001.

VASCONCELLOS. Sylvio de. Arquitetura no Brasil: Sistemas Construtivos. 5. ed. Belo Horizonte: Rona Editora, 1979. 186p.

VASCONCELLOS, Sylvio de. Arquitetura dois estudos. Goiânia: MEC/SESU/PIMEG-ARQ/UCG, 1983.

VIANA, Manoel. História de um Príncipe. Paranaguá:Prefeitura Municipal de Paranaguá, 1980?.

VIEIRA DOS SANTOS, Antonio. Memória Histórica de Paranaguá. Vols. I e II, Curitiba: Vicentina, 2001.

WACHOWICZ, Ruy Cristovan. História do Paraná. 9a Ed. Imprensa Oficial do Paraná: Curitiba: 2001.

WALLE, Paul. Au Brésil de I'Uruguay au Rio São Francisco. Paris: Librarie Orientale \& Américaine, s/d. Disponível em: http//:www.googlebooks.com. Acesso em: 15 de janeiro de 2010.

WESTPHALEN, Cecília Maria. O Porto de Paranaguá em 1822. Paraná - 1822, Curitiba, $n^{\circ} 19$, p. 37-43, 1972.

WESTPHALEN, Cecília Maria. Porto de Paranaguá, um Sedutor. Curitiba: Secretaria do Estado e da Cultura, 1998. 


\section{FONTES}

Instituto Histórico e Geográfico de Paranaguá (IHGP)

Acervo Fotográfico do IHGP

ABRANCHES, Frederico José Cardoso de Araujo Abranches. Relatório com que o Excellentissimo Senhor Doutor Frederico José Cardoso de Araujo Abranches abriu a $1^{\mathrm{a}}$ sessão da $11^{\mathrm{a}}$ legislatura da Assembléia Legislativa Provincial no dia 15 de fevereiro de 1874. Curitiba: Typographia da Viuva Lopes, 1874.

ARAÚJO. José Feliciano Horta de. Relatório apresentado á Assembléia Legislativa da Província do Paraná na abertura da $1^{\text {a }}$ sessão da $8^{a}$ legislatura pelo presidente Bacharel José Feliciano Horta de Araújo no dia 15 de fevereiro de 1868. Curitiba: Typographia de C. Martins Lopes, 1868.

BOUTIN, Leônidas. Arquivo da Câmara Municipal de Paranaguá. Separata dos Anais do V Simpósio Nacional dos Professores de História, Campinas, p. 343347, 1971.

FERREIRA JUNIOR, Joaquim Mariano de. Collecção de Factos Occorridos nos ano de 1853 à 1903. (Manuscrito)

FLEURY, André Augusto de Padua Fleury. Relatório do Presidente da Província do Paraná o Doutor André Augusto de Padua Fleury na abertura da $2^{a}$ Sessão da $7^{a}$ Legislatura em 21 de março de 1865. Curitiba: Typographia de Candido Martins Lopes, 1865.

GÓES e VASCONCELOS, Zacarias de. Relatorio do Presidente da Provincia do Paraná, o Conselheiro Zacarias de Góes e Vasconcellos, na abertura da Assemblea Legislativa Provincial em 15 de julho de 1854. Curitiba: Typ. Paranaense de Candido Martins Lopes, 1854

GUIMARÃES, Manoel Antônio. Relatório que o Exm. Sr. Comendador Manoel Antônio Guimarães apresentou ao Exm. Sr. Dr. Frederico José Cardoso de Araújo Abranches por occasião de passar-lhe a admininstração da Província do Paraná no dia 13 de junho de 1873. Curitiba: Typographia da Viuva Lopes. 1873.

LINS, Adolpho Lamenha. Relatório Apresentado À Assembléa Legislativa do Paraná no dia 15 de Fevereiro de 1876 pelo Presidente da Provincia o 
Excellentissimo Senhor Doutor Adolpho Lamenha Lins. Província do Paraná: Typ. da Viuva Lopes, 1876,

LISBOA, Venancio José de Oliveira Lisboa. Relatório com que o Exmo. Sr. Preszidente Dr. Venancio José de Oliveira Lisboa abriu a $1^{\mathrm{a}}$ sessão da $10^{\mathrm{a}}$ legislatura da Assembléia Legislativa Provincial do Paraná no dia 15 de fevereiro de 1872. Curitiba: Typographia da Viuva \& Filhos de C. M. Lopes, 1872.

LOBO, Juca. Álbum particular contendo diversas imagens de Paranaguá. Imagens coladas em um caderno com descrições do proprietário. Digitalizado por: José Maria Faria de Freitas.

MARCONDES, Moysés. Documentos para a História do Paraná. Rio de Janeiro: Typografia do Annuário do Brasil, 1923.

MARTINS, Romário. Paranaguá. Revista Marinha, Paranaguá, ano II, n 4, janeiro de 1938

MARTINS. Romário. Almanach do Paraná. Curitiba: Typografia da Livraria Econômica, 1900.

MATTOS Francisco Liberato de. Relatório que ao Illustríssimo e Excellentíssimo Senhor Presidente do Paranã Dr. Francisco Liberato de Mattos Apresenta o Dr. Joaquim Ignacio Silveira da Mota, Inspector Geral da Instrução Pública da mesma Província. Curitiba: Typ. Paranaense de Candido Martons Lopes, 1859.

NOGUEIRA, Antonio Barbosa Gomes Nogueira. Relatório apresentado à Assembléia Legislativa da Província do Paraná pelo Presidente Antonio Barbosa Gomes Nogueira na abertura da $2^{a}$ sessão da $5^{a}$ legislatura em 15 de fevereiro de 1863. Curitiba: Typ. de Candido Martins Lopes, 1863.

OTTONI JUNIOR, Christiano B. Ferro-Via de Paranaguá a Coritiba, 1881: Relatorio Apresentado a S. Ex. Sr. Conselheiro Manoel Alves de Araujo, Ministro e Secretário d'Estado dos Negócios da Agricultura, Commercio e Obras Públicas. Paranaguá: 1882.

PALEARE, Ronald Irineu; PALEARE, Eloir Cesar. Apontamentos de Arquitetura de Curitiba e Paranaguá. In: Boletim do Instituto Histórico Geográfico e Etnográfico Paranaense. Vol. XVIII. Curitiba, 1973. 
PARANÁ. Leis da Câmara Municipal de Paranaguá. [s.I.]: Typ. L. M. de Souza, 1902.

PARANAGUÁ. Código de Posturas da Câmara Municipal da Cidade de Paranaguá. Estado do Paraná. Empreza Typographica Paranaguaense. Borio \& Cia. 1893.

PARANAGUÁ. Código de Posturas da Câmara Municipal de Paranaguá. Aprovado pelo decreto $n^{\circ} 448$ de 13 de abril de 1877. Paranaguá: Typographia de F.R. Vianna, 1877.

PARANAGUÁ. Lei nº 33 de 21 de Julho de 1896: Lei Orgânica do Município de Paranaguá. Paranaguá, 1896.

Planta Hydrographica do Porto de Paranaguá - dos Rios Itiberê e dos Correias no Estado do Paraná levantada pela Secção do $5^{\circ}$ Districto Marítimo a Cargo do Engenheiro Augusto Fausto de Souza Junior. Arquivo digital. Paranaguá: 1892. Escala: 1:5000.

VIEIRA DOS SANTOS, Antonio. Memória Histórica, Chronológica, Tophographica da Cidade de Paranaguá e do seu Município. 1850. Disponibilizado por: José Maria Faria de Freitas

Periódicos.

COMMERCIO DO PARANÁ. A Torre de S. Benedicto. Commercio do Paraná, 15 nov. 1862, p 1.

COMMERCIO DO PARANÁ. Annuncios. Commercio do Paraná. Paranaguá, 27 dez. 1862, p. 2.

COMMERCIO DO PARANÁ. Cemitério. Commercio do Paraná. Paranaguá, 23 de julho de 1864, p. 1.

COMMERCIO DO PARANÁ. Cemitério. Commercio do Paraná. Paranaguá, 31 jan. 1863 , p. 1

COMMERCIO DO PARANÁ. Estatística da cidade de Paranaguá da província do Paraná do anno de 1862. Commercio do Paraná, nº 58 de 7 de jan. 1863.

COMMERCIO DO PARANÁ. Largo da Praça do Mercado. Commercio do Paraná, Paranaguá, $n^{\circ} 88$, p. 4, 5 de setembro de 1863 
COMMERCIO DO PARANÁ. Leilão. Commercio do Paraná, 7 de jan. de 1863.

COMMÉRCIO DO PARANÁ. Melhoramento do Porto. Commercio do Paraná, Paranaguá, 30 ago. 1862, p. 1.

COMMERCIO DO PARANÁ. Melhoramentos do Porto de Paranaguá. Commercio do Paraná, Paranaguá, 25 jan. 1862, p. 3.

DEZENOVE DE DEZEMBRO. Cemitério de Paranaguá. Dezenove de Dezembro. Curitiba, 23 de out. de 1880, p. 3.

DEZENOVE DE DEZEMBRO. Noticiário. Dezenove de Dezembro, Curitiba, 19 de maio de 1880 , p.3.

DEZENOVE DE DEZEMBRO. Viagem Imperial. Dezenove de Dezembro, Curitiba, 9 de junho de 1880, p. 1.

O VIGILANTE. Praça do Mercado. Commercio do Paraná. Paranaguá, 1 mar. 1862, p. 4

Instituto Histórico, Geográfico e Etnográfico Paranaense (IHGEP)

Album da Estrada de Ferro do Paraná - Extensão $111 \mathrm{Km}$.

BARROS, José Ferreira de (Org.). Almanak Administrativo, Mercantil e Industrial da Província do Paraná para o Anno de 1888. Curitiba: Typ. Luiz Coelho, 1887.

IMPÉRIO DO BRASIL. Relatório Sobre os Portos de Pedro II e Antonina Apresentado ao Illustríssimo e Excellentissimo Senhor Conselheiro Dr. Jose Fernandes da Costa Pereira Junior, Ministro e Secretário de Estado dos Negócios da Agricultura, Commercio e Obras Públicas pela Commissão encarregada pelo mesmo ministério. Rio de Janeiro: Typographia Nacional, 1875.

CRUZ, Demétrio Acácio Fernandes da Cruz. Apontamentos Históricos Topographicos e Descriptivos da Cidade de Paranaguá. Rio de Janeiro: Typographia do Diário do Rio de Janeiro, 1863.

MARAVALHAS, Joaquim. Estrada de Ferro do Paraná - Notícia acompanhada de seu histórico e de vários esclarecimentos technicos por Joaquim Maravalhas. Curitiba: Typ. da Livraria Econômica, 1903 
Cículo de Estudos Bandeirantes.

PROVÍNCIA DO PARANÁ. Collecções das Leis, Decretos, Regulamentos e Deliberações do Governo da Província do Paraná. Tomo 5. Rio de Janeiro: Typographia Nacional, 1858.

Museu Paranaense

Acervo fotográfico do Museu Paranaense

CARVALHO, Carlos Augusto. Relatório apresentado á Assembléia Legislativa do Paraná por occasião da instalação da $1^{a}$ sessão da $15^{a}$ legislatura no dia 1 de outubro de 1882 pelo Presidente da Província o Exmo. Sr. Dr. Carlos Augusto de Carvalho. Curitiba: Typ. Perseverança de J. F. Pinheiro, 1882.

Instituto de Estudos Brasileiros - USP

SAINT-DENIS, Emille de Saint. Au Brésil de Rio de Janeiro a Paranaguá. Paris: Imprimerie E. Flammarion, 1898.

Prefeitura Municipal de Paranaguá.

Mapa de Paranaguá. Paranaguá: 1999. Mapa digital em AutoCAD. Escala: 1:1000.

Mapa do Setor Histórico de Paranaguá. Paranaguá: 1999. Mapa digital em AutoCAD. Escala 1:1000

Planta da Cidade de Paranaguá - Levantada pela Comissão de Melhoramentos da Barra e Porto. 1 mapa. Paranaguá: 1910. Escala 1:4000. 





\section{ANEXOS}

1. Relação de viajantes que descreveram Paranaguá e suas imediações:

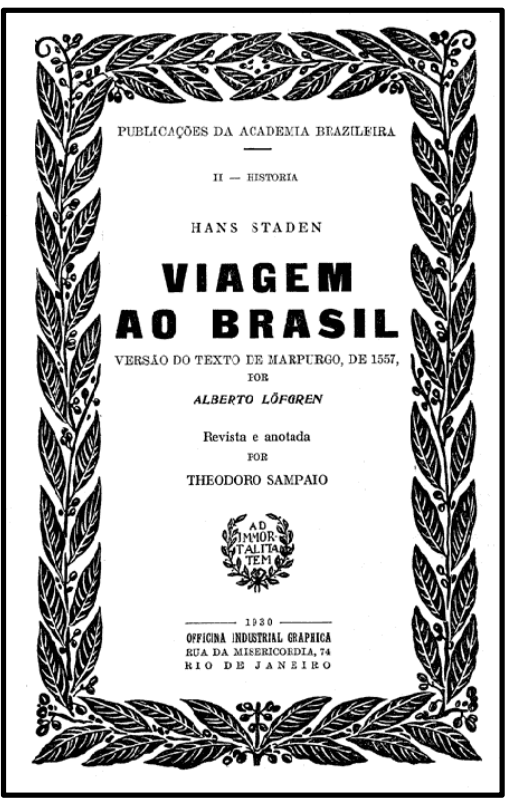

\section{Hans Staden - Viagem ao Brasil - 1557}

Hans Staden, veio ao país em meados do século XVI, e descreveu o modo de vida indígena e suas impressões sobre alguns vilarejos e regiões do país. Em sua narrativa, Hans Staden descreveu sobre um grande vendaval ocorrido durante seu deslocamento para a ilha de Santa Catarina, para se salvarem, os viajantes que acompanhavam o cronista conseguiram atracar a embarcação no porto de "Supraway" ou Superagüí, na região da baía de Paranaguá, encontrando no local portugueses de São Vicente.

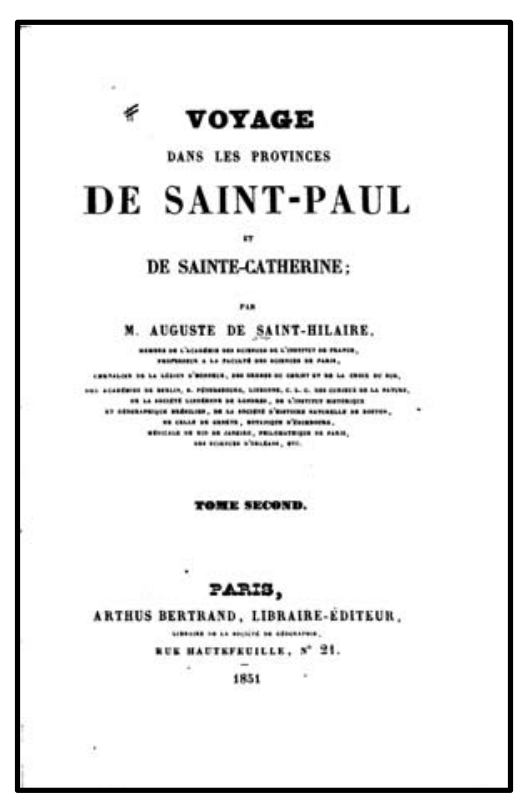

\section{Auguste de Saint-Hilaire - Voyage dans le Province} de Saint Paul et Sante Catherine - $\mathbf{1 8 2 0}$

O naturalista francês esteve em Paranaguá no ano de 1820, e em seus relatos descreveu um grande número de informações e aspectos da pequena vila, que passava por transformações em sua economia naquele período. O viajante esteve presente no período em que eram dados os primeiros passos no desenvolvimento da exportação da erva-mate pelo Porto de Paranaguá, que posteriormente tornou-se 
o principal produto econômico desta região no século XIX. Hilaire foi o responsável pela classificação científica da erva-mate, denominando-a de llex paraguariensis.
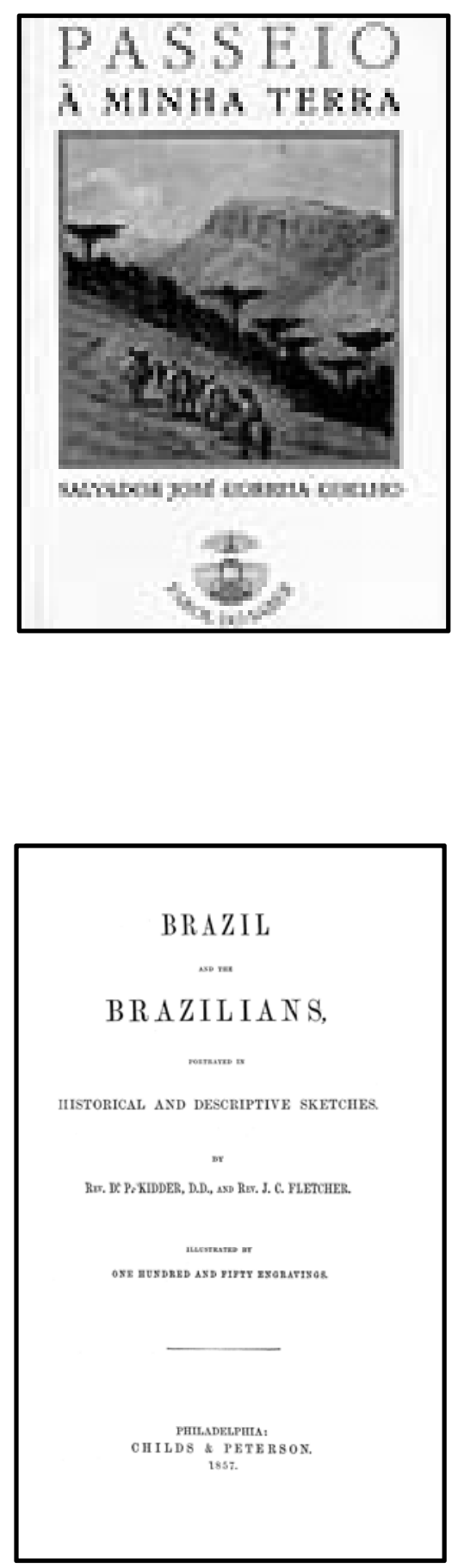

Salvador José Correia Coelho - Passeio à minha terra - 1844

O autor descreve sua viagem entre São Paulo, cidade na qual habitava, até a Lapa, no interior do Paraná, sua cidade de nascimento. Com origem do Porto de Santos, este autor passou por Paranaguá, e comentou alguns aspectos sobre a recém criada cidade e sobre o desenvolvimento de seu porto.

\section{Daniel Parrish Kidder e James Cooley Fletcher - O} Brasil e os Brasileiros - 1855.

Os dois missionários metodistas americanos estiveram no Brasil durante a década de 1850 , e posteriormente reuniram suas impressões nesta publicação editada na década de 1860. Em Paranaguá, Daniel Kidder relatou sobre a exportação da erva-mate, aspectos sobre a cidade, suas principais ruas e das ruínas da igreja dos Jesuítas. 


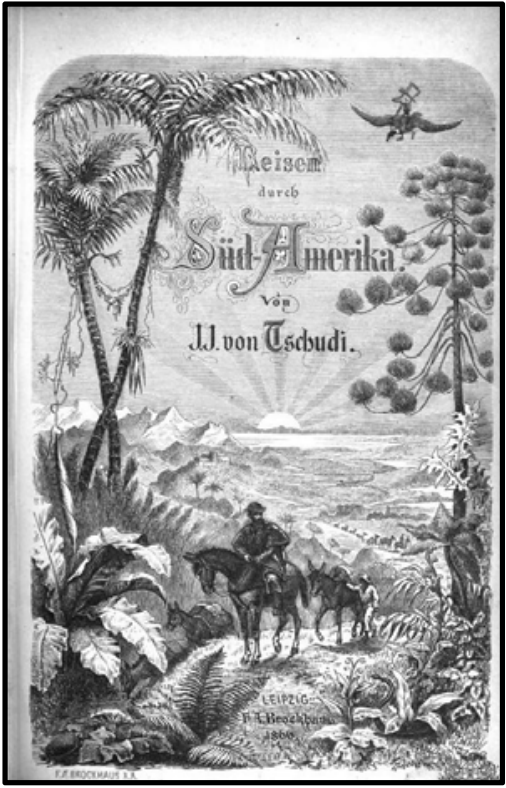

Johann Jakob Von Tschudi - Reisen durch Südamerika - 1860

Este suíço esteve no Brasil em 1860, onde visitou as Províncias do Espírito Santo, Rio de Janeiro, São Paulo e Santa Catarina. Em passagem pelo Paraná, esteve em Paranaguá e descreveu um breve comentário sobre a cidade.

\section{Reije butrd Sitio:Brafilien}

im 3abre 1858.

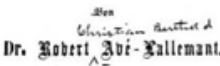
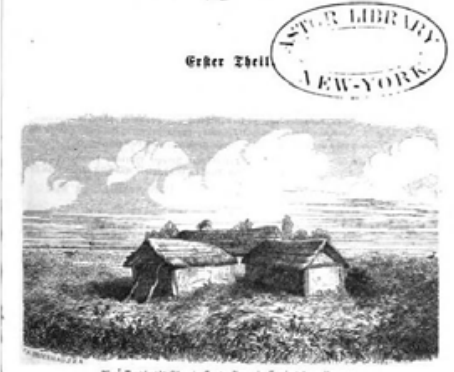

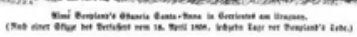

$$
\text { scipsiq: }
$$

8. a. grodbato.

1859 .

(1)
Robert Avé-Lallemant - Viagens pelas províncias de Santa Catarina, Paraná e São Paulo - 1870.

Robert Avé Lallemant, viveu por muito tempo no Brasil e vai descrever a situação que se encontravam as províncias do Paraná, Santa Catarina e Rio Grande do Sul, também sobre a colonização alemã nestas regiões, sua passagem pelo Paraná é marcante pois descreve sobre a cidade de Curitiba, além de Antonina na qual não teve boas impressões. Lallemant também relata sobre a economia da erva-mate e suas impressões sobre os paranaenses. 


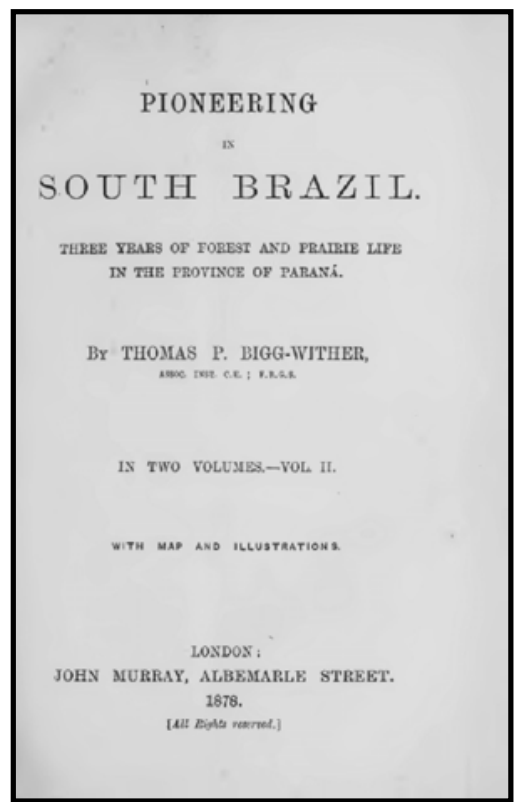

litorânea.

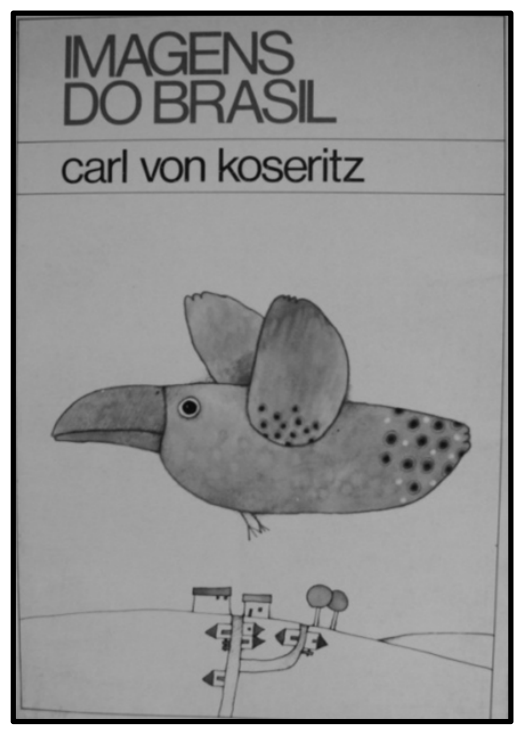

\section{Carl von Koseritz - Imagens do Brasil - 1883}

O alemão Carl von Koseritz, descreveu Paranaguá na década de 1880, principalmente em sua chegada, através do porto, em que descreveu a vista de Paranaguá e de suas construções à partir do rio Itiberê. Koseritz também comenta sobre a economia local e o desenvolvimento da exportação ervateira pelo porto parnanguara. 


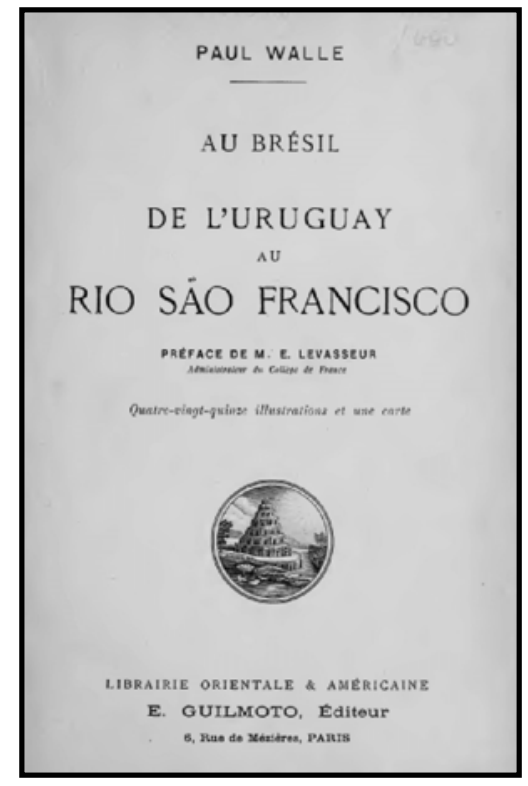

Paul Walle - Au Brésil de I' Uruguay au Rio Sao Francisco - fins do século XIX

Paul Walle descreveu Paranaguá e principalmente a Estrada de Ferro que liga esta cidade à Curitiba, opinando sobre a situação da estação ferroviária de Paranaguá. Suas descrições retratam a Paranaguá do final do século XIX, estruturada em seu porto e recém construída ferrovia.

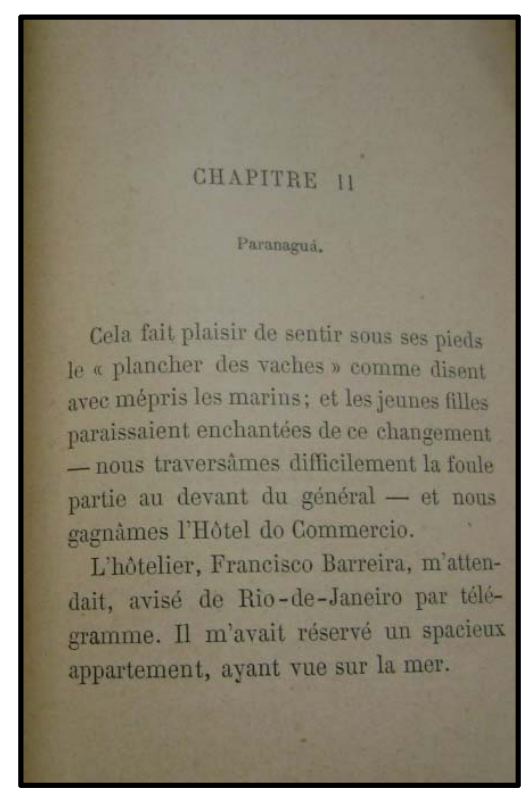

Émille de Saint-Denis - Au Brésil de Rio de Janeiro a Paranagua - 1898

O francês esteve em Paranaguá no final do século XIX e ficou hospedado na residência do Visconde de Nacar, em sua estada relatou sobre a cidade, a Praça do Mercado e festejos realizados no Palacete Nacar, pertencente a um dos maiores exportadores de ervamate da Província do Paraná. 


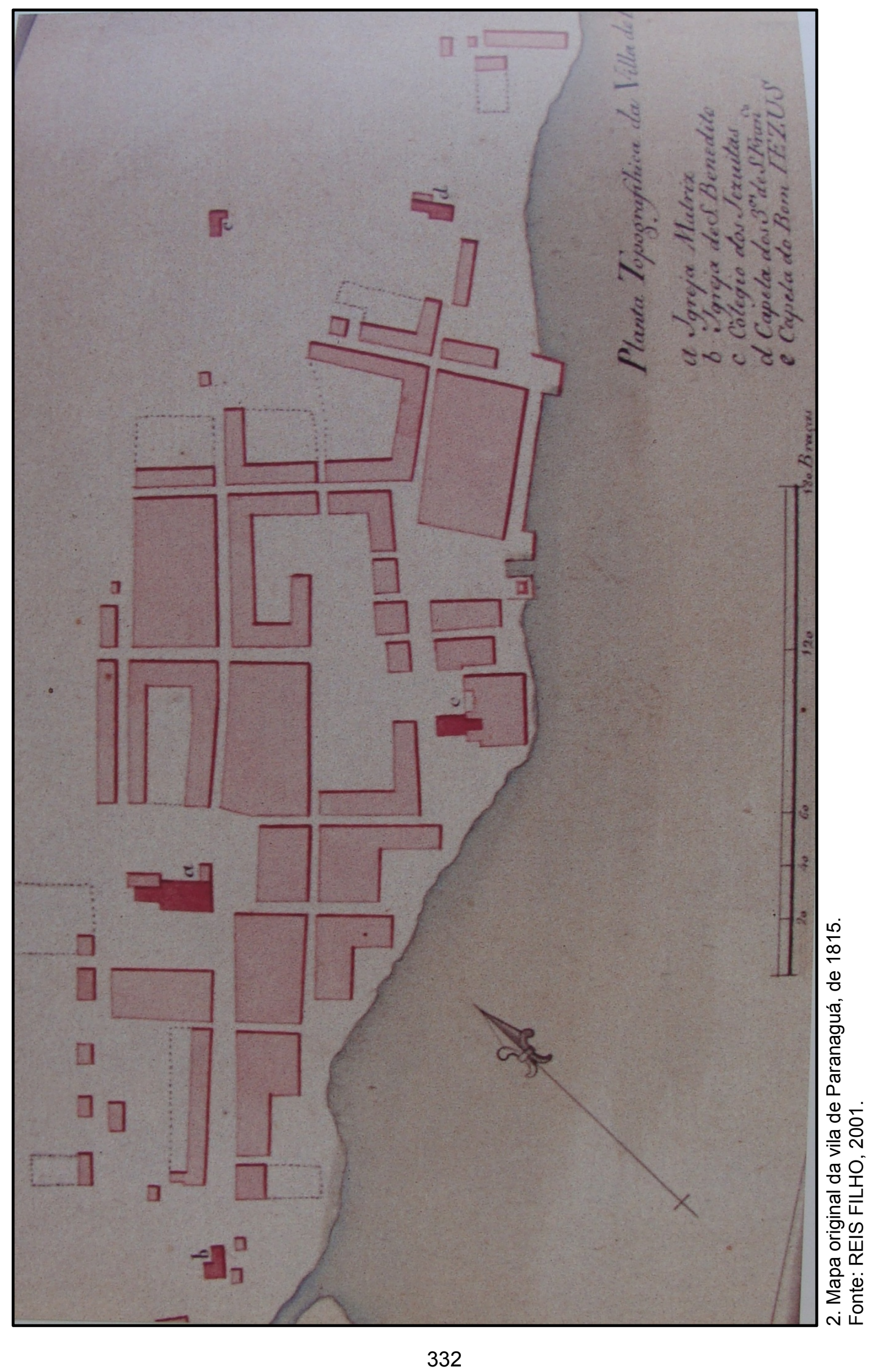




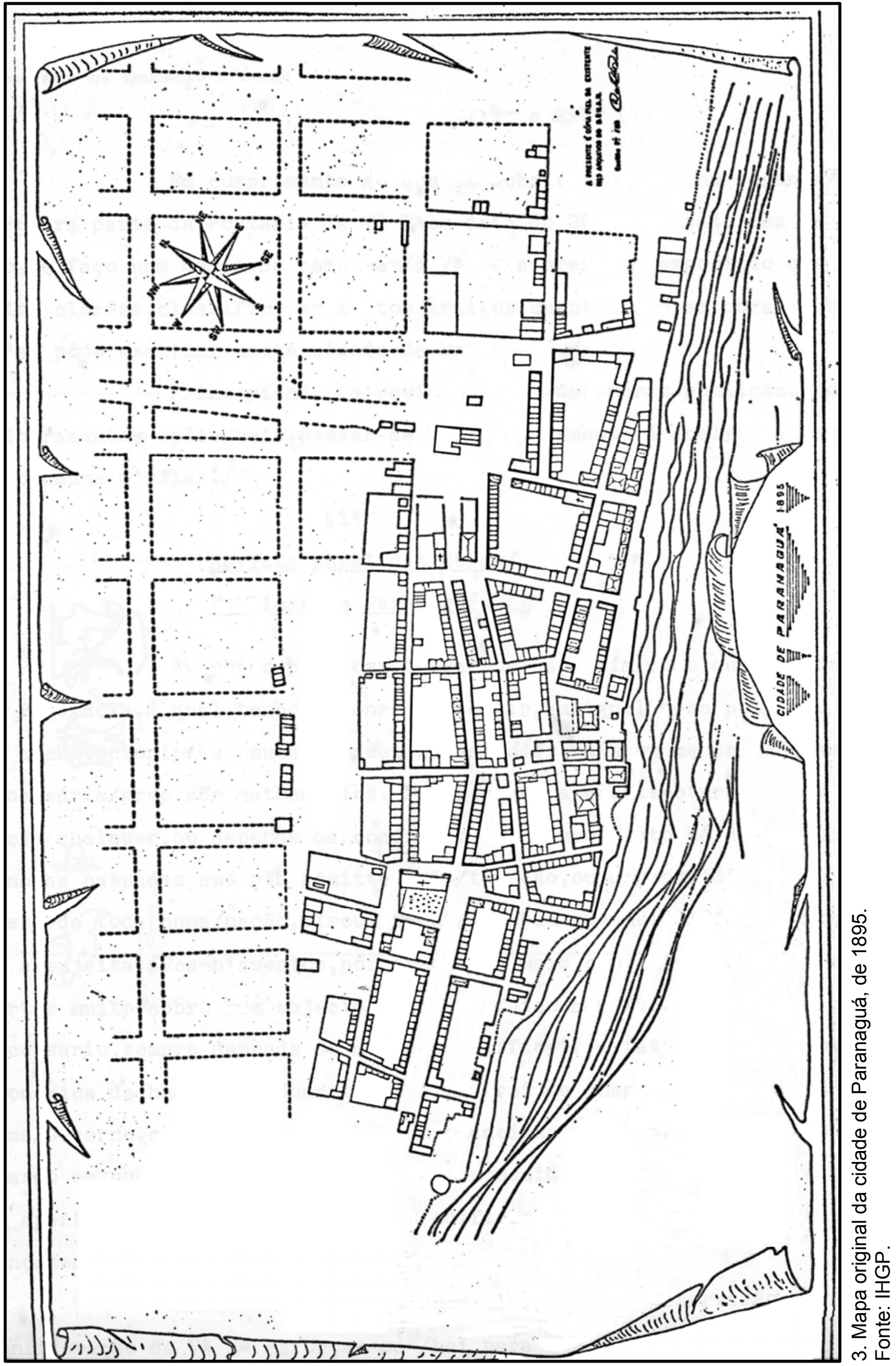


4. Endereço dos acervos pesquisados

Instituto Histórico e Geográfico de Paranaguá (IHGP)

Rua XV de Novembro, 621

Centro Histórico

Paranaguá - Pr

Telefone: (41) 3423-2892

Endereço eletrônico: http://www.ihgp.com.br/index.htm

Prefeitura Municipal de Paranaguá

Rua Júlia da Costa 322

Centro Histórico

Paranaguá - Pr

Endereço eletrônico: http://www.paranagua.pr.gov.br/index.php

Administração dos Portos de Paranaguá e Antonina (APPA)

Avenida Ayrton Senna da Silva 161

D. Pedro II

Paranaguá - $\mathrm{Pr}$

Telefone: (41) 34201100

Endereço eletrônico: http://www.portosdoparana.pr.gov.br

\section{Coordenadoria do Patrimônio Cultural do Paraná}

Rua Ébano Pereira, 240

Centro

Curitiba - $\mathrm{Pr}$ 
Telefone: (41) 3321-4700

Endereço eletrônico: http://www.patrimoniocultural.pr.gov.br/

\section{Círculo de Estudos Bandeirantes}

Rua XV de Novembro, n. ${ }^{\circ} 1050$

Centro

Curitiba - $\mathrm{Pr}$

Telefone: (41) 3222-5193 / 3323-6610

Endereço eletrônico: http://www.pucpr.br/cultura/ceb/

\section{Instituto Histórico Geográfico e Etnográfico Paranaense}

Rua José Loureiro, 43

Centro

Curitiba - Pr

Telefone: (41) 32240683

\section{Museu Paranaense}

Rua Kellers, 289

Alto São Francisco

Curitiba - Pr

(41) $3304-3300$

Endereço eletrônico: http://www.museuparanaense.pr.gov.br/

\section{Instituto de Estudos Brasileiros}

Av. Prof. Mello Morais - Travessa 8, $\mathrm{n}^{\circ} 140$ 
Cidade Universitária

São Paulo - Sp

Telefone: (11) 3091-3197

Endereço eletrônico: http://www.ieb.usp.br/ 